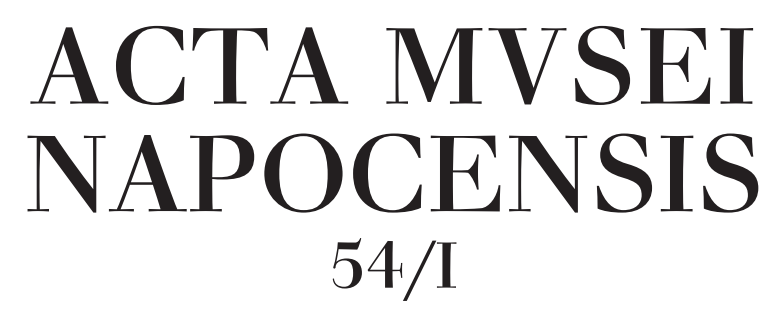



MINISTRY OF CULTURE AND NATIONAL IDENTITY

NATIONAL HISTORY MUSEUM OF TRANSYLVANIA

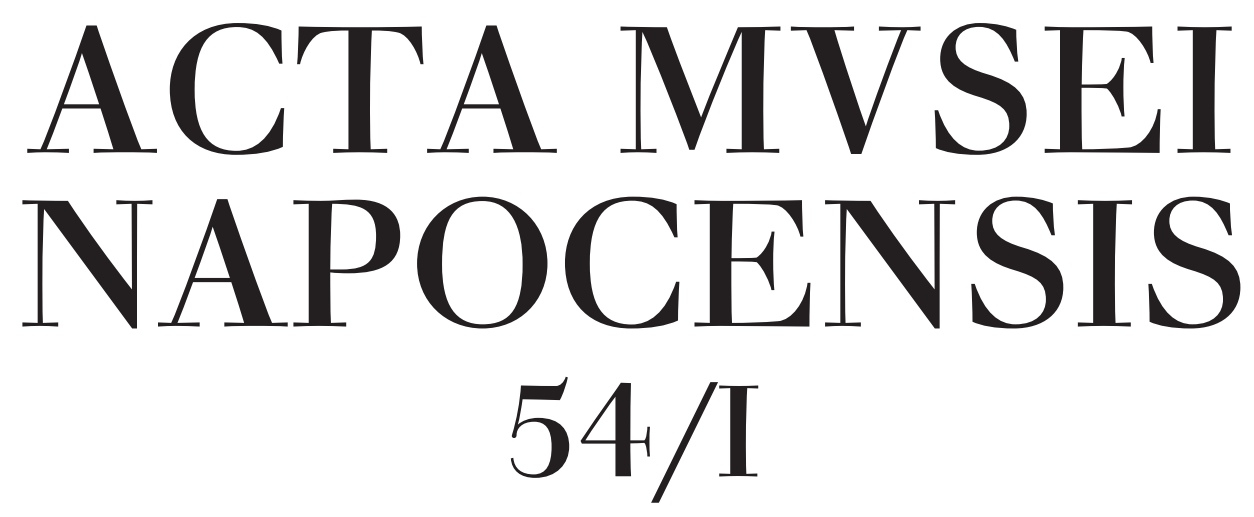

PREHISTORY-ANCIENT HISTORY-ARCHAEOLOGY

CLUJ-NAPOCA

2017 


\section{CONTENTS}

\section{ARTICLES AND STUDIES}

\section{Tibor-Tamás Daróczi}

Early Minoan settlement landscapes. A preliminary study of Cretan Early Bronze

Age settlements and their relative spatial distribution.

\section{Mihai Rotea}

The hoard from the "Cioclovina cu Apă" Cave: content, dating, and significations

\section{Fritz Mitthof}

Vexatissimi nummi: 500 Jahre numismatische Forschung zu den Kosōn-Münzen.

\section{Péter Kovács, István Pánya}

An early Roman tombstone from Dunaszekcső (TRHR 201)

Bence Fehér

Cohort dislocations in Pannonia in the 130s - Consequences of the Bar Kokhba revolt?

\section{Werner EcK}

Die Dedikation einer Statue Plinius D. J. durch die Vercellenses: zu CIL V 5667

\section{Dan Dana, Ion Tuțulescu}

Trois graffites sur céramique du site romain d'Ocnița (Dacie Inférieure)

\section{Sorin Nemeti, Dan Dana}

Malva, la colonie perdue de la Dacie Inférieure

\section{Timea Varga}

The pantheon of Marcus Herennius Faustus, legatus Legionis XIII Geminae

\section{REVIEWS}

Nathan Badoud, Le temps de Rhodes. Une chronologie d'inscriptions de la citéfondée sur l'étude de ses institutions, Vestigia 63, Verlag C. H. Beck, München 2015, 542 pages, 148 illustrations (Dan Dana). 
S. Musteață, Şt. Caliniuc (eds.), Current Trends in Archaeological Heritage Preservation: National and International Perspectives. Proceedings of the international conference, Iaşi, Romania, November 6-10, 2013, BAR International Series 2741, 2015, 132 pages (Florin-Gheorghe Fodorean)

\section{IN MEMORIAM}

Prof. Dr. Ioan Glodariu (01.02.1940 - 21.01.2017) (Răzvan Mateescu).

Abbreviations 
ARTICLES AND STUDIES 



\title{
EARLY MINOAN SETTLEMENT LANDSCAPES. A PRELIMINARY STUDY OF CRETAN EARLY BRONZE AGE SETTLEMENTS AND THEIR RELATIVE SPATIAL DISTRIBUTION
}

\author{
TIBOR-TAMÁS DARÓCZI
}

\begin{abstract}
This paper presents a preliminary examination of the settlement landscape in the Early Minoan period, analysing individual changes within each phase of the Early Bronze Age on Crete island, as well as changes occurring from one phase to another. Furthermore, it seeks to tackle the chronological limitations and possibilities, in an attempt to contribute to our understanding of Early Minoan social and demographic dynamics and relations at an island-wide level. The main goal is to provide a useful tool for the further research of Minoan habitation patterns and a better understanding of the background from which the later palatial systems emerged and developed.
\end{abstract}

Keywords: settlement landscape; Early Minoan period; Bronze Age; Crete.

Rezumat: Articolul de faţă analizează peisajul aşezărilor din Minoicul Timpuriu, punând accent şi pe schimbările care au apărut de la o etapă la alta a epocii bronzului timpuriu pe insula Creta. Studiul tinde, de asemenea, să abordeze limitările şi posibilităţile cronologice într-o încercare de a contribui la o mai bună înțelegere a relaţiilor sociale şi a dinamicii demografice la nivel insular, în perioada Minoicului Timpuriu. Scopul principal este acela de a oferi un instrument de lucru pentru cercetări viitoare privind studiul modelelor de habitare şi o mai bună înțelegere a fundalului cultural din care se nasc şi se dezvoltă sistemele palaţiale mai târzii.

Cuvinte cheie: peisajul așezărilor; Minoic Timpuriu; epoca bronzului; Creta.

\section{Introduction ${ }^{1}$}

The main purpose of this paper is a preliminary assessment of the general trends in settlement mobility, that is, the spatial distribution of settlements (distance from the coast, elevation a.s.l., topographical features) within the island of Crete and within the chronology (relative and absolute) of the Early Minoan (EM) period. It is the intent of the author to contour major shifts in site distribution, correlating them with the features of the cultural landscape in order to obtain a relatively universal picture of the factors which could have affected the choices taken when establishing or continuing activity at a specific site. The present analysis is a brief and preliminary report,

\footnotetext{
${ }^{1}$ First and foremost I would like to express my gratitude for the Erasmus scholarship at the Winckelmann-Institute of the Humboldt University, Berlin, which provided the logistical support for my BA paper, of which the spinoff is the present paper. Furthermore, I am in debt to Joseph Maran, Nicoletta Momigliano, Diamantis Panagiotpoulos and Lærke Recht, for comments made on earlier drafts. Lastly, I would like to acknowledge the guidance, help and support over many years since my stay in Berlin of the late Veit Stürmer, who started me out on the path of Minoan archaeology.
} 
which is part of a wider study that will also involve settlement and funerary landscape, as well as architecture in the EM period.

\section{Early Bronze Age chronology of Crete}

In order to arrange the collected data into different phases and gain a better understanding of the development of settlement patterns through the EM period, we must establish the chronological borders of the study. The most practical is that of the relative chronology; because its sequence is based on ceramic typology, it can be correlated (in most cases) with a stratigraphic sequence of the EBA in Crete. After this, a possible chronology will be presented in order to have some sense of absolute time in relation to site dynamic and distribution.

\section{Relative Chronology}

Minoan chronology was divided by A. J. Evans into three distinct periods: EM, MM and LM. Our main interest for the present study is the first period. The EM period is further divided into three phases: EM I, II and III, each with its own distinct characteristics. $^{2}$ Most of these were documented as being stratified on a preceding level in at least one part of Crete.

EM I is the first period which can be referred to as EBA, although metal finds are rather scarce. So far, no pure EM I levels have been found stratified above Final Neolithic layers. ${ }^{3}$ Its place in the chronological sequence is defined by its forerunner, which is the Final Neolithic (FN), and by the phase following it, namely EM II. ${ }^{4}$ The EM I phase may be subdivided into an earlier and later phase, conventionally named $\mathrm{A}$ and $\mathrm{B}$, respectively.

EM II follows the EM I period, and it may be called a true EBA, because metals abound (although the deliberate mixing of copper with other metals in order to produce bronze is not likely). Only in western Crete was EM II found stratified above EM I levels, at Debla (Debla II being a transitional phase and Debla III a true EM II one). ${ }^{5}$ This phase was divided into two sub-phases (A and B) based on the stratigraphic sequence of Fournou Koriphi, Myrtos and, though slightly more difficult to recognise, may also be found at Vasiliki, Knossos and some other east Cretan sites. ${ }^{6}$

The EM III period is the last period of the Minoan EBA. It shows a multi-coloured picture based on regional varieties; the greatest difficulties are therefore presented by the division of the island into four parts during this period, based on ceramics (western-, south-central-, north-central- and eastern Crete) and, most importantly, the relationship between these local characteristics at an island-wide level. Evidence from stratified EM III layers above EM II or below MM IA is scarce. In most of the cases

\footnotetext{
2 Evans 1906, 5-7.

3 Manning 1995, 42.

4 Warren, Hankey 1989, 13.

5 Warren et alii 1974, 339.

${ }_{6}$ Warren, Hankey 1989, 16.
} 
the homogenous nature of the ceramic inventory is what indicates the phase. No such stratified evidence has been recovered from west Crete and, even worse, the scarcity of EM III material from not stratified layers has also been noted. ${ }^{7}$ South-central Crete is in a similar state, as no documented stratified EM III layers have been found, but usually the pottery that could belong to this period (light-on-dark) is found mixed with polychrome and post-EM II material in Prepalatial strata. ${ }^{8}$ In north-central Crete (Knossos region), the pottery of this phase is defined as light-on-dark, but without polychrome decoration. From this perspective, the discovery of three building phases and several layers of this period stratified above EM II, just south of the later Minoan Palace at Knossos in the Early Houses, was welcomed. ${ }^{9}$ Finally, in east Crete we have the best evidence for homogenous EM III fill, coming from the sites of Pseira, Gournia, Mochlos and Palaikastro. The decoration is light-on-dark with a rich decorative repertoire unparalleled in other regions of Crete. ${ }^{10} \mathrm{~A}$ special mention should be made of the Pyrgos, Myrtos site and its II b-c phases, dated roughly to the EM III period, because this is the place where the north-central wares of Crete (MM IA polychrome) meet the ones from the eastern region (EM III East Cretan White-on-Dark). ${ }^{11}$ The explanation for this could be that the EM III wares of east Crete lasted longer in this part of the island, and when the polychrome pottery appears here (MM IA), the MM IA has already begun in the north-central part of the island, that is to say, east Cretan MM IA began at about the middle of the north-central Cretan MM IA. ${ }^{12}$

After this brief account of the relative chronological sequence of the EM period, one can imagine the difficulties of dating a site, especially considering the fact that most of the sites examined in this study were investigated through archaeological surveys. The inaccuracy of the relative dating extends even further if we consider that some pottery groups can only be dated in a certain period if they are expressed through a relation or proportion to other groups and not dated based on characteristics of a single sherd. In some cases it is necessary to establish a relative chronology of the surveyed area, due to lack of characteristic material. Such local sequences are usually based on the coarsest wares, which appear more often. They are then integrated into the general Cretan periods through the correlation of the surveyed pottery sequence to a known pottery sequence of the area established through excavation. A good example of this is the Kavousi Survey where 18 coarse fabric types were defined, two of which were pure EM (Type II: EM I-II and Type IX: EM I-II). ${ }^{13}$

\section{Absolute Chronology}

The BC years for the EM period, based on radiocarbon dating, are as follows ${ }^{14}$ :

\footnotetext{
7 Warren, Hankey 1989, 17; Manning 1995, 63.

8 Warren, Hankey 1989, 20; Manning 1995, 64.

9 Momigliano, Wilson 1996, 47, 53-54.

10 Warren, Hankey 1989, 17-18.

11 Warren, Hankey 1989, 18-19; Manning 1995, 64.

12 Warren, Hankey 1989, 20.

13 Haggis, Mook 1993, 279-280.

${ }^{14}$ Manning 1995, 143-153, 217-222.
} 


\section{Early Minoan I \\ Early Minoan IB/Early Minoan IIA Transitional Early Minoan IIA \\ Early Minoan IIB \\ Early Minoan III}

$3100-3000$ to $2700-2650$

(2700-) 2650

2650 to $2450-2350$

$2450-2350$ to $2200-2150$

$2200-2150$ to $2050-2000$

all years are BCE

It should be noted that, based on our present knowledge, even though the relative chronological division of the EM periods seems equally spaced, this pictures changes entirely when correlated to absolute dates. The first period is almost 800 years long, the second about 400 years and the last one only about $100-150$ years. This has farreaching implications concerning dating and the interpretation of the archaeological landscape. The accuracy of dating in actual BC years based on pottery exponentially increases as we approach the end of the EM period; due to the fact that about the same amount of pottery groups are used to date periods which last about 800 and 150 years. In terms of archaeological landscape, its implications are severe, as for example sites dated to EM IA actually cover a span of about 400 years as opposed to sites which are dated to EM III, which on the other hand only cover about 150 years. Also it would be foolish to believe that once a site is dated based on pottery, let us say in EM IB, it is in use from the beginning till the end of the period, especially if it did not have any forerunner or continues into the next period.

\section{Early Minoan settlement patterns and dynamic}

The distribution of EM sites will be discussed based on the periods in relation to BCE years, distance from the coast, elevation, emergence and abandonment, and finally topographical location. It is possible that not all of the sites should be identified as habitations; they could, for example, be unrecognised cult places or burials, but the lack of distinct archaeological materials which may attribute them to a specific use, makes the majority of them interpretable as habitation sites. The coastal sites are defined as being within a distance of $300 \mathrm{~m}$ from the coast, meaning a 5 minute walk when carrying different goods; these are also the sites most likely to function as harbours (when there is an existing sandy beach suitable for pulling crafts to shore). After this, the changes from one period to another will be highlighted in order to obtain an understanding of the general tendencies in the change of settlements as well as in other related activity areas.

\section{Site distribution in the Early Minoan I period (Pl. II)}

Considering the difficulty of defining the phases of the EM I period, especially from survey data, the differentiation of site distribution within it will be also difficult, at present almost impossible. Most of the sites are dated to the entire period, regardless of whether they continue from the former Final Neolithic phase or if they are newly established. There are only two sites which do not fit this profile, one being that 
of Lakoudia, Vraskas in the region of Sphakia, the other Malia near the north-central coast. The former is of very early EM I date, therefore it could be attributed to the EM IA period. The latter is highly problematic in terms of dating, because it is located at the site of a later palace, which could obstruct the recognition of such early material, but at the moment it appears that the site began in later EM I, that is to say EM IB.

There is a total of 110 sites in EM I Crete, with 109 in the earlier phase of this period and the same number in the later one (Pl. IV). This means that for about 400-500 years, ranging from the last centuries of the fourth millennium till the middle of the first half of the third millennium, there are about 100 habitations on the entire island (Pl. IV). Not necessarily all of them are contemporary, but at present the archaeological material from this period does not allow a better estimate of their internal chronology. Some may have been only seasonal habitations, as has been suggested for a few sites (e.g. in the Lasithi). ${ }^{15}$ There is only one documented site which was abandoned during the EM I period, that of Lakoudia, Vraskas (Pl. VII), but this may provide a false picture, as it has been pointed out in the above presentation of the poorly known EM I archaeological sequence and material. During the late EM I period, a massive site abandonment occurs, as almost half of the sites are deserted (Pl. VII), but the reasons for this apparent trend could again be related to the difficulties with the inner chronology of the phase. On the other hand, there are 37 newly established sites (Pl. VII), whose establishment should be viewed as part of a process rather than as a temporarily limited event; the same may be assumed about the site abandonment in the late phase of the period. If it could be proved that this occurred over a short period of time, this could indicate an influx of new populations, but it is more likely that this represents the beginning of an exponentially growing local population, expanding and changing habitation and activity sites over a period which is fairly long. The possibility of the appearance of a new demographic element in this period should be kept in mind, though perhaps on a smaller scale. Conclusive evidence for this new element should not only be sought in the Cretan foreign materials, but in the presence of non-moveable archaeological material, such as the Ayia Photia graves of distinct Cycladic character, ${ }^{16}$ and the abundance of foreign luxury goods in Mochlos, ${ }^{17}$ even if they are not as vast as in the later EM phases. Most of these goods seem to concentrate in the eastern part of the island, and they continue their existence into the second EM phase, not only expanding in size but also acquiring a larger quantity of foreign luxury goods, hence proving the existence and intensification of Cretan foreign relations. ${ }^{18}$ The continuing sites and the ones now being founded were placed on a variety of topographical features (Pl. VII). The highest proportion of sites, almost half of them, is situated on slopes, with 15 sites exclusively on them, and the remaining ones associated with other topographical features such as summits, ridges and valleys. The second most popular choice for a habitation in this period is a summit (Pl. VII). There are 17 sites exclusively placed on this feature, the remaining ones, 36

\footnotetext{
15 Watrous 1982, 38, 46, 52, 58, 65.

16 Branigan 1988, 152; Tsipopoulou 1989, 17, 97; Davaras, Betancourt 2004.

17 Branigan 1991, 97.

18 Branigan 1991, 97, 102.
} 
and 35 in EM IA and IB, respectively, extending onto slopes or ridges in the vicinity of the summits. Valleys and plains are not very well represented in the choice of site in this period and the same may be said about the coastal sites (Pl. VII). The remaining sites are to be found in areas which are at the base of hills, ridges, and a few on promontories. The highest number and proportion of cave sites, that do not indicate a funerary use, in all a number of 16 , occur in this period (Pl. VII). If we examine the topographical locations from the perspective of the elevation about sea level (a.s.l.) and distance from the coast, the data seems to arrange itself into some kind of order. More than half of the EM I sites accounted for in the present paper are located between $0-300 \mathrm{~m}$ a.s.l. (Pl. VI). The remaining 31 and 30 sites of the EM IA and IB, respectively, are between 300-1000 m a.s.l. (Pl. VI). Although the majority of the presumed EM habitations is on a relatively low-lying topographical feature, a proportion of $1 / 3$ of the EM I sites occupy the remaining vertical topographic zones until $1000 \mathrm{~m}$ quite homogenously, not showing clustering around any of the height intervals till this highest elevation. If we relate this picture to that of the distance from the coast, which in an area like Crete (namely an island) would surely have constituted another influencing factor on the choice of activity, we can observe a tendency towards proximity to the coast, although the "hinterland" of Crete is also inhabited or at least "scouted" for possible habitation ( $\mathrm{Pl}$. V). It is quite clear that the sites tend to concentrate in a coastal strip of $5 \mathrm{~km}$, almost regardless of the topographic conditions, although the vicinity to the plains and valleys of the area is clearly also a determining factor (Pl. II). After this zone, with the highest concentration of sites, the average distribution based on the distance from the coast is smaller, but these sites do not indicate a gradual fall off of some sort, but rather the difficulties encountered in settling the land, which after the zone of lower-lying coastal plains and hills is followed by the foothills of the high mountain ranges of Crete.

\section{Site distribution in the Early Minoan II period (Pl. III)}

The EM II phase is the best known of all the three phases of the EBA, not only in terms of the ceramic sequence, but also as attested stratified phases and knowledge of other archaeological material. It appears that the island entered into, if not wider, then at least more intensive contact with the other regions of the Aegean and eastern Mediterranean.

There are a total of 116 EM II sites, 114 of which may be dated to the first phase of the period and 113 in the second period (Pl. IV). All except five sites continue all the way through this period, while three end in the EM IIA and the other two only begin in the EM IIB. In terms of relative chronology this would not seem out of the ordinary for EM Crete. However, this picture changes if we correlate it to BCE years, showing that the number of sites increases, compared to the previous period, but the change is misleading as it is not related to absolute dates but to that of the relative chronology. These EM II sites are distributed over a period of 350-400 years, which would mean an intensified site existence and appearance (Pl. IV). The dynamic of the sites related to the BCE years shows a growing exponential curve, which began in the former, EM 
I period. The beginning of this EM II phase is marked by a very high number of site appearances, after which only a few sites emerged during the period (Pl. VII). The abandonment of the sites is at its lowest during the EM IIA phase, meaning site and possibly settlement stability on an island-wide level. A slight increase in desertion of sites is seen in the late EM II period, as 19 sites are no longer in use, and therefore do not reach into the last EM phase (Pl. VII). It seems that settlements are mostly concentrated on slopes and adjoining topographical features such as summits, ridges, valleys and bases of hills (Pl. VII). The number of cave sites is very low, as are those of promontories, and the preference for location of settlements on plains and valleys increases (Pl. VII). In both phases of the EM II period, more than $3 / 4$ of the sites are located between $0-300 \mathrm{~m}$ a.s.l., and the remaining handful are distributed between 300-1300 m a.s.l., showing a gradual fall of sites as we climb higher on the vertical elevation chart (Pl. VI). If we correlate this picture with that of distance from the coast, it is clearly distinguishable that the sites tend to concentrate in a coastal band that only rarely exceeds $4 \mathrm{~km}$ from the coast, and that the remaining less than $1 / 4$ of them are distributed over a fairly long distance, up to $17 \mathrm{~km}$, but not at regular intervals or gradually falling (Pl. V). This means that the "hinterland" was used for certain, possibly specialised, purposes as the sites do not appear to be located at every possible distance from the shoreline, but rather in certain areas, which must have fitted the needs and requirements, elusive at this stage of research to us, of the people in the EM II. Another possible reason for this picture could be that the field research of the areas further away from the shore has only been carried out at a moderate level compared to that of the coastal ones.

\section{Site distribution in the Early Minoan III period (Pl. IV)}

The EM III period constitutes a fairly short period of time, 150-200 years (Pl. IV), showing almost the same number of sites as in the former period (Pl. IV). The newly established sites of this period represent less than $1 / 4$ of the total, showing a stabilised settlement and activity landscape (Pl. VII). The favouring of slopes and associated higher (summits, ridges) or lower (valleys, base of hills) lying topographical features by more than half of the sites of this period allows us to conclude that, in this phase, these still remain the preferred geographical features for the location of sites (Pl. VII). Sites on the coast, in the plains or in valleys come second in order of preference in terms of topographical characteristics; promontories and caves are only rarely inhabited or used (Pl. VII). More than $3 / 4$ of the EM III settlements or areas of activity tend to appear at an elevation between 0 and $300 \mathrm{~m}$ a.s.l., and few remaining ones extend over great height differences, from 300 to $1600 \mathrm{~m}$ a.s.l., with large unused elevation zones (Pl. VI). This choice would indicate once again a specialised use (habitation and/or activities) of the landscape by the EM people. Finally, the distance from the coast provides a similar picture, showing a concentration of sites on the first $3 \mathrm{~km}$ from the coast, after which is a "middle zone" with a lower number of sites (only $1 / 4$ of the total), located between 3 and $6 \mathrm{~km}$ from the shore, and finally reaching the "hinterland" with very few sites, distributed unequally till a maximal distance of $17 \mathrm{~km}$ from the sea (Pl. V). 


\section{Settlement pattern and site dynamics in the Early Minoan period}

Firstly, we may note that in terms of micro-topographic locations, if each site is regarded in its own restrained surrounding, that none of them are on an actual plain, or an extensive flat surface; they are rather situated on small, low-lying mounds and bases of hills, with only about 20 metres at most in height. This may represent a defence against the forces of nature, most likely floods. We know that the climate of the EM period was not so evaporative as in later times, ${ }^{19}$ and species like the lime were at home on the island, ${ }^{20}$ so a more abundant rainfall, even if only seasonal, would also have been possible, and the simplest plan against such disasters would have been a retreat to slightly higher ground.

There is also the problem of defensible sites, which could be the governing reason for present day interpretations, but not necessarily to EM people for the location of sites. The choice of a site or even a settlement on a dominant and possibly well defendable topographical position does not necessarily imply that security concerns were the reasons that lead the inhabitants to establish it in the first place. We should never forget that a settlement on a summit, promontory or other such features is only defensive if it has proper structures for this purpose - a couple of people at one end of a promontory or edge of a summit will not necessarily stop a group with invading and pillaging tendencies. This is the best case scenario, because the inhabitants are aware of the enemy presence. On the other hand, defensive structures of EM date, to my knowledge, are unknown save for a few suggested ones which are highly questionable and not verified through archaeological excavations. One such site could be that of Drepani Akrotiri on the north coast, where a possible FN/EM I structure sealed off the southern entrance to the land prong, but without further excavations nothing more secure may be said. ${ }^{21}$

We may turn our attention to the EM site dynamics. The overall number of the sites seems to remain relatively stable in every EM period; there is no great rise or fall which may indicate a major influx of population. On the other hand, the BCE years distribution of them shows a different picture. We may say that, although their numbers do not change, the length of the time interval during which the sites existed, does, meaning that almost the same number of sites was in use or established for different lengths of period. The first interval is 400-500 years long, the second $350-400$ years long and the third 150-200 years long (Pl. IV), so we may say that we are dealing with an increasing site activity as shorter periods of time sustained the same number of sites as the longer ones. This means not only an increase in number of sites but also an increase in population. Studies researching EM demography features underline the limited data available for detailed accounts of populations based on actual human bone remains. ${ }^{22}$ Such studies of site distribution in relation with other evidence deriv-

\footnotetext{
19 Moody, Rackham 2001, 36; Hayden 2004, 5-6.

20 Hayden 2004, 5-6.

21 Nowicki 1999, 578.

22 Halstead 1977, 111.
} 
ing from the actual paleo-anthropological data, and the assessed inhabitants' number of excavated sites in relation to the spatial extent of the settlement, would enable us to take a further step in evaluating the variables of EM populations of Crete.

The correlation of emergence and abandonment of sites through the EM period would enable us to estimate the wide and lengthy processes which were at work in the third millennium BCE on the island of Crete. As discussed above, we may see (Pl. VII) that there is a strong settlement continuity from the FN period into the EM I period; out of the 109 sites of the EM IA period, only 36 do not have an earlier Neolithic component. This is followed by heavy site abandonment in the later part of the EM I period, as 49 sites do not continue into the EM II period. It should once again be cautioned that this is not an event associated with a horizon of destruction or abandonment; rather, it should be seen as a process, which began in the very last interval of time of the EM I and lasted into the very early EM II period. This inaccuracy in the recognition of the process is due to our limited knowledge about the pottery sequence, since a more detailed one where actual centuries are delimited based on ceramics in this prehistoric period for the time being is impossible. This relatively large-scale abandonment is followed in the very early EM IIA by a high site emergence, possibly indicating the relocation of the populace that was seen leaving their initial habitations or areas of activity at the end of the former period. The fact that the number of abandoned sites and that of the emerging ones is almost the same, supports such a conclusion, and a confirmation of this process will be found below, where the same events may be reconstructed at the transition between EM I and EM II in the site distribution, based on elevation above sea level and distance from the coast in relation to a wider chronology. Further, the difference between these two values (of the abandoned and emerged sites) is not so significant as to allow for an influx of foreign populations to Crete; it should instead be viewed as an internal evolution of the exponentially growing demography of the island. On the other hand, if the foreign demographic element ever appeared on EM Crete, this would have been the only moment in which it can be argued for, based on the luxury goods of Mochlos and the strong Cycladic character of the Ayia Photia graves. ${ }^{23}$ This is also the period in which the strong connections between Knossos and the Greek Mainland are most evident (e.g. the Mainland type sauceboats at Knossos). ${ }^{24}$

At this point, the position of Mochlos should be mentioned in relation to the excellent conclusions drawn by Branigan. In EM II and III this site shows the least Cycladic influence, although the areas surrounding it yielded strong evidence for such a contact; on the other hand, it shows some sort of control over the import and export of certain valuable goods, therefore making it possible to define it as a "settlement of monopolistic market" or a "gateway community". ${ }^{25}$ If we look at the map of the distribution of sites in the EM II period on Crete (Pl. III), we may see a high concentration in the Mirabello bay, and there are some quite extensive ones, such as the settlements of Mochlos, Pseira or even Priniatikos Pyrgos, not to mention the other smaller habi-

\footnotetext{
23 Branigan 1988, 152; Tsipopoulou 1989, 17, 97; Davaras, Betancourt 2004.

24 Warren 1972a, 395.

25 Branigan 1991, 103.
} 
tations of the area that do not exceed the size of hamlets. Compared to other well surveyed areas (Lasithi, western Mesara, Ayiofarango region), the site concentration of the EM II and following period is very high even by MM and LM standards. ${ }^{26}$ Even if the entire environmental landscape and agricultural techniques are not easily reconstructed for this period, the number and size of possible settlements suggest a population, which could not have been supported on a subsistence level. This indicates that they must have been acquiring their different goods, especially food, from other regions through exchange, trade or some other way; hence they would have had one or more of a certain kind of movables, which were not necessarily related to the raw materials found in the region nor the goods that were produced in this landscape. They were rather something which was made exclusively in this part of the island, as they had a monopoly (imposed by geographical and/or diplomatic reasons) over the imported raw materials (e.g. specialised goldsmiths and lapidaries at Mochlos). ${ }^{27}$ The people of this region were not necessarily needed to produce something from the imported raw materials or goods - the simple fact that the materials passed through their hands would have resulted in a substantial profit, regardless of the nature of trade and exchange in this period. Such a system would have resulted in a differentiated society, at least by this EM II period, which is visible in the archaeological material by the distinguished rich and poor graves that are to be found on Crete, especially at Mochlos. ${ }^{28}$ This acquisition of wealth would have facilitated or even set off the concentration of people, in turn yielding the concentrated archaeological evidence for sites seen in the site distribution of the EM II Mirabello bay.

There are other areas which indicate such a nucleation of sites: the same phenomenon appears in the Lasithi Plain, where out of the 15 EM I sites only one survives into the next period and there are four newly established ones, each of a larger size, indicating the movement of the population into settlements of much greater stability. ${ }^{29}$ For such an inland region as the Lasithi, the primary reasons for nucleation are not necessarily related to trade. Looking at this zone (Pl. III), we may see that the sites are situated above the actual plain, on the slopes of the surrounding hills. One possible, and highly probable, reason for such an occurrence could have been the fact that the good arable land of the plain would not have been occupied by actual settlements; it also could have been a good defence against possible floods due to the climate of the period. ${ }^{30}$ The primary impulse for such a concentration of settlements for a higher yield of crop must have come from outside the plain, as the possible need for agricultural products and wood of certain regions (e.g. Mirabello bay region) would have created a need which in turn created the market for such goods and trade connections. We already know that the exchange of ceramic products between different parts of Crete began at least in EM IB and was well on the way by EM II, ${ }^{31}$ which means that the cross-island trade/exchange

\footnotetext{
${ }^{26}$ Blackman, Branigan 1975; Blackman, Branigan 1977; Watrous 1982; Watrous et alii 1993.

27 Branigan 1991, 103-104.

${ }_{28}$ Cosmopoulos 1995, 24-25, 27.

29 Watrous 1982, 9, 11.

30 Moody, Rackham 2001, 36; Hayden 2004, 5-6.

31 Wilson, Day 1994, 85; Betancourt 2003, 120-121.
} 
connections already existed by this period and the specialisation of certain regions based on possibilities provided by their geographical location was simply the next step, inherent in the seeds of these contacts possibly beginning in the FN and EM I.

This is further emphasised by the time of EM III, when the sites from the Mirabello bay seem to move closer to the sea (Pl. IV); the greatest wealth of the community at Mochlos is achieved by this period, ${ }^{32}$ and most importantly, although some sites are abandoned at the end of the former or the beginning of this last EM phase (Pl. VII), most of them show a continuity of use from EM II through EM III. This naturally indicates a relative stability of the settlements and the connections established between them. Even if the number of 19 deserted sites seems much out of the total of 113 of this period (Pl. IV), it does not compare with the other similar process seen at the transition between EM I and II (Pl. VII).

This stability of the settlement landscape suggests a cultural stability of this period, meaning that the relations between different parts of Crete and of course within these regions are well established. It further indicates a stability in the foreign relations of Crete, as the next stage of this will be seen in the MM period.

To refine this picture of the general settlement dynamics of EM Crete, we may turn our attention to the "movement" of sites based on distance from the coast and the elevation above sea level. If in the EM I period, $3 / 4$ of the sites are in a $5 \mathrm{~km}$ coastal strip and the hinterland is fairly homogenously inhabited until a distance from the shore of $17 \mathrm{~km}$, in the following period the sites nucleate in the first $4 \mathrm{~km}$ from the sea, indicating a slight movement from the "hinterland" of Crete towards the coast, thus leaving some inner regions which were previously inhabited totally deserted. This movement is further emphasised in the last EM phase, when the highest nucleation of sites are contained within a coastal zone only $3 \mathrm{~km}$ wide, followed by a "middle zone" characterised by the existence of a moderate site concentration situated between 3 and $6 \mathrm{~km}$ from the shore, and leaving the inner part of the island low on sites. Most of these inner sites are not actual habitation but by now attested cult caves of the Minoan culture (Kamares, Stavromyti caves).

In this general trend of movement towards the coast and nucleation in this region we can also observe a movement from higher topographical features to lower ones (Pl. VI). This does not necessarily mean a movement from the mountains to the hills, but rather a concentration of sites in the lowlands of the coast ( 100 m high topographical features). The distinct break, which indicates a concentration on this low elevation in the area of the coast, is between the EM I and II periods (Pl. VI); on the other hand, by the time of EM III (Pl. VI), this is only further maintained, hence confirming the reached stability of this coastal zone and the achieved good relations between the sites. The higher-lying zones of the island show a gradual desertion over the EM period; if in EM I these zones were well inhabited, by the time of EM II and especially EM III, they were abandoned. The few sites which still exist here are mostly cult places (Kamares) or part of a peak sanctuary system (e.g. SK 8 near the Stavros peak overlooking the Isthmus of Hierapetra).

\footnotetext{
32 Branigan 1991, 98.
} 
In the choice of actual topographical features over the different periods we see an ever high and slightly increasing preference for slopes and associated features like summits, ridges, and bases of hills (Pl. VII). It has been suggested that the introduction of the plough drawn by draught animals should be placed in the beginning of the EBA in the Aegean. ${ }^{33}$ It also has been indicated that such an improvement in agricultural technique would have facilitated the exploitation of the rich, deep soils of the low hills and uplands, which were till that time not easily cultivated due to technological limitations. ${ }^{34}$ The importance of proximity to the coast (a distance of $300 \mathrm{~m}$ from it) remains steady over the entire EM period, representing about $1 / 4$ of the known sites of each period; a slight increase in the number of these is noticeable from EM II onwards (Pl. VII). Plains and valleys as activity sites increase in importance from EM II onwards; it is remarkable that in these topographical regions, the number of sites double from the EM I to the EM II period, maintaining this level even in the EM III period (Pl. VII). Finally, there is a reduction in number of sites located on promontories and caves - especially in the cave sites there is a distinct break, recognisable between EM I and II, and it is known that by the time of the EM III period, most of them became cult places (Pl. VII).

Since negative evidence should also be regarded as valuable information, we take note of the Ziors Survey conducted in east Crete. The surveyed area consists of two basins of the innermost part of this part of the island. Neolithic sherds and sites were found in these regions, as were some from MM I/II onward. ${ }^{35}$ Interestingly, no EM and MM I archaeological evidence was uncovered in either of the basins, which would suggest an occupation or use of this area in these periods. ${ }^{36}$ This would suggest that extremely isolated regions of Crete were not inhabited. Although subsistence in the area would have been possible, quite clearly it was not one of the main concerns of the EM people, hence indicating the importance of contact and possible trade/exchange relations between different habitations, even small ones.

There is a distinct and unique problem in terms of EM foreign contacts and site distribution. With the exception of the site on the island of Gavdhos in the Libyan Sea, all the EM sites are located on the island of Crete. The case of the island of Kythera, just $10 \mathrm{~km}$ south of the Peloponnesus, is a very interesting one, as under the LM houses a stratum of EM II and III ceramic material was uncovered, with no evident structural remains which may have been associated with them, also with west Cretan links. ${ }^{37}$ To make matters even more complicated, it seems that the use of the island by the Minoans was preceded by the use of it by people bearing the Helladic culture, and there is a distinct break in the sequence, because when the EH II material stops, the EM II begins. ${ }^{38}$ If we regard this occurrence of EM II and III material as a colony based on the three forms defined by Branigan (governed -, settlement - and commu-

\footnotetext{
33 Pullen 1992, 51-52.

34 Pullen 1992, 45, 47.

35 Branigan et alii 1998, 80-84.

36 Branigan et alii 1998, 84 .

37 Coldstream, Huxley 1984, 107.

38 Coldstream 1973, 107.
} 
nity colonies) that of Kythera is the only one, even in the later MM and LM period, that may be catalogued as a settlement community, meaning the appearance of settlers which occupy a foreign territory by force or by the use of diplomacy; this is recognisable in the archaeological material as a distinct break in or appearance of a material culture. ${ }^{39}$ This may be regarded as the first attested evidence for the strong influence of the Minoan culture in overseas areas. However, caution should be taken because it could simply be an influence of the Minoan material culture and not the actual presence of the EM people of Crete on Kyther. ${ }^{40}$ Until conclusive evidence for habitation or further information about the relationship between the two converging cultures is brought forward, the phenomenon of Kythera will be left unexplained.

\section{Conclusions}

The present study has shown that there is a general trend of moving towards the coast and nucleating in a coastal strip of varying size $(3-5 \mathrm{~km})$, depending on the phase in question. The settlements show a relative stability in terms of numbers and distribution over the Cretan topographical landscape. Further, they indicate strong regional interconnections, with relatively well definable associated areas of activity for each region, especially from those that were more intensively studied (e.g. east Crete), thus yielding a greater amount of information, and making the conclusions better anchored in the actual archaeological evidence. It has also been indicated that a massive influx of foreign populations does not occur on Crete; its demographic variables based on site distribution, and evolution tendencies rather represent an internal evolution of the island. The appearance in the EM culture of foreign archaeological materials does not imply the coming of a new population to Crete, but the nature of some non-moveable archaeological evidence would suggest a scenario described by Warren where a gradual infiltration of small numbers of individuals over a longer period of time would have contributed to the demographic and cultural pool of EBA Crete. ${ }^{41}$ The most likely interval of time for such a lengthy process would seem to be during the transition from EM I to EM II. In EM II there is an explosion of contact at an intra and inter-island level, which may be the result of the continuation of such connections on a much smaller scale during the previous period. By the time of EM III, the site distribution pattern indicates a well-established network of contacts and trade between different zones of Crete (based on distance from the coast, elevation and topographical location). Similar results were reached by other landscape studies, which focused on the EM settlement landscape, ${ }^{42}$ conclusions, which tie in well with those analysing the EBA funerary landscapes of Crete. ${ }^{43}$

The present study has shown the general evolution of the settlement distribution of EM Crete. Even if the reasons behind the process delimited in this present paper

\footnotetext{
${ }^{39}$ Branigan 1981, 26, 32; Branigan 1984, 49.

40 Branigan 1981, 33.

41 Warren 1973, 41.

${ }^{42}$ E.g. Stürmer 2005.

43 Vavouranakis 2007; Legarra Herrero 2009.
} 
are not always clear, they have a solid foundation, based on the collected site data and cross links with the cultural landscape of the EM period.

\section{Description of the EM sites and their location}

An extended descriptive catalogue will be provided in forthcoming wider research of EM cultural landscape. The purpose of the present catalogue is the enumeration of sites which have so far been surveyed, and which are not funerary in character, and to provide a general indication of their placement, as well as dating. Furthermore, it provides a full bibliography to every site mentioned.

1. Agasterouli, West Coast: EMIII (Hood 1965, 101).

2. Agios Phanourios 1, Vrokastro Area: EMII-EMIII (Hayden et alii 1992, 337; Hayden 2004, 63, Table 3.1).

3. Agios Phanourios 11, Vrokastro Area: EMII-EMIII (Hayden 2004, Table 3.1).

4. Agios Phanourios 7/9, Vrokastro Area: EMI-IIA (Hayden et alii 1992, 338; Hayden 2003, 374; Hayden 2004, 38, 63, Table 2.1, 3.1).

5. Alexenia, Lasithi Plain: EMI (Watrous 1982, 51-52).

6. Alykomouri, Kavousi Area: EMI (Pendlebury 1963, 34; Haggis 1996a, 380, 389; Betancourt 1999, 34).

7. Amygdaloi, South Foot Hills, Lasithi: EMIII (Hood et alii 1964, 82; Batten 1995, 18).

8. Aphendi Christos 3, Vrokastro Area: EMII-EMIII (Hayden et alii 1992, 337; Hayden 2004, Table 3.1).

9. Aphendi Christos 4, Vrokastro Area: EMI-EMIIA (Hayden et alii 1992, 337; Hayden 2004, 40, 65, Table 2.1, 3.1).

10. Aphendi Christos 5, Vrokastro Area: EMII-EMIII (Hayden et alii 1992, 337; Hayden 2004, Table 3.1).

11. Avgo, Kavousi Area: EMI-EMIII (Haggis 1996a, Fig. 4).

12. Ayia Photia caves, Siteia Bay, North-East Coast; EMI (Branigan 1988, 36).

13. Ayia Sophia, Topolia, Central West Crete: EMI (Hood 1965, 104-105).

14. Ayia Triada, West Mesara: EMII-EMIII (Droop 1913, 365; Pendlebury 1963, 92; Laviosa 1970, 407-415; 1973, 503-513).

15. Ayia Varvara, North Coast, Malia: EMII (Müller 1991, 554).

16. Ayios Yioryios 4, South-West Coast: EMII (Hood 1967, 50).

17. Boubouli, South Foot Hills, Lasithi: EMIII (Hood et alii 1964, 81-82; Batten 1995, 15-18).

18. Charakia, Lasithi Plain: EMI-EMIII (Pendlebury et alii 1936, 11; Watrous et alii 1993, 45).

19. Chrysokamino, Kavousi Area: EMI-EMIII (Haggis 1996a, Fig. 4; Betancourt 1999, 34; Betancourt et alii 1999, 343).

20. Chrysoskalitissa, West Coast: EMII-EMIII (Hood 1965, 101-102).

21. Debla, Chania Area: EMI-EMIIA (Greig, Warren 1974, 130-132; Warren et alii 1974, 299-302, 305-320, 340).

22. Diakymi, South Coast, West Crete: EMI (Nixon et alii 1989, 201-215; Nixon et alii 2000, site 3.09).

23. Drepani Akrotiri, North Coast, Malia: EMI (Nowicki 1999, 578).

24. E11, Ayiofarango Valley, South of Mesara: EMI-EMIII (Blackman, Branigan 1977, 41). 
25. E12, Ayiofarango Valley, South of Mesara: EMI-EMIII (Blackman, Branigan 1977, 41-43).

26. E13, Ayiofarango Valley, South of Mesara: EMII-EMIII (Blackman, Branigan 1977, 43).

27. E14, Ayiofarango Valley, South of Mesara: EMII-EMIII (Blackman, Branigan 1977, 43).

28. E18, Ayiofarango Valley, South of Mesara: EMI-III (Blackman, Branigan 1977, 44).

29. E20, Ayiofarango Valley, South of Mesara: EMII-EMIII (Blackman, Branigan 1977, 47).

30. E24-25, Ayiofarango Valley, South of Mesara: EMII-EMIII (Blackman, Branigan 1977, 49).

31. E4, Ayiofarango Valley, South of Mesara: EMII-EMIII (Blackman, Branigan 1977, 31, 71).

32. E5, Ayiofarango Valley, South of Mesara: EMI-EMII (Blackman, Branigan 1977, 31-32).

33. E6, Ayiofarango Valley, South of Mesara: EMII-EMIII (Blackman, Branigan 1977, 32-34).

34. Elias to Nisi, Vrokastro Area: EMI (Hayden et alii 1992, 338; Hayden 2003, 373-374; Hayden 2004, 36-38, Table 2.1).

35. Ephendi Christou, Lasithi Plain: EMII-EMIII (Watrous 1982, 60).

36. Fournou Korifi (Myrtos), South Coast, Hierapetra: EMII (Hood et alii 1964, 95-96; Warren 1969, 224-227; Warren 1972b, 1).

37. Galana Kharakia/Kavousi (Ano Viannos), South Foot Hills, Lasithi: EMIII (Hood et alii 1964, 83; Batten 1995, 27).

38. Gaze, Heraklion Area: EMI/EMIII (Pendlebury 1963, 56, 91).

39. Ginara 1:1, Vrokastro Area: EMII-EMIII (Hayden et alii 1992, 339; Hayden 2004, 65, Table 3.1).

40. Ginara 2A:1, Vrokastro Area: EMII-EMIII (Hayden et alii 1992, 339; Hayden 2004, 64, Table 3.1).

41. Ginara 2A:2, Vrokastro Area: EMI-EMII (Hayden et alii 1992, 339; Hayden 2003, 375; Hayden 2004, 39-40, 64-65, Table 2.1, 3.1).

42. Ginara 4, Vrokastro Area: EMI (Hayden 2004, 39-40, Table 2.1).

43. Gournia, North Coast, Mirabello Bay: EMI-EMIII (Pendlebury 1963, 78; Soles 1979, 150-151).

44. Ioannimiti 1, Vrokastro Area: EMI-EMIII (Hayden et alii 1992, 339; Hayden 2003, 373374; Hayden 2004, 36-38, 62-63, Table 2.1, 3.1).

45. Ioannimiti 10, Vrokastro Area: EMII-EMIII (Hayden 2004, 62-63, Table 3.1).

46. Ioannimiti 11, Vrokastro Area: EMI-EMIII (Hayden 2003, 373-374; Hayden 2004, 36-38, 62-63, Table 2.1, 3.1).

47. Ioannimiti 2, Vrokastro Area: EMII-EMIII (Hayden et alii 1992, 339; Hayden 2004, 62-63).

48. Ioannimiti 3, Vrokastro Area: EMI-EMIII (Hayden et alii 1992, 339; Hayden 2003, 373374; Hayden 2004, 36-38, 62-63, Table 2.1, 3.1).

49. Ioannimiti 5, Vrokastro Area: EMI-EMIII (Hayden 2003, 373-374; Hayden 2004, 36-38, 62-63, Table 2.1, 3.1).

50. Ioannimiti 6, Vrokastro Area: EMII-EMIII (Hayden 2004, 62-63, Table 3.1).

51. Ioannimiti 7, Vrokastro Area: EMI-EMIII (Hayden 2003, 373-374; Hayden 2004, 36-38, 62-63, Table 2.1, 3.1).

52. Ioannimiti 8, Vrokastro Area: EMII-EMIII (Hayden 2004, 62-63, Table 3.1).

53. Ioannimiti 9, Vrokastro Area: EMII-EMIII (Hayden 2004, 62-63, Table 3.1).

54. Istron river 2, Vrokastro Area: EMI-EMIII (Hayden et alii 1992, 340; Haggis 1996b, 656-675; Betancourt 1999, 35; Hayden 2003, 379-380; Hayden 2004, 38-39, 64, Table $2.1,3.1)$. 
55. Kalami 2, South Coast, Lasithi: EMI (Hood et alii 1964, 93).

56. Kalo Chorio 1, Vrokastro Area: EMIII (Hayden 2003, 340; Hayden 2004, 65, Table 3.1).

57. Kalo Chorio 5, Vrokastro Area: EMIIB-EMIII (Hayden 2003, 341; Hayden 2004, 65, Table 3.1).

58. Kalo Chorio 6, Vrokastro Area: EMI-EMII (Hayden et alii 1992, 341; Hayden 2003, 380; Hayden 2004, 40, Table 2.1).

59. Kalyvomouri, East Coast: EMI-EMIII (Nowicki 1999, 576).

60. Kamares, South Slopes, Ida: EMIII (Pendlebury 1963, 92; Faure 1965, 41).

61. Kambria, South Coast, West Crete: EMI (Nixon et alii 1988, 159-173).

62. Kanli Kastelli, Yuktas Area: EMII-EMIII (Evans 1928, 71; Pendlebury 1963, 60, 76, 91).

63. Karavi, Gavdhos, Libyan Sea: EMI (Pendlebury 1963, 76).

64. Kastelli, Chania: EMI-EMIII (Hood 1965, 100, 109).

65. Kastello (Khnondru), South Foot Hills, Lasithi: EMIII (Hood et alii 1964, 82; Batten 1995, 18-23).

66. Kastello, Milatos, North Coast, Malia: EMI (Pendlebury 1963, 56; Nowicki 1999, 578).

67. Kastellos (Sellia), South Coast, Ayios Vasilios: EMI (Hood, Warren 1966, 185; Nowicki 1999, 577).

68. Kastellos, Lasithi Plain: EMII-EMIII (Pendlebury et alii 1938, 7-56; Watrous 1982, 42-43).

69. Kastri (Keratokampou), South Coast, Lasithi: EMIII (Hood et alii 1964, 82-83; Batten 1995, 13-14).

70. Kastri, Xerokampos, East Coast: EMI (Nowicki 1999, 576).

71. Katharo, Lasithi Plain: EMII-EMIII (Watrous 1982, 49).

72. Kato Arniko 1, Vrokastro Area: EMII-EMIII (Hayden et alii 1992, 340; Hayden 2004, 66, Table 3.1).

73. Kato Arniko 2, Vrokastro Area: EMII-EMIII (Hayden et alii 1992, 340; Hayden 2004, 65, Table 3.1).

74. Kato Sarakina/Eleniko, Thersio, Central West Crete: EMI (Hood 1965, 109).

75. Katsoucheiroi, Lasithi Plain: EMI-EMII (Pendlebury et alii 1936, 12; Watrous 1982, 64).

76. Kavousi 2, Kavousi Area: EMI-EMIII (Haggis 1996a, 389-390, Fig. 4; Betancourt 1999, 35).

77. Kavousi 3, Kavousi Area: EMI-EMIII (Haggis 1996a, 389-390, Fig. 4; Betancourt 1999, 35).

78. Kavousi 4, Kavousi Area: EMI-EMIII (Haggis 1996a, 389-390, Fig. 4; Betancourt 1999, 35).

79. Kavousi 5, Kavousi Area: EMI-EMIII (Haggis 1996a, 389-390, Fig. 4; Betancourt 1999, 35).

80. Kefala, Finiakis, South Coast, Ayios Vasilios: EMI-EMII (Nowicki 1999, 577).

81. Kefalia, Spili, Ayios Vasilios Region: EMI-EMIII (Hood, Warren 1966, 174-175).

82. Kendromouri 1, Vrokastro Area: EMIII (Hayden et alii 1992, 341; Hayden 2004, 64, Table 3.1).

83. Kendromouri 1A, Vrokastro Area: EMIIB-EMIII (Hayden et alii 1992, 341; Hayden 2004, 64, Table 3.1).

84. Kendromouri 2, Vrokastro Area: EMII-EMIII (Hayden et alii 1992, 341; Hayden 2004, 64, Table 3.1).

85. Kendromouri 3, Vrokastro Area: EMI-EMII (Hayden et alii 1992, 341-342; Hayden 2003, 374; Hayden 2004, 64, Table 2.1, 3.1).

86. Kera Spiliotissa, Chania Area: EMI-EMIII (Hood 1965, 106). 
87. Keraton or "Vigla", South Coast, Lasithi: EMI (Hood et alii 1964, 84; Batten 1995, 9-10).

88. Kha Gorge, Kavousi Are: EMI-EMIII (Haggis 1996a, Fig. 4).

89. Khori (Amira), South Foot Hills, Lasithi: EMIII (Hood et alii 1964, 86).

90. Knossos, Heraklion Area: EMI-EMIII (Evans 1921, 56-126; Hood 1962, 92-98; Evans 1972, 115-128; Warren 1972a, 392-393; Branigan 1988, 42; Cadogan et alii 1993, 21-28; Wilson 1994, 23-44; Manteli, Evely 1995, 2, 4; Momigliano, Wilson 1996, 1-57; Day, Wilson 2002, 145-167).

91. Kommos, West Mesara: EMI (Evans 1928; Pendlebury 1963).

92. Kopranes 1, Vrokastro Area: EMII-EMIII (Hayden et alii 1992, 342; Hayden 2004, 64, Table 3.1).

93. Kopranes 10, Vrokastro Area: EMI (Hayden 2004, 39, Table 2.1).

94. Kopranes 2,3, Vrokastro Area: EMI (Hayden et alii 1992, 342; Hayden 2003, 380; Hayden 2004, 40, Table 2.1).

95. Kopranes 2/4, Vrokastro Area: EMII-EMIII (Hayden et alii 1992, 342; Hayden 2004, 64, Table 3.1).

96. Kopranes 6, Vrokastro Area: EMI-EMIII (Hayden et alii 1992, 342; Betancourt 1999, 36; Hayden 2004, 39, Table 2.1, 3.1).

97. Korakoskidhaki, South Coast, West Crete: EMI-EMIII (Hood 1965, 113).

98. Korfi tou Koukkoyiani (Ellenes, Amariou), Amari Plain, West of Ida: EMI (Karo 1932, 177; Dunabin 1947, 188; Pendlebury 1963, 55; Hood et alii 1964, 73; Branigan 1988, 39).

99. Koumaro, Akrotiri Peninsula: EMI (Branigan 1988, 36).

100. Lakka tou Dragataki, Lasithi Plain: EMI (Watrous 1982, 58).

101. Lakoudia, Vraskas, South Coast, Sfakia: EMIA (Nowicki 1999, 577-578).

102. Langos, West Mesara: EMII-EMIII (Pendlebury 1963, 77).

103. Lera, Akrotiri Peninsula: EMI-EMIII (Hood 1965, 110).

104. Listis, South Coast, Lasithi: EMII-EMIII (Batten 1995, 10).

105. Malaxa, Chania Area: EMI (Hood 1965, 109).

106. Malia, North Coast, Malia: EMIB-EMIII (Chapouthier, Demargne 1962, 13-22, 41-43; Pendlebury 1963, 56, 76, 91; van Effenterre, van Effenterre 1969, 13-21; van Effenterre 1980, 81-94; Poursat et alii 1984, 880-891; Stürmer 1987, 41-43; Poursat et alii 1989, 762-785; Pelon et alii 1991, 726-746).

107. Maryiou, South Coast, Ayios Vasilios: EMII-EMIII (Hood, Warren 1966, 182).

108. Melidhoni, North Foot Hills, Ida: EMI-EMIII (Hood et alii 1964, 58-59; Branigan 1988, 64).

109. Mesa Kephala 1, Vrokastro Area: EMII-EMIII (Hayden et alii 1992, 343; Hayden 2004, 67, Table 3.1).

110. Miamou, Asteroussia Mountains: EMI (Taramelli 1897, 287-312; Pendlebury 1963, 57; Blackman, Branigan 1977, 67; Branigan 1988, 36, 40).

111. Mochlos, North Coast, Mirabello Bay: EMI-EMIII (Seager 1909, 273-303; Pendlebury 1963, 77, 92; Branigan 1988, 39; Soles, Davaras 1995, 312-313; Soles, Davaras 1996, 178-180; Betancourt 1999, 33, 35).

112. Mokhos, Malia Area: EMII-EMIII (Pendlebury 1963, 76).

113. Moni Vidiani, Lasithi Plain: EMI (Watrous 1982, 38).

114. Mouri, Lasithi Plain: EMI (Watrous 1982, 65).

115. MoW1, Ayiofarango Valley, South of Mesara: EMII-EMIII (Blackman, Branigan 1977, 63).

116. MoW2, Ayiofarango Valley, South of Mesara: EMII-EMIII (Blackman, Branigan 1977, $63-64,71)$. 
117. Nisi Pandeleimon, Vrokastro Area: EMI (Hayden et alii 1992, 343; Hayden 2003, 374; Hayden 2004, 36-37, Table 2.1).

118. Oleros 8, Vrokastro Area: EMI-EMII (Hayden 2004, 41, 67, Table 2.1, 3.1).

119. Palaikastro, East Coast: EMII-EMIII (Pendlebury 1963, 78; Driessen, MacGillivray 1990, 398-399).

120. Patrikies, West Mesara: EMIII (Bonacasa 1968, 7-54).

121. Pesa 3, Vrokastro Area: EMII-EMIII (Hayden et alii 1992, 345; Hayden 2004, 65, Table 3.1).

122. Petras, East Crete, Siteia: EMI-EMIII (Pendlebury 1963, 59; French 1990, 76; Tomlinson 1995, 69-70; Blackman 1999, 121-122).

123. Phaistos, West Mesara: EMI-EMIII (Levi 1958, 167-182, 290-291, 296-297; Vagnetti 1973, 12-15, 27-30, 33-35, 38-40; Levi 1976, 36, 57, 63, 74, 78, 83, 96, 108, 137, 156, 160, 161, 179-181, 230, 275-276, 278, 288-294, 299, 314, 316, 333, 353-354, 358, 370, 409, 414-416, 426, 442, 464, 468, 494, 483, 526, 528, 552-553, 558, 598, 604, 616; Branigan 1988, 41; Benzi 2001, 121-155).

124. Phrouzi 1, Vrokastro Area: EMI-EMIII (Hayden et alii 1992, 345; Hayden 2003, 374; Hayden 2004, 38, 64, Table 2.1, 3.1).

125. Phrouzi 2, Vrokastro Area: EMIII (Hayden et alii 1992, 343; Hayden 2004, 64, Table 3.1).

126. Pirovolos 1, Vrokastro Area: EMI-EMIII (Hayden et alii 1992, 346; Hayden 2004, Table 3.1).

127. Plakaki Kriou, South - West Coast: EMII-EMIII (Hood 1967, 51-52).

128. Plakamoura, Lasithi Plain: EMI (Watrous 1982, 46).

129. Platanomouri, Lasithi Plain: EMI (Watrous 1982, 48-49).

130. Plativola, Central West Crete: EMI (Hood 1965, 111).

131. Poros and Katsambas, Heraklion Area: EMI-EMIII (Blackman 1999, 117-118; Day, Wilson 2002, 153).

132. Poros, Lasithi, Lasithi Plain: EMI (Watrous 1982, 52).

133. Potamoi 1, Vrokastro Area: EMI-EMII (Hayden et alii 1992; Hayden 2003, 2004).

134. Praisos, Ziros Area: EMI (Tomlinson 1995).

135. Prina 1, Vrokastro Area: EMI-EMII (Hayden et alii 1992, 344; Hayden 2003, 382; Hayden 2004, 41, 66, Table 2.1, 3.1).

136. Prina 2, Vrokastro Area: EMII-EMIII (Hayden et alii 1992, 342; Hayden 2004, Table 3.1).

137. Prina 3:1, Vrokastro Area: EMI-EMIII (Hayden et alii 1992, 344; Hayden 2003, 382; Hayden 2004, 41, 67, Table 2.1, 3.1).

138. Priniatikos Pyrgos 1, Vrokastro Area: EMII-EMIII (Pendlebury 1963, 78; Branigan 1988, 43; Hayden et alii 1992, 344; Hayden 2004, 62-63, 71, Table 3.1).

139. Prophitis Ilias 1, Vrokastro Area: EMI-EMIII (Hayden et alii 1992, 343; Hayden 2003, 379; Hayden 2004, 40, 65, table 2.1, 3.1).

140. Prophitis Ilias 5, Vrokastro Area: EMI (Hayden et alii 1992, 344; Hayden 2004, Table $2.1,3.1)$

141. Psathi, Galatas, Chania Area: EMII-EMIII (Hood 1965, 108).

142. Pseira, North Coast, Mirabello Bay: EMI-EMIII (Pendlebury 1963, 92; Betancourt 1999, 33, 35, 39).

143. Psychro, Lasithi Plain: EMI (Watrous 1982, 61-62, Map 4).

144. Pyrgos (Khondru), South Foot Hills, Lasithi: EMIII (Batten 1995, 23-24).

145. Pyrgos (Myrtos), South Coast, Hierapetra: EMII-EMIII (Hood et alii 1964, 93-94; Cadogan 1978, 70-74). 
146. Pyrgos 2, Vrokastro Area: EMI-EMIII (Hayden et alii 1992, 345; Hayden 2004, 40, 65, Table 2.1, 3.1).

147. Pyrgos river valley site, South Foot Hills, Lasithi: EMII-EMIII (Batten 1995, 24).

148. Pyrgos, Prophitis Ilias, North Coast, Malia: EMI-EMII (Pendlebury 1963, 56, 76; Nowicki 1999, 578).

149. Riza, South Coast, West Crete: EMI (Nixon et alii 1988, 159-173).

150. Rouphas, North - East Mesara: EMI (Evans 1928, 80; Pendlebury 1963, 57).

151. Roussanos, Lasithi Plain: EMI (Pendlebury et alii 1936, 12; Watrous 1982, 65).

152. Roussocharakas, South Coast, Hierapetra: EMI (Nowicki 1999, 576).

153. SC 5, South Coast, Mesara: EMI-EMII (Blackman, Branigan 1975, 22-24, 34).

154. Schinauria Koriphi 8, Vrokastro Area: EMI-EMIII (Hayden et alii 1992, 347; Hayden 2003, 383; Hayden 2004, 41, 67, Table 2.1, 3.1).

155. Schinauria Koriphi 9, Vrokastro Area: EMIII (Hayden et alii 1992, 347; Hayden 2004, 67, Table 3.1).

156. Site 2 (Listis), South Coast, Lasithi: EMII-EMIII (Batten 1995, 11).

157. Skallopoula, Lasithi Plain: EMI (Watrous 1982, 45).

158. Skourocharako, South Coast, Lasithi: EMIII (Batten 1995, 12-13).

159. Sopatika (Apodhoulou), South-West Foot Hills, Ida: EMI-EMIII (Dunabin 1947, 188; Hood et alii 1964, 78).

160. Sphoungaras, North Coast, Mirabello Bay: EMI (Pendlebury 1963, 59, 78; Branigan 1988, 41; Betancourt 1999, 33, 36).

161. Spilia 1A, Vrokastro Area: EMII-EMIII (Hayden et alii 1992, 347; Hayden 2004, 65, Table 3.1).

162. sta Khalasmena, Central West Crete: EMI-EMIII (Hood 1965, 112).

163. Stavromyti, Yuktas Area: EMI/EMIII (Evans 1928, 68; Pendlebury 1963, 56, 91).

164. Ta Grivila (Perama), North Foot Hills, Ida: EMI (Hood et alii 1964, 56-58).

165. Tartari (Arvi), South Coast, Lasithi: EMII-EMIII (Hood et alii 1964, 91-92).

166. Troulos, South Coast, West Crete: EMI (Nixon et alii 1989, 201-215; Nixon et alii 2000, site 4.44).

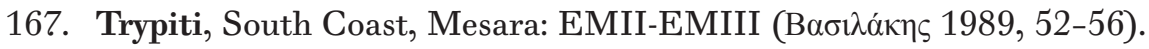

168. Tylissos, Heraklion Area: EMIII (Droop 1913, 365-366; Pendlebury 1963, 80, 92).

169. Tzamachi 10, Vrokastro Area: EMI-EMIII (Hayden 2004, 64, Table 2.1, 3.1).

170. Vasiliki, Hierapetra Isthmus: EMII-EMIII (Seager 1907, 111-129; Zwís 1976, 25-120).

171. Vasilikou Ridge, Lasithi Plain: EMI (Watrous 1982, 52).

172. Virani Episkopi (site $2.3 \mathrm{~km} \mathrm{E),} \mathrm{North} \mathrm{Coast,} \mathrm{Ida:} \mathrm{EMI-EMIII} \mathrm{(Hood} \mathrm{et} \mathrm{alii} \mathrm{1964,} \mathrm{59).}$

173. Voithodos, Ziros Area: EMI (Faure 1965, 30).

174. Vrionisi 1, Vrokastro Area: EMI-EMIII (Hayden et alii 1992, 349; Hayden 2003, 383; Hayden 2004, 37, 63, Tabel 2.1, 3.1).

175. Vrionisi 2, Vrokastro Area: EMI-EMIII (Hayden et alii 1992, 349; Hayden 2003, 383; Hayden 2004, 38, 63, Tabel 2.1, 3.1).

176. Vrokastro 1, Vrokastro Area: EMI (Hayden et alii 1992, 348; Hayden 2004, 66, Table 2.1, 3.1).

177. Vrokastro 7, Vrokastro Area: EMII-EMIII (Hayden et alii 1992, 348; Hayden 2004, 66, Table 3.1).

178. W11B, Ayiofarango Valley, South of Mesara: EMI-EMIII (Blackman, Branigan 1977, 61).

179. W7, Ayiofarango Valley, South of Mesara: EMII-EMIII (Blackman, Branigan 1977, 58).

180. Zakros, East Coast: EMI (Branigan 1988, 36). 


\section{Remarks}

Some sites were identified through intensive survey in different regions of Crete and only a preliminary report has been published about them, without a detailed description of sites and material found in their area. Further publications will help create a better profile of EM settlement distribution patterns.

The Gournia Survey produced evidence for 155 sites. The earliest proof of habitation of this area is of Final Neolithic/EM I date. The sites expand during the EM I period and thrive in EM II, showing remarkable trade contacts. In the EM IIB and EM III periods, the number of sites is reduced, especially in the later period, and a retreat to more defensible, higher ground is noticed. ${ }^{44}$

The Ayios Vasilios Valley Survey in western Crete identified 15 EM sites. Preliminary analysis of pottery suggests that all represent an earlier EM stage (Final Neolithic/EM I) rather than a later one; until now only one EM II sherd has been identified. The lack of plentiful EM II or later EM evidence would suggest a concentration of activity on the coast, and as a result, later EM scatters would be rare to find in a valley bordered on all sides by relatively high hills and mountains. ${ }^{45}$

The Sphakia Survey, ${ }^{46}$ conducted in western Crete, discovered many new EM sites and confirmed the existence of those already identified. It showed that mostly the area between Anopolis and Aradena was settled, although three Final Neolithic/EM I sites were also identified in the high-lying Madhares plateau. ${ }^{47}$

Final publication of these surveys would enable the selection of EM settlements and activity areas based on their chronological distribution within this broad phase and permit us to test or adjust the established conclusions based on the available present data.

\section{Bibliography}

96 $6^{\text {th }}$ MAIA 1995

Batten 1995

Benzi 2001

Betancourt 1999 $96^{\text {th }}$ MAIA, The $96^{\text {th }}$ annual meeting of the Archaeological Institute of America, AJA, 99, 1995, 295-301, 303-358.

V. Batten, EM-MM settlements in the area of Keratokampos and Chondros, southern Crete, AEA, 2, 1995, 7-28.

M. Benzi, Il periodo prepalaziale a Festòs: una ricognizione preliminare. In: I cento Anni dello scavo di Festòs. Giornate Lincee, (Roma, 13-14 dicembre 2000), Atti dei Convegni Lincei 173, Roma 2001, 121-155.

P. P. Betancourt, What is Minoan? FN/EM I in the gulf of Mirabello region. In: P. P. Betancourt, V. Karageorghis, R. Laffineur, W.-D. Niemeier (eds.), MELETEMATA: Studies in Aegean Archaeology Presented to Malcolm H. Wiener as He Enters His $65^{\text {th }}$ Year Aegaeum, 20, Liège 1999, 33-39.

\footnotetext{
${ }^{44} 96^{\text {th }}$ MAIA $1995,313$.

45 Moody et alii 2000, 365.

46 Nixon et alii 1988; Nixon et alii 1989; Nixon et alii 1990; Nixon et alii 2000.

47 Nixon et alii 1989; Nixon et alii 1990.
} 
Betancourt 2003

Betancourt et alii 1999

Blackman 1999

Blackman, Branigan 1975

Blackman, Branigan 1977

Bonacasa 1968

Branigan 1981

Branigan 1984

Branigan 1988

Branigan 1991

Branigan et alii 1998

Cadogan 1978

Cadogan et alii 1993

Chapouthier, Demargne 1962

Coldstream 1973

Coldstream, Huxley 1984
P. P. Betancourt, Interpreting ceramic pectrography: the special product model, a new model for pottery distribution in the Early Minoan period. In: K. P. Foster, R. Laffineur (eds.), METRON. Measuring the Aegean Bronze Age; proceedings of the $9^{\text {th }}$ International Aegean Conference / $9^{e}$ Rencontre Égéenne Internationale, New Haven, Yale University, 18-21 April 2002, Aegaeum 24, Liège 2003, 117-121.

P. P. Betancourt, J. D. Muhly, W. R. Farrand, C. Stearns, L. Onyshkevych, W. B. Hafford, D. Evely, Research and excavation at Chrysokamino, Crete 1995-1998, Hesperia, 68, 1999, 343-370.

D. J. Blackman, Arcaheology in Greece, AR, 45, 1999, 1-124, 192.

D. J. Blackman, K. Branigan, An archaeological survey on the south coast of Crete, between Ayiofarango and Chrisostomos, ABSA, 70, 1975, 17-36.

D. J. Blackman, K. Branigan, An archaeological survey of the lower catchment of the Ayiofarango valley, ABSA, 72, 1977, 13-84.

N. Bonacasa, Patrikies - una stazione medio-minoica fra Haghia Triada e Festos, ASAA, 45-46, 1968, 7-54.

K. Branigan, Minoan colonialism, ABSA, 76, 1981, 23-33.

K. Branigan, Minoan community colonies in the Aegean? In: R. Hägg, N. Marinatos (eds.), The Minoan thalassocracy: myth and reality, Stockholm 1984, 49-53.

K. Branigan, Pre-Palatial: The foundations of Palatial Crete. A survey of Crete in the Early Bronze Age, Amsterdam 1988.

K. Branigan, Mochlos - An Early Aegean "Gateway Community"? In: R. Laffineur, L. Basch (eds.), THALASSA. L'egée prèhistorique et la mer; actes de la 3. Rencontre Égéenne Internationale de l'Université de Liège, Station de Recherches Sous-marines et Océanographiques (StaReSO), Calvi, Corse (23-25 avril 1990), Aegaeum 7, Liège 1991, 97-105.

K. Branigan, T. Carter, P. O'Connor, Prehistoric and early historic settlement in the Ziors region, eastern Crete, ABSA, 93, 1998, 23-90.

G. Cadogan, Pyrgos, Crete, 1970-77, AR, 24, 1978, 70-84.

G. Cadogan, P. M. Day, C. F. MacDonald, J. A. MacGillivray, N. Momigliano, T. M. Whitelaw, D. E. Wilson, Early Minoan and Middle Minoan pottery groups at Knossos, ABSA, 88, 1993, 21-28.

F. Chapouthier, P. Demargne, Fouilles exécutées à Mallia IV: Exploration du palais, bordures méridionale et recherches complémentaires (1929-1935 et 1946-1960), Études Crétoises 12, Paris 1962.

J. N. Coldstream, Kythera: the change from Early Helladic to Early Cycladic. In: R. A. Crossland, A. Birchall (eds.), Bronze Age migrations in the Aegean. Archaeological and linguistic problems in Greek prehistory. Proceedings of the First International Colloquium on Aegean Prehistory, Sheffield, organized by the British Association for Mycenaean Studies and the Departments of Greek and Ancient History of the University of Sheffield, London 1973, 33-36.

J. N. Coldstream, G. L. Huxley, The Minoans of Kythera. In: R. Hägg, N. Marinatos (eds.), The Minoan thalassocracy: myth and reality, Stockholm 1984, 107-112. 
Cosmopoulos 1995

Davaras, Betancourt 2004

Day, Wilson 2002

Driessen, MacGillivray 1990

Droop 1913

Dunabin 1947

Evans 1906

Evans 1921

Evans 1928

Evans 1972

Faure 1965

French 1990

Greig, Warren 1974

Haggis 1996a

Haggis 1996b

Haggis, Mook 1993

Halstead 1977

Hayden et alii 1992

Hayden 2003
M. B. Cosmopoulos, Social and political organization in the Early Bronze 2 Aegean. In: R. Laffineur, W.-D. Niemeier (eds.), POLITEIA. Society and state in the Aegean Bronze Age; proceedings of the 5th International Aegean Conference/5e Rencontre Égéenne Internationale, University of Heidelberg, Archäologisches Institut, 10-13 April 1994, Aegaeum 12, Liège 1995, 23-32.

C. Davaras, P. P. Betancourt, The Haghia Photia cemetery I. The tombs groups and architecture, Prehistory Monographs 14, Philadelphia 2004 .

P. M. Day, D. E. Wilson, Landscapes of memory, craft and power in Prepalatial and Protopalatial Knossos. In: Y. Hamilakis (ed.), Labyrinth revisited: Rethinking 'Minoan' archaeology, Oxford 2002, 143-166.

J. M. Driessen, J. A. MacGillivray, Minoan settlement at Palaikastro. In: P. Darcque, R. Treuil (eds.), L'habitat égéen préhistorique, Bulletin de Correspondance Hellénique Supplément, 19, Paris 1990, 395-412.

J. P. Droop, Archaeology in Greece (1912-1913), JHS, 33, 1913, 361-368.

T. J. Dunabin, Antiquities of Amari, ABSA, 42, 1947, 184-194.

A. J. Evans, Essai de classification des époques de la civilisation minoenne: résumé d'un discours fait au Congrès d'Archéologie à Athènes, London 1906.

A. J. Evans, The palace of Minos at Knossos I. The Neolithic and Early and Middle Minoan Ages, London 1921.

A. J. Evans, The palace of Minos at Knossos II. Part 1. Fresh lights on origins and external relations the restoration in town and palace after seismic catastrophe towards close of M. M. III and the beginnings of the New Era, London 1928.

J. D. Evans, The Early Minoan occupation of Knossos: A note on some new evidence, AS, 22, 1972, 115-128.

P. Faure, Recherches sur le peuplement du montagne en Crète. Sites, cavernes et cultes, $\mathrm{BCH}, 89,1965,27-63$.

E. B. French, Archaeology in Greece 1989-1990, AR, 36, 1990, 2-82.

J. R. A. Greig, P. M. Warren, Early Bronze Age agriculture in western Crete, Antiquity, 48, 1974, 130-132.

D. C. Haggis, Archaeological survey at Kavousi, east Crete: Preliminary report, Hesperia, 65, 1996, 373-432.

D. C. Haggis, Excavations at Kalo Chorio, east Crete, AJA, 100, 1996, 656-675.

D. C. Haggis, M. S. Mook, The Kavousi coarse wares: A Bronze Age chronology for survey in the Mirabello area, east Crete, AJA, 97, 1993, 265-293.

P. Halstead, The Bronze Age demography of Crete and Greece - A note, ABSA, 72, 1977, 107-111.

B. Hayden, J. Moody, O. Rackham, The Vrokastro survey project, 1986-1989: Research design and preliminary results, Hesperia, 61, 1992, 293-353.

B. J. Hayden, Final Neolithic - Early Minoan I/IIA settlement in the Vrokastro area, eastern Crete, AJA, 107, 2003, 363-412. 
Hayden 2004

Hood 1962

Hood 1965

Hood 1967

Hood, Warren 1966

Hood et alii 1964

Karo 1932

Laviosa 1970

Laviosa 1973

Legarra Herrero 2009

Levi 1958

Levi 1976

Manning 1995

Manteli, Evely 1995

Momigliano, Wilson 1996

Moody et alii 2000

Moody, Rackham 2001

Müller 1991

Nixon et alii 1988

Nixon et alii 1989

Nixon et alii 1990
B. J. Hayden, Reports on the Vrokastro area, eastern Crete. Vol. 2: The settlement history of the Vrokastro area and related studies, University Museum Monograph 119, Philadelphia 2004.

M. S. F. Hood, Stratigraphic excavations at Knossos, 1957-61, K $\rho$ X

M. S. F. Hood, Minoan sites in the far west of Crete, ABSA, 60, 1965, 99-113.

M. S. F. Hood, Some ancient sites in south-west Crete, ABSA, 62, 1967, 47-56.

M. S. F. Hood, P. Warren, Ancient sites in the province of Ayios Vasilios, Crete, ABSA, 61, 1966, 163-191.

S. Hood, P. Warren, G. Cadogan, Travels in Crete, 1962, ABSA, 59, 1964, 50-59.

G. Karo, Archäologische Funde von Sommer 1931 bis Mai 1932. Griechenland und Dodekanes, AA, 1932, 103-182.

C. Laviosa, Saggi di scavo ad Haghia Triadha, ASAA, 31-32, 1970, 407-415.

C. Laviosa, L'abitato prepalaziale di Aghia Triadha, ASAA, 50-51, 1973, 503-513.

B. Legarra Herrero, The Minoan fallacy: cultural diversity and mortuary behaviour on Crete at the beginning of the Bronze Age, OJA, 28, 2009, 29-57.

D. Levi, L'archivio di cretule a Festòs, ASAA, 19-20, 1958, 7-192.

D. Levi, Festòs e la civilta minoica, Incunabula Graeca 60, Roma 1976.

S. W. Manning, The absolute chronology of the Aegean Early Bronze Age: archaeology, radiocarbon, and history: archaeology, radiocarbon and history, Monographs in Mediterranean Archaeology, 1, Sheffield 1995.

K. Manteli, D. Evely, The Neolithic levels from the Throne Room system, Knossos, ABSA, 90, 1995, 1-16.

N. Momigliano, D. E. Wilson, Knossos 1993: Excavations outside the south front of the palace, ABSA, 91, 1996, 1-57.

J. Moody, A. Peatfield, S. Markoulaki, Report from the Aghios Vasilios valley survey. Pepragmena tou H'Diethnous Kretologikou Synedriou, Vol. A2, Heraklion 2000, 359-367.

J. Moody, O. Rackham, Die Insel Kreta - Landschaft, Natur und Umwelt. In: H. Siebenmorgen (ed.), Im Labyrinth des Minos. Kreta die erste europäische Hochkultur, München 2001, 29-40.

$\mathrm{S}$. Müller, Routes minoennes en relation avec le site de Malia, $\mathrm{BCH}$, 115, 1991, 545-560.

L. Nixon, J. Moody, O. Rackham, Archaeological survey in Sphakia, Crete, EMC/CV, 32, 1988, 159-173.

L. Nixon, J. Moody, S. Price, O. Rackham, Archaeological survey in Sphakia, Crete, EMC/CV, 33, 1989, 201-215.

L. Nixon, J. Moody, V. Niniou-Kindeli, S. Price, O. Rackham, Archaeological survey in Sphakia, Crete, EMC/CV, 34, 1990, 213-230. 
Nixon et alii 2000

Nowicki 1999

Pelon et alii 1991

Pendlebury et alii 1936

Pendlebury et alii 1938

Pendlebury 1963

Poursat et alii 1984

Poursat et alii 1989

Pullen 1992

Seager 1907

Seager 1909

Soles 1979

Soles, Davaras 1995

Soles, Davaras 1996

Stürmer 1987

Stürmer 2005

Taramelli 1897

Tomlinson 1995

Tsipopoulou 1989

Vagnetti 1973

van Effenterre 1980
L. Nixon, J. Moody, S. Price, O. Rackham. The Sphakia survey, Internet edition 2000. Available from http://sphakia.classics.ox.ac. uk/project.html.

K. Nowicki, Final Neolithic refugees or Early Bronze Age newcomers? The problem of defensible sites in Crete in the late fourth millennium B.C. In: P. P. Betancourt, V. Karageorghis, R. Laffineur, W.-D. Niemeier (eds.), MELETEMATA. Studies in Aegean archaeology presented to Malcolm H. Wiener as he enters his $65^{\text {th }}$ year, Aegeaum, 20, Univ. de Liège, Histoire de l'Art et Archéologie de la Grèce Antique 1999, Liège 1999, 575-581.

O. Pelon, A. Farnoux, J. M. Driessen, S. Müller, Malia, BCH, 115, 1991, 726-746.

H. Pendlebury, J. D. S. Pendlebury, M. B. Money-Coutts, Excavation in the plain of Lasithi I. The cave of Trapeza, ABSA, 36, 1936, 5-131.

H. W. Pendlebury, J. D. S. Pendlebury, M. B. Money-Coutts, Excavations $n$ the plain of Lasithi II, ABSA, 38, 1938, 1-56.

J. D. S. Pendlebury, The archaeology of Crete, New York 1963.

J.-C. Poursat, O. Pelon, C. Baurain, P. Darcque, C. Verlinden, Malia, BCH, 108, 1984, 880-891.

J.-C. Poursat, A. Farnoux, S. Müller, O. Pelon, Malia, BCH, 113, 1989, 762-785.

D. J. Pullen, Ox and plow in the Early Bronze Age Aegean, AJA, 96, 1992, 45-54.

B. Seager, Report of excavations at Vasilike, Crete, in 1906, Transactions Philadelphia, 2, 1907, 111-132.

R. B. Seager, Excavations on the island of Mochlos, Crete, in 1908, AJA, 13, 1909, 273-303.

J. S. Soles, The early Gournia town, AJA, 83, 1979, 149-167.

J. S. Soles, C. Davaras, 1994 excavations at Mochlos, Crete, AJA, 99, 1995, 312-313.

J. S. Soles, C. Davaras, Excavations at Mochlos, 1992-1993, Hesperia, 65, 1996, 175-230.

V. Stürmer, Ein Gründungsdeposit im Palast von Malia. In: W. Schering (ed.), Referate vom Kolloquium zur Ägäischen Vorgeschichte IX, Mannheim 1987, 41-43.

V. Stürmer, Siedlung, Stadt und Palast. Zur Entstehung der minoischen >Stadt< im 3. Jt. v.Chr. In: H. Falk (ed.), Wege zur Stadt. Entwicklung und Formen urbanen Lebens in der alten Welt, Vergleichende Studien zu Antike und Orient, 2, Bremen 2005, 60-81. A. Taramelli, Cretan expedition VIII. The prehistoric grotto at Miamou, AJA, 1, 1897, 287-312.

R. A. Tomlinson, Archaeology in Greece 1994-1995, AR, 41, 1995, 1-74.

M. Tsipopoulou, Archaeological Survey at Aghia Photia, Siteia, Partille 1989.

L. Vagnetti, L'insediamento neolitico di Festòs, ASAA, 50/51, 1973, 7-138.

H. van Effenterre, Le palais de Mallia et la cité minoenne. Étude de synthèse, Incunabula Graeca 76, Rome 1980. 
van Effenterre, van Effenterre 1969

Vavouranakis 2007

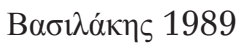

Warren 1969

Warren 1972a

Warren 1972b

Warren 1973

Warren, Hankey 1989

Warren et alii 1974

Watrous 1982

Watrous et alii 1993

Wilson 1994

Wilson, Day 1994

Zڤท́s 1976
H. van Effenterre, M. van Effenterre, Fouilles exécutées à Mallia. Le centre politique I. L'Agora (1960-66), Études Crétoises XVII, Paris 1969.

G. Vavouranakis, Funerary landscapes east of Lasithi, Crete, in the Bronze Age, BAR 1606, Oxford 2007.

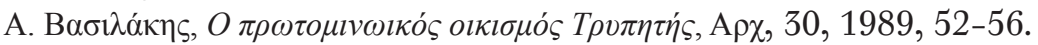

P. M. Warren, An Early Bronze Age potter's workshop in Crete, Antiquity 43, 1969, 224-227.

P. M. Warren, Knossos and the Greek mainland in the Third Millennium B.C., AAA, 1972, 392-398.

P. M. Warren, Myrtos. An Early Bronze Age settlement in Crete, Oxford 1972.

P. M. Warren, Crete, 3000-1400 B.C.: Immigration and the archaeological evidence. In: R. A. Crossland, A. Birchall (eds.), Bronze Age migrations in the Aegean. Archaeological and linguistic problems in Greek prehistory. Proceedings of the First International Colloquium on Aegean Prehistory, Sheffield, organized by the British Association for Mycenaean Studies and the Departments of Greek and Ancient History of the University of Sheffield, London 1973, 41-47.

P. M. Warren, V. Hankey, Aegean Bronze Age chronology, Bristol 1989.

P. M. Warren, Y. G. Tzedhakis, J. R. A. Greig, Debla, an Early Minoan settlement in western Crete, ABSA, 69, 1974, 299-342.

L. V. Watrous, Lasithi. A history of settlement on a highland plain in Crete, Hesperia Suppl. 18, Princeton 1982.

L. V. Watrous, D. Xatzi-Vallianou, K. Pope, N. Mourtzas, J. Shay, C. T. Shay, J. Bennet, D. Tsoungarakis, E. Angelomati-Tsoungarakis, C. Vallianos, H. Blitzer, A survey of the Western Mesara plain in Crete: Preliminary report of the 1984, 1986, and 1987 field seasons, Hesperia 62, 1993, 191-248.

D. E. Wilson, Knossos before the Palaces: An Overview of the Early Bronze Age (EM I - EM III). In: D. Evely, H. Hughes-Brock, N. Momigliano (eds.), Knossos: A Labyrinth of History, Oxford 1994, 23-44.

D. E. Wilson, P. M. Day, Ceramic regionalism in Prepalatial central Crete: The Mesara imports from EM IB to EM IIA Knossos, ABSA, 89, 1994, 1-87.

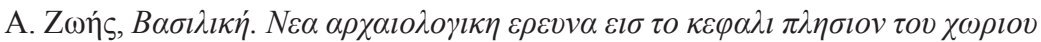

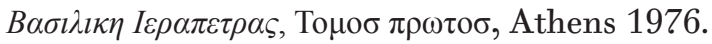

Tibor-Tamás Daróczi csibike3@yahoo.com 


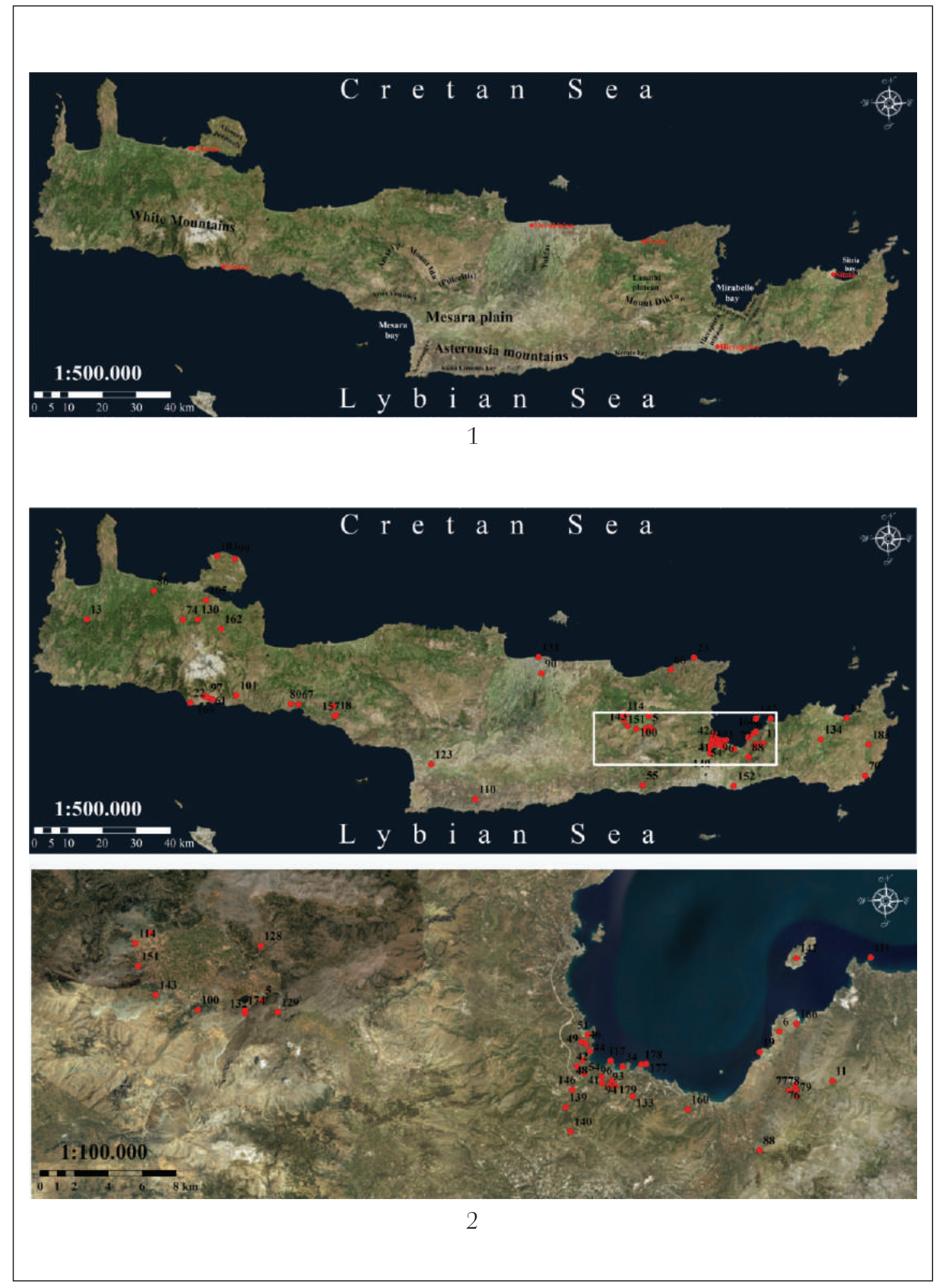

Pl. I. 1. Topography of Crete; 2. Final Neolithic settlements of Crete. 

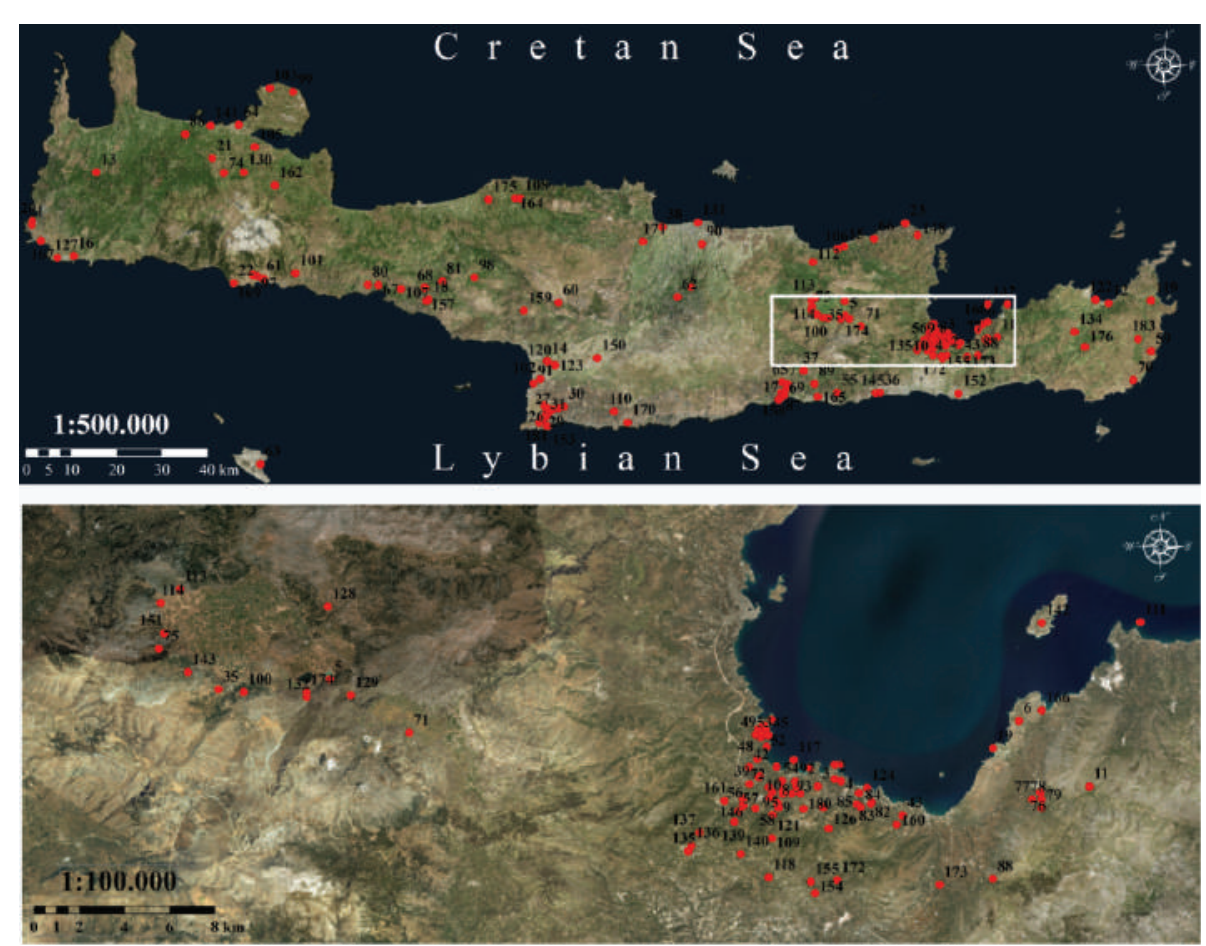
1
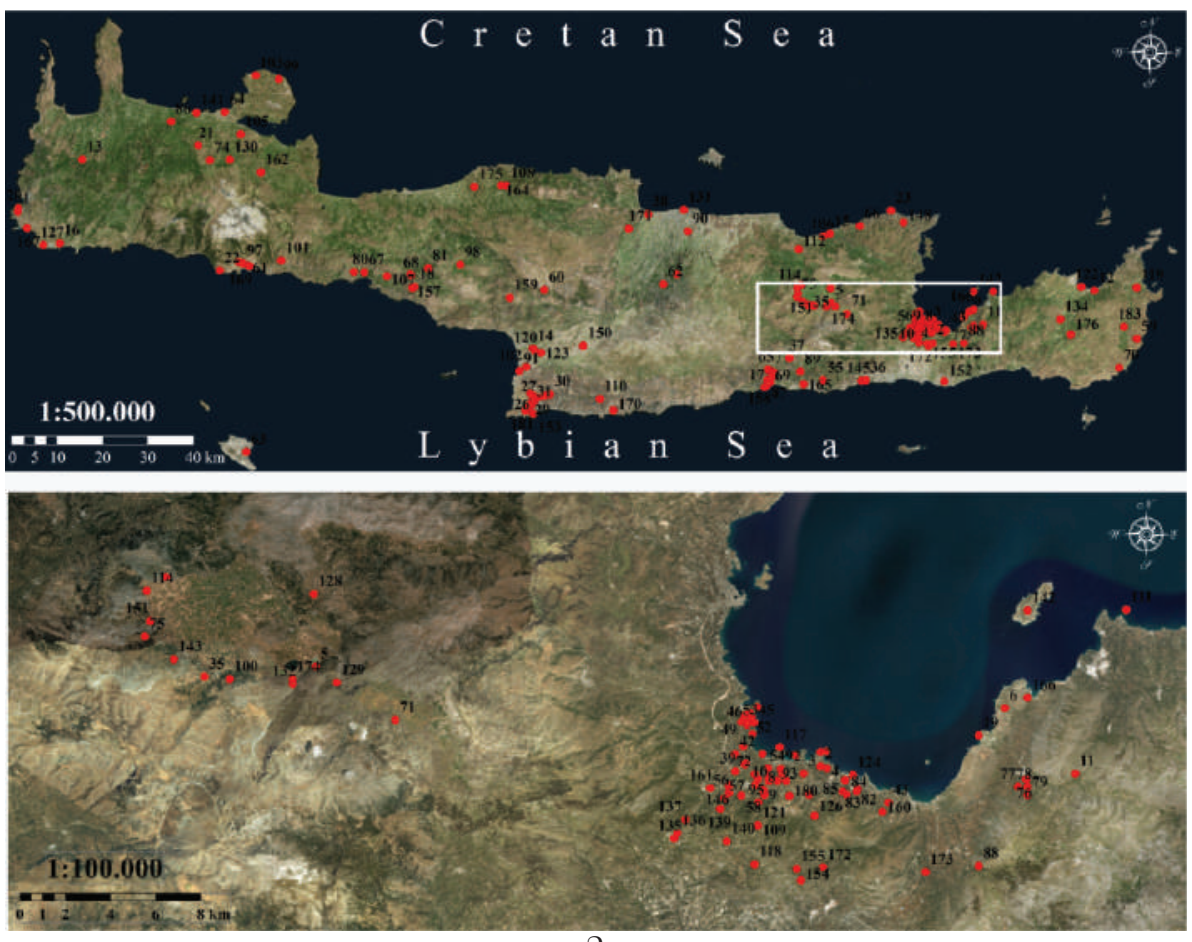

Pl. II. 1. EM IA settlements; 2. EM IB settlements. 

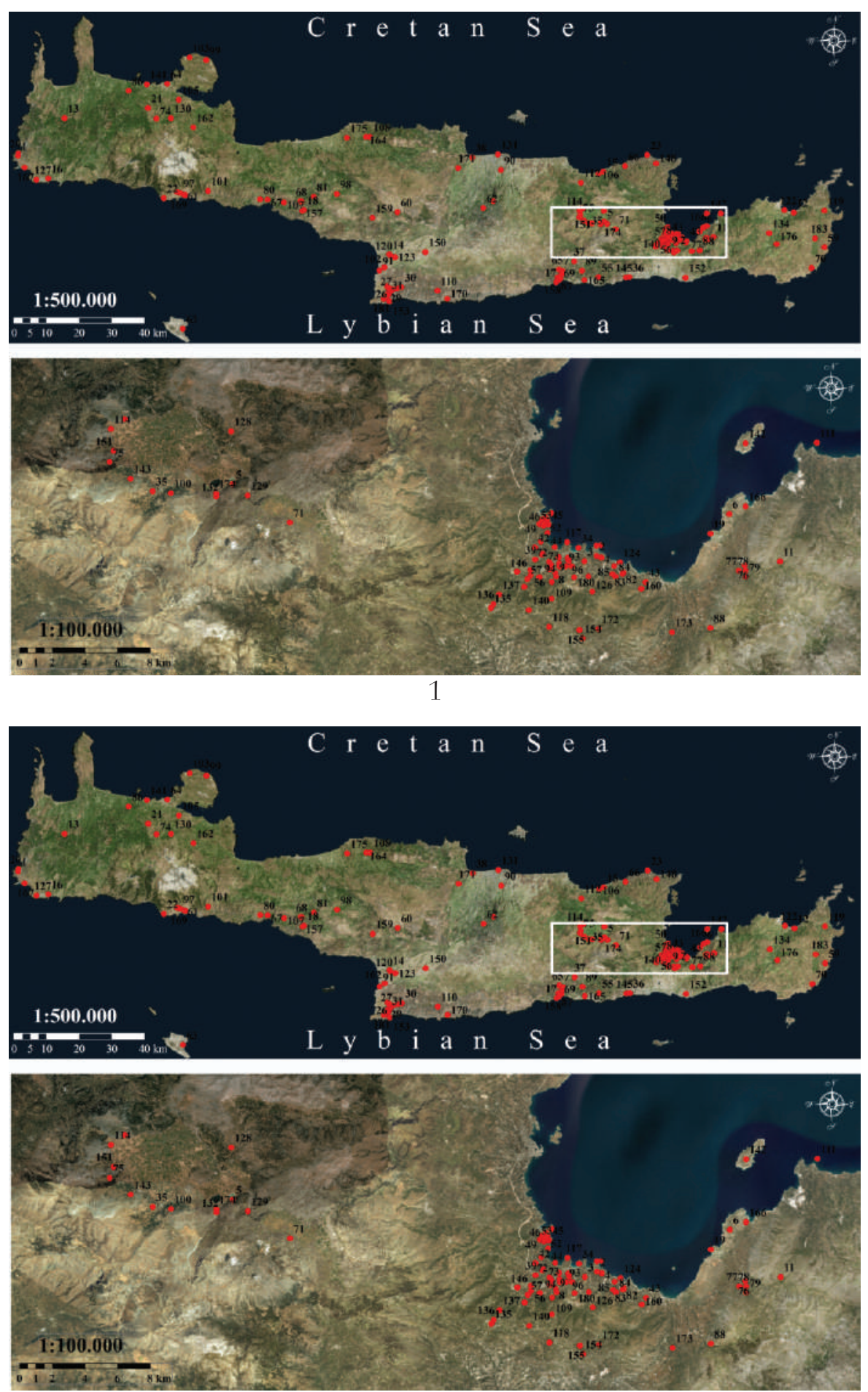

Pl. III. 1. EM IIA settlements; 2. EM IIB settlements. 

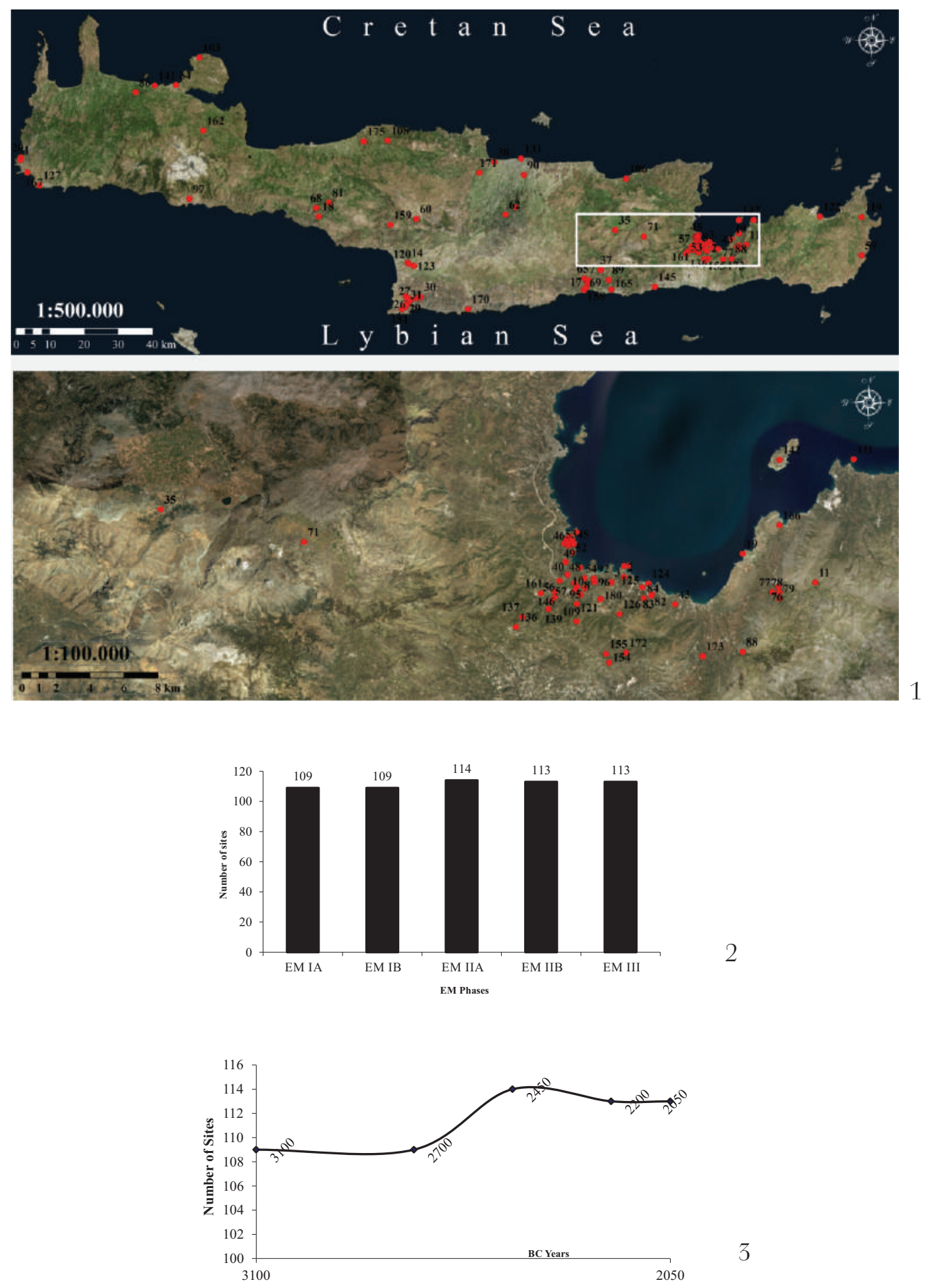

Pl. IV. 1. EM III settlements; 2. Number of sites in the phases of the EM period; 3. The number of EM sites in relation to BC years. 

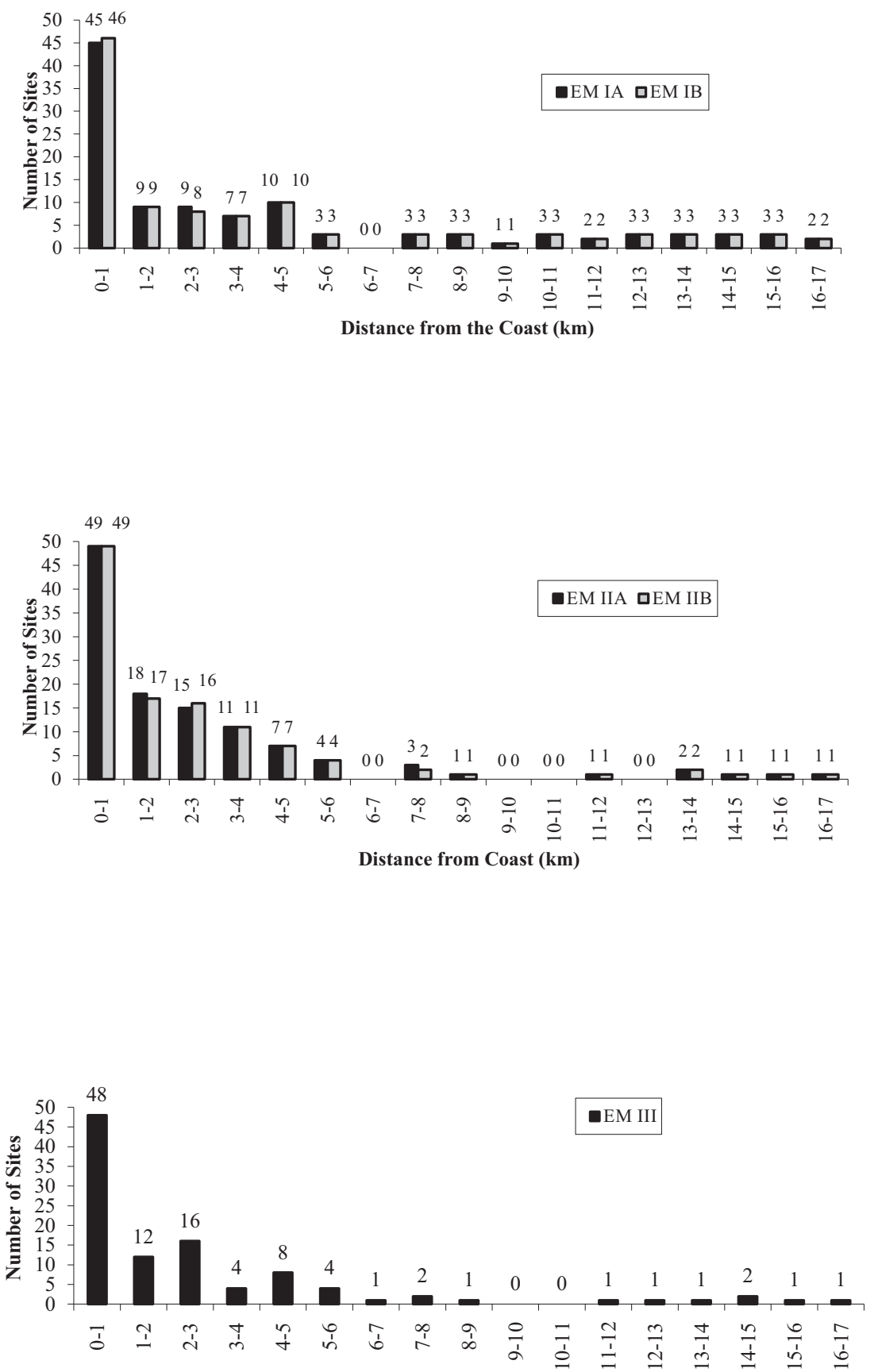

Distance from Coast $(\mathrm{km})$

PI. V. 1. EM I site distribution based on distance from the coast; 2. EM II site distribution based on distance from the coast; 3. EM III site distribution based on distance from the coast. 


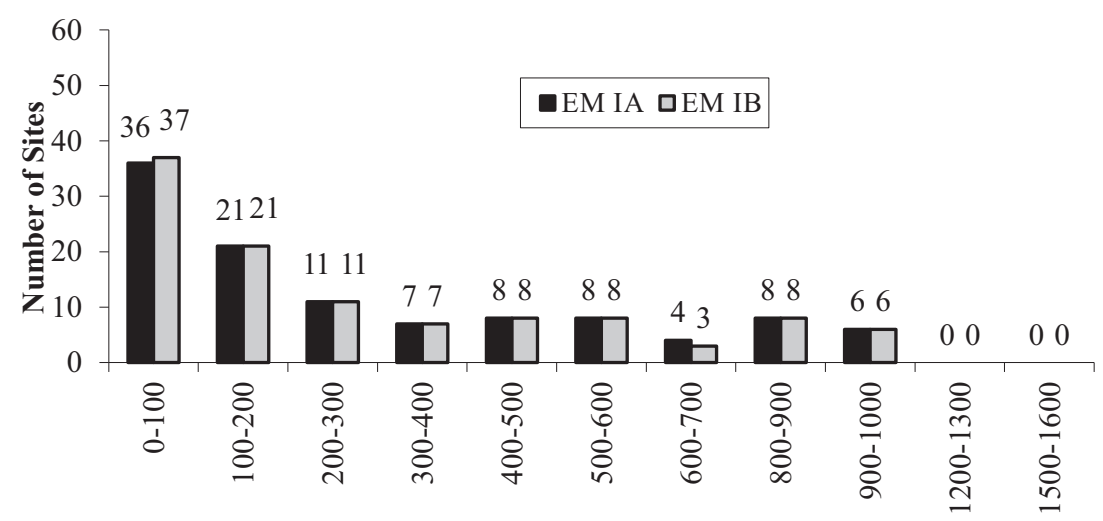

Elevation (m)

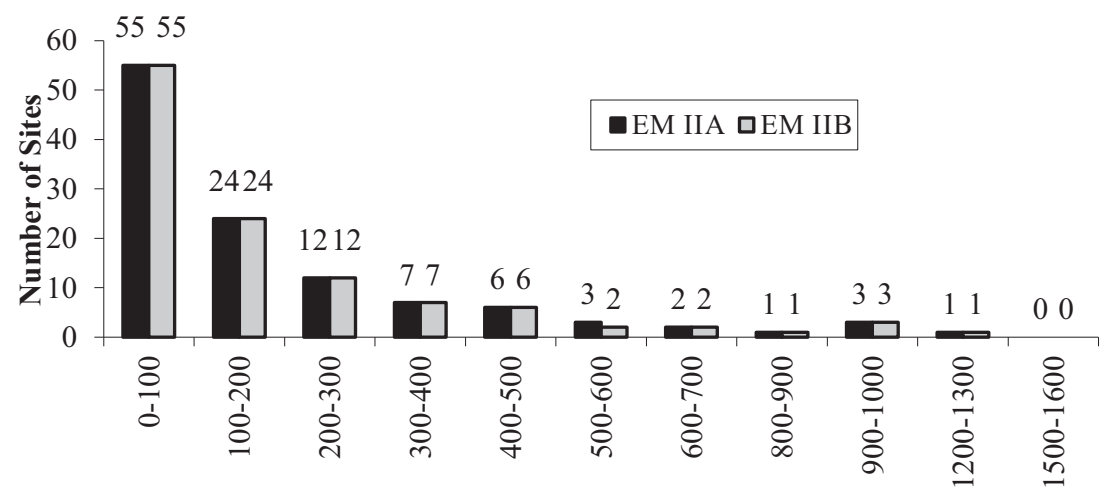

Elevation (m)

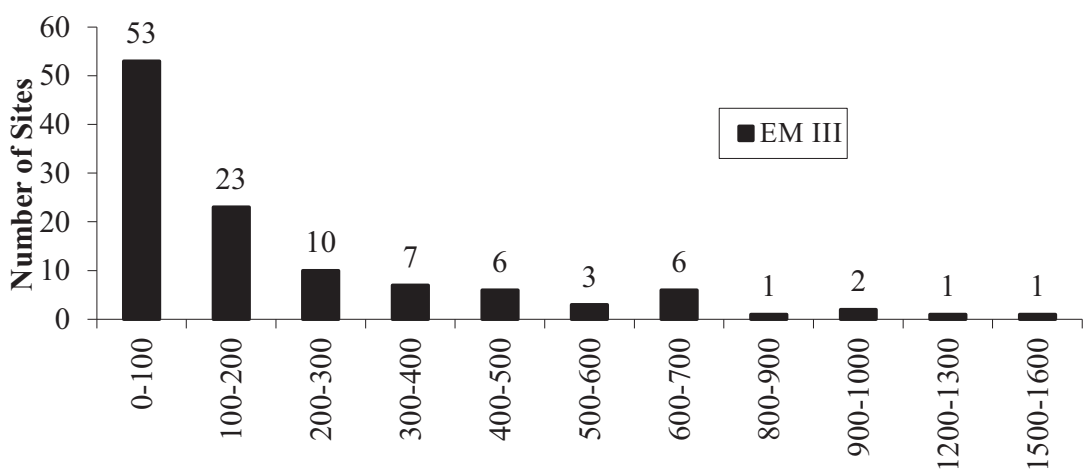

Elevation (m)

PI. VI. 1. EM I site distribution based on elevation above sea level; 2. EM II site distribution based on elevation above sea level; 3. EM III site distribution based on elevation above sea level. 

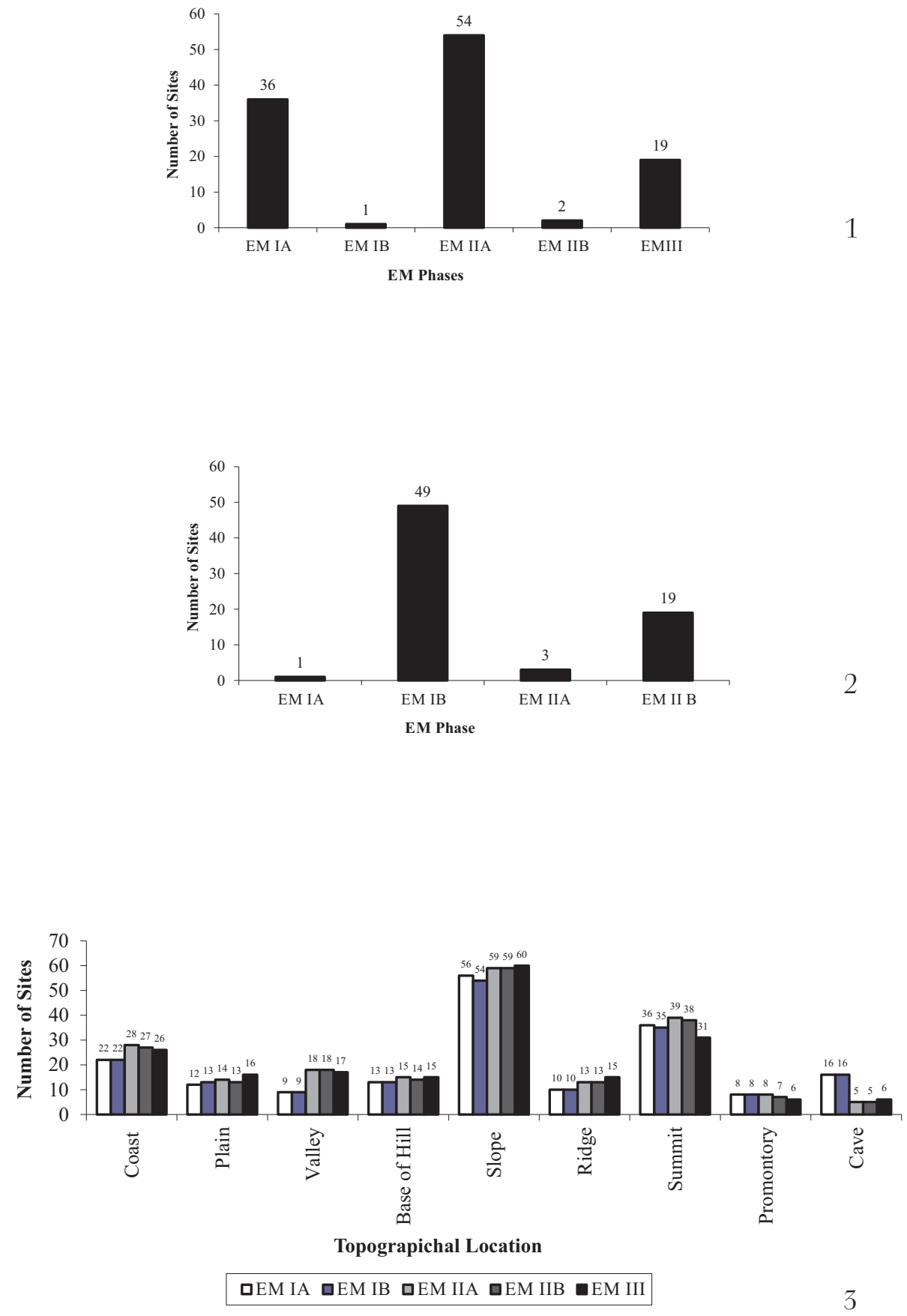

Pl. VII. 1. Emergence of EM sites; 2. Abandonment of EM sites (at the end of each phase); 3. Topographical location of EM sites. 


\title{
THE HOARD FROM THE "CIOCLOVINA CU APĂ" CAVE: CONTENT, DATING, AND SIGNIFICATIONS
}

\author{
MIHAI ROTEA
}

\begin{abstract}
This study is dedicated to the general presentation of the content, the dating and the significations of the known hoard from LBA II discovered in the "Cioclovina cu Apă" Cave / "Wet Cioclovina" Cave (Hunedoara county), discovery that constitutes one of the most remarkable monuments from the Romanian prehistory (over 7500 artifacts, most of them made of exotic materials). The association of at least four fundamental natural elements inside the archaeological monument under research here (mountain, forest, cave, and water) sets the initial starting points of the transformation of the monument into a cult place/sanctuary. There must have also been some revelation, some sign etc. The sanctuary inside the "Cioclovina cu Apă" Cave has attracted very rich and varied offerings (bronze items, exotic objects, pottery, antler cheek-pieces, and meat offerings) that were deposited in three consecrated spots in the Great Hall, places under the mark of the «spring of divinity». Starting from the fact that almost all of the offerings are jewelry items worn by women or elements that decorate horse harness, I have considered the idea that a Nymph or a Nymph associated with another deity was venerated here, in both cases in association with horses, as being the closest to the truth. I pleaded in favor of the possible presence of oracular components. Also, from the presented perspectives I considered that the exceptional ritual practices that took place in this cave place it in the sphere of inter-regional collective/institutional cult manifestations, in which the elites, including the female, played a dominant role.
\end{abstract}

Keywords: Late Bronze Age; the "Cioclovina cu Apă" Cave / "Wet Cioclovina" Cave; sanctuary; exotic votive depositions; female divinity; nymph; oracle.

Rezumat: Acest studiu este dedicat prezentării generale a conţinutului, a datării şi a semnificațiilor cunoscutului tezaur aparţinând celei de a doua etape a perioadei târzii a epocii bronzului aflat în peștera Cioclovina cu Apă (județul Hunedoara), descoperire ce se constituie în una dintre cele mai remarcabile din preistoria României (peste 7500 de artefacte, majoritatea obiecte exotice). Dată fiind asocierea în cadrul monumentului arheologic studiat a cel puţin patru elemente naturale fundamentale (munte, pădure, peșteră și apă), credem că acestea au fost punctele de plecare pentru transformarea acestui spaţiu într-un loc de cult/sanctuar; tuturor acestora trebuie să li se fi adăugat o revelație, un semn etc. Sanctuarul a atras ofrande foarte bogate şi variate (bronzuri, produse exotice, ceramică, psalii de corn şi ofrande de carne), care au fost depuse în trei locuri consacrate din Sala Mare, locuri subsumate «izvorului divinităţii». Pornind de la caracteristicile naturale ale peșterii şi de la faptul că votivele sunt aproape toate podoabe purtate de femei sau care împodobesc harnașamentul cailor, am propus luarea în considerare a ideii venerării unei nimfe, ori a unei nimfe în conjuncţie cu o altă zeitate feminină, în ambele cazuri în asociere cu cai. De asemenea, am pledat pentru posibila prezență a unor componente oraculare. Tot din perspectivele enunțate, am considerat că practicile rituale excepționale din peșteră ne plasează în sfera manifestărilor cultice colective/instituţionale inter-regionale, în care rolul elitelor, inclusiv a celor feminine, a fost dominant.

Cuvinte cheie: Perioada târzie a epocii bronzului; peştera Cioclovina cu Apă; sanctuar; votive exotice; zeitate feminină; nimfe; oracol. 


\section{Foremost $t^{1}$}

It was the hand of destiny that a large number of pupils (M. Miertoiu, D. Diaconescu, R. Olaru, C. Sonoc, P. Erdos, M. Rotea etc.) come together part of the Pupils' Archaeology Society founded in the beginning of the '70s part of the Dacian and Roman Civilization Museum in Deva. Several generous archaeologists, first of all the regretted Mircea Dan Lazăr, coordinator of the society in question, but also reputed researchers $\boldsymbol{O}$. Floca, I. Andriţoiu, and $\boldsymbol{M}$. Valea (unfortunately all of them have passed away) have allowed us to know first-hand the archaeological profession, so complex, but also so captivating and charming. The fruitful activity of these true teachers and their abnegation, transmitted to us youngsters who were passionate about archaeology, has led to the numerous prizes gained by three of the society's members. D. Diaconescu obtained the first prize at the 1973 Pupils' National Session held in Târgoviste, with a paper focusing on the post-Roman period, coordinated by Mircea Dan Lazăr and the late Gh. Lazin; in January 1973, still in Târgoviște, M. Rotea obtained the special prize of the School Inspectorate of Dâmbovița County, with a paper entitled "Contribuții la cunoaşterea aşezării neolitice de la Turdaș" [Contributions to the Knowledge of the Neolithic Settlement in Turdas]; and in 1974 in Cluj-Napoca M. Miertoiu received the first prize of the Third National Pupils' Session. But above all, no matter the paths we followed in life, we were all left with the admiration, respect, and the warm feeling of friendship that is grateful for the diligence, the pleasure, the voluntary strive to accomplishment and the crystallization of high intellectual ethics that these wonderful teachers have inspired us with.

Pious remembering is also due to the late restorer $C$. Avram who was also beside the members of the archaeology group from Deva and who has supported us in performing metallographic analyses at the Mining Institute in Deva, analyzes that substantiate our conclusions on the copper metallurgy during the Neolithic Period. I also remember sociologist M. Bele who has accompanied me in performing the rescue excavation in Bretea Mureșană and should have continued the researches with me if fate had not taken him.

I cannot end these lines without cherishing the memory of my professor Nicolae Gostar who has dedicated so much of his time and devotion to my formation in the field of archaeology and who, in his turn, took part as a student in the researches performed in 1944 in Deva-Tăualaş under the coordination of the late Hortensia Dumitrescu. Professors Mircea Petrescu-Dâmbovița and Dinu Marin have also been close to me in Iaşi and they guided my thoughts and deeds towards the miraculous archaeological field in Cucuteni.

1 These introductory lines should have accompanied a valorization to current standards of the archaeological material that I have collected during the 1970s together with my friend, lawyer M. Miertoiu, from the territory of the settlement in Deva - Tăualaş. The text of that presentation written by M. Miertoiu in 1974 and D. Diaconescu's drawings and photos have remained the only pieces of evidence that were at the basis of the recent research published (T. Daróczi and M. Miertoiu, Middle and Late Neolithic finds from Deva - Tăualaș, ActaTS, 15, 2016, 121-153) in the conditions in which the analyzed artifacts could not be found in the storage rooms of the museum in Deva (I am grateful to colleague C. Rişcuţa for his efforts in searching for them). But it was not meant to be. Neither did they accompany the recent publication of several artifacts from Bretea-Mureșană. But I am happy they are published now. 
Please allow me to - or rather forgive me for associating these perennial names and personalities to a lapidary analysis of the discoveries made in "Cioclovina cu Apă" Cave. The research would not have been possible without the support of Mr. János Emödi, a coryphaeus of Transylvanian archaeology, who did me the honor to help me in this project.

\section{I hold them all in my heart and thoughts.}

The hoard discovered in the "Cioclovina cu Apă" / "Wet Cioclovina" Cave (Hunedoara County) and dated to the LBA is one of the most remarkable finds of Romanian Prehistory, both through quantity (more than 7500 complete or fragmentary artifacts) and quality (the largest part of the artifacts are made of exotic materials such as glass, amber, and faience), ${ }^{2}$ and even of European Prehistory, as it is by far the greatest discovery of its kind in the entire temperate-climate Europe.

The "Cioclovina cu Apă" Cave (also called "Ponorâci-Cioclovina cu Apă" Cave) (Pls. I-II, X-XI) is located next to the settlement of Cioclovina (Boşorod Municipality, Hunedoara County), part of the Ponorâci-Cioclovina Karstic Complex, that belongs to the Sureanu Mountains (part of Romania's Southern Carpathians). The cave opens at the base of Trisciori Hill and is crossed by Cioclovina Creek, also called Morii or Luncanilor Creek downstream. ${ }^{3}$

"Cioclovina cu Apă" Cave is not only unique from the speleological perspective (with galleries that extend for thousands of meters), ${ }^{4}$ but also from an archaeological perspective due to the famous hoard discovered by chance in its galleries. There were two significant moments in its discovery. The first was in 1953, when T. Orghidan found the first artifacts by chance. ${ }^{5}$ These initial discoveries ended up forming a very numerous lot of artifacts (ca. 5000) through the researches that T. Orghidan subsequently performed together with a group of speleologists and archaeologists. ${ }^{6}$ The group included E. Comșa, who published the discovered artifacts. ${ }^{7}$ J. Emődi discovered and published the second lot, also consisting of an impressive number of artifacts (ca. 2500). ${ }^{8}$ J. Emődi researched the cave between 1969 and 1975 and then in 1979 and 1990. One should also mention the fact that, in unknown circumstances, I. Giurgiu discovered several other items in an dimple in the floor of the gallery containing the hoard: 3 bronze tutuli, 14 amber beads (the author of the discovery believed that some of them were ceramic beads), 14 glass beads, and 2 faience beads. ${ }^{9}$

\footnotetext{
2 In the group of artefacts from Oradea (J. Emődi collection), the only one we have researched, the presence of faience beads established only on the basis of visual observations remains uncertain. For differences between faience and glass see: Henderson 1988, 436-437.

${ }^{3}$ Buduran et alii 2013, 5.

4 Buduran et alii 2013, 5-8.

5 Dumitrescu, Orghidan 1959, 60.

${ }_{6}^{6}$ Dumitrescu, Orghidan 1959, 71.

7 Comșa 1966, 169-174.

8 Emődi 1978, 484-487.

${ }^{9}$ I tend to believe that the third and fourth row/line with artifacts published by Mr. Ică Giurgiu (https://sites.google.com/site/romanianatura60/home/carpatii-meridionali/sureanu/comoara-din-pestera-ponorici---cioclovina-cu-apa-muntii-sureanu) illustrate nine pieces of amber (not ceramic), and two other of faience (?).
} 
The archaeological researches performed inside the cave reveal the fact that the prehistoric artifacts had been deposited deep inside it, ca. 120-130 m from the entrance, in hidden places, far beyond the physical border between the area with natural light and the dark area (it is due to this fact that the hoard has remained undisturbed for over three millennia). The artifacts that form the core of the Cioclovina hoard were preserved in an upper, fossil gallery. ${ }^{10} \mathrm{~T}$. Orghidan states that the bronze items had been deposited in conical piles along the edge of the precipice and that a large quantity of glass and amber beads were scattered in all directions. ${ }^{11}$ Recounting the conditions of discovery of the items from the same area (and even publishing a plan of their position), J. Emődi believed that there were at least five small piles of artifacts, ${ }^{12}$ that might have been deposited in textile pouches ( $T$. Orghidan discovered wool yarn ${ }^{13}$ ). Also, both E. Comşa and J. Emődi inform us of discoveries made in another fossil gallery called the niche («Comşa's niche»), ${ }^{14}$ to which J. Emődi added a small amphora found on the cave floor. ${ }^{15}$ As for the significance of the discovery E. Comşa believed that the hoard was intentionally hidden there in hard times, ${ }^{16}$ while J. Emődi believed it was a «votive deposition, an offering hoard». ${ }^{17}$

The discoveries from "Cioclovina cu Apă" Cave have captured the attention of numerous researchers, as they should have, due to their special content. Among these researchers one can mention: W. A. v. Brunn, ${ }^{18}$ M. Rusu, ${ }^{19}$ A. Mozsolics, ${ }^{20}$ T. Bader, ${ }^{21}$ M. Petrescu-Dâmbovița, ${ }^{22}$ H. Müller-Karpe, ${ }^{23}$ S. Hansen, ${ }^{24}$ C. Kacsó, ${ }^{25}$ A. Harding, ${ }^{26}$ and C. Metzner-Nebelsick. ${ }^{27}$ At the same time, benefiting from the contributions of C. W. Beck, ${ }^{28}$ A. Banerjee, ${ }^{29}$ and E. C. Stout, ${ }^{30}$ among others, N. Boroffka, ${ }^{31}$ C. Ghemiş, ${ }^{32}$ and F. Gogâltan ${ }^{33}$ have dealt extensively with the study of prehistoric amber in Transylvania, with numerous references to artifacts from the Cioclovina hoard. Their

10 Dumitrescu, Orghidan 1959, 69; Emődi 1978, 484, Pls. 2-3.

11 Dumitrescu, Orghidan 1959, 71, 74.

12 Emődi 1978, 493.

13 Rusu 1972, 490.

14 Emődi 1978, 484.

15 Emődi 1978, 484.

16 Comșa 1966, 173-174.

17 Emődi 1978, 493.

18 v. Brunn 1968, 38, 72, 193, 280, 290.

19 Rusu 1972, 489-490.

20 Mozsolics 1973, 68, 73, 126-127.

21 Bader 1978, 107.

22 Petrescu-Dâmbovița 1977, 89-90.

23 Müller-Karpe 1980, 799.

${ }^{24}$ Hansen 1994, 580.

25 Kacsó 1995, 107-109; Kacsó 1999, 125.

${ }^{26}$ Harding 2000, 268.

27 Metzner-Nebelsick, Nebelsick 1999, 83, 86, 99.

28 Beck 1985, 191-199.

${ }^{29}$ Banerjee et alii, 593-606. For R 15 samples location see: Boroffka 2002, 149-150.

30 Stout et alii 2000, 665-678.

31 Boroffka 2006, 77-88.

32 Ghemiş 2007, 7-22.

33 Gogâltan 2016, 155-158, with bibliography. 
conclusions differed on the issue of the origin of these artifacts. ${ }^{34} \mathrm{~N}$. Boroffka ${ }^{35}$ even believed that analytical methods are unable to test if Romanian amber sources were employed or if the primary material was brought from the area of the Baltic Sea, as at least three types of amber exist in Romania, among which one is the "Baltic amber", with the most important source located in Colţi and its surroundings; this is the only type identified between the archaeological discoveries. A recent project, the Romanit, coordinated by E. S. Teodor, has also been aimed at studying the geomorphologic and chemical characteristics of amber from Romania and establishing thus the origin of these archaeological artifacts. The project included FTIR-VAR and FT-Raman analyses on 12 beads from the hoard from Cioclovina. ${ }^{36}$ The study concluded that "almost certainly, 10 out of the 12 amber beads of different types must be of Romanian origin (most probably from Colți, Buzău County), and thus with no connection to the Amber Route". ${ }^{37}$ Still, there is also mention of the fact that "as the Banerjee expertise shows, at least some of the Cioclovina beads were made of imported amber brought along extended exchange networks". ${ }^{38}$

Samples were taken in 2014, at the initiative of J. Varberg, from glass beads from two distinct archaeological complexes from Transylvania: the hoard from Wet Cave and a grave part of the Noua Culture necropolis from Cluj-Napoca - Strada Banatului. ${ }^{39}$ The glass from the cave has been analyzed and identified as Mesopotamian/Syrian glass of the same type as the glass found in the Neustrelitz Hoard in North Eastern Germany by the river Oder and in Danish graves. ${ }^{40}$ Thus, for the LBA one has new proof of the extremely long distance (inter-continental) trade connections of which Transylvania was a part. Specialists have also stated that the Cioclovina hoard is by far the largest hoard containing glass beads in Europe and it is therefore a key find in understanding the exchange routes crossing Europe. ${ }^{41}$

An international Romanian-Danish-Dutch collaboration ${ }^{42}$ was initiated and started working in the summer of 2016, aiming for the systematic, inter-disciplinary research of the cave. The starting point was the observation that there were several places in which offerings had been placed repeatedly, and this allows one to conclude that the «Great Hall» in "Cioclovina cu Apă" Cave can be understood, in its entirety, as a sacred prehistoric space (sanctuary). ${ }^{43}$ According to this vision, the significance of the archaeological complex had to be changed from hoard to a sanctuary hoard, consisting of successive depositions. ${ }^{44}$ With all the limitations inherent to such initiatives

${ }^{34}$ Gogâltan 2016, with bibliography.

35 Boroffka 2006, 80.

36 Teodor et alii 2010, 2386-2396.

37 Teodor et alii 2010, 2395.

38 Teodor et alii 2010, 2396.

39 Varberg et alii 2016, 2.

40 Varberg et alii 2016, 1-11; Varberg 2017.

41 Varberg et alii 2016, 10; Varberg 2017.

${ }^{42}$ National History Museum of Transylvania (Romania), Museum of Dacian and Roman Civilisation (Romania), Moesgaard Museum (Denmark), Radbound University Nijmegen (Holand) and Alpine Sports Club (Romania).

43 Rotea 2016

${ }^{44}$ Rotea 2016; for the idea of successive deposits also see: Kacsó 1995, 108; Kacsó 1999, 125. 
in their early stages (extended periods spent for obtaining authorizations and signing collaboration protocols, the acquisition of speleological equipment, and limited funding etc.), the team has discovered two glass beads on the floor of the main gallery, in secondary position, one amber bead, fragmentarily preserved (all had slid from the upper gallery) and a prehistoric pottery fragment (Pl. VIII/4), and this proved that the cave's archaeological potential has not been exhausted. Parallel to the on-site researches, the team has studied and photographed the main artifacts in the J. Emődi collection, which form the core of the illustrative archaeological material of the present research. ${ }^{45}$

By putting together the multidisciplinary analysis of the discoveries published by E. Comşa ${ }^{46}$ and J. Emődi and the results of our investigations, the latter aimed at gaining detailed knowledge of the context in which the hoard had been deposited, we hope we will come closer to grasping the entire content and the multiple significations of this exceptional archaeological-speleological monument. As we are aware of the fact that it is premature to evaluate with precision the depositions and rituals from "Cioclovina cu Apă" Cave, we are left, for the moment, with testing, from a global perspective, three fundamental levels in the knowledge of the hoard: its content, dating, and significations.

Content. The hoard consists of three distinct parts deposited in three different places that we have labeled altar A gallery (altar A hall, upper fossil gallery, Orghidan gallery), altar B gallery (altar B hall, the lower fossil gallery, Comşa niche/gallery), and altar $\mathrm{C}$ gallery (altar $\mathrm{C}$ hall, the cave's current gallery/floor, Emődi gallery). ${ }^{47}$ Altar A gallery/hall is the most important through the variety and great number of artifacts, while the two other locations have secondary, but complementary roles, as we envisage the cave in its entirety as a unitary depositional context. ${ }^{48}$

Altar A gallery. According to T. Orghidan's and J. Emődi's descriptions, in this upper fossil gallery the artifacts had been deposited in several small piles, some distance apart, on two stone altar-benches (one along the wall and another in the middle of the gallery). ${ }^{49}$ Numerous other items have also been found above or under these altars in small cracks or niches. ${ }^{50}$ A relatively large number of items have been recovered from the steep slope that descended from this gallery towards the floor of the main gallery and even on top of this floor. ${ }^{51}$

The following artifacts were found in this context:

45 Warm thanks to Mr. J. Emődi to facilitate our access to all artifacts and informations on "Cioclovina cu Apă" Cave descoveries.

${ }^{46}$ Most of them are in the collections of the National History Museum of Romania and a small part in those of the "Emil Racoviță" Speological Institute, both in Bucharest.

47 The term altar is used here with different meanings: offering table (altar A) and/or offering place (altar B si C).

48 A separate treatment of these two distinct categories of deposits does not have any archaeological basis. On the contrary, there are many arguments to consider them as unitary: unique cultic space, chronological unity of artifacts etc. For a similar situation see minoan peak sanctuaries from the mountain of Juktas (Marinatos 1993, 116-117).

${ }^{49}$ Dumitrescu, Orghidan 1953, 71; Comşa 1966, 169-170; Emődi 1978, 493, Pl. 3.

50 Emődi 1978, 493, Pl. 3.

51 Comşa 1966, 170; Emődi 1978, 484, 493. 
Metal artifacts: large conical ampyx: 69 items (Pl. IV/1), phalerae: 5 items (Pl. III/1, 4), round plaques: 21 items $^{52}$ (Pl. III/2, 5-6), conical tutuli: 1858 items (Pl. III/7), lunulae: 87 items (Pl. IV/4), saltaleons: 271 entire and fragmentary items (Pl. IV/3), wire spirals: 15 items (Pl. III/3, 8), loops-ring: 24 items (Pl. IV/2), all made of bronze, and 520 tin beads (Pl. V/1).

Exotic artifacts: blue glass beads, undecorated, simple and rarely double: 2341 items (Pl. V/3), amber beads of various shapes (bitronconic, tronconic, flat, tubular, polyhedric with numerous sub-variants) and sizes (between $1.5 \mathrm{~mm}$ and $2.5 \mathrm{~cm}$ ): 1785 items (Pl. VI/1-12), and small faience beads: 572 items (Pl. V/2). Among them, two glass beads and a fragmentary amber bead were discovered during our 2016 researches on the floor of the main gallery, fallen from the gallery of altar A.

Antler cheek-pieces: 4 (3 entirely preserved and one fragmentarily preserved) (Pl. VII/1-3).

Counting all the artifacts discovered in the hall of main altar A, we reached a total of 7572. The majority of the artifacts are entirely preserved. Some fragmentary glass or amber beads might be completed with others, but this would change to an insignificant degree the total number of discovered items, ${ }^{53}$ since both E. Comșa and J. Emődi counted usually the complete or reconstructible items. To an equal degree, one must take into consideration the fact that the content of the hoard has not been exhausted; on the one hand, specialists have specifically recorded that part of the items remained embedded into the calcite bedrock ${ }^{54}$ and on the other hand some items have been carried by the torrents and have reached the current creek bed. ${ }^{55} \mathrm{~J}$. Emődi has recovered some of the latter from the rock «steps» that lead down from the altar to the floor of the main gallery and in 2016 we found three other items fallen on the floor of the main gallery. One will never know how many items have been carried away downstream.

Altar B gallery. A niche opens in the left wall of the active gallery at the height of ca. $4 \mathrm{~m}$. It has a box-like aspect and measures approximately $6.70 \times 2 \mathrm{~m}$. Near the entrance of this space (also called Comşa niche/gallery), and only on that spot, E. Comşa and later J. Emődi discovered the following items: several fragments from a conical bowl with inverted rim, black colored, large (Pl. VIII/2), ${ }^{56}$ one bronze earring with boat-shaped body (Pl. VIII/1), small pieces of coal, and several deer and pig bones $^{57}$ (Pl. IX/1-6).

Altar C gallery. On the floor of the main gallery, J. Emődi found a small amphora of which a single fragment from the upper part has been preserved until today (Pl. VIII/3). Also on the cave floor, in a secondary position, we have discovered, during the 2016 researches, a ceramic fragment from a large black pot (Pl. VIII/4).

${ }^{52}$ Comșa 1966, 170.

53 The variation of the number of pieces from one author to another (for discussion see: Gogâltan 2016, 155, with bibliography) is due only to some inattention in the documentation. The data are clear (not in absolute terms, because some completions is possible) considering the studies of E. Comşa (1966, 170-171) and J. Emődi (1978, 484-487).

${ }^{54}$ Dumitrescu, Orghidan 1953, 70; Emődi 1978, 493.

55 Dumitrescu, Orghidan 1953, 73.

${ }_{56}$ Comșa 1966, 169; Emődi 1978, 484, Pl. 2.

57 Emődi 1978, 484, determinations were made by T. Jurcsák. 
Numerous considerations can be made on the content and spots of deposition of this hoard, though I shall only mention here a few.

The simple enumeration of the content of the hoard reveals the fact that this is an exceptional find, unparalleled not only in the Romanian prehistoric area (it is by far the most impressive hoard from the territory of Romania, both through the total number of items ${ }^{58}$ and the number of exotic items), but also in that of temperate Europe (so-called "barbarian" Europe). ${ }^{59}$ The glass, amber, faience, and tin beads represent 98-99.9\% of total amount of their particular type of LBA artifacts discovered on the territory of Transylvania. Also the percentage of the bronze tutuli is not so different either, as, preserving M. Rusu's calculations, ${ }^{60}$ out of the total of 1977 tutuli discovered in Transylvania, 1828 (92.4\%) come from the "Cioclovina cu Apă" Cave.

From the perspective of the places where the offerings have been deposited, the three depositional contexts (A, B, and C) are small galleries (B) or large ones (A and C), provided with complex designs (A) or minor ones (B and C) on which the offerings have been deposited. Altar A consists of two deposition tables. One was parallel to the gallery walls (altar A1) and the other perpendicular to the first (altar A2). ${ }^{61}$ The great majority of the metal items have been deposited on altar A1 and most of the exotic ones on altar A2. ${ }^{62}$ A subterranean room existed under altar A1 and it also contained artifacts. ${ }^{63}$ If we have admitted the natural fact, that the votive were not deposited randomly but only in consecrated places, so we have supported the idea that altars B and C also existed despite the fact that nothing clear or certain is known on the nature or shape of these two. I believe, for example, that the fact that all of the artifacts discovered in hall $\mathrm{B}$ were grouped near the entrance to this space cannot be random. ${ }^{64}$

From the perspective of the contents of these depositions, one can distinguish between two different categories of offerings: on the one hand those deposited on the main altar A and on the other hand those deposited on the secondary altars B and C. It is equally obvious that altar A dominated through the number, nature, and diversity of the offerings, while altars $\mathrm{B}$ and $\mathrm{C}$ are characterized by offerings consisting almost exclusively of pottery and animal bones, far fewer than those in the hall of altar A. The first significant conclusion is that the typology and structuring manner of the lots of artifacts are different. Another conclusion is that they are controlled by strict rules. Finally, one should search for the different significations/meanings/roles of the two major types of votive depositions.

58 The Uioara de Sus hoard is considered to be the largest in Romania, starting from the number of 5812 pieces, but also from the weight of $1133 \mathrm{~kg}$ (after Rusu 1972, 540), but we must keep in mind that the Cioclovina cu Apă hoard has more pieces (7575 only in altar A), and, in our opinion, it is far from being completed. But it is also true that the first lot of artefacts, the most numerous, discovered by T. Orghidan, in gallery A, required three backpacks for transportation (Dumitrescu, Orghidan 1953, 71; Negrea 1979, 31), while for the Uioara de Sus hoard a carriage of oxen was necessary.

59 For glass beads, see: Varberg et alii 2016, 10.

60 Rusu 1972, 251, 489-490.

${ }^{61}$ Emődi 1978, 493, Pl. 3.

62 Emődi 1978, 493, Pl. 3.

63 Dumitrescu, Orghidan 1953, 71-73; Emődi 1978, 493.

${ }^{64}$ Emődi 1978, Pl. 2. 
The fact that the artifacts had been deposited in three different areas (A, B, and $\mathrm{C}$ ) and that those in the same area were placed in separate lots (see the explicit situation in altar $\mathrm{A}$ hall ${ }^{65}$ ), and the numerous typological differences among some of the artifacts (the amber beads, for example) (Pl. VI/1-12), also suggests certain chronological delays, that support my belief that the ritual space remained functional for a certain period and that there was a significant number of successive visits. ${ }^{66}$

On the altar A1 and A2, two large batches of objects were placed, which in turn are composed of several different sets of pieces. If bronze loops-ring (Pl. IV/2) have been used to bind sachets with small pieces (such as beads), then there must have been 24. such assemblies, small sets of pieces/groups.

A good part of the saltaleons and the ampyxes were deposited together, as we see in one of the pictures published by M. Dumitrescu and T. Orghidan (Pl. XII/1) ${ }^{67}$ This may mean that they formed together decorative and/or symbolic chains. Also, on the one hand, it impresses the very large dimensions of saltaleons, some even reaching over $30 \mathrm{~cm}$. On the other hand, are situations when they are associated in decorative string only with lunulae pendants, as in Giula hoard ${ }^{68}$ because this hoard, located in the National History Museum of Transylvania collections, consists only of saltaleons, lunulae, and belts (Pls. XXIV-XXV).

Some decorative pieces, but certainly cheek-pieces demonstrate clear the use of horses for ritual purposes. Their use for utility and military purposes in Late Bronze Age is also proven by numerous discoveries. ${ }^{69}$

It is clear that the two vessels had been deliberately deposited whole (Pl. VIII/23) being discovered in situ. The pottery fragment, discovered in 2016, appeared isolated (Pl. VIII/4), most likely brought by torrents, and we do not know if it is evidence of intentional fragmentation. Dimensions and type of vessels, different from those used for drinking, are talking about storage, transport and offering of same substances.

The skeletal element distribution for the fragments of deer/goat and pig/boar shows a clear overrepresentation of skull parts (mandible and teeth) and body parts (forelegs) (Pl. IX). The first type is bones with very little meat attached suitable for consumption, but with multiple meanings. The second type is opposite of the first in terms of meat. Both types, by repeating, show a deliberate selection. Most likely all have undergone a still undefined thermal preparation.

In the gallery of the altar A were discovered the shells of very small snails (2-4 $\mathrm{mm})$, which will be subjected to a future analysis. The first observations would indicate that they are not of local origin.

The research did not identify any significant archaeological evidence of the use of this space before or after the period under consideration here.

\footnotetext{
${ }_{65}$ Emődi 1978, 493, Pl. 2.

${ }^{66}$ For the idea of successive depositions, see also: Kacsó 1999, 125.

${ }_{67}$ Dumitrescu, Orghidan 1953, 72.

${ }^{68}$ Roska 1942, 131, no. 226; Petrescu-Dâmbovița 1977, 95, Pl. 147/1-7; Kacsó 2009, 168-169.

${ }^{69}$ Harding 2000, 136; Rotea 2016, with bibliography.
} 
The Cioclovina Hoard can be included among the accumulations of jewelry set (Schmuckhorte) or mainly of such items that I. Ordentlich, ${ }^{70}$ A. Mozsolics, ${ }^{71}$ and S. Hansen ${ }^{72}$ drew attention to, but that C. Kacsó has reunited under the label of «Arpăşel-type hoards». ${ }^{73}$

The close analysis of the bronze artifacts in "Cioclovina cu Apă" Cave indicates that inside each category of items the artifacts have traits that set them apart, despite the fact that their general outlook remains unitary (one can speak of the standardization of the votive behavior). Such details include decoration, size, quality of the primary material etc. These latter details lead one to the idea that the objects had been produced in several lots and/or by several workshops. Our observations regarding older bronzes still stand for the glass or faience beads, but especially for those made of amber, that are the most varied in types and colors (due to the variety of the primary material employed).

The issue of the workshops that produced such bronze artifacts which were deposited in caves or other archaeological contexts has not been yet approached with sufficient attention. The rarity of Transylvanian settlements or workshops with complex metallurgical activity also led us to the idea of the existence of itinerant craftsmen who did not hold any power but worked under the control and at the command of the elites. ${ }^{74}$ The discoveries made at Pălatca have aided us in the direction of understanding that mobile character of some of the workshops, but also of the ritual/magic universe in which they evolved..$^{75}$

The materials from which major objects from the cave have been made were not chosen by chance. I shall not discuss here the known symbolic value of glass and amber, ${ }^{76}$ but I shall keep them in mind for a new approach. ${ }^{77}$ The composition of certain bronze items is also certainly not by chance; on the contrary, I believe that it was carefully composed in order to lead to the production of white bronzes. ${ }^{78}$ The presence of tin beads, also silver colored, might be interpreted in the same key. Notable, in this regard, is another hoard discovered in Cluj-Napoca - Tufele Rosii. The bronze artifacts of this hoard, recently discovered by Ms. Adela Galfi and handed over to the National History Museum of Transylvania, ${ }^{79}$ have, with one exception, the same silver color (Pls. XIII-XV). This hoard, typical for Transylvanian LBA II, contains: ten sickles

70 Ordentlich 1968, 398.

71 Mozsolics 1973, 69.

72 Hansen 1994, 356.

73 Kacsó 1990, 43-44; Kacsó 1995, 107-112; Kacsó 2009, 157, 170; Gogâltan, Sava 2014, 199, with adittions to the list of hoards.

${ }^{74}$ Rotea 2009, 37-38.

75 Rotea et alii 2011, 7-38.

76 Bouzek 1993, 141-146; Maran 2013, 147, 161, with bibliography.

77 Possible meanings: blue glass beads-sky/water, amber beads-sun, and metal with silver shimmer (bronze and tin)-moon. For the same combination of artifacts (blue glass beads, amber beads, and metal with silver shimmer) see the necklace discovered at Campu Stefanu (Corsica) (Peche-Quilichini et alii 2016, 67-79).

78 For white bronzes see, for example: Giumlia 2011, 42-45, with bibliography.

79 Thank you very much to Mrs. Adela Galfi for her passion and honesty which she had vis-à-vis that discovery. 
(Pl. XIII/1-10), two socketed axes (Pl. XIV/2-3), and one dagger (Pl. XIV/1). Also, an exceptional Drajna type bronze axe (Nackenknaufäxte/Kugelknaufäxte) (Pl. XV/1) ${ }^{80}$; the axe was deliberately broken when it was deposited, and the hole of one socketed axe was blocked with other fragmentary pieces (Pl. XIV/2).

The deposited artifacts have utilitarian and symbolic connotations. Almost all of the items made of bronze, glass, antler, or amber that we had the chance to research had been used prior to their deposition, displaying obvious traces of wear ${ }^{81}$ (Pls. IIIVII). In the new context though they gained a new status, becoming ceremonial/ritual objects, used as a way of establishing or maintaining the communication between the profane and the sacred. Their main scope was to force the sacred (divine) realm to act or react in a manner favorable to those who took part in the ceremonies.

The chronological position of the hoard is another important issue that has remained controversial. E. Comşa dated it to Hallstatt A1 (the $12^{\text {th }}$ century BC) and included it in the Cincu-Suseni group of hoards, ${ }^{82}$ a perspective shared by most specialists. ${ }^{83}$ But, J. Emődi dated the hoard to the previous period, i.e. Br. D (the $13^{\text {th }}$ century BC) and included it in the Uriu - Ópályi series of hoards. ${ }^{84}$

From my perspective, this lot of artifacts is the result of gradual accumulations, with different places and deposition characteristics, that are nevertheless congruent, and this can raise certain problems of fine chronological delays between its components. ${ }^{85}$ We do not know for certain as yet which were the beginnings of the ritual activities, i.e. which were the first depositions, nor which were the last. Without insisting on such details, I mention several chronological benchmarks that, taken together, provide, in my opinion, a convincing argument regarding the chronological identification of the core, but possibly of the entire hoard, during LBA II (Bronze D in the Central European chronology). ${ }^{86}$

From a typological perspective, all of the bronze items (individually or in certain associations) have analogies among discoveries or hoards dated to the LBA II (Br. D), the Uriu - Ópályi series of hoards (see for example: Ópályi, ${ }^{87}$ Cehăluț I, ${ }^{88}$

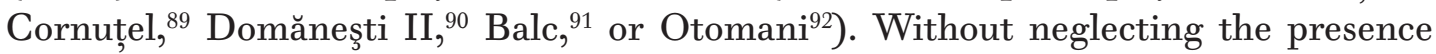

${ }^{80}$ For this type see: Vulpe 1970, 99-100; Bader 1996, 265-302; Soroceanu 2016, 163-180, with bibliography.

81 Emődi 1978, 493, n. 75.

82 Comșa 1966, 173.

${ }^{83}$ For example, see: Petrescu-Dâmbovița 1977, 89-90.

${ }^{84}$ Emődi 1978, 87-92. This series of hoards was at the biginning called Uriu-Domăneşti (for the history of designations see: Kacsó 2017b, 23-29).

85 Rotea 2016; for the idea of successive deposits also see: Kacsó 1995, 108; Kacsó 1999, 125.

${ }^{86}$ I used the chronological system that I have developed for the prehistory of Transylvania (Rotea et alii, 2014; Rotea 2016). This system is based on its own historical-archaeological conception and is based on a number of approximative 100 new C14 analyses. According to him, the LBA has three stages LBA I (ca. 1500/1450-1350 BC), LBA II (ca. 1350-1200 BC) and LBA III (ca. 1200-1100 BC), being close to the proposed systems by C. Kacsó (1990, 41-50) and F. Gogâltan (1998, 196-199), for the same period.

87 Mozsolics 1973, 67-68, Pl. 19.

88 Hampel 1886, 82-83; Roska 1942, 150-151, no. 24; Petrescu-Dâmbovița 1977, 54; Bader 1978, 122; Kacsó 1995, 93, with bibliography.

89 Petrescu-Dâmbovița 1977, 55; Kacsó 1995, 117, with bibliography.

90 Bader 1969, 73-84; Petrescu-Dâmbovița 1977, 59; Bader 1978, 124.

91 Roska 1942, 35, no. 50; Petrescu-Dâmbovița 1977, 52; Kacsó 1995, 93, with bibliography.

92 Ordentlich 1968, 397-404; Petrescu-Dâmbovița 1977, 101; Bader 1978, 126; Kacsó $1995,93$. 
of such analogies in the hoards dated with certainty to the LBA III (Hallstatt A1 in Central Europe) (the ampyx, the phalerae, and the tutuli from the hoards in S,pălnaca $\mathrm{II}^{93}$ and Uioara de Sus, ${ }^{94}$ to which one can add the lunulae and the saltaleons from the same huge hoard in Uioara de Sus ${ }^{95}$ ), I should mention that no item of this type is dated exclusively to this chronological horizon. I thus see no convincing argument to date the metal items in the hoard exclusively to the LBA III.

The bronze earring with boat-shaped body found in gallery B (Pl. VIII/1), associated with the conical bowl (Pl. VIII/2), belongs to type B1d based on E. Zaharia's classification. ${ }^{96}$ Similar artifacts was discovered in Hajdúbagos cemetery ${ }^{97}$ or Cornuţel $^{98}$ and Pecica $I^{99}$ hoards; also in Câmpina ${ }^{100}$ or Zimnicea ${ }^{101}$ cemeteries (southern Romania); all dated in LBA I-II. The shape of some of these may be similar to what we call sometimes diadems (gold pieces from Sărmășag and Sântana ${ }^{102}$ ), which I think are adornments for binding the hair in a hump or a tail (Pl. XXIII/4). ${ }^{103}$

All lunulae pendants discovered belong to the same variants with the perforated vertical rod. They were mindful analyzed by C. Kacsó, being considered, rightly, creations of the metallurgical center in western Romania and eastern Hungary. ${ }^{104}$ They appear starting with LBA II, in the origin space, but in the following period they spread to the west (in Austria and Germany), where they can be found exceptionally through Hallstatt B (from the grave of Líbochovany). ${ }^{105}$ The list of discoveries includes about 60 points, ${ }^{106}$ but the most numerous, more than 100, come from the Giula hoard, ${ }^{107}$ followed by the cave hoards: Cioclovina ( 87 pieces) ${ }^{108}$ and Ungurului (50 pieces)..$^{109}$

The tin beads, discovered in a small crack in the wall above altar A, are very small items (with diameters between 2 and $4 \mathrm{~mm}$ ). ${ }^{110} \mathrm{We}$ only know of two almost identical items from Romania, discovered in tumulus 6 from Lăpuş (phase Lăpuş II). ${ }^{111}$ We can also mention similar discoveries from the European area, but from different periods: 47 tin beads have been discovered in Buxheim, in southern Germany, in a grave dated

\footnotetext{
93 Rusu 1972, 249-251; Petrescu-Dâmbovița 1977, 108-112, with bibliography.

${ }^{94}$ Rusu 1972, 249-251; Petrescu-Dâmbovița 1977, 114-117, with bibliography.

95 Rusu 1972, 251-254; Petrescu-Dâmbovița 1977, 114-117, with bibliography.

96 Zaharia 1959, 119.

97 Kovács 1970, 29, Pls. 1/2, 2/14.

98 Petrescu-Dâmbovița 1977, 55, Pl. 35/8; Kacsó 1995, 117, with bibliography.

99 Roska 1942, 225, Pl. 276a; Petrescu-Dâmbovița 1977, 41-42, Pl. 6/4-5; Soroceanu 2012, 72-76, with bibliography.

100 Frînculeasa 2016, 123, 129.

101 Alexandrescu 1973, Pl. 1a-1b.

102 Dumitrescu 1974, 412-415.

103 Rotea 2016, with bibliography.

104 Kacsó 2009, 168-170.

105 Kacsó 2009, 169.

106 Kacsó 2009, 168.

107 Roska 1942, 131, no. 226; Petrescu-Dâmbovița 1977, 95, Pl. 147/1-7; Kacsó 2009, 168-169. For the number of lunulae pendants see the remarks of Kacsó 2009, 168-169.

108 Kacsó 2009, 169.

109 Kacsó 2009, 169, with bibliography.

110 Emődi 1978, 493.

111 Kacsó 2015, 377, with bibliography.
} 
to the early period of the Bronze Age ${ }^{112}$ and three others from the Hallstatt-era settlement (Ha B2 and through dendrochronology dated to the period between 1011 and 951 BC) in Bevaix-Sud (Switzerland). ${ }^{113}$ As tin was indispensable in the production of bronze and a sparse primary material throughout Europe (reserves of cassiterite, a tin oxide, are attested in France, SW England, Saxony, and Bohemia) ${ }^{114}$ it was only used independently for the production of certain artifacts, in rare cases. As for the prehistoric exploitation of tin in Transylvania, it cannot be excluded, at least on a theoretical level, as long as this metal was identified in numerous sources. ${ }^{115}$

Through the great variety of their types the amber beads ${ }^{116}$ (Pl. VI) describe a wide chronological range, but those which are bitronconic, long and tubular in shape, or those which are rectangular in section (Pl. VI/3-6) are characteristic to the LBA II period, possibly to the beginning of LBA III (Br. D, beginning of Ha. A1). ${ }^{117} \mathrm{We}$ also know of amber beads, but in incomparably smaller number and with a much more restricted typological variety, from other contexts, such as Igriţa Cave. ${ }^{118}$ These discoveries have been attributed to the Igriţa Group, thus grosso modo to the LBA II (Br. D) period as well. ${ }^{119} \mathrm{C}$. Ghemis, for example found in Unguru Mare Cave at Suncuius, (Bihor County) a bronze saltaleon and a small amber bead, ${ }^{120}$ and he has attributed the finds to the same cultural group. ${ }^{121}$ No C14 dates are unfortunately available in order to set the absolute chronology of the Igrița Group, but the dating of its core at least to the LBA II period can be regarded as a certainty. ${ }^{122}$

Regarding diachronically the presence of amber in the area under analysis, one notes the fact that no amber item is known from the Middle Bronze Period (MBA I-III, ca. 2000-1500 cal BC), the Wietenberg Culture, or the subsequent period, the LBA I, ca. 1500/1450-1350 cal BC, the early phases of the Deva - Bădeni ${ }^{123}$ and Noua ${ }^{124}$ cultures. There are a few such discoveries in Western Romania for the MBA: Pecica site ${ }^{125}$ and Satu Mare hoard ${ }^{126}$ (both in Arad County), but numerous south of the Carpathians, part of the Monteoru Culture. ${ }^{127}$ This might mean that local sources

112 Möslein, Rieder 1997, 68-70.

113 Nielsen 2014, 187-188, Pl. 7.

${ }_{114}$ Nielsen 2014, 180-181, Pl. 3; Vandkilde 2016, 105-106, Pl. 1.

115 Kacsó 2015, 391-392, with bibliography.

116 Ghemiș 2006, 126-127.

117 Sprincz, Beck 1981, 469-485; Boroffka 2002, 151; Gogâltan 2016, 155-158, with bibliography.

118 Ghemiş 2006, 125; Gogâltan 2016, 155-158, with bibliography.

119 Chidioşan, Emődi 1982, 22-25.

120 For the amber piece, there is also a spectroscopic analysis performed by C. W. Beck, which would prove the Baltic origin of the raw material (Ghemiș 2006, 130; Ghemiș 2007, 13).

121 Ghemiș 2006, 125; Ghemiș 2007, 10.

122 Chidioșan, Emődi 1982, 22-25.

123 Rotea 2016. We must also keep in mind that, on the one hand, small ones may have escaped quantitative excavations, and on the other hand, incineration could distroy for both cultures the possible amber beads from the tomb inventory.

${ }^{124}$ Wittenberger 2006, with bibliography.

125 Gogâltan 2016, 148, with bibliography.

${ }^{126}$ Kacsó 1998, 11-31, with bibliography; Gogâltan 2016, 148-149. For MBA amber in Hungary see: Sprincz, Beck 1981, 469-485; Jaeger 2014, 205-215, with bibliography and Gogâltan 2016, 149-151, with bibliography.

127 Boroffka 2002, 154, with bibliography; Frînculeasa 2013, 191, 193, with bibliography; Frînculeasa 2016, 123, Tab. 1, 138. 
were exploited for the latter cases (the most important deposit is in Colţi, Buzău County). It is also worth remarking that no discovery is known from Transylvania or Western Romania for Hallstatt B. ${ }^{128}$ Thus, in intra-Carpathian Transylvania amber is documented, at the current stage of research, only during the LBA II and only by the discoveries in "Cioclovina cu Apă" Cave, which is located on the western edge of this area and this might mean that the material was obtained along the Danube.

No glass pots or ingots, kilns or glass bead molds have been documented for Bronze Age in Transylvania. ${ }^{129}$ These are important arguments for one to admit that the blue glass beads discovered in this area are imports from other geographic regions. ${ }^{130}$ As for their dating, several observations can be useful. First of all, I should mention the fact that no blue glass bead is known from Transylvania from the Wietenberg Culture, from the Middle Bronze Age (MBA I-III, ca. 2000-1500/1450 cal BC). On the other hand, several such discoveries are known from the LBA I-III and they can be dated rather accurately. One glass bead was discovered in a grave of the Noua Culture, in the necropolis of Cluj-Napoca - Strada Banatului, besides numerous other items. The grave has not been dated directly, nor has the necropolis it belonged to, ${ }^{131}$ but considering its inventory and especially the absolute chronological benchmarks provided by the necropolis at Florești - Polus, mostly synchronic, one can envisage the interval 1400-1200 cal BC, LBA I-II. ${ }^{132}$ Several bronze objects and 36 glass pearls (Pl. XII/2) were discovered in the hoard of Dobrocina (Sălaj County), in a clay pot. ${ }^{133}$ The hoard has been attributed to the Uriu - Domănești/Uriu - Ópályi series, characteristic to the LBA II, ca. 1350-1200 cal BC. Two glass beads were discovered in tumulus no. 20 from the tumular necropolis, attributed to the Lăpuş Group, phase Lăpuş II, ${ }^{134}$ that is to be dated, based on the C14 samples collected from tumulus no. 26, to the LBA II. ${ }^{135}$ Only the hoard in Pecica II (Arad County), discovered in a clay pot, containing an impressive number of entirely preserved or fragmentary bronze items, had eight amber beads and two glass beads, which have

128 Gogâltan 2016, 156.

129 The same situation in the other territories of Romania, see: Frînculeasa 2013, 189-209, with bibliography.

${ }^{130}$ If the ceramic and metal have enjoyed the attention of Romanian archaeologists, glass is a less discussed problem, and for Transylvania they were missing modern interdisciplinary analysis. In this context, sometimes for the same artifacts, it is used the terms like glass, faience or vitreous material, and differentiations, separation between these is not absolutely clear (for the same opinion see: Frînculeasa 2013, 189). In some cases, analyzes do not help us either. For example, in the context of the international project coordinated by J. Varberg (Varberg et alii 2016), a few small fragments of glassy paste of the Wietenberg I necropolis from Sebeş (MBA I) (Fântâneanu et alii 2013) were analyzed by the courtesy of colleagues C. Fântâneanu and L. Bălan. But the nature of these artifacts we were not been able to determine, because they had a strong second combustion process (with the incineration of the dead) and the scarcity of samples. I also mention that all the glass beads from Transylvania were discovered only in graves or hoards.

131 Wittenberger 2006.

132 Rotea et alii 2014, 34 .

133 Roska 1942, 69, no. 63; Rusu 1963, 194; Petrescu-Dâmbovița 1977, 57.

134 Kacsó 2015, 383.

135 Metzner-Nebelsick et alii 2010, 219-233. Dating was regarded by the authors as too low, but more synchronous discoveries, which will be communicated soon, such as those from Pălatca - Togul lui Mândruşcă, are written in the same chronological order. 
been attributed to the Hallstatt A1 $1^{136}$ (LBA III, ca. 1200-1100 cal BC). A terminus post quem for the circulation of glass beads is around $1200 \mathrm{BC}$, when the invasion of the «Sea Peoples» paralyzed the commerce with these artifacts from South to North or diminished it drastically. ${ }^{137}$ One must thus admit that in Transylvania the use of blue glass beads reached a peak during the LBA II and it is only occasionally and in small numbers that they are found in contexts dated to the periods before and after, i.e. the LBA I and the LBA III (certain situations during this latter horizon might be, why not, the result of treasuring).

The cheek-pieces discovered in the gallery of altar A belong to type Tószeg according to A. Moszolics ${ }^{138}$ or to variant II according to N. Boroffka's typology. ${ }^{139}$ These variants are distributed especially in the Carpathian Basin and east of the Carpathians and are present ever since the MBA (ca. 2000-1500/1450 cal BC), but continued their evolution also during Hallstatt B (1000-800 cal BC). ${ }^{140}$ The decorated items from Cioclovina, with numerous analogies in the $\mathrm{MBA}^{141}$ and LBA I-II, ${ }^{142}$ may be linked to these cultural areas where horses play an important role.

The two ceramic shapes that can be reconstructed from fragments found inside the cave, the small amphora and the conical bowl with inverted rim (Pl. VIII/3) are common types for the LBA II. The double-bodied vessel (Etagengefäße) is very well represented (and the standard shape) among discoveries from caves attributed to the Igrița Group ${ }^{143}$ and is a shape very probably adopted from the ceramic repertory of the Gârla Mare Culture. ${ }^{144}$ Subsequently, this shape features, for example, in level I from Teleac, ${ }^{145}$ dated to the Hallstatt A2, ${ }^{146}$ or in the cultures from the central Danubian area from the Middle Danubian Urnfield. ${ }^{147}$ The conical bowl with inverted rim has an even wider temporal and geographic distribution and is a constant presence among the discoveries belonging to the groups that are characteristic to the LBA in Transylvania: Igrița, ${ }^{148}$ Cruceni - Beleghiş, ${ }^{149}$ Susani, ${ }^{150}$ Deva - Bădeni ${ }^{151}$ etc.

\footnotetext{
136 Petrescu-Dâmbovița 1977, 101-102.

137 Varberg 2017, with bibliography.

138 Mozsolics 1953, 74-80.

139 Boroffka 1998, 100, 102, Pl. 10. Also see: Hüttel 1981, 82-94.

140 Boroffka 1998, 107, 133.

141 Mozsolics 1953, 74-80, Pls. 9-11.

142 Diaconu et alii 2014, 219-227; Kacsó 2017a, 149-150, Pl. 18/1-6, with bibliography.

143 Emődi 1980, 254-256, Pls. 5/7, 12/84, 19/152, 22/182, 26/229; Chidioşan, Emődi 1982, 65, Pls. 2/1-3, 3/1, with bibliography.

${ }_{144}$ Dumitrescu 1961, 134-136; S,andor-Chicideanu 2003, 47-49.

145 Vasiliev 1991, 82-83.

146 Ciugudean 2012a, 229-243.

147 Przybyła 2009, 335, Pl. 94.

148 Emődi 1980, Pl. 19/157-158; Chidioșan, Emődi 1982, Pls. 3/4, 4/1-2, 4-5.

149 Radu 1973, 505-506, Pls. 4/3, 5/2,5; Gumă 1993, Fig. IX/5.

150 Stratan, Vulpe 1977, 37-38, 47-48, Pls. 5/3, 10/79-92, 11; Gumă 1993, 170, Pl. XX/1; Gumă 1995,
} 121, Pl. III/3.

151 Rotea 1994, 54, Pl. 1/1. About the so-called Deva-Româneşti group (Popa, Totoianu 2010, 226), which takes part of the name, but also the archaeological content of the one I have named, since 1994, Bădeni III-Deva, I will say, over the issues of deontological or human evaluation, that in archaeological logic it is only an exacerbation of the particular to the detriment of the general, in other words an 
Finally, the most important element in the dating of the hoard is the result of the C14 analysis of an herbivore's bone discovered in hall B. The analysis was performed by the laboratories of the "Horia Hulubei" National Institute of Research and Development for Nuclear Physics and Engineering from Bucharest and the result placed sample in the interval 1428-1262 cal BC (2 sigma, 95.4\% probability). ${ }^{152}$

Thus, matching the set of chronological benchmarks presented above, one can admit that "Cioclovina cu Apă" Cave, even if it was in use for a longer period, through repeated votive depositions, these do not seem to go beyond the LBA II period (1350$1200 \mathrm{cal}$ BC) (Br. D in the chronology of Central Europe), except in some insignificant marginal manner. The dating to the LBA II of the artifacts from Cioclovina might have a series of significant effects, including the more precise chronological identification of some hoards of the same type from the Arpăşel series. ${ }^{153}$ Another consequence is, for example, the redefinition of the period of maximum use of the tutuli, which becomes the LBA II and not the LBA III, as according to M. Rusu's calculations. ${ }^{154}$ 10 tutuli were found in three hoards during the LBA II (Br. D), while 1967 tutuli were found in 10 hoards during the LBA III (Ha A). Still, according to the counting performed by the same researcher, ${ }^{155} 1828$ out of the 1967 tutuli are from "Cioclovina cu Apă" Cave, so that the proportion becomes reversed: 1838 items in 4 hoards during the LBA II and only 139 in 9 hoards during the LBA III.

The Giula hoard, ${ }^{156}$ which I mentioned, raises another important issue: the time between production and deposition of artifacts (the life of artifacts). This hoard was most likely deposited in LBA II. ${ }^{157}$ But the production of artifacts must have been very early in relation to the deposition moment. Illustrative in this case is the beautiful decorated belt/plaque (Pls. XXIV/1, XXV). It has been kept fragmentary since it has been broken in ancient times, but we have no clear evidence for intentional fragmentation before deposition. But it is absolutely certain that it has been used for a very long time before being deposited. Revealing are cracks or ruptures due to the use (it is however a metal foil, copper, with a high resistance) followed by many repairs it has suffered over time (Pl. XXIV/1a). On the other hand, these repairs help us understand its particular importance for the community that used it, including the symbol that it is covered (the sun and its movement in the sky, the wheel symbolizing the sun, the double axe?) (Pls. XXIV/1, XXV). ${ }^{158}$ Significant is also a technical detail with chronological implications, on which I want to come back with another occasion, the way in

inappropriate regional division of a general phenomenon. The same observations are valid for the so-called Gligorești group (Gogâltan, Popa 2016, 181-202).

${ }^{152}$ From the Cioclovina Cave, some other evidence is being analyzed and the results will be published in detail by the whole research team (coordinators: Tiberiu Sava and Mihai Rotea).

153 An example might be the recently published hoard from Lipova (Gogâltan, Sava 2014, 183-209).

154 Rusu 1972, 251.

155 Rusu 1972, 251.

156 Roska 1942, 131, no. 226; Petrescu-Dâmbovița 1977, 95, Pl. 147/1-7; Kacsó 2009, 168-169.

157 Most likely this hoard belongs to this chronological horizon (also see: Mozsolics 1973) and not to the Hallstatt A (Petrescu-Dâmbovița 1977, 95).

158 Rotea 2016, with bibliography. If the Beotian shield did not exist during the Transylvanian LBA I-II, we need to think of a figure-of-eight shields, of a half rosette frieze or most likely of a labrys. 
which the spokes of the Giula wheels (Pls. XXIV/1, XXV) are caught compared to that of Uioara de Sus (Pl. XXVI).

Therefore, on a global level we must admit that there are several difficulties in dating with certainty the hoards. ${ }^{159}$ Thus, researchers must pay extra attention to the study of the archaeological complexes with complex stratigraphy consisting of pottery and metal items from sites ${ }^{160}$ or of the composite hoards (consisting of heterogeneous artifacts), such as the one under analysis here. Dating problems are also caused by the fact that the differences noted between the LBA deposits speak not of unitary series, but different types of hoards with variable length of evolution/duration and with a more limited geographic distribution ${ }^{161}$ that coexist in different areas or in the same area. The Arpășel-type hoards for example, from the environment of the western cultural groups (Igrița and Cehăluț) are almost exclusively composed of jewelry pieces (Schmuckhorte), ${ }^{162}$ while those in central and eastern Transylvania, from the area of the Noua and Deva-Bădeni cultures, consist preponderantly of weapons and tools ${ }^{163}$ (a recent exemple: Cluj-Napoca - Tufele Roşii; Pls. XIII-XV). This real but generalized picture (because each area contains the other type of deposit beside the dominant type) is not only interesting but it also opens multiple perspectives of interpretation, starting from the fact that the military connotations faded in the first case and became stronger in the second. I shall not approach here this vast and enticing subject, with numerous references to the spiritual, social, and political spheres, but before continuing, I shall note that the different manners in which weapons were valued can even lead to the identification of the possible military resorts of the invasion of the Sea Peoples. ${ }^{164}$

Significations. In order to "read"/explore the significations of the hoard from Cioclovina, I believe we must start from bringing together the following fundamental elements: the cave, the water, the mountain, the forest, the ritual depositions/sanctuaries, the female exotic jewelry items, and horse gear.

Caves are attractive spaces that impress and inspire people; they can provide shelter but can also hide dangers (even if only in exceptional cases). The interaction between people and caves is very old and caves are a special category of archaeological monuments, in connection to the beginnings of human habitation. ${ }^{165}$ They are, to an equal degree, the scene/space for the practice of ritual activities (many of the caves are attested as sanctuaries where offerings were placed). ${ }^{166}$

159 Moreover, for example, the separation of hoards with ornaments (Schmuckhorte) between LBA II (Br D) and LBA III (Ha A1).

160 Unfortunately, the number of sites with relevant metal discoveries is very small in Transylvania.

161 Kacsó 2000, 32; Rotea 2009, 38-39; Rotea 2016; Kacsó 2017b, 29, with bibliography.

162 Kacsó 1995, 81-130, with bibliography; Kacsó 2009, 169.

163 For the contents of these deposits, see: Rusu 1972, passim; Petrescu-Dâmbovița 1977, passim; Bader 1978, 81-108; Kacsó 2017b, passim.

${ }^{164}$ For the general problems of this phenomenon see: Sandars 1978, with bibliography; Vulpe 2001a, 287-289, with bibliography. If the possible contribution of the Danubian space to this phenomenon has often been highlighted, the perspectives are different than those I have invoked.

165 Boroneant 2000, passim; Păunescu 2001, passim.

166 For Transylvania see: Emődi 1978, 489-492; Emődi 1980, 229-273; Kacsó 1999, 113-126; Molnár, Ghemiş 2003, 41-92; Ghemiş et alii 2014, with bibliography. For the Aegean areas: Nilsson 1927, 49-72, 
"Cioclovina cu Apă" Cave is a special cave, ${ }^{167}$ first of all because it is crossed over its entire length by a creek and this renders it unsuitable to habitation (unlike "Cioclovina Uscată" / "Dry Cioclovina" Cave which is located a small distance away), ${ }^{168}$ including the area of the portal (Pls. I/2, II/3, X/2, XI/1-2). The space where the prehistoric artifacts have been deposited is a considerable distance away from the portal (ca. $130 \mathrm{~m}$ ), i.e. from the lit part of the cave, much beyond the border between light and darkness that can signify the border between this world and the one beyond. We must admit that people made unusual efforts to reach the area in question, using modest lighting devices (torches), passing at first through a small lake and then through a narrow gallery crossed by a strong stream; in order to do this, their motivation obviously had to be non-habitational. Taking also into consideration the quantity, quality, and exceptional array of offerings deposited in hidden, inaccessible places, including the possible modelling of the used space («walling-in» certain niches, designing altars), ${ }^{169}$ we are yet again convinced that this was not a usual, profane action, but one with special meanings: sacred/cult-related/ritual ones. ${ }^{170}$

The situations in which dark spaces, removed from daily life, became centers of cults, are not isolated. ${ }^{171}$ Nevertheless, the creation of a cult-related space during Prehistory, including its archaeological interpretation as such, are complex phenomena that involve a large number of factors and observations, even more so as many human actions cannot be possibly detected through archaeology. ${ }^{172}$ Returning to the "Cioclovina cu Apă" Cave and remaining within the terms of archaeological visibility, as long as there are no representations of the adored divinities, ${ }^{173}$ the presence of the altars and of the votive offerings (the latter as results of a repeated behavior) are relevant pieces of evidence for admitting the cult-related status of this space. ${ }^{174}$ In all cult-related spaces, the essential piece of sacred furniture in a sanctuary is the altar. ${ }^{175}$ It is used either to obtain or to receive sacrifices. Placed properly, it is located either in areas where sacrifices are performed or in sanctuaries/temples. Altars are most often tables with a smooth top, in order to support solid offerings, or can have drainage channels for blood or other liquids. As previously indicated, not one but three depositional spaces were in use in the «Great Hall». These depositional spaces that I have already called altars or hall/gallery-altar were repeatedly used to support offerings. The

95, 392-394; Burkert 1985, 24-26, 68-70; Marinatos 1993, 123-126; Moyes 2013; Stampolidis, Kotsona 2013, 188-200, with bibliography.

167 Buduran et alii 2013.

168 Roska 1942, no. 81; Păunescu 2001, 226-232; Boroneanț 2000, 80-90; Luca et alii 2008, 48, with bibliography.

169 Emődi 1978, 493.

170 The standardization of depositing acts and their spatial differentiation from everyday life are indices of ritual character of discoveries (Bell 1992, 90-91).

171 Supra, footnotes 165 and 166.

172 Renfrew 1985, 19-20, 24-29. For the identification of sanctuaries, also see: Prent 2005, 12-26.

173 Also, some sacred caves in Crete did not produce any cult images, see: Prent 2005, 208.

174 Nilsson 1927, 53, 58, 70, 98-101; Renfrew 1985, 25; Jones 1999, 5-6, 23-4, 69-72, 80.

175 Nilsson 1927, 98-101, with bibliography; Marinatos 1993, 5-8, 116, 118, 120, with bibliography. For Transylvania MBA and LBA altars, see: Rotea et alii 2011, 16-17; Costea, Székely 2011, 107-113; Bereczi 2016, 24-26. 
structure of altar A is the closest to the classical description of such an element. Still, the other spaces as well, selected out of other dozens or hundreds of possible options the cave provides, were probably provided with similar structures made of degradable materials; it is also possible that the natural characteristics of the galleries were used, with small interventions. Finally, admitting that all the offering deposition areas in the Great Hall form an ensemble, subordinated to the place where water springs from one of the cave walls, the spring of divinity, we are certain that this was a prehistoric sanctuary, created around this spring.

"Cioclovina cu Apă" Cave also cumulates other constitutive elements (they are not binding, but favoring) of a cult-related space. The first is the geographic context. The cave is located in a remote mountainous area, of unique natural beauty; it opens at the base of a spectacular limestone cliff, surrounded by the forest, by wild vegetation (Pls. I/2, II/1-3). This place, very pleasing to the senses, impresses and overwhelms through greatness and wildness and invites reverie, but it also provides a cool and refreshing environment during the hot periods of the year. The second element is the impressive natural "architecture" of the cave itself: a conglomerate of galleries, niches, passages, rooms, and water basins, the latter allowing those who entered to purify themselves $^{176}$ (Pls. I/2, II/3, X/1-2, XI/1-2). Finally, the impressive dimensions and overwhelming aspect of the gallery called "The Great Hall" could have constituted other fundamental reasons that led to the transformation/setting up of this subterranean room in/as an ideal place for those who worshiped the divinities. The natural «architectural» plan of this hall, with the water springing from one of the walls, could have been interpreted as the work of the gods and thus a place that was very close to them, that opened a line of communication between the supernatural and the human realms. ${ }^{177}$ One thus has all the premises to conclude that this was a consecrated place, a sanctuary where the adored divinity manifested itself naturally and fully.

The use of caves for sacred ritual purposes is also known from other Bronze-Age discoveries in Transylvania. I shall only mention the known ritual complexes dated to the EBA or the LBA from the caves of Izbucul Topliței, ${ }^{178}$ Igrița, ${ }^{179}$ and Mişid. ${ }^{180}$ On the other hand, the sacred caverns of Greece (Agia Paraskevi Cave, Psychro Cave, Idaean Cave etc.) are also full of altars and votive, deposited through rituals, frequented by the ancient adepts of different deities: Zeus, Eleuthia, Demeter, but especially Pan and the Nymphs. ${ }^{181}$

Admitting that "Cioclovina cu Apă" is a prehistoric cult-related place/sanctuary (I use the terms here as synonyms), the next step is to try and identify the adored deity. Even in the absence of ritual images, the hypothesis that a female deity was adored in this cave is directly supported by the artifacts deposited as offerings: the great majority consists in jewelry items made of bronze, glass, tin, faience, and amber,

176 Renfrew 1985, 17-19; Burkert 1985, 86-87.

177 Eliade 1965, 59-62.

178 Halasi, Emődi 1985, 232; Molnár, Ghemiş 2003, 41-92, with bibliography.

179 Emődi 1980, 229-273; Chidioșan, Emődi 1982, passim.

180 Kacsó 1999, 118-119, 124, with bibliography; Ghemiş et alii 2014, 32, 35.

181 Nilsson 1927, 19-67; Burkert 1985, 23-26, 48, 170; Marinatos 1993, 123-126; Jones 1999, passim; Larson 2001, passim; Stampolidis, Kotsona 2013, 188-200, with bibliography. 
preponderantly discovered in women's graves. ${ }^{182}$ The argument in support of the presence of a female deity could be, in my opinion, even stronger, as another fundamental element that defines Cioclovina Cave is the presence of water in multiple manners of presentation: flowing water, lake, cascade, spring. For Mircea Eliade water is "fons et origo, reservoir of all the potentialities of existence", ${ }^{183}$ thus the matrix of life itself, and from this perspective a dominating feminine element. Rivers, water wells, and springs have entered the realm of the sacred since the most ancient times, as they were seen not only as simple eruptions of water, but also as eruptions of spiritual power. Beyond its possible curative properties, water is in all cultures a symbol of regeneration, of purification (as fresh, living water is connected to cleanliness), most often governed by female spirits, by goddesses.

In the context in which several known female deities associated with nature and same time horses (Potnia, Demeter, Artemis etc.) have been envisaged in attempts to explain the discoveries from Cioclovina and other more or less similar ones, ${ }^{184}$ I shall put forward an alternative: the cult of the Nymphs. As one knows, these are female beings, divine or semi-divine in nature. ${ }^{185}$ Caves, rivers, springs, woods, mountains, and valleys were often possessed by Nymphs to which people payed tribute and sometimes even made sacrifices. ${ }^{186}$ Those who were associated with water and springs, as in the case under analysis, were called Naïades (Ancient Greek: Naïó $\delta \varepsilon \zeta)$. It is also worthy of note that in the ancient Greek world the Nymphaeum or nymphaion was often a natural cave, ${ }^{187}$ only subsequently becoming special, complex cult-related constructions.

In the Homeric texts, just like in other literary sources, the Nymphs are strongly connected to caves, springs, and free nature. ${ }^{188}$ Thus:

"At the head of the harbor is a long-leafed olive tree, and near it is a pleasant, shadowy cave sacred to the nymphs called naiads" (Homer, Odyssey, XIII, 103-105);

or

"Cold water flowed down from the rock above, and on the top was built an altar of the nymphs where all passers-by made offerings", (Homer, Odyssey, XVII, 209-211).

182 For example, see: Metzner-Nebelsick, Nebelsick 1999, passim, with bibliography; Frînculeasa 2013 , 191, Pl. 2; Peche-Quilichini et alii 2016, 67-79, with bibliography; Varberg 2013, 147-157; Cwaliński 2014, 194, with bibliography. Part of the recently analyzed glass beads from Denmark was found in a woman's grave from Ølby (Varberg et alii 2016, 5, with bibliography). This grave is also a combination of bronzes, glass and amber, is distinguished by a beautiful belt disk. I note that this disc-belt resembles a lot with the discs of the butted axes from the Carpathian basin, including the symbolic decoration (the mountain and the navel-the center, the spirals-water or sky) (Rotea 2016) (Pl. XXI/f). Also, we do not omit the fact that some of these types of adornments (bronze, glass and amber jewerly are found along with arms or tools and in the graves of men (see, for example, the situation in northern Europe, graves from Serridtslev and Silkeborg) (Varberg 2017, with bibliography) but they are always exceptions to the rule and/ or discoveries whose inventory is far from the variety of jewelry of Cioclovina.

183 Eliade 1952, 151-153; Eliade 1965, 131.

184 Nilsson 1927, 434; Metzner-Nebelsick, Nebelsick 1999, 93-99, with bibliography; Varberg $2013,155$.

185 Larson 2001, 3-11.

186 Larson 2001, 26-27, 43-44, 131-134, 170, 183, 188.

187 Larson 2001, 110.

188 Larson 2001, 8-11. 
If so, the cave in Cioclovina also fulfills all the conditions.

Caves, springs, rich vegetation, even gardens are elements of nature connected with nymphs ${ }^{189}$ about which not only Homer speaks, but also other historical sources. ${ }^{190}$ A bilingual antique inscription (Greek-Latin) with an exceptional content, discovered in Geoagiu (Hunedoara County, the ancient Germisara), that I. Piso has exceptionally interpreted, ${ }^{191}$ falls into the same thematic sphere: cave-water-Nymphs. The inscription speaks of the thermal springs in Germisara: "Sunt Getici fontes divina nympha creati" (The springs of the Getae were created by the divine Nymph) and were under the protection of one or several Nymphs associated with Aesculapius, Hygeia, and Artemis/Diana. ${ }^{192}$

There are also other elements that not only support this scenario, but can also develop it further. For this we shall return to the archaeological content of the hoard. We were able to note that the main types of pieces refer to, even if not each one individually exclusively, ${ }^{193}$ then certainly through their association, to the presence of a feminine divinity (blue glass beads or amber beads besides the numerous types of jewelry items made of bronze), ${ }^{194}$ while others (cheek-pieces) were certainly part of some horse gear. I have excluded here many artifacts with double function such as phalerae, saltaleoni, tutuli, that can decorate both parade horse gear and human attire. ${ }^{195}$ Thus, accepting the hypothesis that this is a case of veneration of a feminine deity who could be, as I have suggested, a Nymph, or a Nymph with the joint attributes of another female deity, one must accept that this deity or deities was/were associated with horses. The woman-horse relation is not a unique association. There are numerous examples in Greek mythology (Potnia, Demeter, Athena etc.) ${ }^{196}$ and not only. Epona, the Celtic goddess venerated as Epona Augusta in the Roman imperial cult, was considered to be both woman and mare and monuments in her honor depicted her extensively besides horses. ${ }^{197}$ The beginnings of her adoration have been connected to the importance of the cavalry for the Celts. The same can be held true for the society of Transylvania during the LBA. ${ }^{198}$

The working hypotheses regarding the interpretation of the significations of the hoard from Cioclovina do not stop here and neither do they, imperatively, exclude each other. I have insisted that the spot in the "Great Hall" where water springs from one of the cave walls (the cave is otherwise dry) represents the epicenter of the cult-related

${ }^{189}$ For example, not only the link between nymphs and gardens is known (Larson 2001, passim), but also between gardens and elites in LBA (Day 2006, 189-195, with bibliography).

190 Larson 2001, 14, 16-18, 26-28, 75, 229.

191 Piso 2015, 47-68.

192 Piso 2015, 49, 51, 57.

193 Some adornments could also be worn by men, see: Varberg 2017, with bibliography.

194 This combination of artifacts is found, for example, in the graves of women in southern Europe (Cwaliński 2014, 194, with bibliography).

195 For the use of tutuli or phalerae, see: Pârvan 1926, 432-433; Rusu 1972, 251; Bader 1978, 106; Emődi 1980, 256; Gogâltan, Sava 2014, 192-201, with bibliography.

196 Nilsson 1927, 400, 434; Metzner-Nebelsick, Nebelsick 1999, 93-99; Varberg 2013, 153-156, with bibliography.

197 Green 1986, 91-94, 173-174.

198 Rotea 2016, with bibliography. 
space (Pl. XI/2). Starting from this point, the creek crosses the cave, forming small cascades and producing a specific sound, loud, filling the entire hall. Nothing stopped prehistoric men and women from interpreting these sounds as a «voice», a voice of the cavity, a speaking-trumpet of the world beyond. We thus tend to believe that in the case of the rituals performed in "Cioclovina cu Apă" Cave, even if a Nymph was venerated or a Nymph combined with another deity, in both cases associated to horses, one cannot exclude oracle-like significations. ${ }^{199}$ If one accepts my hypothesis, then there is also the possibility that those who performed these rituals (possibly women) and who entered the cave to place the offerings, were most likely into a trance (under the influence of alcohol, opium, or mystic fervor) and could have had visions of the future starting from these sounds. Could Hypnos have played his part, as the ancient inscription from Germisara suggests, ${ }^{200}$ since we know from Ovid that Hypnos used to live and sleep in a cave? Remember the interpretation given by N. Marinatos to a seal stone from Cnossos, ${ }^{201}$ in which a woman rests her head on a stone (if the stones is a cult monument, I think they can symbolize a cave) possible to asleep dreaming visions (a state of incubation). The limits of prehistoric archaeology though force us, at least for the time being, settle on the idea that Nymphs were often associated not only with sacred springs, woods, caves etc., but also often with oracles. ${ }^{202}$

From a global point of view, we must admit that the archaeological documentation speaks clearly about the personality of the divinity as well as that of the communities that serve it. As for the first aspect, I will discuss the second something further, J. Levy ${ }^{203}$ rightly warns us about the fragility of the arms-male-violence-authority and ornaments-female-display-passivity chains. An example may be the horse-woman combination that we often find, accompanied by warlike connotations, in many archaeological contexts. ${ }^{204}$ However, we must admit that, at least for the moment, these are missing in the Cioclovina Cave.

$$
* * *
$$

Recognizing a deity's power triggers the obligation to show it obedience, respect, gratitude, and adoration by actively taking part in rituals, through words, gestures, and prayers, but also through sacrifices. The global picture of the sacred activities performed in "Cioclovina cu Apă" Cave would remain partial in the lack of several observations regarding the sacrifice and purification rituals that certainly took place, under the coordination of priests, outside the cave (open-air sacrificial area), near or under the cave portal (Pls. I/2, II/3).

The animal bones discovered in Gallery $\mathrm{B}^{205}$ speak of the ritual sacrifice of certain animals, which must have taken place near the entrance to the cave, not in interior.

\footnotetext{
199 Larson 2001, 11-13, 162-163.

200 Piso 2015, 47, 63.

201 Marinatos 2009, 80-81, Pl. 7/3a.

202 Larson 2001, 11-13, 162-163.

203 Levy 1999, 216.

204 See for example: Varberg 2013, 147-157, with bibliography.

205 Emődi 1978, 484.
} 
A small part of the sacrificed animal was then transported and deposited inside the cave by the men and women who served the cult. Analyses performed on the discovered osteological remains have identified the presence of deer/goat and pig $^{206}$ (in one case most likely a boar ${ }^{207}$ ). The fact that horses are missing is significant and makes us believe that they were not sacrificed, as one could theoretically presume, considering that their ceremonial tack elements had been deposited in the cave, but most likely venerated. Coal fragments discovered in the same gallery B also indicate the practice of ritual burnings, ${ }^{208}$ as does the ash that must have also been envisaged as an offering. ${ }^{209}$ Ritual fires, often seen as sacred or even of divine origin, fulfill several functions, including that of purifying. ${ }^{210}$ One should attribute the same purifying role to the water that crosses the cave and that must have also played an essential role in these ceremonies. Besides an altar, weapons and pots were also required in performing the sacrificial rituals and we shall attempt to identify them through future researches. Nothing is known on the sacrificial weapons there, but the pots found in halls B and $\mathrm{C}$ could have been initially used in these rituals and then deposited inside the cave together with other, perishable offerings. Thus, all these ceremonies took place before the act of depositing the offerings inside the cave and they completed it, and incantations, music, and dance must have also had an important role; ${ }^{211}$ everything was meant to ensure that the divinity had a beneficent attitude towards the people, and to ward against its nefarious actions.

Also, do not forget that the isolated location of the cult place/sanctuary implies other consequences. Because getting to the sanctuary was already a memorable event with many spiritual and physical experiences along the way. In other words, the sacred route/way, which physically connected the site for guests with the sanctuary, included stationary public rituals (sacrifices, prayers) or for short pauses for catching breath. We do not know about all of this and we probably will not know significant things for a long time.

The hoard of the sanctuary discovered in "Cioclovina cu Apă" Cave provides exceptional data not only on the beliefs during the LBA, but it also enlightens certain elements of the economic, social, and political life during this period, as ritual is often considered as a form of social control. ${ }^{212}$

"Cioclovina cu Apă" Cave was a sanctuary-cave located in a remote, wild area where no settlement from the Late Bronze Age has been identified over a radius of at

\footnotetext{
206 Emődi 1978, 484. The osteological differences between these and goats are very small. The presence of goats in nymph cults is a constant (Larson 2001, passim).

207 The observation belongs to our colleague, Dr. Diana Bindea (National History Museum of Transylvania), and we thank her for studying the photos of the bone material from the J. Emődi collection.

208 Some of these could be the remains of the torches used for lighting.

209 See for example: Rotea et alii 2011, 12, 15-17, with bibliography.

210 See for example: Rotea 2003, 52-56, with bibliography.

211 Larson 2001, 24, 62, 75, 78; for the inscription from Germisara, see: Piso 2015, 51, 63.

212 Bell 1992, 171-181, 189, with bibliography.
} 
least 10-15 km. ${ }^{213}$ Despite this fact, the place became, for a good period of time, one of the most frequented and important prehistoric sanctuaries that managed to hold one of the most valuable prehistoric hoards, not only from Romania, but from the entire temperate Europe. Leaving beside the special spiritual connotations of this fact, one must remark that the hoard is also the most eloquent evidence of the economic prosperity of the Transylvanian area during the LBA. It was foremost the prosperity of the Mureş Valley, as a crucial economic axis during Prehistory in Transylvania; Cioclovina Cave is $35-40 \mathrm{~km}$ away from this valley following the routes of Streiului and Luncanilor valleys (Pl. I/1). Behind this economic prosperity, pointed out by the remarkable results of researches performed on numerous LBA sites along the Mureş, ${ }^{214}$ one must certainly discern the benefic role of the local elites. ${ }^{215}$

For a long time specialists have been studying the long-distance contacts between the Aegean-Anatolian region and Central, and Northern Europe, starting from the analysis of the numerous types of artifacts, ${ }^{216}$ among which amber played a determining role. ${ }^{217}$ The «amber routes» have thus been identified (some including Transylvania as well) and the manner in which amber circulated has been analyzed. ${ }^{218}$ The most recent analysis of the origin of the amber beads from Cioclovina has led to the conclusion that the south-Carpathian source was used, though the northern European one cannot be excluded (from the Baltic). ${ }^{219}$ From these perspectives one must also take into consideration the fact that the closest source of amber is at Colți, ca. $400 \mathrm{~km}$ from Cioclovina (using south-east Transylvanian road), while the Baltic sources are several times further. Recently important steps have been taken in defining a route for glass, as there is palpable evidence of an intercontinental commerce that connected Mesopotamia/Syria and Egypt, passing through Greece, with the central and northern parts of Europe. ${ }^{20}$ Another, ongoing project focuses on studying the origin of Bronze-Age tin from the territory of Romania. ${ }^{21}$ The project has also included the analysis of samples from the hoard from Cioclovina and the results, soon to be structured, also open new perspectives on the inter-connections between different cultural spaces. Still, the file of the pan-European commercial routes that are connected to the

213 Luca et alii 2008, 36, for Boșorod commune area.

214 For the sites on the Mureș Valley in the Deva-Simeria area, see: Andrițoiu 1992, 124-125; Luca et alii 2008, 66-70, 158-159, with bibliography; Rişcuța, Marc 2015, 41-80.

215 Rotea 2016.

${ }^{216}$ For example, see: Bouzek 1985; Primas, Pernicka 1998, 25-66; Harding 2000, passim; Kristiansen, Larsson 2005, passim; Maran, Van de Moortel 2014, 529-548; Vandkilde et alii 2015, 5-37, with bibliography; Vandkilde 2016, 109-112; Varberg et alii 2016, 1-11, with bibliography; Rotea 2016.

217 Harding 2000, 175, 187, 189-190; Kristiansen, Larsson 2005, 122, 158; Czebreszuk 2011, passim; Maran 2013, 147-69, with bibliography; Cwaliński 2014, 194-196.

218 Czebreszuk 2011, passim, Pl. 32, with bibliography.

219 Teodor et alii 2010, 2395.

220 The analysis of LBA glass beads over larger areas is starting to bear fruit (for example: Henderson 1988, 435-451; Nikita et alii 2006, 39-46; Henderson 2013, 127-202, with bibliography; Varberg et alii 2016, 1-11; Purowski et alii 2016, 1-20, with bibliography) even if not all of the conclusions are still accepted unanimously. From our point of view, the addition of Transylvania to a European glass route, connected to the Oriental one (Varberg et alii 2016), remains a notable fact on which we intend to come back on another occasion.

${ }^{221}$ A Romanian-American international project (coordinated by A. Bankoff, W. Powell and M. Rotea). 
hoard from Cioclovina and the world that created it remains voluminous and open; this is a vast topic that I have only approached in passing. Before closing it, I mention the fact that the discoveries invoked on this occasion, besides many others, speak of a dense network of routes spreading in all directions, along which different materials circulated and that place Transylvania in a significant, if not priority position in the prehistoric European area, not only from the perspective of amber and glass, but also from that of gold, salt, or copper. ${ }^{222}$ Once opened, commercial routes mediated, not only the circulation of one good, but of different products together with diverse technical knowledge; through the use of terms such as amber, glass, tin, or gold route one only indicates the artifacts from which researches have started identifying them.

Some Transylvanian milestones help us to understand the situation of circulation of good, techniques, ideas, symbols and/or beliefs. All the roads that followed the important rivers descending from the Apuseni Mountains (Arieş, Aiud, Certej, Ampoi etc.) and flowing into Mureș river created the gold corridor/road; ${ }^{223}$ even the Romanian name of the Arieș River comes from the Hungarian aranyos, that means gold. But all of these road also circulated other important raw materials: copper, silver, wood etc. Extremely interesting is that at their confluence with Mureş important economic, social and politic Middle and Late Bronze Age sites were born, which I believe that had the role of harbors (through their location and very probably by their wealth). ${ }^{224}$ In my opinion, Gligorești - Holoame, ${ }^{225}$ at the confluence of Arieș with Mureș river, Aiud - Cetătuie, ${ }^{226}$ at the confluence of Aiud with Mureș river, Uroi Sigheti ${ }^{227}$ and S,oimuş - Teleghi, ${ }^{228}$ at the confluence of Certej with Mureș, are some examples. Therefore, the discovery of a boat-shaped wagon model in the Uroi - Sigheti site does not appear to me as a hazard, as it is completed by a bird-shaped vessel, both of which belong to the Wietenberg culture (phase II, MBA II) (Pl. XVI/2-3). ${ }^{229}$ They are not a unique discovery, because there are various and different combinations of birds-boats/ships-wagon-vessels ${ }^{230}$ and these do not remain only in the economic, transportation area. ${ }^{231}$ Moreover, while there is much evidence for these spectacu-

${ }^{222}$ Harding 2000, 198, 251-254; Kristiansen, Larsson 2005, passim; Harding, Kavruk 2013; Rotea et alii 2011, 13, Pl. 7/1; Rotea 2016, with bibliography.

${ }^{223}$ Ciugudean 2012b, 219, 223, used this term only for Ampoi valley.

${ }^{224}$ Rotea 2016. The detailed study of the harbour sites remains to be done with the necessary publication of all their archaeological content. But, I have preferred to use the term harbour site, to define a site that also performs this type of activity and which was very close to the Mureș riverbed, and is suitable for landing boats.

225 Gogâltan, Popa 2016, 181-202, with bibliography.

${ }_{226}$ Ciugudean 1978, 49-62, with bibliography.

227 Marc et alii 2015, 81-92.

228 Rișcuța, Marc 2015, 41-80.

229 Marc et alii 2015, 81-92, Pl. II.

230 Boroffka 1994, 167-168, for Derșida and Ciceu-Corabia artifacts; Marc et alii 2015, 83, with bibliography. Some observations are needed. In my opinion, Ciceu-Corabia boat-wagon model belongs to the Deva-Bădeni group, phase I, and not to the Wietenberg culture. Also, I think we need to be very careful when we look at fragments of artifacts of this type, for example the one from Derșida might not be a birdboat-wagon model, because it could be just a bird-boat or bird-boat-vessel model (Pl. XVII/1). More than that, some pieces with wagon general form can have vertical perforations to be suspended (Pl. XVI/1), so a different category of artifacts.

${ }^{231}$ Rotea 2016, with bibliography. 
lar models starting with the last part of Wietenberg Ib (MBA Ib), they flourished later, in Wietenberg II (MBA II) (Valea Chioarului - T, Tualău metallurgical horizon) and Wietenberg III (MBA III) (Ighiel - Târgu Mureș metallurgical horizon) culture phases. ${ }^{232}$ The new and special long butted-axes of MBA is another example, because his poll, from my point of view, is a representation of the Minoan ship (Pls. XVIIIXIX). ${ }^{233}$ The Minoan ships with stern bifurcation ${ }^{234}$ and/or representations of waves of water (Pls. XVIII-XIX), human silhouettes on the board boat or in different situations (Pls. XVIII/1-2/a, XXI/a), on disk butted-axes (Pl. XXI), are just some other elements of a possible taurokahapsia scene (Pl. XVIII/1); boat mast or tree of life (Pl. XXI/2c), the boat and the sun which travels (Pls. XIX, XXI/2b, d) are also symbols found in the new set of beliefs of Wietenberg - Otomani/Füzesabony cultures (MBA) and not only, ${ }^{235}$ most of them being taken from the Minoan civilization, remodeled/redesigned ${ }^{236}$ and transmitted further to central and northern Europe..$^{237}$ Similar representations of boats on the Nebra disc and the Carpathian swords have already been noted; ${ }^{238} \mathrm{I}$ just add the presence of human silhouettes and/or of water waves on the Hajdúsámson-Apa swords. ${ }^{239}$ Furthermore, I believe that bracelets from the Transylvanian Middle Bronze Age (certainly belonging to the second phase of the Wietenberg culture $)^{240}$ (Pl. XXIII/1) and the Late Bronze Age with the double axe symbol/labryx (Pl. XXIII/3) should be considered of Minoan influences; most likely the same rule applies to the LBA belts from Giula hoard (Pl. XXV/a) and from Uioara de Sus hoard (XXVI/b), as they contain that particular symbol. ${ }^{241}$

Remarkable in all these changes, more complex and varied than I have outlined here, which debuted shortly after the beginning of the second millennium, is the promoter role of Wietenberg culture which, together with other cultures, has created a called Carpatho-Danubian or Carpathian Basin Middle Bronze Age identity, but behind these broad notions we must not confuse its own personality. ${ }^{242}$ That's why I

${ }^{232}$ For the definitions of these phases and these melalurgical horizons of Wietenberg culture see: Rotea 2016, with bibliography. For the content of these hoards, see: Mozsolics 1968; David 2010, passim; Soroceanu 2012.

233 This type of axes I think was used by the ruling elite (political, administrative and religious), and those with disk by the warrior elite of the Wietenberg culture (Rotea 2016).

234. Van de Moortel 201, 263-268.

235 For the other cultures of the Carpathian Basin see: Fischl et alii 2013, 355-371, with bibliography.

${ }^{236}$ For a selection a Carpatho-Danubian cultures symbols, see: David 2010, 439-486, with bibliography; for Minoan symbols, see: Burkert 1985, 19-54; Marinatos 1993, with bibliography. For sun-boat journey, see: Kaul 1998.

237 For these influences, see: Kristiansen, Larsson 2005, passim, with bibliography; Vandkilde 2007, 125-129; Vandkilde et alii 2015, 8. Three distinct aspects I think they need to be mentioned. On the one hand, the transformations begin in Transylvanian space around 1900 BC. On the other hand, the contacts have been pursued not only in one direction, from south to north, but also vice versa (for example see: Maran, Van de Moortel 2014, 529-548, with bibliography; Rotea 2016). Finally, we need to talk about a „package” of goods and ideas that circulated, not just a decorative element (for example: spiral) or a metallurgical product (for example: Mycenaean swords) (Rotea 2016, with bibliography).

238 David 2010, 443, with bibliography.

239 David 2010, 443-445, Pl. 2/1-2.

240 For a similar piece discovered in a sure context Wietenberg II, see: Kacsó 2015, 429.

241 Rotea 2016.

${ }^{242}$ For wide image of the Middle Bronze Age Carpathian Basin cultures see: Fischl et alii 2013, 355-371, 
have often talked about the "Transylvanian style" and the "Transylvanian metallurgical revolution" (the second metallurgical boom after the one occured in the Eneolithic) as the "Renaissance of Transylvania", a distinct part of the general phenomenon, arising from different creative influences, the Minoan ones being the strongest. ${ }^{243}$ Transformations, evolutions are also on a smaller scale, within the same culture, from one stage to the next, but not without major significance. We know, for example, that the spiral ${ }^{244}$ (a symbol of sky or sometimes of water, of movement in general) (Pl. XX/1) and the decoration called waves (Pls. XVIII/1c, XIX/b, XX/2, XXI/e) of the Wietenberg culture are unique in variety, in decorative techniques or decorative combinations in all the temperate European MBA. It is interesting that, after 1700 BC, with Wietenberg III phase, Ighiel - Târgu Mureş metallurgical horizon, MBA III, a part of these decorative motifs turn into meanders (Pl. XVII/1), which reopens the discussion about relationship between Mycenaean civilization and Wietenberg culture. $^{245}$

In this context, so-called "bird-sun-ship" (Vogelsonnenbarke) of the Late Bronze Age from Prehistoric Europe ${ }^{246}$ is nothing more than a development of an already existing theme, for example, in Wietenberg and Otomani-Füzesabony cultures. ${ }^{247}$ Therefore, they reflect the fundamental importance of water-borne mobility in the Bronze Age Europe, including for cultural areas far from the shores of the sea, and how this was integrated in mythological cosmology, and this process debuted in $\mathrm{MB}$ I-II (ca. 1900 BC) and reached its peak in LBE.

It is equally true that the nature or technical, morphological and stylistic characteristics of an artifact can indicate a certain workshop, from a certain cultural environment, but these cannot always be considered an indication of the origin of

with bibliography. For the European connections in the Bronze Age, see: Kristiansen, Larsson 2005, passim, with bibliography; Vandkilde 2007, 125-129; Vandkilde et alii 2015, 8. With the observation that often the distinct personality of Wietenberg culture or it is not called, or is melted into the general one of the Carpathian basin. Even the close cultural relationship between Wietenberg and Otomani-Füzesabony cultures, the two cultures that dominate Carpathian basin space for a long time (ca. 2000-1500 BC, and their cultural derivatives - Deva-Bădeni, Cehăluț, Hajdúbagos cultures etc. - for another 200-300 years) should be seen as a unity relationship in diversity. For example, the spiral decoration in fulness is only a characteristic of the "Transylvanian style" of the Wietenberg culture, with parallels in Scandinavian Bronze Age.

${ }^{243}$ Rotea 2016, with bibliography. All these processes will reach the peak in the LBA. When, for example, some hoards exceed one tonne of metal (Uioara de Sus or S,pălnaca II) (Rusu 1972, 528-536, 540-546; Petrescu-Dâmboviţa 1977, 22, 108-112, 114-117) and the variety of artifacts talks about the democratization of bronze (the metals down from the elite to the majority of people).

${ }^{244}$ For the spiral decoration of the Wietenberg culture, see: Horedt 1960, passim; Chidioșan 1980, 57-59; Boroffka 1994, passim. In my opinion, A. Vulpe (2001, 9-21) has correctly seen, in general terms, the origins of Wietenberg culture spiralic decorations in the Aegean space, but it has to be linked to the Middle Minoan IA/IB (Rotea 2016, with bibliography) and not to the Early Cycladic I-II (for arguments, see: Daróczi 2012, 47-61). The distance in time between those two cultural horizons invoked by A. Vulpe (2001, 9-21) is exaggeratedly minimized by the author quoted and excessively maximized by T. Daróczi $(2012,54)$. For example, the appearance of the spiral decoration in Wietenberg culture starting around 1900 BC (Rotea 2016) and not after 1700 BC (Daróczi 2012, 47-61, with bibliography).

245 Boroffka 1994, with bibliography; Dietrich, Dietrich 2011, 67-84; Rotea 2016, with bibliography.

${ }^{246}$ For example, see: Hänsel 2012, 109-117; Wirth 2009, 1-15, with bibliography; Bilić 2016, 445-465, with bibliography.

${ }^{247}$ David 2010, 439-486; Rotea 2016, with bibliography. 
their last owner/dedicator. Exotic artifacts could have been acquired in multiple ways: through the caravans that crossed impressive distances, through exchanges between commercial groups with inter-regional activity, through the circulation of artisans working for the elites, ${ }^{248}$ through the custom of exchanging gifts between the elites etc. ${ }^{249}$ Two facts seem visible in this variable/fluctuating global context: that the sanctuary in Cioclovina managed to attract worshipers from different communities and regions, and also the dominating role that members of the elite groups played in the ceremonies practiced there. These are naturally general considerations on the origin of the most important devotees, generated by the complex mechanisms involving the circulation and acquiring of precious votive objects which due to the quantity and variety they displayed were not available to all or to small, local, isolated communities. During sacred ceremonies of the scale of those from Cioclovina, members of the local elites could have felt closer, from an identity perspective, to the elites of other, distant places, than to the common people in their close proximity. ${ }^{250}$ It is also interesting to note, for the economy of those times, M. Strathern's observation that in a goods-oriented economy people express their interest towards goods as a desire to become rich and in a gift-oriented economy their desire is to extend their social relations. ${ }^{251}$ Thus, the very precious materials and the high-quality execution of the votive objects from "Cioclovina cu Apă" Cave suggest that some of the pilgrims who prayed and worshiped there were part of the elite of the society of those times; they must have come from wider areas and must have had, directly or indirectly, commercial contacts that reached a pan-European level. ${ }^{252}$ It also suggests that some of the most precious types of female jewelry known during that period (such as glass or amber beads) might indicate an inter-regional female elite component of the cult. ${ }^{253}$ Let us also mention, before taking the analysis further, the fact that the cult of the Nymphs is also to be connected with common people, and from this perspective the clay pottery deposited in the cave represent a visible sign of the participation of non-elite members to the ceremonies. Also, this combination of poor and rich votive seems to be the rule for Minoan peak sanctuaries from the mountain of Juktas. ${ }^{254}$

Another topic that must be analyzed with caution is that of the number and time of the visits. Taking into consideration the two levels on which the rituals were practiced, the daily one and the one more rarely performed (from the level of the

248 For example, even the Old Testament gives us clear indications of the circulation of metal artisans (Rotea 2009, 37-38); also, the LBA site from Pălatca - Togul lui Mândruşcă (Rotea et alii 2011, 7-38, with bibliography).

249 Mauss 1967.

250 For example, see: Bell 1992, 185, 188-189; Hodder 1982, 150, with bibliography.

251 Strathern 1990, 143.

${ }^{252}$ In Transylvanian LBA social differences have definitely played a significant role. We have more and more archaeological evidence suggesting the existence of an at least bipartite system with an aristocratic elite and ordinary people in the analyzed space (Rotea 2016). If we interpret these results in light of previous knowledge of MBA (Wietenberg culture), nothing seems to be in other way/key. Maybe just an increase in wealth standards (Rotea 2016).

253 The female component was sensed in certain hoards: Boroffka, Luca 1995, 226, n. 3.

${ }^{254}$ Marinatos 1993, 116-117. 
community), there is no doubt that one must relate to the second. As for the rhythmicity of the sacrificial ceremonies and of the deposition of artifacts, one can presume, starting also from the high quality of the votive deposits, that they were not held very often but only in some moments of the year or even at wider intervals. The hypothesis is also supported by the fact that access into the cave becomes impossible or very dangerous during the seasons with abundant rains.

Conclusions. The life of prehistoric people was in constant reference to the supernatural/sacred and the complex spiritual phenomena were manifested through cult which was, in its turn, structured by rituals and ceremonies. The sacred has been studied by numerous humanities researchers: James Frazer, ${ }^{255}$ Emile Durkheim, ${ }^{256}$ Claude Lévi-Strauss, ${ }^{257}$ Marcel Mauss, ${ }^{258}$ Mircea Eliade, ${ }^{259}$ Ian Hodder, ${ }^{260}$ Colin Renfrew, ${ }^{261}$ Martin Nilsson ${ }^{262}$ etc. and their conclusions reflect the full diversity of human imagination.

The birth of a sanctuary implies a number of factors, but all starting from a revelation, a sign of a deity. Also, a dedicated space and a topographic marker are fundamental, without which the relationship between the profane and the divine cannot be done, what necessarily opens the relationship of the sanctuary with the territory around it. Therefore, the association of at least four fundamental natural elements (mountain, forest, cave, and water) is the essential next points of the transformation of the "Cioclovina cu Apă" Cave into a cult place/sanctuary. Prehistoric sanctuary status determination required also careful examination of archeological documentation. In this regard, I will remind you, for the beginning, that the votive have been deposited in a virgin place of any previous cultic occupation.

The sanctuary inside "Cioclovina cu Apă" Cave has attracted very rich and varied offerings (bronze items, exotic goods, pottery, antler cheek-pieces, and meat offerings) that were deposited in three consecrated place in the Great Hall, places under the mark of the «spring of divinity». The unique quantity, quality, and value of the discovered artifacts for a temperate European area, but also other elements (such as the possible transformation of the cult space, the erection of altars) indicate the very high level of the cult activities and this involves, on the one hand, an important number of religious servants and on the other hand an important number of pilgrims-worshipers. Starting from the fact that almost all of the offerings are jewelry items worn by women or elements that decorate horse gear, we have considered the idea that a Nymph or a Nymph associated with another deity was venerated here, in both cases in association with horses, as being the closest to the truth. We also plead in favor of the possible presence of oracular components. From the presented perspectives, we believe that the exceptional ritual practices that took place in this cave place it in the sphere of

\footnotetext{
255 Frazer 1922.

256 Durkheim 1995.

257 Lévi-Strauss 1958.

258 Mauss 1967.

259 Eliade 1949; Eliade 1965.

260 Hodder 1982.

${ }^{261}$ Renfrew 1985.

262 Nilsson 1927.
} 
inter-regional collective/institutional cult manifestations (in which the elites, including the female, played a dominant role) and not in that of communal manifestations of limited interest.

The abundance of data regarding the sacred activities in "Cioclovina cu Apă" Cave (cult places, offerings, ritual objects, remains of different ceremonies), unparalleled on the territory of Romania vis-à-vis such a prehistoric archaeological monument supports our claim that we are increasingly close, despite the difficulties of interpretation, to sketching not only isolated rituals, but parts of a cult of some female divinity. The steps taken in the interpretation of the signification of the sanctuary in "Cioclovina cu Apă" Cave are on a much safer ground than that of similar accumulations, hoards or other deposits, despite the fact that the cult aspects gain increasing support in the interpretation of the latter as well. ${ }^{263}$ Still, we do not know to what degree the cult meanings of the sanctuary at Cioclovina are encountered in the explanation of the signification of the Arpășel-type hoards. We shall have to carefully analyze if Cioclovina illustrates a solitary initiative or a more wide spread cult phenomenon, as I tend to believe.

Even if it is still difficult to test who was, beyond doubt, the adored deity in question, the attempts to identify her seemed much more productive despite the fact that they are much more difficult. Future researches and debates should probe deeper into all these directions of investigation, even more so as the life of Transylvanian communities during the LBA still remains obscure under many aspects. The "Cioclovina cu Apă" Cave, like other of its type, represents a fabulous archaeological context, holding a fundamental place, not only in the knowledge of the spiritual life, but also in that of the economical-social-political structures of the LBA II (ca. 1350-1200 cal BC). In other words, such contexts can reveal, along numerous directions of analysis, a much more fruitful potential and, why not, a more spectacular one than ground-level contexts.

\section{Acknowledgments}

Many thanks to Dr. Jeanette Varberg for discussions and cooperation in this spectacular project. Also many thanks to colleagues Ana Maria Gruia for translation and to Dana Gheorghe Șerban, Mihaela Rotea and Dan Rotea for design of plates.

\section{Bibliography}

Alexandrescu 1973

Andriţoiu 1992

Bader 1969
A. D. Alexandrescu, La nécropole du bronze récent de Zimnicea (dép. de Teleorman), Dacia, N. S., 17, 1973, 77-97.

I. Andriţoiu, Civilizația tracilor din sud-vestul Transilvaniei în epoca bronzului, Bucureşti 1992.

T. Bader, Depozitul de bronzuri de la Domănești, StComSatuMare, 1, 1969, 73-84.

${ }^{263}$ For example: Rotea et alii 2011, 7-8, with bibliography. 
Bader 1978

Bader 1996

Banerjee et alii 1999

Beck 1985

Bell 1992

Berecki 2016

Bilić 2016

Boroffka 1994

Boroffka 1998

Boroffka 2002

Boroffka 2006

Boroffka, Luca 1995

Boroneanț 2000

Bouzek 1985

Bouzek 1993

v. Brunn 1968

Buduran et alii 2013

Burkert 1985

Chidioșan, Emődi 1982

Chidioşan 1980

Ciugudean 1978

Ciugudean 2012a
T. Bader, Epoca bronzului în nord-vestul Transilvaniei, Bucureşti 1978.

T. Bader, Neue Bronzefunde in Nordwestrumänien. In: T. Kovács (ed.), Studien zur Metallindustrie im Karpatenbecken und den benachbarten Regionen. Festschrift für A. Mozsolics zum 85. Geburtstag, Budapest 1996, 265-302.

A. Banerjee, V. Ghiurcă, B. Langer, M. Wilhelm, Determination of the provenance of two archaeological amber beads from Romania by FTIR - and Solid-State Carbon - 13 NMR spectroscopy, AKB, 29, 4, 1999, 593-606.

C. W. Beck, The role of the scientist: the amber trade, the chemical analysis of amber, and the determination of Baltic provenience, Journal of Baltic Studies, 1985, 191-199.

C. Bell, Ritual Theory, Ritual Practice, Oxford University Press 1992.

S. Berecki, The Bronze Age Site from Luduş, Cluj-Napoca 2016.

T. Bilić, The swan chariot of a solar deity: Greek narratives and prehistoric iconography, Documenta Praehistorica, XLIII, 2016, 445-465.

N. Boroffka, Die Wietenberg-Kultur. Ein Beitrag zur Erforschung der Bronzezeit in Südosteuropa, UPA, 19, Bonn 1994.

N. Boroffka, Bronze- und früheisenzeitliche Geweihtrensenknebel aus Rumänien und ihre Beziehungen. Alte Funde aus dem Museum für Geschichte Aiud, Teil II, Eurasia Antiqua, 4, 1998, 81-135.

N. Boroffka, Observații asupra descoperirilor preistorice de chihlimbar din Romania, Apulum, 49, 2002, 145-167.

N. Boroffka, Resursele minerale din România şi stadiul actual al cercetărilor privind mineritul preistoric, Apulum, 43, 1, 2006, 71-94.

N. Boroffka, S. Luca, Archäologische Metallfunde aus der Schulsammlung Beliu, Kr. Arad. In: T. Soroceanu (ed.), Bronzefunde aus Rumänien, PAS 10, Berlin 1995, 225-228.

V. Boroneant, Arheologia peșterilor şi minelor din România, Bucureşti 2000.

J. Bouzek, The Aegean, Anatolia and Europe: Cultural Interrelations in the Second Millennium BC, Göteborg 1985.

J. Bouzek, The Shifts of the Amber Route. In: C. Beck, J. Bouzek (eds.), Amber in archaeology, Prague 1993, 141-146.

W. A. v. Brunn, Mitteldeutsche Hortfunde der jüngeren Bronzezeit, RGF, 29, Berlin 1968.

S. E. Buduran, A. C. Sopincean, M. S. Sopincean, M. R. Isfan, C. O. Stan, L. L. Gherman, Peştera Ciclovina-Pogorâci cu Apă, Deva 2013.

W. Burkert, Greek Religion, Harvard 1985.

N. Chidioşan, J. Emődi, Grupul cultural Igrița de la sfârşitul Epocii Bronzului, Crisia, 12, 1982, 33-86.

N. Chidioșan, Contribuții la istoria tracilor din nord-vestul României. Assezarea Wietenberg de la Derşida, Oradea 1980.

H. Ciugudean, Săpături de salvare la Aiud-Cetăție, ActaMN, 15, 1978, 49-62.

H. Ciugudean, The chronology of the Gáva culture in Transylvania. In: W. Blajer (ed.), Peregrinationes archaeologicae in Asia et Europa Joanni Chochorowski dedicatae, Krakow 2012, 229-243. 
Ciugudean 2012b

Comşa 1966

Costea, Székely 2011

Czebreszuk 2011

Cwaliński 2014

Daróczi 2012

David 2010

Day 2006

Diaconu et alii 2014

Dietrich, Dietrich 2011

Dumitrescu, Orghidan 1959

Dumitrescu 1961

Dumitrescu 1974

Durkheim 1995

Eliade 1949

Eliade 1952

Eliade 1965

Emődi 1978

Emődi 1980
H. Ciugudean, Ancient gold mining in Transylvania: the Roşia Montană - Bucium area, Caiete ARA, 3, 2012, 219-232.

E. Comşa, Le dépôt en bronze de Cioclovina (Carpates Méridionales), Acta Archaeologica Carpathica, 8, 1966, 169-174.

F. Costea, Zs. Székely, Aspects of the Ritual Life of the Wietenberg. Culture. Miniature religious shrines from Racos, Transylvania. In: S. Bereczki, E. R. Németh, B. Rezi (eds.), Bronze age Rites and Rituals in the Carpathian Basin. Proceedings of the International Colloquium from Târgu Mureş, 8-10 October 2010, Târgu Mureş 2011, 107-113.

J. Czebreszuk, Bursztyn w kulturze mykeńskiej, Poznań 2011.

M. Cwalinski, The influx of amber to the circum-Adriatic areas during the Bronze Age. Proposition of an interpretative model, Fontes Arheologici Posnanienses, 50, 2014, 183-199.

T. Daróczi, From "diachronic judgement" to the theory of possible types of symmetry: an investigation into cycladic and Transylvanian Bronze age relations, ActaMN, 47-48, 1, 2010-2011 (2012), 47-61.

W. David, Die Zeichen auf der Scheibe von Nebra und das altbronzezeitliche Symbolgut des Mitteldonau-Karpatenraumes, Tagungen des Landesmuseums für Vorgeschichte Halle, 5, 2010, 439-486.

J. Day, Flower-Lovers? Reconsidering the gardens of Minoan Crete. In: J.-P. Morel, J. T. Juan, J. C. Matamala (eds.), The archaeology of crop fields and gardens. Proceedings of the 1st Conference on Crop Fields and Gardens of Archeology Barcelona (Spain), 1-3 June 2006, Bari 2006, 189-195.

V. Diaconu, A. Adamescu, D. Calistru, Piese de harnaşament din Bronzul târziu. Despre două psalii de corn din Moldova, ArhMold, 37, 2014, 219-227.

L. Dietrich, O. Dietrich, Wietenberg ohne Mykene? Gedanken zu Herkunft und Bedeutung der Keramikverzierung der WietenbergKultur, PZ, 86, 1, 2011, 67-84.

M. Dumitrescu, T. Orghidan, Călătorii în lumea subpămînteană, București 1959.

V. Dumitrescu, Necropola de incinerație din epoca bronzului de la Cârna, Bucureşti 1961.

V. Dumitrescu, Arta preistorică în România, București 1974.

E. Durkheim, The Elementary Forms of the Religious Life, New York 1995.

M. Eliade, Traité d'histoire des religions, Paris 1949.

M. Eliade, Images and symbols: studies in religious symbolism, Princeton 1952.

M. Eliade, Le sacré et le profane, Paris 1965.

J. Emődi, Noi date orivind depozitul de la Cioclovina, SCIVA, 29, 1978, 481-495.

J. Emődi, Necropola de la sfârşitul epocii bronzului din peștera Igrița, SCIVA, 31, 1980, 229-273. 
Fântâneanu et alii 2013 C. Fântâneanu, G. Bălan, D. Tentiş, S. Popa, The Bronze Age necropolis at Sebeş-Între Răstoace. Preliminary considerations. In: V. Sîrbu, R. Ştefănescu (eds.), The Thracians and their Neighbors in Bronze and Iron Ages. Proceedings of the $12^{\text {th }}$ International Congress of Thracology, Braşov 2013, 173-191.

Fischl et alii 2013

K. Fischl, V. Kiss, G. Kulcsár, V. Szeverényi, Transformations in the Carpathian Basin around 1600 BC. In: H. Meller (ed.), Thera eruption 1600 BC and social change, Halle 2013, 355-371.

Frazer 1922

Frînculeasa 2013

J. Frazer, The golden Bough, New York 1922.

A. Frînculeasa, Podoabe preistorice din materiale vitroase: descoperiri în cimitirul din epoca bronzului de la Câmpina (jud. Prahova), Studii de Preistorie, 10, 2013, 189-209.

Frînculeasa 2016

A. Frînculeasa, Developements in Mid-Second Millennium BC in northern Muntenia (archaeological investigations in the Prahova River basin). In: F. Gogâltan, C. Cordoș (eds.), Prehistoric settlements: social, economic and cultural aspects. Seven studies in the Carpathian area, Cluj-Napoca 2016, 115-180.

Ghemiş 2006

C. Ghemiş, Prehistoric discoveries of amber in Transilvania. In: A. Palavestra, C. W. Beck, J. M. Todd (eds.), Proceedings of the fifth international conference on amber in archaeology, Belgrad 2006, Belgrade 2009, 124-131.

Ghemiș 2007

C. Ghemiş, Issues on Pre and Protohistoric Amber, Crisia, 37, 2007, 7-22.

Ghemiş et alii 2014

Giumlia 2011

Gogâltan 2001

C. Ghemiş, T. Rus, R. Kovacs, Between sacred and profane - a discovery belonging to the Cotofeni Culture inside "Stanu Cerbului" cave (Bihor County), Ziridava, 28, 2014, 31-38.

A. Giumlia-Mair, The analyses of the copper-based finds from the $L B A$ metalurgical site at Pălatca, ActaMN, 45-46, 1, 2008-2009 (2011), 39-52.

F. Gogâltan, The Settlement of Căsseiu and Some Problems Conserning. the Late Bronze Age in the Center and Northern Transylvania. In: C. Kacsó (ed.), Der nordkarpatische Raum in der Bronzezeit. Symposium Baia Mare, 7-10 Oktober 1998, Bibliotheca Marmatia, 1, Baia Mare 2001, 191-214.

Gogâltan 2016

Gogâltan, Sava 2014

F. Gogâltan, Chihlimbarul preistoric de la frontiera estică a Bazinului Carpatic, AB, 24, 2016, 143-170.

F. Gogâltan, V. Sava, Depozitul de bronzuri de la Lipova, jud. Arad, Terra Sebus, 6, 2014, 183-209.

Gogâltan, Popa 2016

F. Gogâltan, C. Popa, Gligorești „Holoame” (Kreis Cluj), eine spätbronzezeitliche Siedlung aus Mittelsiebenbürgen. In: A. Zanoci, E. Kaiser, M. Kashuba, E. Izbitser, M. Băț (eds.), Man, Culture, and Society from the Copper Age until the Early Iron Age in northern Eurasia. Contributions in honour of the 60th anniversary of Eugen Sava, Tyragetia International, 1, 2016, 181-202.

Green 1986 M. J. Green, The Gods of the Celts, Gloucester 1986.

Guba, Szeverényi 2007

Sz. Guba, V. Szeverényi, Bronze Age Bird Representations from the Carpathian Basin, CommArchHung, 2007, 75-110.

Gumă 1993

M. Gumă, Civilizația primei epoci a fierului în sud-vestul României, Biblioteca Thracologica IV, Bucureşti 1993. 
Gumă 1995

Hampel 1886

Hansen 1994

Harding 2000

Harding, Kavruk 2010

Harding, Kavruk 2013

Hänsel 2012

Henderson 1988

Henderson 2013

Hodder 1982

Horedt 1960

Hüttel 1981

Jaeger 2014

Jones 1999

Kacsó 1990

Kacsó 1995

Kacsó 1998

Kacsó 1999

Kacsó 2000

Kacsó 2009

Kacsó 2015
M. Gumă, The end of the Bronze Age and the beginning of the Early Iron Age in SW Romania, N Serbia and NW Bulgaria. A short review, Thraco-Dacica, 16, 1995, 99-137.

J. Hampel, Trouvailles de l'âge de bronze en Hongrie, Budapest 1886.

S. Hansen, Studien zu den Metalldeponierungen währendder älteren Urnenfelderzeit zwischen Rhônetal und Karpatenbecken, UPA, 21, Bonn 1994.

A. Harding, European societies in the Bronze Age, Cambridge 2000.

A. Harding, V. Kavruk, A Prehistoric Salt Production site at Băile Figa, România, Eurasia Antiqua, 16, 2010, 131-167.

A. Harding, V. Kavruk (with contributions by K. Bukowski, Al. Chiricescu, R. Brunning, A. Kovács, D. Buzea, M. Uckelmann, D. Stefan, E. Bánffy, T. Ważny, I. Popa, A. Semeniuc, G. Ticuleanu, R. Gale, N. Mildwaters and S. Allen), Explorations in Salt Archaeology in the Carpathian zone, Budapest 2013.

B. Hänsel, Zum Aufkommen des Vogelsonnenbarken-Symbols vor der Urnenfelderzeit. In: J. Kujovskŷ, V. Mitáš (eds.), Václav Furmánek a doba bronzová. Zborník k sedemdesiatym narodeninám, Nitra 2012, 109-117.

J. Henderson, Glass production and Bronze Age Europe, Antiquity, 62, 1988, 436-437.

J. Henderson, Ancient glass: an interdisciplinary exploration, Cambridge 2013.

I. Hodder, The Present Past. An introduction to anthropology for archaeologists, London 1982.

K. Horedt, Die Wietenbergkultur, Dacia N. S., 4, 1960, 107-137.

H. G. Hüttel, Bronzezeitliche Trensen in Mittel- und Osteuropa, PBF, 16, 2, München 1981, 82-94.

M. Jaeger, Middle Bronze Age amber finds in Hungary. In: L. Cellarosi, R. Chellini, F. Martini, A. Montanaro, L. Sarti (eds.), The Amber Roads. The Ancient Cultural and Commercial Communication between the Peoples, Millenni: Studi di Archeologia Preistorica 13, 2014, 205-215.

D. W. Jones, Peak Sanctuaries and Sacred Caves in Minoan Crete: A Comparison of Artifacts, Göteborg 1999.

C. Kacsó, Bronzul târziu în nord-vestul României, Symposia Thracologica, 8, 1990, 41-50.

C. Kacsó, Der Hortfund von Arpășel, Kr. Bihor. In: T. Soroceanu (ed.), Bronzefunde aus Rumänien, PAS 10, Berlin 1995, 81-130.

C. Kacsó, Das Depot von Satu Mare, Jósa András Múzeum Évkönyve, 39-40, 1998, 11-31.

C. Kacsó, Descoperiri de epoca bronzului în peștera Valea Rea de la Vălenii S,omcutei, SCIVA, 50, 1999, 113-126.

C. Kacsó, Die späte Bronzezeit im Karpaten-Donau-Raum (14.-9. Jahrhundert v. Chr.). In: M. Rotea, T. Bader (eds.) Traker und Kelten beidseits der Karpaten, Cluj-Napoca 2000.

C. Kacsó, Depozitul de bronzuri de la Sânnicolau de Munte (jud. Bihor, România), AB, 17, 2009, 167-173.

C. Kacsó, Repertoriul arheologic al județului Maramureș, I, BaiaMare 2015. 
Kacsó 2017a

Kacsó 2017b

Kaul 1998

Kovács 1970

Kristiansen, Larsson 2005

Larson 2001

Levy 1999

Levi-Strauss 1958

Luca et alii 2008

Maran 2013

Maran, Van de Moortel 2014

Marc et alii 2015

Mauss 1967

Metzner-Nebelsick,

Nebelsick 1999

Metzner-Nebelesick et alii

Marinatos 1993

Marinatos 2009

Molnár, Ghemiş 2003

Moyes 2013

Möslein, Rieder 1997
C. Kacsó, Necropola tumulară din bronzul târziu de la Bicaz (jud. Maramureș, România), Apulum, 54, 2017, 189-210.

C. Kacsó, Descoperirile de bronzuri din depresiunea Oaşului. Cu specială privire asupra depozitului de la Bătarci, Baia-Mare 2017.

F. Kaul, Ships on Bronzes: A Study in Bronze Age Religion and Iconography, Copenhagen 1998.

T. Kovács, A Hajdúbagosi bronzkori temető, FolArch, 21, 1970, $27-47$.

K. Kristiansen, T. Larsson, The Rise of Bronze Age Society: Travels, Transmissions and Transformations, Cambridge 2005.

J. Larson, Greek Nymphs, Oxford 2001.

J. E. Levy, Metals, Symbols, and Society in Bronze Age Denmark. In: J. Robb (ed.), Material Symbols: Culture and Economy in Prehistory, Carbondale 1999, 205-223.

C. Levi-Strauss, Anthropologie structurale, Paris 1958.

S. Luca, D. Diaconescu, I. V. Ferencz, C. C. Roman, A. Sonoc, C. Suciu, S. Tincu, Repertoriul arheologic al județului Hunedoara, Alba-Iulia 2008.

J. Maran, Bright as the sun: the appropriation of amber objects in Mycenaean Greece. In: H. P. Hahn, H. Weiss (eds.), Mobility, Meaning and the Transformations of Things: Shifting Contexts of Material Culture through Time and Space, Oxbow Books 2013, 147-169.

J. Maran, A. Van de Moortel, A Horse-Bridle Piece with CarpathoDanubian Connections from Late Helladic I Mitrou and the Emergence of a Warlike Elite in Greece During the Shaft Grave Period, AJA, 118, 4, 2014, 529-548.

A. Marc, I. Barbu, C. Bodó, M. Barbu, Representation and symbol reflected by two Bronze Age artefacts from Uroi-Sigheti (Hunedoara County). In: N. C. Rișcuța, I. V. Ferencz, O. T. Bărbat (eds.), Representations, Signs and Symbols, Cluj-Napoca 2015, 81-92.

M. Mauss, The gift, New York 1967.

C. Metzner-Nebelsick, L. D. Nebelsick, Frau und Pferd. Ein Topos am Übergang von der Bronze- zur Eisenzeit Europas, Mitteilungen der Anthropologischen Gesellschaft in Wien, 129, 1999, 69-106.

C. Metzner-Nebelsick, C. Kacsó, L. D. Nebelsick, A Bronze Age ritual structure on the edge of the Carpathian Basin, StComSatuMare, XXVI/1, 2010, 219-233.

N. Marinatos, Minoan religion. Ritual, image, and symbol, University of South Carolina Press 1993.

N. Marinatos, Minoan kingship and the solar Goddess: a Near Eastern Koine, University of Illinois Press 2009.

Z. Molnár, C. Ghemiș, O descoperire aparținând perioadei bronzului timpuriu din Pestera Izbucu Topliței (jud. Bihor). Considerații privind Grupul Roşia, EN, 13, 2003, 41-92.

H. Moyes, Sacred darkness: a global perspective on the ritual use of caves, Colorado University Press 2013.

S. Möslein, K. H. Rieder, Zinnperlen aus einem frühbronzezeitlichen Grabfund von Buxheim, Landkreis Eichstätt, Oberbayern, Das archäologische Jahr in Bayern 1997, 68-70. 
Mozsolics 1953

Mozsolics 1968

Mozsolics 1973

Müller-Karpe 1980

Negrea 1979

Nielsen 2014

Nikita et alii 2006

Nilsson 1950

Ordentlich 1968

Păunescu 2001

Pârvan 1926

Petrescu-Dâmbovița 1977

Peche-Quilinchini et alii 2016

Piso 2015

Popa, Totoianu 2010

Prent 2005

Primas, Pernicka 1998

Przybyła 2009

Purowski et alii 2016

Radu 1973

Renfrew 1985
A. Mozsolics, Mors en bois de cerf sur le territoire du bassin des Carpathes, AArchHung, 3, 1953, 69-111.

A. Mozsolics, Goldfunde des Depotfundhorizontes von Hajdúsámson, Bericht der Römisch-Germanischen Kommission 1965-1966, 46-47, 1968, 1-62.

A. Mozsolics, Bronze und Goldfunde des Karpatenbeckens. Depotfundhorizonte von Forró und Ópályi, Budapest 1973.

H. Müller-Karpe, Handbuch der Vorgeschichte, München 1980.

S. Negrea, Prin peșterile lumii, București 1979.

E. Nielsen, A Late Bronze Age Tin Ingot from Sursee-Gammainseli (Canton Lucerne, Switzerland), AKB, 44, 2014, 177-193.

K. Nikita, J. Henderson, G. Nightingale, An archaeological and scientific study of mycenaean glass from Elateia-Alonaki, Greece. In: K. Janssens, P. Degryse, P. Cosyns, J. Caen, L. Van't dack (eds.), Annales of the 17th Congress of the International Association for the History of Glass, Antwerp 2006, 39-46.

M. Nilsson, Minoan-Mycenaean Religion, and its survival in Greek Religion, Lund 1927.

I. Ordentlich, Depozitul de bronzuri de la Otomani, ActaMN, 5, 1968, 397-404.

A. Păunescu, Paleoliticul și mezoliticul din spațiul transilvan, Bucureşti 2001.

V. Pârvan, Getica, București 1926.

M. Petrescu-Dâmbovița, Depozitele de bronzuri din România, Bucureşti 1977.

K. Peche-Quilichini, L. Bellot-Gurlet, E. Canobbio, J. Cesari, B. Gratuze, F. Leandri, C. Leandri, P. Nebbia, C. Paris, Campu Stefanu (Sollacaro, Corsica). Middle Bronze Age amber and glass beads analyses. A new evidence for Mycenaean connection in Corsica?, Fontes Archaeologici Posnanienses, 52, 2016, 67-79.

I. Piso, Ein Gebet für die Nymphen aus Germisara, ActaMN, 52, 1, 2015, 47-68.

C. A. Popa, R. Totoianu, Aspecte ale epocii bronzului in Transilvania (intre vechile şi noile cercetări), Cluj-Napoca 2010.

M. Prent, Cretan Sanctuaries and Cults: Continuity and Change from the Late Minoan IIIC to the Archaic Period, Brill Academic Publishers 2005.

M. Primas, E. Pernicka, Der Depotfunde von Oberwilflinger. Neue Ergebnisse zur Zirkulation von Metallbarren, Germania, 76, 1998, 25-66.

M. Przybyła, Intercontacts in the Western Carpathian area at the turn of the $2^{\text {nd }}$ and $1^{\text {st }}$ millennia BC, Warsaw 2009.

T. Purowski, L. Kępa, B. Wagner, Glass on the Amber Road: the chemical composition of glass beads from the Bronze Age in Poland, Archaeological and Anthropological Sciences, 2016, 1-20.

O. Radu, Cu privire la necropola de la Cruceni (jud. Timis), SCIV, 24, 1973, 503-520.

C. Renfrew, The Archaeology of Cult, the Sanctuary at Phylakopi, London 1985. 
Rișcuța, Marc 2015

Roska 1942

Rotea 1994

Rotea 2003

Rotea 2009

Rotea 2016

Rotea et alii 2011

Rotea et alii 2014

Rusu 1972

Sandars 1978

Soroceanu 2012

Soroceanu 2016

Sprincz, Beck 1981

Stampolidis, Kotsona 2013

Stout et alii 2000

Stratan, Vulpe 1977

Strathern 1990

Sandor-Chicideanu 2003

Teodor et alii 2010
C. Rișcuța, A. Marc, Descoperiri cu caracter cultic aparținând bronzului târziu din așezarea de la S,oimuş-Teleghi (jud. Hunedoara), Sargetia N. S., 6, 2015, 41-80.

M. Roska, Erdély régészeti repertóriuma I. Öskor, Kolozsvár 1942.

M. Rotea, Penetrația culturii Otomani în Transilvania. Intre realitate şi himeră, Apulum, 31, 1994, 39-58.

M. Rotea, Grupul Copăceni. I, Cluj-Napoca 2003.

M. Rotea, Pagini din preistoria Transilvaniei. Epoca Bronzului, ClujNapoca 2009.

M. Rotea, Culture, Metal and Interaction in Transylvanian Prehistory, 2016, manuscript.

M. Rotea, M. Tecar, T. Tecar, M. Wittenberger, Bronze Age metallurgy in Transylvania: craft, art and ritual/magic, ActaMN, 45-46, 1, 2011, 7-38.

M. Rotea, M. G. Netea, C. De-La-Rua, T. Tecar, M. Hervella, S. Alonso, Z. Maxim, M. Răchită, The archaeological contexts of DNA samples collected from prehistoric sites in Transylvania, ActaMN, 51, 1, 2014, 21-60.

M. Rusu, Metalurgia bronzului din Transilvania la începutul Hallstattului, 1972, manuscript.

N. K. Sandars, The Sea Peoples: Warriors of the Ancient Mediterranean 1250-1150 BC, London 1978.

T. Soroceanu, Die Kupfer-und Bronzedepots der Frühen und Mittleren Bronzezeit in Rumänien / Depozitele de obiecte din cupru şi bronz din România. Epoca timpurie şi mijlocie a Bronzului, Bronzefunde aus Rumänien, IV, Cluj-Napoca - Bistrița 2012.

T. Soroceanu, Der Bronzefund von Jabeniţa (Görgénysóakna), Kr. Mureş, Siebenbürgen, Tyragetia International, I, 2016, 163-180.

E. Sprincz, C. W. Beck, Classification of the amber beads of the Hungarian Bronze Age, Journal of Field Archaeology, 8, 1981, 469-485.

N. Stampolidis, A. Kotsona, Cretan Cave Sanctuaries of the Early Iron Age to the Roman Period. In: F. Mavridis, J. T. Jensen (eds.), Stable places and changing perceptions: cave archaeology in Greece, Oxford 2013, 188-200.

E. C. Stout, C. W. Beck, K. B. Anderson, Identification of rumanite (Romanian amber) as thermally altered succinite (Baltic amber), Physics and Chemistry Minerals, 27, 2000, 665-678.

I. Stratan, A. Vulpe, Der Hügel von Susani, PZ, 52, 1977, 28-60.

M. Strathern, The Gender of the Gift: problems with women and problems with society in Melanesia, University of California Press 1990.

M. Şandor-Chicideanu, Cultura Žuto Brdo-Gârla Mare. Contribuții la cunoaşterea epocii bronzului la Dunărea Mijlocie şi Inferioară, Cluj-Napoca 2003.

E. S. Teodor, E. D. Teodor, M. Virgolici, M. M. Manea, G. Truică, S. C. Lițescu, Non-destructive analysis of amber artefacts from the prehistoric Cioclovina hoard (Romania), Journal of Archaeological Science, 37, 2010, 2386-2396. 
Van de Moortel 2017

Vandkilde 2007

Vandkilde 2016

Vandkilde et alii 2015

Varberg 2013

Varberg 2017

Varberg et alii 2016

Vasiliev 1991

Vulpe 1970

Vulpe 2001a

Vulpe 2001b

Wirth 2009

Wittenberger 2006

Zaharia 1959
A. Van de Moortel, A New Typology of Bronze Age Aegean Ships: developments in Aegean shipbuilding in their historical context. In: J. Litwin (ed.), Baltic and beyond. Change and continuity in shipbuilding. Proceedings of the Fourteenth International Symposium on Boat and Ship Archaeology, Gdańsk 2015, Gdańsk 2017, 263-268.

H. Vandkilde, Culture and Change in Central European Prehistory, 6th to 1st millennium BC, Aarhus 2007.

H. Vandkilde, Bronzization: The Bronze age as Pre-Modern Globalisation, PZ, 91, 1, 2016, 103-123.

H. Vandkilde, S. Hansen, K. Kotsakis, K. Kristiansen, J. Müller, J. Sofaer, M. L. S. Sørensen, Cultural Mobility in Bronze Age Europe. In: P. Suchowska-Ducke, S. S. Reiter, H. Vandkilde (eds.), The Mobility of Culture in Bronze Age Europe, 1, BAR 2771, 2015, 5-37.

J. Varberg, Lady of the battle and of the horse: on anthropomorphic gods and their Cult in Late Bronze Age Scandinavia. In: S. Bergerbrant, S. Sabatini (eds.), Counterpoint: essays in archaeology and heritage studies in honour of Professor Kristian Kristiansen, BAR 2508, 2013, 147-157.

J. Varberg, The glass road, 2017, manuscript.

J. Varberg, B. Gratuze, F. Kaul, A. Haslund Hansen, M. Rotea, M. Wittenberger, Mesopotamian glass from Late Bronze Age Egypt, Romania, Germany and Denmark, Journal of Archaeological Science, 74, 2016, 184-194.

V. Vasiliev, I. Al. Aldea, H. Ciugudean, Civilizația dacică timpurie în aria intracarpatică a României. Contribuţii arheologice: assezarea fortificată de la Teleac, Cluj-Napoca 1991.

A. Vulpe, Die Äxte und Beile in Rumänien. I, PBF, 9, 2, München 1970.

A. Vulpe, Marea migrație egeică. In: Istoria Românilor, București 2001, 287-289.

Al. Vulpe, The Aegean-anatolian and south-eastern Europe in the light of a revision of the Bronze Age chronology. In: C. Kacsó (ed.), Der nordkarpatische Raum in der Bronzezeit. Symposium Baia Mare, 7.-10. Oktober 1998, Bibliotheca Marmatia, 1, Baia Mare 2001, 9-21.

S. Wirth, Sonnenbarke und zyklisches Weltbild - Überlegungen zum Verständnis der spätbronzezeitlichen Ikonographie in Mitteleuropa, Tagungen des Landesmuseums für Vorgeschichte Halle, 2, 2009, 1-15.

M. Wittenberger, Cultura Noua, 2006, manuscript.

E. Zaharia, Die Lockenringe von Sărata-Monteoru und ihre typologischen und chronologischen Beziehungen, Dacia N. S., 3, 1959, 103-134.

Mihai Rotea

National History Museum of Transylvania, Cluj-Napoca rotea_mihai@yahoo.com 


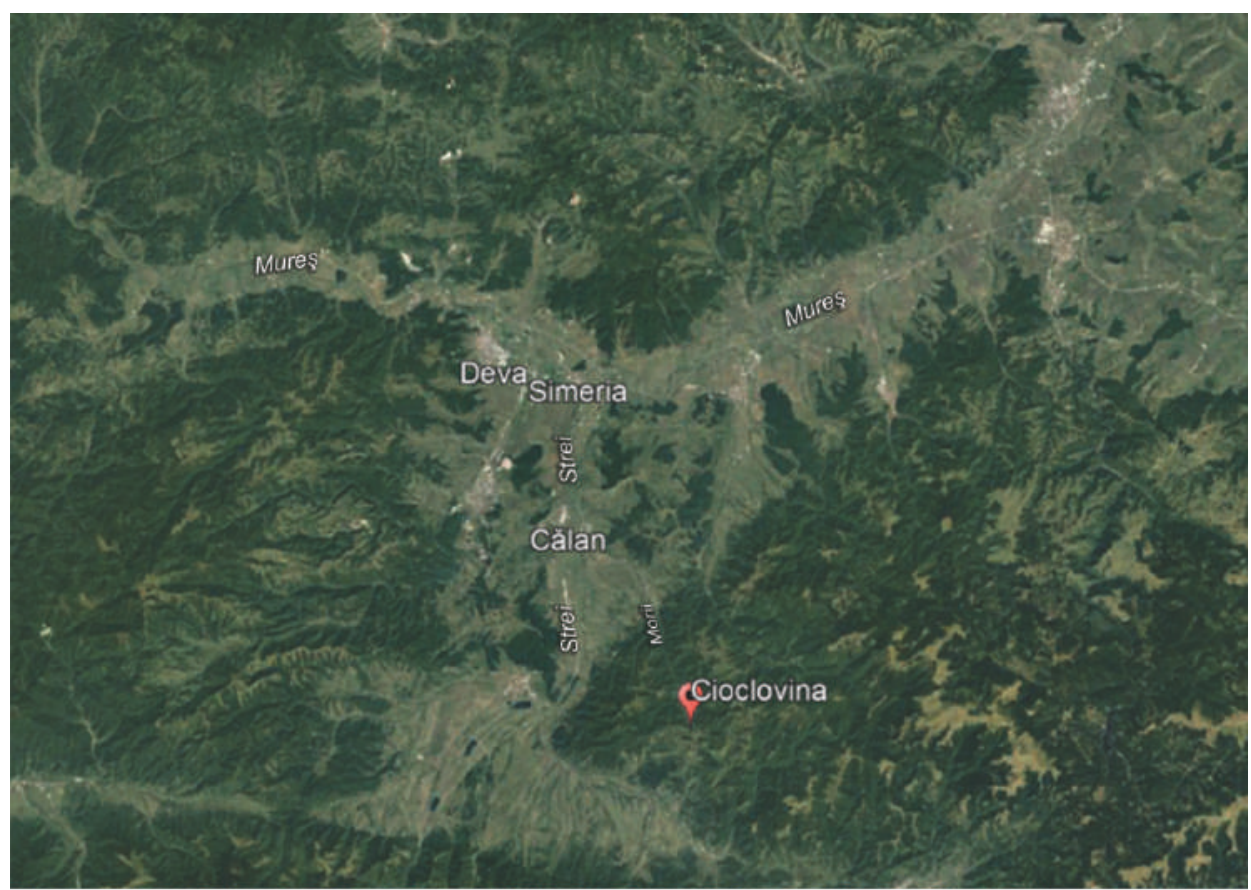

1

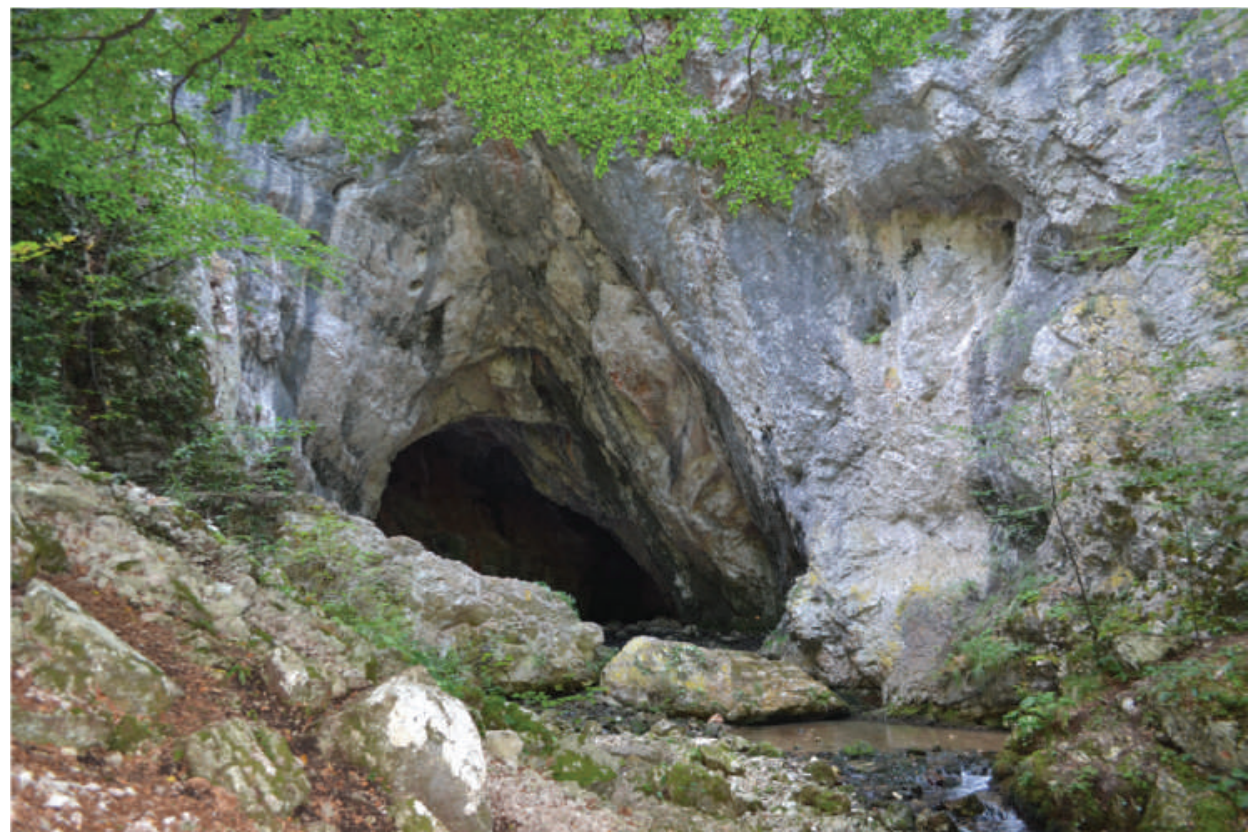

2

Pl. I. "Cioclovina cu Apă” Cave. 1. Map; 2. Cave entrance. 

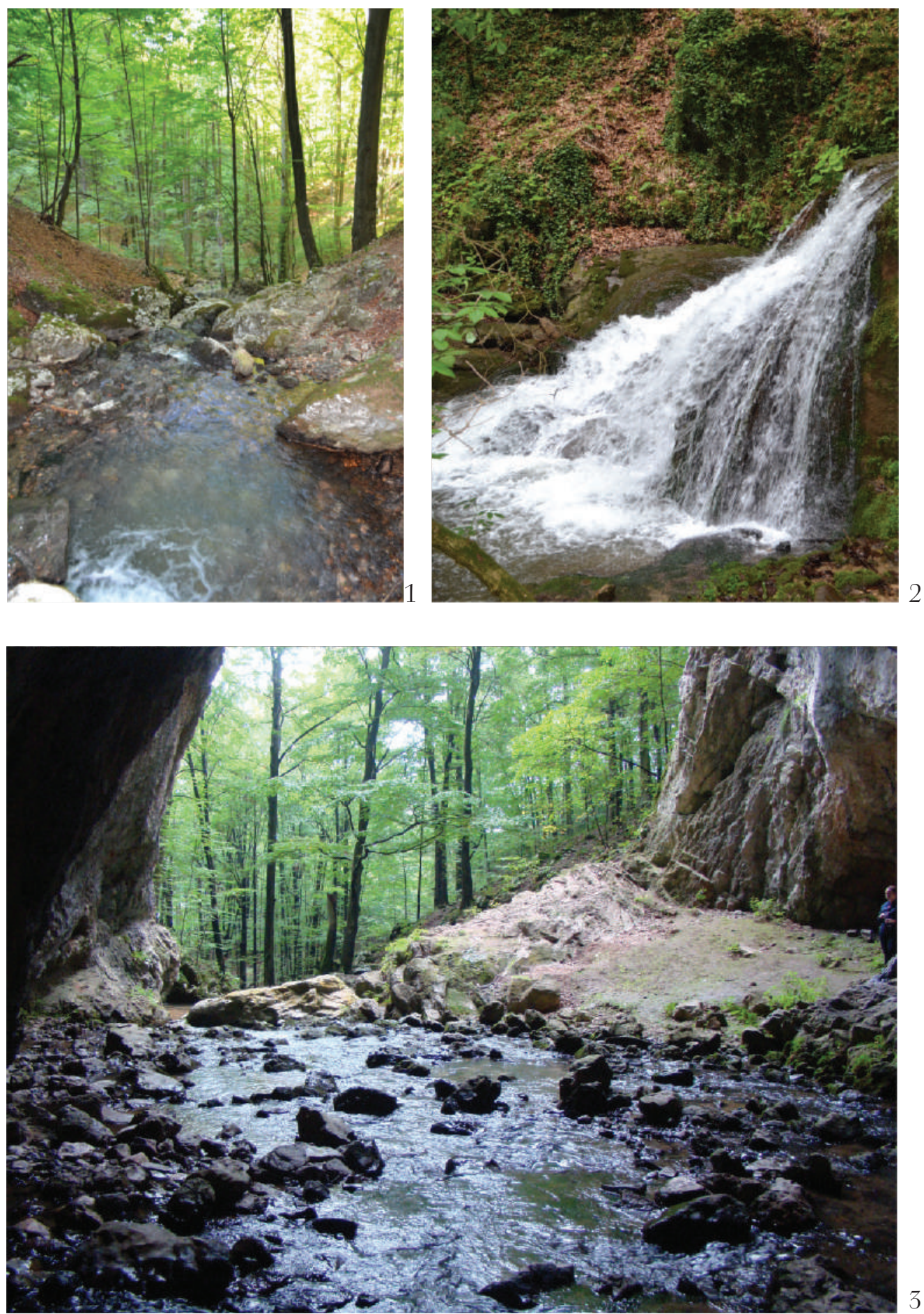

Pl. II. 1-3. "Cioclovina cu Apă" Cave. Inside and outside view. 


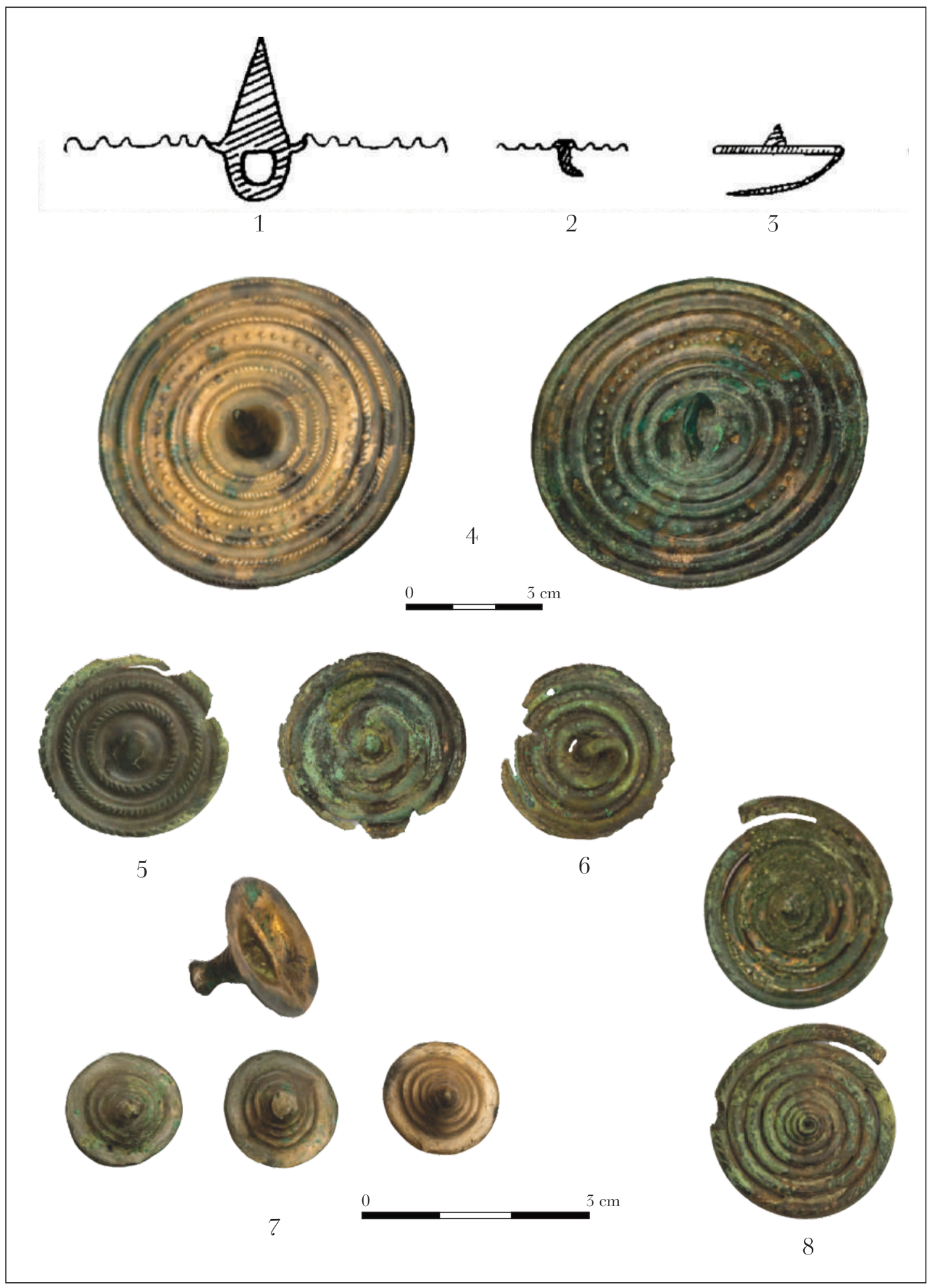

Pl. III. 1-8. Bronze artifacts from "Cioclovina cu Apă" Cave (1-3 apud Emődi 1978). 


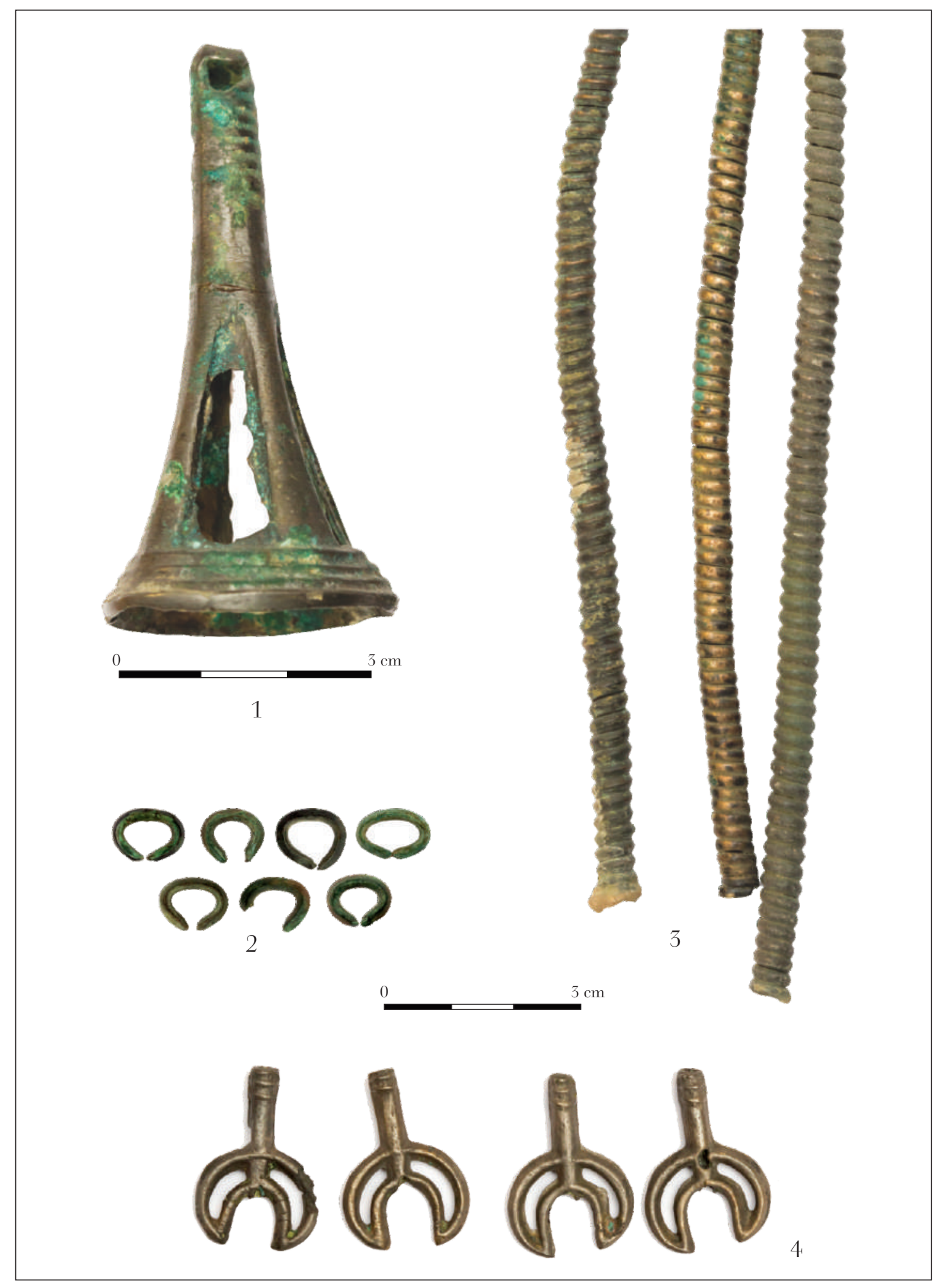

Pl. IV. 1-4. Bronze artifacts from "Cioclovina cu Apă" Cave. 


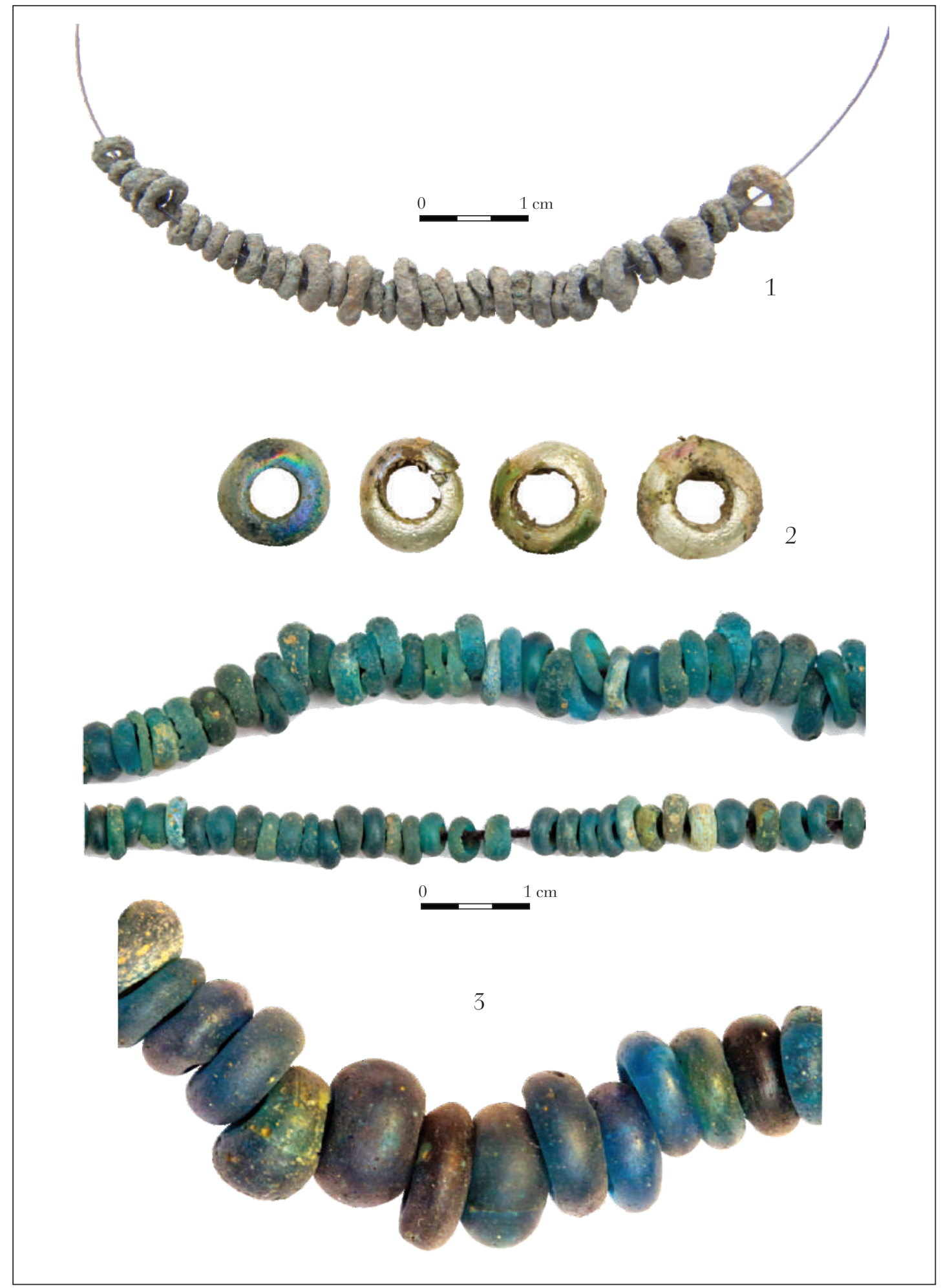

Pl. V. Beads from "Cioclovina cu Apă" Cave. 1. Tin beads; 2. Faience beads (?); 3. Glass beads. 


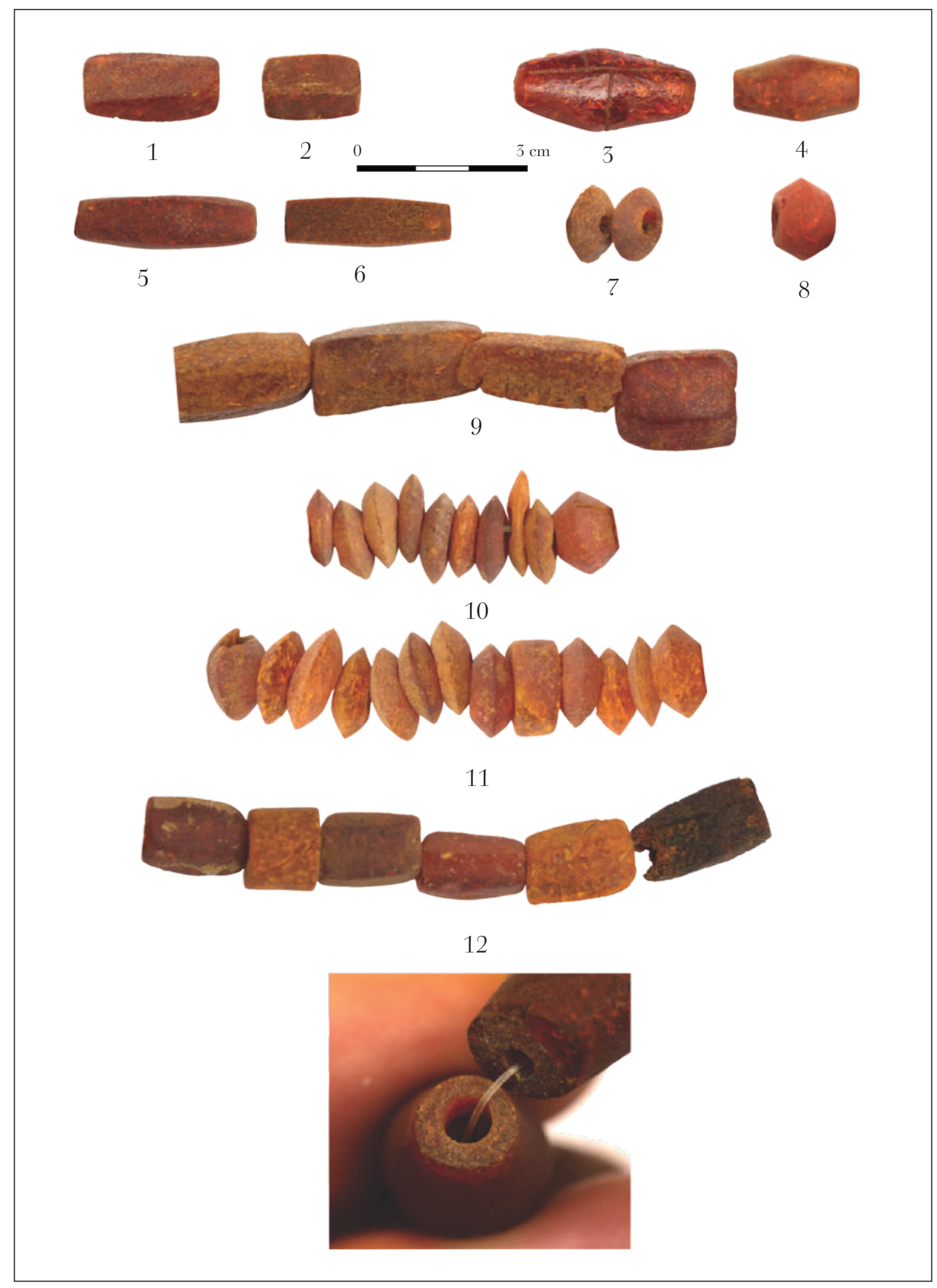

Pl. VI. 1-12. Amber beads from "Cioclovina cu Apă" Cave. 


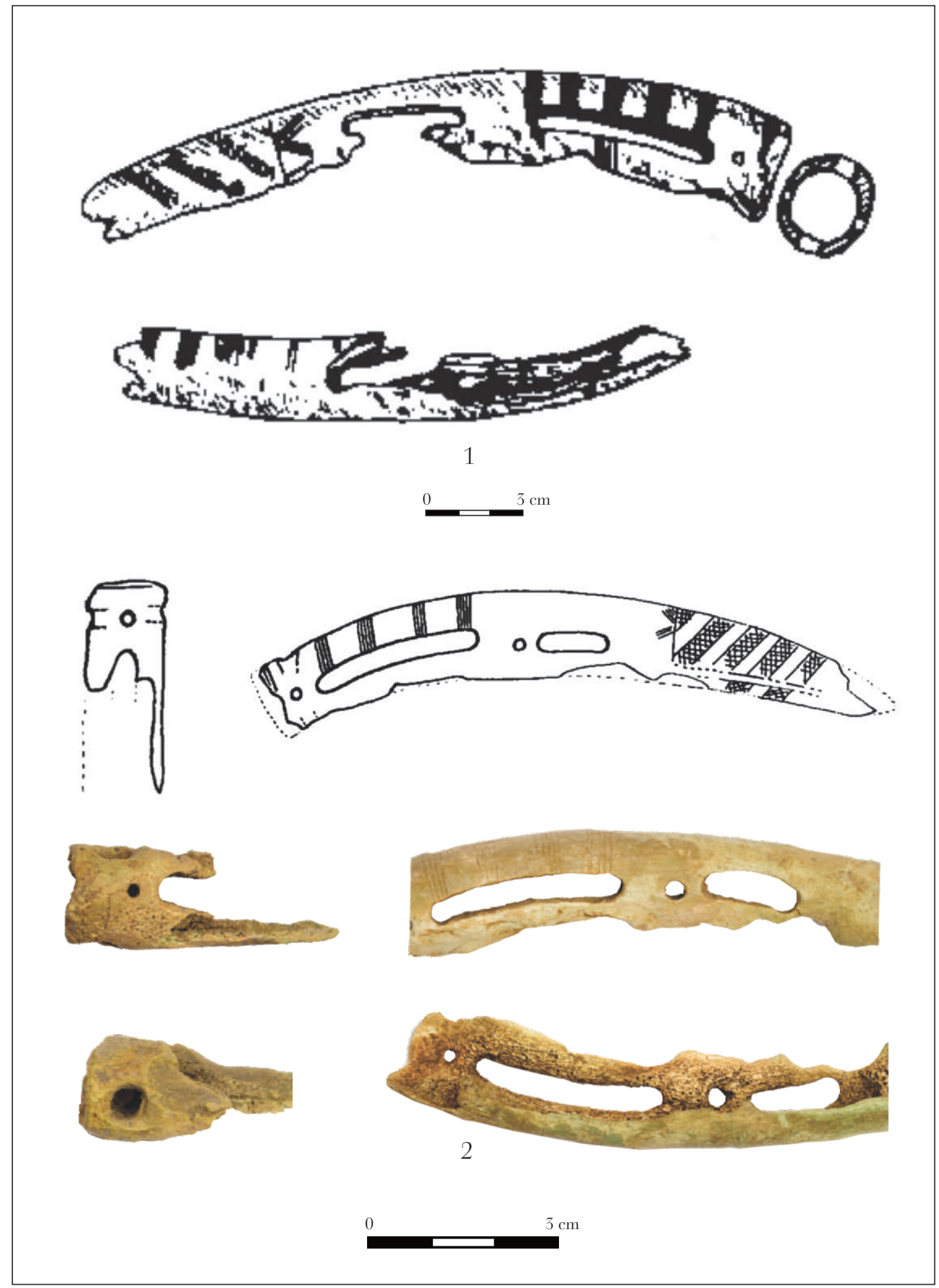

Pl. VII. Horse cheek-pieces from "Cioclovina cu Apă” Cave. 1. Drawing apud Comşa 1966; 2. Drawing and photo apud Emődi 1978. 


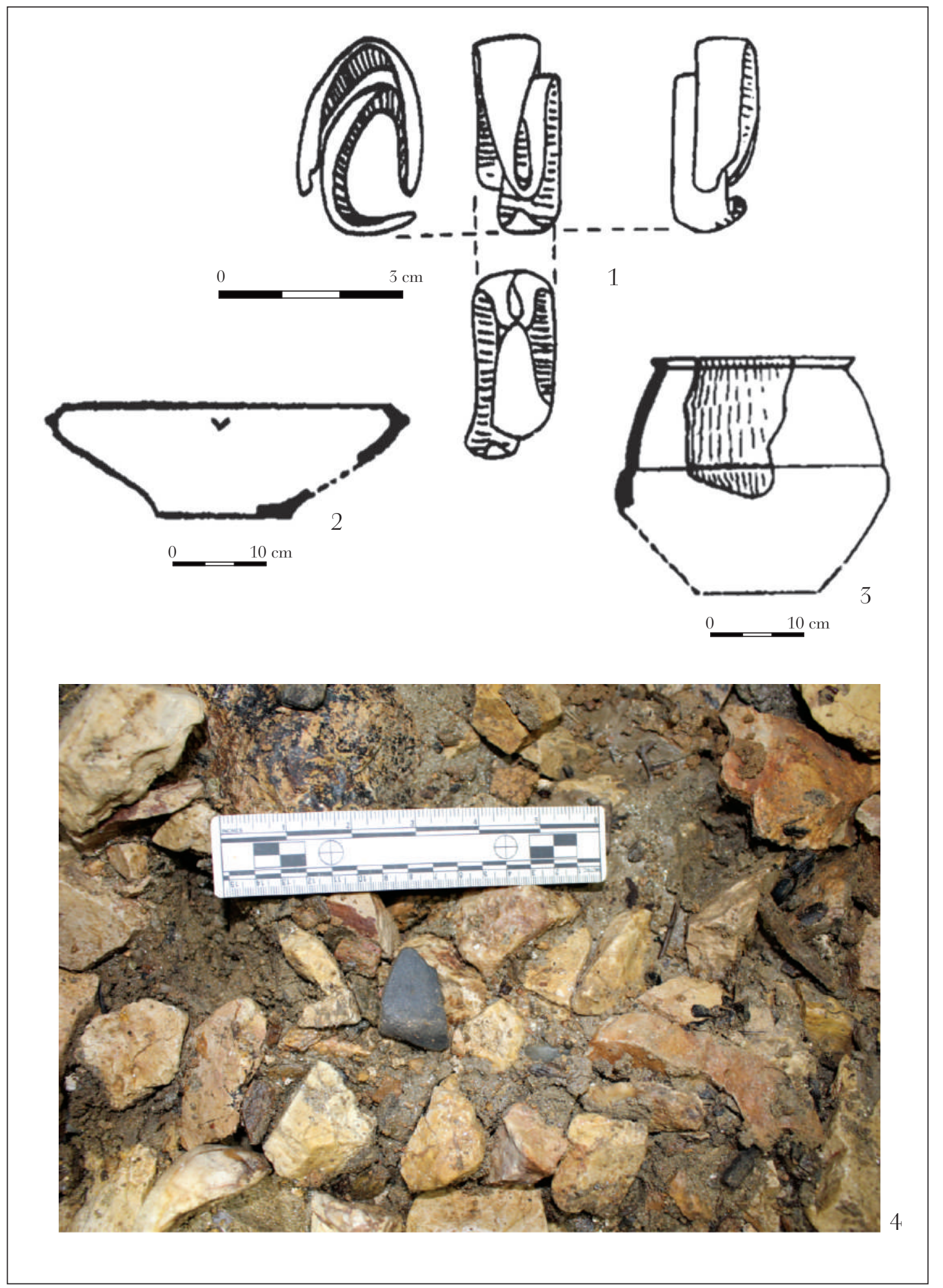

PI. VIII. Artifacts from "Cioclovina cu Apă" Cave. 1. Bronze earring; 2-4. Pottery vessels (1-3 apud Emődi 1978). 


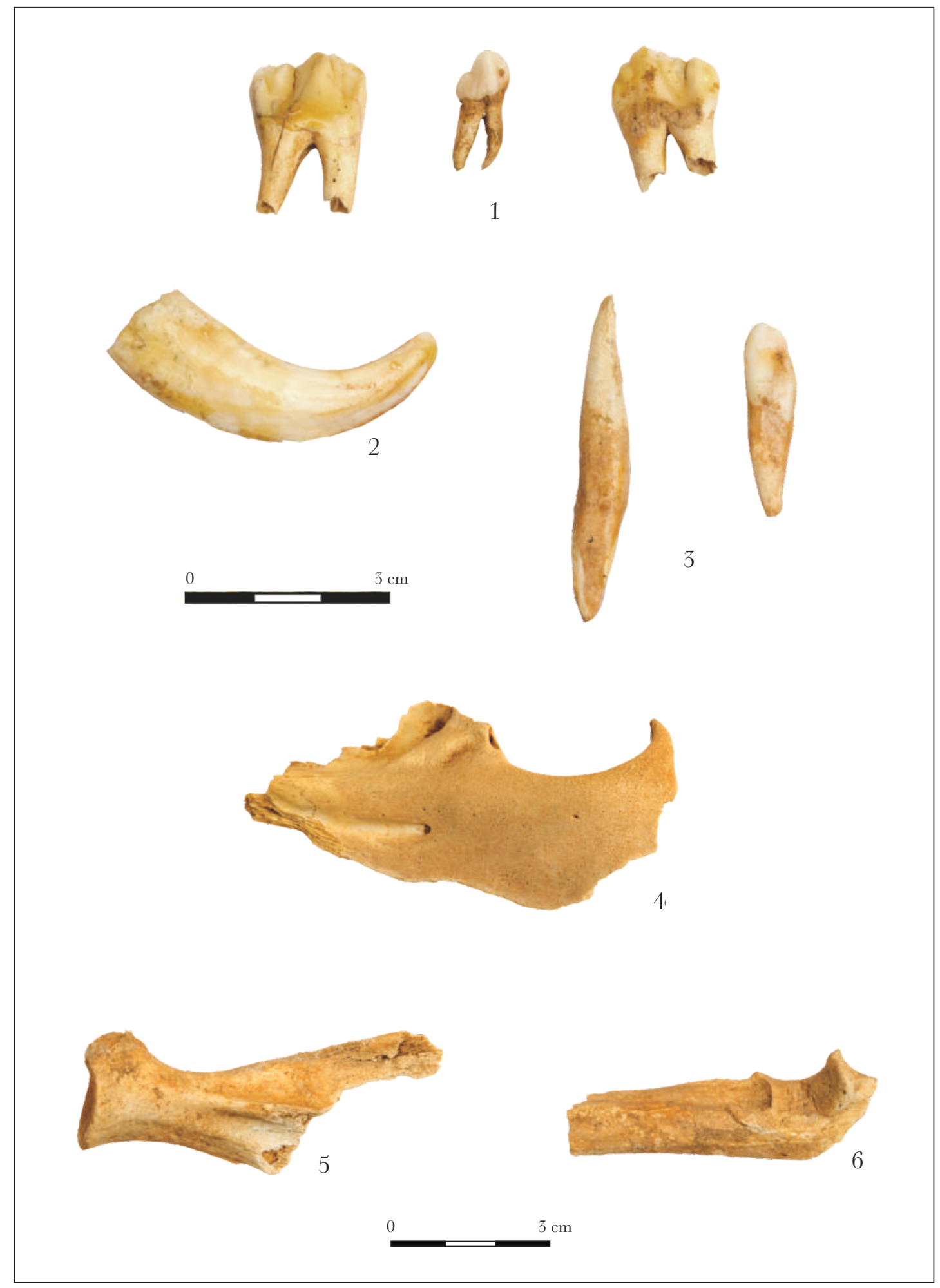

Pl. IX. 1-6. Animal bones from "Cioclovina cu Apă" Cave. 

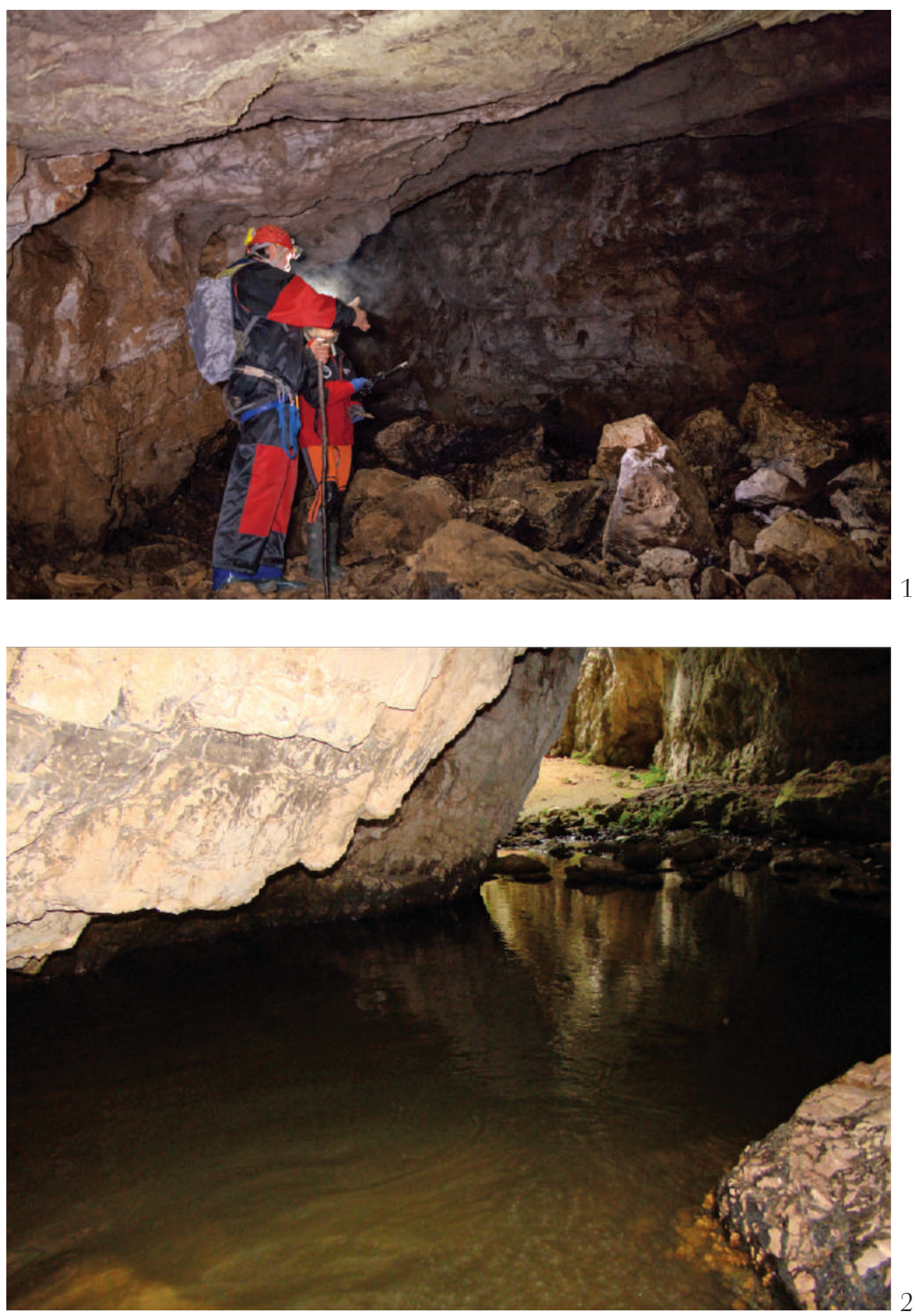

Pl. X. 1-2. "Cioclovina cu Apă" Cave. Inside view. 

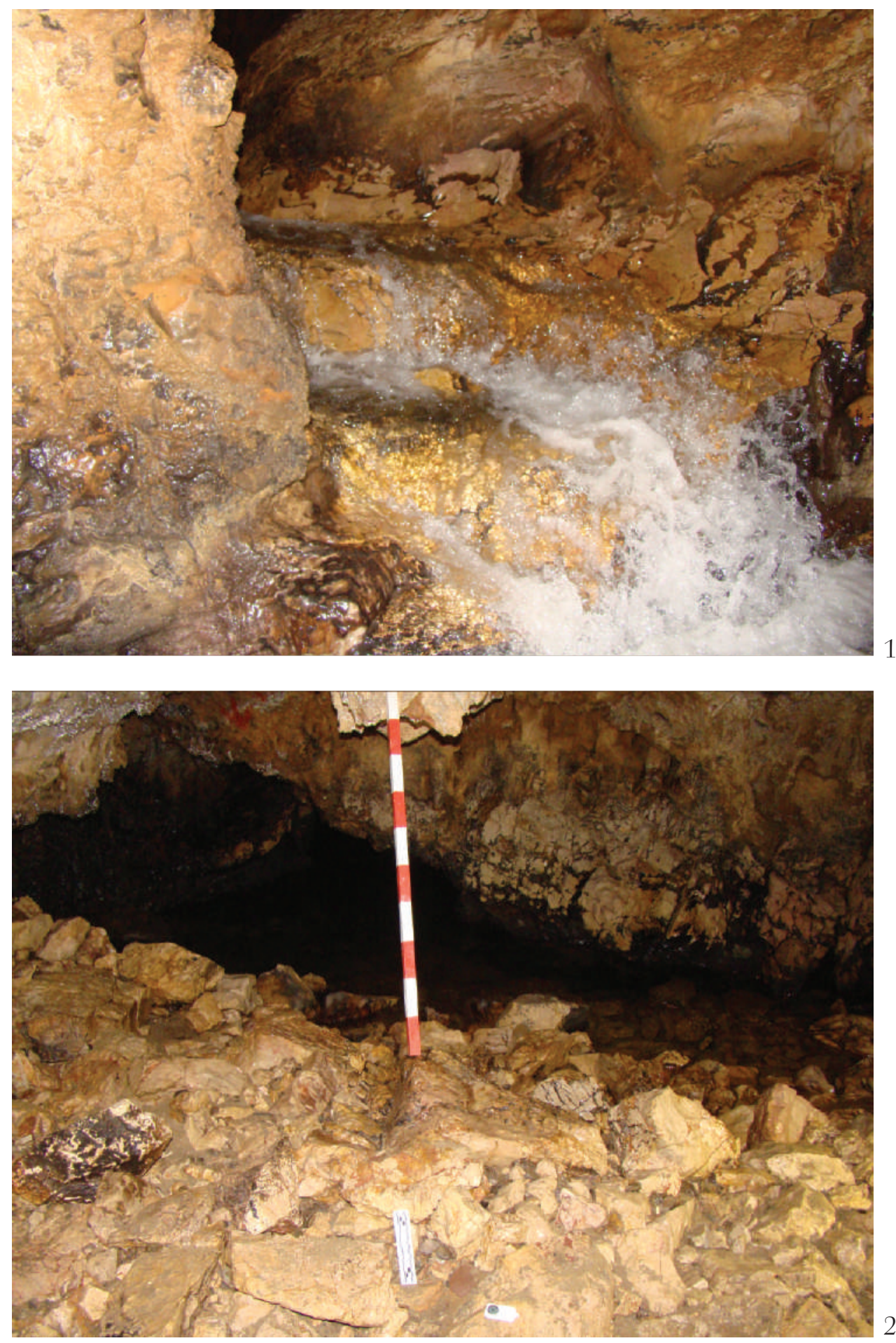

Pl. XI. 1-2. "Cioclovina cu Apă" Cave. Inside view. 

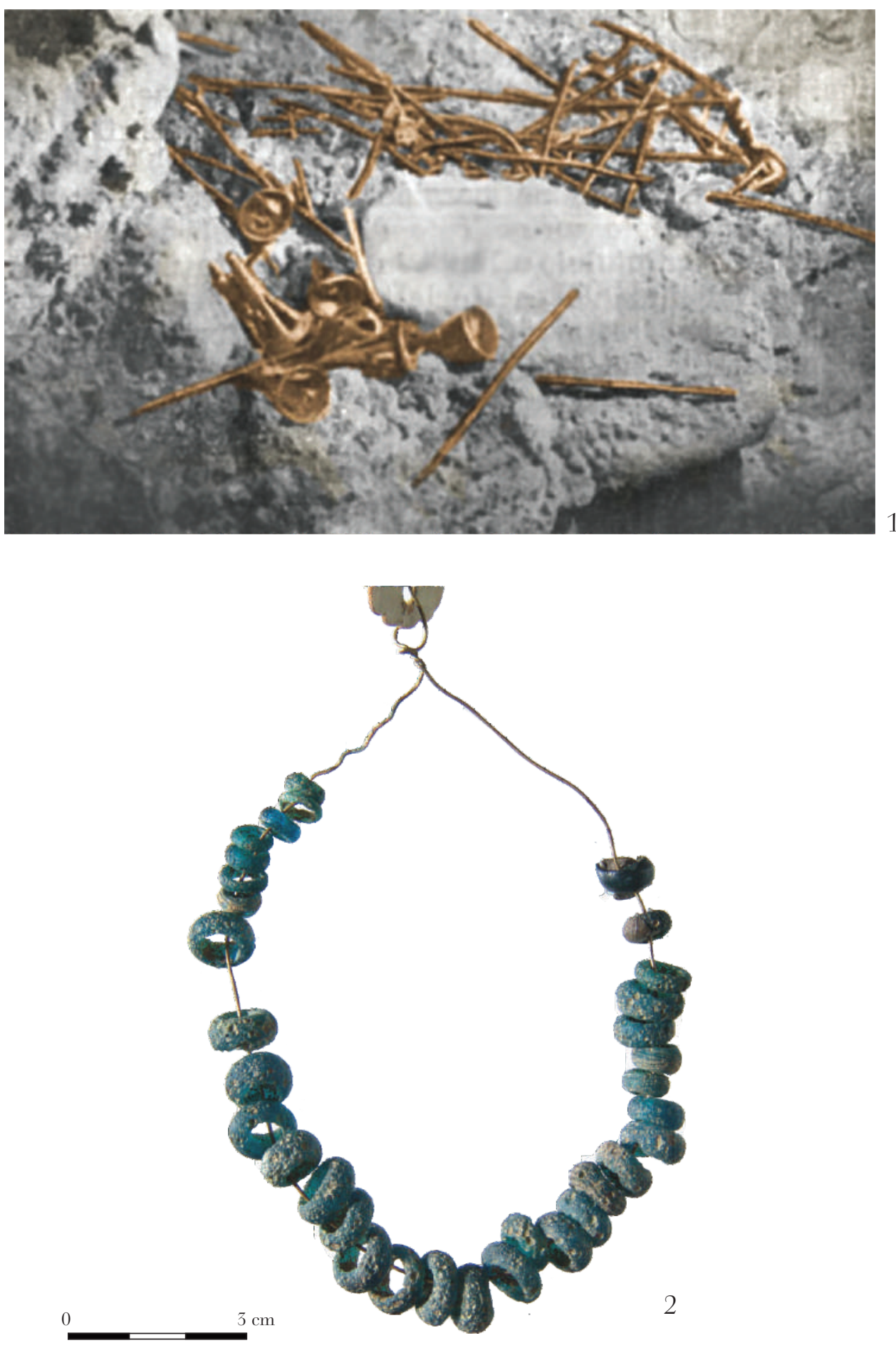

Pl. XII. Artifacts from "Cioclovina cu Apă" Cave. 1. Bronze artifacts (apud Dumitrescu, Orghidan 1959); 2. Glass beads from Dobrocina hoard. 


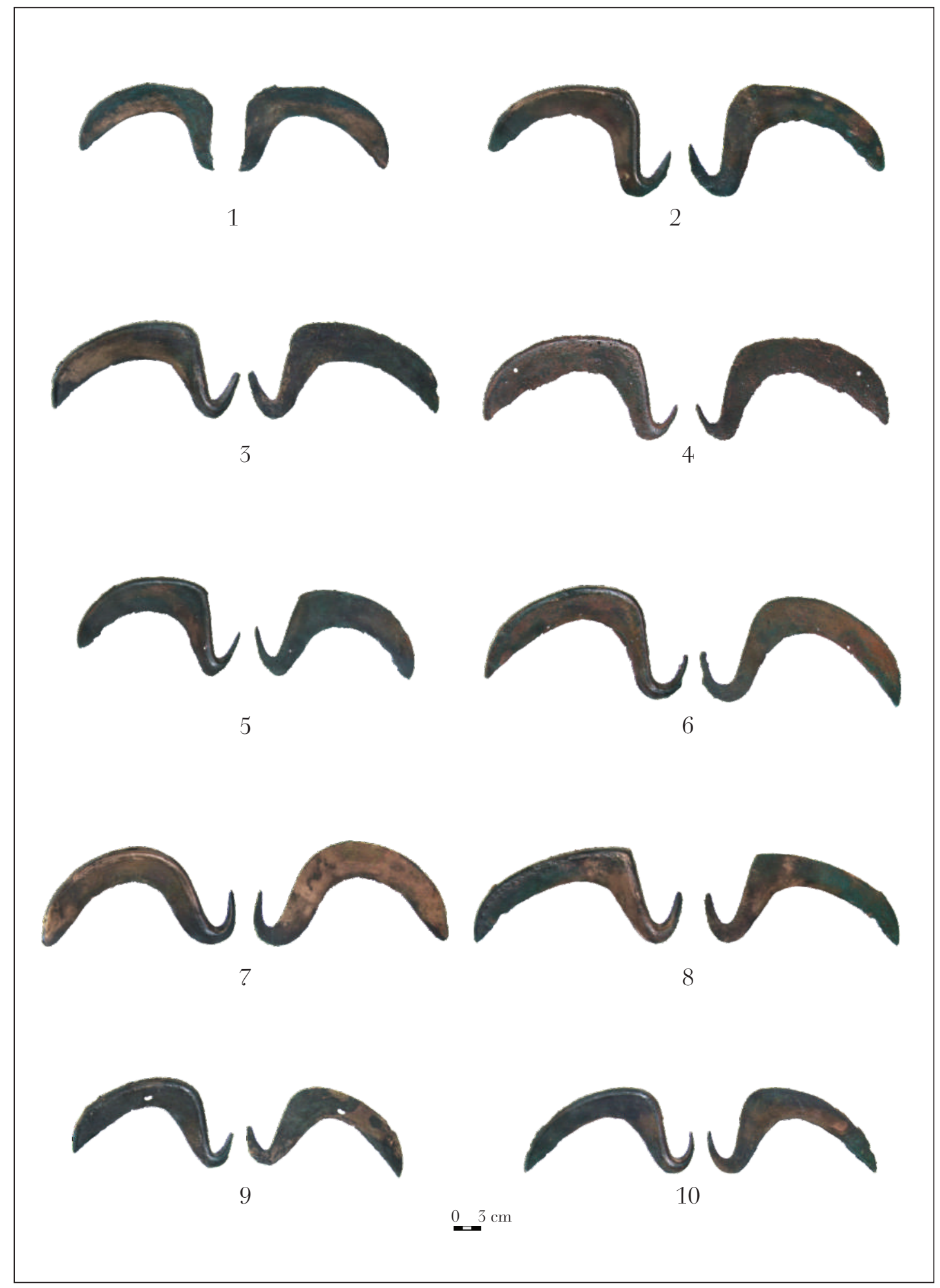

Pl. XIII. 1-10. Sickles from the Cluj-Napoca - Tufele Roşii hoard. 


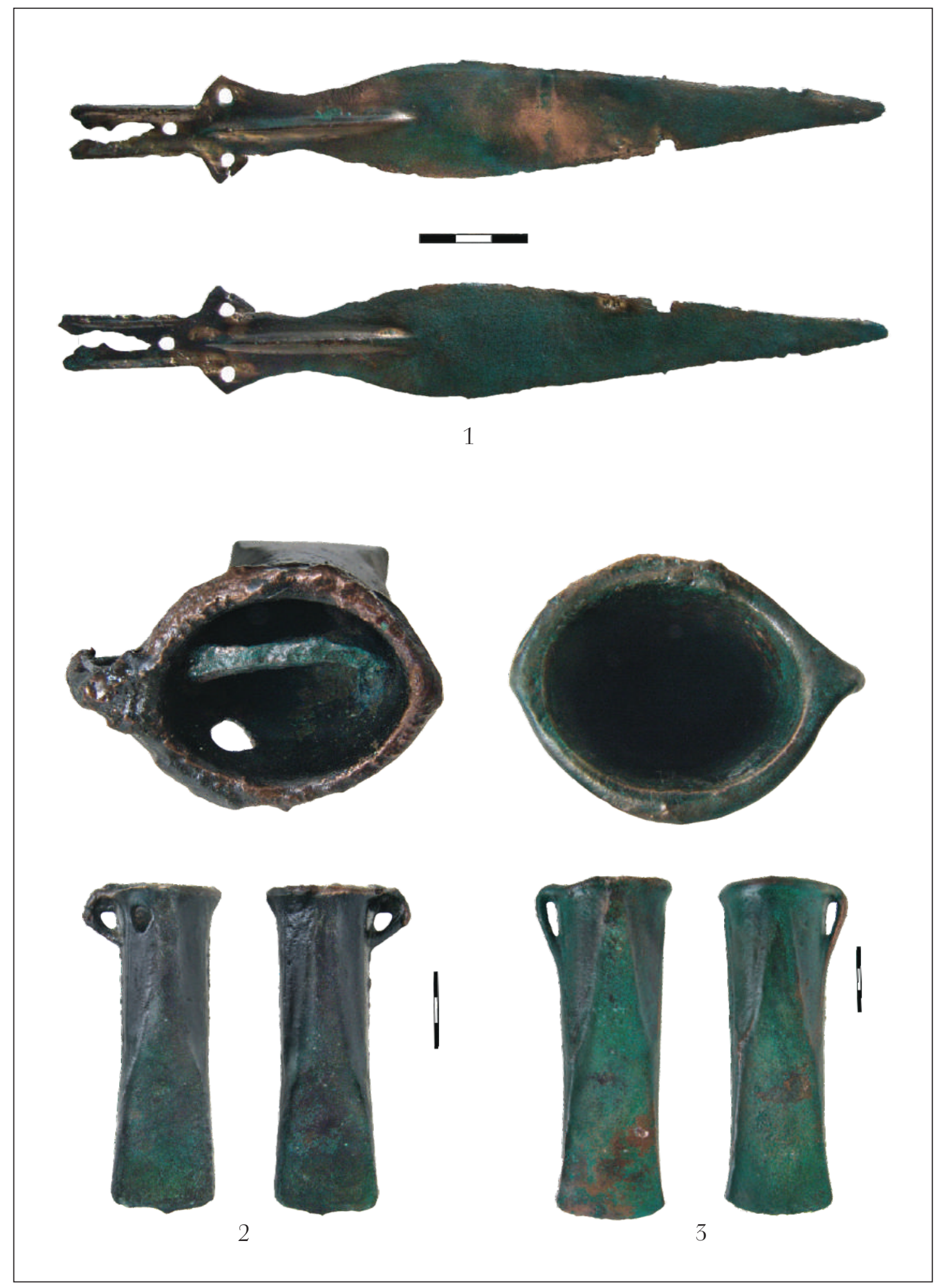

Pl. XIV. Artifacts from the Cluj-Napoca - Tufele Roşii hoard. 1. Dagger; 2-3. Socketed axes. 


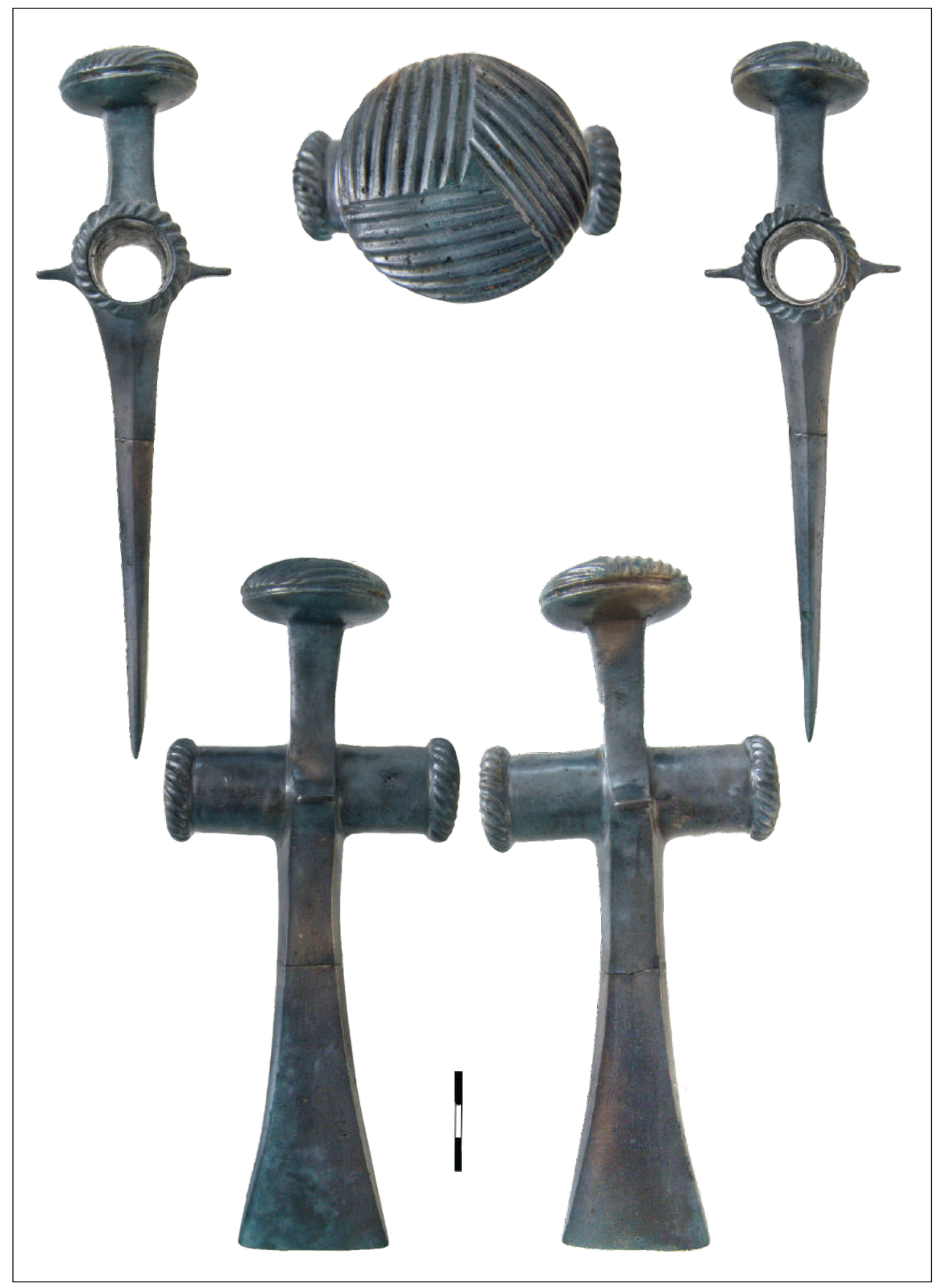

Pl. XV. Cluj-Napoca - Tufele Roşii hoard. Bronze axe-sceptre. 


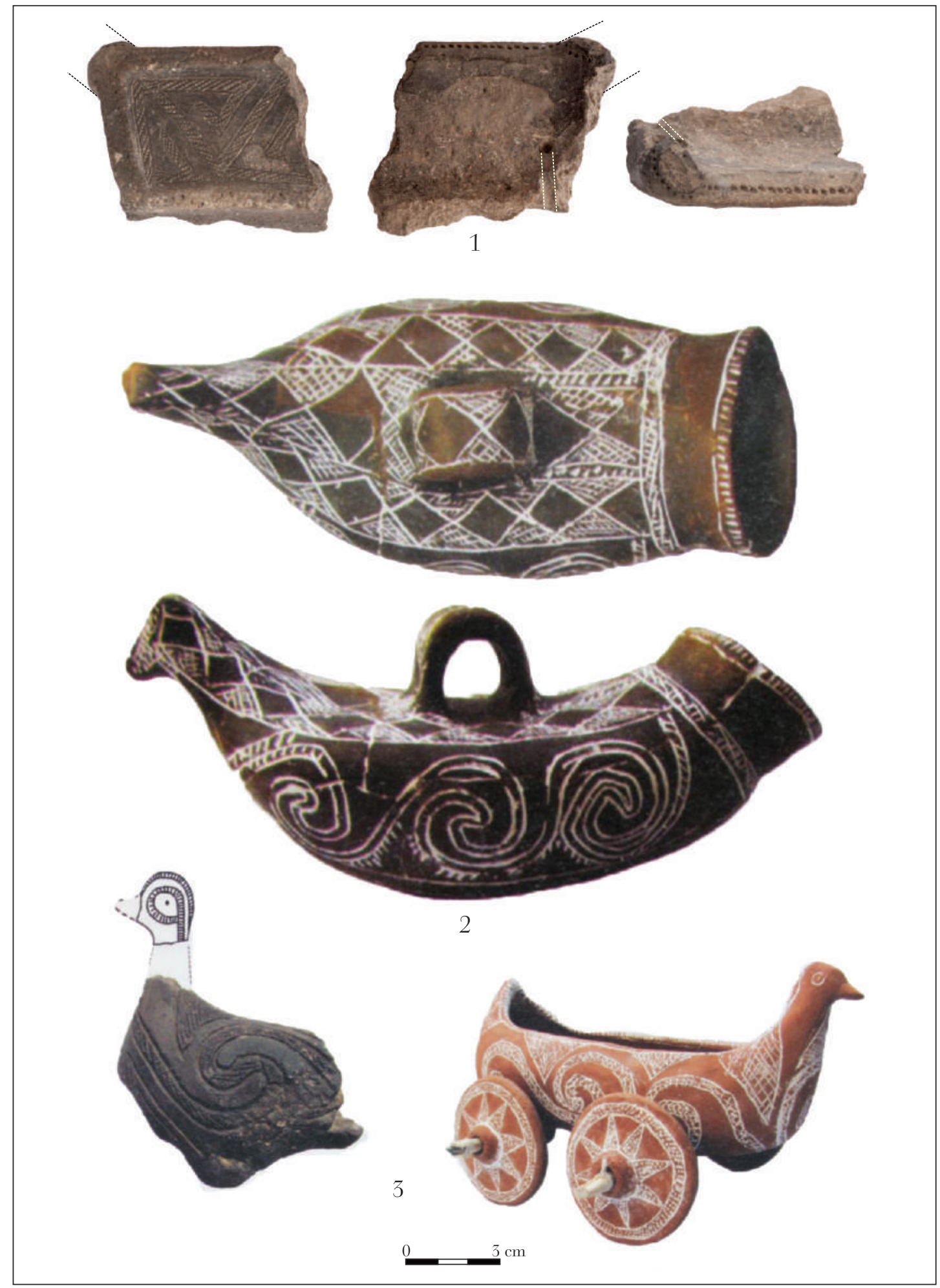

Pl. XVI. Wietenberg culture artifacts. 1. Tureni - Poderei; 2-3. Uroi - Sigheti (apud Marc et alii 2015) (original artifact and hypothetical reconstruction). 


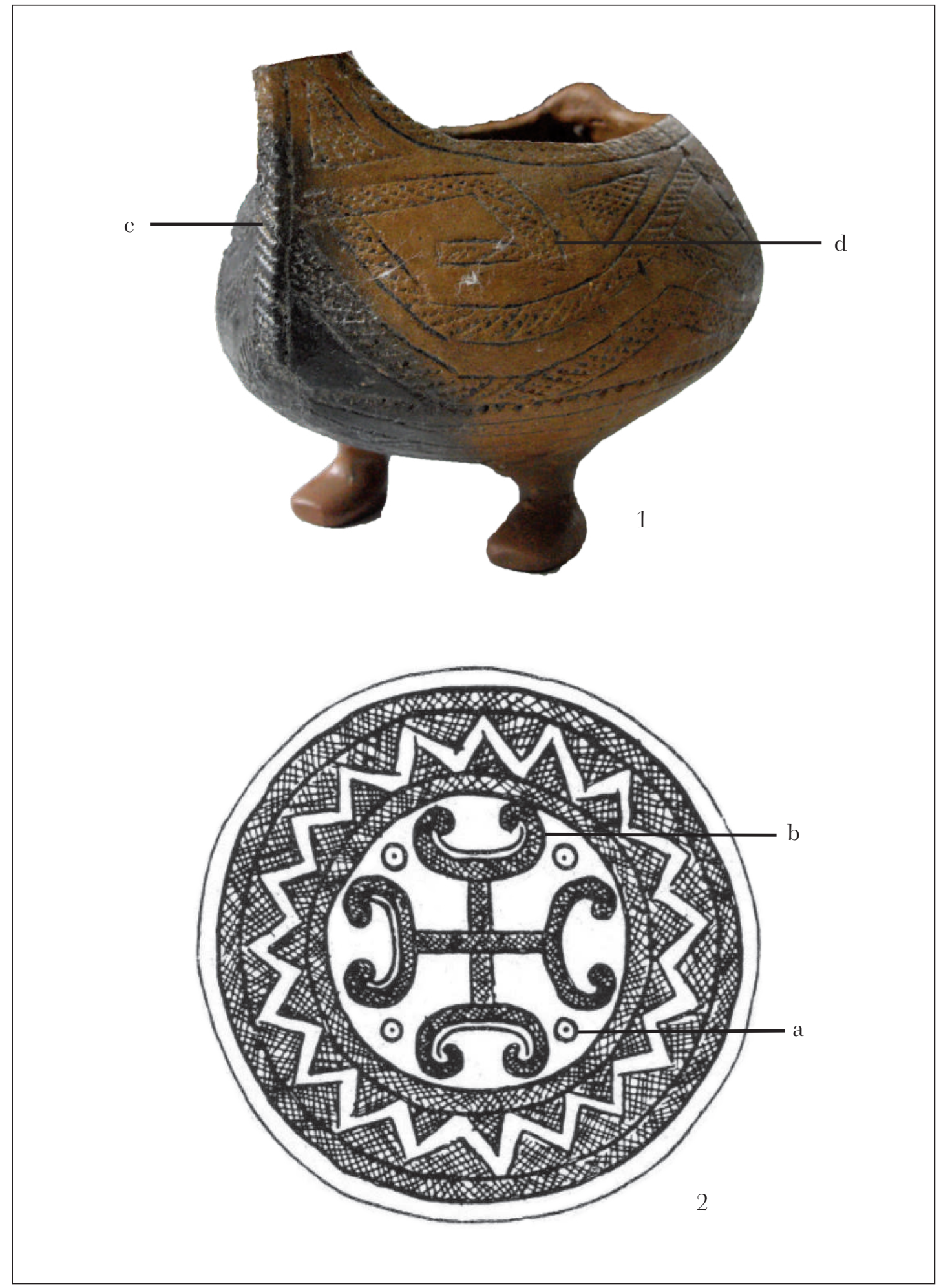

Pl. XVII. Wietenberg culture. 1. Bird-boat-vessel from Sânpaul (highway A3, site 9); 2. Decorated plate (apud Horedt 1960); a - sun, b - boat, c - boat stem, d - wave. 


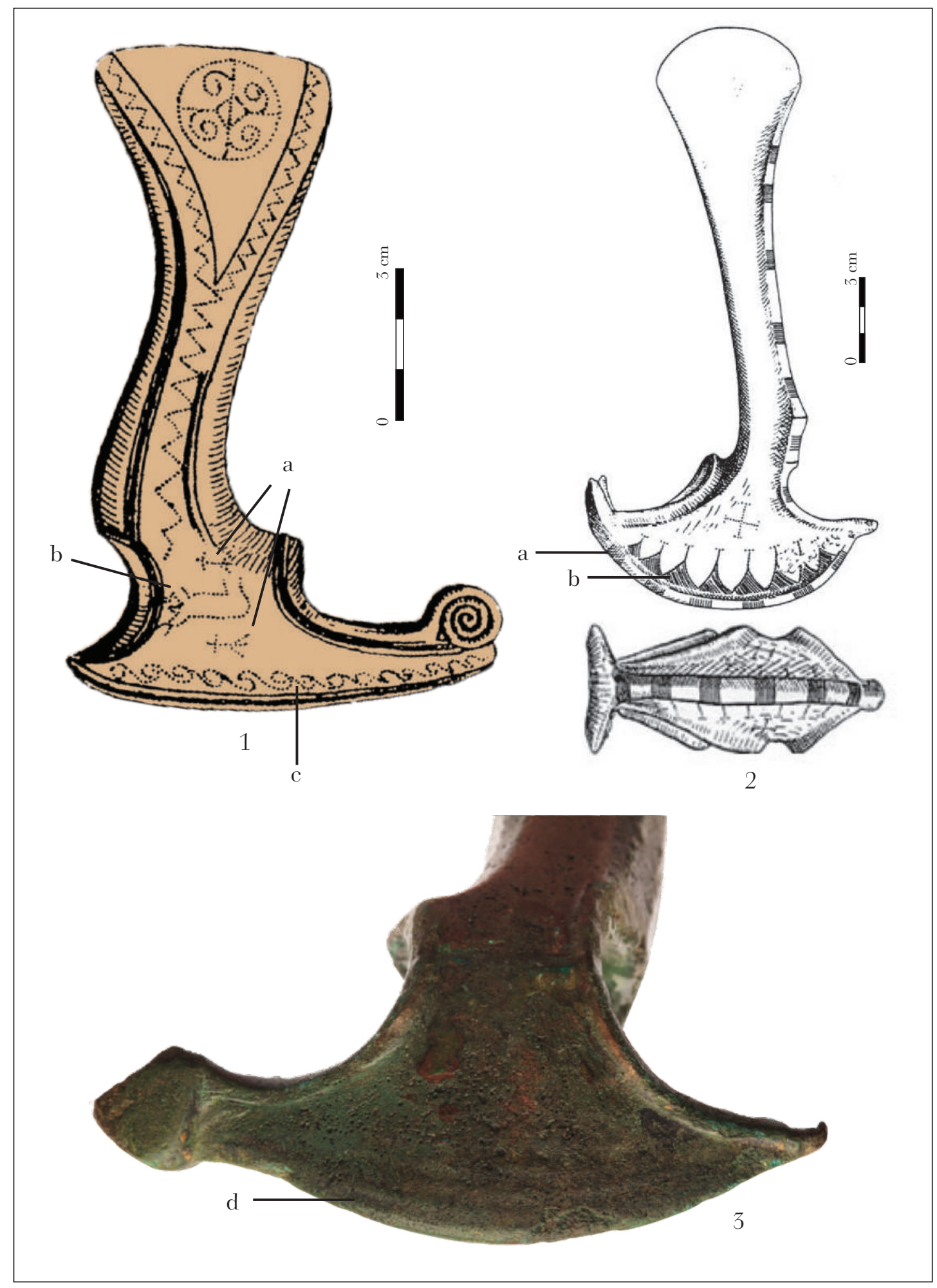

Pl. XVIII. 1. Gold axe from Tufalău hoard (apud Mozsolics 1968); 2. Bronze axe from Apa hoard (apud Soroceanu 2012); a - human silhouette, b - paddle, c - wave, d - wooden boat. 


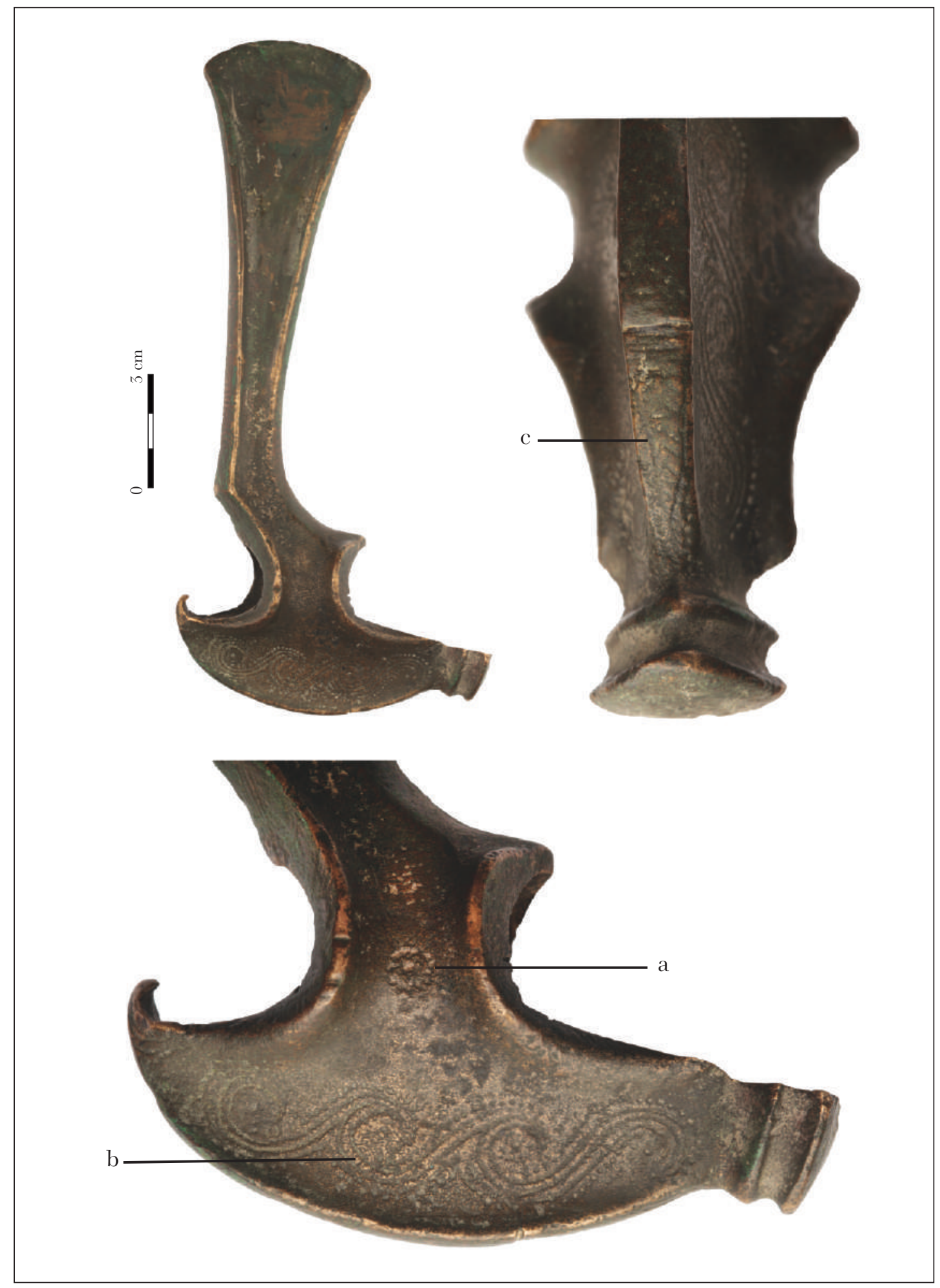

Pl. XIX. Wietenberg culture. Bronze axe from Ernei; a - sun, b - wave, c - stern of the ship. 


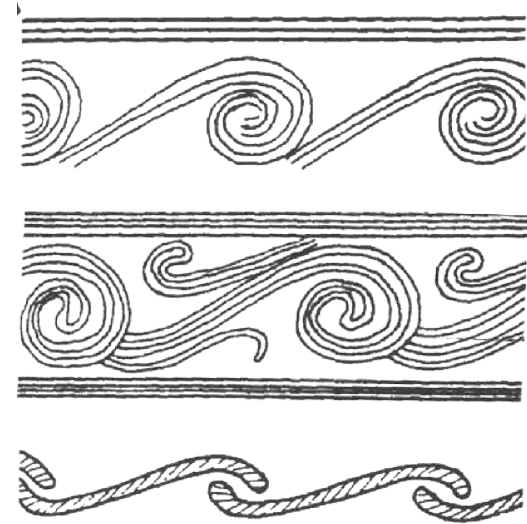

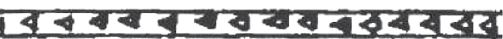
1.

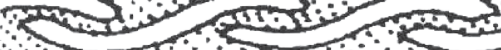
$\therefore \because \because \because \because \cdots$

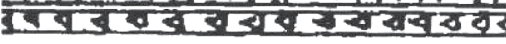

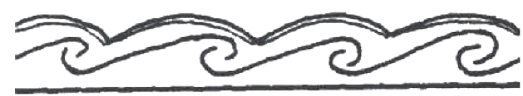

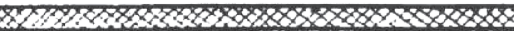
$\because \because \because$ - $\because 11+10$ $>20$ (

\$Q002000
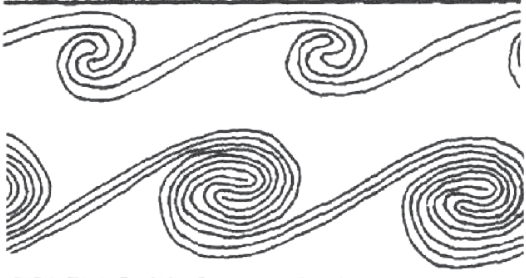
\%oscosos
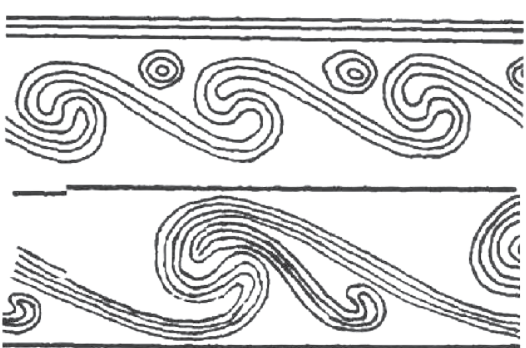

1
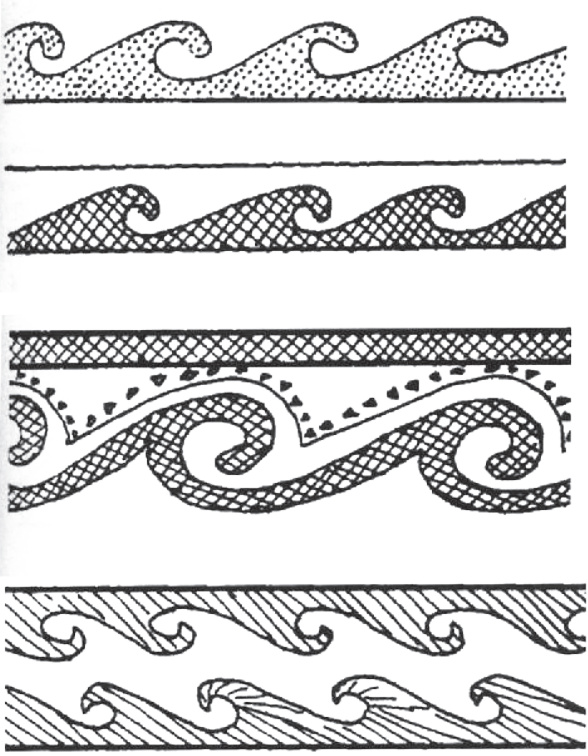

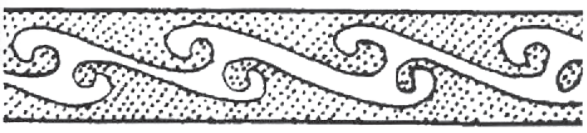

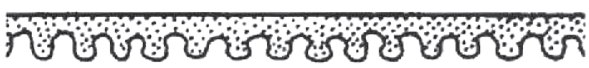

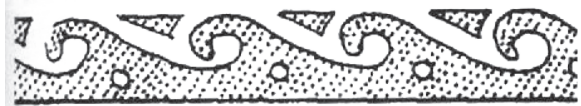

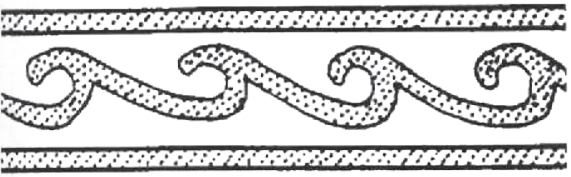

त.

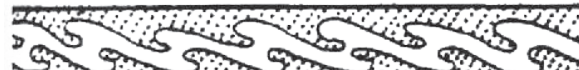

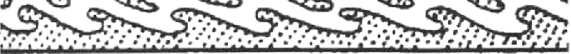
2

Pl. XX. Wietenberg culture. 1. Spiral motive; 2. Wave motive. 


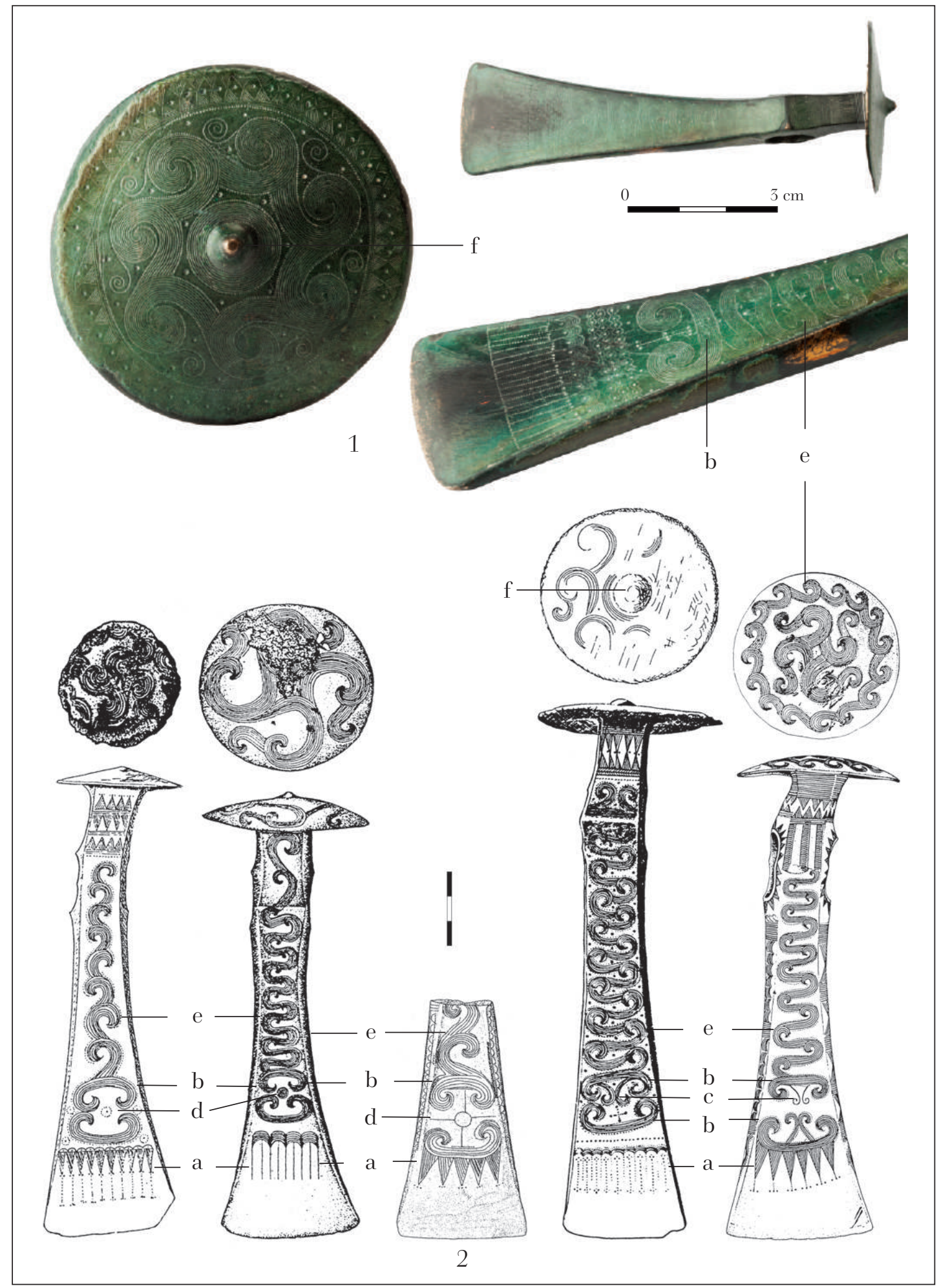

Pl. XXI. Bronze artifacts. 1. Axe from Valea Chioarului; 2. Axe from Carpathian Basin (apud David 2005); a - human silhouette, b - boat, c - boat mast/tree of life, d - sun, e - wave, f mountain/centre/axis mundi. 

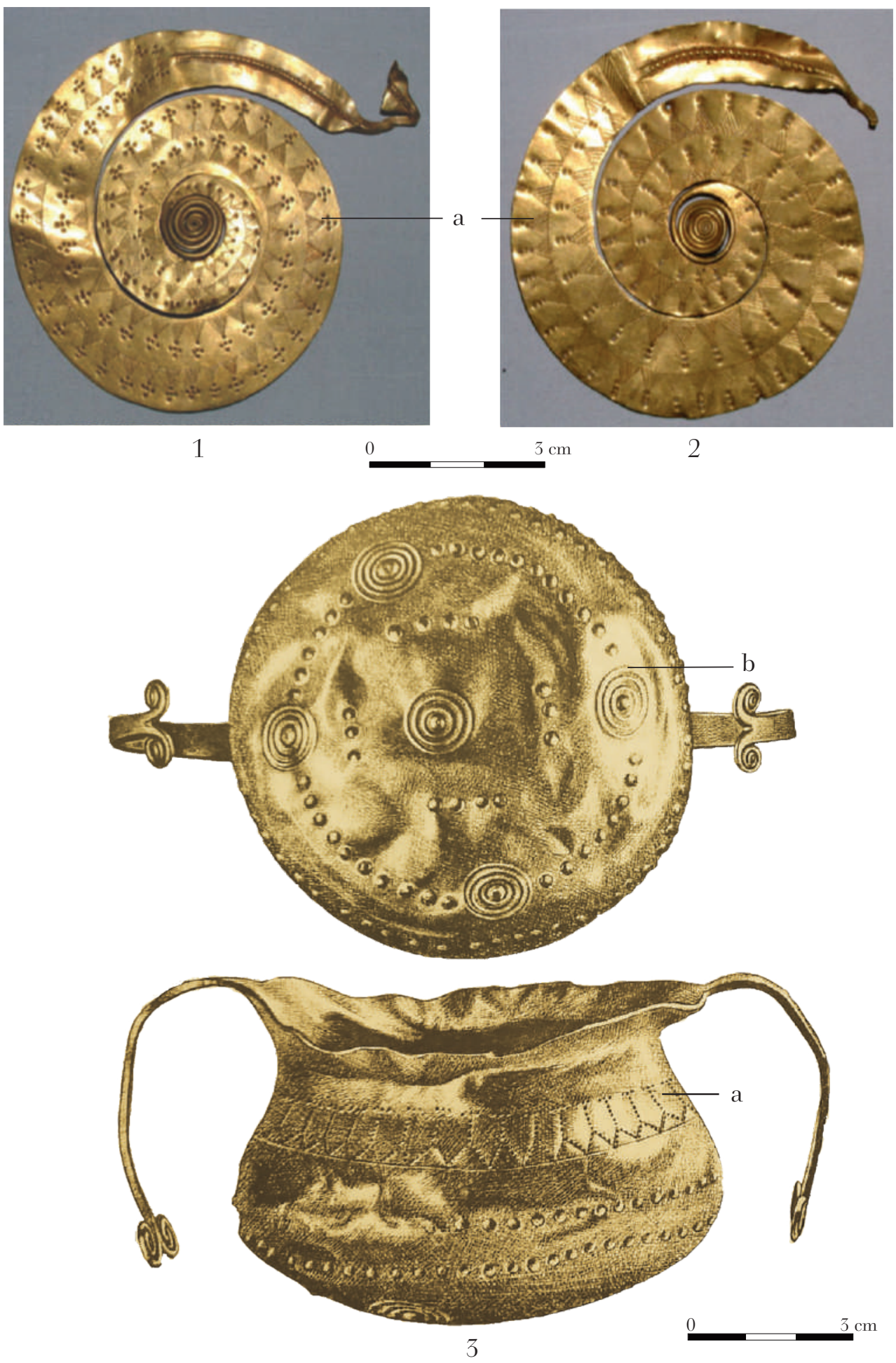

Pl. XXII. Gold artifacts. 1-2. Sarasău; 3. Biia (apud Mozsolics 1968); $\mathrm{a}$ - human silhouette; b - sun/sun travel. 


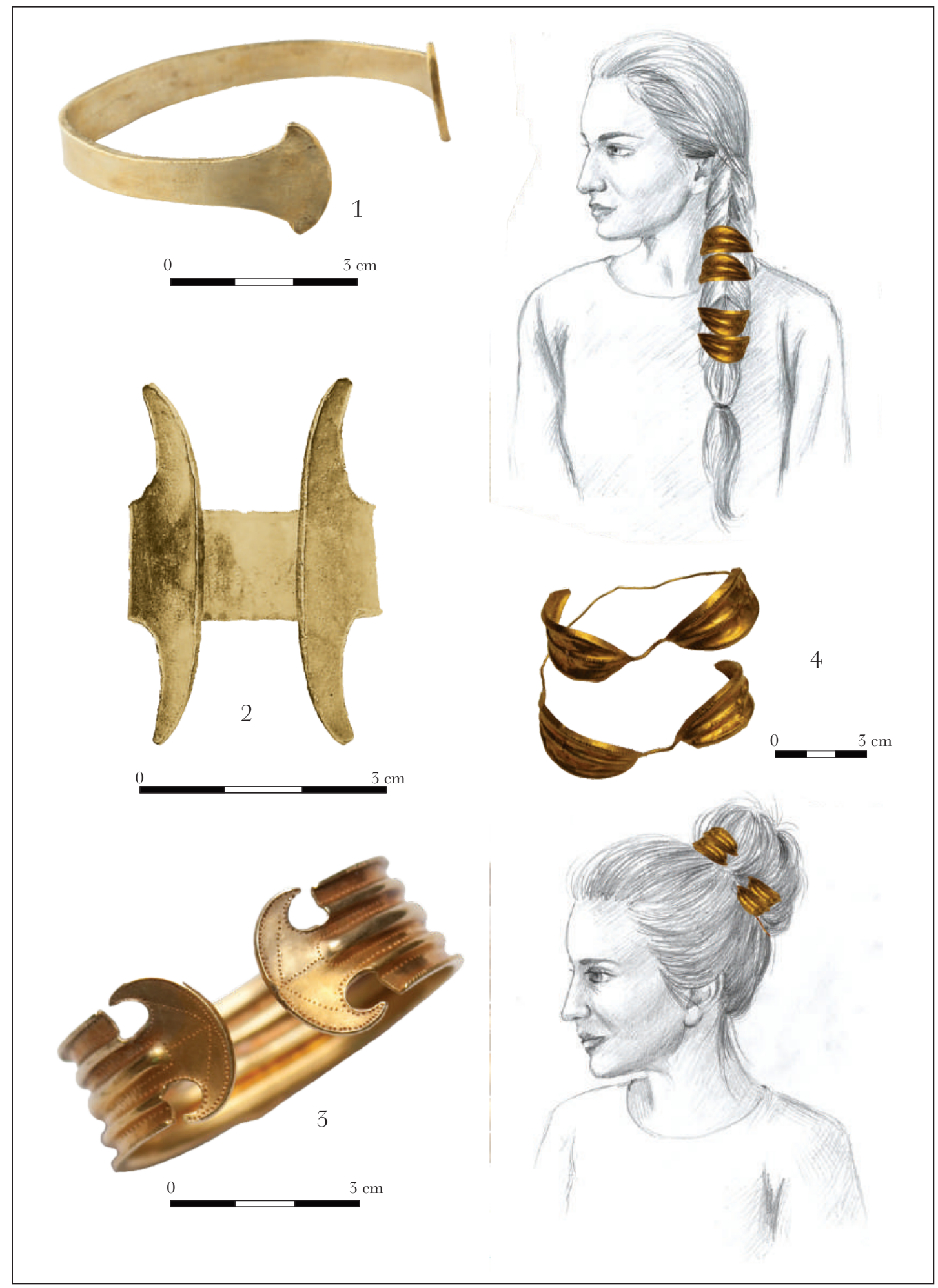

Pl. XXIII. Gold artifacts. 1. "Transylvania" hoard; 2. Abrud (apud Mozsolics 1968); 3. Boarta; 4. Sărmăşag (suggestions for use). 


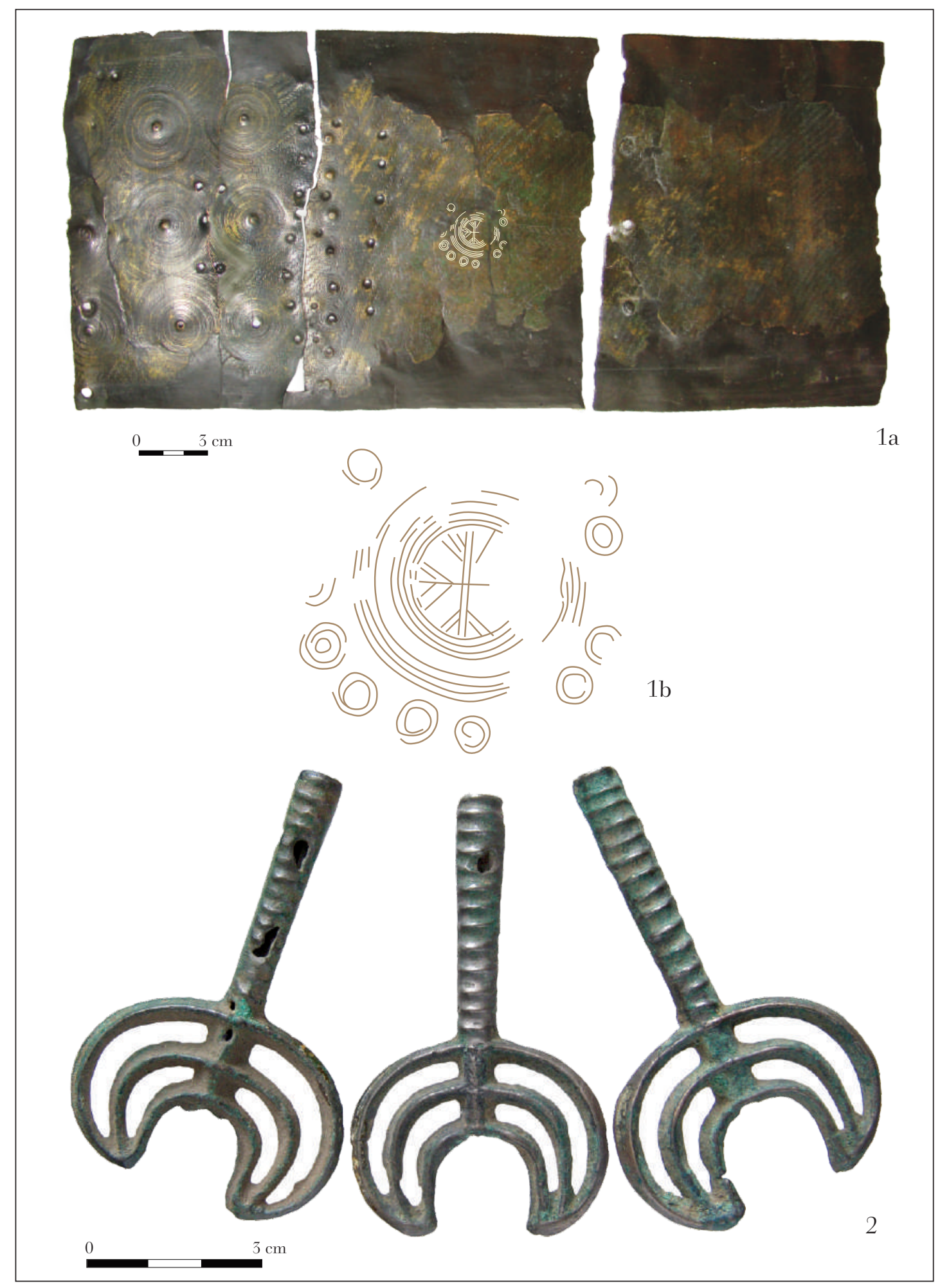

PI. XXIV. Giula hoard. 1. Belt; b - sun-wheel travel; 2. Lunulae. 


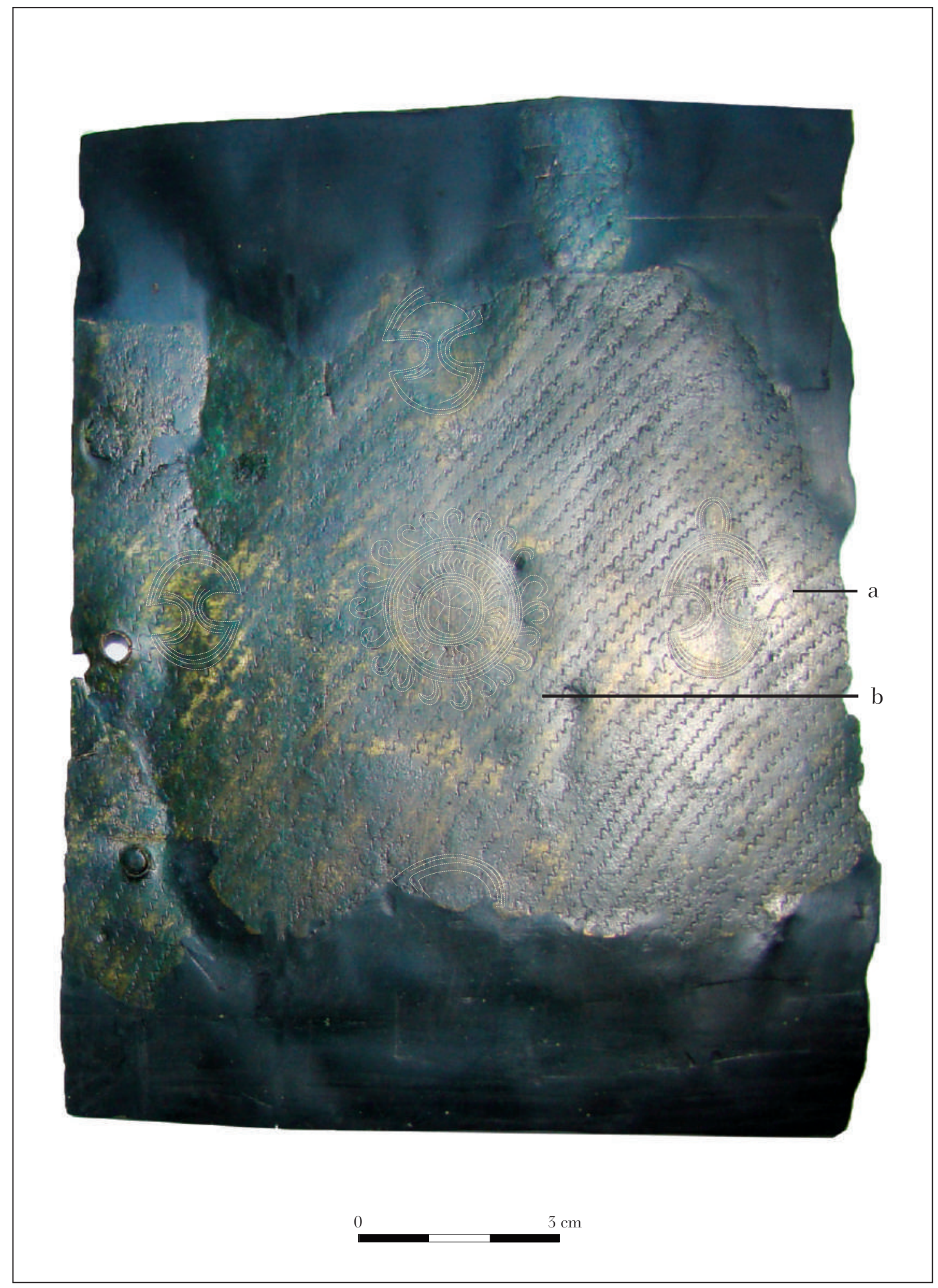

Pl. XXV. Giula hoard. Belt; a - labryx or shield, b - sun-wheel. 


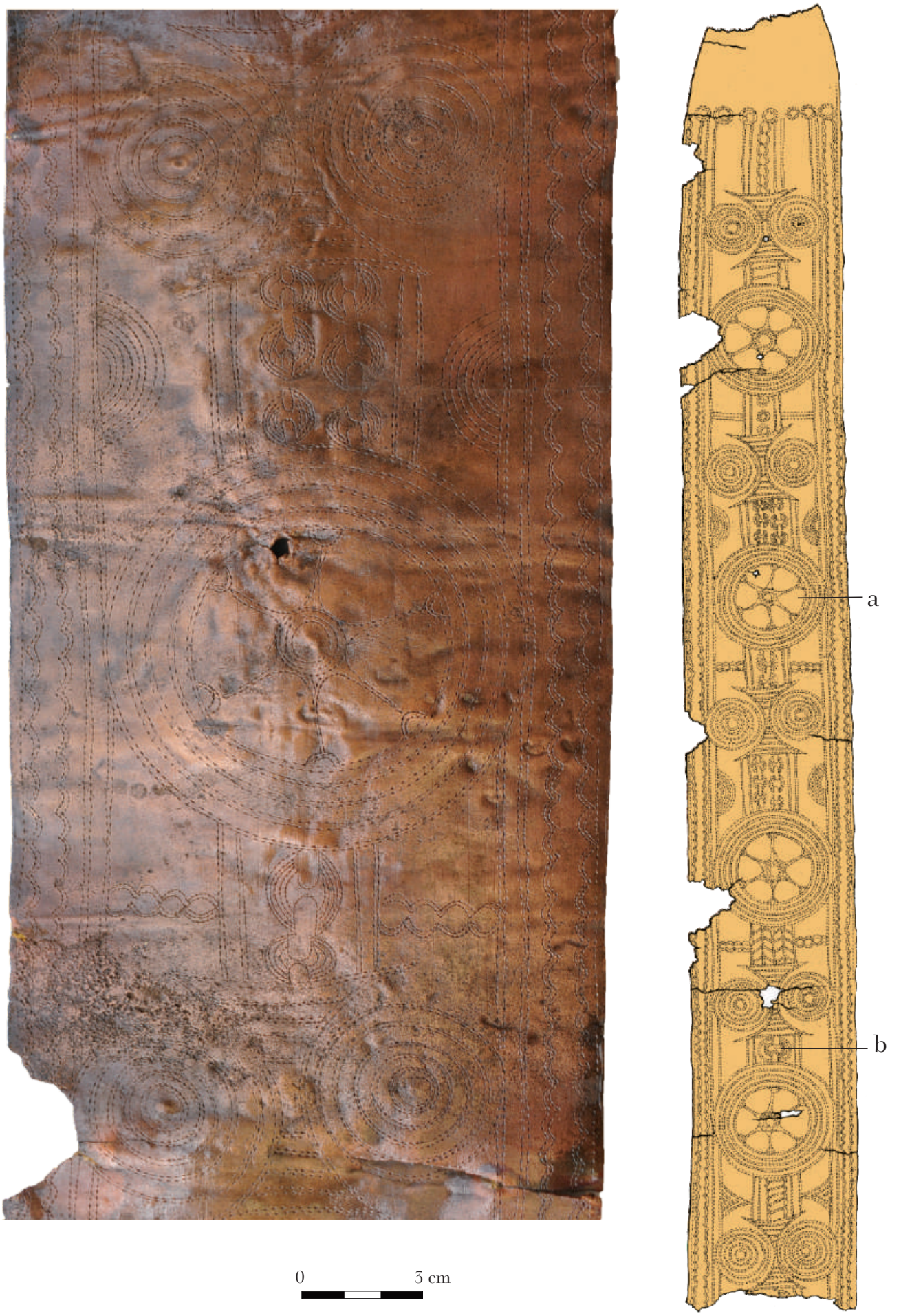

Pl. XXVI. Uioara de Sus hoard. Belt; a - sun-wheel, b - labryx or shield. 


\title{
VEXATISSIMI NUMMI: 500 JAHRE NUMISMATISCHE FORSCHUNG ZU DEN KOSŌN-MÜNZEN*
}

\author{
FRITZ MITTHOF
}

\begin{abstract}
Zusammenfassung: Die Kosōn-Münzen, die erstmals 1520 von Erasmus von Rotterdam erwähnt werden, geben der Forschung bis auf den heutigen Tag Rätsel auf. Der Beitrag verfolgt das Ziel, die Entwicklung des gelehrten bzw. wissenschaftlichen Diskurses zu diesen Münzen vom Zeitalter des Humanismus bis in die moderne Forschung nachzuzeichnen. Es werden zunächst die derzeit bekannten Münztypen (ein Gold-Stater in drei Varianten und zwei SilberDrachmen) und ihre Fundgeschichte beschrieben, die mit Sarmizegetusa Regia und der Zone der Orăstie-Berge im südwestlichen Siebenbürgen verbunden ist. Sodann werden in diachroner Reihenfolge die Deutungen vorgestellt, die sich zu diesen Münzen in der numismatischen Literatur des 16.-19. Jh. finden. Im Anschluss hieran wird die Entwicklung der Forschung zu dieser Thematik seit dem frühen 20. Jh. skizziert und der aktuelle Forschungsstand zusammengefasst. Abschließend werden neue Beobachtungen und Überlegungen zur Deutung der Kosōn-Münzen und zu ihrem historischen Kontext vorgestellt, die sich aus der laufenden Forschungsarbeit des FWF-Projektes P 23975-G21 ergeben haben. In diesem Zusammenhang werden auch bislang unbekannte Dokumente der Habsburger Verwaltung des Großfürstentums Siebenbürgen aus der Zeit um 1800 angeführt.
\end{abstract}

Schlüsselwörter: Kosōn-Münzen (Goldstater und Silberdrachmen); Lysimachos-Stater (posthume Emissionen); Münzprägung und Münzumlauf im vorrömischen Dakien; barbarisierte Prägungen; Imitation von republikanischen Denaren; Metall- und Stempelanalyse antiker Münzen; Sarmizegetusa Regia; Orăștie-Berge; Siebenbürgen; Raubgrabungen; Humanismus; Antiquarianismus; frühneuzeitliche Numismatik; Dokumente der Habsburger Verwaltung.

Abstract: Vexatissimi nummi: 500 years of numismatic research on the Coson-coins. The Coson-coins were first mentioned by Erasmus of Rotterdam in 1520 and have puzzled scholars up to the present day. The aim of this contribution is to trace the development of the learned or scientific discourse on these coins from the age of humanism to modern-day scholarship. First, the currently known coin types (a gold stater in three variants and two silver drachmae) will be described alongside the history of their discovery that is connected with Sarmizegetusa Regia and the area of Orăștie-mountains in south-western Transylvania. Then, the interpretations will be presented in a diachronic sequence as found regarding these coins in the numismatic literature of the $16^{\text {th }}$ to $19^{\text {th }}$ century. This will be followed up by a sketch of the development of the research on this issue since the early $20^{\text {th }}$ century and the current state of research will be summarized. Finally, new observations and ideas for the interpretation of the Coson-coins and their historical context will be presented that developed out of the current research for the FWF-project P 23975-G21. In this context, previously unknown documents on

* Der vorliegende Beitrag ist ein Ergebnis des vom Verfasser geleiteten Forschungsprojektes „Von der Schatzsuche zur Archäologie“ (FWF P 23975-G21). Für wertvolle Hinweise danke ich Victor Dumitru, Wolfgang Fischer-Bossert, Gelu Florea, Cristian Găzdac, Daniela Haarmann, Loránd Mádly, Răzvan Mateescu, Ulrike Peter, Karl Strobel, Klaus Vondrovec, Daniela Williams und Bernhard Woytek. - Die Formulierung vexatissimi nummi ist inspiriert von einer Stelle bei Wachter 1740, 104 (s. unten Anm. 67). Die Bibliographie am Ende des Beitrages hat zwei Abschnitte: Ältere Literatur (16.-19. Jh.) und Neuere Literatur (20.-21. Jh.). Alle Zeitangaben sind, sofern nicht anders vermerkt, als nachchristlich zu verstehen. 
the Habsburg administration of the Great Principality of Transylvania from the period around 1800 will also be mentioned.

Keywords: Coson-coins (gold stater and silver drachma types); Lysimachus-coins (posthumous gold stater type); coinage and money circulation in pre-Roman Dacia; barbarized coinage; imitation of Roman Republican denarii; composition and analysis of ancient coins; Sarmizegetusa Regia; Orăștie Mountains; Transylvania; clandestine treasure hunt; Humanism; Antiquarianism; early modern numismatic literature; documents of the Habsburg administration.

Rezumat: Monetele de tip Koson au fost menționate pentru prima dată de Erasmus din Rotterdam în 1520, punându-i în încurcătură pe cercetători până în zilele noastre. Scopul acestei contribuții este de a urmări dezvoltarea discursului învățat sau al celui științific cu referire la aceste monete, începând din perioada umanismului până la cerectările din epoca modernă. În primul rând, vor fi descrise tipurile de monete cunoscute (un stater de aur în trei variante și două drahme de argint), alături de istoria descoperirii lor care este legată de Sarmizegetusa Regia şi de zona Munţilor Orăștiei din sud-vestul Transilvaniei. Apoi, interpretările vor fi prezentate într-o secvență diacronică, așa cum reiese din studiile de numismatică ce provin din secolele XVI-XIX referitoare la aceste monete. Va urma apoi o prezentare a dezvoltării cercetării pe această temă, începând din prima parte a secolului al XX-lea, iar în final se va rezuma stadiul actual al cercetărilor. În cele din urmă vor fi prezentate noile observații și idei de interpretare a monetelor de tip Koson, precum și a contextului lor istoric, rezultate obținute în urma cercetărilor actuale din cadrul proiectului FWF P 23975-G21. În acest context, vor fi menţionate şi documente necunoscute până în prezent privind administraţia habsburgică a Marelui Principat al Transilvaniei din jurul anului 1800.

Cuvinte cheie: monete de tip Coson (tipurile stater de aur şi drahmă de argint); monete tip Lysimachus (tipul stater de aur postum); moneta și circulația monetară în Dacia preromană; monete barbare; imitații de denari republicani romani; compoziția și analiza monetelor antice; Sarmizegetusa Regia; Munţii Orăştiei; Transilvania; vânătoare de comori; Umanism; colecţionarism; literatura numismatică modernă timpurie; documente ale administrației habsburgice.

Gliederung: 1. Einleitung - 2. Beschreibung des Kosōn-Staters - 3. Beschreibung der Kosōn-Drachmen - 4. Die Fundzone der Kosōn-Münzen: Sarmizegetusa Regia - 5. Die Schatzfunde von Kosōn-Münzen seit 1803 - 6. Keine Kosōn-Statere im Strei-Fund von 1543 7. Erste Zeugnisse für Kosōn-Statere aus dem 16. Jh. - 8. Die Kosōn-Münzen in der numismatischen Fachliteratur des 16.-18. Jh. - 9. Der Kosōn-Stater bei Eckhel und Neumann 10. Die Rezeption der Theorien Eckhels und Neumanns zum Kosōn-Stater im 19. Jh. - 11. Der Kosōn-Stater und die Gelehrtenwelt des frühneuzeitlichen Siebenbürgen - 12. Die moderne Forschung und der aktuelle Forschungsstand zu den Kosōn-Münzen - 13. Neue Perspektiven - Appendix: Eine anonyme Explication zum Kosōn-Stater von 1803.

\section{Einleitung}

Unter der Bezeichnung „Kosōn-Münzen“ lassen sich drei Münztypen erfassen, auf denen die griechische Legende $\mathrm{KO} \Sigma \Omega \mathrm{N}$ erscheint, nämlich erstens ein gut bekannter und weit verbreiteter Goldstater, der bereits von frühneuzeitlichen Autoren beschrieben wird, zweitens eine mit diesem Stater in Bild und Legende identische Silberdrachme, die möglicherweise schon in der älteren Literatur gelegentlich Erwähnung findet, in jedem Fall aber infolge illegaler Schatzfunde in den letzten 
beiden Jahrzehnten in größerer Zahl in den Münzhandel gelangt ist, sowie drittens eine weitere Silberdrachme, die sich in Bild und Legende von den beiden soeben genannten Münztypen unterscheidet. Auch dieser zweite Drachmentyp stammt aus Raubgrabungen der jüngeren Vergangenheit und ist ebenfalls vor wenigen Jahren im Münzhandel aufgetaucht; in diesem Fall existieren aber mit Sicherheit keine Erwähnungen in der Fachliteratur vor dem frühen 21. Jh. Alle drei Münztypen geben der Forschung Rätsel auf.

Der Gelehrtendiskurs zur Deutung des Kosōn-Staters setzt bereits im 16. Jh. ein. Im Laufe der Zeit wurden höchst verschiedene Ansichten zur Herkunft und zu den historischen Umständen der Prägung dieses Münztyps vorgetragen und zahlreiche Theorien entwickelt. In den beiden letzten Jahrzehnten hat diese Debatte aufgrund von Neufunden sowohl von Kosōn-Stateren als auch der beiden Kosōn-Drachmen neuerlich an Intensität gewonnen. ${ }^{1}$ Dennoch besteht in der Forschung bis heute selbst in Grundfragen kein Konsens. Schuld hieran sind zunächst drei Faktoren:

1.) Die Bilder und Inschriften der drei Münztypen liefern keinen für uns nachvollziehbaren Hinweis auf ihre Herkunft und genaue Zeitstellung. Vor allem ist noch immer offen, wer mit der Bezeichnung KO $\Omega$ N gemeint sein könnte, die auf allen drei Münztypen erscheint. Bislang wurde vermutet, dass es sich, den Gepflogenheiten antiker Münzprägung entsprechend, entweder um einen Städtenamen oder ein Ethnikon im Genetiv Plural oder aber um ein Anthroponym - im Nominativ oder in einem abgekürzten Genetiv - zur Bezeichnung des Prägeherrn handelt. Denkbar wäre grundsätzlich, so sei ergänzend bemerkt, auch eine Deutung als Name einer mythischen Gestalt. ${ }^{2}$

Die Auffassung, dass die Angabe KO $\Omega$ N als Anthroponym und Herrschername zu deuten sei, gewann erheblich an Überzeugungskraft, nachdem Max (von) Bahrfeldt 1912 bemerkt hatte, dass in einem Passus der Vita des Augustus von Sueton anstelle des Cotiso rex Getarum, der in den späteren Handschriften und modernen Textausgaben an dieser Stelle erscheint, in den ältesten Codices ein Coso rex Getarum genannt wird. König Cotiso ist auch aus anderen Quellen bekannt (dort wird er freilich als rex Dacorum bezeichnet), während der Name Coso im unteren Donau- und Balkanraum ansonsten nirgends aufscheint, weder für einen Herrscher noch für irgendeine andere Person. ${ }^{3}$ Es spricht also vieles für Bahrfeldts Vermutung, dass ein

${ }^{1}$ Zur Chronologie der offiziell dokumentierten Schatzfunde von Kosōn-Münzen s. unten Abschnitt 5.

${ }^{2}$ Eine andere Interpretation als die hier genannten scheint nicht in Betracht zu kommen. Jedenfalls

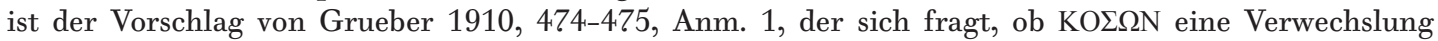
mit BH $\Sigma \Omega \mathrm{N}$, dem Volksnamen der thrakischen Bessi, darstellt, nicht sinnvoll. Das Gleiche gilt für die These von Halévy 1961 (vgl. Vîlcu 2010, 201), wonach es sich um einen Prüfvermerk zur Bestätigung der Echtheit oder Reinheit der Münze handeln könnte, was in dieser Form völlig singulär wäre und auch sprachlich höchst problematisch ist.

${ }^{3}$ Zum Namen Cotiso, der nur für den besagten König bezeugt ist, s. Dana 2014, 90 (mit den Belegstellen). - Die Tatsache, dass Cotiso bei den anderen Autoren als rex Dacorum bezeichnet wird, könnte auf den ersten Blick Bahrfeldts These stützen, dass Sueton sich nicht auf ihn bezieht. Allerdings ist einschränkend zu bemerken, dass die Frage, welche der beiden ethnischen Bezeichnungen Daker und Geten ein antiker Autor jeweils verwendet, immer auch von seinen (für uns oftmals verlorenen) Quellen abhängt. Bestes Beispiel hierfür ist Strabo, der beide Begriffe parallel verwendet, weil er sie aus seinen verschiedenen Vorlagen übernommen hat, ohne die Diktion anzugleichen. Zur generellen Problematik der ethnischen Bezeichnungen Daker und Geten s. zuletzt Strobel 2018. - Zur sprachwissenschaftlichen Einstufung und onomastischen Kontextualisierung des gemutmaßten dakisch-getischen Anthroponyms Kosōn gibt es bis 
frühneuzeitlicher Kopist des Sueton-Textes, dem der Name Coso nicht geläufig war, wohl aber der des Cotiso, die Stelle emendiert hat. ${ }^{4}$ Den Gelehrten des 16.-19. Jh., die sich mit den Kosōn-Münzen befasst haben, war jedenfalls der Name Kosōn bzw. Coso völlig unbekannt.

2.) Es liegen so gut wie keine wissenschaftlich verwertbaren Angaben zum archäologischen Kontext von Funden von Kosōn-Münzen vor. Dies betrifft unter anderem auch die Frage, in welcher Form die Münzschätze in der Antike deponiert wurden und ob sie regelmäßig mit apotropäischen Objekten (z. B. goldenen Spiralen bzw. Armreifen in Schlangenform) bedeckt waren, wie in den Berichten der Finder immer wieder angedeutet wird. ${ }^{5}$

3.) Es sind keine dokumentierten Hortfunde bekannt, in welchen Kosōn-Münzen mit anderen Münztypen vergesellschaftet gewesen wären. ${ }^{6}$

Daneben sind aber noch zwei weitere Umstände zu nennen, die eine Erhellung der Thematik erschweren. Da ist zum einen die allgemeine Quellenlage: Unsere Wahrnehmung der „Daker“ und unsere Kenntnis ihrer Geschichte ist bestimmt durch eine stark fragmentierte, auf Episoden reduzierte und zugleich diskurshafte, von Stereotypen geprägte Überlieferung seitens griechisch-römischer Autoren. Wir besitzen kein durchgängiges Narrativ und schon gar keine belastbaren Selbstzeugnisse der Daker. Von der Darstellung der Dakerkriege Trajans durch Cassius Dio sind nur byzantinische Exzerpte erhalten; dessen diesbezüglichen Quellen sind verloren, ebenso die Getika des Dio Chrysostomos und des Cassiodor; und die Gotengeschichte des Jordanes aus dem 6. Jh. bietet zu den Dakern kaum mehr als eine wirre Kollage. Selbst grundlegende Fragen wie die nach dem ethnisch-kulturell-sprachlichen Zusammenhang zwischen den Dakern innerhalb des östlichen Karpatenbogens und den Geten entlang der unteren Donau und im west- bzw. nordpontischen Raum einerseits sowie andererseits nach dem Verhältnis der Geten und Daker zu den Thrakern und anderen Völkerschaften des unteren Donau- und Balkanraumes sind nicht sicher zu beantworten. Die archäologischen Quellen stellen zwar eine immer wichtigere Basis unserer Kenntnisse dar, sind aber für Fragen nach den politischen Strukturen nur sehr bedingt aussagekräftig. ${ }^{7}$

heute keine belastbaren Erkenntnisse, sondern allenfalls Spekulationen; s. Detschew 1957, 256; Petolescu 2011b, 164; LGPN IV (2005), S. 199; Dana 2014, 90. Der Name begegnet sehr sporadisch auch inschriftlich im Mittelgriechenland des 4.-3. Jh. v. Chr., so in SEG XXVIII 724, B.130 (Eretria, Euboia); IG IV ${ }^{2}$ 1, 95, 17 (Echinos, Akarnanien); SEG XXVI 492 (Akraiphia, Boiotien); vgl. LGPN I (1987), S. 270; III.A (1997), S. 256; III.B (2000), S. 244. Bei keinem dieser Belege ist ein Bezug zur nicht-griechischen oder gar dakisch-getischen Welt erkennbar.

${ }^{4}$ Siehe unten Abschnitt 12 (zur Sueton-Stelle ebd. Anm. 107).

${ }^{5}$ Eine solche Überlieferung existiert bereits für den Schatzfund von 1543 (s. unten Abschnitt 6); ähnliche Gerüchte kursierten auch in den Jahren 1802-1804; vgl. Mitthof, Mádly (in Vorbereitung). In den Schatzfunden der vergangenen Jahrzehnte (s. unten Abschnitt 5) werden neben den Münzen regelmäßig auch sogenannte „dakische“ Goldspiralen entdeckt; vgl. Spânu 2010; Lazăr 2013 \& 2015. Auf solche Objekte dürften sich die früheren Erzählungen von schlangenartigen Wesen, welche angeblich die KosōnSchätze bewachen, bezogen haben.

${ }^{6} \mathrm{Zu}$ dieser für den Gesamtbefund grundlegenden neuen Erkenntnis s. unten Abschnitt 13; bislang wird in der Forschung allgemein angenommen, der Kosōn-Stater sei in Schatzfunden häufig oder sogar generell mit dem Stater vom Lysimachos-Typ vermischt (zu diesem Münztyp s. unten Anm. 21).

${ }^{7}$ Zur Frage, wie sich das Phänomen „Dake“" (das von römischer Seite geschaffene Ethnonym erscheint 
Da ist zum zweiten das Problem der illegalen Schatzsuche, das die Fundgeschichte der Kosōn-Münzen schon immer geprägt hat. Alle größeren Funde von Kosōn-Münzen, von denen wir Kenntnis haben, wurden von Raubgräbern geborgen, und der größte Teil dieser Funde wurde in weiterer Folge heimlich weiterveräußert oder eingeschmolzen, ohne Spuren hinterlassen zu haben - in früheren Jahrhunderten ebenso wie heute. Daher befinden sich nach wie vor nur wenige hundert Kosōn-Münzen in öffentlichen Sammlungen, während ein Vielfaches ihrer Zahl über den Globus verstreut in privaten Sammlungen verborgen ist oder im Münzhandel zirkuliert. Dieses Faktum hat gravierende Auswirkungen auf unseren Kenntnisstand über den Fundkontext solcher Münzen. Selbst wenn Schatzsucher von den Behörden gefasst und verhört werden, ganz gleich ob im Jahr 1543, 1803/1804 oder 1996 (um nur die spektakulärsten uns bekannten Schatzfunde zu nennen), so sind ihre Aussagen generell wenig hilfreich. Im Gegenteil, ihre Angaben folgen einem eigenen Diskurs, der generationen- und epochenübergreifend stets dieselben märchenhafte Motive beinhaltet und den man als "Schatzfund-Narrativ" bezeichnen könnte. Hierzu gehören Geschichten von prächtig ausgestatteten unterirdischen Kammern; von umgestürzten Bäumen, deren Wurzelwerk Schätze freilegt; von Begegnungen mit Feen oder Teufelsmächten; von Kindern als unschuldigen Findern; oder von alten Männern, die auf dem Sterbebett einem Priester gegenüber den Fund eines Schatzes beichten, den sie aus Furcht vor Gottes Strafe niemals zu bergen wagten, dessen Lage sie nun aber preisgeben wollen, um ihr Seelenheil zu retten. In solchen Aussagen ist also immer das rationale Motiv der Desinformation aus Furcht vor der Konkurrenz durch andere Schatzsucher, aber auch vor den Sanktionen des Strafrechts, mit fest etablierten Denkmustern aus der Sphäre des Aberglaubens verbunden. ${ }^{8}$

Es dürfte deutlich geworden sein, dass bei dieser diffizilen Spurensuche jede Information zu den Kosōn-Münzen von Bedeutung ist, ganz gleich aus welchem Kontext und aus welcher Zeit sie stammt. Daher scheint es sinnvoll, die in der aktuellen Forschungsdebatte weitgehend in Vergessenheit geratenen Aussagen der frühneuzeitlichen Numismatik zu den Kosōn-Münzen erstmals möglichst vollständig zusammenzustellen, einer kritischen Prüfung zu unterziehen und mit den Ergebnissen der modernen Forschung zu verbinden.

erstmals in lateinischen Quellen des späten 1. Jh. v. Chr.) historisch korrekt beschreiben lässt, s. zuletzt Strobel 2018. Im Gegensatz zur traditionellen Anschauung, nach welcher die Daker eine „autochthone“ Ethnie gewesen seien, die in großen Teilen des modernen Rumänien siedelte, argumentiert Strobel (im Anschluss an Rustoiu, s. etwa 2005 \& 2012) dafür, dass es sich um eine Kriegeraristokratie handelte, die sich vergleichsweise spät (ab dem 2. Jh. v. Chr.) von südlich der Donau in den oltenischen und siebenbürgischen Raum ausgebreitet und andere ethnische Strukturen, vor allem Latène-Gruppen, überlagert hat. Es besteht dabei anscheinend ein direkter Zusammenhang mit der archäologisch fassbaren Padea-Panagjurski Kolonii-Gruppe. Zur Kritik am Konzept einer ethnisch homogenen Zone innerhalb des östlichen Karpatenbogens s. auch Pupeză 2012, 452. - Auf sprachlicher Ebene wird, soweit dies anhand des verfügbaren Materials an Orts- und Personennamen überhaupt möglich ist, mittlerweile nicht mehr von der Existenz einer einzigen thrakisch-dakisch-getischen Sprache ausgegangen, sondern ein Modell von mehreren, mehr oder minder verwandten Sprachzonen bevorzugt: (pan)thrakisch - westthrakisch - dakisch bzw. „dako-mösisch“ - bithynisch (s. Dana 2014, S. LXIII-CXII; ähnlich Janakieva 2014).

8 Für Beispiele zu diesem Schatzfund-Narrativ aus dem frühneuzeitlichen Siebenbürgen s. Marțian 1921 \& 1923; Mitthof, Mádly 2015. 
Hinzu kommt, dass die Debatte zur numismatischen Deutung und historischen Einbettung der Kosōn-Münzen in den letzten Jahren, wie eingangs angedeutet, durch mehrere um die Jahrtausendwende entdeckte Münzschätze, die einerseits Goldstatere, andererseits Silberdrachmen in größeren Quantitäten enthielten, neue Dynamik erhalten hat. Dank dieser Funde ist der Forschung nämlich erstmals ausreichend Münzmaterial verfügbar geworden, um genauere Stempel- und Metallanalysen aller drei Kosōn-Typen zu ermöglichen. ${ }^{9}$

Der vorliegende Beitrag verfolgt das Ziel, die Entwicklung des gelehrten bzw. wissenschaftlichen Diskurses über die Kosōn-Münzen von den Anfängen bis auf den heutigen Tag nachzuzeichnen. Zunächst werden die Münztypen und ihre Fundgeschichte beschrieben (Abschnitte 2-6). Sodann folgt eine Behandlung der diversen Deutungsmuster, von den ersten greifbaren Erwähnungen der Kosōn-Münzen im 16. Jh. (Abschnitt 7) über die führenden Numismatiker des 16.-18. Jh. (Abschnitt 8) bis zu den beiden am Wiener Hof tätigen Gelehrten Joseph Eckhel und Franz Neumann (Abschnitt 9) und deren Zeitgenossen und direkten Nachfolgern (Abschnitt 10). Das diachrone Vorgehen soll Kontinuitäten und Brüche in der Debatte aufzeigen, zugleich aber auch deutlich machen, dass Eckhel und Neumann der Behandlung dieser Frage eine entscheidende Wende gegeben haben.

Da ferner, wie wir gleich sehen werden, die Kosōn-Münzen aus Siebenbürgen stammen und in dieser Region über Jahrhunderte in nicht geringer Zahl präsent waren, soll auch ihre Behandlung durch die dortige Gelehrtenwelt im Rahmen der „vaterländischen Altertumskunde" anhand prominenter Beispiele nachgezeichnet werden (Abschnitt 11). Dies wird zugleich auch die Möglichkeit eröffnen zu prüfen, welche Werke der führenden Vertreter der frühneuzeitlichen Numismatik in diesem Land an der östlichen Peripherie des damaligen gelehrten Europas bekannt waren und wie sie dort gegebenenfalls rezipiert wurden.

Im Anschluss hieran wird die Entwicklung der Forschung zu den Kosōn-Münzen seit dem frühen 20. Jh. bis zum heutigen Tag skizziert (Abschnitt 12). Abschließend sollen neue Beobachtungen und Überlegungen in die aktuelle Debatte eingebracht werden, die sich aus der laufenden Forschungsarbeit des eingangs angeführten FWFProjektes ergeben haben (Abschnitt 13).

Auf diese Weise wird im Folgenden nicht nur erstmals eine umfassende Gesamtschau der Thematik geboten, welche die frühneuzeitliche und moderne Numismatik ebenso wie die „rumänische“ und „westliche“ Forschung zusammenführt, sondern es werden auch Präzisierungen zur laufenden Forschung präsentiert und neue Akzente gesetzt. Jedoch sei schon jetzt betont, dass betreffs der wesentlichsten offenen Fragen, die mit den Kosōn-Münzen verbunden sind, nämlich denen nach ihrem Prägeherrn, -ort und -zeitpunkt, auch der vorliegende Beitrag keine definitive Klärung, sondern nur neue Hypothesen anbieten kann.

\footnotetext{
${ }^{9}$ Hierzu s. unten Abschnitte 12-13.
} 


\section{Beschreibung des Kosōn-Staters ${ }^{10}$}

Der Kosōn-Stater ist eine Goldmünze mit einem durchschnittlichen Gewicht von ca. 8,5 g und einem Durchmesser von ca. 17-20 mm. Auf der Vorderseite zeigt er im Perlkreis einen Konsul, der in Begleitung zweier Liktoren, die Rutenbündel mit Beilen tragen, nach links schreitet, und auf der Rückseite, ebenfalls im Perlkreis, einen Adler nach links mit ausgebreiteten Flügeln, der auf einem Szepter steht und im erhobenen rechten Fang einen Kranz hält. ${ }^{11}$ Im Abschnitt unterhalb der Personengruppe auf dem Avers erscheint die griechische Legende KO $\Sigma \Omega$ N. Ferner ist bei etwa zwei Dritteln der bekannten Exemplare links der Gruppe ein Monogramm zu sehen, das in zwei Formen (einfach und komplex) vorkommt. ${ }^{12}$ Es sind demnach drei Typen der Münze zu unterscheiden (Taf. I/1-3): Typ A mit einfachem Monogramm in Form eines B mit nach rechts verlängerter Basislinie bzw. mit einem Häkchen unten rechts; Typ B mit komplexem Monogramm aus mehreren Buchstaben; Typ C ohne Monogramm. ${ }^{13}$ Die

10 Als wichtigste Etappen der Forschungsgeschichte zum Kosōn-Stater sind vier Arbeiten zu nennen: Bahrfeldt 1912; Winkler 1972; Iliescu 1990; Petolescu 2011a \& 2011b (Petolescu 2011b ist eine italienische Zusammenfassung der rumänischen Monographie derselben Autorin 2011a). Synthesen des jeweiligen Forschungsstandes finden sich bei Preda 1973, 353-361; Preda 1998b, 226-233; Munteanu 2002 \& 2003 (vgl. auch dens. 2011); Părpăuță 2006, 132-137; Vîlcu 2010; Strobel 2018; für das breite Publikum Ardevan 2007. - Als bezeichnende Beispiele für die nach wie vor ungenügende Wahrnehmung des Kosōn-Staters in der außer-rumänischen, „westlichen“ Forschung können seine Präsentation in Standardwerken wie Crawford 1985, 237-238, Nr. 96, mit Anm. 60 oder RPC I, S. 312-313 Nr. 1701 gelten; die betreffenden Einträge sind überaus lücken- und teilweise auch fehlerhaft. - Gelegentlich geäußerte "Zweifel an der Echtheit der Münze“ (Peter 1999 unter Verweis auf Preda 1998a; s. jetzt auch Preda 2008-2009) sind unbegründet, da - um nur einen schlagenden Einwand zu nennen - der antike Fundkontext für die wichtigsten Schatzfunde von Kosōn-Stateren, von denen wir Kenntnis haben, gesichert ist; zudem ist Predas These, die auf einem Analogieschluss zu in der frühen Neuzeit produzierten schweren Goldmünzen beruht, die nach dem Vorbild von Stateren des Lysimachos-Typs, allerdings im Gewicht von Tetradrachmen, gefertigt wurden, nicht zwingend (vgl. Vîlcu 2010 mit einer ausführlichen Widerlegung der Ansichten Predas).

11 Die Frage, welche die Vorder- und welche die Rückseite der Münze sei, ist von den Gelehrten im Laufe der Jahrhunderte zwar unterschiedlich beantwortet worden, doch überwiegt die hier genannte Auffassung. Von den Bildmotiven her lässt sie sich nicht zweifelsfrei klären, da die Münze nicht den üblichen antiken Konventionen folgt und es sich, was die Bildvorlagen betrifft, ursprünglich um zwei Rückseitenmotive handelt (s. das Folgende). Die Sache wird aber prägetechnisch dadurch eindeutig entschieden, dass die Seite mit der Konsul-Szene konvex (Unterstempel) und die Seite mit dem Adler konkav gewölbt ist (Oberstempel). Anders dagegen Winkler 1972, 178 und zuletzt wieder Vîlcu 2010 und Petolescu 2011a, 79 bzw. 2011b, 169-170. Bei Vîlcu hat dies zur Konsequenz, dass er jedem der von ihm so gedeuteten "Reverse“ (Konsul-Szene) mehrere „Averse“ (Adler) zuordnet (s. S. 211-212), was aus produktionstechnischen Gründen ausgeschlossen ist, da die Abnutzung der beweglichen Oberstempel immer wesentlich höher war als die der fixierten Unterstempel; richtig dagegen die umgekehrte Zuordnung bei Hourmouziadis 2010.

${ }^{12}$ Im Großteil der Literatur ist nur von einem Monogramm-Typ die Rede; vorgeschlagene Deutungen waren dabei bei den älteren Autoren lateinisch B, BR oder LB für (Lucius) Brutus, sodann griechisch $\mathrm{O} \Lambda \mathrm{B}=\mathrm{O} \lambda \beta \beta^{\prime} \alpha$ durch Head $(1911,289 ;$ s. unten Anm. 112) und BA = $\beta \alpha \sigma t \lambda \varepsilon v ́ \varsigma$ durch Bahrfeldt, wobei Letzterer im Detail drei Varianten unterschied (1912, 363), sowie zuletzt neuerlich BR für Brutus (Constantinescu et alii 2015b). Für die Beobachtung, dass zwei Monogramm-Typen existieren und dass ferner der komplexe Monogramm-Typ nur auf solchen Kosōn-Stateren (und -Drachmen, s. unten) erscheint, bei denen die Darstellung der von den beiden Liktoren geführten Fasces keine Oberlängen mit Beilen aufweist, s. Chiriac 1996-1997, 247; Cojocaru et alii 2000; Dima, Ilie 2007; Vîlcu 2010, 199; Petolescu 2011a, 79-80 \& 2011b, 178. Zur Thematik s. auch das Folgende, bes. Anm. 14 und 51.

${ }_{13}$ Die drei Typen weisen daneben noch weitere Unterscheidungsmerkmale auf, nämlich Feingehalt, Durchmesser und Schärfe der Konturen in Bild- und Textelementen; s. unten Abschnitt 12. 
Typen A und C werden bereits in der ältesten Literatur des 15.-18. Jh. beschrieben. Der Typ B scheint hingegen erst im Laufe des 19. Jh. bekannt geworden zu sein; als möglicherweise frühestes (indirektes) Zeugnis ist ein Silberfalsum im Wiener Münzkabinett zu nennen, das zwischen ca. 1800 und 1875 erworben wurde (s. unten Anm. 122).

Beide soeben genannten Bildmotive sind von den Rückseiten spätrepublikanischer Münzen inspiriert, nämlich der Adler von einem Denar des Münzmeisters Pomponius Rufus (73 v. Chr.) und die Konsul-Szene von einem solchen des M. Iunius Brutus (54 v. Chr.) (Taf. II/1-2). ${ }^{14}$ Bereits diese Aspekte, nämlich die Verbindung zweier Reversmotive auf den beiden Seiten einer einzigen Münze ebenso wie die Kombination römischer Bildvorlagen mit einem nicht-römischen Gewichtsstandard und einer Legende in griechischen Buchstaben, machen den Kosōn-Stater zu einem höchst ungewöhnlichen numismatischen Objekt.

\section{Beschreibung der Kosōn-Drachmen ${ }^{15}$}

Seit einigen Jahren kursieren im Münzhandel mehrere hundert Exemplare zweier Typen von Silberdrachmen (Durchschnittsgewicht 4,2-4,4 g; Durchmesser ca. 17-20 mm), die in enger Verbindung zum Kosōn-Stater stehen. Beim DrachmenTyp B handelt es sich um eine bildgleiche Silberversion des Kosōn-Staters des Typs B mit komplexem Monogramm vom selben Durchmesser (Taf. II/4). Der DrachmenTyp A ist wiederum von etwa derselben Größe wie die beiden anderen Münztypen, zeigt aber andere Bildmotive und eine erweiterte Inschrift (Taf. II/3). Diese Münze imitiert das äußere Erscheinungsbild des wesentlich größeren Macedonia PrimaTetradrachmons (Durchschnittsgewicht 16,5 g; Durchmesser ca. 30-33 mm), einer

${ }^{14}$ Für die beiden genannten republikanischen Denare und ihre Datierung s. Crawford 1974, 410, Nr. 398/1, Taf. 50 (Pomponius) und 455, Nr. 433/1, Taf. 52 (Brutus). Zu beachten ist dabei allerdings, dass die Bildmotive auf dem Kosōn keine exakten Kopien dieser Vorlagen darstellen; vielmehr haben die für die Prägung Verantwortlichen im Detail Änderungen vorgenommen, und zwar offenkundig zumindest teilweise - nicht aufgrund eines Missverständnisses, sondern ganz bewusst. Die wichtigsten Änderungen sind: 1.) Im processus des Konsuls fehlt der Herold (accensus), der in der Vorlage die Gruppe anführt; offenbar wurde er ausgelassen, um Platz für das Monogramm zu schaffen. - 2.) Die Beile in den Rutenbündeln sind, sofern sie überhaupt dargestellt sind (nur im Stater des Typs A), nach vorne gerichtet, während sie in der Vorlage in drei unterschiedlichen Anordnungen erscheinen: beide nach vorne gerichtet; das Beil des linken Liktors nach vorne, das des rechten nach hinten gerichtet; beide nach hinten gerichtet; in den Stater-Typen B und C (sowie im Drachmen-Typ B) fehlen die Oberlängen der Fasces mit den Beilen gänzlich, weshalb sie eher kurzen Stangen oder Ruten ähneln (s. oben Anm. 12; vgl. auch Hourmouziadis 2010, 289). - 3.) Der Adler hat den Kopf nicht zur Seite gewendet, sondern hält ihn gerade nach vorne gestreckt. - 4.) Das Szepter ist nicht stabförmig dargestellt, sondern als gerade Kette kleiner Kügelchen, ähnlich denen der Perlkreise. - Zu den Abweichungen zwischen den Bildmotiven auf dem Kosōn-Stater und den beiden als Vorlage dienenden Denaren s. bes. Munteanu 2003, wobei allerdings dessen Schlussfolgerung aus diesem Befund - dass nämlich eine enge Verbindung des Kosōn-Staters zur Münzprägung west- und nordpontischer Städte bestehe und damit auch eine dortige Produktion anzunehmen sei (ähnlich bereits Head 1911, 289, der den Adler mit ähnlichen Darstellungen auf Münzen aus Olbia verband) - abzulehnen ist; zum mutmaßlichen Produktionsort der Kosōn-Münzen Sarmizegetusa Regia s. unten Abschnitte 12-13.

${ }^{15}$ Von den Kosōn-Drachmen handeln Hourmouziadis 2010; Fischer-Bossert 2016; Strobel 2018; s. auch unten Abschnitte 12-13. 
Silber-Emission aus der Zeit zwischen dem römischen Sieg über Perseus im Jahre 168 und der Einrichtung der Provinz Macedonia im Jahre 148 v. Chr. (Taf. III/1). Die Vorlage zeigt auf dem Avers Artemis auf dem makedonischen Schild und auf dem Revers die Keule des Herakles in einem Eichenkranz und links davon ein Blitzbündel. Innerhalb des Kranzes erscheint in zwei Zeilen ober- und unterhalb der Keule der Schriftzug MAKE $\triangle \mathrm{ON} \Omega \mathrm{N} \mid \Pi \mathrm{TP} \Omega \mathrm{TH}$. Auf der Kosōn-Drachme finden sich dieselben Bilder (freilich in wesentlich schlechterer Qualität), zugleich aber eine andere Inschrift, und zwar wiederum auf dem Revers ober- und unterhalb der Keule: KO $\Sigma \Omega N$ | $\triangle$ POYEI $\Sigma$.

\section{Die Fundzone der Kosōn-Münzen: Sarmizegetusa Regia}

In den letzten Jahren wird immer deutlicher erkennbar, dass die Kosōn-Münzen auf das Engste mit Sarmizegetusa Regia in Verbindung stehen, dem herausragenden politischen und sakralen Zentrum und Sitz dakischer Herschaftsbildung in den Orăştie-Bergen, einer Gebirgszone im südwestlichen Siebenbürgen, die sich südlich der Stadt Orăştie (ung. Szászváros, dtsch. Broos) erstreckt und an ihrer Süd- bzw. Westflanke vom Strei-Fluss begrenzt wird (zur Lage s. Taf. VII und Taf. VIII). ${ }^{16}$ In dieser Zone entstand in der späten Eisenzeit ein Verbund von Festungen, Heiligtümern und Siedlungen, der im Laufe des 1. Jh. n. Chr. seine Blütephase erreichte. Baulich sind diese Stätten durch monumentale Befestigungsmauern, ausgedehnte Siedlungsund Tempelanlagen auf künstlichen Terrassen, gepflasterte Straßenzüge, tönerne Wasserleitungen sowie zahlreiche Spuren von Eisenverarbeitung gekennzeichnet. Im Gefolge der beiden Dakerkriege Trajans von 101-102 und 105-106 wurde die gesamte Zone von den römischen Truppen zerstört und ein neues Sarmizegetusa ca. $35 \mathrm{~km}$ Luftlinie westlich als trajanische Kolonie am westlichen Rand der Niederung des Hatzeger Landes angelegt. ${ }^{17}$

${ }^{16}$ Dass die Kosōn-Münzen ausschließlich aus dem Karpatenbecken stammen, haben schon frühere Autoren gesehen, so z. B. Halévy 1961; Ciofu 1993 - In der Karte auf Taf. VII ist mit Grădiștea de Munte die moderne Ortschaft im Tal gemeint; die Ruinen von Sarmizegetusa Regia liegen auf dem Hügel östlich hiervon (s. den Plan auf Taf. VIII).

17 Die Namengleichheit der beiden antiken Sarmizegetusae, in Verbindung mit der Tatsache, dass auch die neuzeitlichen Bezeichnungen der Plätze, nämlich ung. Várhely und rum. Grădiște (was beides soviel wie „Burgort“ bedeutet und eine Ruinenstätte kennzeichnet), für beide dieselben sind, hat häufig zu Verwechslungen geführt, die bisweilen sogar noch in jüngsten Publikationen anzutreffen sind. - Zwar wurde die römische Kolonie (Grădiștea Hațegului) von Gelehrten bereits im Zeitalter des Humanismus anhand von Inschriftenfunden eindeutig identifiziert, doch hat man damals aus gut nachvollziehbaren Gründen angenommen, an derselben Stelle habe auch der dakische Königssitz gelegen. Die Erkenntnis, dass letzterer sich in Wirklichkeit nicht im Tal, sondern in den Bergen befand (Grădiștea de Munte bzw. Grădiștea Muncelului), während die Kolonie eine Neugründung darstellte, die aus einem römischen Militärlager hervorging, hat sich erst seit dem fortgeschrittenen 19. Jh. allmählich durchgesetzt, ist mittlerweile aber durch die moderne Archäologie bestätigt; s. Glodariu et alii 1996; Benea 2004; Florea 2014 \& 2017; Mateescu 2017; Oltean, Hanson 2017; vgl. auch Mitthof 2014; zur Geschichte der Wiederentdeckung des Platzes von ca. 1800 bis zum Ersten Weltkrieg s. jetzt Pețan 2017. - Zur Frage, ob Decebals Herrschaftssitz sich tatsächlich direkt in Grădiștea Muncelului befand oder aber in einem anderen Teil der Orăștie-Berge und ob daher nicht besser die gesamte Zone unter dem antiken Namen „Sarmizegetusa Regia" subsumiert werden sollte, s. Strobel 2018. 


\section{Die Schatzfunde von Kosōn-Münzen seit 1803}

Der enge räumliche Zusammenhang der Kosōn-Münzen mit Sarmizegetusa Regia ist bereits daran erkennbar, dass alle offiziell verbürgten Schatzfunde, die mit Sicherheit Kosōn-Münzen enthielten, sich in der genannten Gebirgszone konzentrieren. Die beiden ersten amtlich bestätigten Schatzfunde von Kosōn-Stateren fallen in die Jahre 1803 und 1804. Sie sind durch Aufzeichnungen der habsburgischen Kameralverwaltung des Großfürstentums Siebenbürgen, die heute in den Staatsarchiven zu Wien, Cluj-Napoca und Budapest verwahrt werden, bestens dokumentiert. Angeblich wurden damals jeweils ca. 500 bzw. 1.000 Münzen direkt auf dem Hügel von Sarmizegetusa Regia gefunden. ${ }^{18}$ Ein dritter großer Schatzfund von angeblich ca. 3.000 Kosōn-Stateren wurde im Jahr 1996 bekannt. Er wird in der Forschung nach dem anfänglich gemutmaßten Fundort Luncani-Târsa, com. Boşorod (ca. 10 km Luftlinie westlich von Sarmizegetusa Regia), als „Târsa-Fund“ bezeichnet, stammt tatsächlich aber aus der nächsten Umgebung von Sarmizegetusa Regia. ${ }^{19}$ Schließlich wurde in den Jahren 1998-2004 in der Zone von Sarmizegetusa Regia eine ganze Reihe weiterer illegaler Schatzfunde bekannt, ${ }^{20}$ so unter anderem ein Hort mit ca. 2.300 Kosōn-Drachmen, ein Depot von 24 Goldspiralen und ein weiterer Hort mit $30 \mathrm{~kg}$ Goldmünzen, der fast auschließlich Statere des Lysimachos-Typs ${ }^{21}$ (ca. 3.600 Exemplare), aber keine Kosōn-Statere enthielt. ${ }^{22}$

18 Siehe Dumitru (Diss.); Mitthof, Mádly (in Vorbereitung); zum bisherigen Kenntnisstand Ferenczi 1989b; Munteanu 2002, 260-266; Pețan 2010-2011 \& 2017; vgl. auch IGCH 672 (für den Fund von 1803). Ein Teil des Archivmaterials wurde bereits von S. Jakó in einer Aufsatzserie publiziert, und zwar in ActaMN 3, 1966; 5, 1968; 8, 1971; 9, 1972; 10, 1973. - N. B.: Die hier wie auch im Folgenden genannten, in der Regel auf den Aussagen der Finder beruhenden Zahlen der jeweils gefundenen Münzen sind, wie immer bei illegalen Schatzfunden, nicht zuverlässig und dürften in Wirklichkeit ein Vielfaches betragen haben.

19 Zu diesem Fund von einem Platz namens Dealul Bodii (Fețele Albe) s. Chiriac 1996-1997; Petolescu 1997; Munteanu 2002, 266-267; Dima, Ilie 2007; Vîlcu 2010, 202-204; Petolescu 2011, 9-14, 79-84; Petolescu 2011b, 157-158, 176-182; sowie unten Abschnitte 12-13.

20 Siehe zusammenfassend Lazăr 2013 \& 2015.

21 Es sind dies pseudo-lysimachische Statere, also posthume Nachprägungen eines Münztyps des Diadochen, der auf dem Avers den Kopf des vergöttlichten Alexander d. Gr. mit Ammonshorn und auf dem Revers die thronende Athena Nikephoros sowie die Legende BA $\Sigma$ I $\Lambda$ E $\Omega \Lambda$ Y $\Sigma$ IMAXOY zeigt (Taf. III/2). Daneben erscheinen Beizeichen, welche sich auf die jeweilige Prägestätte und Münzbeamte beziehen. Solche Nachprägungen hat es das gesamte hellenistische Zeitalter hindurch gegeben, sowohl im pontischen Raum als auch in Kleinasien; vgl. Poenaru Bordea 1979; Callataÿ 1995a; 1995b; 1997. Jedoch sind, was das Hinterland des westlichen Pontos- bzw. des unteren Donau- und Karpatenraumes betrifft, die Orăștie-Berge die einzige Zone, wo solche Münzen in größeren Mengen gefunden werden (s. Torbágyi 1991, 42 [wo die betreffenden Münzen allerdings fälschlicherweise nicht als posthume, sondern als echte Lysimachen eingestuft werden]; Munteanu 2005 \& 2011). Die in den Orăştie-Bergen gefundenen Statere des Lysimachos-Typs zeigen die Beizeichen der westpontischen Städte Histria, Tomis und Kallatis sowie von Byzanz und sind von wesentlich geringerer Qualität als ihre ursprüngliche Vorlage (für ein Beispiel aus Kallatis s. Taf. III/3). Sie wurden nicht nur, wie bisher angenommen, unter Mithradates VI. Eupator ausgeprägt (ca. 100-70 v. Chr.), sondern offenbar sogar bis zum Ende der Herrschaft des Byrebistas / Burebista (ca. 44 v. Chr.) - zur korrekten Namensform des berühmten Herrschers s. unten Anm. 125. Überdies ist mit der Möglichkeit zu rechnen, dass der Münztyp - zumindest in der allerletzten Phase seiner Emission - im barbarischen Hinterland der westpontischen Küste und eventuell sogar in Sarmizegetusa Regia selbst geprägt wurde; hierzu s. jetzt Mitthof 2018 sowie unten Abschnitt 13.

${ }^{22} \mathrm{Zu}$ diesem Fund, der 1998 auf einem kleinen Hochplateau im Bereich von Grădiștea Muncelului 
Es besteht kein Zweifel, dass die hier aufgeführten Funde nur einen kleinen Teil der seit dem Altertum in der Zone der Orăştie-Berge entdeckten antiken EdelmetallSchätze ausmachen. Die im Folgenden behandelten Texte des 16.-19. Jh. weisen in dieselbe Richtung; sie machen direkt oder indirekt deutlich, dass zumindest die Kosōn-Statere über die Jahrhunderte hinweg sowohl in Siebenbürgen selbst als auch weit über dieses hinaus bekannt und verfügbar waren. Münzen dieser Art wurden beständig und in vielfacher Weise getauscht, gesammelt, gehandelt, außer Landes geschmuggelt oder eingeschmolzen. ${ }^{23}$ Die Dunkelziffer ist also enorm hoch.

Im Übrigen dürfte der Umstand, dass Kosōn-Statere in allen Zeitaltern im Umlauf waren, auch die Erklärung dafür sein, dass auf dem Gebiet des heutigen Rumänien und angrenzender Länder wie Serbien, Moldawien, Ukraine und Türkei im Laufe der Jahrhunderte gelegentlich Streufunde solcher Münzen bekannt geworden sind. Es gibt nämlich in keinem dieser Fälle einen Beleg dafür, dass die Münzen bereits in der Antike an dem betreffenden Ort deponiert worden wären - etwa in Form eines gesicherten archäologischen Kontextes. Vielmehr spricht alles dafür, dass sie erst im Mittelalter oder (mehr noch) in der Neuzeit aus den Orăștie-Bergen verschleppt, von ihren damaligen Besitzern versteckt (oder verloren) und in weiterer Folge nicht mehr geborgen wurden. ${ }^{24}$

\section{Keine Kosōn-Statere im Strei-Fund von $1543^{25}$}

Der erste und bei weitem umfangreichste Fund von antiken Goldmünzen im siebenbürgischen Raum, von dem wir Kenntnis haben, trat angeblich im Jahre 1543 im Bett des Strei-Flusses am Westrand der Orăştie-Berge zutage und soll dem Wiener Humanisten Wolfgang Lazius zufolge 40.000 (oder sogar 400.000?) Münzen sowie ferner auch ungeprägtes Gold umfasst haben. ${ }^{26}$ Der gewaltige Schatz, der zumindest

mit dem Namen Șesu Căprăreței zutage getreten und 1999 im internationalen Münzhandel aufgetaucht ist, s. jetzt Mitthof 2018. Ein großer Hort in exakt derselben Zusammensetzung war bereits im Winter 1802/1803 in der Gemarkung ung. Csáta / rum. Ceata (ca. 10 km nordwestlich von Grădiștea Muncelului bzw. ca. 5 km südlich von Costești) entdeckt worden; s. ebd. sowie unten Abschnitt 13.

${ }^{23}$ In den Akten der siebenbürgischen Kameralverwaltung aus der Zeit um 1803-1805 ist immer wieder zu hören, dass die Goldmünzen aus den Orăștie-Bergen, also Statere des Kosōn- und des Lysimachos-Typs, in großem Stil in die benachbarten Fürstentümer Moldau und Walachei geschmuggelt wurden. Sie waren ein begehrtes Handelsgut und wurden besonders von den ,griechischen“ Kaufleuten, die in umliegenden Städten wie Szászváros (Orăștie) oder Hatzeg (Hațeg) ansässig waren, systematisch angekauft und weiterveräußert; s. Mitthof, Mádly (in Vorbereitung).

${ }^{24}$ Eine Verbreitungskarte der Kosōn-Funde bietet Winkler 1972, 185, Fig. 7 (mit geringfügigen Ergänzungen wieder abgedruckt von Iliescu 1990, 212, Tav. I; Munteanu 2002, 254, Fig. 1; Petolescu 2011a, 20, Fig. 2; Petolescu 2011b, 158, Fig. 1); für eine Auflistung der (angeblichen) Fundorte von Kosōnen s. etwa Ruzicka 1922, 15-18; Preda 1998b, 231; Munteanu 2002, 267-270; Părpăuță 2006, 315-317; Petolescu 2011a, 19-20; Petolescu 2011b, 152-153.

${ }^{25}$ Genaueres zu den in diesem Abschnitt behandelten Fragen bei Mitthof (in Vorbereitung).

${ }_{26} \mathrm{Zu}$ diesem Fund s. Schmidt 1860, 166-175; Marțian 1921, 14-18; IGCH 670; Russu 1966; Makkay 1994, bes. 192-212; Makkay 1995; Ferenczi 1989a; Munteanu 2002, 253-258; Spânu 2006; Anghel 2008, 335-336; Deppert-Lippitz 2010, bes. 10-23; Petolescu 2011, 15-18 sowie das Folgende. Zeitgenössische Berichte sind bei Lazius und Mathesius zu finden (s. unten Abschnitt 7) sowie bei Centorio 1566, 198-199 (s. das Folgende); daneben existiert eine kurze Notiz des Johannes Honterus (1498-1549), die von Teutsch 1883 mitgeteilt wird (s. unten Anm. 135); vgl. ferner Zamosius 1593, 93-94; Tröster 1666, 61-62; Miles 
für kurze Zeit bewirkt haben dürfte, dass Siebenbürgen den Zeitgenossen als neues Eldorado und östliches Pendant zu Amerika erschien, hatte eine gravierende politische Affäre zur Folge. Anfangs gelang es den Findern, einfachen Fischern oder Bauern, so heißt es, Münzen aus dem Schatz entweder vor Ort zu veräußern oder außer Landes in die Moldau zu schmuggeln; manche von ihnen gelangten dabei zu großem Reichtum. Recht bald jedoch brachte Georg Martinuzzi, Bischof von Großwardein (Oradea), der seit 1540 als Vormund des erst im selben Jahr geborenen Königs Johann Sigismund Zápolya wirkte und somit faktisch Landesherr war, einen großen Teil des Schatzes in seine Gewalt. Als Martinuzzi schließlich im Jahre 1551 auf Betreiben eines Condottieres Karls V. namens Giovanni Castaldo ermordet wurde, bildete sein von den Zeitgenossen gemutmaßter unermesslicher Reichtum ein wichtiges Motiv für die Bluttat. Ob es wirklich so viel Gold war, wie die Quellen berichten, und was aus diesem Schatz letztlich geworden ist, lässt sich nicht mehr feststellen. Nach den eindeutigen Hinweisen der zeitgenössischen Autoren und Dokumente enthielt dieser Fund große Mengen an Stateren des Lysimachos-Typs; hingegen fehlt jeder konkrete Hinweis auf Kosōn-Statere, die den Zeitgenossen, wie wir gleich sehen werden, wohlbekannt waren. Für die in der Forschung immer wieder zu lesende Annahme, der Strei-Fund habe auch solche Münzen enthalten, gibt es keinen Beleg. ${ }^{27}$

Ferner ist in diesem Zusammenhang zu beachten, dass die in den folgenden Jahrhunderten oftmals aufgegriffene Version vom Schatzfund in einem Hohlraum im Bett oder am Ufer des Flusses Strei, was die zeitgenössischen Berichte angeht, nur bei Honterus und Lazius greifbar ist. ${ }^{28}$ Centorio hingegen, dem wir ebenfalls einen ausführlichen Bericht über den Vorfall verdanken, spricht davon, der Schatz sei nach heftigen Regenfällen auf einem Hügel unweit von Deva bei einer alten Schlossruine entdeckt worden. ${ }^{29}$ Eine solche Beschreibung würde bestens zu Sarmizegetusa Regia mit der dort zu allen Zeiten gut sichtbaren Burgruine passen. Bei Mathesius schließlich, unserem vierten Gewährsmann, ist nur vage von einem Gewölbe und einem umgestürzten Baum die Rede, und der Schatz sei durch „Tagwasser" freige-

1670, 45; Köleseri 1717, 23-26; Bethlen 1782, 512-513; Schoenvisner 1801, 23-25; Hene 1836, 83-85. Die ursprüngliche Angabe des Lazius, es habe sich um 400.000 Münzen (ca. 3.400 kg!) gehandelt (1551, S. $1094=1598$, S. 927): milia ut ex fide dignis audivimus plus quam quadringenta / quadringinta), ist höchst suspekt; vermutlich liegt ein Lapsus vor, und die Formen quadringenta in der ersten bzw. quadringinta (sic) in der posthumen zweiten Ausgabe des Werks stehen für quadraginta. Hierfür spricht auch ein Brief des päpstlichen Nuntius in Wien Girolamo Martinengo vom 7. März 1552, in welchem der Verfasser angibt, es seien nach seinen Informationen mehr als 30.000 Lysimachos-Münzen gefunden worden (Hurmuzaki 1894, 686, Nr. 438). Jedenfalls reduzieren fast alle späteren Autoren die Zahl stillschweigend auf 40.000 (ca. $340 \mathrm{~kg}$ ). - Der Strei-Fund wurde sofort nach seiner Entdeckung von den Zeitgenossen mit Decebals Schatz in Verbindung gebracht, den dieser laut Cass. Dio 68, 14 im Bett des Flusses Sargetia verstecken ließ. Nach dieser Annahme wäre das antike Hydronym Sargetia mit dem modernen Namen des Flusses (rum. Strei / ung. Sztrygy / dtsch. Strell oder Strey) zu verbinden, was allerdings eine rein hypothetische Annahme ist; es gäbe viele weitere Kandidaten für eine Identifizierung, so vor allem das Flüsschen Apa Grădiştei / Apa Oraşului, das direkt am Fuß des Hügels von Sarmizegetusa Regia aus dem Zusammenfluss zweier Bäche hervorgeht und nordwärts fließt, aber beispielsweise auch die weiter östlich verlaufenden Flüsse Romoş, Cugir oder Sebeș, alle vier ebenso wie der Strei linke Zuflüsse des Mureș (ung. Maros / lat. Marisus).

$27 \mathrm{Zu}$ dieser Frage s. unten Abschnitt 13.

${ }_{28} \mathrm{Zu}$ Honterus s. unten Anm. 135, zu Lazius Abschnitt 7.

29 Centorio 1566, 198-199. 
spült worden; ${ }^{30}$ das passt, wie es scheint, eher zu Centorio als zu Lazius. Ob diese Abweichungen in den Details der Fundumstände auf die Finder zurückgehen, die den Leuten des Martinuzzi unterschiedliche Versionen präsentiert haben könnten, oder ob es hingegen damals in etwa zur selben Zeit zwei separate Schatzfunde gegeben hat, einen im oder beim Strei-Fluss und einen weiteren in den Orăștie-Bergen bzw. in Sarmizegetusa Regia, lässt sich nicht klären; grundsätzlich scheinen beide Annahmen denkbar. Immerhin könnten die im folgenden Abschnitt präsentierten Zeugnisse des Erasmus und des Calcagnini als deutlicher Hinweis verstanden werden, dass es in der Region bereits mehr als zwei Jahrzehnte vor 1543 einen Schatzfund von KosōnStateren gegeben hat (sofern solche Funde sich in der Region nicht sogar regelmäßig ereignet haben sollten). ${ }^{31}$

\section{Erste Zeugnisse für Kosōn-Statere aus dem 16. Jh.}

Es ist seit langem bekannt, dass die älteste Beschreibung des Kosōn-Staters, von der wir Kenntnis haben, in einem Brief des Erasmus von Rotterdam (1466/14691536) vom 31. Aug. 1520 an den Fürstbischof von Breslau Johannes V. Turzo/Thurzo (1466-1520) zu finden ist. Zugleich wird aber in der Forschungsliteratur fast immer verschwiegen, dass es sich dabei eigentlich um ein Antwortschreiben des großen Humanisten handelt, und zwar in Reaktion auf einen Brief, den Turzo ihm bereits neun Monate zuvor, am 1. Dez. 1519, übermittelt hatte, verbunden mit einigen wertvollen und zugleich symbolischen Geschenken. Erasmus nahm beide Briefe in seine nur ein Jahr später veröffentlichte Auswahlsammlung Epistolae ad diversos auf, sicherlich ein Zeichen besonderer Wertschätzung für Turzo. ${ }^{32}$ Ein genaueres Verständnis des Kontextes, in welchem die Kosōn-Statere hier auftauchen, ist somit nur möglich, wenn beide Briefe in Zusammenschau betrachtet werden.

Um seiner Verehrung des Erasmus nicht nur mit Worten Ausdruck zu verleihen, übersandte Turzo diesem zusammen mit dem Brief vier Sanduhren, eine Mütze

\footnotetext{
30 Siehe unten Anm. 41.

31 Munteanu 2002, 253-260 nimmt an, dass es in der Zeit um das Jahr 1543 in Wirklichkeit zwei große Schatzfunde gegeben habe: den Strei-Fund, über den Lazius berichtet (nach Munteanus Meinung enthielt dieser neben Lysimachos- auch Kosōn-Statere), und einen zweiten Fund in den Bergen, den Centorio beschreibt (dieser habe nur Lysimachos-, aber keine Kosōn-Statere enthalten); dem steht allerdings entgegen, dass Statere des Lysimachos- und des Kosōn-Typs niemals vermischt gefunden worden sind (s. unten Abschnitt 13). Daher auch unrichtig die Annahme Munteanus, dass der Csáta-/Ceata-Fund von 1802/1803 beide Münztypen enthalten habe (ebd. S. 262); mittlerweile ist nämlich ein numismatischer Bericht des Abbé Eder von 1803 aufgetaucht, der die Zusammensetzung dieses Hortes genau beschreibt (s. Mitthof 2018 mit Edition des Textes). - Nebenbei sei bemerkt, dass Hinweise auf einen noch früheren Schatzfund in derselben Zone existieren, der sich laut einer Urkunde von 1494 bereits im Jahr 1491 ereignet haben soll; s. Anghel 2008, 333-334 und Ardevan 2014. Die genaue Provenienz dieses Schatzes - angeblich eine Burg bei Mühlbach (Sebeş) - ebenso wie seine Größe und Zusammensetzung sind aber völlig ungewiss. Die Urkunde macht diesbezüglich keine genaueren Angaben. Immerhin scheint auch in diesem Fall ein Zusammenhang mit (dem damals als solchem noch unbekannten) Sarmizegetusa Regia durchaus denkbar, insofern der Ausdruck „Burg bei Mühlbach“ sich auf die Ruinen von Grădiștea Muncelului bezogen haben könnte.

32 Erasmus 1521, 559-561. Nach moderner Zählung sind dies die Briefe Nr. 1047 und 1137; vgl. Erasmus 1988 (Letters), S. 36-37.
} 
aus dem Pelz des mus ponticus (vermutlich Zobel oder Hermelin) sowie vier Stücke „reinsten und ursprünglichen Goldes“, wie er es nannte, die unlängst in seiner Diözese „in unterirdischen Kammern, gleichsam in den Eingeweiden der Erde selbst", gefunden worden seien. ${ }^{33}$ Die Uhren standen für die Vergänglichkeit des Lebens, die Mütze sollte dem "heiligen Haupt" des Adressaten Schutz und Wärme bieten (und ihn zugleich an die Zuneigung Turzos erinnern), und die „lebendige Kraft des Goldes“ sollte von seinem Anspruch auf Unsterblichkeit künden.

In seiner Antwort ist Erasmus, ganz im Topos der Bescheidenheit verweilend, um Versachlichung und Umdeutung der Symbolik mit Blick auf den Absender bemüht. Dies gilt etwa für das Aufgreifen des memento mori-Motivs, nicht wissend (oder doch?), dass Turzo bereits einen Monat vor Abfassung von Erasmus' Schreiben, am 2. Aug. 1520, verstorben war. Erasmus bekundet zunächst Freude über den Reichtum der Diözese Turzos an Bodenschätzen, nicht ohne diesen jedoch zugleich zu ermahnen, er solle lieber im Evangelium nach „Gold“ schürfen und seine Gemeinde an diesem Schatz teilhaben lassen. Am Ende seines Briefes kommt Erasmus schließlich auf die Münzen zu sprechen, die nun zum antiquarischen Studienobjekt mutieren: Erasmus berichtet, dass ihr Anblick viele sehr beschäftigt habe (er hatte sie also offenbar in den vorangegangenen Monaten herumgezeigt oder herumgeschickt), und es seien zwei Deutungen vorgebracht worden: Die Bilder zeigten die drei Söhne Noahs nach dem Verlassen der Arche und die Taube mit Ölzweig, oder aber zwei militärische Anführer, dazwischen einen Gefangenen, und einen Adler mit Lorbeerzweig. Erasmus bietet dem Leser also eine biblische und eine weltliche Lesart. Jedoch habe niemand, so der Gelehrte weiter, die Bildlegende entziffern können, weder Kenner des Griechischen noch solche des Lateins oder Hebräischen. ${ }^{34}$

Mindestens ebenso interessant für die Geschichte der Kosōn-Statere wie diese ersten dokumentierten Deutungsversuche aus dem Umfeld des Erasmus (oder von ihm selbst?) ist die Beschreibung der angeblichen Herkunft der Münzen durch Turzo. Seine Darstellung des Fundes erinnert an das eingangs erwähnte „Schatzfund-Narrativ“. Zugleich besteht aufgrund der bereits in Abschnitt 4 angedeuteten geographischen Verteilung der Funde von Kosōn-Stateren der starke Verdacht, dass die Münzen nicht in Schlesien gefunden worden sein können; sollte die Behauptung Turzos richtig sein, müsste es sich um ein Depot von im Mittelalter oder in der Neuzeit verschleppten Münzen gehandelt haben. Die wahrscheinlichste Erklärung ist aber wohl, dass Turzo, der einer reichen Kaufmannsfamilie angehörte, deren mitteleuropäisches Bergbauund Handelsimperium sich damals von Polen bis just nach Siebenbürgen erstreckte,

33 Erasmus 1521, 560: Adiunxi praeterea auri puri nativique quatuor particulas, sive ramenta, e subterraneis specubus, adeoque ex ipsis terrae visceribus, in ditione meae dioeceseos, qualia vides nuper eruta, nempe ut auri vivax vis te immortalite dignissimum declaret.

${ }_{34}$ Ebd. S. 561: Aureum numisma multos exercuit, aliis coniectantibus esse tres Noe filios ex arca revertentes, et ex altera parte columbam olivae ramum deferentem; aliis duces duos, qui medium captum ducerent, et aquilam lauri ramum in coronam deflexum gestantem. Subscriptionem nullus adhuc legere potuit, neque Graecus, neque Latinus, neque Hebraeus. - Die Tatsache, dass dem großen Humanisten und seinem Umfeld keine Entzifferung der Legende gelang, mag zwar zunächst erstaunen, doch sei nochmals daran erinnert, dass der Name Kosōn damals nicht bekannt und von daher eine sinnvolle Entzifferung den Zeitgenossen gar nicht möglich war; zudem ist zu bedenken, dass die Inschrift, bedingt durch schlechte Stempelqualität, bei manchen Kosōn-Stateren nur sehr schlecht lesbar ist. 
die Münzen eben von dort bezogen hatte, gegenüber Erasmus aber (aus Eitelkeit?) den Eindruck erwecken wollte, als handele es sich um lokale Funde.

Als zweitältestes Zeugnis für die Existenz des Kosōn-Staters ist eine Schrift des Diplomaten und Gelehrten Celio Calcagnini (1479-1541) zu nennen, der am Hof der Este wirkte. Calcagnini erstellte in seinen letzten Lebensjahren, zwischen 1538 und 1541, einen Katalog der Sammlung antiker Goldmünzen des Herzogs Ercole II. d'Este. ${ }^{35}$ In diesem Katalog, der handschriftlich überliefert ist, wird auch ein Kosōn-Stater aufgelistet, den Calcagnini wie folgt beschreibt: Drei Personen, von denen die beiden äußeren eine Rute, ein Szepter oder einen Knüppel auf der rechten Schulter tragen, darunter der griechische Schriftzug $K O \Sigma \Omega N$; auf der Rückseite ein Adler mit Kranz im erhobenen rechten Fang. ${ }^{36}$ Wann und auf welchem Weg diese Münze in die Sammlung der Este gelangte, ist nicht dokumentiert. Es könnte aber gut sein, dass ihre Erwerbung in die Jahre 1517-1519 fällt, als Calcagnini sich zunächst zusammen mit, dann im Auftrag von Ippolito d'Este in Ungarn und vorübergehend auch in Polen aufhielt. Dies ist übrigens vielleicht nicht zufällig genau dieselbe Zeit, als Johannes Turzo jene Kosōn-Statere erworben haben dürfte, die er dann Erasmus übersandte. Möglicherweise erlebte der Handel mit Kosōn-Münzen gerade in diesen Jahren im ungarischen Raum eine besondere Intensität.

Der in zeitlicher Folge dritte Hinweis auf Kosōn-Statere ist beim bereits erwähnten Wolfgang Lazius (1514-1565) zu finden. Der Leibarzt und Hofhistoriker Kaiser Ferdinands I. berichtet in seinen Schriften an mindestens vier Stellen über zeitgenössische Funde antiker Goldmünzen in Siebenbürgen, von denen er in Wien Kenntnis erlangt hatte. ${ }^{37}$ Dabei handelte es sich seinen Informanten zufolge hauptsächlich um Statere des Lysimachos-Typs, die aus dem obengenannten Schatzfund von 1543 stammten und von denen man eine größere Zahl nach Wien an Ferdinand übersandt hatte, der sie von Lazius prüfen ließ. Lazius hatte aber, wie er bemerkt, auch schon zuvor in Wien immer wieder solche Münzen zu Gesicht bekommen, die von

35 Der Katalog wurde zunächst 1825 von Cavedoni beschrieben und kommentiert, sodann 1879 von Fiorelli herausgegeben (s. Calcagnini 1538-1541). Für eine moderne Reproduktion des Katalogs Calcagninis sowie der später nach Florenz gelangten Este-Münzen s. den Ausstellungskatalog „Si tiene pegno in guardaroba" (2014).

36 Calcagnini 1538-1541, 148 (zu Tab. 47, 14): Tres imagines stantes palliatae, duae extremae virgam vel sceptrum vel clavam habent super dextro humero nitentem, media nihil habet. Sub imaginum pedibus graecae litterae exesae KO $\Sigma \omega N$. A tergo. Aquila passis alis, elato pede dextro unguibus coronam porrigens. Es handelt sich, wie die Internet-Abbildung zeigt (http://www.esteproject.it/en/monete-greche/t-p-6), um ein Exemplar des Stater-Typs C ohne Monogramm und folglich mit zu Stangen verkümmerten Fasces (s. oben Anm. 14); es ist also leicht nachvollziehbar, warum Calcagnini die Fasces nicht als solche erkannt hat. - Zur Geschichte der Handschrift und zu Calcagnini als Numismatiker s. Missere, Missere Fontana 1993, zum weiteren Schicksal der Münzsammlung der Este, die im 17. Jh. in Florenz verpfändet wurde und dann an die Medici überging, Poggi 2003. Alle (ehemaligen) Este-Münzen sind mit einer Kontermarke versehen, die einen Adler zeigt; hierzu s. wiederum Poggi 2003. Im Fall unserer Koson-Münze wurde diese Marke links der Personengruppe angebracht, in dem Bereich also, wo sich sonst das Monogramm befindet, sofern ein solches vorhanden ist (s. oben Abschnitt 2).

37 Zweimal in seinen gedruckten Werken (Lazius 1551, 1094 [= 1598, 927] und 1558 [1605], S. 2) sowie ferner in ungedruckten Manuskripten, und zwar in einer kurzen Abhandlung aus einer Münchener Handschrift (= Lazius, s. d. 1) - dieser Text wird vom Verfasser in Kürze herausgegeben werden (Mitthof [in Vorbereitung]) - sowie im 8. Buch der 5. Dekade seines unvollendet gebliebenen Hauptwerkes einer österreichischen Gesamtgeschichte (= Lazius s. d. 2). 
Wiener Händlern in Siebenbürgen bei der walachischen (d. h. rumänisch-sprachigen) Bevölkerung angekauft worden waren. ${ }^{38}$ An einer der genannten Stellen beschreibt Lazius im Zusammenhang mit dem Fund von 1543 neben den Lysimachos-Stateren auch einen zweiten Münztyp, dessen Legende er mit $\Sigma \Omega Z O N$ wiedergibt, die er im Sinne von „Retter“ oder „Befreier“ deutet. Zweifelsfrei bezieht er sich dabei auf den Kosōn-Stater. Lazius' etwas forcierte Fehldeutung ist durchaus verständlich, da, wie bereits betont, die Legende der Münze nach damaligem Kenntnisstand keinen Sinn ergab und je nach Qualität des zu ihrer Herstellung verwendeten Stempels teilweise nur schwer zu entziffern ist. ${ }^{39}$

Die vierte frühe Erwähnung von Kosōn-Stateren geht auf die Sammlung von Predigten für Bergleute aus der Feder des böhmischen Pfarrers, Lutherschülers und -biographen Joannes Mathesius (1504-1565) vom Jahre 1562 zurück. ${ }^{40}$ In der zweiten Predigt berichtet Mathesius über zwei Münztypen, von denen er „etliche gesehen“ habe und die aus einem großen siebenbürgischen Schatzfund seiner Zeit stammten er bezieht sich also offenbar auf den bereits mehrfach angesprochenen Strei-Fund von 1543. Mathesius rekurriert dabei, wie bereits in Abschnitt 6 bemerkt, auf das Motiv des umgestürzten Baumes, der eine unterirdische Kammer freilegt - ein Stereotyp in Erzählungen über Schatzfunde (s. oben Abschnitt 1). Laut der Beschreibung, die Mathesius von den Münzen gibt, handelte sich um Statere des Lysimachos- und des Kosōn-Typs. Letztere böten nämlich auf der einen Seite „drey Bilder“ (also drei menschliche Figuren), darunter auf Griechisch den Schriftzug KOSON, und auf der anderen „Phenix in seinem Neste““.11 Der Zusatz „wie ich’s lese“ soll vielleicht bedeuten, dass damals auch andere Deutungen der Inschrift im Umlauf waren, was ja im übrigen durch die soeben angeführte Stelle bei Lazius bestätigt wird. Das Gewicht der Münzen beziffert Mathesius auf etwas mehr als zwei Ungarische Gulden (d. h. etwas über $7 \mathrm{~g})$.

38 Lazius s. d. 2, fol. 189f., zitiert nach Mayr 1894, S. 57: Porro non illos solum mille aureos conspexi, quorum quilibet trium ducatorum habebat pondus, a Caesare ipso mihi ad interpretandum exhibitos, verum etiam a mercatoribus passim, qui a Walachis in Dacia emerant, pluribus antea annis oblatos conspexeram, quorum erat omnium eadem inscriptio idemque symbolum, videlicet facies iuvenis imberbis, diademate cincti in capite, in quo duo cornua hircina eminebant, et in altera parte icon Palladis sedentis cum inscriptione

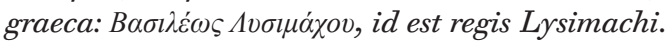

${ }^{39}$ Lazius s. d. 1, fol. 11: Numi aurei ex thesauro recens apud Transylvanos opera piscatoris cuiusdam detecto, quorum mihi copia fieri potuit, duas Graecas habuere inscriptiones, quarum altera litteris his

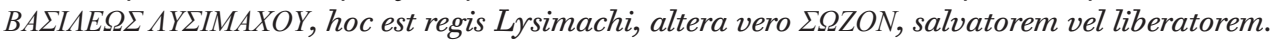

${ }^{40}$ Das Werk ist mehrfach neu aufgelegt worden; zunächst erschien es unter dem Titel „Sarepta oder Bergpostill“, dann nur noch als „Sarepta“.

${ }_{41}$ Mathesius 1562 (1618), 65-66: „Zu unsern zeiten hat man in Siebenbürgen ein Gewelb gefunden / welches ein Kläffteriger Bawm der drauff gewachsen / im umbfallen entblösset hat / das ist steck voller geschlagener Goldgülden gelegen / der ich etliche gesehen / auff einem stehet Greckisch / Basilij Lisymachon (!), auf eim andern stehen drey Bilder / darunter (wie ichs lese) Koson, auff der andern Seiten ein Phenix in seinem Neste / Es wigt aber einer mehr als zween Ungerische Gülden / diese Gülden hat endlich das Tagwasser aus dem Gewelb in grund geflösset / darvon ein Custer ist reich worden / welchs sich endlich Georg Münch (sc. Mönch Georg = Martinuzzi) hat angemasset." 


\section{Die Kosōn-Münzen in der numismatischen Fachliteratur des 16.-18. Jh.}

Calcagnini und Lazius haben sich in ihren Forschungen zwar auch bereits in systematischer Form mit antiken Münzen befasst, aber ihre diesbezüglichen Schriften sind (weitgehend) unpubliziert geblieben. Das früheste gedruckte Werk zur Numismatik des Altertums, in welchem der Kosōn-Stater erscheint, ist Hubertus Goltzius (1526-1583) zu verdanken. Der niederländische Künstler und Gelehrte berichtet im ersten Band seiner Geschichte Griechenlands auf Grundlage der Münzen vom Jahre 1576, der Sizilien und Großgriechenland abdeckt, unter dem Eintrag KO$\Sigma \Omega$, den er als griechischen Genetiv Plural zum Namen der Stadt Cosa deutet, Folgendes: ${ }^{42}$ Die Rückseite der Münze zeige einen Adler, den Vogel Jupiters, mit Szepter und Lorbeerkranz. Wegen der Vorderseite sei sie auf die Stadt Cosa zu beziehen. Auf dieser Seite seien nämlich, wie manche meinten, der Magistrat einer Colonia oder aber Triumvirn dargestellt, was als Hinweis auf die Ansiedlung von eintausend Neubürgern in Cosa zu verstehen sei, über die Livius berichte. ${ }^{43}$ Es gebe aber auch Vertreter der Ansicht, dass die Darstellung drei Männer zeige, die aus ihrer Stadt auszögen, als Hinweis darauf, dass Cosa von seinen Einwohnern wegen einer Rattenplage aufgegeben wurde, wie Volaterranus berichte. ${ }^{44}$ Über diese Legende mache sich allerdings der Dichter Rutilius Numantius (!), Stadtpräfekt Roms unter Kaiser Honorius, lustig, ${ }^{45}$ und auch Goltzius hält diese Episode für eine Mär. Im Folgenden führt Goltzius die Münze als Testimonium für die vermeintlich korrekte antike Namensform der Stadt an, die Cosae (Plural) gelautet habe, nicht Cosa (Singular) und auch nicht Cossa(e), d. h. mit doppeltem S, wie ein Vers Vergils zeige. ${ }^{46}$

${ }^{42}$ Goltzius 1576, 315-317. - Das Werk ist gegliedert in Abschnitte nach urbes bzw. populi (gelegentlich erscheinen auch Herrscher), zu deren Bezeichnung in der Hauptüberschrift zumeist das Ethnikon bzw. Toponym dient, das Goltzius, den Usus der antiken griechischen Münzen imitierend, im Genetiv Plural wiedergibt. Dabei erscheint der Name in der Überschrift der einzelnen Einträge auch bei nicht-griechischen Gemeinden oftmals in gräzisierter Version, nicht so dagegen in den Kopfzeilen und Stichwörtern am Rand, wo immer die lateinische bzw. latinisierte Form begegnet.

${ }^{43}$ Goltzius bezieht sich dabei auf Liv. 33, 24, 8-9, wo von der Verstärkung der römischen Kolonie gehandelt wird (196 v. Chr.): Cosanis eodem anno postulantibus ut sibi colonorum numerus augeretur, mille adscribi iussi, dum ne quis in eo numero esset, qui post P. Cornelium et Ti. Sempronium consules hostis fuisset. - Andere Textstellen, auf die Goltzius und spätere Autoren im Zusammenhang mit der Geschichte von Cosa immer wieder Bezug nehmen, so vor allem zur ersten Deduktion der Kolonie 273 v. Chr., sind Plin. HN 3, 51: Cosa Volcientium a populo Romano deducta und Vell. 1, 14, 6: At Cosam et Paestum abhinc annos ferme trecentos Fabio Dorsone et Claudio Canina consulibus ... coloni missi ...; ferner Vergil (s. unten Anm. 46) und Rutilius Namatianus (s. unten Anm. 45); vgl. C. Hülsen, RE IV 2 (1901), Sp. 1666-1667 s.v. Cosa und M. Cataudella, DNP 3 (1997), Sp. 211 s.v. Cosa(e); ausführlich Brown 1951.

${ }^{44}$ Gemeint ist ein Eintrag in den Commentarii urbani des Raffaello Maffei Volterrano / Raphael Maffeus Volaterranus (1451-1522), und zwar Maffeus 1544, 53: perierunt ob murium multitudinem teste Plinio.

45 Eigentlich Rut. Namat. De reditu 1, 285-292: cernimus antiquas nullo custode ruinas / et desolatae moenia foeda Cosae. / ridiculam cladis pudet inter seria causam / promere, sed risum dissimulare piget. / dicuntur cives quondam migrare coacti / muribus infestos deseruisse Lares. / credere maluerim Pygmaeae damna cohortis / et coniuratos in sua bella grues.

${ }^{46}$ Verg. Aen. 10, 166-169: Massicus aerata princeps secat aequora Tigri, / sub quo mille manus iuvenum, qui moenia Clusi / quique urbem liquere Cosas, quis tela sagittae / gorytique leves umeris et letifer arcus. Goltzius irrt in diesem Punkt; nach heutigem Kenntnisstand wurde die Pluralform Cosae in der Antike lediglich literarisch gebraucht. 
In der von Goltzius beigefügten Umzeichnung erscheint kein Monogramm

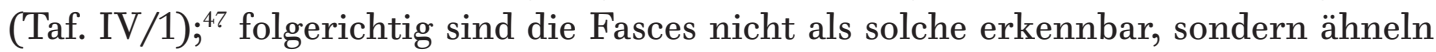
einfachen Stangen (Stater-Typ C). ${ }^{48}$ Goltzius deutet auf seiner Tafel auch an, dass er Exemplare sowohl aus Gold als auch Silber kennt, die allerdings unterschiedlicher Größe seien, und zwar die silbernen kleiner als die goldenen (AR $\gamma$ und AV $\beta$ ). Im Übrigen zeigt die Tatsache, dass Goltzius sich in seinem Referat auf divergierende Meinungen anderer Gelehrter beruft, dass der Kosōn-Stater in seinem Umfeld bzw. in der damaligen Gelehrtenwelt schon vor 1576 Gegenstand einer Debatte war. Wie lange diese Debatte zurückreichte, können wir nicht sagen. Ob der Münztyp erst 1520 durch Erasmus in diese Kreise eingeführt wurde, der ihn für uns zum ersten Mal explizit bezeugt, oder ob er schon vorher bekannt war, ist kaum zu entscheiden. Jedenfalls scheinen die oben angeführten Deutungsvorschläge, die Erasmus wiedergibt, in den Tagen des Goltzius kein Thema mehr gewesen zu sein. Dies bestätigt indirekt auch das Zeugnis des Calcagnini, der die Münze, soweit damals möglich, korrekt beschreibt, aber nicht im Sinne des Erasmus hypothetisch zu deuten versucht.

Fast siebzig Jahre nach Goltzius geht Jean Tristan de Saint-Amant / Joannes Tristanus (1595-1656) im ersten Band seiner Kommentare zur Geschichte der römischen Kaiser auf Grundlage ihrer Münzprägung von 1644 (1657) auf den Kosōn-Stater ein, und zwar im Abschnitt zu Nerva anlässlich der Besprechung einer - wie wir heute wissen, unechten - Münze mit Jupiter Ammon und der Legende col. Iul. Cossa auf dem Avers. ${ }^{49}$ Es handele sich beim Kosōn-Stater, so Tristan, um eine Rarität, von deren Existenz er über die beiden Herren Du Mont, Vater und Sohn, der eine ehemaliger „Eschevin d'Amiens“, der andere „Conseiller au Présidial“", Kenntnis erlangt habe. Beide seien große Liebhaber solcher antiker Besonderheiten („fort amateurs de ces singularitez antiques“). Die Münze wiege „2 gros 20 grains“ (= ca. 8,3 g). Die beigefügte Umzeichnung beweist, dass Tristan die Münze im Original oder Abdruck gesehen haben muss (Taf. IV/2). Es werden nämlich alle Elemente recht genau wiedergegeben, auch die Rutenbündel mit den nach vorn gerichteten Beilen sind gut erkennbar, und die beiden Figuren interpretiert er dementsprechend richtig als Liktoren. Es muss sich also um ein Exemplar des Stater-Typs A gehandelt haben. Irrig ist allerdings seine Umdeutung des Monogramms zu einem Schiffsbug. Zudem hält der Konsul in Tristans Umzeichnung in der leicht nach vorn gestreckten linken Hand ein kleines, zylindrisches Objekt, das auf den Kosōn-Stateren eigentlich nicht vorkommt.

Tristan erwähnt die Münze, weil sie aus seiner Sicht die Namensform von Cosae bestätige; $\mathrm{KO} \Sigma \Omega \mathrm{N}$ sei nämlich als Genetiv Plural (= Cosarum) zu deuten. Er erläutert, dass die kleine und unbedeutende Stadt, als Koloniegründung des Augustus, wie er aus dem Titel colonia Iulia auf der (unechten) Ammon-Münze Nervas meint erschließen zu können, aus unbekanntem Grund die besondere Ehre erhalten habe, eine Goldmünze zu Ehren des Princeps zu prägen. Der Adler auf dem Revers beziehe sich auf die Unterstützung des Augustus durch Jupiter, der ihm zu Herrschaft (Szepter)

${ }^{47}$ Goltzius 1576, Tab. XXXVI, Nr. VII.

48 Siehe oben Anm. 14. Offenkundig ungenau ist die Abbildung insofern, als die Perlkreise fehlen.

49 Tristan 1644, 365-366. Die Ammon-Münze ist Nr. 5 der von Tristan behandelten Nerva-Münzen. Das Werk wurde 1657 unverändert nachgedruckt. 
und Siegen (Kranz) verholfen habe. Der Konsul auf der Vorderseite sei dagegen laut Tristan als Augustus zu deuten, wie er in Richtung einer vor Anker liegenden Flotte schreite, die durch den (vermeintlichen) Bug symbolisiert sei, offenbar um für eine militärische Unternehmung in See zu stechen. Im Folgenden geht Tristan auf weitere Zeugnisse zur Geschichte von Cosae ein und erwähnt dabei ebenfalls die Episode bei Rutilius Namatianus.

Charles Patin / Carolus Patinus (1633-1693) behandelt den Kosōn-Stater im Jahre 1663 in der von ihm überarbeiteten Fassung der auf Münzen gestützten Darstellung der Familien des republikanischen Rom durch Fulvio Orsino / Fulvius Ursinus (1529-1600), und zwar unter dem Eintrag zur gens Iunia in Form eines Exkurses..$^{50}$ Ein auffälliges Element der beigefügten Umzeichnung ist, dass sie Fasces mit Beilen zeigt, obschon kein Monogramm erscheint, und mehr noch, dass die Beile nach hinten gerichtet sind, was quasi singulär ist (Taf. IV/3)..$^{51}$

Patin bemerkt zunächst, dass der Kosōn-Stater aufgrund der Ähnlichkeit der Reversdarstellung mit der Rückseite des von ihm kurz zuvor behandelten Denars, der Brutus als Konsul oder Prätor zeige (es ist dies die oben in Abschnitt 2 angesprochene Münze von 54 v. Chr.), von den Gelehrten üblicherweise der Familie Iunia Brutorum zugewiesen und daher in den Sammlungen zusammen mit deren Gepräge aufbewahrt werde. Diese Verbindung überzeuge ihn allerdings nicht, da es klare Indizien gebe, dass der Kosōn-Stater der Stadt Cosa zuzuschreiben sei. Die folgenden Ausführungen decken sich teilweise mit Goltzius, ohne dass dieser von Patin genannt würde: Die Kolonie Cossa bzw. Cosae, zu welcher letzteren Namensversion die Legende KO $\Omega \mathrm{N}$ bestens passe, sei laut Livius a. u. c. 490 erstmals deduziert und a. u. c. 557 neuerlich mit Kolonisten verstärkt worden. Hierauf beziehe sich das Bild der Triumvirn (bei Patin auf dem Revers). Manche seien aber der Auffassung, die Szene spiele auf die Aufgabe der Stadt wegen einer Rattenplage an (bzw. auf die nachträgliche Rückkehr ihrer Bewohner), doch mache sich Rutilius Numacianus (!) über diese Legende lustig. Der Adler mit Szepter und Kranz hingegen verweise auf Jupiter Vicilinus, dessen Heiligtum, wie Patin annimmt, im ager Cosanus lag. Dort geweihte Waffen hätten den damaligen Konsuln, wiederum Livius zufolge, zweimal durch ihr Klirren ein mahnendes Vorzeichen gegeben (a. u. c. 538) ${ }^{52}$

Der für sonderbare Ansichten berüchtigte Jean Hardouin / Joannes Harduinus (1646-1729) führt in der ersten Ausgabe seiner Nummi illustrati zwei Zeugnisse für

50 Patin 1663, 140-141 s. v. Iunia. In der ursprünglichen Fassung des Werkes von Ursinus selbst ist dieser Passus noch nicht enthalten (1577, S. 126-127). Aber auch in der nach Patins Tod erschienen neuerlichen Bearbeitung des Stoffs durch Jean Foy-Vaillant (1632-1706) fehlt ein Verweis auf den Kosōn (1703, Bd. II, S. 4-5).

51 In der bisherigen Literatur zu den Kosōn-Münzen wird ein solcher Typ, soweit ich sehe, nicht erwähnt; bekannt sind Kosōn-Statere nur mit nach vorn gerichteten Beilen oder aber ohne Beile. Möglicherweise hat Patin die Beile in der Umzeichnung selbst hinzugefügt. Er könnte dabei von der Vorlage des Motivs, dem Brutus-Denar von 54 v. Chr. (dass er sich des Zusammenhangs zwischen beiden Münzen bewusst war, zeigt das Folgende), beeinflusst gewesen sein, denn dort sind die Beile mitunter beide nach hinten gerichtet (s. oben Anm. 14). Allerdings ist bei Haverkamp (s. unten Anm. 61) ebenfalls ein solcher Kosōn-Stater wie bei Patin abgebildet; ob das Bild dieses Staters von Morell, auf dem Haverkamp basiert, aus Patin übernommen wurde, oder ob Morell sich auf ein anderes Exemplar gestützt hat, ist nicht zu klären.

52 Zur Stelle und der Problematik der Textüberlieferung s. unten Anm. 59. 
die Stadt Cossa an, nämlich jene (unechte) Münze des Nerva, die bereits bei Tristan erscheint, sowie den Kosōn-Stater. ${ }^{53}$ Er verweist knapp auf Goltzius und Tristan und bemerkt außerdem zur Schreibweise, dass die Griechen das Toponym nur mit einem $S$ geschrieben hätten, und so erscheine es auch bei Vergil..$^{54}$

In der zweiten Ausgabe des Werkes aus dem Jahr 1709 ist die Nerva-Münze verschwunden. Stattdessen ist der Abschnitt zum Kosōn-Stater erheblich erweitert. Hardouin führt aus, dass er die Sache zuvor nicht sorgfältig genug erforscht habe, und bietet sodann eine elaborierte Theorie zur Deutung der Münze..$^{55}$ Der Kosōn könne sich nicht auf das etrurische Cossa beziehen, erstens weil dessen Name offiziell - pace Vergil - mit doppeltem S geschrieben worden sei, zweitens weil diese Stadt sich als römische Kolonie niemals der griechischen Sprache bedient habe, und drittens weil sie so unbedeutend war, dass es nicht plausibel erscheint, dass sie Münzen in Gold und Silber zu Ehren des Augustus hätte schlagen lassen sollen, wo dies damals doch auch keine andere italische Stadt getan habe. Dennoch stamme der Kosōn-Stater aus der Zeit des Augustus, wie die Mache der Münze und die Form des Adlers zeigten. Letzterer begegne nämlich erst seit dieser Zeit in solcher Gestalt. Somit sei der Konsul auf dem Revers weiterhin mit Augustus zu identifizieren.

Bis zu diesem Punkt sind Hardouins Argumente grundsätzlich methodisch akzeptabel und enthalten teilweise auch gute Beobachtungen. Nun jedoch verfällt er auf den völlig abwegigen Gedanken, die Legende könnte als Abkürzung zu deuten sein: $\mathrm{K}(\alpha \tilde{\sigma} \sigma \alpha \rho) \ddot{~ o ̈ ~}(\lambda \eta v) \Sigma(v \rho i ́ \alpha v) \grave{\omega} v(\eta \dot{\eta} \sigma \alpha \tau)$, was er auf Latein mit Caesar opem toti Syriae tulit wiedergibt. Die beiden Begleiter symbolisierten, so Hardouin, den westlichen und östlichen Landesteil Syriens (Syria maritima und mediterranea), der erste mit einem Fuß auf dem Schiffsbug (den er also, Tristan folgend, auf der Münze zu erkennen glaubt). Hintergrund der Prägung sei folglich der „Sieg“" Octavians über die Parther im Osten, von Hardouin ins Jahr 31 v. Chr. (a. u. c. 223) gesetzt, als auch in den Städten Syriens eine neue Ära begonnen habe. Auf den Anlass eines großen Sieges verweise auch der Revers des Kosōn-Staters mit dem Adler, der Szepter und Kranz führt. Im übrigen betont Hardouin, dass in der Sammlung des Hofbeamten Nicolas-Joseph Foucault (1643-1721) und bei Tristan nur die goldene Ausführung des Kosōn zu finden sei, bei Goltzius daneben aber auch eine silberne erwähnt werde.

Im Katalog der Münz- und Gemmensammlung der Pfälzischen Kurfürsten von Lorenz Beger / Laurentius Begerus (1653-1705) aus dem Jahre 1685 erscheint Cosa unter den Städten Etruriens als Nr. XXII. ${ }^{56}$ Als einzigen Münztyp aus dieser Stadt führt Beger den Kosōn-Stater an, unter Verweis auf Goltzius und Patin. Er berichtet, dass die kurpfälzische Sammlung 16 Stücke dieser Münze aus Gold besitze. Der Adler steht bei Beger ebenfalls für Jupiter Vicilinus, die drei Personen jedoch möchte er nicht mit Triumvirn oder einer Flucht aus der Stadt verbinden; vielmehr wolle er sich eher jenen anschließen, die in der Szene einen Konsul erkennen, der von zwei Liktoren begleitet werde, womit ein Magistrat der Stadt Cosa gemeint sei. Untermauern ließe

\footnotetext{
53 Harduinus 1684, S. 127.

${ }^{54}$ Zur Vergil-Stelle s. oben Anm. 46.

55 Harduinus 1709, 46-47.

${ }^{56}$ Begerus 1685, 194.
} 
sich dies mit der Nachricht des Livius, dass Romulus sich zu seiner Erhöhung zwölf Liktoren zugelegt habe, einer etruskischen Tradition folgend, wonach jedes Mitglied des Zwölfstädte-Bundes dem gemeinsamen König einen Liktor zu stellen hatte. Wenn diese Städte aber dem König Liktoren stellten, so sei es doch sehr wahrscheinlich, dass auch ihre eigenen Oberbeamten über solche verfügten. Die abgedruckte Umzeichnung (Taf. IV/4) zeigt ein Exemplar ohne Monogramm und demzufolge auch mit kurzen Stangen anstelle von Rutenbündeln mit Beilen (Stater-Typ C) ${ }^{57}$ obschon letztere von Beger im Text explizit genannt werden. Möglicherweise ist dies damit zu erklären, dass es in der Heidelberger Sammlung Kosōn-Statere sowohl des Typs A als auch des Typs C gab.

Viereinhalb Dezennien später, im Jahre 1730, veröffentlichte Christian Sigismund Liebe (1687-1736) seinen Katalog der Gothaischen Münzsammlung Herzog Friedrichs II. In diesem Werk wird auch der Kosōn-Stater behandelt. Es enthält die Umzeichnung eines Exemplars mit einfachem Monogramm und Fasces mit nach vorn gerichteten Beilen (Taf. V/1).$^{58}$ Auf der einen Seite erkennt Liebe zweifelsfrei einen Konsul mit zwei Liktoren, die Rutenbündel tragen, darunter die Legende KO $\Sigma \Omega N$, auf der anderen einen Adler mit Szepter und Kranz. Liebe erwähnt Goltzius, Tristan, Patin, Beger und Hardouin und gibt die von diesen vorgetragenen Deutungen wieder. Im Anschluss an Patin will auch er die Münze nicht auf Brutus beziehen, sondern auf die Stadt Cosa. Zugleich bemerkt er, dass der von Tristan angenommene Schiffsbug zumindest auf seinem Exemplar nicht erkennbar sei. Die Verbindung zu Jupiter Vicilinus sei ebenfalls fraglich, da es sich beim Wort Cosano in der LiviusStelle um eine Korruptel handele. ${ }^{59}$ Gegen Hardouin gewendet meint Liebe, sowohl eine griechische Legende als auch eine Prägung in Gold seien im Falle von Cosa denkbar, ebenso eine Zeitstellung der Münze schon vor Augustus. Der Adler auf dem Kosōn-Stater gleiche nämlich jenem auf dem zu Beginn der vorliegenden Studie erwähnten Pomponius-Denar, der sicher vor-augusteisch sei. Liebe ist somit der erste, der eine Verbindung zwischen den beiden Bildmotiven und damit auch beiden Münztypen erkennt, und er gelangt in weiterer Folge zu einem neuen Deutungsansatz: Der Kosōn-Stater sei nämlich als Dankesgabe von Cosa für die durch Brutus wiedererlangte Freiheit zu deuten. Die Bewohner der Stadt seien möglicherweise Klienten des Brutus gewesen. Als wichtiges Argument für diese Interpretation dient ihm das Monogramm, das er - wiederum als erster - als Ligatur BR für Br(utus) deutet.

57 Siehe oben Anm. 14.

58 Liebe 1730, 15-19 $\$ \mathbb{S}$ XIII-XVI.

${ }^{59}$ Liebe 1730, 15-16. Er bezieht sich dabei auf Gronovius 1645, 257, der nicht die Form Cosano oder Compsano, sondern Pomptino annahm. In den modernen Ausgaben lautet die Stelle wie folgt (Liv. 24, 44, 8): ... et in Iovis Vicilini templo, quod in Compsano agro est, arma concrepuisse ... - Liebe verweist in seinem Abschnitt zum Kosōn-Stater auch auf den Kommentar des Luis Nuñez / Ludovicus Nonnius (1553-1645) zu Goltzius. Es handelt sich dabei aber um einen Irrtum Liebes, da Nonnius nicht den von Goltzius selbst herausgegebenen ersten Band seines auf vier Bände angelegten Werkes, also denjenigen zu Sizilien und Magna Graecia (inkl. der Städte Italiens und Etruriens) kommentiert hat, sondern die von Goltzius geplanten drei weiteren Bände zum griechischen Mutterland, den griechischen Inseln und Kleinasien. Dieser Kommentar (Nonnius 1644) beruht auf einem unveröffentlichten Manuskript des Goltzius. Das Versehen wird auch von Hanthaler moniert: Post Harduinum Nonnii (ut ait [sc. Liebe], cum tamen Goltzius ipse Historiae suae Siculae Author sit) atque Patini sentientias aggreditur (1735, S. 69). 
Kurz darauf, im Jahre 1734, erschien der erste Teil des von Andreas Morell / Andrea Morellius (1646-1703) begonnenen Thesaurus Morellianus zu den römischen Familien-Münzen in der kommentierten Fassung von Syvert Haverkamp / Sigebert Havercampus (1684-1742) ${ }^{60}$ In diesem Werk sind zwei Kosōn-Statere abgebildet und behandelt (Taf. V/2-3). ${ }^{61}$ Ihre Beschreibung durch Haverkamp lautet: Auf der einen Seite (bei ihm Avers) ein Adler mit Szepter und Kranz, auf der anderen (Revers) ein Konsul mit zwei Liktoren und die Legende $K \Omega \Sigma \Omega N$ (irregeleitet durch die falsche Umzeichnung Morells nahm Haverkamp eine Schreibung mit zwei Omegas an), ${ }^{62}$ die für Cosarum oder Coson stehe. Das eine der beiden Stücke, das Haverkamp, wie er mitteilt, selbst besaß, weise ein Monogramm auf, das LB zu lesen sei.

Im Kommentar wendet sich Haverkamp gegen die älteren Ansichten zur Deutung der Münze. Zwar geht auch er zunächst davon aus, dass es sich um eine Prägung der etrurischen Stadt Cosa handeln könnte, doch stellt er fest, dass eine griechische Legende auf der Emission einer römischen Kolonie undenkbar sei. Die von Patin als Beleg angeführte Livius-Stelle zu Jupiter Vicilinus sieht er ebenfalls, wie schon Liebe, kritisch, da sie sich auf den ager Compsanus und nicht Cosanus beziehe. Er spricht sich daher dafür aus, die Münze in die Frühzeit zu setzen (d. h. vor die erste Deduktion einer römischen Kolonie nach Cosa), also in das Zeitalter der Tarquinier, und sieht daher in der Darstellung „römischer“ Amtsinsignien auf einer Münze aus vorrömischer Zeit eine Bestätigung für die Annahme, dass die Römer diese Insignien von den Etruskern übernommen hätten.

Am Ende des Eintrags gibt Haverkamp allerdings zu bedenken, dass die (in Morells Vorlage falsch wiedergegebene) Legende $K \Omega \Sigma \Omega N$ dieser Deutung eigentlich entgegenstehe, da Cosa ein kurzes $\mathrm{O}$ erfordere, und dass vor allem in Italien in dieser frühen Epoche noch keine Goldmünzen geprägt worden seien. Daher schlägt er als Ausweg vor, dass es sich um die Prägung einer Stadt Asiens oder Griechenlands aus der Zeit des Cassius und Brutus handeln könnte, deren Oberbeamter K $\Omega \Sigma \Omega N$ hieß. Das Monogramm LB könnte dabei für den ersten römischen Konsul Lucius Brutus stehen.

Nur ein Jahr später, 1735, wird der Kosōn-Stater im Lehrbuch für Studenten (tirones) der Numismatik des österreichischen Zisterziensers Chrysostomus Hanthaler (1690-1754) ausführlich behandelt. Das Buch besteht aus 22 fiktiven einführenden Gesprächen (dialogi prooemiales) zwischen dem Lehrer (docens) Tullius und dem Schüler (discens) Publius. Einer dieser Dialoge ist im Wesentlichen dem Kosōn-Stater

60 Zu Haverkamp s. Woytek 2015, zum Thesaurus Morellianus ebd. S. 543-545.

${ }_{61}$ Havercampus 1734, Bd. 1, S. 223-224: Junia, Tab. I, Litera E \& F. - Eines der Stücke (E) erscheint ohne Monogramm und mit nach hinten gerichteten Beilen, das andere (F) mit einfachem Monogramm und nach vorn gerichteten Beilen. Letzteres ist offenkundig ein Stater des Typs A; s. oben Anm. 14. Erstere Form der Darstellung ist auch bei Patin anzutreffen, auf erhaltenen Kosōn-Stateren aber, soweit ich sehe, unbekannt. Morell dürfte diese vermutlich hybride Version (Stater des Typs C mit ergänzten Fasces) von Patin übernommen haben; s. oben Anm. 51. Für eine mögliche Abhängkeit Morells bzw. Haverkamps von Patin spricht auch, dass sie wie dieser die Seite mit dem Adler als Avers auffassen, während alle anderen früheren Autoren sie als Revers betrachten.

${ }^{62}$ In manchen Exemplaren ist das Omikron tatsächlich nur schwer zu lesen und der Fehler daher verständlich. 
gewidmet. ${ }^{63}$ Der Münztyp habe, so der Lehrer, bereits viele Geistesgrößen nicht zur Ruhe kommen lassen, ${ }^{64}$ und er sei von manchen einer griechischen Stadt, von anderen einem römischen Adelsgeschlecht zugewiesen worden. Das Exemplar, das der Schüler in der Hand hält, wird vom Lehrer in der üblichen Weise angesprochen: auf der Vorderseite ein Consul oder Magistrat mit zwei Liktoren, auf der Rückseite der Adler mit Szepter und Kranz; die Legende KO $\Sigma \Omega N$ sei auf Cosa zu beziehen. Als Besonderheit wird vom Lehrer allerdings hervorgehoben, dass die Münze, anders als die meisten in der Literatur behandelten Stücke, weder ein Monogramm noch einen Schiffsbug, aber auch keine Spur eines anderen Bildes an deren Stelle zeige. ${ }^{65} \mathrm{Im}$ Folgenden referiert der Lehrer zunächst die Theorien von Goltzius, Patin, Tristan und Hardouin. Der Schüler ist ob dieser Vielfalt von widersprüchlichen Meinungen verunsichert, wird aber vom Lehrer ermutigt, da im Bereich der irdischen Wissenschaften und zumal in der Geschichte keine „ewige Wahrheit“ (aeterna veritas) möglich sei. Im Übrigen brauche der Schüler sich nicht zu schämen, wenn selbst die Meister des Fachs sich nicht einig seien. Hieran anschließend bittet der Schüler, dass ihm die Meinung des Liebe dargelegt werde, welchem Wunsch der Lehrer in ausführlicher Weise nachkommt. Damit endet die Behandlung des Kosōn-Staters, und Liebe wird somit faktisch ein Vorrang gegenüber den anderen zitierten Autoren eingeräumt. Der erst kurz zuvor erschienene Haverkamp ist in diesem Dialog noch nicht berücksichtigt.

Im Jahr 1740 wird der Kosōn-Stater in der Archaeologia nummaria des vor allem als Sprachforscher bekannten Johann Georg Wachter (1663-1757) thematisiert. Es handelt sich bei diesem Werk um ein auf zehn Kapitel angelegtes Lehrbuch der antiken Münzkunde. Im achten Kapitel, das sich den Münzen der griechischen Städte und Stämme widmet, werden in Abschnitt XXXI die Prägungen aus Italien besprochen. Dabei geht Wachter vor allem auf die Frage ein, wie mit Münzen zu verfahren sei, die in Bild und Legende nicht zur stadtrömischen Münzprägung passten. ${ }^{66}$ Diese sollten, so der Autor, anderen Städten Italiens zugewiesen werden. Hierzu zählten auch etruskische Prägungen, von denen ihm der Kosōn-Stater als prominentestes Beispiel dient. Von dieser cosanischen Münze, die von den Gelehrten viele Male mit unterschiedlichem Ergebnis behandelt worden und dennoch eigentlich noch immer unverstanden sei - so ist Wachters prägnante Wortwahl vexatissimus (sc. nummus) wohl zu verstehen -, besitze der Senat von Leipzig mehrere Exemplare, und zwar sowohl in Gold als auch in Silber. ${ }^{67}$ Da Wachter gegen Ende seines Lebens in dieser Stadt ansässig war, dürften ihm die Kosōn-Münzen aus eigener Anschauung bekannt gewesen sein. Hierzu passt, dass die beigefügte Umzeichnung (Taf. V/4) ebenso wie die wörtliche Beschreibung akkurat sind, und dass die Umzeichnung auch nicht von

${ }^{63}$ Hanthaler 1735, 64-73: Dialogus VII: De numis Cosanorum, \& alio Romanorum.

${ }_{64}$ Hanthaler 1735, 64: Multa hic Numus praeclara hucusque ingenia fatigavit.

65 Hanthaler 1735, 65: Ast Numus tuus, ut ipse hisce oculis usurpas, nec proram, nec monogramma, immo nec tenuia quidem vestigia cujuscunque demum figurae ostendit. Es handelt sich also wiederum um ein Exemplar ohne Monogramm und Beile des Stater-Typs C; s. oben Anm. 14. Mit dem Schiffsbug bezieht sich der Lehrer auf Tristan (s. oben).

66 Wachter 1740, 103-104.

67 Wachter 1740, S. 104: Hoc pacto cum Romana historia conciliari etiam possunt nummi Hetrusci, et inprimus vexatissimus ille Cosanus, quem in auro et argento possidet Magnific. hujus Urbis SENATUS. 
Haverkamp bzw. Morell abhängt, die er in einer Anmerkung lobend zitiert. Das von Wachter abgebildete Exemplar weist nämlich das einfache Monogramm und nach vorn gerichtete Beile auf, repräsentiert also den Stater-Typ A. Höchst bemerkenswert ist allerdings, dass es sich, wie die Beischrift AR anzeigt, um eine Silbermünze handeln soll. Singulär ist auch, dass Wachter die mittlere Figur auf dem Avers „als Lucumo bzw. Magistrat von Cosa" anspricht; dies passt freilich zu seiner bereits erwähnten Vorstellung, es handele sich beim Kosōn-Stater um eine etruskische Münze.

Der Kosōn-Stater wird auch im zweiten Band des Diccionario Numismatico General des Thomas Andres de Gússeme vom Jahre 1775 unter dem Lemma Cossa, ó Cosa erwähnt. Hinter den beiden Toponymen vermutet der Gelehrte, unter Verweis auf die antiken Autoren, zwei verschiedene Städte. ${ }^{6}$ Jeweils einer von diesen seien zwei Prägungen zuzuweisen, an erster Stelle der Kosōn-Stater (KO $\Sigma \Omega \mathrm{N}=$ Cosorum), sodann die bereits oben mehrfach erwähnte (unechte) Ammon-Münze Nervas. Dabei gibt Gússeme eine sehr knappe Beschreibung der Bildmotive der Kosōn-Münze. Die drei Figuren auf dem Avers beschreibt er als togati, von denen die zwei äußeren Rutenbündel trügen, während er die mittlere unidentifiziert lässt. Schließlich sind im Katalog der Münzsammlung des Anatomisten William Hunter (1718-1783) von Charles Combe (1743-1817) aus dem Jahr 1782 zwei Kosōn-Statere erfasst, die vom Autor wiederum der Stadt Cosa zugeordnet werden; verwiesen wird dabei einzig auf Morell. ${ }^{69}$

Um diesen Abschnitt zusammenzufassen: Der Kosōn-Stater wird in der numismatischen Literatur des 16.-18. Jh. quasi ausschließlich mit Cosa verbunden und die Legende im Sinne von lateinisch Cosarum bzw. Cosorum gedeutet. ${ }^{70}$ Dabei werden verschiedene Szenarien genannt, die den gemutmaßten historischen Hintergrund der Prägung bilden: Es könne sich um den Magistrat der etruskischen Stadt; um Triumvirn für die Deduktion bzw. Aufstockung der römischen Kolonie; um flüchtende Bürger wegen einer Rattenplage; um eine Prägung der Stadt zu Ehren von Brutus (für die Ermordung Cäsars); oder aber um eine Prägung der Stadt zu Ehren von Augustus (eventuell für seine Erfolge im Osten) handeln. Einzig Haverkamp erwägt als Alternative, die Münze könnte aus einer Stadt im griechischen Osten stammen und in die Zeit des Brutus fallen, und mit der Legende könnte der Münzmeister dieser Stadt gemeint sein - ein Deutungsansatz, der von späteren Autoren weiter verfolgt werden sollte. Das einfache Monogramm wird, sofern es vorkommt, erst als Schiffsbug (Tristan, Hardouin), sodann als Kombination der Buchstaben BR oder LB für Brutus gedeutet (Liebe und Haverkamp).

Schon sehr früh (spätestens seit den Zeiten Patins) wird die Konsul-Szene von Gelehrten und Sammlern mit dem Brutus-Denar von 54 v. Chr. verbunden und die Münze daher unter der Familie Iunia eingeordnet. Nur eine Generation später, mit Liebe, wird auch die Nähe des Adlers zum Pomponius Rufus-Denar von 73 v. Chr. erkannt.

${ }^{68}$ Gússeme 1775, Bd. 2: C, S. 383-384.

${ }^{69}$ Combe 1782, 114: Cosa in Italia.

${ }^{70}$ Die Form Cosarum ist theoretisch denkbar, doch wurde der Plural Cosae im offiziellen Namen nicht gebraucht (s. oben Anm. 46); Cosorum ist, wenn ich recht sehe, keine mögliche Form, weder zu Cosa noch zu ihren Bürgern, den Cosani. 
Die in den hier behandelten Werken bildlich dargstellten Exemplare des KosōnStaters zeigen teils das einfache Monogramm, teils kein Monogramm (Typen A und C) ${ }^{71}$ Der Stater-Typ B mit komplexem Monogramm scheint damals nicht bekannt gewesen zu sein. Als besondere Auffälligkeit ist die Ausrichtung der Beile in den Rutenbündeln der Liktoren nach hinten bei Patin und auch bei Morell/Haverkamp zu nennen, doch dürfte es sich hierbei um neuzeitlich ergänzte Bild-Versionen zu handeln, die durch Abgleich mit der Vorlage, dem Brutus-Denar, entstanden sind.

Die Existenz von silbernen Exemplaren bezeugen Goltzius und Wachter. Laut Goltzius ist die ihm bekannte Silberversion allerdings kleiner als die goldene, und laut Wachter zeigt sie das einfache Monogramm. Beides trifft auf die Originalmünzen des Drachmen-Typs B nicht zu (s. oben Abschnitt 3). Dies lässt vermuten, dass die fraglichen Silberstücke in Wirklichkeit neuzeitliche Kopien oder Imitationen von Kosōn-Stateren der Typen A oder C waren.

\section{Der Kosōn-Stater bei Eckhel und Neumann}

In den Schriften von Joseph (Hilarius) Eckhel (1737-1798) und Franz de Paula Neumann (1744-1816), die einander in der Leitung des kaiserlichen Münzkabinetts zu Wien ablösten, ${ }^{72}$ erreicht die Deutung des Kosōn-Staters eine neue Qualitätsstufe. Bei Eckhel erscheint die Münze erstmals in seinem Catalogus des Wiener Kabinetts vom Jahre 1779. Die Beschreibung folgt dem bekannten Muster: auf der Vorderseite ein Konsul mit Liktoren, auf der Rückseite ein Adler, der einen Kranz hält (das Szepter bleibt unerwähnt). Eckhel führt vier Exemplare an, drei goldene und „ein ähnliches" in Silber. Eines der goldenen Stücke zeige das Monogramm BL, ein weiteres sei schlechterer Qualität. Zwar ordnet er die Münze hier noch, seinen Vorgängern folgend, unter der etrurischen Stadt Cosae ein, bemerkt aber, dass diese Zuweisung zu Recht angezweifelt werden könne. ${ }^{73}$

Zum zweiten Mal geht Eckhel dann in seiner Sylloge von 1786 auf den KosōnStater ein, und zwar im Vorspann des Werkes, wo er Münzen bespricht, die ihm erst kurz vor der Drucklegung bekannt geworden sind. Zwei von diesen stammen

${ }^{71}$ Ohne Monogramm: Goltzius, Patin, Hanthaler; mit einfachem Monogramm: Tristan, Hardouin, Liebe, Wachter; sowohl ohne als auch mit einfachem Monogramm: Beger (?); Haverkamp.

72 Zur Geschichte des Wiener Münzkabinetts im 18. Jh. s. Hassmann - Winter 2016; Eckhel fungierte in den Jahren 1774-1798, Neumann 1798-1816 als dessen Direktor; s. ebd. 200-201.

${ }^{73}$ Eckhel 1779, 14: Sintne hi numi revera hujus urbis, jure dubitari potest. - Auch in diesem Fall handelt es sich, wie schon bei den früheren Autoren, um Statere der Typen A (ein Stück) und C (zwei Stücke). Das Silberstück ist in Wirklichkeit ein Falsum (s. unten). - Nur kurze Zeit später, nämlich 1781, listet Eckhel einen weiteren Kosōn-Stater im Katalog der ehemaligen Privatsammlung des Schatzmeisters Maria Theresias Joseph de France, der im Auftrag der Erben zum Zwecke der Verkaufs der Sammlung. erstellt wurde, unter der Zuweisung Cosae Etruriae, aber ohne weitere Erläuterungen auf (1781, S. 151). Dieses Stück dürfte in die Sammlung Hunter gelangt sein; s. oben Anm. 69. - Das Wiener Münzkabinett hat nach dem Erscheinen von Eckhels Katalog 1779 bis zum Jahr 1875 einige weitere Kosōn-Münzen erworben. Heute besitzt es 14 Kosōn-Statere, davon 8 vom Typ A (KHM, Inv. GR 9113; 9118; 9120-9123; 9125-9126) und 4 vom Typ C (GR 9114-9116; 9124); bei zwei Stücken ist eine Zuordnung nicht möglich (GR 9117 \& 9119). Einige dieser Stücke weisen Doppelschläge auf (s. unten Abschnitt 12 zu I. Winkler). Daneben finden sich 3 goldene und 3 silberne Falsa (Inv. FA 904-908; 5480); zu letzteren s. unten Anm. 122. 
aus Cosae, und er nimmt diese Gelegenheit zum Anlass, nochmals hervorzuheben, dass es völlig unglaubhaft sei, die Kosōn-Münzen, von denen eine große Zahl in Gold und Silber nach Wien gelange, dieser unbedeutenden etrurischen Stadt zuzuweisen. Vielmehr habe Brutus diese Münzen schlagen lassen, wie er an anderer Stelle zur Familie Junia darlegen wolle. ${ }^{74}$

Dieses Versprechen löst Eckhel dann im 6. Band seiner Doctrina von 1796 ein, und zwar im Abschnitt zu M. Iunius Brutus. ${ }^{75}$ Die Beschreibung gleicht der im Catalogus (also auch hier bleibt das Szepter unerwähnt); das Monogramm auf einem der Stücke steht jetzt für LB statt BL. Von diesem Typ gebe es, so Eckhel, eine große Zahl an Exemplaren, wobei silberne seltener seien als goldene. Vom Gewicht reichten sie ungefähr an die Aurei der frühen Kaiserzeit heran, seien aber ziemlich rissig ( $f a b$ rica satis hiulca). Eckhel nennt Tristan, Patin, Liebe und Haverkamp, setzt sich aber nur mit Letzterem eingehend auseinander. Die oftmals angenommene Verbindung mit Cosae sei wenig glaubhaft, da diese Stadt viel zu unbedeutend gewesen sei, während ansonsten nicht einmal mächtige griechische Städte Italiens und Siziliens wie Syrakus Gold in solchen Quantitäten hätten ausprägen lassen. Daher sei eher anzunehmen, dass die Kosōn-Münzen auf Veranlassung des Brutus in einer griechischen Stadt unter einem Münzmeister namens Kosōn geschlagen worden seien, freilich in geringer Qualität, und zwar aus jenem Gold und Silber, das laut Appian die thrakische Dynastin Polemokratia dem Brutus überlassen hatte. ${ }^{76}$ Für eine solche Annahme spreche, so Eckhel, auch die regionale Streuung der Funde, da diese Münzen „ex Dacia, et inferiore Hungaria" zu ihm nach Wien gelangten, ebenso wie auch Münzen von Philipp II., Alexander d. Gr. und Lysimachos. Zu einer solchen Deutung passe schließlich auch das Monogramm LB, das für Lucius Brutus stehe. Daher ordne er die Münze der gens Iunia zu.

Eckhel erwähnt am Ende seiner Ausführungen in der Doctrina auch die Meinung Neumanns, die dieser bereits 1783 im zweiten Band seines Hauptwerkes Populorum et Regum numi veteres inediti unter der Überschrift „Thracia: Cossea sive Cosa“ vorgelegt hatte. ${ }^{77}$ Es ist dies neben Liebe die umfangreichste und zugleich originellste Behandlung der Thematik in der frühneuzeitlichen Numismatik. Neumann erwähnt

${ }^{74}$ Eckhel 1786, nach S. VIII: Explicatio parergorum, Cosa Etruriae: Nam hujus esse urbis opus diu crediti illustres numi aurei argenteique, qui inscriptum KO$\Sigma \Omega N, \&$ consulis inter lictores processum offerunt, quorumque ingens ad nos numerus pervenit. Esse in Cosanorum moneta putandos, vix jam eruditis probabitur, quorum fere sententia est, signatos a M. Bruto Caesaris parricida, \& quam praestare aliis, aliquando in numis gentis Juniae latius comprobabo.

${ }^{75}$ Eckhel 1796, 22-24.

${ }^{76}$ App. B. Civ. 4, 10, 75. Polemokratia hatte nach der Ermordung ihres Mannes mit ihrem Sohn bei Brutus Zuflucht gesucht und dabei auch beträchtliche Mengen an Gold und Silber mitgebracht, die Brutus ausprägen ließ. Den Sohn übergab er den Kyzikenern, damit diese ihn aufzögen, um ihn später in sein Königreich zurückzuführen. - Es sei in diesem Zusammenhang darauf hingewiesen, dass wir mittlerweile aus der folgenden Inschrift wissen, dass der Mann der Polemokratia Sadalas und ihr Sohn Kotys hießen (Dumont, Homolle 1892, 365, Nr. 62a = IGR I 775; Bizye, 42-16 v. Chr.; cf. IGBulg I 43

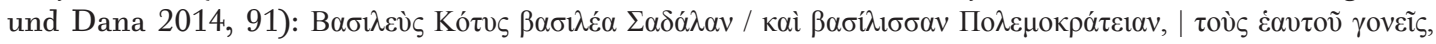

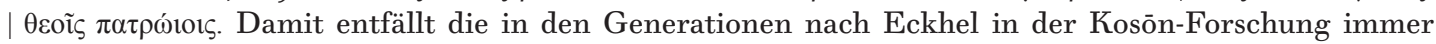
wieder geäußerte Mutmaßung, mit Kosōn könne einer der beiden Herrscher, Vater oder Sohn, gemeint gewesen sein.

77 Neumann 1783, 128-134. 
alle namhaften Vorgänger: Goltzius, Tristan, Patin, Hardouin, Beger und Liebe (nicht aber Haverkamp). Die Theorie Hardouins sei lächerlich und verdiene keine Beachtung, und die allgemein angenommene Verbindung mit dem etrurischen Cosae sei wenig glaubhaft, da erstens die Münze in Italien und besonders in Etrurien nicht vorkomme (weder als Fundmünze noch als Bestandteil von Sammlungen, ${ }^{78}$ dies wisse er von seinen dortigen Informanten), da zweitens aus den etrurischen Städten keine Goldprägung bekannt sei und da drittens römische Kolonien keine Edelmetall prägen durften. Dass der Kosōn-Stater aber nicht aus vorrömischer, sondern aus römischer Zeit stamme, zeige die Darstellung des Konsuls und seine Verwandtschaft mit dem Brutus-Denar von 54 v. Chr. Seine lange gehegte Meinung, so Neumann, bezüglich der Herkunft der Münze tendiere zu Thrakien oder Makedonien. Kosōn-Münzen seien sehr häufig in Österreich und Ungarn, und sie würden in großer Zahl aus „Hungaria inferior" nach Wien gebracht, wie er aus eigener Anschauung wisse. In Siebenbürgen würden Kosōn-Statere quasi täglich gefunden, und sie würden aus benachbarten Gegenden dorthin gebracht; dies habe ihm Baron Bruckenthal, Gubernator des Großfürstentums und gelehrter Kenner und Sammler alter Münzen, brieflich versichert. ${ }^{79}$ Auch sei das Land reich an Edelmetallvorkommen. Vor diesem Hintergrund nach einem passenden Toponym in der Region suchend, kommt er auf die thraki-

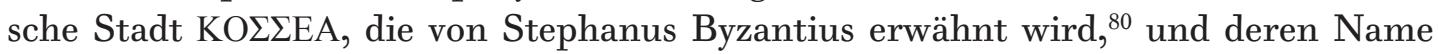

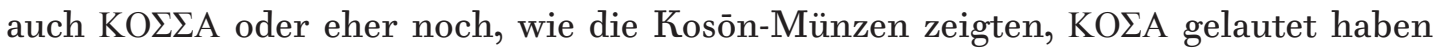
könnte. Als Anlass und Zeitpunkt ihrer Prägung seien die Kriegsvorbereitungen der Cäsarmörder anzunehmen. Die Kosōn-Münzen seien auf Geheiß des Brutus nach dem Vorbild seines eigenen Denars geprägt worden, um Verbündete zu bezahlen. Diese turbulenten Umstände würden auch die schlechte Qualität der Prägung erklären.

Eckhel und Neumann argumentieren somit beide in einem klar durchdachten Viererschritt: 1. Ausschluss der Cosa-These, da die Annahme einer Goldprägung für diese etruskische Stadt aus mehreren Gründen nicht plausibel ist. - 2. Lokalisierung des räumlichen Kontextes der Kosōn-Münzen im unteren Donau- und Balkanraum (Kosōn-Münzen werden in großer Zahl in Siebenbürgen gefunden und sind dort auch in Sammlungen sehr verbreitet; hingegen gibt es keine Exemplare aus Italien). 3. Rekonstruktion des zeitlichen Rahmens und historischen Hintergrunds aufgrund des (vermeintlichen) Brutus-Monogramms. - 4. Herstellen einer Zusammenhangs mit der literarischen Überlieferung, bei Eckhel über die Polemokratia-Episode, bei Neumann über Stephanus Byzantius.

${ }^{78}$ Einschränkend ist zu bemerken, dass es, wie wir jetzt wissen (s. oben Abschnitt 7 zu Calcagnini), damals durchaus zumindest ein Exemplar in Italien gegeben hat, nämlich in Florenz den Kosōn-Stater aus der ehemaligen Este-Sammlung; diese Münze dürfte allerdings, wie ebd. vermutet, in Ungarn erworben worden sein. Somit ist der Befund Neumanns im Grunde nach wie vor richtig.

79 Neumann 1783, S. 130: Valedixi penitus, ab oculatis auctoribus instructus, fere indies hodiedum ocurrere hos numos in Transilvania, eoque deportari frequenter e vicinia. Unus instar omnium sit nobis testis Exc. Dominus Baro Bruckenthalius, Transilvaniae Gubernator, pecuniae priscae dives doctusque possessor, qui literis ad me datis ejus rei fidem certam fecit. - Samuel von Bruckenthal (1721-1803), Stifter des Bruckenthal-Museums in Hermannstadt (Sibiu), das unter anderem auch seine Münzsammlung verwahrt, war 1777-1787 Gubernator von Siebenbürgen.

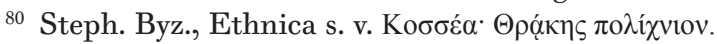




\section{Die Rezeption der Theorien Eckhels und Neumanns zum Kosōn-Stater im 19. Jh.}

Die angeführten Arbeiten von Eckhel und Neumann zu den Kosōn-Münzen, besonders aber ihr spätestens seit 1783 bzw. 1786 erkennbarer Ansatz, diese historisch mit den Bürgerkriegen der ausgehenden Republik zu verbinden und räumlich im unteren Donau- und Balkanraum zu verorten, wird in den folgenden Jahrzehnten zunächst nur zögerlich übernommen. Im Lexicon universae rei numariae veterum von Johann Christoph Rasche (1733-1805) von 1785 ist der Kosōn-Stater weiterhin unter Cosa besprochen, doch teilt der Verfasser immerhin die Skepsis Eckhels. Der Eintrag orientiert sich an dessen Catalogus und führt die ältere Literatur an (außer Patin und Beger), nicht aber Neumann. ${ }^{81}$ Théodore Edme Mionnet (1770-1842) ordnet den Kosōn-Stater im ersten Band seiner Description de médailles antiques, grecques et romaines von 1806 zunächst Cosa zu; ${ }^{82}$ erst im 2. Band des Supplements von 1822 übernimmt er die Auffassung Neumanns, dass die Münze ins thrakische Cossea gehöre. ${ }^{83}$ Auch im Handbuch der Alten Numismatik von Johann Georg Theodor Grässe (1814-1885) von 1854 wird der Kosōn-Stater noch immer Cosa zugewiesen. ${ }^{84}$ Celestino Cavedoni reiht den Kosōn-Stater in seiner kommentierenden Beschreibung des Katalogs der Sammlung Este von Calcagnini von 1825, zwar unter Nennung von Morell/Haverkamp und Eckhel, aber ohne weitere Vertiefung der Problematik, in sehr traditioneller Manier unter der Familie der Junier ein..$^{85}$

Mit dem Werk von Henry Cohen (1806-1880) zu den Médailles consulaires von 1857 ändert sich der allgemeine Trend. Der Kosōn-Stater wird hier in einem Exkurs zum Brutus-Denar von 54 v. Chr. behandelt, dessen Revers als Vorlage für seine Vorderseite gedient habe. Es handele sich, so Cohen, um eine Prägung der thrakischen Stadt Cossea, die auf Veranlassung von Brutus erfolgt sei - Neumann stand hier also Pate, ohne jedoch genannt zu werden. ${ }^{86}$ Theodor Mommsen (1817-1903) beruft sich in seiner Geschichte des römischen Münzwesens von 1860 einzig auf Eckhel, wenn er festhält, kurz vor der Schlacht von Philippi sei ausnahmsweise „dem thrakischen Fürsten Koson zum Lohne dafür, dass er sich und seine Schätze der republikanischen Partei auslieferte ... verstattet worden, mit seinem voll ausgeschriebenen Namen in griechischer Sprache, unter Beifügung des Namens des römischen Feldherrn in lateinischer Sprache und im Monogramm, in Gold zu prägen". ${ }^{87}$ Der Passus wurde 1878 quasi wörtlich von François Lenormant (1837-1883) in den zweiten Band seines Werkes La monnaie dans l'Antiquité übernommen, ohne das Zitat als solches auszuweisen. ${ }^{88}$ Dagegen bezieht Ernest Babelon (1854-1924) den Kosōn-Stater in seinem zweibändigen Handbuch zur Münzprägung der römischen Republik von 1886 wieder,

${ }^{81}$ Rasche 1785, Sp. 1044-1045.

82 Mionnet 1806, 98, Nr. 11.

${ }^{83}$ Mionnet 1822, 276-277, Nr. 445-446 (mit und ohne Monogramm).

${ }^{84}$ Grässe 1854, 217.

${ }^{85}$ Cavedoni 1825, 96 mit Anm. 1: Moneta Romanorum, Numi familiarum, Nr. 8. Zu Calcagnini s. oben Abschnitt 7.

${ }^{86}$ Cohen 1857, 174-175 Anm. 1.

87 Mommsen 1860, 693.

${ }^{88}$ Lenormant 1878, 122. 
wie schon Neumann, auf Cossea; auch er nennt allerdings den Wiener Gelehrten nicht. ${ }^{89}$ Babelon betont zudem, die Münze habe aus diesem Grund nichts mit einem (anderweitig unbekannten) thrakischen König des Namens Kosōn zu tun.

\section{Der Kosōn-Stater und die Gelehrtenwelt des frühneuzeitlichen Siebenbürgen}

Die älteste erhaltene Beschreibung des Kosōn-Staters aus der Feder eines siebenbürgischen Gelehrten ist dem aus Klausenburg (Cluj-Napoca) stammenden Stephanus Zamosius / Szamosközy István (1570-1612) zu verdanken. Sein Werk Analecta Lapidum aus dem Jahre 1593, in welchem die Geschichte des antiken Siebenbürgen (= Dakien) vornehmlich auf Grundlage von Inschriften dargestellt wird, behandelt in Kapitel XI die dort aufgefundenen griechischen Münzen. An letzter Stelle wird der Kosōn-Stater besprochen.

Zamosius deutet die Münze als Emission der Einwohner der Insel Kos (= Coorum) $\cdot{ }^{90}$ Seine Beschreibung des Gepräges lautet wie folgt: Auf der einen Seite ein Adler, der mit der Kralle einen Ölkranz hochhebt, darunter die Legende KO$\Sigma \Omega N$, auf der anderen drei Männer in griechischem Gewand, das bis zu den Knien reicht; der erste führe einen Lorbeerzweig, der zweite trage einen Kranz auf dem Kopf, der dritte halte in erhobener Hand eine Opferschale..$^{91}$

Johann Tröster (vor 1640-1670?) aus Hermannstadt (Sibiu) behandelt in Kapitel XXII seiner Landesbeschreibung Siebenbürgens mit dem Titel Das Alt- und NeuTeutsche Dacien von 1666 die dort gefundenen antiken griechischen und römischen Münzen, darunter auch den Kosōn-Stater. Tröster weist die Münze der „Ionischen Republik" zu, womit er Kos meint. Seine Beschreibung ist eine wörtliche Übersetzung der oben zitierten Stelle aus Zamosius' Analecta Lapidum; er verwendet allerdings, wie dies auch später Morell/Haverkamp tun sollten, die Form K $\Omega \Sigma \Omega N$ mit zwei Omegas. ${ }^{92}$

Wie zu erwarten, führten die Schatzfunde von 1803-1804 in Siebenbürgen zu einer deutlich gesteigerten Aufmerksamkeit für den Kosōn-Stater. An erster Stelle

\footnotetext{
${ }^{89}$ Babelon 1886, 114. Daher ist auch die Bemerkung von Grueber 1910, 474-475, Anm. 1, die Zuweisung an Cossea sei ein Vorschlag Babelons, nicht richtig.

${ }^{90}$ Das ist allerdings sprachlich unmöglich; der Genetiv Plural des Ethnikons hat auf Griechisch die

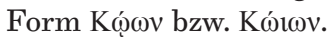

${ }_{91}$ Zamosius 1593, 101-102: Coorum quoque, numus aureus altera ex parte aquilam habet, coronam oleaginam unguibus levantem, cum literis infra, $K O \Sigma \Omega N$, idest, Coos insulae, quae est in mari Icario Rhodo proxima. Altera parte tres viri sunt Graeco habitu vestibus poplite tenus demissis. Eorum primus ramum laureum gestat, pone qui sequitur, serto caput redimitus est. Tertius manu sublata patera tenet. - Weitere Äußerungen des Zamosius zum Kosōn-Stater finden sich angeblich in seiner unpublizierten Schrift Schediasma de veteribus monetis, die von Winkler erwähnt wird (1972, S. 173, Anm. 1 und 188, Anm. 83); non vidi.

${ }_{92}$ Tröster 1666, 476: „Auf einer andern (sc. Münze der Ionischen Respublic) stehet ein Adler / der einen Ölkranz mit dem einen Fuß aufhebet / darunter stehet: K $\Omega \Sigma \Omega N$. Auf der andern Seiten stehen drey Griechische Männer / in langen Kleidern / der erste hat einen Lorbeer-Zweig in der Hand / der andere trägt einen Kranz aufm Kopf / der Dritte hat eine Schale in der Hand." - Die Lesung der Inschrift mit zwei Omegas kann Tröster nicht von Morell oder Haverkamp (zu diesen s. oben Abschnitt 8) übernommen haben, da diese später datieren; vielmehr ist sie vermutlich, wie schon bei Morell selbst, auf die mehrfach angesprochene schlechte Lesbarkeit mancher Kosōn-Statere zurückzuführen.
} 
ist in diesem Zusammenhang der aus Kronstadt (Braşov) stammende Abbé Joseph Karl Eder (1761-1810) zu nennen, der als einer der Begründer der wissenschaftlichen Geschichtsforschung in Siebenbürgen gelten kann. Eder zeigte großes Interesse an den Funden aus den Orăștie-Bergen. Nur wenige Wochen nach dem öffentlichen Bekanntwerden des ersten Schatzfundes, im August 1803, publizierte er eine Studie, in welcher er den Kosōn-Stater analysiert. ${ }^{93}$ Eder nennt Gewicht (2 1/4 Dukaten = ca. 8,75 g) und Feingehalt (23 Karat 5 Grän) der Münze. Diese Angaben verdankte er dem Münzamt (Domus Monetaria) zu Karlsburg (Alba Iulia), an welches Münzschätze von ihren Findern abzuliefern waren. Überdies unterscheidet Eder drei „Varietäten“: im Durchmesser größere Stücke mit Monogramm sowie kleinere, mit oder ohne Monogramm - Eder nimmt hier also die oben in Abschnitt 2 erwähnte, erst in der jüngsten Forschung fest etablierte Unterscheidung von drei Typen des Kosōn-Staters bereits vorweg. Seine Beschreibung der Bildmotive ist präzise. Das Monogramm liest er LB. Solche Münzen gebe es, so Eder, in der Gegend in großer Zahl, und sie seien in jedem Kabinett enthalten, auch dem Bruckenthal'schen in Hermannstadt. An Literatur scheint er Hardouin, Liebe, Eckhels Doctrina und Neumanns Populorum et Regum numi eingesehen zu haben, nicht aber Tristan und Patin. Zamosius' (unhaltbare) Kos-Theorie bleibt unerwähnt. Eckhels Vorbehalten gegenüber der Verbindung mit Cosa sei zuzustimmen, weil die etrurische Stadt zu unbedeutend war, Neumanns Verbindung mit dem thrakischen Cossea aus demselben Grund abzulehnen. Hardouins Theorie sei phantastisch; im Übrigen finde sich auf der Münze kein Schiffsbug. Stattdessen bestehe vermutlich eine Verbindung zum Revers des Brutus-Denars, den Eder aus Eckhel kennt, was durch die Polemokratia-Episode bei Appian und letztlich auch das Monogramm (= Lucius Brutus) untermauert werde. Der Adler sei möglicherweise als Symbol für den Sturz des nach dem Königtum strebenden Caesar zu verstehen; das Motiv könne aber auch mit dem Revers des Pomponius-Denars zu verbinden sein. In diesen Punkten stützt Eder sich offenkundig auf Liebe.

In den Dokumenten der siebenbürgischen Kameralverwaltung, welche die Untersuchung der Schatzfunde von 1802-1804 in den Orăștie-Bergen betreffen, ${ }^{94}$ werden nur wenige konkrete numismatische Hinweise zu den gefundenen Münzen gemacht. Die meisten Nennungen beziehen sich auf Statere vom Lysimachos-Typ. Diese Münze war sowohl der lokalen Beamtenschaft als auch der Bevölkerung recht vertraut, und die Legende BA $\Sigma I \Lambda E \Omega \Sigma \Lambda Y \Sigma I M A X O Y$ wird mehrfach zitiert. Über das Aussehen der Kosōn-Münzen werden hingegen vor Ort nur selten Andeutungen gemacht. In den Verhören, die im Sommer 1803 in den umliegenden Dörfern durchgeführt wurden, berichten die Befragten manchmal vage von einer Münze mit drei „Bildern“ (= Figuren) auf der einen und einem Vogel auf der anderen Seite. Hingegen sind die Wiener Dienststellen in diesem Punkt genauer; sie sprechen von Kosonischen Goldmünzen bzw. Dukaten und von den „Monogrammen Lysimachus und Koson" (womit die Inschriften auf den Münzen gemeint sind). Auf Latein ist

93 Eder 1803. Der Kronstädter Gelehrte hat sich zur selben Zeit auch mit dem Schatzfund von Stateren des Lysimachos-Typs aus Csáta/Ceata von 1802/1803 befasst und hierzu eine lateinische Studie verfasst, die damals aber unpubliziert geblieben ist; s. Mitthof 2018 mit der Erstedition des Textes.

${ }^{94} \mathrm{Zu}$ diesen Vorgängen und den betreffenden Dokumenten s. jetzt Mitthof, Mádly (in Vorbereitung). 
in solchen Dokumenten von aurei Cosonei oder ducati Koson dicti bzw. von aurei Lysimaci die Rede.

Gelegentlich wird in diesem Kontext auch ein Münztyp „mit dem Bildnis Kaisers Octavianus" genannt. Dieser Ausdruck bezieht sich ebenfalls auf den KosōnStater, wie eine „Explication“ aus dem Jahr 1803 deutlich macht, die zu dieser Dokumentation gehört und in welcher der Kosōn-Stater numismatisch eingeordnet wird (zum originalen Wortlaut dieses Dokuments s. unten Appendix): Der anonyme Verfasser referiert die Diskussion der Fachliteratur, von Goltzius über Patin und Eckhel - mit einem wörtlichen Zitat aus dessen Catalogus - bis zu Hardouin. Nach seiner Ansicht stünden zwei Meinungen im Raum, nämlich dass es sich entweder um eine Prägung der Stadt Cosae oder aber um eine solche des Octavian (gemäß der Theorie Hardouins) handele, womit die Münze im letzteren Fall 1830 Jahre alt sei, im erstgenannten sogar nochmals 200 Jahre älter. Der Verfasser, in dem wir ein gebildetes und belesenes Mitglied der siebenbürgischen Beamtenschaft vermuten dürfen, neigt der Auffassung Hardouins zu. Diese Einschätzung hatte offenkundig zur Folge, dass die amtlichen Dienststellen in Siebenbürgen, die mit der Aufklärung der Schatzfunde befasst waren, sich teilweise seinem Urteil anschlossen, so auch das Karlsburger Münzamt, das auf Empfangsbestätigungen (recepisse) mitunter die Münze dem „Octavian“ zuweist. ${ }^{95}$

Eine längere, auf Ungarisch abgefasste Abhandlung zum Kosōn-Stater veröffentlichte im Jahre 1812 der Klausenburger Gubernialsekretär Kenderesi Mihály von Felsőszálláspatak (Salașu de Sus, jud. Hunedoara). ${ }^{96}$ Wie Kenderesi festhält, war die Deutung des Münztyps zu seiner Zeit in den gelehrten Kreisen der Siebenbürger Gesellschaft ein häufiges Gesprächsthema. Er leugnet die Thesen von einem Zusammenhang mit Brutus, Cotiso ${ }^{97}$ oder dem etrurischen Cosa, ohne Namen ihrer Vertreter zu nennen. Vielmehr handele es sich um Gepräge der Insel Kos, die vor der Zeit des Lysimachos eine freie und reiche Republik gewesen sei. ${ }^{98}$ Die Inschrift KO$\Sigma \Omega N$ steht also auch bei Kenderesi für Cosorum bzw. Coorum (Genetiv Plural); den Zamosius, der diese Kos-These ja bereits mehr als 200 Jahre zuvor vertreten hatte, erwähnt er allerdings nicht.

${ }_{95}$ Dass diese „Explication“ aus Wien stammt, ist kaum anzunehmen, denn dort wäre Neumann befragt worden, und der war sicher nicht der Verfasser dieser Zeilen, vertrat er doch ganz andere Ansichten zu dem Münztyp, wie oben dargelegt. Auch Eder kommt nicht in Frage, der sich, wie wir gesehen haben, klar gegen Hardouin ausspricht, und der im Folgenden erwähnte Kenderesi ist ebenfalls auszuschließen, da er, wie wir gleich sehen werden, die Kos-These vertrat.

96 Kenderesi 1812.

97 Die Stelle ist insofern bemerkenswert, als hier erstmals der aus Suetons Augustus-Vita und anderen Quellen bekannte dakische Dynast Cotiso (s. oben Anm. 3) zumindest indirekt in Bezug zur Kosōn-Münze gesetzt wird. Offenbar wurde diese These, die erst einhundert Jahre später von Bahrfeldt in die Forschung eingeführt werden sollte (s. unten Abschnitt 12 mit Anm. 107), damals in Siebenbürgen schon ventiliert. Wir kennen bislang aber keine schriftliche Fixierung.

98 Kenderesi 1812, 49: „A KO$\Omega$ N Aranyok pedig, se nem Brutusé, se nem Cotisoné, se nem Cosa Hetruriai Városé, hanem a Cos szigeti igen nevezetes, és Lysimachus ideje előtt Xerxestől fogva szabad, gazdag Közönséges Társaságnak Respublicának Pénze.“ (Übersetzung L. Mádly: „Die KOIQN-Münzen waren weder die Münzen des Brutus, noch des Cotiso, und auch nicht der Stadt Hetruria Cosa, sondern es waren die Münzen der bereits vor den Zeiten des Lysimachus, beginnend mit Xerxes, freien und reichen Respublica der Insel $\left.\operatorname{Cos}^{6}\right)$. 
Ausgangspunkt der Überlegungen Kenderesis ist die von ihm postulierte Tatsache, dass Statere des Lysimachos- und des Kosōntyps in den Schatzfunden immer vermischt auftreten würden. Beide Münztypen müssten also aus derselben Zeit stammen, was eine Verbindung mit Brutus und Cotiso verbiete, ebenso aber auch die von Eder geäußerte Vermutung ausschließe, Kosōn könne der Münzmeister eines "Gotenkönigs" (gemeint sind die Geten) gewesen sein. ${ }^{99}$ Vielmehr erklärt Kenderesi den Befund so, dass Lysimachos sich zunächst der Goldreserven der Stadt Kos bemächtigt habe, nachdem Alexander d. Gr. deren Freiheit beendet hatte, später aber im Zuge der Dromichaites-Episode dieses Gold dem getischen König als Lösegeld zahlen oder als Geschenk überlassen musste. ${ }^{100}$ Abschließend räumt Kenderesi allerdings ein, dass gegen seine These eingewendet werden könnte, dass der Genetiv Plural des Ethnikons der Einwohner von Kos eigentlich $\mathrm{K} \Omega \Omega \mathrm{N}$ lauten müsste, denn seine Kenntnis des Griechischen sei gering; jedoch in Analogie zu anderen, modernen Sprachen sei ja nicht völlig auszuschließen, dass die Form KO $\Omega$ N aufgrund dialektaler Varianten oder der allgemeinen Sprachentwicklung ebenfalls existiert habe. ${ }^{101}$

Etwa zwanzig Jahre später, im Jahre 1838, deutet Johann Michael Ackner (1782-1862) aus Schässburg (Sighişoara), Verfasser zahlreicher Schriften zu den Altertümern Siebenbürgens, den Kosōn-Stater wie folgt: Die Münze sei nach Cäsars Ermordung auf Geheiß des Brutus in großer Menge geprägt worden, „in einer griechischen Stadt, zu Koson", und dann als Sold oder Beute zum Sitz eines dakischen Herrschers nach Siebenbürgen gelangt. ${ }^{102}$

Schließlich ist an dieser Stelle der preußische Geheimjustizrat und Schriftsteller Johann Daniel Ferdinand Neigebaur (1783-1866) zu nennen. Neigebaur, der zeitweise als Generalkonsul in der Walachei und Moldau fungierte, war ein intimer Kenner der Altertümer Siebenbürgens, wie sein Buch Dacien, aus den Überresten des klassischen Alterthums, mit besonderer Rücksicht auf Siebenbürgen von 1851 eindrucksvoll zeigt. ${ }^{103}$ Dass Neigebaur sich eine eigene Meinung zum Kosōn-Stater gebildet hatte, ersehen wir indirekt aus einer Miszelle des Demetrio Diamilla (1826-1908) vom Jahre 1847, der über ein Gespräch berichtet, das er mit Neigebaur in Rom geführt hatte. Da in Siebenbürgen, so Neigebaur, und nur dort, unzählige Exemplare der Münze gefunden würden, müsse es sich um eine lokale Prägung handeln, die aus diesem Land stamme.

${ }^{99}$ Kenderesi 1812, 43: „Abbé Éderról (ki meglehetős olvasású, és aki a mint értettem, Schlötzernek az Erdélyi Szászok Historiájára sok igaz, de közbe a pártfogáson kívül való egyenességgel meg nem egyező dátumokat is adott volt) azt hallottam megvallom mosolyogva, és ez lenne már az Ötödik Vélekedés: hogy ő, azt akarta volna vitatni: hogy a KO $\Omega$ N név semmi nem egyébb, hanem valamelyik Gothus Király Müntz Mesterének neve lett légyen. Ennek meg cáfolása, se pennát, se papirosat nem érdemel: és ezzel az eddig fenn forgott Vélekedéseket bé rekesztem“ (Übersetzung L. Mádly: „Vom Abbé Eder ... habe ich etwas gehört, wie ich es mit einem Lächeln gestehe, und dies wäre dann die fünfte Überlegung: Er beabsichtigte ins

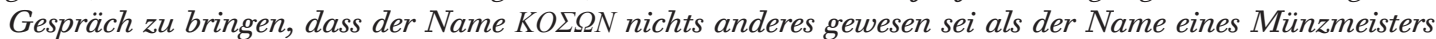
irgendeines Gotenkönigs. Die Widerlegung dieser Annahme ist weder die Feder noch das Papier wert, und damit beende ich meine dargelegten Überlegungen").

100 Der getische Herrscher Dromichaites (ca. 300 v. Chr.) nahm im Jahre 292 v. Chr. den Diadochen Lysimachos auf einem Feldzug gefangen, behandelte ihn aber zuvorkommend und entließ ihn schließlich gegen eine Geldzahlung.

101 Kenderesi 1812, 71-72.

102 Ackner 1844, 29-30.

103 Neigebaur 1851. 
Der Kosōn-Stater sei also keine Imitation des Brutus-Denars und sicherlich auch keine Münze der Stadt Cosa, sondern das Gepräge einer antiken Stadt in Siebenbürgen, die noch wiederzuentdecken sei. ${ }^{104}$

Die siebenbürgischen Gelehrten stützen sich somit vielfach auf die in Abschnitt 8 behandelten Autoren der frühneuzeitlichen Numismatik, verfolgen aber auch eigene Deutungsansätze, die ihrer Zeit insofern voraus sind, als sie in der „westlichen“ Forschung erst ab dem Beginn des 20. Jh. begegnen. Ihre Ausführungen zum Thema zeugen von dem Versuch, den Kosōn-Stater in das getisch-dakische Geschichtsnarrativ des unteren Donau- und Karpatenraumes einzubetten und damit als Element der „heimatlichen“ Frühgeschichte Siebenbürgens zu sichern. Dabei wird nicht nur eine Verbindung mit der Polemokratia-Episode erwogen, die auch bei Eckhel begegnet, sondern alternativ mit der Dromichaites- und sogar (allerdings für uns nur indirekt fassbar) mit der Cotiso-Episode operiert. Auf diese Weise werden die antiken Goldschätze Siebenbürgens mit Stateren des Lysimachos- und des Kosōntyps auf Kriegsbeute oder Subsidienzahlungen zurückgeführt, die an einem noch nicht identifizierten Herrschaftssitz innerhalb des Karpatenbogens gehortet worden seien. ${ }^{105}$

\section{Die moderne Forschung und der aktuelle Forschungsstand zu den Kosōn-Münzen}

Mit Beginn des 20. Jh. wurde die Erforschung der Kosōn-Münzen auf eine völlig neue Grundlage gestellt. Dies ist vor allem Max Bahrfeldt (1856-1936; seit 1913 von Bahrfeldt) zu verdanken, der in einer Studie vom Jahre 1912 erstmals alle damals in Sammlungen verwahrten oder in Auktionskatalogen angezeigten Kosōn-Statere (insgesamt 112 Stück) systematisch miteinander verglich. ${ }^{106}$ Zugleich warf Bahrfeldt die Fragen auf, ob mit Kosōn ein dakisch-getisch-thrakischer Dynast gemeint und ob dieser eventuell mit dem aus Horaz, Florus und Sueton bekannten Teilkönig frühaugusteischer Zeit namens Cotiso, einem der Nachfolger des Burebista (besser: Byrebistas; s. unten Anm. 125), gleichzusetzen sei. Wesentliche Grundlage für diese Annahme war die bereits eingangs erwähnte Beobachtung, dass die älteren SuetonHandschriften die Form Cosoni statt Cotisoni zeigen, woraus sich der gut begründete Verdacht herleitet, dass hier von einem späteren Emendator, der Horaz und Florus kannte, in den Text eingegriffen worden ist. ${ }^{107}$

104 Diamilla 1847, 124.

105 Ein anderer im frühneuzeitlichen Siebenbürgen verbreiteter Erzählstrang über sagenhafte Goldschätze ist die Legende vom Dareios-Schatz, besonders in der Gegend um Klausenburg; s. Mitthof, Mádly 2018; Haarmann et alii (in Vorbereitung).

106 Bahrfeldt 1912; vgl. auch dens. 1923.

107 Siehe oben Abschnitt 1 mit Anm. 3. - Es handelt sich um folgende Textstellen: Hor. Carm. 3, 8, 17-20: mitte civilis super Urbe curas: / occidit Daci Cotisonis agmen, /Medus infestus sibi luctuosis / dissidet armis; Flor. 2, 28: Daci montibus inhaerent. Inde Cotisonis regis imperio, quotiens concretus gelu Danuvius iunxerat ripas, decurrere solebant et vicina populari. Visum est Caesari Augusto gentem aditu difficilem summovere. Misso igitur Lentulo ultra ulteriorem perpulit ripam; citra praesidia constituta. Sic tum Dacia non victa, sed summota atque dilata est; Suet. Aug. 63: M. Antonius scribit primum eum Antonio filio suo despondisse Iuliam, dein Cotisoni (cosoni* $\mathrm{M}$, cosoni GV, cosini X) Getarum regi, quo tempore sibi quoque in vicem filiam regis in matrimonium petisset. 
An zweiter Stelle ist Iudita Winkler (1925-1985) zu nennen, die in einem substantiellen Aufsatz vom Jahre 1972 Bahrfeldts Ansatz weiter vertiefte und erstmals anhand der Wiener Stücke auch auf Stempelmerkmale und Fehlprägungen durch Doppelschläge hinwies. ${ }^{108}$

Hervorzuheben ist drittens Octavian Iliescu (1919-2009), der klarstellte, dass ebenso wie römische Denare und ihre Motive im Allgemeinen, so auch die beiden Denar-Vorlagen der Kosōn-Münzen im vorrömischen Dakien durchaus verbreitet waren. ${ }^{109}$ Vom Brutus-Denar von 54 v. Chr. liegt aus dakischen Hortfunden mittlerweile immerhin ein Dutzend Exemplare vor, vom Pomponius-Denar von 73 v. Chr. zumindest eines. Dies hängt damit zusammen, dass im Münzumlauf Dakiens im ausgehenden 1. Jh. v. Chr. römisches Geld an die Stelle der Typen aus der griechisch-hellenistischen Welt trat. Parallel hierzu wurden ab diesem Zeitpunkt in Dakien römische Denare kopiert oder imitiert, teils auch durch die Verbindung von Bildern verschiedener Vorlagen, wie dies ja auch beim Kosōn-Stater der Fall ist. ${ }^{110}$

Eine weitere Zäsur in der Forschung zum Kosōn-Stater wurde durch den sogenannten Târsa-Fund von Jahre 1996 bewirkt (s. oben Abschnitt 5). Aus diesem Hort haben die Rumänische Nationalbank und das Nationalmuseum zu Bukarest etwa 500 Exemplare angekauft; kleinere Tranchen wurden von den Museen in Deva und Cluj-Napoca sowie von weiteren Institutionen erworben. ${ }^{111}$ Anhand dieses Materials sind Stempel- und Metallanalysen des Kosōn-Staters auf erheblich breiterer Basis als noch zu Bahrfeldts oder Winklers Zeiten möglich geworden. Kurz darauf wurden schließlich die Funde der silbernen Kosōn-Drachmen bekannt, wodurch sich ebenfalls wichtige neue Gesichtspunkte ergeben haben.

Der aktuelle Kenntnisstand lässt sich wie folgt skizzieren:

a.) Monogramm: Anstelle der Deutungen als lateinisches BR oder LB für (Lucius) Brutus, die in der älteren Literatur angenommen werden (wie wir heute wissen, unter Bezug auf den Kosōn-Stater des Typs A), schlug Bahrfeldt 1912 die griechische Interpretation BA (= $\beta \alpha \sigma i \lambda \varepsilon v ́ \varsigma)$ vor, im Sinne eines Herrschertitels als Ergänzung zum Namen KO$\Sigma \Omega N$ (diese Deutung bezieht sich, wie jetzt feststeht, auf den Stater des Typs B). Beide Möglichkeiten wurden bis in die jüngste Zeit immer

108 Winkler 1972.

109 Iliescu 1990. - Zur Frage der Präsenz von Denaren im vorrömischen Dakien hat die Forschung besonders in den letzten Jahren erhebliche Fortschritte erzielt; nach Glodariu 1971 und Chițescu 1981 sind jetzt vor allem zu nennen: Mihailescu-Bîrliba 1990; Pop, Găzdac 1999; Lockyear 2008; Mihailescu-Bîrliba 2013; Strobel 2018. Für ein Verzeichnis der Funde von römischem Geld in Dakien aus der Zeit vor 106 n. Chr. s. Părpăuță 2006, S. 319-405.

110 Ein deutliches Indiz hierfür ist die Entdeckung eines Depots von einem Dutzend Ober- und Unterstempeln im Typus römischer Denare aus der Zeit von 150 bis 75 v. Chr. in einer dakischen Siedlung, deren Reste sich beim heutigen Dorf Tilișca (jud. Sibiu) befinden. - Der massive Zufluss römischer Denare in den nord-danubischen Raum ebenso wie das Aufkommen lokal gefertigter Nachahmungen solcher Münztypen setzte allerdings, anders als noch von Iliescu und anderen angenommen, erst im späten 1. Jh. v. ein (nach ca. 30 v. Chr.) und erstreckte sich bis ins 1. Jh. n. Chr.; s. jetzt Strobel 2018.

111 Zum Târsa-Fund und zur Analyse besonders der nach Bukarest gelangten Exemplare s. Chiriac 1996-1997; Petolescu 1997; Dima, Ilie 2007; Vîlcu 2010, 204; Petolescu 2011a (vgl. dies. 2011b). - Weitere Sammlungsbestände von Kosōn-Münzen behandeln z. B. Bodzek 2006, 72-78, 163-184 (Krakau); Vîlcu et alii 2006, 9-11 und Nr. 68-71 (Bukarest, Archäologisches Institut); Călian et alii 2007, 28-38 (Cluj-Napoca, Nationalmuseum für die Geschichte Transsilvaniens); Suciu, Ardevan 2007 (Alba Iulia). 
wieder in Betracht bezogen, obschon sie wenig plausibel sind, vor allem da es in der gesamten antiken Numismatik keine Parallelen für derartige Formen von Beizeichen gibt. Daneben ist die von B. V. Head in seinem Handbuch von 1911 geäußerte These zu nennen (auch er dürfte sich dabei auf den Stater des Typs B bezogen haben), dass das Monogramm für die griechischen Buchstaben $\mathrm{O} \Lambda \mathrm{B}$ stehe und die nordpontische, an der Mündung des Bug gelegene Stadt 'O $\lambda \beta i ́ a$ meine, und dass demnach KO$\Sigma \Omega N$ einen skythischen Herrscher bezeichne. ${ }^{112}$ Diese Idee, die in den Auktionskatalogen des Münzhandels selbst heute noch immer vorherrscht, ist schon aufgrund der oben in Abschnitt 4 skizzierten, klar umgrenzten geographischen Verteilung der KosōnFunde auszuschließen.

Die aktuelle Deutungslinie wird vor allem von C. M. Petolescu repräsentiert, die betont, dass es zwei unterschiedliche Monogramme gibt, ein einfaches und ein komplexes. ${ }^{113}$ Überdies weist ein nennenswerter Teil der Kosōn-Statere, und zwar etwa ein Drittel, gar kein Monogramm auf. Es existieren also, wie schon oben in Abschnitt 2 hervorgehoben, drei Typen von Kosōn-Stateren. Dies ist ein starkes Indiz dafür, dass diese Münzen in drei Phasen emittiert wurden, und zwar wohl eher zeitlich aufeinander folgend als gleichzeitig, da sich die drei Typen hinsichtlich der technischen Daten (Gewicht, Durchmesser, Feingehalt) voneinander unterscheiden. Unklar bleibt dabei, ob ihre Produktion an einem Ort oder aber in verschiedenen Münzstätten geschah. Im übrigen schließt Petolescu aus diesem Befund völlig überzeugend, dass es sich bei den Monogrammen am ehesten um Marken mit produktionsbezogener Bedeutung handeln dürfte, ${ }^{114}$ ähnlich denen, die auf dem Revers der Statere des Lysimachos-Typs zu finden sind (oder zumindest, so ließe sich anfügen, um Zeichen, die solche Marken imitieren sollten).

b.) Gewicht: Der Kosōn-Stater ist im Durchschnitt 8,4-8,6 g schwer; fast alle Exemplare liegen zwischen 8,2-8,8 g; die größten bislang festgestellten Abweichungen lauten 7,69 und 9,26 g. ${ }^{115}$ Eine solche Schwankungsbreite im Gewicht der Schrötlinge ist bei Prägestätten der griechischen oder römischen Welt nicht anzutreffen. Überdies liegt das durchschnittliche Gewicht des Kosōn-Staters deutlich über dem, was unter Caesar und Brutus für den römischen Aureus als Standard galt (Caesar 1/40 Pfund = $8,19 \mathrm{~g}$; Brutus 1/42 Pfund = 8,1 g). Damit ist in jedem Fall auszuschließen, dass Brutus oder eine andere römische Instanz diese Münzen selbst emittiert hat. Aber auch nach den Standards der griechischen Münzwelt sind 8,5 g für einen Stater ziemlich schwer. Gemäß der Norm des zeitgenössischen attischen Standards von 4,15 g wären für den Stater (Didrachmon) etwa 8,3 g zu erwarten. Die Statere des Lysimachos-Typs der westpontischen Städte, die räumlich und zeitlich am ehesten als Referenzprägung zu den Kosōn-Stateren dienen können, zeigen zwar in ihrer vorletzten Emissionsphase (2. Hälfte des 2. Jh. v. Chr.) ein durchschnittliches Gewicht von 8,4-8,5 g, werden

${ }^{112}$ Head 1911, 272, 289 (unter „Olbia“ bzw. „Kings of the Scythians“); ihm folgt unter anderem Kahrstedt 1922. In der ersten Ausgabe hatte Head die Münze noch im Abschnitt „Thracian kings and dynasts" behandelt und das Monogramm mit BR wiedergegeben (1887, S. 244).

113 Petolescu 2011a, 79-80 bzw. 2011b, 178; s. auch Vîlcu 2010 und jetzt Strobel 2018.

114 Petolescu 2011a, 74.

115 Petolescu 2011a, 80-84 bzw. 2011b, 179-182. 
dann aber in ihrer letzten Emissionsphase (ca. 100-70, eventuell sogar ca. 100-45 v. Chr.) auf nur noch 8,2-8,4 g reduziert. ${ }^{116}$ Der Kosōn-Stater, der in jedem Fall später ausgeprägt worden sein muss als die Statere vom Lysimachos-Typ, liegt also deutlich über dem letztgenannten Referenzwert. Ähnliches gilt für die beiden Serien von Kosōn-Drachmen: Auch sie zeigen eine vergleichsweise breite Streuung von 4,50 bis 4,15 g, und ihr Standard liegt mit 4,4 g ebenfalls über der soeben genannten Norm der attischen Drachme von 4,15 g. ${ }^{117}$ Sowohl der auffällige Gewichtsstandard als auch die Schwankungsbreite im Gewicht der Schrötlinge liefern somit erste Indizien, dass alle drei Kosōn-Münzen aus „barbarischer" Produktion stammen.

c.) Feingehalt: Der Târsa-Fund hat, wie bereits erwähnt, umfangreiche Metallanalysen zu den Kosōn-Stateren initiiert, vor allem anhand der in Bukarest verwahrten Exemplare. ${ }^{118}$ Dabei hat sich ergeben, dass die drei Typen von Kosōn-Stateren im Feingehalt deutlich voneinander differieren, und zwar wie folgt: Typ A mit einfachem Monogramm: ca. 92-96\%; Тyp B mit komplexem Monogramm: ca. 97-98,8\%; Typ C ohne Monogramm: ca. 80-90\%. Die Typen A und B dürften aus geläutertem Gold hergestellt worden sein, das durch Einschmelzen hellenistischer Münzen oder von Schmuck, Gefäßen etc. gewonnen und gegebenenfalls gestreckt wurde, Typ C hingegen aus ungeläutertem siebenbürgischen Fluss- und Seifengold (das einen wesentlich höheren Silberanteil aufweist). Dies alles ähnelt dem Schema, das auch beim Stater des Lysimachos-Typs in seinen spätesten Emissionen (1. Jh. v. Chr.) zu beobachten ist; auch bei diesen Münzen sind unterschiedliche Qualitätsstandards bzw. Produktionsphasen mit stufenweise abnehmendem Feingehalt (von 97\% auf 91\%) zu beobachten.

d.) Stempelkoppelungen: Anhand der Kosōn-Statere aus dem Târsa-Fund lassen sich für diesen Münztyp erstmals auch Stempelkoppelungen festmachen. Bei der Produktion der Münzen aus diesem Hort wurden drei fixe Unterstempel A-C für den Avers (Konsul-Szene) mit jeweils zwei bzw. vier Oberstempeln a-k für den Revers (Adler) kombiniert, und zwar wie folgt: A/a-b; B/c-f; C/g-k. ${ }^{119}$ Es sind bislang keine Stempelkoppelungen zwischen diesen Serien nachzuweisen. Dieses Faktum spricht ebenfalls dafür, dass ihre Emission in mehreren Phasen erfolgte - ob in ein und derselben oder aber in mehreren Münzstätten, ist nicht zu entscheiden.

e.) Echtheit der Kosōn-Drachmen: Zu diesen beiden Münztypen ist zu bemerken, dass sie - nach anfänglichen Zweifeln der Forschung - mittlerweile mit Sicherheit als echt eingestuft werden können. ${ }^{120}$ Das entscheidende Argument liefert dabei die Beobachtung, dass die beiden Stempel, die zur Produktion der bislang bekannt gewordenen Kosōn-Drachmen des Typs B (bildgleich mit dem Kosōn-Stater des Typs B) verwendet wurden, in mindestens einem Fall auch zur Prägung eines solchen Kosōn-

${ }^{116}$ Callataÿ 1995a; vgl. dens. 1995b; zu den Stateren des Lysimachos-Typs s. ferner Munteanu 2005 \& 2011; Mitthof 2018 sowie unten Abschnitt 13.

117 Fischer-Bossert 2016, 90.

118 Siehe z. B. Cojocaru et alii 2000; Constantinescu, Bugoi 2009; Constantinescu et alii 2009a \& b; 2011; 2012; 2013; 2015a \& b; Vîlcu et alii 2008; 2010; 2011; Vasilescu et alii 2011; vgl. auch Spânu 2010.

${ }^{119}$ Hourmouziadis 2010.

120 Siehe die Beiträge von Hourmouziadis 2010 und Fischer-Bossert 2016. Für erste Metallanalysen der Kosōn-Drachmen s. jetzt Constantinescu et alii 2015a \& b. 
Staters dienten. Zwischen der Gold- und der Silberemission dieser Kosōn-Typen besteht also eine Überkoppelung. ${ }^{121}$

Die Kosōn-Drachme des Typs A (bildgleich mit dem Tetradrachmon des Macedonia Prima-Typs) wird in der älteren Literatur niemals beschrieben; offenkundig war sie den früheren Autoren unbekannt. Inwieweit hingegen die silbernen Kosōn-Münzen, die in der älteren Literatur seit dem 16. Jh. immer wieder erwähnt werden (s. Goltzius, Wachter, Eckhel, Neumann), antike Originale von KosōnDrachmen des Typs B darstellen oder aber neuzeitliche Imitate, die nach dem Modell von Kosōn-Stateren produziert worden sein könnten, bleibt unklar. Allerdings gibt es, wie oben am Ende von Abschnitt 8 festgestellt, mehrere Indizien, dass es sich um neuzeitliche Kopien oder Imitate handelt. Die Angaben von Goltzius und Wachter zu den ihnen vorliegenden Silberstücken passen nämlich nicht zu den bislang bekannten Originalmünzen des Drachmen-Typs B. Wenn Goltzius eine unterschiedliche Größe von Gold- und Silberversion angibt, dann deutet dies wohl in jedem Fall auf ein Imitat hin, denn die echten Kosōn-Drachmen des Typs B haben denselben Durchmesser wie der Kosōn-Stater (sonst wäre die oben konstatierte Stempelkoppelung nicht möglich). Umgekehrt bedeutet die identische Größe eines Kosōn-Silberstücks im Vergleich zum Kosōn-Stater selbstverständlich nicht, dass es echt wäre. Im Gegenteil kann es sich um ein Stück handeln, das anhand des Abdrucks eines Kosōn-Staters gegossen wurde. Die drei Silber-Stücke, die heute im Wiener Münzkabinett verwahrt werden, sind als solche Gussfalsa einzustufen und damit sicherlich nicht antik; dennoch könnte zumindest eines von ihnen nach einer echten, heute aber nicht mehr auffindbaren Kosōn-Drachme des Typs B produziert worden sein. Genauso gut könnte bei seiner Fertigung aber auch ein Stater des Typs B als Vorlage gedient haben. ${ }^{122}$ Frühneuzeitliche Gussfalsa des Kosōn-Typs sind auch anderswo nachgewiesen, z. B. in Budapest und Nitra. ${ }^{123}$ Insgesamt betrachtet ist in der Frage, ob die Kosōn-Drachme des Typs B schon vor den illegalen Schatzfunden der Jahre um 2000 bekannt war, derzeit keine eindeutige Antwort möglich, doch geht die Tendenz eher zu einem Nein.

f.) Prägeort, Prägeherr und Zeitstellung der Prägung: In diesen Fragen werden nach wie vor höchst unterschiedliche Ansichten vertreten. Zumeist wird Kosōn als dakischer, getischer, thrakischer oder sogar skythischer Fürst betrachtet, der enorme Vorräte an Gold (und Silber) aus Beute oder Subsidiengeldern angehäuft habe. Teilweise wird angenommen, dieser Herrscher habe seinen Sitz nicht in Sarmizegetusa Regia gehabt, und die Münzschätze seien erst nachträglich infolge von Kriegszügen, Subsidienzahlungen oder anlässlich eines Herrschaftswechsels nach Sarmizegetusa Regia transferiert worden (und damit letztendlich in die Gewalt Decebals gelangt). ${ }^{124}$

121 Hourmouziadis 2010; Fischer-Bossert 2016, 89.

122 Fischer-Bossert 2016, 91. - Die drei Wiener Silber-Falsa (Taf. VI/1-3) sind: KHM Inv. FA 906 nach einem Stater des Typs C; FA 907 nach einem Stater des Typs B oder nach einer Drachme des Typs B; FA 908 nach einem Stater des Typs A (dieses Falsum ist wohl mit dem Silberstück in Eckhels Katalog 1779, S. 14, Nr. 4 zu identifizieren).

123 Vîlcu 2010, 202.

124 So etwa Morawiecki 1987, der den Cotiso (= Coso) aus Sueton in Muntenien (d. h. südlich der Karpaten) verortet, womit er nicht mit Sarmizegetusa Regia in Verbindung stünde. 
Im Gefolge Bahrfeldts wird vielfach vermutet, Kosōn sei mit dem dakischen Teilherrscher Cotiso (ca. 44-29 v. Chr.), einem Nachfolger des Burebista (besser: Byrebistas), zu identifizieren, der später bei Kämpfen gegen die Römer unterging. ${ }^{125}$ Eine gegenteilige Meinung postuliert, Kosōn/Coso sei nicht mit Cotiso gleichzusetzen, sondern ein anderer dakischer Teilherrscher gewesen, der ebenfalls nach dem Tode des Byrebistas an die Macht gelangte und zunächst mit Brutus in Verbindung stand. ${ }^{126}$ Die Kosōn-Münzen seien für die Finanzierung des Bürgerkriegs der Cäsarmörder gegen Octavian und Marc Anton bestimmt gewesen, nach deren Scheitern bei Philippi 42 v. Chr. aber nutzlos geworden und daher bei diesem Herrscher verblieben. Da Kosōn/ Coso zu einem späteren Zeitpunkt (ca. 32-31 v. Chr.), wie die Sueton-Stelle zeigt, angeblich gute Kontakte mit Octavian pflegte, müsste dieser ihm zwischenzeitlich sein Paktieren mit den Cäsarmördern vergeben haben - schon für sich genommen, so sei bemerkt, kein sehr plausibles Szenario. ${ }^{127}$ In diesem Zusammenhang wird bisweilen auch vermutet, die Münzen seien direkt unter der Aufsicht von Brutus in Makedonien geprägt worden. ${ }^{128}$ Die letztgenannte Annahme ist allerdings, wie wir bereits gesehen haben, aufgrund der technischen Merkmale der drei Münztypen ausgeschlossen; dieses Geld stammt mit Sicherheit nicht aus einer römischen Prägestätte.

Aber auch der indirekte Bezug der Kosōn-Prägungen zu Brutus lässt sich hinterfragen. Die älteren Deutungen der Monogramme auf den Münzen sind, wie oben gezeigt, ${ }^{129}$ allesamt nicht haltbar. Damit entfällt aber das wichtigste Argument für die Brutus-These, und es eröffnet sich die Möglichkeit einer zeitlichen Einordnung der Kosōn-Münzen unabhängig von den Cäsarmördern ebenso wie von den Ereignissen des römischen Bürgerkrieges. Wirklich sichere chronologische Anhaltspunkte gibt es somit eigentlich nur drei, nämlich für die Kosōn-Drachme des Typs A der Beginn der Emission des Macedonia Prima-Tetradrachmons (168 v. Chr.) und für alle Kosōn-Statere sowie für die Kosōn-Drachme des Typs B das Datum der Emission des Brutus-Denars (54 v. Chr.) als termini post quem; zudem steht für alle Kosōn-Münzen der Fall von Sarmizegetusa Regia im Jahr 106 n. Chr. als terminus ante quem fest.

Allerdings kommen jetzt zwei neue Argumente hinzu, die für diese Fragen entscheidend sind: Erstens die Tatsache, dass der Kosōn-Stater, wie im Vorangehenden ausgeführt, in mehrere Typen zerfällt, die sich in der Mache deutlich voneinander

125 Die Kosōn = Cotiso - These Bahrfeldts wurde in der Folgezeit mehrfach aufgegriffen, so etwa von Ruzicka 1922, 15-18; vgl. auch Mihailescu-Bîrliba 1990, 92. - Traditionell wird in der Forschung die Namensform Burebista verwendet, doch Strobel 2018 bringt überzeugende Argumente vor, dass die korrekte Namensform Byrebistas lauten sollte.

126 Siehe etwa A. Stein, PIR² C 1536: Coson; Premerstein 1935, 67; Daicoviciu 1965.

${ }^{127}$ Zur Sueton-Stelle s. oben Anm. 107. - Es ist klar, dass die von Sueton überlieferte Nachricht, Octavian habe damals ein wechselseitiges Ehebündnis mit Cotiso/Coso erwogen, nichts anderes als eine diffamierende Unterstellung M. Antons gewesen sein dürfte; aber ein solcher Vorwurf war dem Publikum ja nur dann wirklich plausibel zu machen, wenn allen bekannt war, dass Octavian und Cotiso/Coso zu diesem Zeitpunkt tatsächlich ein politisches Nahverhältnis pflegten.

128 So wird etwa in den allerjüngsten substantiellen Beiträgen zu den Kosōn-Münzen (Constantinescu et alii 2015a \& b) eine gemeinsame Produktion sowohl der Stater- als auch der Drachmen-Typen in ein und derselben Münzstätte südlich der Donau, genauer in Makedonien, zur Zeit der römischen Bürgerkriege vermutet.

129 Siehe oben Abschnitt 12 a.). 
unterscheiden. Dieses Faktum lässt annehmen, dass diese Münzen nicht in einem einzigen historischen Moment geschlagen wurden, sondern über einen längeren Zeitraum hinweg. Zweitens ist zu beachten, dass die Zeitstellung der erst seit kurzem bekannten Kosōn-Drachme des Typs A sich recht genau bestimmen läßt. Seit dem späten 2. Jh. v. Chr. waren Tetradrachmen des Thasos- und des Macedonia Prima-Typs, ebenso wie Drachmen des Apollonia- und des Dyrrhachium-Typs, im Unteren Donauraum massiv präsent. Nördlich der Donau fällt die stärkste Verbreitung des Tetradrachmons des Macedonia Prima-Typs in die 80er bis 40er Jahre des 1. Jh. v. Chr. Kurz darauf wurden solche griechischen bzw. gräzisierenden Münzen von römischen Denaren und deren „barbarischen“ Nachahmungen verdrängt. Hieraus folgt, dass die Emission der KosōnDrachme des Typs A am ehesten ins frühe oder mittlere 1. Jh. v. Chr. zu datieren sein dürfte. ${ }^{130}$ Der gemutmaßte Teilkönig Kosōn wäre somit, sofern es sich überhaupt um einen Herrscher gehandelt haben sollte, ins Zeitalter des Byrebistas zu setzen. Ein solches Szenario erscheint angesichts der Machtfülle, die Byrebistas nach allgemeiner Überzeugung damals erlangt haben soll, wenig glaubhaft. Strobel spricht sich daher für die Annahme aus, dass das Wort KO$\Sigma \Omega N$ nicht als Herrscher-, sondern als Sippenoder Stammesname im Genetiv Plural zu deuten sei. ${ }^{131}$

Für die Kosōn-Drachme des Typs B nimmt Strobel hingegen eine Emission in den Jahren 49-44 v. Chr. an, als sich die Pompeianer vor Caesar in den Osten und einige von ihnen vermutlich zu Byrebistas flüchteten. Wichtigstes Argument ist dabei der gemutmaßte anti-cäsarische Charakter des Bildmotivs des Konsuls auf dem Avers (diese Gedankenfigur ist, wie wir gesehen haben, in der früheren Forschung verwendet worden, um die Bildszene nicht mit Pompeius, sondern mit Brutus zu verbinden). Von diesem Moment an seien dann auch die Kosōn-Statere ausgeprägt worden, und zwar zunächst auf Byrebistas' Geheiß, später dann von anderen dakischen Herrschern, darunter auch Decebal, die sich damit auf das Erbe des Byrebistas berufen hätten. ${ }^{132}$

Die Ausführungen Strobels implizieren unter anderem, dass zunächst die KosōnDrachmen des Typs B und dann die Kosōn-Statere allesamt in Sarmizegetusa Regia geprägt wurden, was sich bestens zur oben in Abschnitt 5 beschriebenen räumlichen Konzentration der Funde in der Zone der Orăştie-Berge fügt. Im Übrigen ist die Annahme, die Kosōn-Münzen seien nicht nur teilweise, sondern alle an einem einzigen dakischen Herrschaftssitz produziert worden, auch schon früher von anderer Seite vertreten worden. ${ }^{133}$

\section{Neue Perspektiven}

Angesichts der Tatsache, dass weder die Vertreter der frühneuzeitlichen Numismatik noch die moderne Wissenschaft den historischen Kontext der

130 Wichtigste Grundlage für diese Datierung ist die Studie von Prokopov 2012, der unter anderem zeigt, dass der Umlauf des Macedonia Prima-Tetradrachmons in den Gebieten nördlich der Donau (Rumänien) recht spät anzusetzen ist, und zwar in den Zeitraum 90/80-40/30 v. Chr. (bes. S. 30-39).

131 Strobel 2018.

132 Strobel 2018. Für die Drachmen des Typs A ist dagegen laut Strobel eher eine Produktion an einem unbekannten Ort südlich der Donau anzunehmen.

133 So etwa von Vîlcu 2010, 207. 
Kosōn-Münzen bislang haben sicher rekonstruieren können und selbst nach einem halben Jahrtausend des Forschens noch immer grundlegende Fragen offen sind, scheint es auf den ersten Blick gut nachvollziehbar, wenn Wachter, wie oben in Abschnitt 8 dargelegt, den Kosōn-Stater als „vexatissimus nummus“ bezeichnet oder aber Hanthalers fiktiver Schüler Publius angesichts der Unmöglichkeit, eine überzeugende wissenschaftliche Lösung zu finden, Zweifel nicht nur an seinen eigenen Fähigkeiten, sondern sogar an den methodischen Grundlagen der Disziplin äußert. Dem lässt sich allerdings entgegenhalten, dass die Bemühungen der Gelehrten der frühen Neuzeit ebenso wie der modernen Forscher immerhin eine allmähliche Annäherung an die Wahrheit ermöglicht haben. Geographisch ist man vom etruskischen Cosa in den Donau- und Karpatenraum und hier genauer ins südwestliche Siebenbürgen gelangt, und chronologisch aus der frührömischen Geschichte in das Zeitalter der späten Republik bzw. des frühen Prinzipats. Zugleich steht aufgrund der Typologie, des Gewichts und des Feingehalts der drei bekannten Typen von KosōnMünzen fest, dass es sich um „barbarische“ Prägungen handeln muss.

Im Zuge des eingangs genannten FWF-Projekts konnten anhand bislang noch nicht ausgewerteter Dokumente der Kameralverwaltung des Großfürstentums Siebenbürgen neue Beobachtungen zu den Schatzfunden von Stateren des Kosōnund des Lysimachos-Typs der Jahre 1802-1804 gemacht werden, die eine weitere Präzisierung des im Vorangehenden referierten Kenntnisstandes erlauben:

a.) Es hat sich nochmals bestätigt, dass alle Hortfunde von Kosōn-Münzen aus der Zone von Sarmizegetusa Regia stammen, also aus den Ruinen der antiken Zentralsiedlung der Orăștie-Berge, einem länglichen Hügel, der sich über 4-5 km in ost-westlicher Richtung erstreckt und in etwa 250 künstliche Terrassen unterteilt ist, sowie aus dem direkten Umkreis dieser Siedlung inklusive ihrer Nachbar- oder Vorstadt Fețele Albe (Taf. VIII). Alle anderen Fundplätze von Kosōn-Münzen sind entweder sekundär, insofern die Münzen dort von ihren Findern oder späteren Käufern versteckt oder verloren wurden, oder sie gehen auf fehlerhafte, missverstandene oder gar bewusst gefälschte Informationen aus diesem Personenkreis zurück. Hingegen sind für die Statere des Lysimachos-Typs Hortfunde sowohl in Sarmizegetusa Regia (z. B. Șesu Căprăreței 1998) als auch anderswo im Gebiet der Orăștie-Berge (StreiFluss? 1543; Csáta/Ceata 1802/1803) zu verzeichnen. ${ }^{134}$ In diesem Punkt besteht also eine strukturelle Differenz zwischen „Kosonen“ und „Lysimachen“.

b.) Der soeben genannte Befund impliziert zugleich, dass Statere des Kosōnund des Lysimachos-Typs niemals vermischt gefunden wurden. Das widerspricht, wie bereits erwähnt, der früheren Ansicht, die aber unbegründet war. Bislang wurde die Tatsache, dass zwei der drei frühesten Berichte zum Strei-Fund, nämlich von Lazius und Mathesius (s. oben Abschnitte 6-7), beide Münztypen gemeinsam beschreiben, stets als sicheres Indiz betrachtet, dass der Schatz auch beide Münztypen enthielt. Diese Auffassung ist keineswegs zwingend, denn beide genannten Autoren waren keine unmittelbaren Augenzeugen, sondern hielten sich in großer Entfernung zum Herkunftsort der Münzen auf und könnten somit Statere aus verschiedenen Funden

${ }^{134}$ Siehe Mitthof 2018; Mitthof, Mádly (in Vorbereitung). 
vor sich gehabt haben. Dass im Übrigen der Kosōn-Stater schon vor 1543 im westlichen Europa zirkulierte, beweisen die Turzo/Erasmus-Episode von 1519-1520 und Calcagninis Erwähnung eines Exemplars im Katalog der Este-Sammlung, das vermutlich ca. 1517-1519 in Ungarn erworben wurde. Überhaupt lassen die Ausführungen der Autoren der frühneuzeitlichen Numismatik erahnen, dass Kosōn-Statere schon vor 1803-1804 beständig und in großer Zahl in Siebenbürgen gefunden wurden (man denke besonders an die Aussagen von Lazius, Eckhel, Neumann [der sich auf Bruckenthal beruft] und Neigebaur), und dass der Münztyp daher in vielen Teilen Europas als Sammelobjekt sehr verbreitet war (Goltzius, Patin). Hinzu kommt, dass keine andere Quelle zu den Vorkommnissen um Martinuzzi, vor allem aber keines der nach seiner Ermordung verfassten Schriftstücke mit Angaben zu seinen Besitztümern, jemals auch nur einen einzigen Kosōn-Stater erwähnt, sondern immer nur solche des Lysimachos-Typs. Ebenso berichtet schon der Kronstädter Pfarrer Johann Honterus, dem wir die früheste erhaltene Nachricht über den Strei-Fund verdanken, nur von Stateren des Lysimachos-Typs. ${ }^{135}$

c.) Für die Kosōn-Münzen ist angesichts eines solchen auf eine Fläche von wenigen hundert Hektar beschränkten Verbreitungsgebietes kein Umlauf anzunehmen. Hierzu passt, dass die gefundenen Exemplare keine Abnutzung zeigen, wie sie bei kursierenden Münzen zu erwarten wäre. Dies bedeutet wiederum, dass wir bei den Kosōn-Münzen von einer Produktion in Sarmizegetusa Regia selbst ausgehen müssen, und zwar über einen längeren Zeitraum hinweg in mehreren Phasen, zunächst aus geläutertem, später aus ungeläutertem Gold. Ähnliches dürfte auch für die Statere des Lysimachos-Typs gelten, die in den Orăștie-Bergen gefunden wurden. Allerdings ist deren Zeitstellung in jedem Fall vor den Kosōn-Stateren bzw. der Kosōn-Drachme des Typs B anzusetzen, da ihren Horten, wie wir erst seit kurzem wissen, nordpontische Statere des Pharnakes II. und Asander beigemengt sind, mit einer mutmaßlichen Schlussmünze, die um das Jahr 44/43 v. Chr. datiert. ${ }^{136}$

d.) Wir haben keine Möglichkeitzu verstehen, wie die Bildmotive des Kosōn-Staters einerseits von den dakischen Auftraggebern ausgewählt und gestaltet und andererseits von den von diesen intendierten Adressaten interpretiert wurden. Höchst fraglich scheint allerdings die Annahme eines bewussten Aufgreifens römischer Bildsprache und damit einer Akzeptanz des römischen Vorbilds. Wenn es darum gegangen wäre, römische Bilder mit politischen Botschaften wiederzugeben, die Römern verständlich waren, so hätte man bei der Produktion wohl darauf geachtet, Abweichungen von den Vorlagen zu vermeiden. Nun gibt es aber solche Abweichungen, und diese sind offenkundig nicht als Versehen oder Missverständnisse zu deuten. Hiergegen spricht schon der Umstand, dass die Motive von den Verantwortlichen teilweise ganz bewusst verändert wurden. ${ }^{137}$ Zugleich dürfen wir grundsätzlich annehmen, dass die Bilder dem Prägeherrn als politische oder religiöse Symbole dienten, sich an die eigene

135 Ad Sargetiam aurei antiqui plurimi a piscatoribus reperti cum inscriptione BA IIE $\triangle \triangle Y \Sigma I M A X O Y$, ex altera parte ejusdem regis effigie (zitiert bei Teutsch 1883); der betreffende Brief an Sebastian Münster wurde zwischen 1544-1549 verfasst.

136 Siehe Mitthof 2018.

137 S. oben Anm. 14. 
Bevölkerung richteten und in politisch-religiöser Hinsicht Ordnung, Hierarchie und Identität stiften sollten. Letztlich dürften also die Bildmotive des Kosōn-Staters bzw. der Kosōn-Drachme des Typs B als Ausdruck von Herrschaftsgewalt und politischer Macht zu verstehen sein.

Aus allen diesen Beobachtungen ergibt sich allerdings noch immer keine Lösung für die beiden drängendsten Fragen, die mit den Kosōn-Münzen verbunden sind: Wie kommt es, dass diese Münztypen in enormen Quantitäten am Herrschaftssitz Decebals gehortet und von diesem offenkundig nicht direkt für die Finanzierung seiner Kriegskosten, etwa als Sold für Verbündete, verwendet wurden - ansonsten wäre mit Kosōn-Funden in weiten Teilen des unteren Donau- und Balkanraums und auch in der nordpontischen Zone zu rechnen -, und warum tragen die Münzen weder den Namen des Byrebistas noch den des Decebal, zweier Herrscher, die immerhin beide über mehr als zwei Jahrzehnte regierten und zu einer für dakische Dynasten ganz außerordentlichen Machtfülle gelangten?

Hier betreten wir notgedrungen den Bereich der Spekulation. Verfolgten die Herrscher des unteren Donau- und Karpatenraumes mit der Anhäufung solcher Schätze, die in der Region auch andernorts zu beobachten ist, möglicherweise nicht so sehr ökonomische Ziele, sondern suchten sie vielmehr, ihr Prestige und ihre Macht symbolisch zu steigern? ${ }^{138}$ Oder haben wir es mit einer Hortung aus sakralen Gründen zu tun, weswegen das Edelmetall als „tabu“ galt?139 Solche Erklärungen würde aber noch nicht die Identität des KO $\Sigma \Omega N$ erklären. Sollte es sich bei dieser Figur tatsächlich um einen dakischen Herrscher der Zeit um 44-29 v. Chr. gehandelt haben, der möglicherweise in Sarmizegetusa Regia residierte, so wäre schwer verständlich, warum seine (uns unbekannten) direkten Nachfolger und besonders Decebal nicht ebenfalls Münzen in ihrem eigenen Namen prägen ließen.

In die Erörterung dieser Fragen ist jetzt die erst seit kurzem bekannte KosōnDrachme des Typs A miteinzubeziehen. Dieser Münztyp zeigt uns nicht nur, wie schon erwähnt, dass Kosōn, sofern es sich um einen Herrscher gehandelt haben sollte, in die Frühzeit des Byrebistas zu stellen wäre. Zugleich liefert uns diese Drachme mit dem

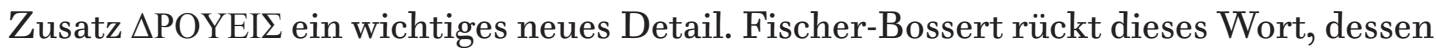
Bedeutung und sprachliche Herleitung noch völlig offen sind, in die Nähe zum keltischen Druiden, allerdings nicht als tatsächliche Bezeichnung in dem Sinne, dass Kosōn ein solcher Priester gewesen wäre, sondern als Zeichen für seine herausragende, mit sakralem Prestige unterfütterte Position. ${ }^{140}$ Dies würde die im Vorangehenden geäußerten Überlegungen weiter untermauern. Im Übrigen wären ost-keltische Einflüsse

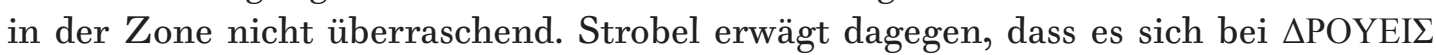
um den eigentlichen Fürstennamen handeln könnte, während er, wie bereits erwähnt, $\mathrm{KO} \Sigma \Omega \mathrm{N}$ als Ethnonym deutet. ${ }^{141} \mathrm{Um}$ diesen Spekulationen noch eine weitere hinzuzu-

${ }_{138}$ Zur Problematisierung der alten These, die dakischen Herrscher hätten eine Art von Goldmonopol ausgeübt, s. jetzt Spânu 2004.

139 Siehe hierzu Preda 1998a; Deppert-Lippitz 2010; Mateescu 2017; ablehnend Fischer-Bossert 2016, 93. Von den möglichen apotropäischen Beigaben zu den Horten war bereits in Abschnitt 1 die Rede.

${ }^{140}$ Fischer-Bossert 2016, 95-98.

141 S. oben Abschnitt 12. Alternativ erwägt Strobel, dass $\triangle \mathrm{POYEI} \Sigma$ als Nominativ Plural im Sinne einer Selbstbezeichnung der „emittierenden herrschenden Gruppe“ zu deuten ist. 
fügen: War KO $\Sigma \Omega N$ vielleicht ein mythischer Heros oder Stammvater? Und könnte es sein, dass dieser Name in „historischer“ Zeit von einzelnen dakischen bzw. getischen Dynasten - wie etwa dem mutmaßlichen Coso bei Sueton - als Individualname getragen wurde? ${ }^{142}$

Diese Fragen lassen sich beim derzeitigen fragmentarischen Kenntnisstand über die Daker und ihre Geschichte nicht beantworten. Immerhin gibt es, wie mir scheint, triftige Gründe, sich von den älteren Thesen endgültig zu lösen und hinter dem Wort KO $\Sigma \Omega N$, das auf den Münzen erscheint, die Bezeichnung einer Person oder eventuell auch einer Personengruppe zu erblicken, die einzelne Dynasten wie den Coso Suetons, aber auch Byrebistas, Cotiso oder Decebal in ihrer Stellung und Bedeutung deutlich überragte, sei es in religiös-mythisch-legendärer oder historischer Perspektive, und die daher dauerhaft als übergreifende Integrationsfigur bzw. Integrationsinstanz jener Herrschaftsformation dienen konnte, deren Zentrum - entweder schon seit ihren Anfängen oder aber erst zu einem späteren Zeitpunkt - Sarmizegetusa Regia war.

\section{Appendix: Eine anonyme Explication zum Kosōn-Stater von 1803 (Taf. IX-X) ${ }^{143}$}

[63] „Abschrift. Explication. In Betreff der goldenen Münze, welche auf einer Seite drey männliche Figuren, deren die äussersten Beile auf der Achsel tragen,

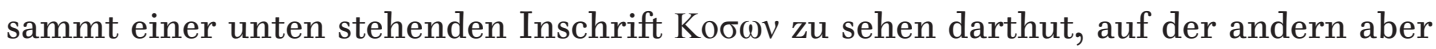
einen sitzenden Adler, welcher in den Klauen jenes rechten Fußes einen Kranz hält, vorstellt, sind die in der Numismatic bewanderten Schriftsteller nicht einer Meinung. Goltzius in Magna Graecia, Patinus in Familiis Romanis, und anderere mehrere hal-

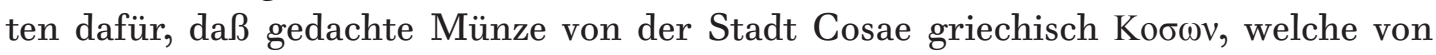
Alters in Etrurien lag, geprägt worden sey. Dieser Meinung hält auch Joseph Eckhel in Cathalogo Musei Caesarei Windobonensis numorum veterum pag[ina] 14 obwohlen nicht ohne allen Zweifel bei, alwo folgendes von dieser Münze zu sehen ist: Etruriae

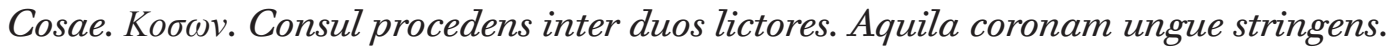

Joanes Harduinus in Numis antiquis Populorum et Urbium illustratis hingegen behauptet, dass dieselbe zur Ehre des Octaviani Caesaris von Syrien, als welchen er ganze Hilfe leistete, verfertigt worden sey. Nach dessen Meinung stellet die eine Seite den Octavianum Caesarem, wie er zwischen zween Syrier, welche Beile auf den Achseln tragen, und von denen einer im Begriffe ist, dass Vordertheil eines Schiefes mit einem Fuß zu betretten, einem Schiefe zu eilet, mit einer unten angebrachten

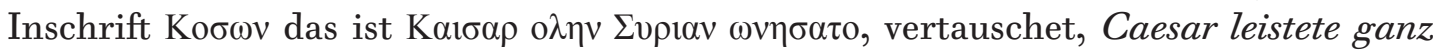
Syrien Hilfe, die andere aber einen mit dem linken Fuß auf eine Szepter sitzenden, mit dem rechten [64] einen Lorbeer-Kranz haltenden Adler vor.

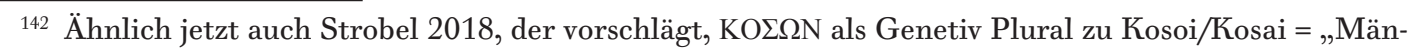
ner/Volk/Sippe des Koso" zu deuten.

${ }^{143}$ Ungarisches Staatsarchiv zu Budapest; Akten des Siebenbürgischen Thesaurariats für Münz- und Bergwesen: MNL-OL F189. Erd. Kincstári Lvt., Thesaurariatus, Eln. iratok, Nr. 703/1803 (Mf. 33150), 63-64. Die Wiedergabe des Textes folgt der Schreibung im Dokument. - Zur Deutung des Textes s. oben Abschnitt 11. 
Welche von diesen zween Meinungen als wahr anzunehmen sey, ist nicht leicht zu bestimmen, doch scheint die des Harduini mehr an das Wahre zu gränzen. Nehmen wir die Meinung des Harduini an, so ist die Münze beiläufig 1830 Jahre alt, tretten wir aber der andern Meinung bei, so ist sie gegen 200 Jahr älter."

\section{Literaturverzeichnis}

1. Ältere Literatur (16.-19. Jh.)

Ackner 1844

M. J. Ackner, Reisebericht über einen Theil der südlichen Karpathen, welche Siebenbürgen von der kleinen Walachei trennen, aus dem Jahre 1838 (Schluss), Archiv des Vereins für siebenbürgische Landeskunde, I. Band, II. Heft, Hermannstadt 1844, 1-33.

Babelon 1886

E. Babelon, Description historique et chronologique des monnaies de la République romaine, Tome deuxième, Paris 1886.

Begerus 1685

L. Begerus, Thesaurus ex Thesauro Palatino selectus, sive gemmarum et numismatum quae in Electorali Cimeliarchio continentur elegantiorum aere expressa, et convenienti commentario illustrata dispositio, Heidelbergae 1685.

Bethlen 1782

W. de Bethlen, Historia de rebus Transilvanicis, Editio secunda, Tomus primus, Cibinii 1782.

Calcagnini 1538-1541 C. Calcagnini, Aureorum Numismatum Illustrissimi Herculis secundi, Ducis Ferrariae quarti, Elenchus, Biblioteca Estense di Modena, Cod. Lat. 152 = a.T.6,16; ediert in: G. Fiorelli, Documenti inediti per servire alla storia dei Musei d'Italia pubblicati per cura del Ministero della Pubblica Istruzione, Volume Secondo, Firenze, Roma 1879, 100-155: III. Medagliere Estense a. 1540 (s. auch ebd. S. IV-V).

Cavedoni 1825 (1858) Delle monete antiche in oro un tempo nel Museo Estense, descritte da Celio Calcagnini intorno all'anno MDXL. Memoria dell'Abate Sig. D. Celestino Cavedoni ... letta nell' adunanza del 13 maggio del 1825. In: Memorie della Reale Accademia di Scienze, Lettere e d'Arti di Modena, Tomo I, Parte III, Modena 1858, 77-122.

Centorio $1566 \quad$ Ascanio Centorio degli Hortensii, Commentarii della Guerra di Transilvania, Vinegia 1566.

Cohen 1857

H. Cohen, Description générale des monnaies de la République romaine communément appelées médailles consulaires, Paris 1857.

Combe 1782

C. Combe, Nummorum veterum populorum et urbium, qui in Museo Guglielmi Hunter asservantur, descriptio figuris illustrata, Londini 1782.

Diamilla 1847

D. Diamilla, Alcune medaglie d'oro della collezione Esterhassi, ed osser-

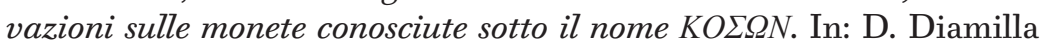
(ed.), Memorie numismatiche per l'anno 1847, Roma 1847, 122-124.

Eckhel 1779

J. H. Eckhel, Catalogus Musei Caesarei Vindobonensis numorum veterum ..., Pars prior, Vindobonae 1779.

Eckhel 1781

J. Eckhel, in: Musei Franciani descriptio, Pars prior, comprehendens numismata et gemmas, Descriptio numismatum, Series V: Pondera, numi urbium et populorum omnis metalli, Lipsiae 1781, 149-155.

Eckhel 1786

J. Eckhel, Sylloge I numorum veterum anecdotorum thesauri Caesarei ..., Viennae 1786. 
Eckhel 1796

Eder 1803

Erasmus 1521

Erasmus 1988

Foy-Vaillant 1703

Goltzius 1576

Grässe 1854

Gronovius 1645

Gússeme 1775

Hanthaler 1735

Harduinus 1684

Harduinus 1709

Havercampus 1734

Hene 1836

Hurmuzaki 1894

Kenderesi 1812

Köleseri 1717

Lazius 1551/1598

Lazius 1558/1605

Lazius s. d. 1
J. Eckhel, Doctrina numorum veterum, Pars II: De moneta Romanorum, Vol. VI, Vindobonae 1796.

Abbé (J. K.) Eder, Antiquarische Erörtung neulich in Siebenbürgen gefundener Goldmünzen und Ruinen, Zeitschrift von und für Ungern ..., hrsg. von L. von Schedius, 4, Pesth 1803, 113-116.

D. Erasmus, Epistolae ad diversos, et aliquot aliorum ad illum per amicos eruditos, Basileae 1521.

The Correspondence of Erasmus: Letters 1122-1251 (1520 to 1521), translated by R. A. B. Mynors, annotated by P. G. Bietenholz, Toronto 1988 (Collected Works of Erasmus).

J. Foy-Vaillant, Nummi antiqui familiarum Romanarum, Amstelaedami 1703.

H. Goltzius, Graecia sive Historiae urbium et populorum Graeciae ex antiquis numismatibus restitutae libri quatuor, Liber primus: Sicilia et Magna Graecia, Brugis Flandrorum 1576.

J. G. Th. Grässe, Handbuch der Alten Numismatik, Leipzig 1854.

J. F. Gronovius, Ad Titi Livi Patavini libros superstites notae, Lugd. Batav. 1645.

Th. Andres de Gússeme, Diccionario Numismatico General, Tomo segundo: $C$, Madrid 1775.

C. Hanthaler, Exercitationes faciles de numis veterum pro tyronibus...: Exercitatio prooemialis de numis aliquot Graecis ..., Norimbergae 1735.

J. Harduinus, Nummi antiqui populorum et urbium illustrati, Parisiis 1684.

J. Harduinus, Opera selecta, tum quae iam primis Parisiis edita nunc emendatiora multo auctiora prodeunt, tunc quae nunc primum edita, Amstelodami 1709.

S. Havercamp, Thesaurus Morellianus, sive familiarum Romanarum numismata omnia, $2 \mathrm{Bd}$., Amstelaedami 1734.

F. X. Hene, Beyträge zur dacischen Geschichte, Hermannstadt 1836.

Documente privitóre la Istoria Românilor, culese de E. de Hurmuzaki, Vol. II 4: 1531-1552, Bucuresci 1894.

M. Kenderesi, A KO $\Omega N$ Aranyakról. Vizsgálódó Értekezések (Über

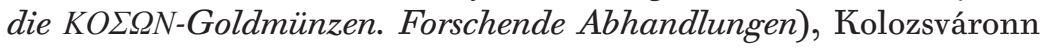
1812.

S. Köleseri de Keres-Eer, Auraria Romano-Dacica, Cibinii 1717.

W. Lazius, Commentariorum reipublicae Romanae illius, in exteris provinciis, bello acquisitis, constitutae, libri duodecim, Basileae 1551; revidierte, posthume Zweitausgabe: Reipublicae Romanae in exteris provinciis bello acquisitis constitutae commentariorum libri duodecim, Francofurti 1598.

W. Lazius, Historicarum commentationum rerum Graecarum libri duo (Erstausgabe 1558), Hanoviae 1605.

W. Lazius, Explicatio thesauri recens apud Transylvanos reperti et per piscatorem quendam in vado fluvii cuiusdam detecti, Bayerische Staatsbibliothek München, Cod. Lat. (Clm) 9216, fol. 11r-13r (Edition durch Verfasser in Vorbereitung). 
Lazius s. d. 2

Lenormant 1878

Liebe 1730

Maffeus 1544

Mathesius 1562 (1618)

Mayr 1894

Miles 1670

Mionnet 1806

Mionnet 1822

Mommsen 1860

Neigebaur 1851

Neumann 1783

Nonnius 1644

Patin 1663

Rasche 1785

Schmidt 1859-1860

Schoenvisner 1801

Teutsch 1883

Tristanus 1644

Tröster 1666
W. Lazius, Decadis V: Historiae Hungaricae liber octavus, Österreichische Nationalbibliothek Wien, Cod. 7688, fol. 182-190 (non vidi).

F. Lenormant, La monnaie dans l'Antiquité, Tome II, Paris 1878 (Nd. Bologna).

C. S. Liebe, Gotha numaria, sistens thesauri Fridericiani numismata aurea, argentea, aerea, Amstelaedami 1730.

Commentariorum urbanorum Raphaelis Volaterrani octo \& triaginta libri, accuratius quam antehac excusi ..., Basileae 1544.

J. Mathesius, Sarepta, darin von allerly Bergwerk und Metallen ..., auf ein newes mit fleis durchgesehen ... (Erstausgabe 1562), Leipzig 1618.

M. Mayr, Wolfgang Lazius als Geschichtsschreiber Österreichs, Innsbruck 1894.

Matthias Miles, Siebenbürgischer Würg-Engel oder Chronicalischer Angang der 15 Seculi nach Christi Geburth aller theils in Siebenbürgen theils in Ungern, und sonst Siebenbürgen angräntzenden Ländern fürgelauffener Geschichten, Hermannstadt 1670.

Th. E. Mionnet, Description de médailles antiques, grecques et romaines, Tome premier, Paris 1806 (Nd. Graz 1972).

Th. E. Mionnet, Description de médailles antiques, grecques et romaines, Supplément, Tome second, Paris 1822 (Nd. Graz 1973).

Th. Mommsen, Geschichte des römischen Münzwesens, Berlin 1860.

J. F. Neigebaur, Dacien, aus den Überresten des klassichen Alterthums, mit besonderer Rücksicht auf Siebenbürgen, Kronstadt 1851.

F. Neumann, Populorum et Regum numi veteres inediti, Pars altera, Vindobonae 1783.

L. Nonnius, Commentarius in Huberti Goltzi Graeciam, Insulas, et Asiam Minorem, Antverpiae 1644.

C. Patin, Familiae Romanae in antiquis numismatibus, ab urbe condita ad tempora Divi Augusti ..., Parisiis 1663.

J. C. Rasche, Lexicon universae rei numariae veterum, et praecipue Graecorum ac Romanorum ..., Tomus primus (A-C), Tomi primi pars posterior C, Lipsiae 1785.

W. Schmidt, Die Geten und die Daken: Ein historischer Versuch als Beitrag zur siebenbürgischen Landeskunde, Archiv des Vereins für Siebenbürgische Landeskunde, Neue Folge 4/1, 1859, 1-79; 4/2, 1860, 135-199.

S. Schoenvisner, Notitia Hungaricae rei numariae ab origine ad praesens tempus, Budae 1801.

G. D. Teutsch, Ein Schreiben des Honterus - angeblich - an Sebastian Münster, Korrespondenzblatt des Vereins für siebenbürgische Landeskunde VI, 6, 1883, 61-67.

J. Tristan de Saint Amant, Commentaires historiques, contenans l'histoire générale des Empereurs, Imperatrices, Caesars, et Tyrans de l'Empire Romain. Illustrée, enrichie, \& augmentée ... Tome premier, Paris 1644.

J. Tröster, Das Alt- und Neu-Teutsche Dacia. Das ist: Neue Beschreibung des Landes Siebenbürgen ..., Nürnberg 1666. 
Ursinus 1577

Wachter 1740

Zamosius 1593

Zamosius s. d.
F. Ursinus, Familiae Romanae quae reperiuntur in antiquis numismatibus ..., Romae 1577.

J. G. Wachter, Archaeologia numaria, continens praecognita nobilissimae artis, quae nummos antiquos interpretatur, Lipsiae 1740.

S. Zamosius, Analecta lapidum vetustorum et nonnullarum in Dacia antiquitatum, Patavii 1593.

S. Zamosius, Schediasma de veteribus monetis (non vidi).

2. Neuere Literatur (20.-21. Jh.)

Anghel 2008

Ardevan 2007

Ardevan 2014

Bahrfeldt 1912

Bahrfeldt 1923

Benea 2004

Bodzek 2006

Brown 1951

Călian et alii 2007

Callataÿ 1995a

Callatä̈ 1995b

Callataÿ 1997

Chiriac 1996-1997

Chițescu 1981
Gh. Anghel, Descoperiri de tezaure antice din aur în zona Munților Orăștie menționate în cronicile medievale şi documentele moderne. In:

A. Lazăr et alii (eds.), Combaterea criminalității contra partimoniului arheologic european / Combating the Criminality Against the European Archaeological Heritage. Proceedings of a Conference Held in 2007 in Alba Iulia, București 2008, 333-368.

R. Ardevan, Adevărata istorie a kosonilor dacici, Ziarul Financiar, I: 20.4.2007, II: 27.4.2007; III: 4.5.2007.

R. Ardevan, Die erste Entdeckung von Koson-Münzen in Siebenbürgen. In: S. Cocis (Hrsg.), Archäologische Beiträge. Gedenkschrift zum hundertsten Geburtstag von Kurt Horedt, PAT 7, Cluj-Napoca 2014, 43-47.

M. Bahrfeldt, Über die KO $\Omega N-M \ddot{n} z e n$, Berliner Münzblätter, Neue Folge 33, 1912, 251-255; S. 323-326; S. 360-369 (= Über die

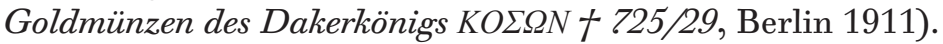

M. v. Bahrfeldt, Die römische Goldmünzenprägung, Halle 1923.

D. Benea, Istoricul cercetărilor arheologice de la Grădiştea de Munte. In: A. Pescaru, I. V. Ferencz (ed.), Daco-Geții. 80 ani de cercetări arheologice sistematice la cetăţile dacice din Munții Orăşstiei, Deva 2004, 9-37.

J. Bodzek, Ancient Coins from the Northern Coast of the Black Sea. In: Treasures from the Black Sea Coast, Catalogue of the Exhibition at the National Museum in Cracow, March-June 2006, Kraków 2006. F. E. Brown, Cosa I: History and Topography, Rome 1951.

L. Călian, C. Găzdac, Á. Alföldy-Găzdac, Coins from Roman Sites and Collections of Roman Coins from Romania, Vol. III/2: The Ancient and Byzantine Gold Coinages in the National History Museum of Transylvania (= Moneda de aur antică şi bizantină în Muzeul Național de Istorie a Transilvaniei), Cluj-Napoca 2007.

F. de Callataÿ, Les derniers statères posthumes de Lysimaque émis à Istros, Tomis et Callatis, Dobrudža 12, 1995, 39-50.

F. de Callatä̈, Les tétradrachmes de Lysimaque frappés à Callatis, SCN, 11, 1995, 55-58 (= Omagiu lui Constantin Preda la 70 de ani). F. de Callataÿ, L'histoire des guerres mithridatiques vue par les monnaies, Numismatica Lovanensia 18, Louvian-la-Neuve 1977.

M. Chiriac, $O$ achiziție de monede de tip Koson făcută de Banca Națională a României, BSNR, 90-91, 1996-1997 (2002), 247-252.

M. Chitescu, Numismatic Aspects of the History of the Dacian State: The Roman Republican Coinage in Dacia and the Geto-Dacian Coins of Roman Type, BAR 112, Oxford 1981. 
Ciofu 1993

Cojocaru et alii 2000

Constantinescu, Bugoi 2009

Constantinescu et alii 2009

Constantinescu et alii 2011

Constantinescu et alii 2012

Constantinescu et alii 2013

Constantinescu et alii 2015a

Constantinescu et alii 2015b

Crawford 1974

Crawford 1985

Daicoviciu 1965

Dana 2014

Deppert-Lippitz 2010

Detschew 1957
V. L. Ciofu, Ancient Numismatics around the Lower Danube, RBN, 139, 1993, 31-36.

V. Cojocaru et alii, EDXRF and PAA Analyses of Dacian Gold Coins of "Koson" Type, Journal of Radioanalytical and Nuclear Chemistry, 246, 1, 2000, 185-190.

B. Constantinescu, R. Bugoi, Gold Provenance Studies on Bronze Age Objects and Greek and Dacian (KOSON) Coins from Romanian Museums in Relation to Transylvanian Gold Sources, AGLAEExperiment, 12-14 January 2009.

B. Constantinescu et alii, Micro-SR-XRF Studies for Archaeological Gold Identification - The Case of Carpathian Gold and of Romanian Museal Objects. In: Proceedings of the $7^{\text {th }}$ Conference on Nuclear and Particle Physics, 11-15 Nov. 2009, Sharm El-Sheikh, Egypt, 627-634.

B. Constantinescu et alii, A Study on Gold and Copper Provenance for Romanian Prehistoric Objects Using Micro-SR XRF, Journal of Analytical Atomic Spectometry, 26, 5, 2011, 917-921.

B. Constantinescu et alii, Archaeometallurgical Characterization of Ancient Gold Artifacts from Romanian Museums Using XRF, MicroPixe and Micro-SR-XRF Methods, Proceedings of the Romanian Academy, Series A, 13, 1, 2012, 19-26.

B. Constantinescu, D. Stan, D. Ceccato, New Analyses on Romanian Archaeological Gold Samples and on Some Bronze Age Artifacts, Legnaro (Padova), 6-8 June 2012, AIP Conference Proceedings 1530, 25 (2013).

B. Constantinescu, E. Oberländer-Târnoveanu, D. Cristea-Stan, Information on Silver and Gold Dacian Kosōn Coins Based on Alloys Composition Analyzed by X-Ray Fluorescence and Their Possible Emissions to Chronology, XV International Numismatic Congress Taormina, 21-25 September 2015 (ppt-Präsentation).

B. Constantinescu, D. Cristea-Stan, C. Chiojdeanu, E. OberländerTârnoveanu, T. Martin, Cronologia monedelor dacice de argint şi aur de tip Koson pe baza informațiilor despre compoziția lor elementală. In: ArheoVest III: In memoriam Florin Medeleț. Interdisciplinaritate in Arheologie și Istorie, Timişoara, 28 noiembrie 2015, Vol. 2: Metode interdisciplinare și Istorie, Szeged 2015, 709-721.

M. H. Crawford, Roman Republican Coinage, I-II, Cambridge 1974.

M. H. Crawford, Coinage and Money under the Roman Republic, London 1985.

H. Daicoviciu, Coson sau Cotiso?, ActaMN, 2, 1965, 107-110.

D. Dana, Onomasticon Thracicum (Onom Thrac). Répertoire des noms indigènes de Thrace, Macédoine orientale, Mésies, Dacie et Bithynie, ME $\Lambda$ ETHMATA 70, Athènes 2014.

B. Deppert-Lippitz, Thesauro monachi - Der grosse dakische Goldfund aus dem Strei (1543), Annales Universitatis Apulensis. Series Historica, 14, 1, 2010, 9-27.

D. Detschew, Die thrakischen Sprachreste, ÖAW, Schriften der Balkankommission 14, Wien 1957. 
Dima, Ilie 2007

Dumitru (Diss.)

Dumont, Homolle 1892

Ferenczi 1989a

Ferenczi 1989b

Fischer-Bossert 2016

Florea 2014

Florea 2017

Glodariu 1971

Glodariu et alii 1996

Grueber 1910

Haarmann et alii

(in Vorbereitung)

Halévy 1961

Hassmann, Winter 2016

Head 1887 (1911)

Hourmouziadis 2010

IGCH
M. Dima, D. Ilie, Tezaurul de monede de tip Koson descoperit la Târsa, com. Boșorod, jud. Hunedoara. Lotul păstrat la Banca Națională a României. In: Simpozion de Numismatică: organizat cu ocazia comemorării Sfântului Ştefan cel Mare, domn al Moldovei (1504-2004), Chișinău, 29 septembrie-2 octombrie 2004, București 2007, 35-65.

V. Dumitru, Monumentum antiquitatis conspicuum: Die Schatz- und Altertümergrabung in Sarmizegetusa Regia unter Kaiser Franz II./., Diss. Wien (in Vorbereitung).

A. Dumont, Th. Homolle, Inscriptions et monuments figurés de la Thrace. In: Mélanges d'archéologie et d'épigraphie, par A. Dumont, réunis par Th. Homolle, Paris 1892, 309-351.

Șt. Ferenczi, Primele știri referitoare la cetățile dacice. In: H. Daicoviciu et alii (ed.), Cetăți și așezări dacice în sud-vestul Transilvaniei, I, București 1989, 121-124.

St. Ferenczi, Descoprirea tezaurului și urmările ei. In: H. Daicoviciu et alii (ed.), Cetăți și așezări dacice în sud-vestul Transilvaniei, I, București 1989, 125-132.

W. Fischer-Bossert, KOEQN $\triangle P O Y E I \Sigma$. In: H. Schwarzer, H. H. Nieswandt (Hrsg.), „Man kann es sich nicht prächtig genug. vorstellen!" Festschrift für Dieter Salzmann zum 65. Geburtstag, Marsberg/Padberg 2016, Bd. 1, 87-102.

G. Florea, Sarmizegetusa Regia - The Identity of a Royal Site? In: C. N. Popa, S. Stoddart (eds.), Fingerprinting the Iron Age, Approaches to Identity in the European Iron Age. Integrating SouthEastern Europe into the Debate, Oxford, Philadelphia 2014, 63-75.

G. Florea, Excavations in Sarmizegetusa Regia: Recent Results and Perspectives. In: F. Mitthof, G. Schörner (Hrsg.), Columna Traiani - Traianssäule. Siegesmonument und Kriegsbericht in Bildern, Tyche Sonderband 9, Wien 2017, 363-368.

I. Glodariu, Considerații asupra circulației monedei străine în Dacia, sec. II î.e.n. - I e.n., ActaMN, 8, 1971, 71-90.

I. Glodariu, E. Iaroslavschi, A. Rusu-Pescaru, F. Stănescu, Sarmizegetusa Regia: capitala Daciei preromane, Deva 1996.

H. A. Grueber, Coins of the Roman Republic in the British Museum, II, London 1910.

D. Haarmann, L. Mádly, F. Mitthof, Über Koson-Münzen und die Legende vom Schatz des Darios in Siebenbürgen: Eine Abhandlung. des Kenderesi Mihály von 1812 (in Vorbereitung).

Mayer A. Halévy, Autour d'un problème de numismatique antique: $Y$ a-t-il une monnaie d'or dace? A propos du statère à la légende $K O \Sigma \Omega N$, $\mathrm{StCl}, 3,1961,89-92$.

E. Hassmann, H. Winter, Numophylacium Imperatoris. Das Wiener Münzkabinett im 18. Jahrhundert, Schriften des Kunsthistorischen Museums 14, Wien 2016.

B. V. Head, Historia Numorum. A Manual of Greek Numismatics, Oxford 1887 (New and enlarged edition Oxford 1911).

J. Hourmouziadis, KO $\Sigma \Omega N$ Gold Staters and Silver Drachmae - a Die Study, RN, 166, 2010, 287-296.

M. Thompson, O. Mørkholm, C. M. Kraay, An Inventory of Greek Coin Hoards, New York 1973. 
Iliescu 1968

Iliescu 1990

Janakieva 2014

Kahrstedt 1922

Lazăr 2013

Lazăr 2015

Lockyear 2008

Makkay 1994

Makkay 1995

Marțian 1921

Marțian 1923

Mateescu 2017

Mitthof 2018

Fontana 1993

Mitthof 2014
O. Iliescu, Les «tétrastatères» de Lysimaque, trouvés à Baia Mare, StCl, 10, 1968, 87-92.

O. Iliescu, Sur les monnaies d'or à la légende KO$\Sigma \Omega N$, Numismatica e Antichità Classiche - Quaderni Ticinesi 19, 1990, 185-214.

S. Janakieva, Thrakisch und Dakisch - Sprachen oder Dialekte?, Orpheus. Journal of Indo-European and Thracian Studies, 21, 2014, 21-37.

U. Kahrstedt, RE XI 2, 1922, 1499 s.v. Kosōn.

A. Lazăr, „Recuperarea trecutului". Despre circumstanțele repatrierii tezaurelor dacice sustrase din situl arheologic Sarmizegetusa Regia - "Recovering the Past". On the Circumstances of Repatriating. the Dacian Royal Treasures Stolen from Sarmizegetusa Regia Archaeological Site. In: A. Lazăr et alii (eds.), Combaterea traficului cu bunuri culturale - Recuperarea trecutului. Fighting the Trafficking in Cultural Goods - Recovering the Past, Patrimonium III, București 2013, 49-72.

A. Lazăr, Illicit trafficking in Cultural Goods in South East Europe: ,Fiat Lux!' In: F. Demarais (eds.), Countering Illicit Traffic in Cultural Goods. The Global Challenge of Protecting the World's Heritage, Paris 2015, 107-124.

K. Lockyear, Aspects of Roman Republican Coins found in Late Iron Age Dacia. In: V. Spinei, L. Munteanu (eds.), Miscellanea numismatica antiquitatis in honorem septagenarii magistri Virgilii Mihailescu-Bîrliba, București - Iaşi 2008, 147-176.

J. Makkay, The Treasures of Decebalus, Specimina Nova Universitatis Quinqueecclesiensis 10, 1, 1994, 151-215.

J. Makkay, The Treasures of Decebalus, OJA, 14, 1995, 333-343.

I. Marțian, Comori Ardelene, BSNR, 16, 37, 1921, 13-21.

I. Marțian, Alte comori Ardelene: Comoara popilor, BSNR, 18, 45, 1923, 26-28.

R. Mateescu, Digging and Excavating in Sarmizegetusa Regia in the $19^{\text {th }}$ and $20^{\text {th }}$ Century. In: F. Mitthof, G. Schörner (Hrsg.), Columna Traiani - Traianssäule. Siegesmonument und Kriegsbericht in Bildern, Tyche Sonderband 9, Wien 2017, 357-362.

Mihailescu-Bîrliba 1990 V. Mihailescu-Bîrliba, Dacia răsăriteană în secolele VI-I e.n.: Economie şi monedă, Iaşi 1990.

Mihailescu-Bîrliba 2013 V. Mihailescu-Bîrliba, Noi analize şi interpretări privind moneda romană republicană, ArhMold, 36, 2013, 153-157.

Missere, Missere

G. Missere, F. Missere Fontana, Una silloge numismatica del secolo XVI: Celio Calcagnini e la raccolta Estense, Modena 1993.

F. Mitthof, Sarmizegetusa? Zu den Varianten eines dakischen Toponyms in den lateinischen und griechischen Quellen. In: I. Piso, R. Varga (eds.), Trajan und seine Städte. Colloquium Cluj-Napoca, 29. Sept.-2. Okt. 2013, Cluj-Napoca 2014, 233-244.

F. Mitthof, Goldstatere vom Lysimachos-Typ sowie des Pharnakes II. und Asandros. Die Analyse eines siebenbürgischen Schatzfundes durch Abbé Eder aus dem Jahr 1803. In: B. Woytek, D. Williams (eds.), Ars Critica Numaria. Joseph Eckhel (1737-1799) and the Development of Numismatic Method, Wien 2018 (im Druck). 
Mitthof (in

Vorbereitung)

Mitthof, Mádly 2015

Mitthof, Mádly

(in Vorbereitung)

Morawiecki 1987

Munteanu 2002

Munteanu 2003

Munteanu 2005

Munteanu 2011

Oltean, Hanson 2017

Părpăuţă 2006

Pețan 2010-2011

Pețan 2017

Peter 1999

Petolescu 1997

Petolescu 2011a

Petolescu 2011b

Poenaru Bordea 1979
F. Mitthof, Explicatio thesauri recens apud Transylvanos reperti - Eine Abhandlung des Wolfgang Lazius zum siebenbürgischen Schatzfund von 1543 (in Vorbereitung).

F. Mitthof, L. Mádly, Ein Golddepot aus der Zeit des HoreaAufstandes? Zur Geschichte eines siebenbürgischen Schatzfundes aus dem Jahre 1796. In: I. M. Balog, I. Lumperdean, L. Mádly, D. Țeicu (Hrsg.), Multikulturalismus, Identität und Diversität. Historische Perspektiven. Festschrift für Professor Rudolf Gräf zum 60. Geburtstag, Cluj-Napoca 2015, 183-194.

F. Mitthof, L. Mádly, Antikes Gold in den Orăştie-Bergen: Die Schatzfundevon Kosōn-und Lysimachos-Münzen derJahre 1802-1804 und ihre Untersuchung durch die siebenbürgische Kameralverwaltung. (in Vorbereitung).

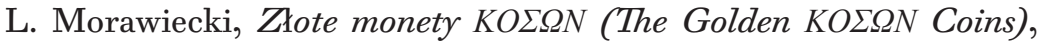
Wiadomości Numizmatyczne 31, 1987, 1-2 (119-120), 52-59.

L. Munteanu, Despre descoperirile monetare de tip Kosōn, Arheologia Moldovei, 25, 2002, 253-270.

L. Munteanu, Despre emiterea monedelor de tip Kosōn, Arheologia Moldovei, 26, 2003, 241-264.

L. Munteanu, Quelques considérations concernant les découvertes des monnaies d'or de type Lysimaque dans la Dacie intra-carpatique. In: V. Cojocaru (ed.), Ethnic Contacts and Cultural Exchanges North and West of the Black Sea from the Greek Colonization to the Ottoman Conquest, Iași 2005, 237-254.

L. Munteanu, Some Remarks Concerning the Gold Coins with the Legend 'KOIQN'. In: N. Holmes (ed.), Proceedings of the XIV International Numismatic Congress, Glasgow 2009, I, Glasgow 2011, 304-309.

I. A. Oltean, W. S. Hanson, Conquest Strategy and Political Discourse: New Evidence for the Conquest of Dacia from LiDAR Analysis at Sarmizegetusa Regia, JRA, 30, 2017, 429-446.

T. D. Părpăuță, Moneda în Dacia preromană (secolele IV a. Chr. - I p. Chr.), Iaşi 2006.

A. Pețan, Coin Finds at Grădiştea Muncelului During the Excavation Campaigns of 1803-1804, ActaMN, 47-48, 1, 2010-2011 (2012), 81-90.

A. Pețan, Cercetările de la Grădiștea Muncelului (jud. Hunedoara) până la primul război mondial, Diss. Iași 2017.

U. Peter, Der Neue Pauly 6, 1999, 779-780 s. v. Koson.

C. M. Petolescu, Un tezaur de monede de aur de tip Koson (A Hoard of Koson-type Gold Coins). In: 130 de ani de la crearea sistemului monetar românesc modern (130 Years since the Establishment of the Modern Romanian Monetary System), București 1997, 84-92.

C. M. Petolescu, Monedele regelui Coson, București 2011.

C. M. Petolescu, L'enigma delle monete KO $\Omega \Omega N$, Dacia N. S. 55, 2011, 149-182.

Gh. Poenaru Bordea, Les statères ouest-pontiques de type Alexandre le Grand et Lysimaque, RBN, 125, 1979, 37-51. 
Poggi 2003

Pop, Găzdac 1999

Preda 1973

Preda 1998a

Preda 1998b

Preda 2008-2009

Premerstein 1935

Prokopov 2012

Pupeză 2012

Rozanova 1956

Rustoiu 2005

Rustoiu 2012

Russu 1966

Ruzicka 1922

„Si tiene pegno in guardaroba" 2014

Spânu 2004

Spânu 2006

Spânu 2010
C. Poggi, La diaspora della numismatica di Alfonso II d'Este. In: Atti del XIII Congresso Internazionale di Numismatica, Madrid 2003, 95-103.

H. Pop, C. Găzdac, The Roman Hoard from Şimleul Silvaniei, ActaMN, 36, 1999, 169-187.

C. Preda, Monedele geto-dacilor, București 1973.

C. Preda, Ein neuer Vorschlag zur Chronologie der Koson-Münzen. In: U. Peter (ed.), Stephanos nomismatikos: Edith Schönert-Geiss zum 65. Geburtstag, Berlin 1998, 555-561 (Griechisches Münzwerk).

C. Preda, Istoria monedei în Dacia preromană, Colecția „Biblioteca Băncii Naționale“, București 1998.

C. Preda, Note numismatice: 2. Din nou despre monedele de Tip KOIQN, SCIVA, 59-60, 2008-2009, 182-193.

A. v. Premerstein, Der Daker- und Germanensieger M. Vinicius (cos. 19 v. Chr.) und sein Enkel (cos. 30 und 45 n. Chr.). Beilage zum Abschnitt II, Jahreshefte des Österreichischen Archäologischen Instituts in Wien 29, 1935, 60-81.

I. S. Prokopov, The Silver Coinage of the Macedonian Regions, $2^{\text {nd }}-1^{\text {st }}$ Century BC, Wetteren 2012.

P. Pupeză, Veacul întunecat al Daciei. Arheologie şi istorie în spațiul carpato-danubian de la sfârșitul secolului III a. Chr. până la începutul secolului I a. Chr. (The Dark Age of Dacia. Archaeology and History in the Carpathian-Danubian Region between the End of the $3^{\text {rd }}$ and the Beginning of the $1^{\text {st }}$ Century BC), Cluj-Napoca 2012.

M. P. Rozanova, $O$ zolotih monetah s nadpisom KO $\Sigma \Omega N$, Kratkie soobščenija Instituta Istorii Material'noj Kul'tury 66, 1956, 118-123.

A. Rustoiu, The Padea-Panagjurski Kolonii Group in South-western Transylvania (Romania). In: H. Dobrzańska, V. Megaw, P. Poleska (eds.), Celts on the Margin. Studies in European Cultural Interaction (7th Century BC-1st Century AD) Dedicated to Zenon Woźniak, Kraków 2005, 109-119.

A. Rustoiu, Commentaria Archaeologica et Historica (I), EN, 22, 2012, 159-183 (bes. S. 171-183: 2. The Padea-Panagjurski Kolonii group in Transylvania. Old and new discoveries).

I. I. Russu, Comorile regelui Decebal, Sargetia, 4, 1966, 97-107.

L. Ruzicka, Die Frage der dacischen Münzen, BSNR, 17, 4, 1922, 5-31 (= ders., Cu privire la monetele Dacilor, ebd. 31-54).

Si tiene pegno in guardaroba. Monete d'oro con la contramarca di Casa d'Este nel Medagliere mediceo, Firenze, Archivio di Stato, 6 dicembre 2014-10 gennaio 2015, Firenze 2014.

D. Spânu, Consideraţii privind teoria "monopolului" regal dacic şi circulația metalelor prețioase în Dacia preromană, Argesis. Studii şi comunicări, seria Istorie 13, 2004, 59-96.

D. Spânu, Misterioasele descoperiri de monede și podoabe de aur dacice din secolul al XVI-lea. Contribuție la istoricul descoperirilor dacice din Munții Orăștiei, Argesis. Studii și comunicări, seria Istorie 15, 2006, 77-89.

D. Spânu, Zur Analyse der Goldspiralen von Grădistea de Munte, Rumänien, Das Altertum, 55, 2010, 271-314. 
Strobel 2018

Suciu, Ardevan 2007

Torbágyi 1991

Vasilescu et alii 2011

Vîlcu 2010

Vîlcu et alii 2006

Vîlcu et alii 2008

Vîlcu et alii 2010

Vîlcu et alii 2011

Winkler 1972

Woytek 2015
K. Strobel, Südosteuropa unter römischer Herrschaft, Teil I: Die Entwicklung Südosteuropas vom Beginn der Späten Eisenzeit bis zur Mitte des 3. Jh. n. Chr. In: O. J. Schmitt, F. Mitthof (eds.), Handbuch zur Geschichte Südosteuropas, Band I: Herrschaft und Politik in Südosteuropa von der römischen Antike bis 1300, Berlin - Boston 2018 (im Druck).

V. Suciu, R. Ardevan, Quelques monnaies "Koson" gardées au Musée d'Alba Iulia. In: S. Nemeti et alii (eds.), Dacia Felix. Studia Michaeli Bărbulescu oblata, Cluj-Napoca 2007, 83-87.

M. Torbágyi, Griechischer Münzumlauf im Karpatenbecken, AarchHung, 43, 1991, 25-55.

A. Vasilescu et alii, Micro-SR-XRF Studies of Gold Provenance in Archaeology, Romanian Journal of Physics 56, 3-4, 2011, 366-372.

A.Vîlcu, Sur les statères en or de type Koson. In: R. Băjenaru, G. Bodi, C. Opreanu, V. V. Zirra (eds.), Recent Studies on Past and Present I: Human Heritage and Community: Archaeology in the Carpathians and Lower Danube Area from Prehistory to the Early Medieval Age, Transylvanian Review, 19, Suppl. 5, 1, 2010, 199-212.

A. Vîlcu et alii, Les monnaies d'or de l'Institut d'Archéologie de Bucarest, Collection Moneta 57, Wetteren 2006.

A. Vîlcu, V. Cojocaru, On the Origin of Koson Type Coinage in the Light of XRF Analyses, Pontika 2008, International Colloquium, Cracow, April 21 $1^{\text {st }}-26^{\text {th }} 2008$ (non vidi).

A. Vîlcu et alii, Some Considerations on Dacian Gold Coins of Koson Type in the Light of Compositional Analyses, RN, 166, 2010, 297-310. A. Vîlcu, E. Petac, B. Constantinescu, C. Chiojdeanu, D. Stan, G. Niculescu, Considerations Regarding the Greek Gold Coins Struck during the $4^{\text {th }}$ to the $1^{\text {st }}$ Centuries BC in the Light of XRF Analysis, Peuce S. N., 9, 2011, 501-512.

I. Winkler, Considerații despre moneda "Koson", SCIV, 23, 1972, 173-199.

B. Woytek, Sigebert Havercamp (1684-1742) als Numismatiker. In: H. Winter, B. Woytek (eds.), Numismatik und Geldgeschichte im Zeitalter der Aufklärung. Beiträge zum Symposium im Residenzschloss Dresden, 4.-9. Mai 2009, Wien 2015, 525-597 (= NZ, 120./121. Band).
Fritz Mitthof Universität Wien, Institut für Alte Geschichte und Altertumskunde, Papyrologie und Epigraphik, Wien email: fritz.mitthof(e)univie.ac.at 


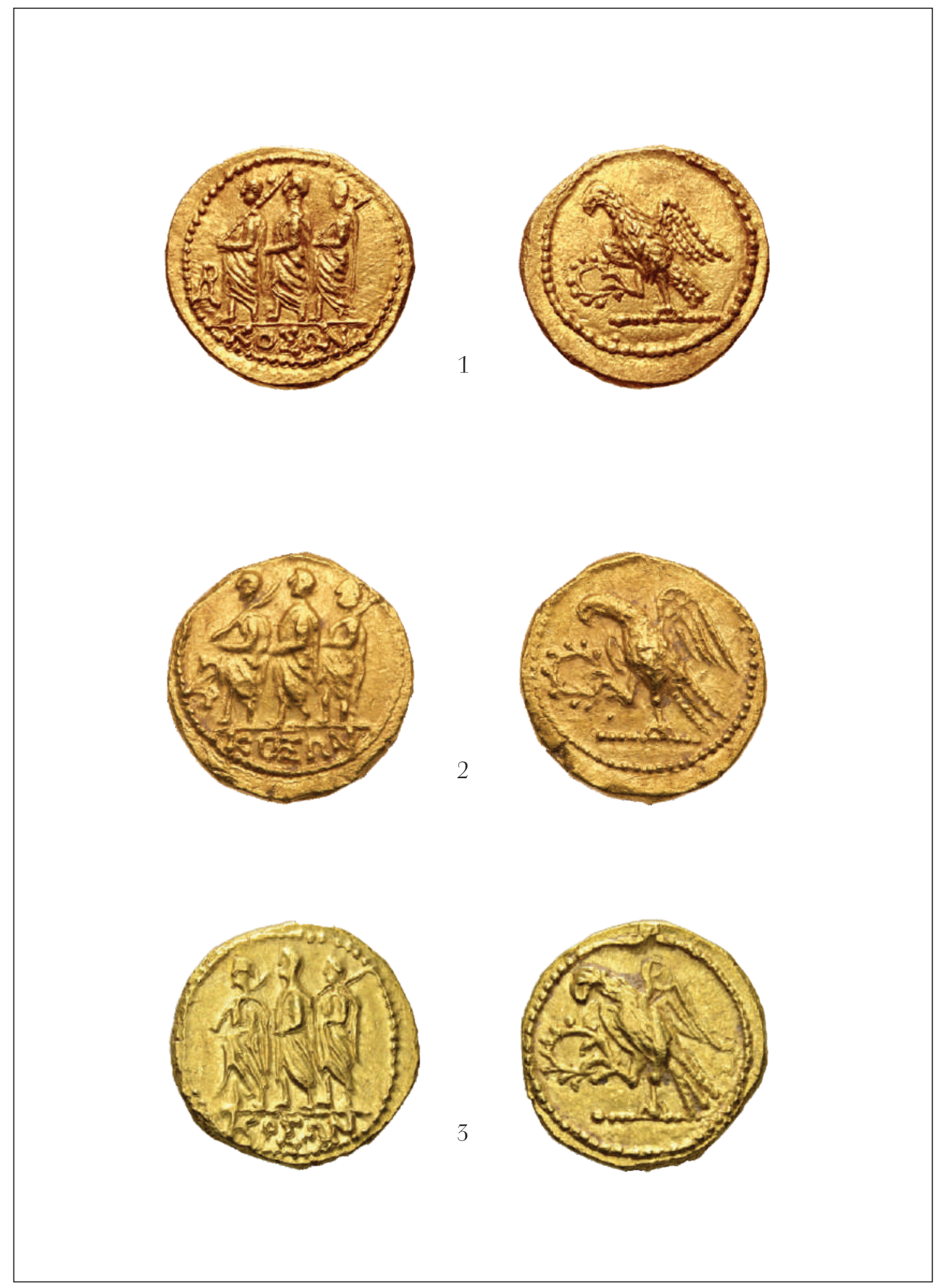

Taf. I. 1. Kosōn-Stater Typ A (mit einfachem Monogramm); 2. Kosōn-Stater Typ B (mit komplexem Monogramm); 3. Kosōn-Stater Typ C (ohne Monogramm). 

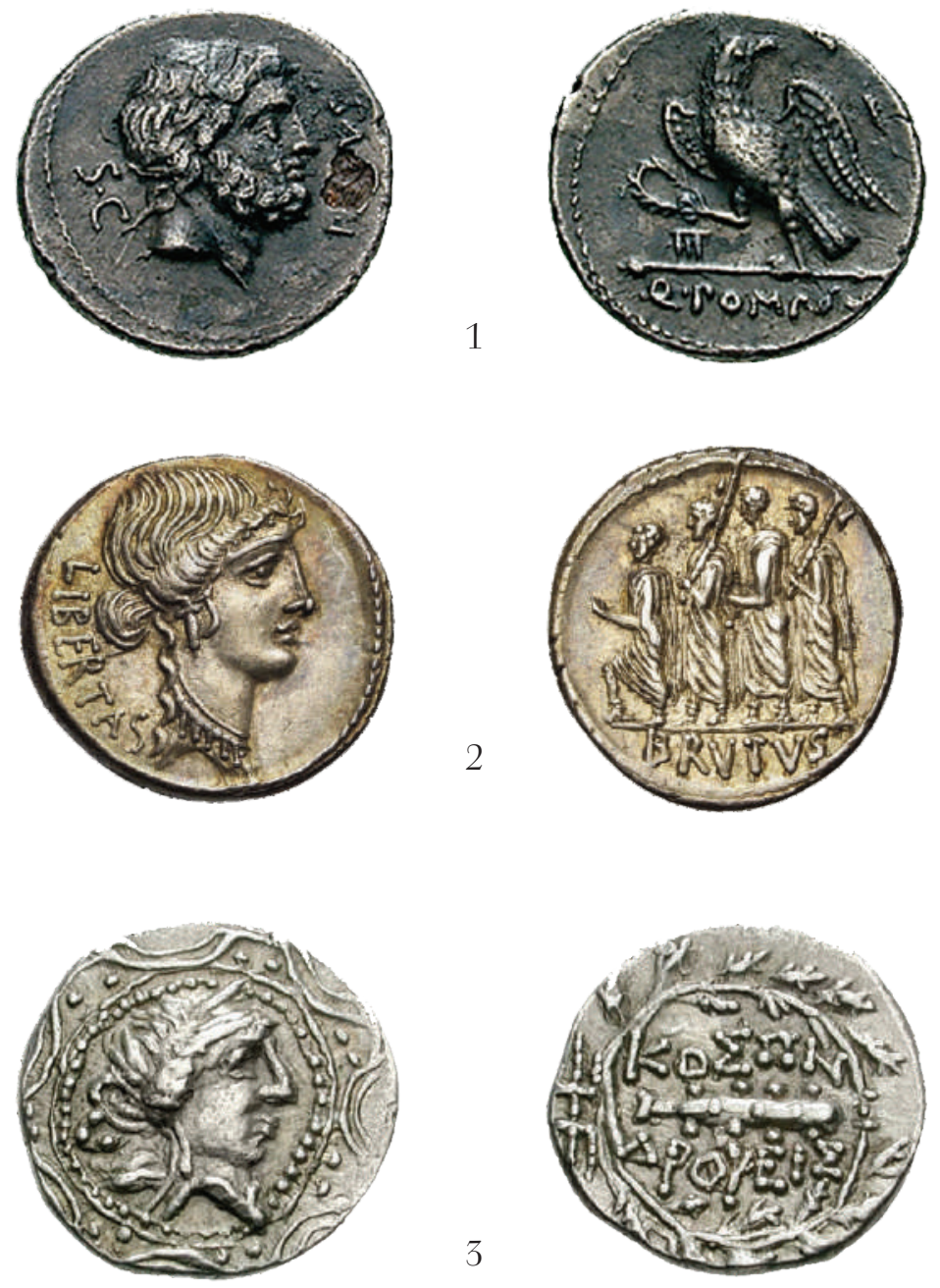

3
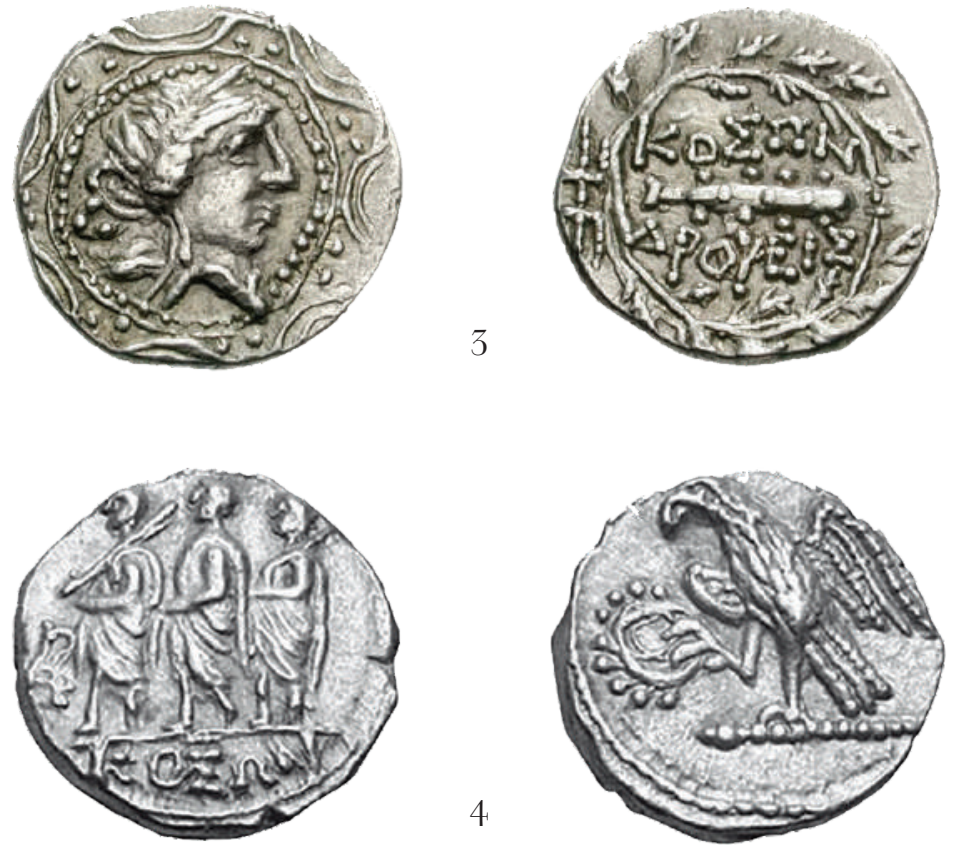

Taf. II. 1. Denar des Pomponius Rufus (73 v. Chr.); 2. Denar des M. Iunius Brutus (54 v. Chr); 3. Kosōn-Drachme Typ A; 4. Kosōn-Drachme Typ B. 


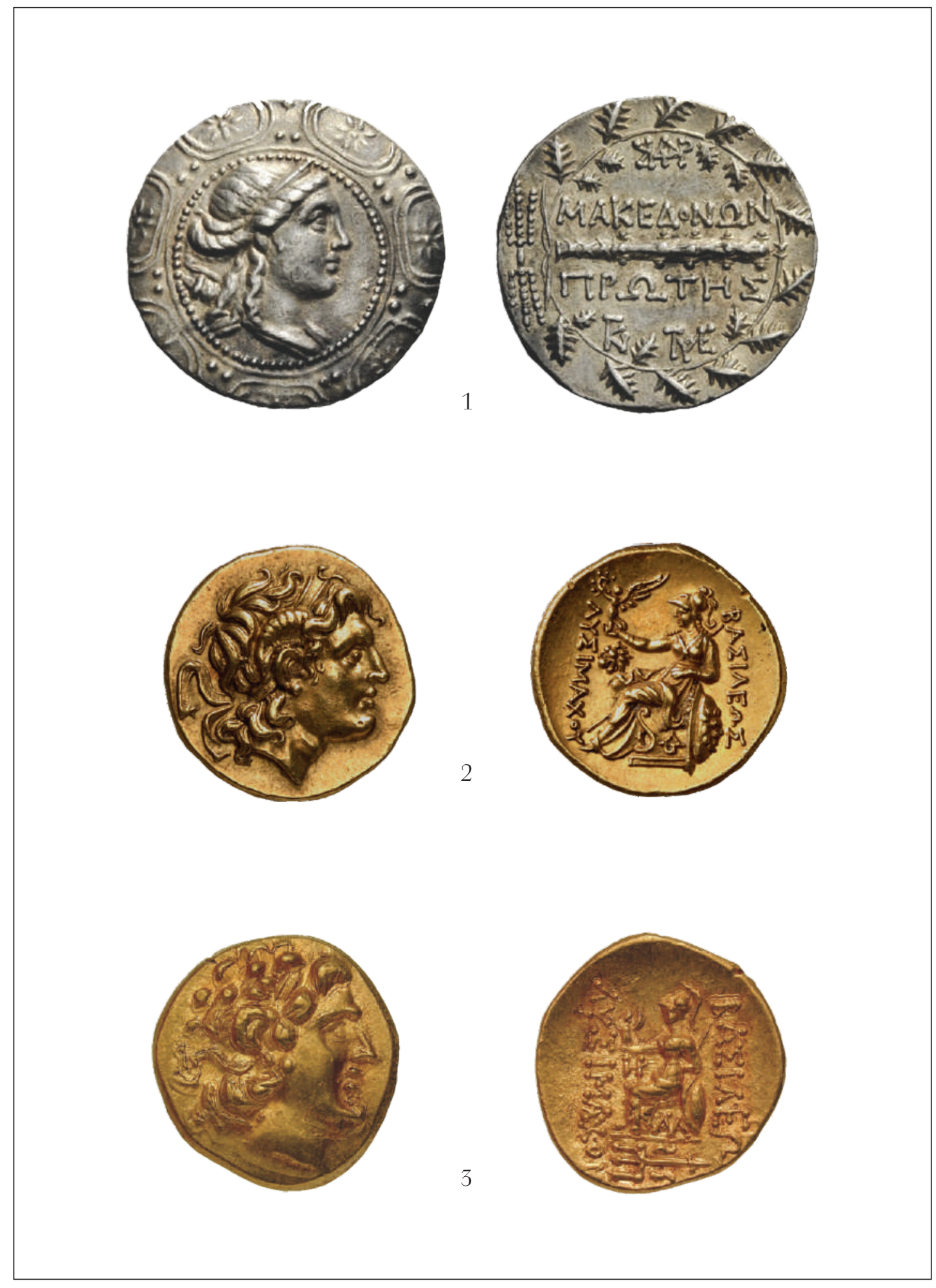

Taf. III. 1. Tetradrachmon des Macedonia Prima-Typs; 2. Stater des Lysimachos; Münzstätte: Lysimacheia; ca. 297-281 v. Chr. (CNT 3101); 3. Stater des Lysimachos-Typs (posthume Prägung); Münzstätte (nominell): Kallatis; 1. Jh. v. Chr. 

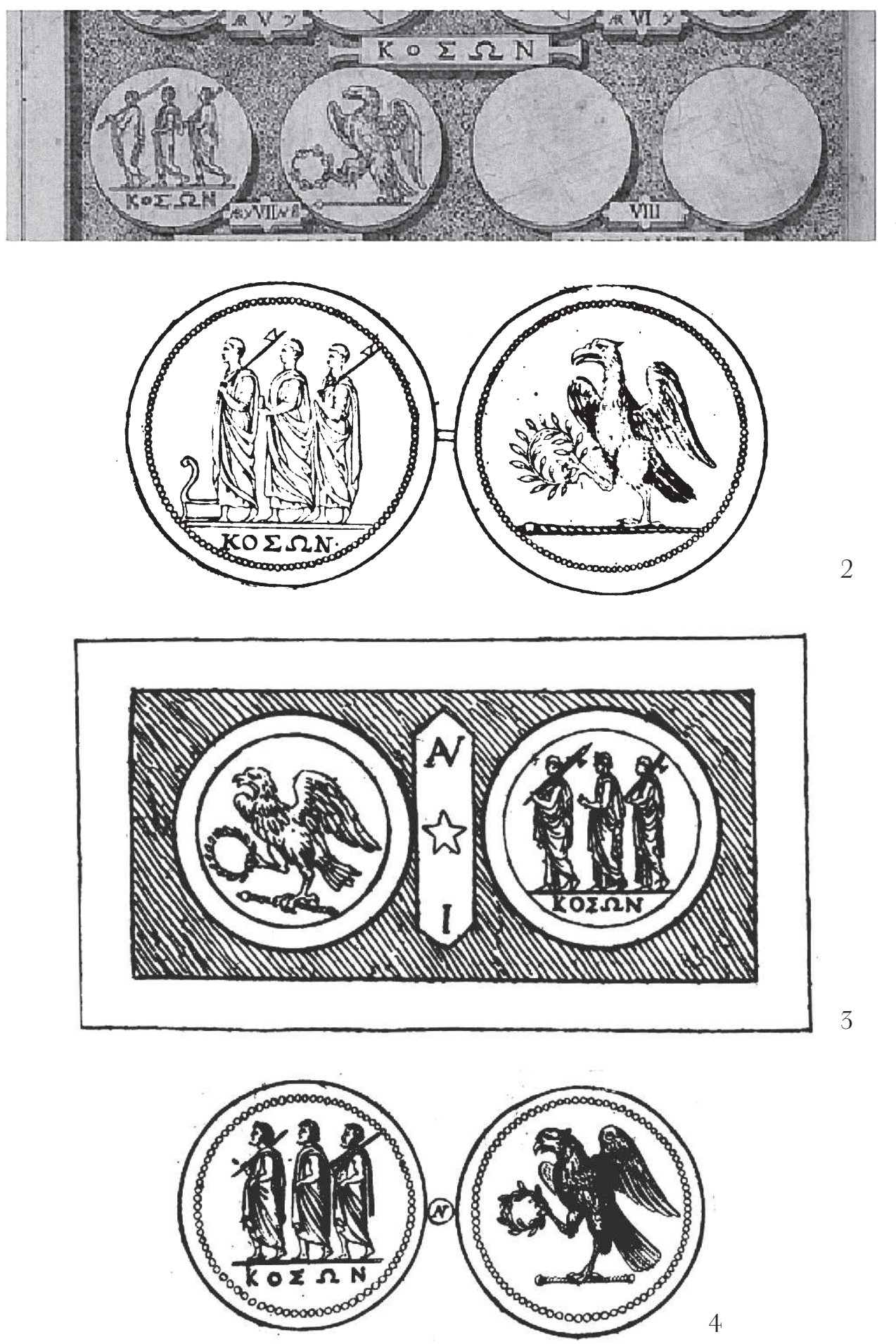

Taf. IV. 1. Kosōn-Münze (AV/AR) nach Goltzius 1576, Tab. XXXVI, Nr. VII; 2. Kosōn-Stater nach Tristan 1644 (1657), S. 366; 3. Kosōn-Stater (AV) nach Patin 1663, S. 140; 4. KosōnStater (AV) nach Beger 1685, S. 194. 


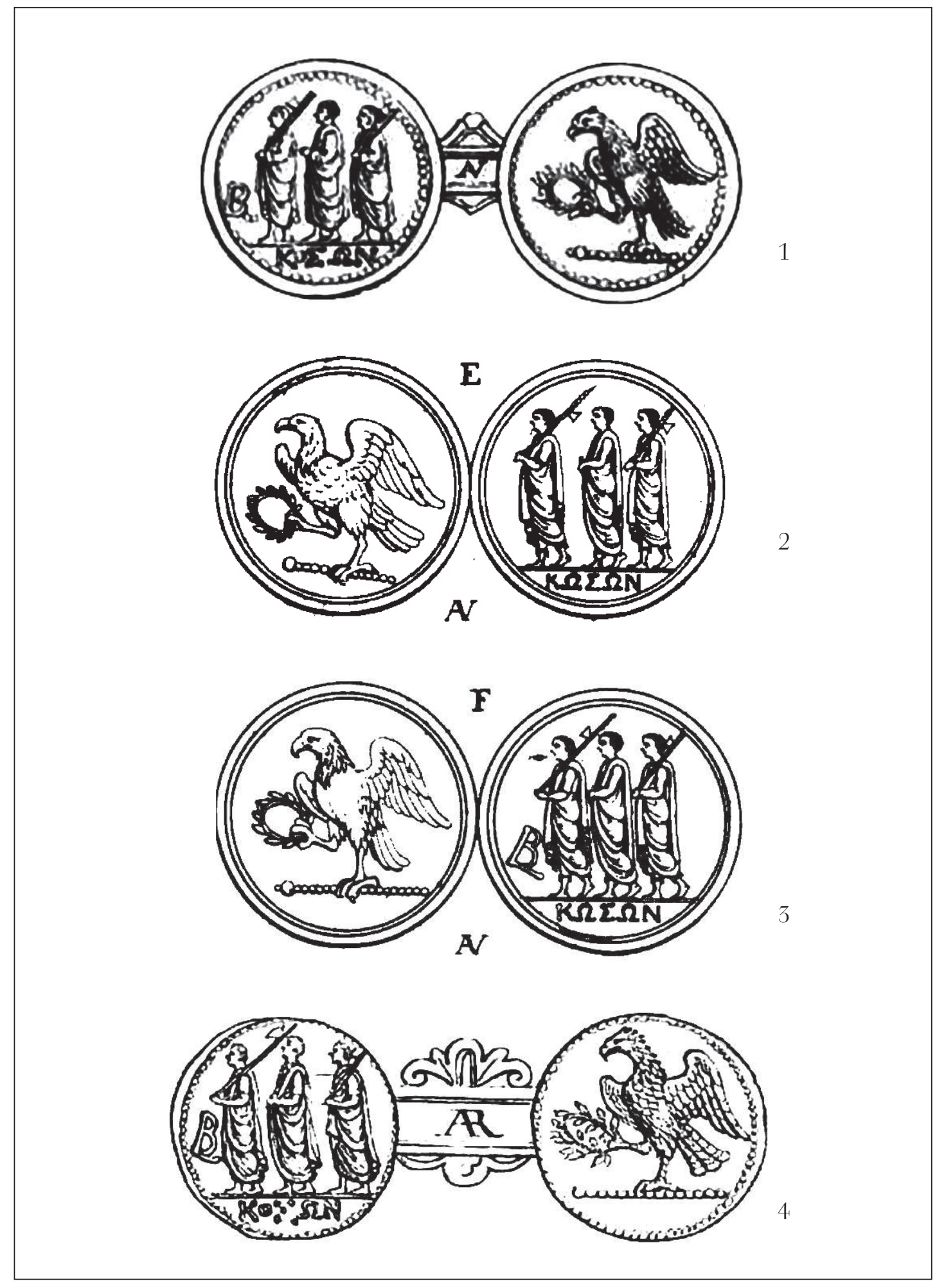

Taf. V. 1. Kosōn-Stater (AV) nach Liebe 1730, S. 15; 2. Kosōn-Stater (AV) nach Haverkamp 1734: Junia, Tab. 1, E; 3. Kosōn-Stater (AV) nach Haverkamp 1734: Junia, Tab. 1, F; 4. KosōnMunze (AR) nach Wachter 1740, S. 104. 


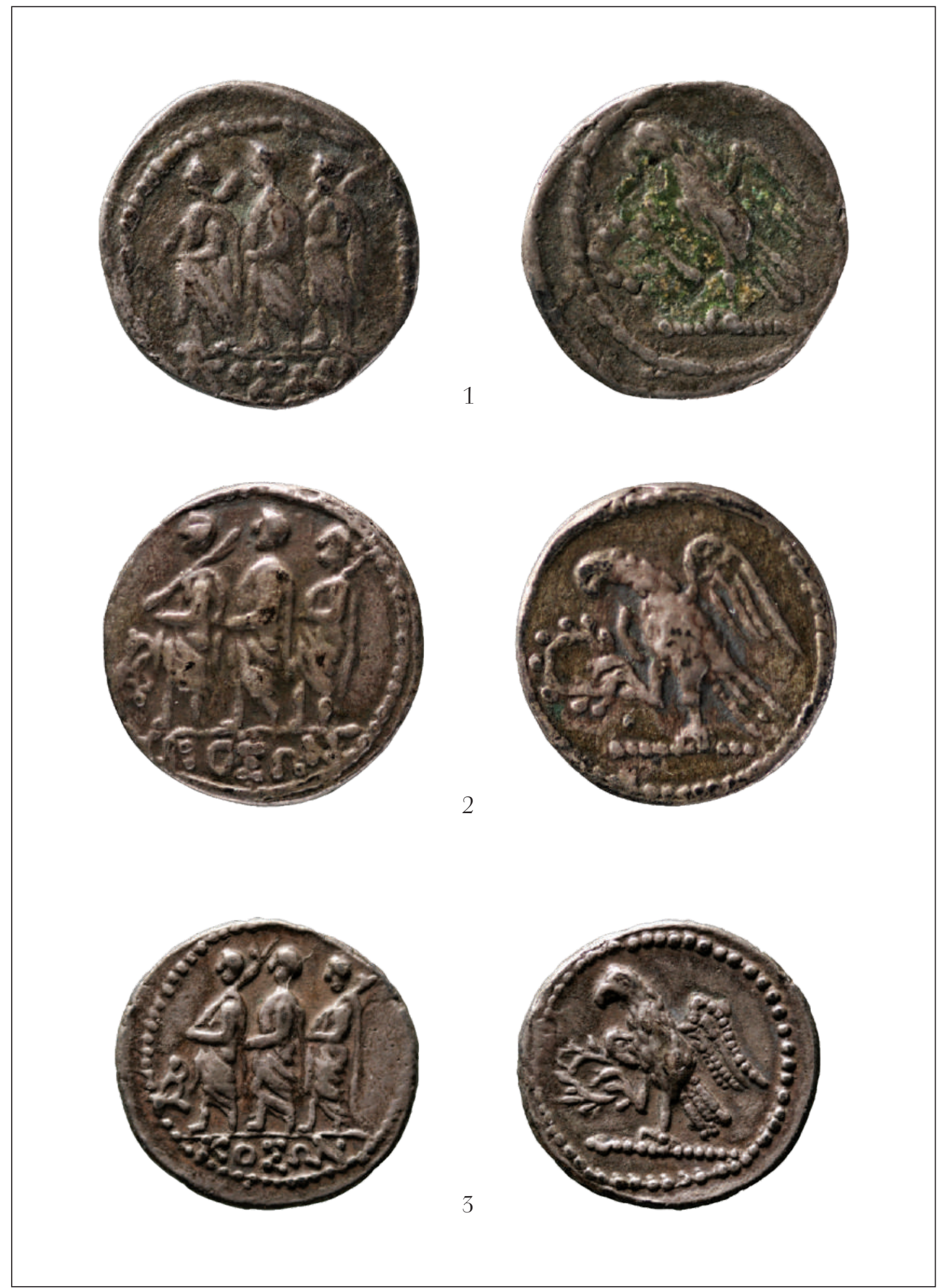

Taf. VI. 1. Silber-Falsum eines Kosōn-Staters Typ C (Wien, KHM, Inv. FA 906; Foto: Klaus Vondrovec); 2. Silber-Falsum eines Kosōn-Staters Typ B oder einer Kosōn-Drachme Typ B (Wien, KHM, Inv. FA 907; Foto: Klaus Vondrovec); 3. Silber-Falsum eines Kosōn-Staters Typ A (Wien, KHM, Inv. FA 907; Foto: Klaus Vondrovec). 


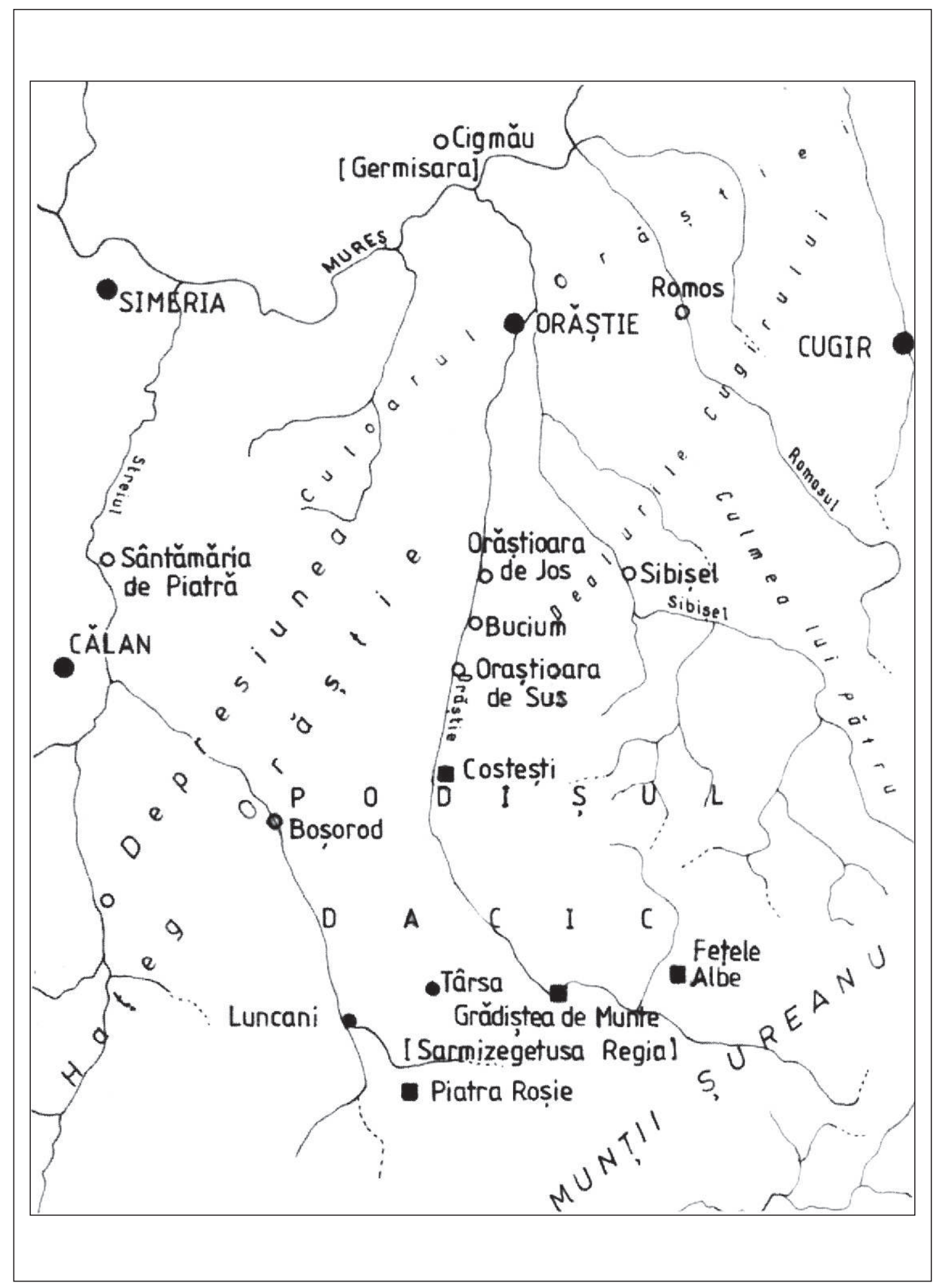

Taf. VII. Karte der Zone der Orăştie-Berge (nach Petolescu 2011b, S. 159, Fig. 2). 


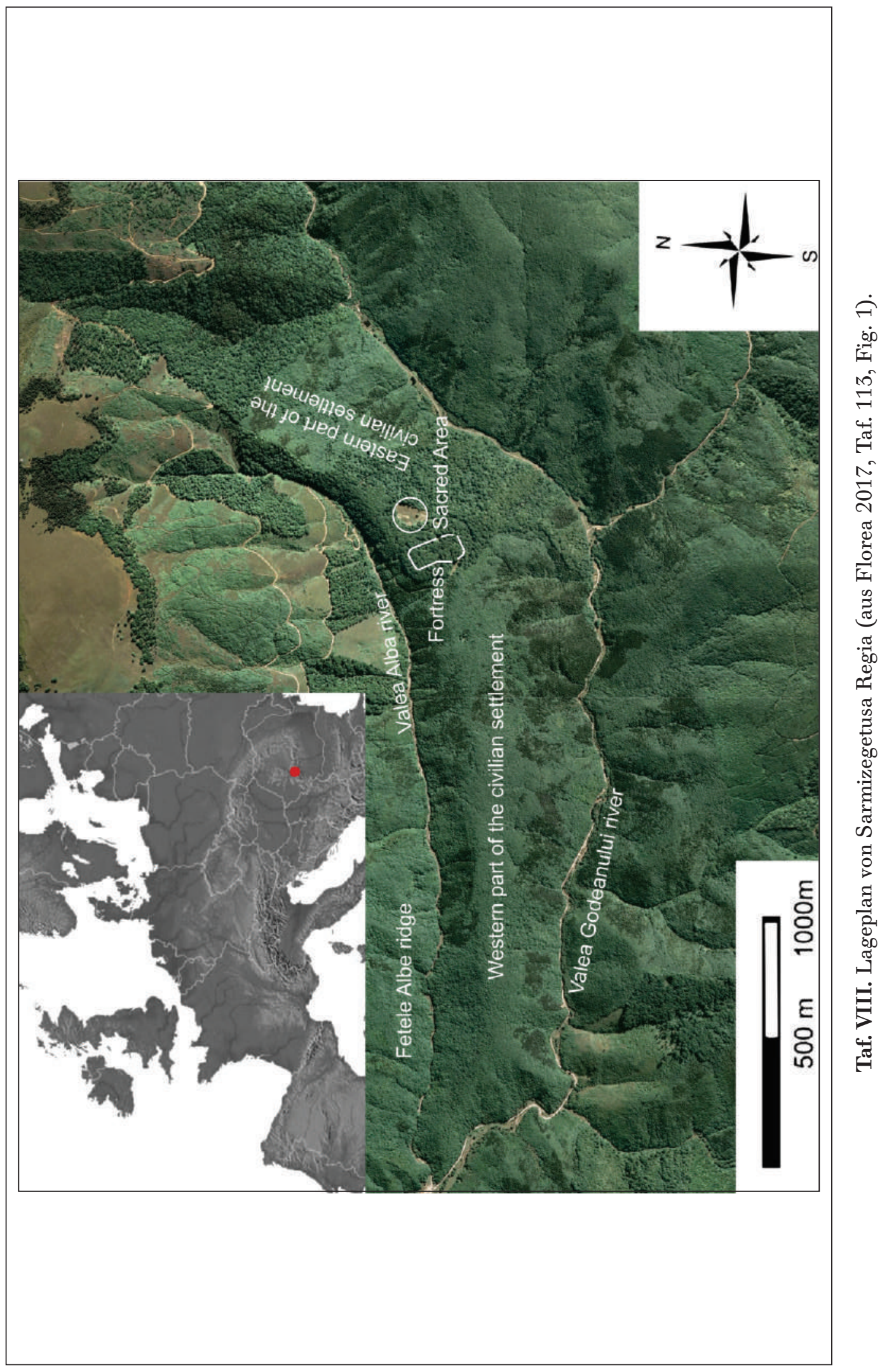




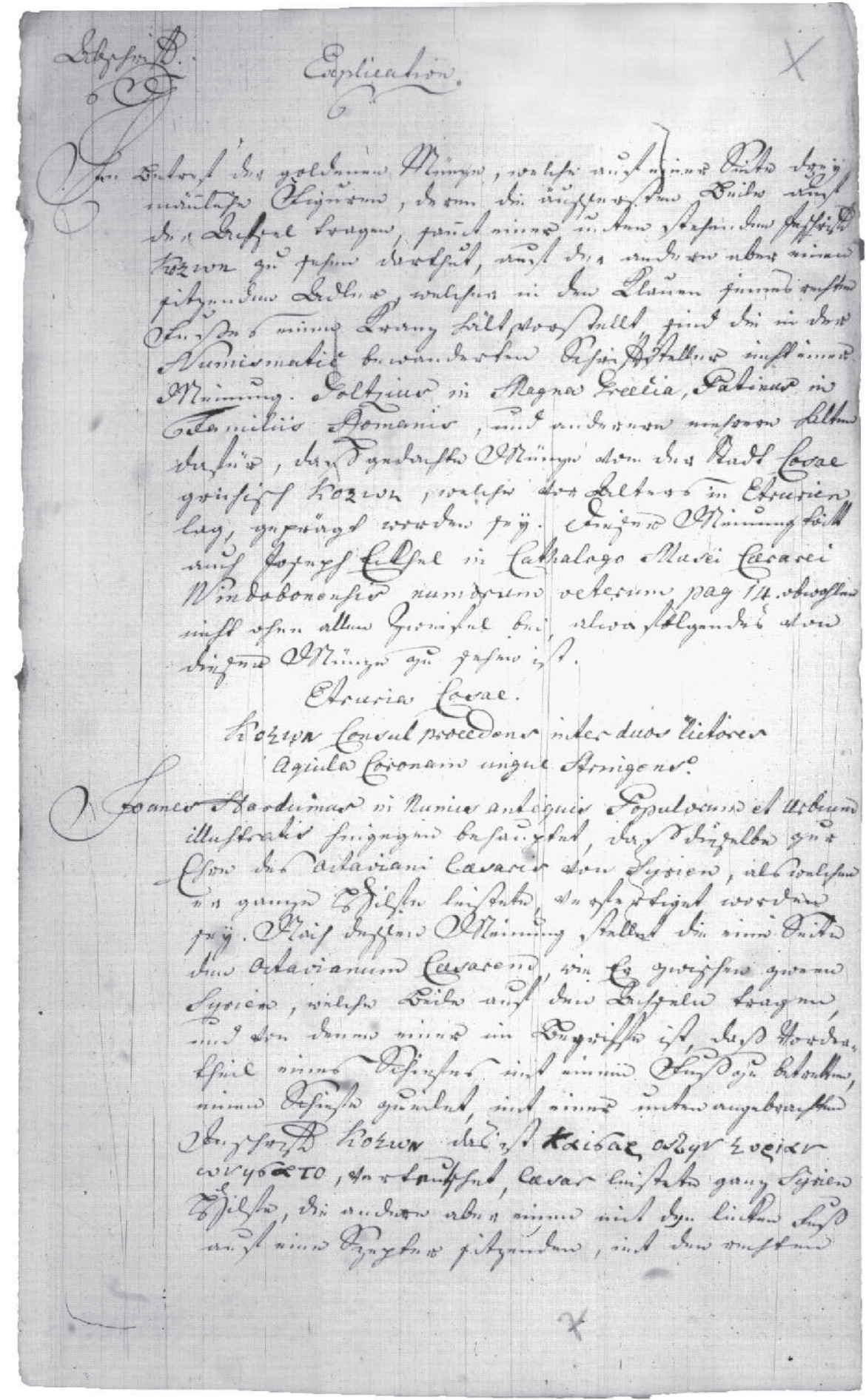

Taf. IX. Explication zum Kosōn-Stater, Siebenbürgisches Thesaurariat für Münz- und Bergwesen, 1803, S. 1 (MNL-OL F189. Erd. Kincstári Lvt., Thesaurariatus, Eln. iratok, Nr. 703/1803 [Mf. 33150], 63). 


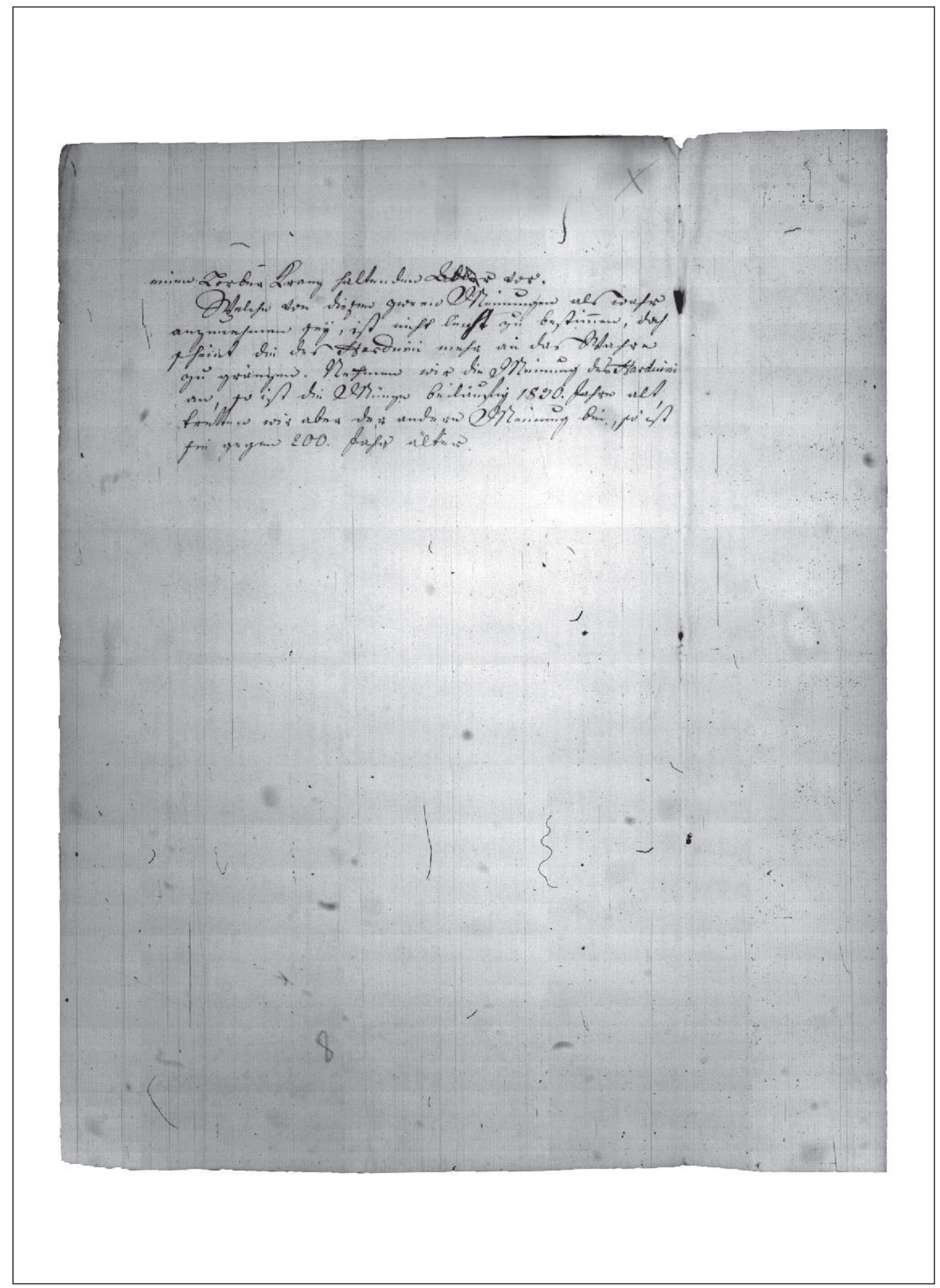

Taf. X. Explication zum Kosōn-Stater, Siebenbürgisches Thesaurariat für Münz- und Bergwesen, 1803, S. 2 (MNL-OL F189. Erd. Kincstári Lvt., Thesaurariatus, Eln. iratok, Nr. 703/1803 [Mf. 33150], 64). 



\title{
AN EARLY ROMAN TOMBSTONE FROM DUNASZEKCSÖ (TRHR 201)
}

\author{
PÉTER KOVÁCS, ISTVÁN PÁNYA
}

\begin{abstract}
A Roman tombstone from Dunaszekcső that can be dated to the middle of the $1^{\text {st }}$ century AD is the subject of this paper. The stela is one of the earliest inscribed stone monuments in Eastern Pannonia and proves the existence of the early auxiliary fort of Lugio. As the missicius served 37 years and as he was a Tiberius Claudius (receiving his citizenship in 54 AD, at the latest), the tombstone clearly shows the existence of the cohors I Alpinorum around 17 $\mathrm{AD}$, at the latest.
\end{abstract}

Keywords: epigraphy; Pannonia; military history; Early Roman occupation.

Rezumat: Subiectul acestei lucrări îl constituie un monument funerar de la Dunaszekcső, databil la mijlocul secolului I p. Chr. Stela reprezintă unul din cele mai timpurii monumente cu inscripție din Pannonia răsăriteană și certifică existenţa castrului auxiliar timpuriu de la Lugio. De vreme ce numitul missicius a servit 37 de ani în armată şi a fost un Tiberius Claudius (primind cetățenia cel târziu în anul 54 p. Chr.), monumentul indică clar existența cohortei $I$ Alpinorum cel târziu în anul 17 p. Chr.

Cuvinte cheie: epigrafie; Pannonia; istorie militară; ocupație romană timpurie.

Ferenc Halász, the well-known local historian of Dunaszekcső, reported in the 1940 s $^{1}$ that in Ádám Heim's property at Dunaszekcső-Püspökhegy an inscribed Roman tombstone was found in 1940. Few years later the inscription was lost, therefore A. Radnóti and L. Barkóczi, in their paper on the military history of Pannonia published in 1951, only mentioned the inscription in a note with the text of the first two lines. ${ }^{2}$ Despite this fact, the inscription, important from the point of view of the military history of Pannonia, was mentioned several times and it was published in the supplement of the series Die Römischen Inschriften Ungarns (TRHR) as follows:

Ti(berius) Claudius [Ma]giatus equ(es) coh(ortis) I Alp(inorum) [- - -] / - - - - - .

Literature: Radnóti, Barkóczi 1951, 199, n. 75; Saddington 1982, 217, n. 81, Lőrincz 2001, 225, no. 219; Kakoschke 2010, 383; DuBois 2015, 279, TRHR 202.

The Roman stone monument has been recently emerged at Dunafalva in a private property where we could describe the inscription (the $5^{\text {th }}$ of May 2017). As far as

\footnotetext{
1 Halász 2000. The tombstone is not mentioned in this work.

2 We received information about an early tombstone from Mr. Ferenc Halász, a Dunaszekcső collector; he made a drawing of a tombstone with the following inscription: Ti. Claudius . . ciatus eqv. coh. I Alp . . . The stone was found in 1940 at Dunaszekcső, in Mr. Ádám Heim's vineyard on Püspökhegy; since it has disappeared, our only evidence for the presence of one of the cohortes I Alpinorum (perhaps the cohors equitata) is this rather uncertain drawing.
} 
we know, the tombstone was transported to Dunafalva in the 1940s and kept in the house of Ádám Heim which was sold around 1964 to the family of the recent owner, Ferenc Balogh. Now, it can be found in the courtyard of his house at Dunafalva (Posta street No. 9). ${ }^{3}$

Description: The middle part of the fragmentary stela (Pl. I/1-2) (above, below and its left side) has been cut because of the secondary use. Below, the inscription can be seen, framed by a cymatium $(52 \times 45 \mathrm{~cm})$. Above, in the undecorated picture field $(36 \times 49 \mathrm{~cm})$ the very fragmentary togati protoma of the veteran can be found in a medallion.

Material: limestone.

Dimensions: height: $108 \mathrm{~cm}$, width: $54 \mathrm{~cm}$, thickness: $12 \mathrm{~cm}$.

Letters height: 1. 1: $6.2 \mathrm{~cm}$; 1. 2: $5.5 \mathrm{~cm}$; $1.3-5: 5 \mathrm{~cm}$; 1. 6: $4.8 \mathrm{~cm}$; 1. 7: $3.7 \mathrm{~cm}$. The last letter of line 4 (a D) can be found in the frame, similarly to the letter $\mathrm{A}$ in lines 2 and 4. Triangular interpunctiones were consequently used between the words; there is no ligature in the text. The letters were carefully carved and no mistake committed by the stonecutter can be observed. Above and below the letters the lines of the ordination can still be recognized. Horizontal stroke above a numeral was used only in the case of ordinal number I of the military unit. The stone monument was secondarily repainted after 1940 but traces of the original red painting can still be seen as well.

In the inscription field the following letters can be seen:

CLAVDIVS
GIATVS EQV
HO I ALPI MI
CIVS AN LXXV D
I XXXVII H S E
A SECVND
LIB ET HER
POS P P M

The findspot - Püspökhegy (Bishop's hill) - is located north of the auxiliary fort of Lugio-Florentia, where the late Roman cemetery (and the early Principate civilian settlement) has recently been identified and some of the graves have been revealed. ${ }^{4}$ The tombstone was most probably reused in this cemetery. Based on the inscription, it surely belonged to an auxiliary soldier in the $1^{\text {st }}$ century $\mathrm{AD}$, who, as he was a Tiberius Claudius, received his Roman citizenship under Tiberius' or Claudius' reign. Earlier he served as rider in the cohors I Alpinorum equitata, therefore the cohors I Alpinorum peditata must be ruled out. ${ }^{5}$ The cohors equitata garrisoned in Pannonia in the entire $1^{\text {st }}$ century AD (CIL XVI 4; CIL XVI 26; CIL XVI 30; CIL XVI 31); its first fort was at Lugio/Dunaszekcső (based on this text), but its stamped tiles show that it was transferred into Western Pannonia (Carnuntum?) at the end of Claudius' reign

\footnotetext{
${ }^{3}$ We would like to thank Ferenc Balogh and László Kaszur for their help in processing the information related to the monument.

4 Kovács 1996, 46; Visy 2002, 105-106; Gábor, Nagy 2004, 10.

5 Spaul 2000, 262-263. The cohort was later transferred in Pannonia.
} 
(Lőrincz 2001, no. 220). During the Flavian period the cohort stationed probably at Gorsium (RIU 1551). ${ }^{6}$ The tombstone belongs to an early (no younger than the Flavian period) type that occurs rarely in Eastern Pannonia, in which, in the picture field, the protoma of the deceased togatus was depicted in a medallion or crown (e.g. CIL III 15197; AE 1992, 1396; RIU 149, 156; TitAq 582). ${ }^{7}$ In the case of this tombstone only the folds of toga can be recognized. The date of its erection is confirmed also by the fact that it was erected by the freedman of the veteran, i.e. he had no family. Based on this fact, the first letter in line 6 (an A) can only be restored as [Cl]a(udius). In line 1 the praenomen Ti(berius) is missing, which means that only two letters are broken in each line. The cognomen can only be restored as Magiatus that was a very rare Celtic personal name (cf. Appendix 1). ${ }^{8}$ Based on the occurrence of the name in Belgica (primarily in the territory of the tribe Mediomatrici) it is also supposed that Magiatus came from this province. ${ }^{9}$ On the other hand, the origin/home of the soldiers of the cohortes Alpinorum (given in Appendix 2), who were not enrolled in the province of the garrison clearly shows that they all came from the Alpine region (including Noricum) (most of the tribal names can be found in the inscription of the Tropaeum Augusti among the tribes conquered by Augustus: CIL V $7817=$ Plin. HN III.137): Bodionticus (Gallia Narbonensis: cf. Plin. HN III.37), Caturix, Eguius, Noricus (later: Virunum), Velaunus. ${ }^{10}$ Based on this fact, Magiatus' tribe can be found here, too. The word MI[---]CIVS can only be restored as mi[ssi]cius as no similar tribal name is attested. Based on this and on the fact that Magiatus was 75 year old one can suppose that the word missicius was used as a synonym of veteranus (and he could be identified with an active soldier who has not yet received the honesta missio). ${ }^{11}$ It cannot be supposed that a 75-year-old man would have recently been discharged or he would have been enrolled at the age 38 (he served 37 years in the Roman army).

The word missicius was used in similar sense in the tombstones of auxiliary soldiers in Pannonia too (CIL III 3273 = 10258; RIU 982; TitAq 593). The number XXXVII in line 5 surely suggests the length of Magiatus' military service, therefore the word before the numeral (with the letter I) can only be restored as [st]i(pendiorum). More problematical is the interpretation of the letter $D$ at the end of line 4 in the frame that did not belong closely to the funerary text. It is evident that it cannot be expanded as $d$ (ies) as there is no enough room in the next line for a numeral. Based on this fact, the most obvious possibility is that it was the rare abbreviation of the participle defunctus that occurs rarely in Pannonia (RIU 1256; TRHR 38). The letters P P can most probably be expanded as $p$ (atrono) $p$ (ientissimo), because the tombstone was

\footnotetext{
${ }^{6}$ Spaul 2000, 259-261; Lőrincz 2001, 27, no. 1.

7 Schober 1923, 55-56, 126-130; Gáspár 2016, 45-46. see Spaul 2000, 257.

9 Lőrincz 2001, 225.

10 Holder 1896, II, 459, 859-860, 1409, III, 149-150.

11 Domaszewski 1981, p. XX, 78-80; Todisco 1999, 256-259.
}

8 For the name see Holder 1896, II, 375; OPEL III, 45; Kakoschke 2010, 383. The Celtic names with the beginning Mag(i)- are frequent in all Celtic areas including Pannonia (cf. OPEL II, 45-46, e.g. Magio, Magionus can be found in Belgica, Noricum and Pannonia), therefore Magiatus' home remains uncertain: Holder 1896, II, 375, 378-379; Mócsy 1959, 179; Meid 2005, 197. On the personnel of the Alpine cohorts 
erected by the freedman of the deceased veteran. In line 7 , between the words libertus and heres, EI is written. Here, the hasta transversa of the T is omitted, and the word must be restored as $e t$.

Based on these data the inscription can be restored as follows:

[Ti(berius)] Claudius
[Ma]giatus equ(es)
[c(o)]ho(rtis) I Alpi(norum) mi-
[ssi]cius an(norum) LXXV d(efunctus)
[st]i(pendiorum) XXXVII h(ic) s(itus) e(st).
[Cl]a(udius) Secund-
[us] lib(ertus) e「t her-
[es] pos(uit) p(atrono) $p$ (ientissimo) m(emoriam).

Magiatus' tombstone reveals several new data on the military history of Pannonia in the middle of the $1^{\text {st }}$ century $\mathrm{AD}$ and it clearly shows that the eastern Pannonian limes was established during the reign of Claudius latest. The first Pannonian garrison of cohors I Alpinorum equitata was in Lugio. Based on North-Italian Samian ware finds from the archaeological site at Dunaszekcső-Várhegy, it was already supposed that the earth-timber period auxiliary fort of Lugio was built during Claudius' reign. ${ }^{12}$ Based on the tria nomina, the missing Dis Manibus formula, ${ }^{13}$ the use of the nominative and the type of the stone monument and the paleography, the tombstone can be dated latest to the beginning of the Flavian period, but a Claudian-Neronian date seems to be more probable based on the history of the military unit cited above. Magiatus received the Roman citizenship in the year 54, at the latest, as he was a Tiberius Claudius. He served 37 years that clearly proves that his stela was erected latest in $75 \mathrm{AD}$ if he entered the army at the age of $17 / 18$ as usually. The formula hic situs est occurs in this period in Pannonia (e.g. TitAq 593; AE 1906, $111=1909,198$ ), but the expression posuit ... memoriam is not attested in the $11^{\text {st }}$ century. ${ }^{14}$ Based on the length of his military service (37 years) and on the fact that Magiatus did not serve in another unit, the cohortes Alpinorum must have existed already around $17 \mathrm{AD}$. This fact agrees with the supposed Augustan date of Iulius Iccus' tombstone found in Aquitania (CIL XIII 922). ${ }^{15}$ Magiatus as veteran settled down in the auxiliary vicus of Lugio and he did not follow his unit when it was transferred to Western Pannonia.

${ }^{12}$ Nagy 1931, 267-271; Visy 2002, 46; Gabler 1997, 85-92, esp. 87.

13 Schober 1923, 11; Mosser 2003, 20, 153 (from the Flavian period).

${ }^{14}$ Cf. the funerary formulas Fitz 1961-1962, 33-48. Based on this fact, the expansions m(onumentum) or $m$ (emoriae) (without an object as e.g. titulum) cannot be excluded either, but they are also unattested in Pannonia.

${ }_{15}^{15}$ Villeneuve-sur-Lot/Aginnum Iul(ius) Attonis fil(ius) / Icco miles ex / cohor(te) Alpinor(um) / I ann(orum) LV stipend(iorum) / XXXVh(ic) s(itus) est / her(e)des pie fec(erunt): Saddington 1982, 59, 73; Spaul 2000, 260. 


\section{Appendix 1 - The occurrence of the cognomen Magiatus}

CIL XIII 4498 = ILS 4655, Saint-Avold: Mediomatrici Deae Dironae /Maior Ma/giati filius / $v$ (otum) s(olvit) l(ibens) m(erito);

CIL XIII 11313, Trier: ... / [---] Maciatus /...;

CIL XIII 11453, Fontoy, Fentsch, Mediomatrici: D(is) [M(anibus)] / Magiatius [---]/nus sibi et Am[miae Ne]/mauso con[iugi et Mar]/cello fil(io) p[osuit];

AE 1933, 118, Bad Cannstatt: Genio Da/sag(--) Magiatu(s) / et Fla(vius) Senecia/nus d(e) $s$ (uo) $p$ (osuerunt).

\section{Appendix 2 - The home of the soldiers of the cohortes Alpinorum}

CIL III $6366=8491$, Caturix;

CIL III 8495, Bodionticus;

CIL III 9907, Bodionticus;

ILJ 115, Eguius;

CIL III 14935, Noricus;

ILJ 1922, Velaunus [cf. also RIU 1033 (coh. III Lusitanorum)];

RIU 1435, Virunum.

\section{Enrolled in the province where the cohort garrisoned}

CIL XVI 104, Azalus;

RMD 266, Eraviscus, Vetus Salina;

CIL XVI 112, Eraviscus;

RIU 1551, Sirmium.

\section{Bibliography}

Domaszewski 1981

DuBois 2015

Fitz 1996

Gabler 1997

Gábor, Nagy 2004

Gáspár 2016

Halász 2000

Holder 1896
A. v. Domaszewski, Die Rangordnung des römischen Heeres, KölnWien $1981^{3}$.

M. S. DuBois, Auxiliae. A compendium of non-legionary units of the Roman army, Cincinnati 2015.

J. Fitz, Titulum memoriae posuit, Alba Regia, 2-3, 1961-1962, 33-48.

D. Gabler, Early Roman occupation in the Pannonian Bend. In: W. Groenman van Waateringe, B. van Beck, W. J. H. Willems, S. L. Wynia (eds.), Roman Frontier Studies 1995. Proceedings of the $X V I^{\text {th }}$ International Congress of Roman Frontier Studies, Oxford 1997, 85-92.

O. Gábor, L. Nagy, Római kori erőd és település Dunaszekcsőn (Várhegy, Sz. János-hegy, Püspök-hegy) - Römerzeitliche Festung und Siedlung in Dunaszekcsö (Burgberg, Johannesberg, Bischofsberg), Budapest 2004.

D. Gáspár, Római síremlékek Magyarországon, Budapest 2016.

F. Halász, Mit tudunk Dunaszekcsőröl az öskortól napjainkig, Dunaszekcső 2000.

A. Holder, Alt-Celtischer Sprachsatz I-III, Leipzig 1896-1907. 
Kakoschke 2010

Kovács 1996

Lőrincz 2001

Meid 2005

Mócsy 1959

Mosser 2003

Nagy 1931

Radnóti, Barkóczi 1951

Saddington 1982

Schober 1923

Spaul 2000

Todisco 1999

Visy 2002
A. Kakoschke, Die Personennamen in der römischen Provinz Gallia Belgica, Hildesheim - Zürich - New York 2010.

P. Kovács, Vicus és castellum kapcsolata az alsó-pannoniai limes mentén, Piliscsaba 1996.

B. Lőrincz, Die römischen Hilfstruppen in Pannonien während der Prinzipatszeit I: Die Inschriften, WAS 3, Wien 2001.

W. Meid, Keltische Personennamen Pannoniens, Budapest 2005.

A. Mócsy, Die Bevölkerung von Pannonien bis zu den Markomannenkriegen, Budapest 1959.

M. Mosser, Die Steindenkmäler der Legio XV Apollinaris, WAS 5, Wien 2003.

L. Nagy, Római régiségek Dunaszekcsőról, AErt, 45, 1931, 267-271.

A. Radnóti, L. Barkóczi, The distribution of troops in Pannonia Inferior during the $2^{\text {nd }}$ century A.D., AArchHung, 1, 1951, 191-226.

D. B. Saddington, The development of the auxiliary forces from Caesar to Vespasian: 49 B.C. - A.D. 79, Harare 1982.

A. Schober, Die römischen Grabsteine von Noricum und Pannonien, Sonderschriften des Österreichischen Archäologischen Institutes in Wien X, Wien 1923.

J. Spaul, Cohors'. The evidence for and a short history of the auxiliary infantry units of the Imperial Roman Army, BAR 841, Oxford 2000.

E. Todisco, I veterani in Italia in età imperiale, Bari 1999.

Zs. Visy, The ripa Pannonica in Hungary, Budapest $2002=$ A ripa Pannonica Magyarországon, Budapest 2000.

Péter Kovács

Pázmány Péter Catholic University, Piliscsaba kovacs.peter(o)btk.ppke.hu

István Pánya

Kecskeméti Katona József Múzeum, Kecskemét panyaistvan(a) gmail.com 


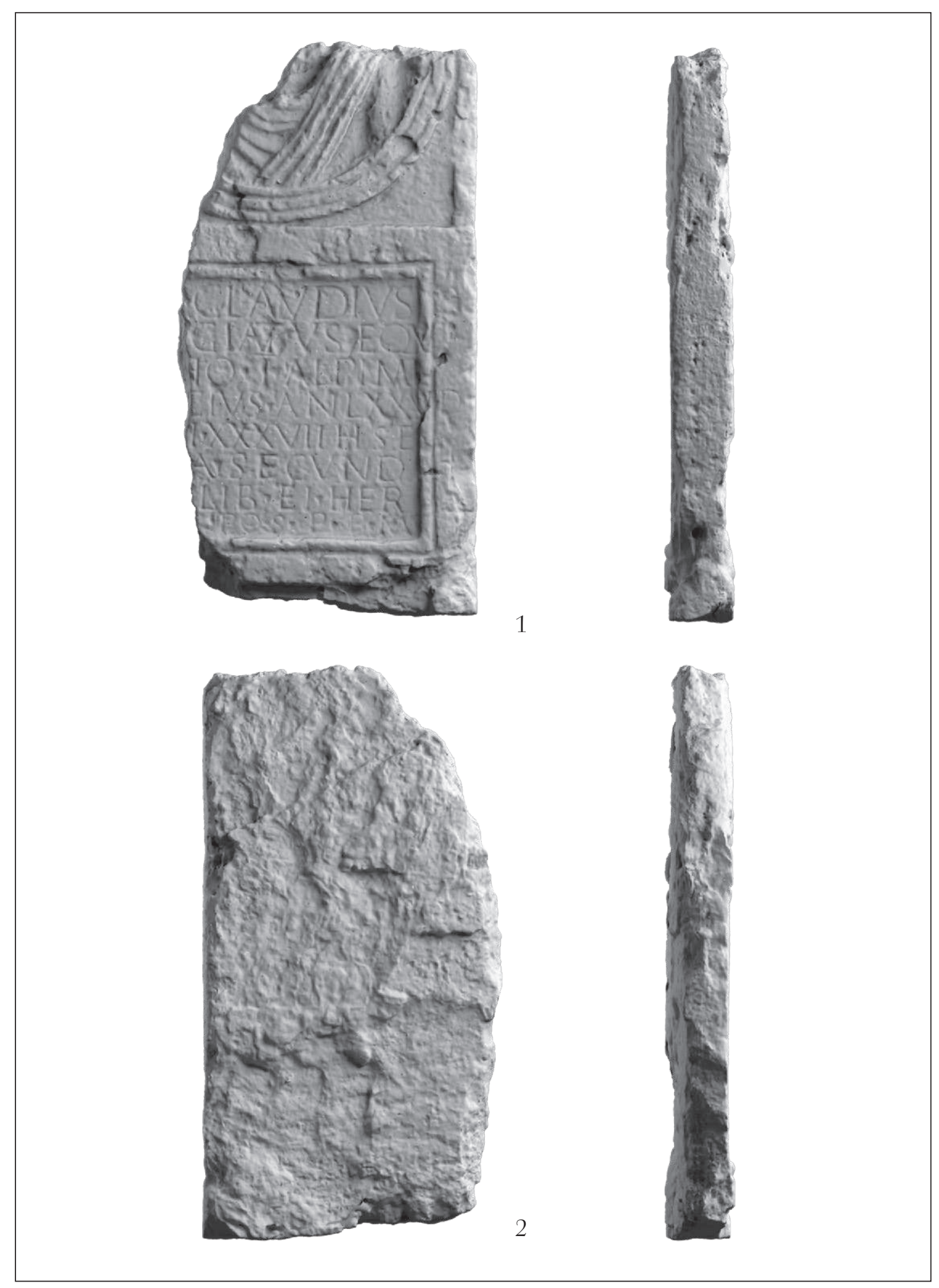

Pl. I. Roman tombstone from Dunaszekcső. 1. Front view; 2. Back view. 


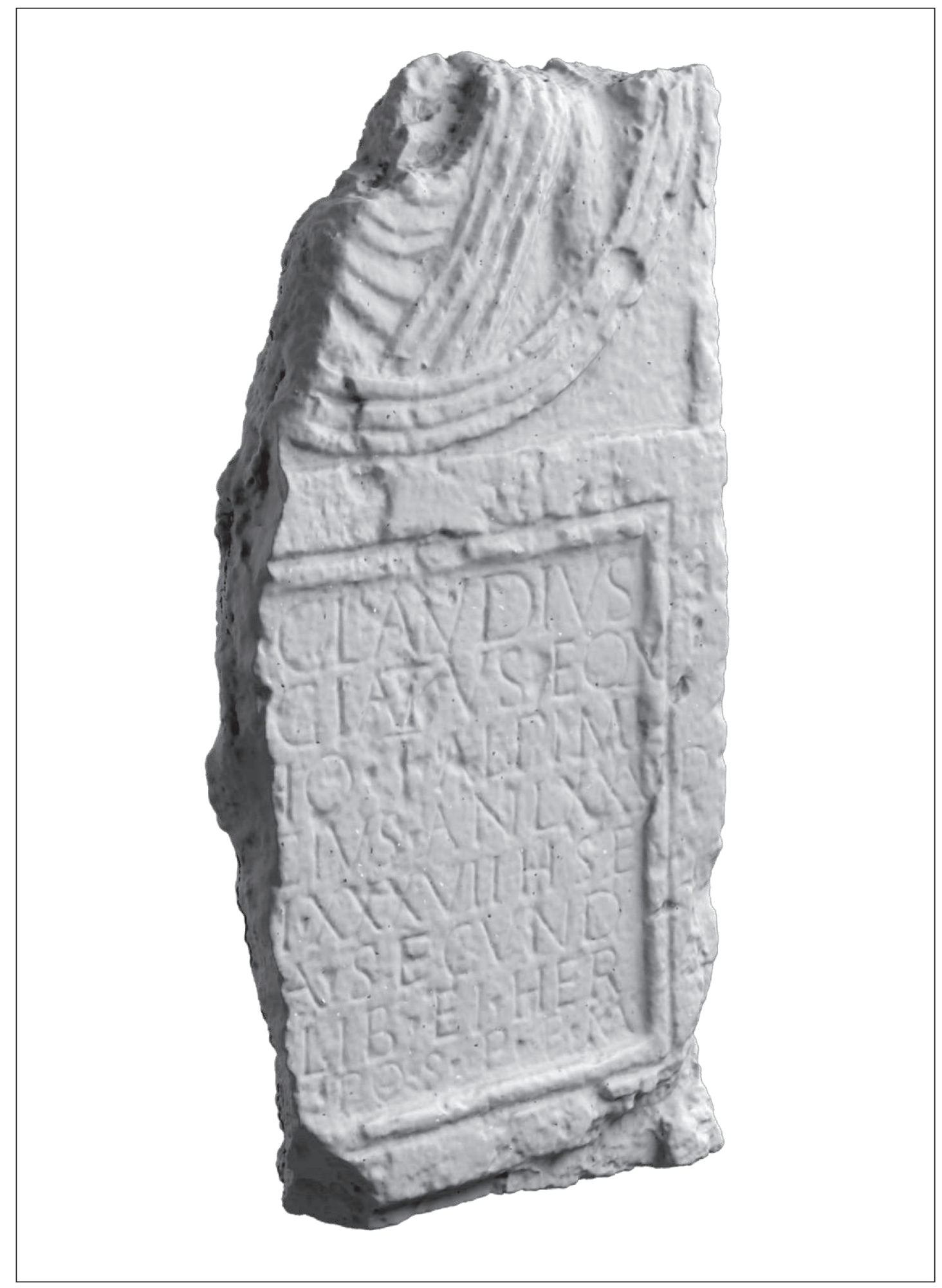

Pl. II. Roman tombstone from Dunaszekcső, detailed view. 


\title{
COHORT DISLOCATIONS IN PANNONIA IN THE 130S - CONSEQUENCES OF THE BAR KOKHBA REVOLT?
}

\author{
BENCE FEHÉR
}

\begin{abstract}
It is generally accepted that vexillations of the legio I Adiutrix and legio II Adiutrix were sent to Judaea for the repression of the Bar Kokhba revolt, although epigraphic testimonies are missing. We did not know anything about a possible participation of Pannonian auxiliary units. A military diploma from $135 \mathrm{AD}$ shows the lack of a cohort and the presence of another cohort, cohors I Brittonum, but probably in a different garrison. The article discusses of the possibility the cohors I Brittonum was brought here as a substitution, and the exact identity of this troop. It may have been either the cohors I Ulpia, dislocated from Dacia for cca. two years, or the cohors I Aelia, which was most likely constituted for the occasion. The probable garrison of this unit was Albertfalva in these two years, where it might substitute a vexillation of the legio II Adiutrix; an epigraphic relic of this short period is a little altar in Aquincum dedicated to Mithras for the common welfare of a certain troop called $C$ I B.
\end{abstract}

Keywords: Pannonia; military diploma; cohors I Brittonum; Mithras cult; Albertfalva.

Rezumat: Este general acceptat faptul că vexilaţii din legiunile I Adiutrix şi II Adiutrix au fost trimise în Iudeea în vederea reprimării revoltei lui Bar Kokhba, cu toate că lipsesc mărturiile epigrafice. Nu s-a știut nimic despre o posibilă participare a unităților auxiliare panonice. O diplomă militară din anul 135 p. Chr. indică absența unei cohorte şi prezența alteia, cohors I Brittonum, dar probabil într-o altă garnizoană. Articolul ia în considerare posibilitatea ca această cohors I Brittonum să fi fost adusă aici cu scopul de a înlocui, dar discută şi despre identitatea exactă a acestei trupe. E posibil să fi fost cohors I Ulpia, dislocată din Dacia pentru cca. doi ani, sau cohors I Aelia, cel mai probabil constituită cu această ocazie. În acești doi ani, garnizoana probabilă a unităţii a fost la Albertfalva, unde ea putea înlocui o vexilaţie a legiunii II Adiutrix; o moștenire epigrafică a acestei scurte perioade de timp o reprezintă un altar din Aquincum, dedicat zeului Mithras pentru bunăstarea comună a unei anumite trupe $C I B$.

Cuvinte cheie: Pannonia; diplomă militară; cohors I Brittonum; cultul lui Mithras; Albertfalva.

Pannonian military forces are generally supposed to have been sent to Judaea for the repression of the Bar Kokhba revolt (132-135 AD). In fact, the evidences of such a participation are so rare that we cannot say with certainty which units we speak of (mostly vexillations of the legio I Adiutrix and legio II Adiutrix are mentioned). The most recent and most elaborate researches do not take this participation as granted, but as a hypothesis presently without satisfactory proofs. ${ }^{1}$ The lack of pro and contra arguments is due mostly to the silence of written - literary and epigraphic - sources. But this silence is not decisive, because we are scarcely informed of the organization of Roman forces in this war on the whole.

\footnotetext{
${ }^{1}$ Mor 2016, 209. On the contrary, Hungarian researchers still assert that the existing arguments for the Pannonian participation are decisive at least for the legio I Adiutrix and legio X Gemina (based on the career of its commander): Grüll 2017, 347, 350.
} 
There is one inscription which proves the participation of some auxiliary units from Pannonia Superior, but does not refer to any definite unit (and no legion at all). ${ }^{2}$ All the other arguments are taken from 'silent' sources, mostly numismatics. The legio I Adiutrix is accepted as a participant because Bar Kokhba's coins were found in the locality of its garrison, Brigetio. ${ }^{3}$ But it cannot mean the whole legion but a detachment, since another vexillation showed building activity in Pannonia Superior in the same years, 136-138 AD. ${ }^{4}$ Another vexillation sent to Judaea seems certainly a strong possibility - yet not an undebatable fact, because it is only unlikely and not impossible, that the coins were brought from Judaea to Pannonia in a different way. As for the legio II Adiutrix, the situation is far more uncertain. ${ }^{5}$ There are some pro arguments: the presence of Hadrian's cistophori coins in Aquincum, ${ }^{6}$ and the fact that a few recruits of oriental origin appear in the legion roughly in the same time. ${ }^{7}$ A supposal that they were enlisted during the war, seems reasonable for some of them, but doubtful enough for others. If the numismatic arguments had not been added, I think nobody would have really thought their inscriptions were related to an oriental campaign. ${ }^{8}$ All these soldiers were buried in Aquincum, and therefore if this argu-

\footnotetext{
2 AE 1938, 13 (Samaria).

3 The most recent comprehensive study on the legion was done by B. Lőrincz, who takes it as a fact: „Die Truppe hat am Judenkrieg der Jahre 132-135 (zumindest mit einer Vexillation) teilgenommen” (Lőrincz 2010a, 155). The coins were published by Barkóczi 1958, 19, Bíró-Sey 1977, 47, n. 226.

4. That was accepted by Lőrinc loc. cit. too.

${ }^{5}$ Lőrincz 2010b, 168: ... sprechen dafür, daß die Legio II Adiutrix ... zumindest mit einer Vexillation teilgenommen hat.

${ }^{6}$ Alföldi 1956. Certainly it makes probable some kind of military connection of this region with the Roman Orient in the Hadrian era, because these Asian coins are related typically to wars and military usage, but it cannot be dated inevitably to the three years of the revolt.

7 This kind of argument goes back to the observations of A. Mócsy (Mócsy 1959, 82), who found it probable for four soldiers from Aquincum (TitAq 500 from Pelagonia - but P. Kovács in TitAq II, p. 405 recommended Pella -, 507 and 509 from Thessalonica, 511 from Ancyra). We can accept the two cases from Thessalonica unreserved. The soldier from Ancyra (altough his citizenship was given by Hadrian, we do not have any information of his age) is related to an ampler group. They are people of Galatan/Ancyran origin, mostly soldiers, from the Fabia tribus, coming to Pannonia in the turn of the $1^{\text {st }} / 2^{\text {nd }}$ centuries and in the Hadrianic period. There are other members of this group who were possibly recruited about 132 AD: TitAq 700 [P. Ae?]l(ius) Eq[- - -]us; perhaps TitAq 640, but this inscription could be also earlier. Seemingly people arrived from the region of Galatia sporadically during half a century (cf. Bölcske 40). We cannot be certain that the coming of any of them is connected with an actual military campaign. As for the soldier from Pella or Pelagonia, he certainly was not given citizenship for the sake of military service (indeed his father was a citizen too), and consequently he might have come during the whole reign of Hadrian (or even Antonine). There is another possible newcomer: TRHR 216 T. Ba[- - -]. He was a legionary born in Ephesus, his gravestone seems to be dated to the first half of the $2^{\text {nd }}$ century. This possibility is debilitated too by the fact that he was not a new citizen either.

${ }^{8}$ On the contrary, we cannot exclude that the inscription TitAq 682 is another relic of the campaign. It is a cenotaph of a legionary who died in Alexandria. The peculiar monument was interpreted by several scholars, who tried to date it upon stylistic grounds and because of the lack of DM formula. They connected it either with Trajan's Parthian War (L. Nagy, T. Nagy, B. Lőrincz, M. Németh) or the Jewish revolt repressed by Quietus (B. Lőrincz) or the Egyptian revolt in the same time (J. Fitz). (Strobel 1988, 207, n. 85 denies the possibility of an exact attribution.) Nevertheless J. Fitz was aware of the difficulties of these theories (Fitz 1986, 360, n. 197): this soldier died after 15 years of service, and he was born in Noricum. If he would have died about the end of Trajan's reign, he must have been just enlisted here in 101/102 AD, and served all his time in other provinces (according to the history of the legio II Adiutrix). What was it which connected him with Pannonia so strong, that he had got his epitaph here, and not in the place of
} 
ment is reliable, they must have been enlisted to a vexillation sent from Aquincum. Up to now, there was no acceptible argument for the participation of any auxiliary troop from Pannonia Inferior.

If we do not deny the participation of the legions, the lack of evidences might be partially explained by the peculiarities of the military organization, namely that both legions sent only vexillations. An absent vexillation from the ten cohortes does not leave conspicuous marks either in the epigraphic or in the archaeologic material, and probably no supplementary force will come instead, because both the camps of Aquincum and Brigetio remain manned, if only scantily. The occasional absence of an auxiliary troop is far easier detectable. Now, although we did not know about such occasion, we may suppose by pure military logic that a legionary vexillation was accompanied by some auxiliary unit. Then, a supplementary force might become necessary, or else a section of the ripa remained undefended. Naturally a period of three years (at the most) is not easy to detect (at least via archaeology). The military diplomas may offer us doubtless testimony: if in the years 132-135 AD they contain such alae and/or cohortes which did not appear before, nor afterwards, or such troops are missing which were garrisoned certainly in Pannonia Inferior.

Of course the major part of the diplomas does not show the entire list of troops: they are mostly fragmentary, and sometimes the soldiers are discharged selectively, only from a part of the existing troops.

Presently only one diploma is useful to us: RMD IV $251=$ AE 1999, 1352. Doubtless, it contains the troops of Pannonia Inferior, although it is of unknown provenance. The list is theoretically complete (5 alae, 13 cohortes). Seemingly two units are missing from the typical post-Trajan schematism: the cohors I Campanorum voluntariorum ${ }^{9}$ and the cohors VII Breucorum. ${ }^{10}$ Instead of those, two units appear which were stationed habitually in other provinces: a cohors I Britt(onum) (milliaria) and the cohors VII Lusitanorum. The remaining units are as usual. Such is their sequence:

\author{
Alae V: 1. I Thr(acum) vet(erana) 2. I Fl(avia) Aug(usta) Br(itannica) o 3. I CR 4. I \\ Aug(usta) Itu(raeorum) 5. (I) $\operatorname{pr}$ (aetoria) CR. \\ cohortes XIII: 1. I Alp(inorum) 2. I Thr(acum) CR 3. I Alp(inorum) 4. I Nor(icorum) 5. I \\ Lus(itanorum) 6. I Mont(anorum) 7. I Thr(acum) CR 8. I Britt(onum) $\infty$ 9. II Ast(urum) et
}

his death? But very similar gravestones were made until the middle $2^{\text {nd }}$ century, cf. TitAq 668 . I think it is not impossible to date this example to the 130s; if it were so, the deceased soldier would have done all his service in Aquincum, save for the campaign where he died.

9 In Pannonia, the first datable appearance of the cohors I Campanorum voluntariorum is known presently from 143 AD (RMD IV 266). In spite of that fact, it is likely it was here in the 120s already, based on the name of one of its praefecti (CIL VI 3520): this person was praefectus cohortis in Germania too, roughly in this period (according to Lörincz 2001, n. 287 at the end of Trajan's reign).

10 According to the former opinions, the cohors VII Breucorum was brought here only in the Antonine period. Recently we have a proof that it was garrisoned in Pannonia Inferior in the early Hadrian period too (AE 2010, 1861: 126 AD). We must mention that this is a sorely fragmentary diploma, and the suppletion of the text, widely accepted since its first publication (Eck, Pangerl 2010), is inevitably mistaken, because it follows the scheme of the presently discussed diploma from $135 \mathrm{AD}$. It cannot be correct, because the cohors VII Lusitanorum was surely in Africa in 127 and 128/9 AD (RMD V 368, 373). One thing is certain, the cohort could not jump from Africa to Pannonia and back again, to and fro almost every year. As for the suppletion of the name I Brittonum, we shall discuss the situation in the following passages. 
Call(aecorum) 10. II Aug(usta) Thr(acum) 11. III Batav(orum) o 12. III Lus(itanorum) 13. VII Lus(itanorum).

Except for that, the cohors VII Lusitanorum was never mentioned in Pannonia, it did non leave any epigraphic traces. In spite of this fact, B. Lőrincz accepted the cohort as a real Pannonian unit, ${ }^{11}$ in all probability mistaken. This troop was garrisoned in Africa in the years before; ${ }^{12}$ after $135 \mathrm{AD}$ we never find it in Europe. Could it be brought here temporarily as a substituting unit? It was quite irrational to transfer a cohort or part of a cohort all the way from Africa to Pannonia, for only two years. The name appears in the diploma on the spot where we expected the cohors VII Breucorum, and the name of the cohors III Lusitanorum stands before it (as usual). The palaeographic situation is quite clear: the clerk made a mistake, he contaminated the names III Lusitanorum and VII Breucorum to VII Lusitanorum, while the real Lusitan cohort lived its everyday life in Africa as ever.

The other possibility is cohors I Brittonum; one thing is questionable, whether it was garrisoned here for a longer time, against our former knowledge, in the Hadrian era, or it was disposed here only temporarily, for the years of the war.

Now a cohors I Brittonum was attested in Pannonia (since Trajan with the name of Ulpia Brittonum). It was the garrison troop of Vetus salina, ${ }^{13}$ but in the Second Dacian War it left for Dacia, ${ }^{14}$ and remained there, at least according to our present knowledge, almost continuously attested until Marcus' reign. ${ }^{15}$ We did not know any other cohors Brittonum in Pannonia until now, not in far later periods either. Evidently such a unit reappears in Pannonia Inferior only once and only for a short period, in a transitory way - and evidently it is the last year of the war. It is not I who first took note of this appearance, B. Lörincz did it first, ${ }^{16}$ but he did not endeavour to localize the troop. However it is not improbable that it was brought here to fill the gap left by the units disposed to the Judaean war in these years. It is more questionable, from where. There are three possibilities. In the Danube region several cohortes I Brittonum exist in the first half of the $2^{\text {nd }}$ century. One is that which was transferred from here, stationing in Dacia Porolissensis. ${ }^{17}$ Another cohors I Brittonum (Augusta Nervia Pacensis) is in Dacia Inferior from about the beginning of Hadrian's reign doubtless to the middle century, ${ }^{18}$ possibly and credibly to the $3^{\text {rd }}$ century. ${ }^{19}$ And there is a less known unit with

11 Lőrincz 2001, 38.

12 RMD V 368 (127), 373 (128/9); AE 2011, 1807 (127).

13 RMD V 339 = AE 1999, 1258.

${ }^{14}$ It appears in Dacia already in 106 AD: RMD V 343 = AE 2002, 1741.

15 CIL XVI 163; RMD III 148 (110 AD), V 351 (119 AD), I 21 (123 AD); AE 2009, 1177 (128 AD); RMD I 35 (133 AD); AE 2011, 1073, 2012, 1951 (probably after 135 AD); RMD V 404 (151 AD); CIL XVI 110 (159 AD), and so on continuously. For its stationing in Dacia in the $2^{\text {nd }}$ century, see comprehensively Piso, Deac 2016, 66.

16 Lőrincz 2001, n. 507.

17 The identity of the cohort is proven not only by the time sequence, but by the fact that Pannonianborn soldiers were dismissed in Dacia (RMD V 404 - moreover he was recruited later from the earlier recruiting field, being enlisted in the middle 120s!)

18 RMD I 39 (140); AE 2011, 1791 (146).

19 Probably the same troop was mentioned in AD 200, with an imperial epithet Aurelia: IDR II 174 = CIL III 14485a. 
the name of cohors I Aelia Brittonum, probably appearing from the Antonine period, ${ }^{20}$ but known mostly from the first half of the $3^{\text {rd }}$ century.

B. Lőrincz did not form an opinion of this question either. ${ }^{21}$ Naturally the question is very difficult: we know about the Dacian presence of two troops almost continually, but the existing data do not exclude an interim disposition for about two years. The cohors I Ulpia Brittonum was in Dacia in $132 / 133$ AD, ${ }^{22}$ and about the end of Hadrian's reign too. ${ }^{23} \mathrm{~A}$ detachement for the critical years of the war, 133-135 AD is just possible, and it cannot be excluded either that only a part of the cohort was detached. ${ }^{24}$ Certainly such motion had had its military sense: a troop which knew the terrain well and had old soldiers recruited here, was most able for a temporary defence. But naturally it is by no means an evidence. The same possibility exists in the case of the cohors Augusta Nervia Pacensis Brittonum, because it was attested in Dacia in 133 $\mathrm{AD}^{25}$ and after that in 146 next time. ${ }^{26} \mathrm{We}$ can object but a poor counter-argument that this cohort lacked the expertness of the terrain.

As for the third one, the cohors Aelia Brittonum, its history is almost unknown. We do not know its origin, but the epithet makes it evident that it was established by either Hadrian or Antonine. It appears first during Antonine's reign. Of course, if Antonine was the founder, we cannot take it into account - but we do not see any real reason, why Antonine would have established a new troop in Noricum in a generally peaceful period. If it was Hadrian, he did it probably about the end of his reign (otherwise we would have heard of the troop in his years), and it is an obvious idea he might have formed a new unit then, to compensate the withdrawal of some forces during the Bar Kokhba revolt. Then, the first garrison of this unit might be Pannonia, and after the revolt it was disposed from here to Noricum, where it remained for long. It is a very suggestive supposal, but still it lacks evidence.

(We must concede, that there are sporadical mentions of another troop named cohors Flavia Brittonum, but these data are mostly dubious, ${ }^{27}$ and much dispersed in time and space. Trustworthy mentions of this unit do not occur after the Flavian era, ${ }^{28}$ therefore, in all likelihood, the unit changed its epithet after the fall of Domitian.)

${ }^{20}$ AE 2012, 1080 (145-161 AD), although it is a fragmentary diploma and the name is only probable, not certain.

21 Lőrincz 2001, 32.

22 RMD I 35.

${ }^{23}$ AE 2011, 1073 and AE 2012, 1951: they are dated with the $2^{\text {nd }}$ imperial acclamation of Hadrian. Although we have no decisive proof, probably the acclamation was due to the victory in the Bar Kokhba war, $135 \mathrm{AD}$ - by no means earlier.

${ }^{24}$ The diploma does not speak about a vexillation of a divided cohort. But we have an analogy: the cohors III Batavorum had but a vexillation in Pannonia Inferior, and only roughly a half of the existing diplomas name this half-unit as a vexillation, the others simply as a cohort.

25 AE 2009, 1832.

${ }^{26}$ AE 2011, 1791.

27 For example, CIL III $4811=11504$ (Noricum) is almost certainly a wrong interpretation, instead of (A)elia Brittonum. AE 1973, 431, CIL III 13704 are erroneously read or written in all probability. There is only one example from the $3^{\text {rd }}$ century, Italia, which seems creditable - it is a reasonable supposal that here the stone-cutter made a failure in the name, misspelling either the serial number, or Britt(onum) instead of Brit(annica), or even the imperial epithet, incorrectly remembering.

${ }^{28}$ CIL III 2024; AE 2009, 993. 
Two other questions are easier to answer than the exact identification of the troop. Where was it garrisoned between 133-135, instead of which unit? Did it leave any written monument?

\section{Garrisoning between 133-135}

As we have seen, the only surely missing troop is the cohors I Campanorum voluntaria, which was stationed certainly in Acumincum in the middle $2^{\text {nd }}$ century. For this reason, it is probable enough this troop was dislocated from Acumincum, but not probable that only this and only from here, even if all the other units are the same in these years as in the whole 130s. There are two garrisons the units of which are quite unknown in this period: those of Albertfalva and Campona. ${ }^{29}$ Evidently it were an absurd presumption that there was no known discharge from these two garrisons in the whole reign of Hadrian; in consequence, the common opinion is that these were manned with detachements of the legio II Adiutrix. For such soldiers, there is a good chance to have participated the vexillation in the Judaean war, and therefore these three camps must be taken into account, as possible transitory garrisons for a cohors I Brittonum.

The so-called topographic order of the diplomas will not help us. On one hand, it was never used without exceptions: a few diplomas totally violate the order from an unknown reason. ${ }^{30} \mathrm{On}$ the other hand, this topography does not date back before 140 $\mathrm{AD},{ }^{31}$ some segments were arranged at random in the diplomas before that (unless in the 130s troops were constantly dislocated within a province, without other traces left). Certainly the above discussed diploma has such segments: anyway the cohortes I Lusitanorum, I Montanorum, III Lusitanorum are written in an unreasonable order. ${ }^{32}$ The cohors I Brittonum is mentioned formally in the position where the later diplomas locate the cohors VII Breucorum, but the VII Breucorum appears too, at the end of the list, and therefore it was present somewhere in the province. Evidently the recently arrived troop was written in a random position; if its garrison was a camp otherwise unmentioned in diplomas (that means, Albertfalva/Campona), it is no great wonder.

${ }^{29}$ The garrison troop of Lugio was not identified by B. Lőrincz, but only because he did not accept that the cohors VII Breucorum was here before 138. This mistake occurred because of the phantom presence of the cohors VII Lusitanorum. Ulcisia is a still debated garrison; T. Nagy and after him B. Lőrincz put here the cohors I Thracum CR in the Hadrian era, based on their brick stamps (Nagy 1973, 41; Lőrincz 2001, 42). I think they were quite right, but it is not universally accepted; anyway there is scarcely any other place left for this cohort.

${ }^{30}$ AE 2009, 1079 (RMD II 103 is faultless, from the same year), CIL XVI 112, 113.

31 The topographic order becomes (mostly) consistent from 148 AD, but, according to Zs. Visy (Visy $1986,507,510)$, we may take it into account earlier too. That is evidently true for the diplomas RMD V 397, AE 2008, 1116 (144 and 146 AD); but the system of the diploma CIL XVI 175 from 139 AD is certainly partially disordered.

32 I do not think we must count with a dislocation within the province, because this variant is much alike to the atypical variant from $157 \mathrm{AD}$ (AE 2009, 1079); now we know the correct positions of 157 , which are much different. The similar atypical variants originate probably from the same source, that is, a non-topographical tradition of the clerks. 
2. Inscriptions left by the transitory troop

A negative answer seemed far more likely to our question, because all the possible units had their weak side in leaving inscriptions. The cohors Nervia Pacensis is known almost exclusively from military diplomas. ${ }^{33}$ As for the cohors Ulpia, one gravestone remained in Pannonia from the beginning of the century ${ }_{3}{ }^{34}$ and three other sure data from Dacia, ${ }^{35}$ where it was stationed far longer. Several altars of the cohors Aelia are known from the $3^{\text {rd }}$ century, but no lapidary monument from the $2^{\text {nd }}$ century until know.

Beyond all hope, yet there is an inscription from Aquincum which cannot be dedicated but by one of these cohorts. It is a short and almost unintelligibly abbreviated inscription of a poorly formed altar, consequently it was never accurately deciphered..$^{36}$ The poor elaboration is not strange: we must suppose the cohort was never accustomed to erecting stone monuments or even to writing. They must have had no competence to order a stone-cutting work of high standards, in spite of the fact that it was a communal altar of the cohort.

The bare letters of the inscription were easily legible:

\section{INVICTO \\ DEVO \\ V S L M \\ PBOCO \\ M CO I B}

Triangular interpunctions appear in the verses 4-5 but inconsequently.

Although all the former solutions contained misinterpretations, it was at least guessed since Mommsen, ${ }^{37}$ that the abbreviations refer to a well-known Mithraic formula, pro bono communi. ${ }^{38}$ The more recent solution of the TitAq, with a proper name in v. $4,{ }^{39}$ although theoretically possible, yet not convincing, because a dialectal variation is needed, which was rare in Pannonia, mostly known from the $4^{\text {th }}$ century (Voconius $>$ Boconius). ${ }^{40}$ This gentilicium is known from West Pannonia, ${ }^{41}$ but rare; an abbreviated form were not intelligible, even to an antique reader. Not to mention a supposed abbreviated cognomen CO(- - ), the solution of which is missing from the TitAq too.

\footnotetext{
33 Not counting here the building inscription IDR II 174. Here the unit bears the imperial epithet Aurelia, maybe it was re-established.

34 RIU 1457, Vetus Salina.

35 Piso 2015, 209-210, n. 29; ILD 685, 697. (The name of the unit is only a reconstruction in the building inscription ILD 656.)

${ }^{36}$ Its last publication was TitAq 78, with references to all former editions.

37 CIL III 3476: num latet in extremis pro communi bono?

${ }^{38}$ It was in use in Aquincum, cf. TitAq 186.

39 TitAq 78: P(ublius) Bo(conius) Co(- - -).

40 Fehér 2007, 386. The form Boconius is known only from Rome, with one exception (CIL XII 1940, Gallia Narbonensis).

${ }^{41}$ CSIR (Österreich I-III), Suppl. 1, 715, P(ublius) Voc(onius) Valens.
} 
If v. 4 contains a Mithraic formula, surely v. 5 must refer to them who dedicated the altar; since there is a clear numeral note I, it had to be a military unit. But as far as we know there was never any cohors $I$ B (- - -) in Aquincum or the neighbourhood. Three such units were known from Pannonia up to now: the above discussed cohors $I$ Brittonum in Vetus salina, a cohors I Batavorum in Solva, and a cohors I B(ritannorum) in Rittium. ${ }^{42}$ Theoretically, we may suppose that a cohort from Solva or Vetus salina erected an altar in Aquincum, but they were stationed there too early: ${ }^{43}$ it were a bold venture to date the little altar to the turn of the $1^{\text {st }}-2^{\text {nd }}$ centuries. It is quite another thing if the cohors I Brittonum reappears in 135.

The characteristics of the monument do not contradict a date of around the middle of the $2^{\text {nd }}$ century, even if the edition of TitAq puts it to the $3^{\text {rd }}$ century - in an assertoric style without argumentation; indeed one cannot find any arguments for a late date. There are practically no linguistic or palaeographic clues to datation (the linguistic variant devo is unique in Pannonia and consequently not appliable). The only existing clues are the formal criteria of the stone-work. Similar abaci (a roughly triangular pediment between simple polylobe rosettes) are unfrequent in Aquincum as much as similar proportions of the pillar of the altar and the cymatium. It may be characteristic when both occur together: and such examples appear in Aquincum and its territory mostly in altars which must be dated to the $2^{\text {nd }}$ century. ${ }^{44}$ Even distantly parallelous examples are more frequent in the $2^{\text {nd }}$ century, ${ }^{45}$ including those of similar proportions, the pediments of which are different. ${ }^{46}$ That makes likely enough that this altar must be attributed to the $2^{\text {nd }}$ century. Those parallels which can be exactly dated originate from the 160s: TitAq 38, 83, 92, but according to Á. Szabó's publication in the TitAq, 92 contains a palimpsest inscription. Consequently, the sculptural work of the altar must be some decades earlier. In Sirmium, the altar Mirković 1994, n. 49 can be dated back to the first half of the century. Regrettably, that period is so poorly attested in Pannonia Inferior in terms of sacral monuments, that it is no great wonder we knew no more examples until now. Thus it is really possible and indeed probably to date the discussed inscription to the 130 s or 140 s.

Regarding all these facts, I read the inscription as follows:

\section{Invicto \\ $d e\{v\} o$ \\ $v$ (otum) \\ $p$ (ro) bo(no) co(mmuni) \\ 5 m(ilites) co(hortis) I B(rittonum).}

${ }^{42}$ Lőrincz 2001, 29-32.

43 The cohors I Batavorum remained until 118/119, the dislocations made after the death of Trajan: Lőrincz 2001, 81-82, 87-89. And they were in Pannonia Superior. Why would they not have gone better to Brigetio for sacrificing to Mithras?

${ }^{44}$ TitAq 38 (162-166), 101; RIU 834 (end of $2^{\text {nd }}$ century), 1491 (?). Those beneficiary altars from Sirmium which have closer resemblances are all from the $2^{\text {nd }}$ century (Mirković 1994, n. 36, 42, 49 [first half of the century], 70, and mostly the further resembling ones too: n. 24, 25, 36; for the datings see ibid. p. 348).

45 TitAq 102, 245; RIU 1298.

46 TitAq 83 (162-166 AD), 92 (162-166 AD, but the inscription is secondary), 400 (if it is true that it is a primary inscription of a palimpsest). 
The imperial epithet is missing, but it is not unprecedented, whichever of the three possible cohorts is mentioned. As for the cohors I Ulpia Brittonum, its name was sometimes abbreviated exactly so, $C I B$, similar even in the form of the number note. ${ }^{47}$ Naturally, it is no decisive argument, since the other two units are so poorly attested.

As far as we know, there was no other occasion in the whole history of the three cohorts when a communal altar was erected. Probably it was an event of great importance. Although a dedication $p$ (ro) bo(no) co(mmuni) is typical for the Mithras cult, this time it might have a special meaning: an inaugurational offer for the welfare of the cohort in a new garrison or even when it was established, and/or for the successful end of the war, which might bring the end of the out-of-home garrisoning too. It is a pity that the cohort could order a monument of such inferior quality, but they were far from expertness in literacy. Probably they did not recognize the low quality, and the stone-cutters of Aquincum would not help the newcomers in an altruistic way, to win the bliss of Mithras.

What can be our conclusion, which cohort transferred was and where?

The findspot of the altar speaks for a troop in the relative neighbourhood. It seems to have been futile to travel from Acumincum to Aquincum for the sake of a cultic object of the huge dimension of $58 \mathrm{~cm}$. On the contrary, such a travel could be quite easily done from Campona or Albertfalva. Either of the two garrisons is possible, more probably Albertfalva, because Campona was later used as an ala camp, it were unreasonable to station a cohort or even a part of a cohort here this time.

It is unlikely that the unit was the cohors Nervia Pacensis: a) we could not explain the lack of the epithet, b) there is no acceptable reason why this troop were transferred.

The cohors I Ulpia is far more acceptable: a) we know the exact analogy of the name form, b) it was reasonable to bring them here, from a military aspect: the older soldiers were acquainted with the terrain. This reason is not quite flawless, because such translations do not fill the gap left by a unit but move it to another province; but if several units left for Iudaea from Brigetio to Albertfalva, here the weakening of the defence system was unproportionally greater and had to be mended, even at the cost of the presently peaceful Dacia Porolissensis. ${ }^{48}$ Moreover, possibly we may suppose the transposition of half a cohort too.

Yet the most likely unit of the three remains the cohors I Aelia. Then we may suppose a brand-new troop established for the sake of reinforcement, in order of filling the gap, while the well exercised original cohors of Albertfalva went to war (we must not forget: if it was a legionary vexillation, Hadrian personally knew them since his governorship). When the war was won, the original unit came back, and the cohors I Brittonum, if it was a Dacian troop, went back too; if it was the cohors Aelia, a new

47 Piso 2015, 209-210, n. 29. Nevertheless, the name was abbreviated differently in brick stamps: Piso, Deac 2016, 66-69.

${ }^{48}$ It is unlikely Hadrian would have left a gap open just on the Sarmatian frontier! (By the way, it is another argument against the cohors Nervia Pacensis, which was stationed on the other Sarmatian frontier zone.) 
garrisoning place was found for them, in all likelihood in Noricum, because we hear of its existence nowhere but in Noricum since the reign of Antoninus Pius.

Our conclusion is that both the military diploma and the inscription make more probable the interpretation and date of each other, according to which the inscription was erected between 133-135, and both prove that one or more than one units were brought from Pannonia to the oppression of the Bar Kokhba revolt (most probably a troop from Albertfalva too, perhaps as part of a vexillation of the legio II adiutrix), and a new cohort was transferred or indeed newly established as a transitory solution for the problem of the weakened Pannonian frontier.

\section{Bibliography}

Alföldi 1956

Barkóczi 1958

Bíró-Sey 1977

Eck, Pangerl 2010

Fehér 2007

Fitz 1986

Grüll 2017

Lőrincz 2001

Lőrincz 2010a

Lőrincz 2010b

Mirković 1994

Mócsy 1959

Mor 2016

Nagy 1973

Piso 2015

Piso, Deac 2016
M. R. Alföldi, Beiträge zur Frage der Cistophori Kaisers Hadrian, FolArch, 8, 1956, 89-95.

L. Barkóczi, Hadrianus-kori éremlelet Brigetióból [A coin find of Hadrian's era from Brigetio], Numizmatikai Közlemények, 56-57, 1957-1958, 19.

K. Bíró-Sey, Coins from Identified Sites of Brigetio and the Question of Local Currency, Régészeti Füzetek II 18. MNM, Budapest 1977.

W. Eck, A. Pangerl, Neue Diplome für die pannonischen Provinzen, Tyche, 25, 2010, 23-37.

B. Fehér, Pannonia latin nyelvtörténete [The linguistic history of Latin Pannonia], Károli Egyetemi Kiadó, Budapest 2007.

J. Fitz, Geschichtliche Probleme des Forums von Gorsium, Oikumene, 5, 1986, 329-369.

T. Grüll, Ézsau három könnycseppje [The three tears of Esau], DSc theses, Budapest 2017.

B. Lőrincz, Die römischen Hilfstruppen in Pannonien während der Prinzipatszeit. Teil I: Die Inschriften, WAS 3, Wien 2001.

B. Lőrincz, Legio I adiutrix. In: B. Lőrincz, Zur Militärgeschichte der Donauprovinzen des römischen Reiches, HPS 19, 1, Budapest Debrecen 2010, 145-157.

B. Lőrincz, Legio II adiutrix. In: B. Lőrincz, Zur Militärgeschichte der Donauprovinzen des römischen Reiches, HPS 19, 1, Budapest Debrecen 2010, 158-174.

M. Mirković, Beneficiarii consularis in Sirmium, Chiron, 24, 1994, 345-404.

A. Mócsy, Die Bevölkerung von Pannonien bis zu den Markomannenkriegen, Budapest 1959.

M. Mor, The Second Jewish Revolt. The Bar Kokhba War, 132-136 $C E$, The Brill Reference Library of Judaism 50, Brill, Leiden Boston 2016.

T. Nagy, Ulcisia Castra, Budapest Régiségei, 23, 1973, 39-58.

I. Piso, Studia Porolissensia VI, ActaMP, 38, 2015, 193-214.

I. Piso, D. Deac, Inscriptiones Daciae Romanae Appendix

I. Inscriptiones laterum Musei Zilahensis, Cluj-Napoca 2016. 
Strobel 1988

Visy 1986
K. Strobel, Bemerkungen zur Dislozierung der römischen Legionen in Pannonien zwischen 89 und 118 n. Chr., Tyche, 3, 1988, 193-222. Zs. Visy, Die kryptotopographische Truppenaufzählung in den Auxiliardiplomen von Pannonien. In: W. Eck, H. Wolff (eds.), Heer und Integrationspolitik. Die römischen Militärdiplome als historische Quelle, Theiss, Stuttgart 1986, 482-517.

Bence Fehér

Károli Gáspár University of the Reformed Church, Budapest guy_devere@)hotmail.com 



\title{
DIE DEDIKATION EINER STATUE PLINIUS D. J. DURCH DIE VERCELLENSES: ZU CIL V 5667
}

\author{
WERNER ECK
}

Zusammenfassung: Der kurze Beitrag zeigt, dass die Inschrift unter einer Ehrenstatue, die die Bürger von Vercellae Plinius d. Jüngeren aufstellten (CIL V 5667), einen vollen cursus honorum enthielt, in dem die Ämter als Prätor und Volkstribun nicht gefehlt haben. Möglicherweise handelte es sich um eine statua equestris, die vielleicht auf einem Landgut des Senators errichtet wurde.

Schlüsselwörter: Plinius d. Jüngere; Vercellae; Ehrenstatue; CIL V 5667.

Abstract: The dedication placed on a statue of Pliny the Younger by the Vercellenses: CIL V 5667. This short article shows that the inscription placed under an honorary statue of Pliny the Younger dedicated by the citizens of Vercellae (CIL V 5667) contained a full cursus honorum in which the offices of praetor and tribunus plebis were not missing. It may have been a statua equestris, possibly erected on the senator's estate.

Keywords: Pliny the Younger; Vercellae; honorary statue; CIL V 5667.

Rezumat: Articolul demonstrează faptul că inscripţia plasată sub o statuie onorifică a lui Plinius cel Tânăr, dedicată de cetățenii din Vercellae (CIL V 5667), conţinea un cursus honorum complet, din care nu lipsesc funcțiile de praetor şi tribunus plebis. Trebuie să fi fost o statua equestris, ridicată probabil pe una din proprietăţile senatorului.

Cuvinte cheie: Plinius cel Tânăr; Vercellae; statuie onorifică; CIL V 5667.

Beim heutigen Ort Cantù rund $9 \mathrm{~km}$ süd-südöstlich von Como wurde eine Inschrift entdeckt, die einst unter einer Statue des jüngeren Plinius zu lesen war. Der Text steht auf einer Platte, die nicht in situ, sondern verbaut gefunden wurde. Sie ist in drei Fragmente zerbrochen, die partiell aneinander anschließen. Heute befindet sich die Platte im Besitz der Civiche Raccolte Archeologiche di Milano (Inv. Nr. A 0.9.28125). Die Maße der Platte betragen in der Höhe $126 \mathrm{~cm}$, in der Breite $71 \mathrm{~cm}$, und in der Dicke 14.5-15 cm. Ein Abguss davon befindet sich im Museum von Como, der hier auch abgebildet wird (Abb. 1). ${ }^{1}$

Mommsen hat die drei Fragmente, in die die Inschrift zerbrochen war, selbst gesehen, wie Unterlagen in der Arbeitsstelle des CIL in Berlin zeigen (Abb. 2). ${ }^{2}$

\footnotetext{
${ }^{1}$ Für die Informationen zu den Maßen sowie zum gegenwärtigen Aufbewahrungsortes der Inschrift, vor allem aber für die Erlaubnis, hier einige der Photos abbilden zu dürfen, danke ich Antonio Sartori und Serena Zoia (beide Mailand), die mir in bereitwilligster Weise geholfen haben.

2 Marcus Dohnicht (CIL Berlin) danke ich für die Übersendung der Scheden Mommsens zu der Inschrift.
} 


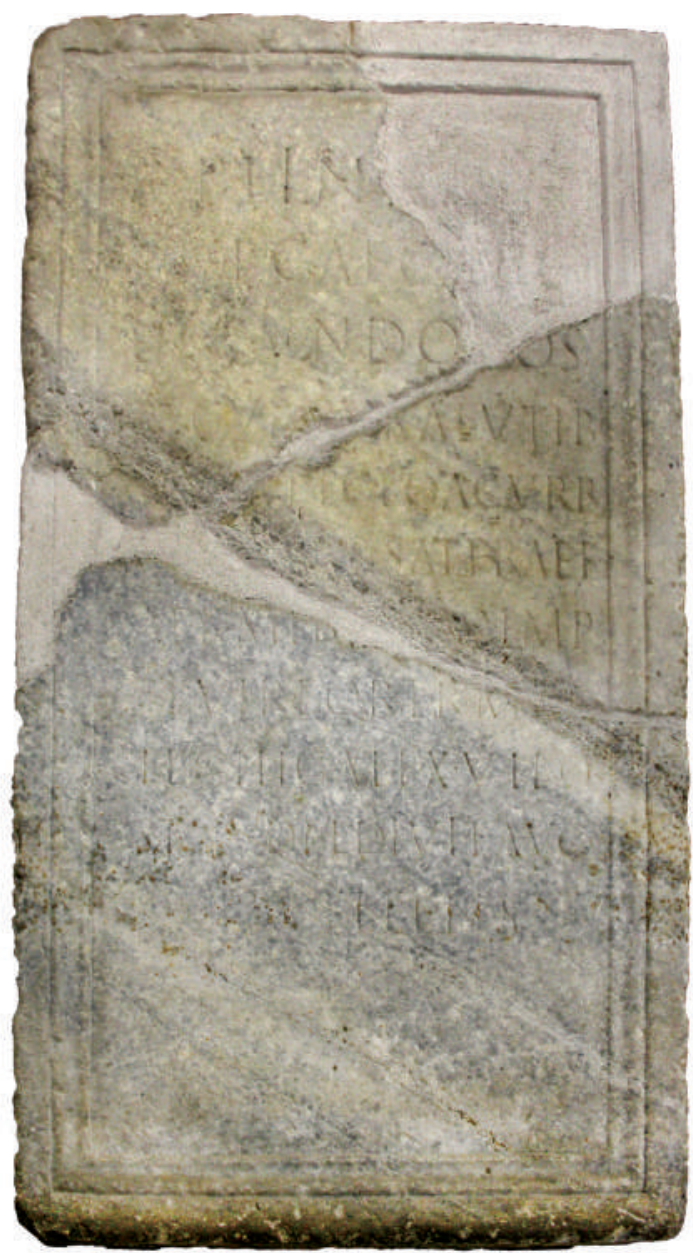

Abb. 1

In Band V des CIL hat er den Text unter der Nr. 5667 publiziert, die die Grundlage bildet für alle weiteren „Publikationen“ der Inschrift, die nirgends in der Forschung verändert wurde:

C(aio) Plini[o L(uci)f(ilio)]

Ouf(entina) Caec[ilio]

Secundo [c]o(n)s(uli),

augur(i), $\operatorname{cur}$ (atori) alv(ei) Tib(eris)

e[t ri]p(arum) et cloac(arum) urb(is),

p[raef(ecto) a]er(arii) Sat(urni), praef(ecto)

aer(arii) mil[--], ${ }^{3} q$ (uaestori) Imp(eratoris),

sevir(o) eq(uitum) $R$ (omanorum), ${ }^{4} \operatorname{tr}$ (ibuno) $m[$ i]l(itum)

\footnotetext{
3 Teilweise ergänzt als mil[itaris oder it(aris)].

${ }^{4}$ Übersehen wurde bisher meist, dass in der großen Inschrift des Plinius (CIL V $5262=$ ILS 2927) in Zeile 7 nach sevir equitum [Romanorum] die Zeile nicht gefüllt ist. Dort muss man mit Sicherheit turmae .... ergänzen, wobei natürlich die Ziffer der Turma unbekannt bleibt; anderes kann hier nicht
} 
leg(ionis) III Gall(icae), Xviro

stl(itibus) iud(icandis), fl(amini) divi T(iti) Aug(usti)

Vercellens(es)

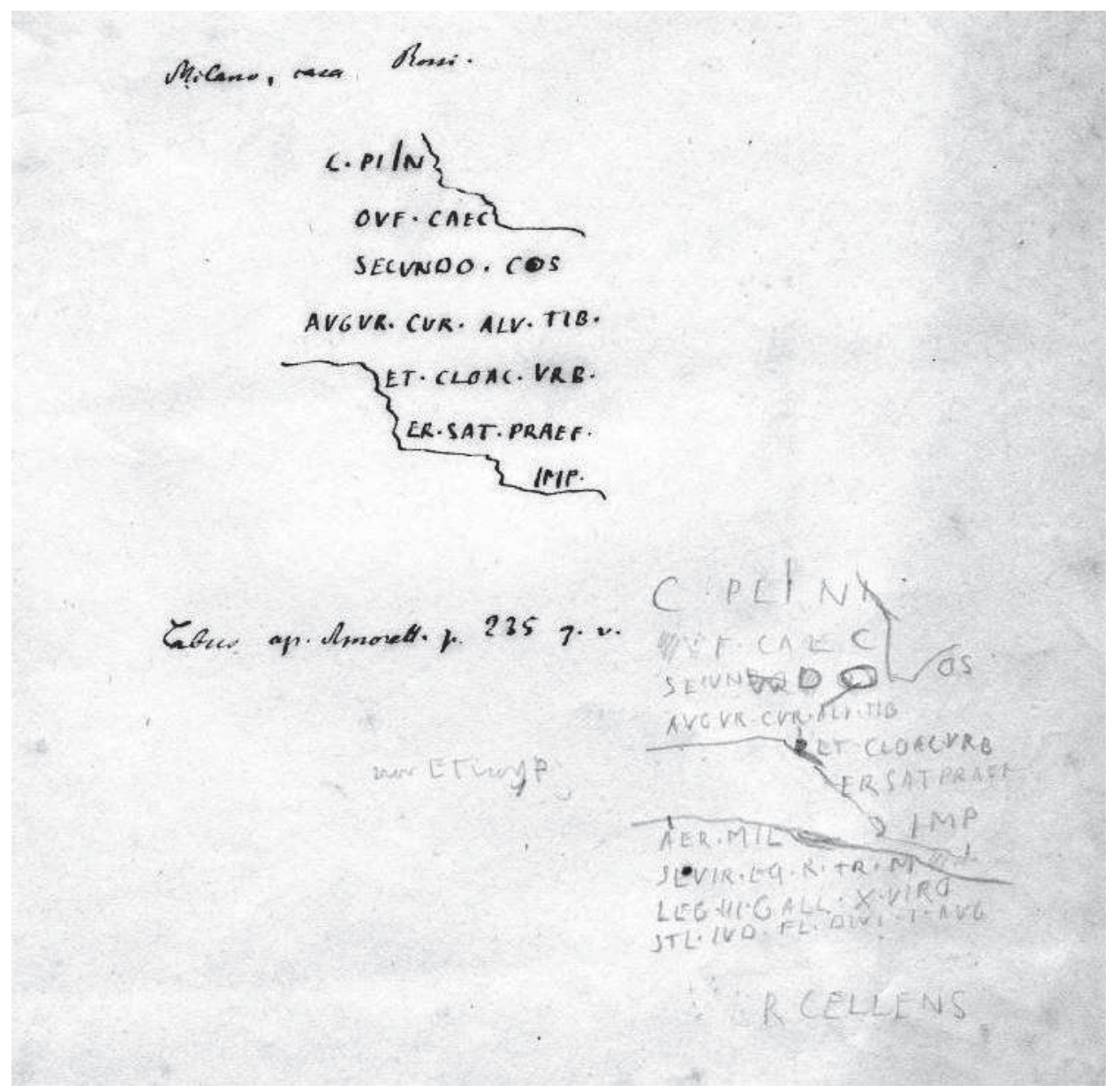

Abb. 2

Plinius erscheint in dem Text mit seinem gesamten cursus honorum, von der Funktion als decemvir stlitibus iudicandis bis zum Konsulat und der darauf folgenden cura alvei Tiberis et riparum et cloacarum urbis. Auffällig ist allerdings, dass in Zeile 7 zwischen der Präfektur über das aerarium militare und der Aufgabe als quaestor imperatoris weder Volkstribunat noch Prätur erwähnt werden, die er in domitianischer Zeit bekleidet hatte, was er selbst in seinen Briefen erwähnt. ${ }^{5}$ Angesichts der sonstigen Vollständigkeit des cursus erscheint dies sehr überraschend und nicht gerade glaubhaft.

Die Zeile weist an der Stelle, an der diese Ämter gestanden haben müssten, eine Lücke auf, weil der Stein dort zerbrochen ist, wie auch die Photos zeigen. Die Lücke

gestanden haben. G. Alföldy hat in seiner Rekonstruktion von CIL V 5262 das Wort turma eingefugt, siehe G. Alföldy, Städte, Eliten und Gesellschaft in der Gallia Cisalpina, Stuttgart 1999, 243.

5 Plin. Ep. 7, 16, 2. 
zwischen MIL und Q IMP hat Mommsen offen gelassen. Man könnte natürlich daran denken, die Abkürzung MIL mit millita(ris)] oder sogar mil[itaris] zu ergänzen und damit die Lücke zu füllen. Doch ist wenig wahrscheinlich, dass man bei der Präfektur des aerarium militare so verfahren darf, während in der vorausgehenden Zeile bei der Präfektur des aerarium Saturni nur SAT geschrieben wurde. Zumal bei einer Lücke verbietet es sich, solch unterschiedliche Abkürzungen anzunehmen. Zudem ist auch sonst keines der Ämter vollständig oder fast vollständig ausgeschrieben; lediglich bei augur(i) fehlt nur ein Buchstabe, sonst ist die Abkürzung stets deutlich stärker. Damit darf man davon ausgehen, dass dort nur die Abkürzung MIL stand. ${ }^{6}$

Es lässt sich mit recht großer Wahrscheinlichkeit zeigen, dass Volkstribunat und Prätur keineswegs gefehlt haben. Aus den in der Arbeitsstelle des CIL in Berlin vorhandenen Scheden zu dieser Inschrift ergibt sich das sehr deutlich. Mommsen hat natürlich das seltsame Fehlen der beiden Ämter bemerkt, aber aus Platzgründen die erwartbare Ergänzung von Prätur und Volkstribunat vermieden. Er schreibt im textkritischen Apparat: l. 7, quod requiritur supplementum sex minimum litterarum PR.TR.PL spatium excedit.

In der 7. Zeile der Inschrift ist am Anfang der Rest der Stellung als Präfekt des aerarium militare erhalten: AER MIL; darauf folgt eine deutliche Lücke, an deren Ende der Rest eines Q steht, worauf IMP folgt (siehe Photo). Gerade das Amt des Quästors ist hier so kurz wie möglich, nur mit einem einzigen Buchstaben angeführt, während das Amt in seiner von ihm selbst verfassten, vermutlich in seiner Bibliothek oder den Thermen in Comum angebrachten Inschrift in der Form quaestor Imp (eratoris), also voll ausgeschrieben, erscheint. ${ }^{7}$ Wenn aber die Quästur, bei der er mit dem Kaiser verbunden war (dass es Domitian war, wird natürlich nach dessen Ermordung nicht gesagt), so stark abgekürzt wurde, dann ist das erst recht bei Prätur und Volkstribunat möglich. Beide Ämter kommen auch in starker Abkürzung vor. Praetor ist als $\operatorname{pr}$ (aetor) sehr häufig nachweisbar, einmal sogar als $p$ (raetor), freilich in Verbindung mit $k$ (andidatus). ${ }^{8}$ Das Amt des Volkstribuns wird oft in der Abkürzung tr(ibunus) pl(ebis) angeführt, zweimal findet sich sogar die Abkürzung $p$ (lebis), allerdings verbunden mit trib(unus). ${ }^{9}$ Kürzt man die beiden Ämter in der Form PR TR PL oder TR P ab, dann kann man diese Buchstaben durchaus in die Lücke einsetzen. Dass diese Abkürzungen eher ungewöhnlich sind, ist nicht zu leugnen; doch kann das weniger Anstoß erregen als das motivlose Fehlen der beiden Ämter in einer Aufzählung, die ansonsten alle Funktionen sogar detailgenau aufführt. Dass in der

${ }^{6}$ Die Vercellenses haben den Text des cursus honorum wohl direkt von Plinius erhalten. Dass sie die beiden Ämter bewusst weggelassen hätten, ist völlig unwahrscheinlich. Und dass der Steinmetz sie nicht aus Unachtsamkeit vergessen haben kann, zeigt die Lücke, die zwischen MIL und Q IMP bestand. Dort muss also etwas gestanden haben.

7 CIL V 5262 = ILS 2927. Ähnlich war es wohl auch in CIL XI 5272. Zum Typus der Inschrift und zum Aufstellungsort W. Eck, Die große Pliniusinschrift aus Comum: Funktion und Monument. In: A. Bertinelli, A. Donati (Hrsg.), Varia Epigraphica, Faenza 2001, 225-235; siehe idem, Die Inschrift: Fragment einer Kultur. In: Acta XII Congressus Internationalis Epigraphiae Graecae et Latinae, Barcelona 2007, 449-460.

8 CIL VI 1418 = ILS 2941.

${ }^{9}$ CIL III 6154 = ILS 1174; EDCS-64800465. 
Lücke noch ein Text gestanden haben muss, wird auch unmittelbar deutlich, wenn man die Inschrift in der bisher üblichen Form, also ohne Prätur und Volkstribunat, in Kapitälchen umsetzt. Diese Zeile wäre die bei weitem kürzeste im gesamten Text (die ersten drei Zeilen sind mit weiterem Abstand und größeren Buchstaben geschrieben und deshalb irrelevant):

\author{
AVGVR CVR ALV TIB \\ ET RIP ET CLOAC VRB \\ PRAEF AER SAT PRAEF \\ AER MIL Q IMP \\ SEVIR EQ R TR MIL \\ LEG III GALL X VIRO \\ STL IVD FL DIVI T AVG \\ VERCELLENS
}

Es spricht also alles dafür, dass beide Ämter in diesem titulus angeführt waren, wenn auch in sehr starker Verkürzung, die nicht genau angegeben werden kann. Das gewinnt nun noch mehr Wahrscheinlichkeit, weil auf einer Photographie des Originals, die ich Serena Zoia verdanke, nach MIL noch ein kleiner Teil einer senkrechten Haste zu erkennen ist (Abb. 3).

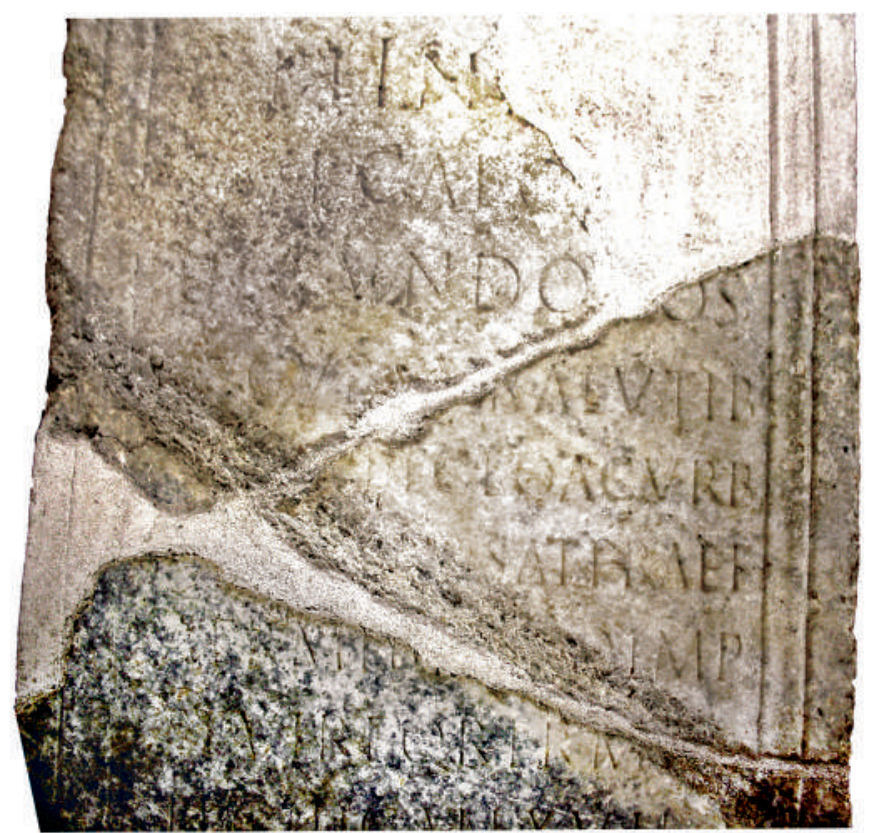

Abb. 3

Man könnte zwar behaupten, dies sei der Rest eines I, nämlich die Fortsetzung von MIL zu mili[taris]. Doch dies ist, wie schon ausgeführt, aus dem Gesamtbefund des Textes, wie er auf dem Stein präsentiert wird, höchst unwahrscheinlich. Der Rest sollte vielmehr zu dem anlautenden $\mathrm{P}$ von praetor gehören. Zeile 7 darf somit 
in folgender Weise ergänzt werden: aer(arii) mil(itaris), $p[r$ (aetori), $\operatorname{tr}$ (ibuno) pl(ebis) oder $p$ (lebis),] q(uaestori) imp(eratoris). Die genauen Abkürzungen beider Ämter bleiben notwendigerweise unsicher.

Da nunmehr dank der Hilfe von Serena Zoia und Antonio Sartori die Maße der Inschrift bekannt sind, ergibt sich noch eine weitere, nicht unwichtige Folgerung für das statuarische Monument. Der Text steht nicht, wie man vielleicht erwarten könnte, auf einer vollausgearbeiteten Basis, auf der sich einst eine Statue erhob, er steht vielmehr auf einer Tafel, die 14.5-15 cm dick ist. Darauf allein kann aber keine Statue Platz gefunden haben. Die notwendige Standfläche lieferte erst die eigentliche Basis, der die Platte mit der Inschrift vorgeblendet war. Inzwischen hat man erkannt, dass nicht selten solche Platten mit einer Dicke zwischen 10 und $25 \mathrm{~cm}$ zu Reiterdenkmälern, statuae equestres, gehörten, deren Basis gemauert war oder aus einem längeren Block bestand..$^{10}$ So könnte es sein, dass die Bewohner von Vercellae Plinius, der in ihrer Gemeinde den Flaminat des divus Titus übernommen hatte, in besonders herausragender Weise geehrt haben, nicht nur mit einer statua pedestris. Ob es ein besonderes Motiv gab für diese Ehrung, sagt der Text - wie üblich in dieser Zeit - nicht.

Die Platte wurde in Cantù gefunden; der Ort ist heute auf der Straße knapp $13 \mathrm{~km}$ süd-südöstlich von Como entfernt. Warum die Bewohner von Vercellae Plinius dort ehrten, und nicht in Comum oder in seiner im heutigen Bellagio gelegenen villa am lacus Larinus, ist dem Text nicht zu entnehmen. Doch ist es keineswegs singulär, wenn eine Gemeinde einer verdienten Person eine statuarische Ehrung außerhalb eines städtischen Zentrums errichtete. Da Senatoren über größeren Landbesitz verfügen mussten, waren die Landgüter nicht selten auch Aufenthaltsorte für ihre Besitzer, die deshalb auch diese Anwesen entsprechend ausstatten ließen, auch mit Statuen und ähnlichem kulturellen Accessoires. Plinius selbst spricht davon, dass auf einem seiner Güter eine aedes Cereris stehe, die er besser und größer ausstatten wolle, unter anderem mit Säulen aus Marmor. ${ }^{11}$ Somit liegt es recht nahe, dass die Vercellenses auf einem Landgut des Plinius diese Statue errichteten. Cantù, der Fundort der Inschrift ist von Como nicht weit entfernt, weiter dagegen von Vercellae, etwas mehr als $100 \mathrm{~km}$. Die Entfernung ist allerdings kein Gegenargument. Solche Entfernungen spielten bei derartigen Ehrungen keine Rolle. Man braucht nur an die zahlreichen statuarischen Ehrungen zu erinnern, die von provinzialen Städten für Senatoren in Rom oder in deren Heimatorten errichtet wurden. Allein im nicht so weit von Vercellae entfernten Augusta Taurinorum, dem heutigen Turin, haben mindestens drei provinziale Gemeinden einem Q. Glitius Atilius Agricola Reiterstatuen errichtet. ${ }^{12}$ Gleiches ist aus dem heutigen Sirmione bekannt geworden: ${ }^{13}$ Für den

10 Siehe dazu W. Eck, Mommsen e il metodo epigrafico. In: Concordia e la X Regio. Giornate di Studio in onore di Dario Bertolini, Atti del Convegno Portogruaro 22-23 ottobre 1994, Padua 1995, 107-112; ders., Tradition and Progress. The Roman World seen through Inscriptions in the Digital Age, Digital and Traditional Epigraphy in Context. Proceedings of the Second EAGLE International Conference, Roma 2017, 13-36.

11 Plin. Ep. 9, 39.

12 Siehe CIL V 6984-6987; dazu W. Eck, H. von Hesberg, Tische als Statuenträger, MDAI (R) 111, 2004 (2006), 143-192; F. Battistoni, ZPE 169, 2009, 183-187.

13 A. Albertini, Un patrono di Verona del secondo secolo d.C.: Erennio Ceciliano. In: Il territorio 
Senator C. Herennius Caecilianus wurde dort eine Reiterstatue errichtet, und zwar durch den Dekurionenrat von Verona, der Stadt, die rund $50 \mathrm{~km}$ östlich von Sirmione liegt. Nach dem senatorischen cursus honorum wird hinzugefügt: IIIIviro i(ure) $d$ (icundo) Veronae, patrono d(ecreto) d(ecurionum). Allein durch diese Formel wird klar, dass die Ehrung nicht in Verona erfolgte, sondern außerhalb. Deshalb war es nötig gewesen anzufügen, in welcher Gemeinde Herennius Caecilianus den Quattuorvirat übernommen hatte. Eine vergleichbare Formulierung steht auch in dem Text, den die Vercellenses unter ihrer Statue für Plinius einmeißeln ließen: $f$ (amini) divi T(iti) Aug(usti) Vercellenses. Den Flaminat hatte er in dieser Stadt übernommen, nicht etwa in Mailand oder in Comum, wie man einige Male angenommen hatte. ${ }^{14}$ Ohne den Namen der Bewohner der Stadt hätte der Leser der Inschrift den Flaminat keiner Stadt zuordnen können. Wäre es ein Flaminat in Comum gewesen, hätten die Bewohner von Vercellae diese Funktion nicht einmal erwähnt; sie taten das nur, weil es ihr eigener städtischer Flaminat war.

Vermutlich hatte sowohl Herennius Caecilianus als auch Plinius denen, die die Botschaft von der Ehrung aus Verona bzw. Vercellae überbrachten, zu verstehen gegeben, wo die Statuen aufgestellt werden sollten. Warum hätten sich die Gemeinden diesem Wunsch wiedersetzen sollen? Warum diese beiden Senatoren so wie viele andere ihrer Standesgenossen es bevorzugten, ${ }^{15}$ solche Ehrenmonumente im eher privaten Bereich aufstellen zu lassen, wissen wir kaum je. Zu diesem persönlichen Bereich aber gehörten neben der domus in der Vaterstadt und in Rom auch ihre Landgüter. Plinius unterschied sich dabei in keiner Weise von seinen Standesgenossen.

Werner Eck

Universität zu Köln, Historisches Institut-Alte Geschichte, 50923 Köln Werner.Eck(o)uni-koeln.de

\footnotetext{
Veronese in età romana, Verona 1973, 439-459; G. Alföldy, Römische Statuen in Venetia et Histria, Heidelberg 1984, 253; R. Bertolazzi, V. Guidorizzi, Supplementa Italica 28, nr. 7.

${ }_{14}$ Mommsen hatte Mailand als Gemeinde erwogen, wo Plinius flamen gewesen sei (Ges. Schriften Bd. 4, 1906, 434); R. Duncan-Jones, The Roman Economy, Cambridge 1982, 19 Anm. 5 dachte an Comum. Doch siehe schon A. Andermahr, Totus in praediis. Senatorischer Grundbesitz in Italien in der Frühen und Hohen Kaiserzeit, Bonn 1998, 384.

15 Siehe z.B. die Monumente für die Fufidii Neratii, die ca. drei km nordöstlich von Saepinum gefunden wurden, siehe Andermahr (Anm. 14) 350 f.
} 



\title{
TROIS GRAFFITES SUR CÉRAMIQUE DU SITE ROMAIN D'OCNIȚA (DACIE INFÉRIEURE)
}

\author{
DAN DANA, ION TUT,ULESCU
}

Résumé : Trois graffites sur céramique du $\mathrm{II}^{\mathrm{e}}$ s. ap. J.-C. (deux en latin et un en grec) furent découverts en 2009 sur le site romain d'Ocnița (dép. de Vâlcea), en Dacie Inférieure. Ils livrent deux marques de propriété et sans doute une indication de capacité accompagnée de mentions énigmatiques.

Mots-clés : céramique ; Dacie romaine ; épigraphie ; graffiti ; Ocnița.

Abstract: Three graffiti on ceramic from the Roman site of Ocnița (Lower Dacia). Three graffiti on ceramics from the $2^{\text {nd }}$ century $\mathrm{AD}$ (two in Latin and one in Greek) were discovered in 2009 in the Roman settlement at Ocnița (Dept. Vâlcea), in Lower Dacia. These documents provide two ownership marks and, maybe, an indication of capacity with some enigmatic mentions.

Keywords: ceramics; Roman Dacia; epigraphy; graffiti; Ocnița.

Rezumat: Trei graffiti pe ceramică din sec. II p. Chr. (doi în latină şi unul în greacă) au fost descoperiți în 2009 în situl roman de la Ocnița (jud. Vâlcea), în Dacia Inferioară. Ei oferă două mărci de proprietate şi probabil o indicaţie de capacitate însoţită de menţiuni enigmatice.

Cuvinte-cheie: ceramică; Dacia romană; epigrafie; graffiti; Ocnița.

En 2009, des archéologues du Musée Départemental « Aurelian Sacerdoțeanu » de Râmnicu-Vâlcea ont mené des fouilles de sauvetage ${ }^{1}$ au point « Baraj aval » d'Ocnița (sur le territoire de la ville d'Ocnele Mari, dép. de Vâlcea), situé sur la terrasse gauche de la rivière Sărata $(\mathrm{Pl}$. I/1). En effet, les travaux effectués lors de la construction du barrage « Buridava », ainsi que l'opération d'évacuation de la terre dans la zone affectée, ont causé la destruction partielle du site, plus précisément de son niveau d'habitation. Pendant six mois (mai-octobre 2009), les fouilles, qui n'ont pu être effectuées que sur le terrain situé à l'Est du barrage (la partie Ouest étant inondée) ont mis au jour douze structures d'habitation d'époque romaine, dont deux (L. 7 et L. 12) avec des fondations en pierre (Pl. I/2-4). Elles ont livré une quantité importante de céramique - soit de production romaine provinciale (amphores, cruches, pots à une ou deux anses, gobelets, assiettes, lucernes, etc.), soit d'importation (terra sigillata, mortaria), sans oublier un pourcentage considérable de céramique de tradition locale (dace) -, ainsi que des outils et des bijoux. Les 18 monnaies de bronze et 4 d'argent, qui s'étalent de Trajan à Antonin le Pieux, avec un pic sous Hadrien, ont permis de préciser la chronologie du site ${ }^{2}$. Ont été identifiés en outre deux ateliers de forgerons,

\footnotetext{
1 Après l'écroulement de « Câmpul II de sonde » de Ocnele Mari, à l'occasion des travaux pour ériger rapidement un barrage afin de retenir la saumure. Collectif de recherche: Mariana Iosifaru, Ion Tuțulescu, Claudiu Tulugea. Nous remercions Dorel Bondoc (Craiova) pour son aide concernant la typologie des vases.

2 Purece, Tuţulescu 2016.
} 
deux fours de réduction du minerai de fer, trois fours à pain, quatre âtres et neuf habitations à structures en bois ${ }^{3}$.

Ce site romain est situé à environ $300 \mathrm{~m}$ au Nord du site dace fortifié de Cosota ${ }^{4}$ et à 7-8 km à vol d'oiseau à l'Ouest de Stolniceni, deux centres importants qui sont traditionnellement identifiés à Buridava dace, respectivement romaine ${ }^{5}$. En rapport direct avec l'exploitation du sel de la région d'Ocnele Mari ${ }^{6}$, l'une des nombreuses salines de la Dacie romaine (Pl. I/1), il a connu son apogée sous Hadrien, avant une destruction par incendie dans la seconde moitié du $\mathrm{II}^{\mathrm{e}} \mathrm{s}$., sans doute à l'époque des guerres marcomanniques.

Trois graffites sur céramique (deux en latin et un en grec) figurent parmi ces matériaux inédits; ils datent du $\mathrm{II}^{\mathrm{e}}$ s. ap. J.-C., comme l'ensemble de l'inventaire trouvé sur place. Le premier a été découvert dans la structure d'habitation L. 5 (Pl. I/4), tandis que les deux autres dans la structure L. 7, avec la fondation en pierre (ép. du mur: $0.60 \mathrm{~m}$ ). Appartenant au genre de l'« épigraphie mineure $»^{7}$, ces témoignages sur support céramique complètent l'image très fragmentée que nous avons de la diffusion des pratiques épigraphiques ${ }^{8}$ dans la province nord-danubienne. On compte ainsi des documents qui illustrent la variété de la paléographie usuelle, marquée par le recours fréquent aux caractères cursifs et par le dialogue indirect avec l'épigraphie sur pierre. Enfin, ils nous laissent entrevoir l'omniprésence de l'écriture dans le monde romain et enrichissent la connaissance de la société provinciale des sites moins connus de la Dacie Inférieure, province dont la production épigraphique connue à ce jour est plutôt pauvre $^{9}$.

${ }^{3}$ Des fragments céramiques daces et romains ont été trouvés en 1964 à Ocniţa (point « Bozasca ») (Petre 1966). Cf. aussi Tudor 1965, 19 ; 1968a, 239 ; 1968b, 367 ; Tudor 1978, 233 ; Tabula Imperii Romani. Romula - Durostorum - Tomis, Bucarest 1969, 54. Sur le site et les fouilles de 2009, voir un rapport préliminaire chez Iosifaru 2011, 88-98 et Tulugea 2012, 98-99.

${ }^{4}$ Cf. la monographie classique de Berciu 1981 et la présentation de Iosifaru 2011, 83-86.

${ }^{5}$ Le rapport avec Buridava d'époque romaine reste débattu ; voir, en dernier lieu, Dana, Nemeti 2016 , 81-89; Nemeti, Dana 2017.

6 Tudor 1958, 10 ; Macrea 1969, 307 ; Benea 2007a (sur Ocnele Mari, en partic. 42) ; Benea 2007b. Sur l'exploitation du sel dans cette région depuis l'Antiquité à nos jours, voir Schuster, Tuțulescu, Dumitrescu 2010, en part. 264 ; Purece 2016, en part. 116.

7 Au sujet des inscriptions sur vases en Dacie romaine, voir l'étude de Gudea, Cosma 1992 (29 localités ayant livré des inscriptions sur vases, dont 11 en Dacie Inférieure, 9 en Dacie Supérieure et 9 en Dacie Porolissensis). Pour quelques exemples récents, voir Ruscu, Flutur 2008 (AE 2008, 1169 = ILD II 875, marque de propriété en grec d'un légionnaire, à Berzovia) ; Dana, Gaiu, Zăgreanu 2012 (marque de propriété d'un duplicarius, à Arcobara/Ilişua (AE 2012, 1201 = ILD II 1021) ; Dana, Petruţ 2015 (marque de propriété d'un militaire d'une cohorte auxiliaire, à Buciumi); Deac 2015 (graffites de Romita et Porolissum).

8 Voir de nombreux exemples illustrés chez Reuter, Scholz 2004 et 2005. Pour les ateliers céramiques en Dacie romaine et les inscriptions, voir Pop 1994.

9 Popilian 1976, 128-131 fournissait une douzaine de graffites sur vases en Olténie romaine. Les graffites sont naturellement présents dans l'inventaire des fouilles récentes ; ainsi, des lettres et des signes isolés dans les trouvailles du balneum de Cioroiu Nou (dép. de Dolj) (Bondoc 2015, 110-111, nºs 399-411, Pl. LVII-LVIII). 


\section{Cruche portant la marque de propriété d'un certain Marius}

Cruche à une seule anse, en pâte fine de couleur brique, reconstituée à partir de plusieurs fragments, dont il manque l'extrémité inférieure ; vase typique pour l'Olténie romaine (type Popilian V.2/a), du milieu du $\mathrm{II}^{\mathrm{e}}$ s. Découverte dans l'habitation L. 5, à $1.70 \mathrm{~m}$ de profondeur. Sur la panse, parmi d'autres gribouillages, un graffite gravé après cuisson avec un stylus très fin, en position centrale, sur un périmètre d'environ 4.5 x $4.2 \mathrm{~cm}$. Ht. des lettres: $1.3-1.8 \mathrm{~cm}$. Ligature MAR. Musée Départemental d'Histoire de Râmnicu-Vâlcea, inv. no 1439 (Pl. II/1-3).

\section{Mari.}

La marque de propriété comporte quatre lettres, dont les trois premières en ligature (MAR) ; la barre oblique du $\mathrm{R}$, à caractère cursif ${ }^{10}$, a été prolongée à droite sur $3.2 \mathrm{~cm}$, étant entrecoupée par le I qui est à son tour prolongé vers le bas, sur $4.2 \mathrm{~cm}$. Il en résulte une certaine symétrie ${ }^{11}$. Ce nom au génitif, Mari, autorise un nominatif Marius; il s'agit d'un nom banal (OPEL III 59), désignant soit un idionyme pérégrin, soit le nomen, voire le cognomen d'un citoyen romain ${ }^{12}$.

En Dacie Inférieure on connaissait un petit nombre de marques de propriété sur céramique. On peut citer: dans l'important site voisin de Stolniceni, l'abréviation VAL sur la paroi d'un vase ${ }^{13}$; à Romula, un fragment de pot, après cuisson, Valeri ${ }^{14}$; dans la nécropole de Locusteni (dép. de Dolj), le graffite [V]lpius, réalisé ante cocturam sur un vase avec un médaillon en relief (Sol dans une quadriga) ${ }^{15}$.

On retrouve un graffite similaire, étant donné la banalité du nom, à Saldum (auj. Dobra), en Mésie Supérieure: sur un vase-pot, on aperçoit en effet Marị ${ }^{16}$.

\section{Marque de propriété (?) abrégée}

Fond d'un petit vas d'argile (tasse ? ; diam. $3.6 \mathrm{~cm}$ ), de couleur grisâtre, avec des traces de vernis gris foncé. Découvert dans l'habitation L. 7, à $1.80 \mathrm{~m}$ de profondeur. Graffite réalisé post cocturam, sur le fond du pied du vase, centré ; gravure assez profonde, mais négligée ; ht. des lettres: 1.2-1.5 cm. Musée Départemental d'Histoire de Râmnicu-Vâlcea, sans $n^{0}$ d'inv. (Pl. II/4-5).

\section{CEN() (?).}

\footnotetext{
10 Sur l'écriture cursive en Dacie romaine, voir Voloşciuc 2007.

${ }^{11}$ Cf. une autre marque de propriété de Cioroiu Nou, sur une meule céramique, où la dernière lettre conservée, un E cursif (à savoir, deux barres verticales), entrecoupe un $\mathrm{R}$, dans la séquence Iuli Cre[scentis] (IDR II 156 = Dana 2013-2014, 47-48 = ILD II 1028) ; les lectures antérieures étaient fautives: IVLI CTH[---] (D. Tudor) ; ...IVXICTHS... (Gudea, Cosma 1992, 207, no 4) ; Iulius C...T...H... (Pop 1994, 42).

12 Il convient d'écarter l'homonymie avec le célèbre conductor pascui et salinarum P. Aelius Marius (sur lequel voir, en dernier lieu, Dana, Zăgreanu 2013, 28-32).

13 Popilian 1976, 130 ( $\mathrm{n}^{\mathrm{o}}$ 11) et 184 ( $\mathrm{n}^{\circ}$ 397). Abréviation de Valerius ou Valens.

${ }_{14}$ Gudea, Cosma 1992, 210, no 32 ; ILD I 142.

15 ILD I 104; dans la même nécropole, une urne funéraire présente la lettre A (ILD I 103).

16 Jeremić 2009, 92 (dessin) et 98, Cat. $\mathrm{n}^{\circ}$ 257, avec la lecture fautive Mar[a].
} 
Cette abréviation d'une marque de propriété (ou d'un mot ?) reste toutefois énigmatique. En effet, après la première lettre (C), la lecture demeure incertaine: la deuxième lettre est plutôt un $\mathrm{E}$ assez cursif. Après, on aperçoit un $\mathrm{N}$, mais aussi un gribouillage qui affecte les deux dernières lettres, et qui pourrait difficilement passer pour une ligature (AN ou $\mathrm{AV}$ ). Les deux premières lettres permettent à leur tour plusieurs possibilités d'interprétation, dont l'abréviation d'un praenomen (Caius ?), mais cette éventualité est rendue difficile par l'abréviation E d'un nomen (sauf si l'on envisage Elius pour Aelius). Il est donc plus prudent de ne pas développer l'abréviation.

\section{Graffite en grec avec une indication de capacité}

Grand tesson de la paroi d'une cruche d'argile (14.2 x $11.5 \mathrm{~cm}$; ép. $0.6 \mathrm{~cm})$, à vernis rouge brique, déjà brisé dans l'antiquité. Découvert dans l'habitation L. 7, à $1.80 \mathrm{~m}$ de profondeur. Sur la paroi extérieure, recouverte de multiples points d'éclat et d'autres petits accidents, trois lignes inscrites en grec, après cuisson. Leur exécution, très soignée, imite parfois l'épigraphie sur pierre (1.3, pour les lettres ny et ypsilon, avec des apices) ; ht. des lettres : 1.2-1.4 cm (1. 2), 2-2.2 cm (1. 3, et petit omikron). Epsilon et sigma lunaires; $x i$ avec petite boucle. Signalé auparavant comme une mention de Junon $^{17}$, ce qui est inexact. Musée Départemental d'Histoire de Râmnicu-Vâlcea, $\mathrm{n}^{0}$ inv. 1477 (Pl. III/1-3).

$$
\begin{aligned}
& {[---]++[---]} \\
& \text { vac. } \xi \dot{\varepsilon} \sigma \tau[\alpha \mathrm{l}-] \\
& \text { vac. } \\
& {[---] \text { OYNON +[---]. }}
\end{aligned}
$$

Ce troisième graffite est de loin le plus remarquable, bien qu'il soit malheureusement incomplet. Sur la première ligne ne sont conservées que deux traces de signes, dont le second n'évoque pourtant aucune lettre grecque (lettre latine ? abréviation ?).

Sur la l. 2, après un espace vide, la première lettre est un xi élégant (plutôt qu'un $z e ̂ t a$, car on observe une petite boucle dans la partie supérieure $)^{18}$. Il convient alors de lire $\xi \dot{\varepsilon} \sigma \tau[\alpha-]$, en rapport manifeste avec la quantité du produit contenu dans le vase (le setier, $\xi \dot{\varepsilon} \sigma \tau\rceil$, lat. sextarius).

Sur la l. 3, après la séquence [---]OYNON, profondément gravée et de dimensions plus grandes que la ligne précédente, on aperçoit partiellement un signe qui n'évoque aucune lettre grecque. Il s'agit soit de la fin d'un mot à l'accusatif, par exemple

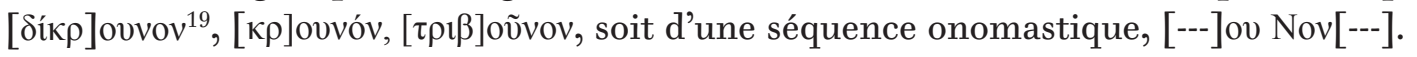

\footnotetext{
${ }^{17}$ Iosifaru 2011, 89; Tulugea 2012, 99.

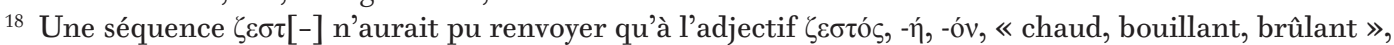
ou à l'un de ses dérivés, en rapport avec un liquide. Un graffite de l'Agora d'Athènes, de la seconde moitié du Irr s. ap. J.-C., lu par A. N. Oikonomides $\zeta \varepsilon \sigma \tau[\grave{\alpha}] \mid \delta \delta \kappa \rho[\varepsilon \dot{\varepsilon} \alpha \tau \alpha]$ (cf. SEG XXXVI 128), doit être lu en réalité

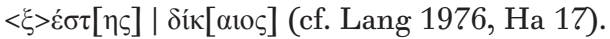

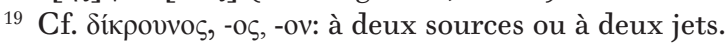


Le fragment est remarquable d'abord par son support, céramique (un vas entier, avant qu'il ne soit cassé), puis par l'usage de la langue grecque. On connaît en effet un certain nombre de vases ou tessons inscrits en grec en Dacie romaine ${ }^{20}$ :

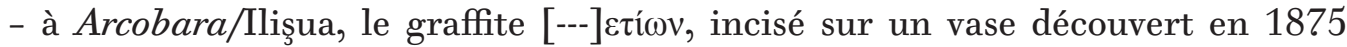
(CIL III 8077,13 = CIGD 56).

- à Porolissum, sur un pichet : $\Pi Y \mathrm{P}+{ }^{21}$;

- à Tibiscum, sur le fragment d'un pot: [---]ПYP+ ${ }^{22}$;

- à Berzovia, un vase en argile (imitation locale de terra sigillata ?) découvert en 2006 dans les canabae, près du camp légionnaire ${ }^{23}$, qui porte la marque de propriété

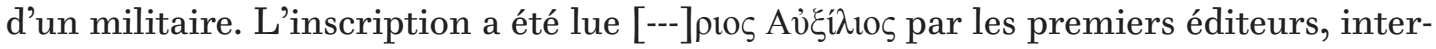
prétation suivie dans les corpus de référence, comme s'il s'agissait d'une occurrence du nom latin Auxilius. D'après la photo, la lecture est pourtant différente, car le caractère

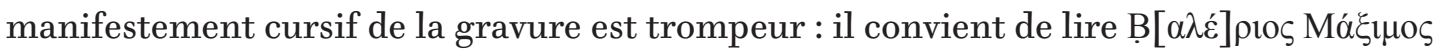
(= Valerius Maximus), ce légionnaire hellénophone portant une onomastique banale, typique des militaires dont l'accès à la citoyenneté romaine a été récent ${ }^{24}$;

- à Romula, le nom iranien $\Gamma \alpha \delta \alpha \tau \eta \varsigma$ sur un vase ${ }^{25}$;

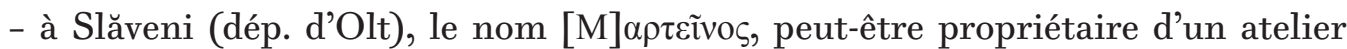
dans la région des fours de céramique, près des thermes du camp ${ }^{26}$.

Ce grand tesson du site romain d'Ocnița avait appartenu à un vase sur lequel a été soigneusement gravé un texte grec sur au moins deux lignes, de disposition et de taille différentes. C'est un témoignage précieux de la présence d'hellénophones dans ce site du centre de la Dacie Inférieure, en rapport avec l'exploitation du sel, activité qui impliquait la présence de spécialistes et d'une population composite.

Des groupes significatifs d'hellénophones d'Asie Mineure ou plus généralement de l'Orient grec se sont établis en Dacie romaine, principalement des artisans et divers autres spécialistes ainsi que des négociants - sans que les militaires hellénophones, auxiliaires et légionnaires, soient absents ${ }^{27}$. Jusqu'à présent, on avait identifié

20 Sur d'autres supports dans la catégorie instrumentum, citons deux exemples de Romula: un exercice d'écriture évoquant la guerre de Troie (IDR II $390=$ CIGD 85) ; une copie sur tuile, en écriture cursive, du début d'une lettre (officielle? ou plutôt un exercice), traduite en grec, dans la seconde moitié du $\mathrm{II}^{\mathrm{e}} \mathrm{s}$.

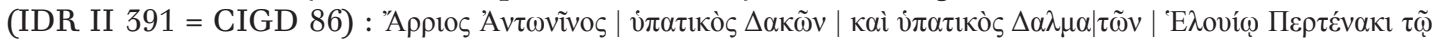

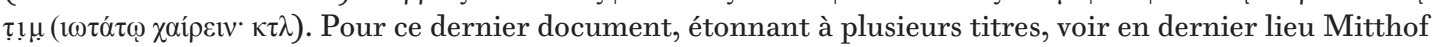
2015 (avec la meilleure édition et le commentaire). Cf. aussi un fragment de brique de Bivolari (Arutela) (IDR II 580 = CIGD 37) ; un fragment de vase de Stolniceni (IDR II $567=$ CIGD 40) ; des lettres grecques et latines sur un vase à provisions de Copăceni (dép. de Vîlcea) (CIGD 42). Les graffites grecs sur céramique sont plus nombreux à Romula: IDR II 403 (= CIGD 89), 406 (= CIGD 90), 407 (= CIGD 91) et 408 (= CIGD 92).

${ }^{21}$ Gudea, Cosma 1992, 219, no 116 (dessin p. 245, Fig. 116) ; CIGD 66 ; le dernier signe a la forme d'un $\mathrm{V}$, mais avec la deuxième haste verticale.

${ }^{22}$ Gudea, Cosma 1992, 213, nº 60, dessin p. 237 ; CIGD 130 ; le dernier signe est une ligne serpentiforme.

${ }^{23}$ Ruscu, Flutur 2008 (AE 2008, 1169 = SEG LVIII 736 = ILD II 875). Pour la relecture du graffite, voir Dana 2015b.

${ }^{24}$ Dana 2011, 56-57.

25 SEG XXVI 843 = CIGD 88 = ILD I 141.

${ }^{26}$ Popilian 1976, 130 ( $\mathrm{n}^{\mathrm{o}}$ 19) et 145, dessin Pl. LXXX ; IDR II 543 ; Gudea, Cosma 1992, 211, $\mathrm{n}^{\circ} 45$; Pop 1994, 45 .

27 Sur les hellénophones en Dacie romaine, voir quelques considérations dans Dana 2014, 93-94 ; Dana 2015a, 117-119. Pour le mélange démographique en Dacie romaine, cf. Mihailescu-Bîrliba 2011. 
des groupes importants d'hellénophones dans les régions urbaines plus cosmopolites (Apulum, Vlpia Sarmizegetusa), dans la région minière d'Alburnus Maior, ou plus proches de l'espace hellénophone, comme Sucidava et Romula. L'exemple d'Ocnița apporte une nouvelle touche de couleur aux réalités mises en place par les individus et les groupes arrivés en Dacie ex toto orbe Romano.

\section{Bibliographie}

Benea 2007a

Benea 2007b

Berciu 1981

Bondoc 2015

Dana 2011

Dana 2013-2014

Dana 2014

Dana 2015a

Dana 2015b

Dana, Gaiu, Zăgreanu 2012

Dana, Nemeti 2016

Dana, Petruţ 2015

Dana, Zăgreanu 2013

Deac 2015

Gudea, Cosma 1992

Iosifaru 2011
D. Benea, Cu privire la administrarea salinelor din Dacia romană, AB, S. N., 15, 2007, 41-46.

D. Benea, Cu privire la organizarea exploatării sării în Dacia romană. In: Meşteșuguri şi artizani în Dacia romană, BHAUT, 8, Timişoara 2007, 91-114.

D. Berciu, Buridava dacică, București 1981.

D. Bondoc, Cioroiu Nou. Edificiul termal (balneum) al legiunii VII Claudia. The Bath House (balneum) of Legio VII Claudia, Craiova 2015.

D. Dana, L'impact de l'onomastique latine sur les onomastiques indigènes dans l'espace thrace. In: M. Dondin-Payre (éd.), Les noms de personnes dans l'Empire romain. Transformations, adaptation, évolution, Scripta Antiqua 36, Bordeaux 2011, 37-87.

D. Dana, Trois dédicaces et un graffite de Cioroiu Nou (réédition), Oltenia, 20-21, 2013-2014, 44-49.

D. Dana, "Orientaux » en Dacie romaine. Réédition d'une dédicace grecque d'Arcobara/Mişua (SEG LVII $683=A E$, 2006, 1131), Classica et Christiana, 9, 2014, 85-95.

D. Dana, «Bonjour, madame! » sur le couvercle d'un miroir : nouvelle inscription grecque d'Ilişua sur instrumentum, RevBistriței, 29, 2015, 113-122.

D. Dana, Relecture d'une inscription grecque cursive sur un vase trouvé à Berzovia (SEG LVIII 736), ActaMN, 52, 2015, 93-98.

D. Dana, C. Gaiu, R. Zăgreanu, Un nou duplicarius din ala I Tungrorum Frontoniana atestat pe un vas descoperit in castrul roman de la Arcobara/Ilişua, RevBistriței, 26, 2012, 49-56.

D. Dana, S. Nemeti, Ptolémée et la toponymie de la Dacie (VI-IX), Classica et Christiana, 11, 2016, 67-93.

D. Dana, D. Petrut, A Military Graffito on a Pottery Plate from the Auxiliary Fort at Buciumi (Roman Dacia), Tyche, 30, 2015, 19-24.

D. Dana, R. Zăgreanu, Deux dédicaces latines inédites de Porolissum (Dacie romaine), Tyche, 28, 2013, 27-35.

D.-A. Deac, Graffiti aus Dacia Porolissensis (I). In: S. Cociş et alii, Ad finem Imperii Romani. Studies in Honour of Coriolan H. Opreanu, Bibliotheca Ephemeris Napocensis 9, Cluj-Napoca 2015, 101-106.

N. Gudea, C. Cosma, Contribuții la paleografia latină romană din Dacia II. Inscriptii incizate sau zgâriate pe vase de la Porolissum si problema inscriptiilor pe vase din provinciile dacice, ActaMP, 16, 1992, 201-247.

M. Iosifaru, Situri arheologice din oraşul Ocnele Mari, județul Vâlcea, Buridava, 9, 2011, 82-94. 
Jeremić 2009

Lang 1976

Macrea 1969

Mihailescu-Bîrliba 2011

Mitthof 2015

Petre 1966

Pop 1994

Popilian 1976

Purece 2016

Purece, Tuțulescu 2016

Reuter, Scholz 2004

Reuter, Scholz 2005

Ruscu, Flutur 2008

Schuster, Tuțulescu, Dumitrescu 2010

Tudor 1958

Tudor 1965

Tulugea 2012

Voloşciuc 2007
G. Jeremić, Saldum. Roman and Early Byzantine Fortification, Cahiers des Portes de Fer Monographies 6, Beograd 2009.

M. Lang, Graffiti and Dipinti, The Athenian Agora 21, Princeton (N.J.) 1976.

M. Macrea, Viața în Dacia romană, București 1969.

L. Mihailescu-Bîrliba, Ex toto orbe Romano: Immigration into Roman Dacia. With Prosopographical Observations on the Population of Dacia, Colloquia Antiqua 5, Louvain - Paris - Walpole (MA) 2011.

F. Mitthof, Arrius Antoninus an Helvius Pertinax. Beobachtungen zur Ziegelinschrift IDR II 391 aus Romula-Malva. In: L. Zerbini (ed.), Culti e religiosità nelle province danubiane. Atti del II Convegno Internazionale Ferrara 20-22 Novembre 2013, Bologna 2015, 671-682.

G. I. Petre, Urme romane necunoscute la Ocnele Mari, SCIV, 17, 1, 171-173.

C. Pop, Ateliere particulare de ceramică în Dacia romană, RevBistriței, 8, 1994, 41-48.

G. Popilian, Ceramica romană din Oltenia, Craiova 1976.

S. I. Purece, Ancient Coins and the Olt Valley, Studia Universitatis Cibiniensis. Series Historica, 13 (Suppl.), 109-119.

S. Purece, I. Tuțulescu, Descoperiri monetare din posibilul centru administrativ roman al exploatării salinifere din zona Ocnelor Mari, Transilvania, 10, 2016, 1-6.

M. Reuter, M. Scholz, Geritzt und entziffert. Schriftzeugnisse der römischen Informationsgesellschaft, Stuttgart 2004.

M. Reuter, M. Scholz, Alles geritzt: Botschaften aus der Antike, München 2005.

L. Ruscu, A. Flutur, Eine griechische Inschrift auf einem Gefäss von Berzovia, AB, S. N., 16, 2008, 107-111.

C. Schuster, I. Tutulescu, I. Dumitrescu, Câteva gânduri cu privire la exploatarea sării în nord-estul Olteniei. Din preistorie şi până în epoca modernă, Angustia, 14, 2010, 261-270.

D. Tudor, Oltenia romană, București $1958^{2}$.

D. Tudor, Tabula Imperii Romani. Drobeta - Romula - Sucidava, București 1965.

C. A. Tulugea, Cronica cercetărilor arheologice pe anii 2009-2010 în județul Vâlcea, Buridava, 10, 2012, 98-116.

A. Voloşciuc, Scrierea cursivă în Dacia romană, AB, S. N., 15, 2007, 57-68.

Dan Dana

CNRS/ANHIMA, Paris

ddana_ddan(j)yahoo.com

Ion Tuţulescu

Musée Départemental d'Histoire «Aurelian Sacerdoțeanu » Vâlcea, Râmnicu-Vâlcea iontutulescu@yahoo.com 

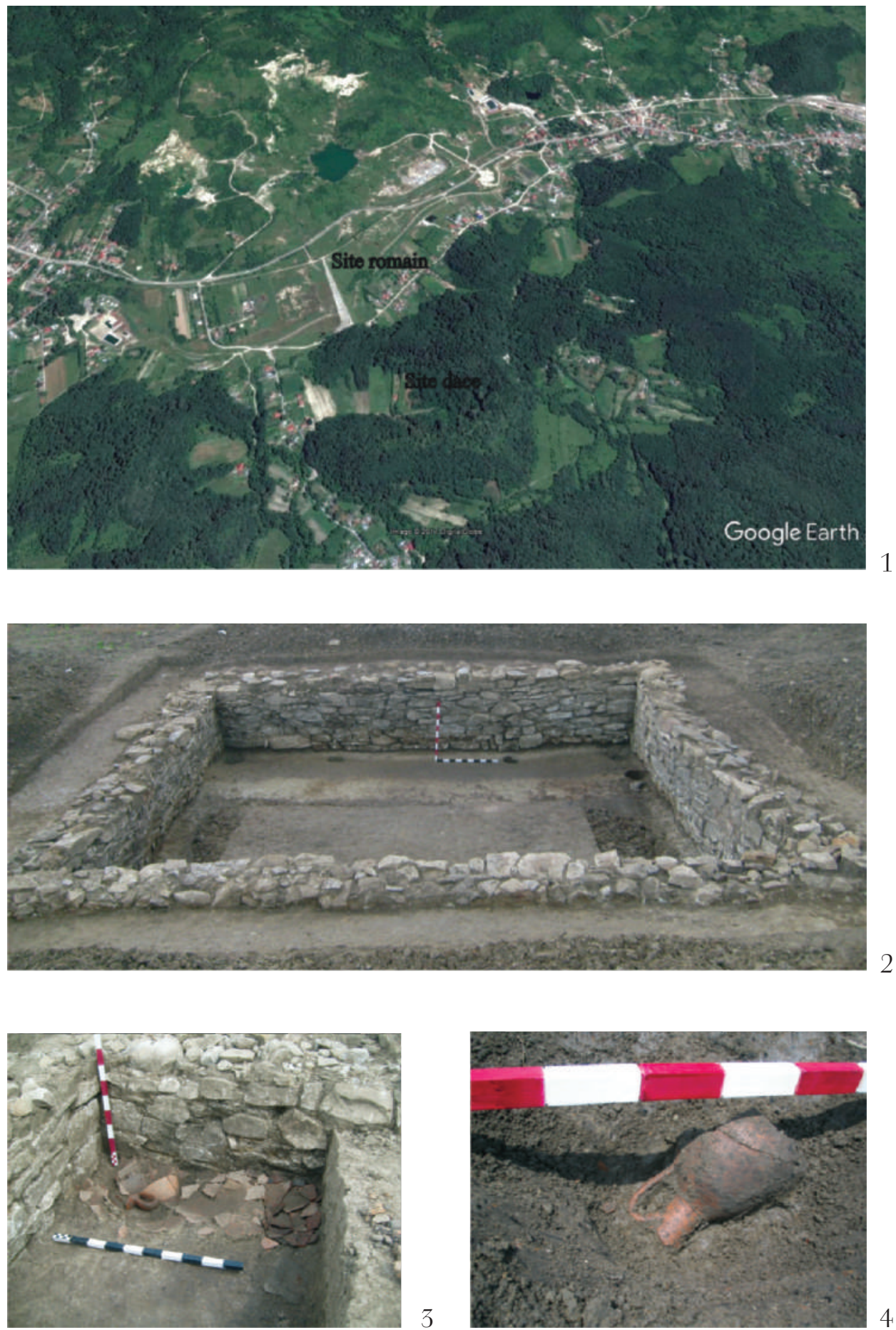

PI. I. 1. Carte de la région ; 2. Fouilles de 2009 d'Ocnița (L. 12) ; 3. Détail (L. 12) ; 4. Photo de la cruche au moment de la découverte (L. 7). 


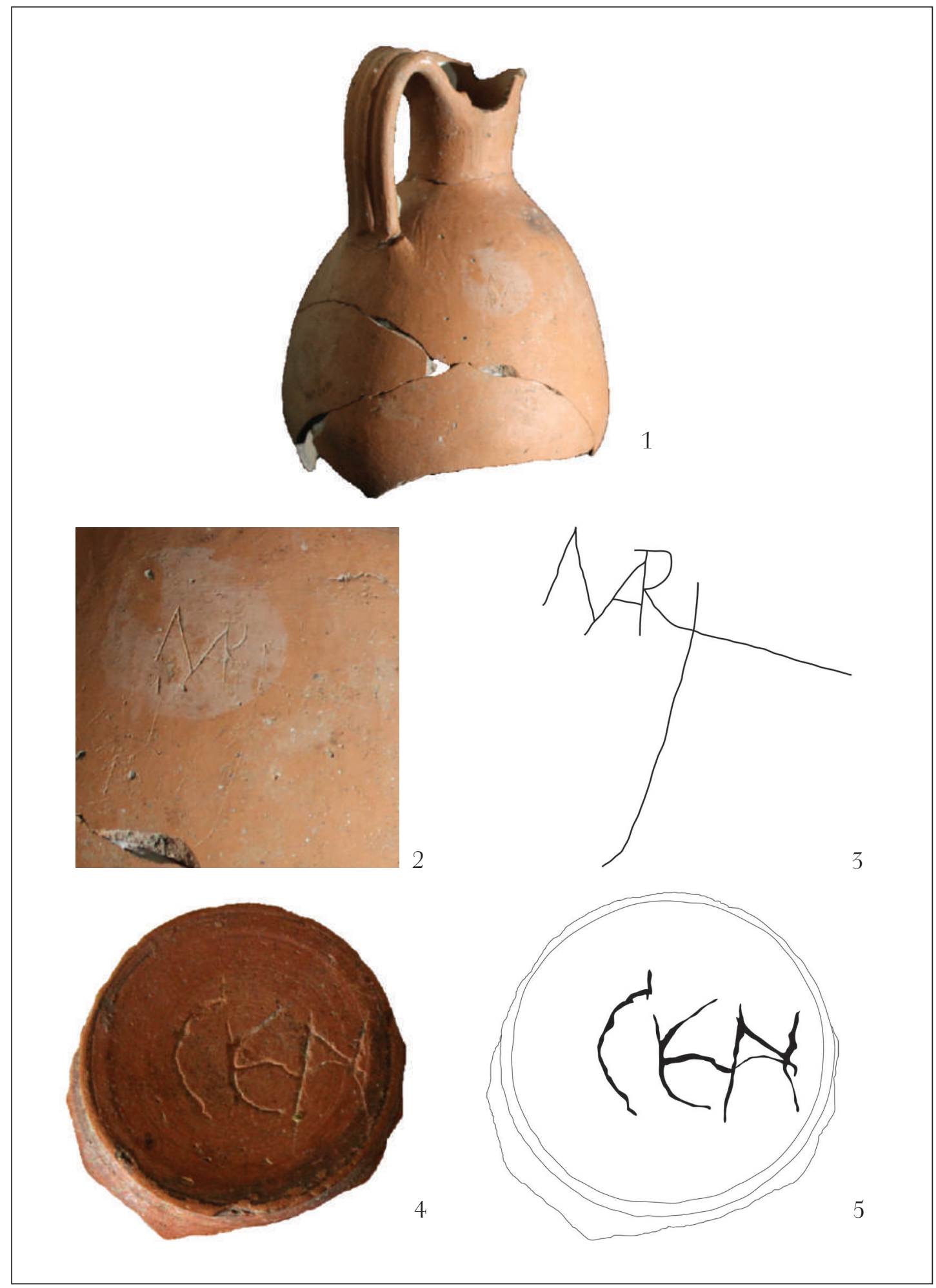

Pl. II. 1. Photo de la cruche; 2. Photo du graffite latin sur cruche ; 3. Fac-similé du graffite latin sur cruche ; 4. Photo du graffite latin sur le fond du pied ; 5. Fac-similé du graffite latin sur le fond du pied. 


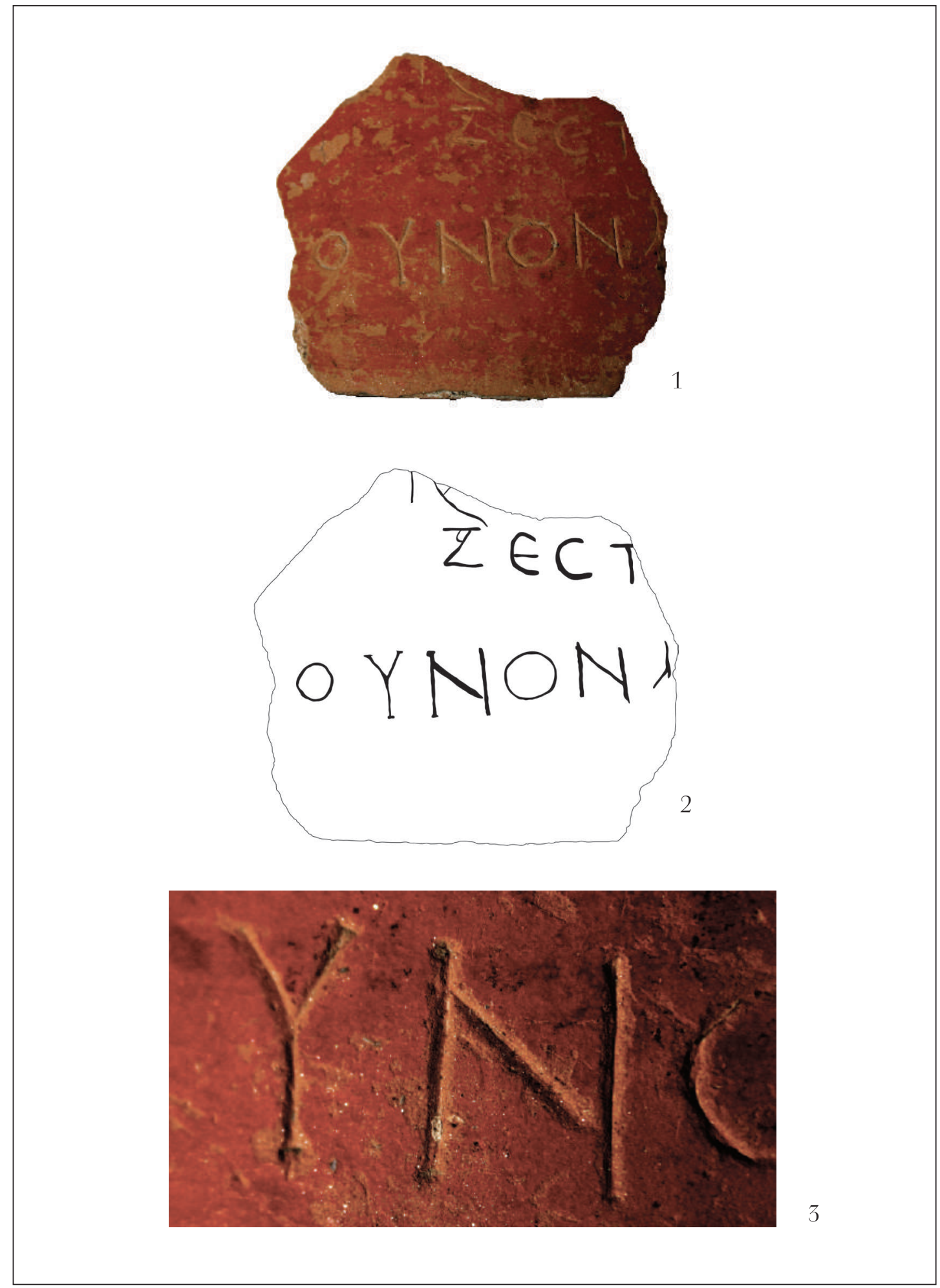

Pl. III. 1. Photo du graffite grec sur tesson ; 2. Fac-similé du graffite grec sur tesson ; 3. Détails de la ligne 3 du graffite grec. 


\title{
MALVA, LA COLONIE PERDUE DE LA DACIE INFÉRIEURE
}

\author{
SORIN NEMETI, DAN DANA
}

Résumé : Cette étude reprend la question épineuse de la localisation et du statut de Malva (colonia Malvensis), qui a donné, après la réorganisation du temps des guerres marcomanniques, le nom d'une subdivision de la Dacie romaine, à savoir la Dacia Malvensis, superposant la Dacie Inférieure. Rejetant l'identification traditionnelle de Malva à Romula, à partir du réexamen du dossier épigraphique concernant Malva (y compris les termes Malvensis et Malvenses), des découvertes archéologiques sur la ligne de l'Olt, et en particulier de l'itinéraire Drobeta-Romula-Apulum sur la Table de Peutinger, on propose une localisation de ce centre sans doute militaire à Stolniceni (dép. de Vâlcea), où était communément placée Buridava.

Mots-clés : cartographie ; Dacia Malvensis ; épigraphie; Malva ; procurateurs ; Table de Peutinger.

Abstract: Malva, the lost colony of Lower Dacia. This study tackles the problematic question of localization and status of Malva (colonia Malvensis), which gave, after the reorganization of Roman Dacia during the Marcomannic wars, the name of one of its subdivisions, namely Dacia Malvensis, overlapping the former province of Dacia Inferior. Rejecting Malva's traditional identification with Romula, on the basis of a review of the epigraphic dossier of Malva (including the terms Malvensis and Malvenses), a reassessment of the archaeological finds on the Olt valley, and especially the re-interpretation of the itinerary given on Peutingers' Map (the road Drobeta-Romula-Apulum), we consider that the localization of this possible military center should be at Stolniceni (Vâlcea County), where the previous bibliography located Buridava.

Keywords: cartography; Dacia Malvensis; epigraphy; Malva; procurators; Peutinger's Map.

Rezumat: Acest studiu reia problema spinoasă a localizării şi statutului localităţii Malva (colonia Malvensis), care a dat, după reorganizarea din vremea războaielor marcomanice, numele unei subdiviziuni a Daciei romane, Dacia Malvensis, suprapunând Dacia Inferior. Respingând identificarea tradiţională a Malvei cu Romula, pe baza unei reexaminări a dosarului epigrafic despre Malva (inclusiv termenii Malvensis şi Malvenses), a descoperirilor arheologice de pe linia Oltului, dar mai ales a itinerariului Drobeta-Romula-Apulum de pe Tabula Peutingeriana, este propusă o localizare a acestui centru, fără îndoială militar, la Stolniceni (jud. Vâlcea), unde era localizată îndeobşte Buridava.

Cuvinte-cheie: cartografie; Dacia Malvensis; epigrafie; Malva; procuratori; Tabula Peutingeriana.

Cette étude reprend le débat épineux sur l'identité et la localisation de Malva, colonie et capitale de la Dacie Malvensis ${ }^{1}$. Tour à tour seront analysés la titulature de la province, le dossier épigraphique que nous avons constitué, ainsi que les différentes

\footnotetext{
${ }^{1}$ Nous avons choisi de donner ici les références principales en rapport avec ce sujet. Cet article a été réalisé dans le cadre des projets PN-III-P4-ID-PCE-2016-0255 et PN-III-P4-ID-PCE-2016-0186. Nous remercions vivement pour des renseignements et la documentation photographique Dorel Bondoc (Craiova), Giuseppe Camodeca (Naples) et Ion Tuțulescu (Râmnicu-Vâlcea).
} 
tentatives de localisation de Malva, avant de proposer, à partir d'un faisceau d'indices archéologiques, épigraphiques et cartographiques, une localisation à Stolniceni (dép. de Vâlcea), important site romain partiellement exploré, situé sur la rive droite du fleuve Alutus/Olt.

\section{La forme Malvensis et la titulature des provinces}

Dans la titulature des provinces romaines on trouve souvent une forme adjectivale d'un nom propre qui désigne un chef-lieu, en particulier le caput provinciae ou le siège du gouverneur provincial. À titre d'exemples, les Galliae Narbonensis et Lugdunensis, appelées ainsi d'après Narbo Martius et Lugdunum, Hispania Tarraconensis d'après Tarraco, les deux Mauretaniae Caesariensis et Tingitana d'après Caesarea et Tingis. Dans le cas des Dacies, à part les deux provinces Inferior et Superior (119), une troisième est constituée par le même empereur Hadrien (avant avril 123), sous le nom de Dacia Porolissensis, dont le chef-lieu se trouvait à Porolissum (auj. Moigrad, dép. de Sălaj). Pendant les guerres marcomanniques, les circonscriptions financières d'une province consulaire réunie, Daciae tres, s'appellent respectivement Apulensis, Porolissensis et Malvensis, d'après Apulum (auj. Alba Iulia, dép. d'Alba), Porolissum et l'énigmatique Malva ou Malvum², dont non seulement la localisation, mais l'existence même sont encore débattues.

Logiquement, s'il existe Narbo Martius, Lugdunum, Tarraco, Tingis et Porolissum, on s'attend de manière obligatoire à l'existence de Malva ou Malvum, un toponyme qui puisse donner le nom de cette province. Le dossier épigraphique que nous présentons ici, après avoir examiné chaque document ainsi que les quelques cas problématiques, n'est pas très riche ; qui plus est, la plupart des occurrences se rencontrent en dehors de la province qui nous intéresse, et souvent dans des contextes qui prêtent à l'ambiguïté.

\section{Le dossier épigraphique}

Plusieurs inscriptions ont été discutées, souvent émendées, afin d'illustrer l'existence d'une ville du nom de Malva, avec le rang de colonie, dans la province Dacia Inferior, plus tard Malvensis. Nous n'avons retenu que sept documents qui mentionnent le nom de la province (1, 2 : Dacia Malvensis) ou de ses habitants (3 : Malvenses ; 4 : Malvensium, gén. pl. de Malvenses), un déterminatif ou un adjectif qui concerne une unité auxiliaire (5:Malvensium ; 2 : Malvensis), ou bien la capitale [6, 7 : colonia Malvensis/Malva]. Leur relevance est inégale, puisqu'aucune n'offre la clé d'une localisation quelque part sur le territoire de la Roumanie d'une ville romaine du nom de Malva/Malvum ou avec un double nom composé, du type Romula-Malva, d'après l'opinion commune ${ }^{3}$. D'entrée de jeu, nous précisons que nous ne partageons pas l'hypothèse de l'identité Romula-Malva, en cours dans l'historiographie roumaine

\footnotetext{
2 Piso 2013, 4, 10 ; Petolescu 2014, 179-180.

3 Ardevan 1998, 28.
} 
depuis Grigore Tocilescu ${ }^{4}$ et reprise par Dumitru Tudor dans son commentaire de l'inscription de Sex. Iulius Possessor de Séville ${ }^{5}$. Même la forme du toponyme reste hypothétique : la variante Malva a été préférée car elle s'accordait avec Romula, et elle est considérée en général comme étant d'origine indigène/dace ${ }^{6}$, même si une explication par le latin est également possible, voire préférable ${ }^{7}$. Mais la forme du toponyme aurait très bien pu être $\mathrm{Malvum}^{8}$, avec la même terminaison que d'autres toponymes d'origine dace en graphie latine (e.g. Apulum, Porolissum).

Il convient d'exclure d'entrée du jeu de ce débat sur la colonia Malvensis l'inscription de Denta (dép. de Timiş) ${ }^{9}$ où la simple abréviation DCM peut être diversement développée, la meilleure solution étant $d$ (ecurio) c(oloniae) M(ursae) (colonie en Pannonie Inférieure, auj. Osijek, en Croatie), et moins probablement $d$ (e)c(urio) m(unicipii) ${ }^{10}$. Qui plus est, cette inscription lue par C. Patsch d(ecurio) c(oloniae) $M$ (alvensis) $^{11}$ a généré toute une discussion stérile et alimentée avec moult passions par des patriotismes régionalistes entre Constantin Daicoviciu et Dumitru Tudor au sujet de la localisation de la Dacie Malvensis dans le Banat pour le premier, ou bien en Olténie pour le second, leurs « petites patries » ${ }^{12}$. De même, il est plus prudent d'exclure l'épitaphe de L. Quesidius Praesens de Smederevo (Mésie Supérieure $)^{13}$; la pierre, perdue, n'est connue que par deux copies divergentes. La séquence supposée COL MAL (car aucune des copies ne présente cette forme), à développer selon $\mathrm{H}$. Wolff ${ }^{14}$ en IIvir col(oniae) Mal(vensis), est à juste titre rejetée

${ }^{4}$ Tocilescu 1902, 636.

5 Tudor 1944, 523-531.

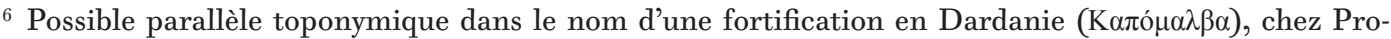
cop. Aed. 4. 4, dont au moins la première partie est latine. Plusieurs savants ont spéculé sur une étymologie de Malva en rapport avec un mot du substrat prélatin (roum. mal, « bord, rive, rivage », « colline, hauteur »; alb. mal', « montagne, lieu escarpé »), rapportant les propos de N. Jokl et P. Kretschmer ; voir Detschew 1957, 283 ; Duridanov 1969, 45 ; Duridanov 1995, 834. Cette proposition semble compromise par le fait que les premiers à lancer cette hypothèse pensaient à une possible traduction de Dacia Malvensis en Dacia Ripensis, ce qui est historiquement faux, car le nom de cette dernière fonctionne en binôme avec Dacia Mediterranea, la nouvelle province située à l'intérieur de la Péninsule Balkanique, alors que l'autre se trouvait sur la rive méridionale du fleuve. Voir aussi Russu 1969, 127 ; Russu 1981, 344 (qui insiste sur le lien douteux du terme roumain/albanais avec Malva).

? Observons qu'il existe le mot latin malva, désignant une plante (« mauve », qui a donné en roumain nalbă).

${ }^{8}$ Vittinghoff 1969, 132.

${ }^{9}$ CIL III 1555 (= 12594) = IDR III/1, 109 = ILD I 175: I(ovi) O(ptimo) $M$ (aximo) / I(unoni) R(eginae) M(inervae) T(errae) M(atri) / C(aius) Kaniniu[s] / Sabinianu[s],/ d(ecurio) c(oloniae?) M() IIvir / [---]. Voir aussi Lupa 15187 ; HD 044778.

${ }^{10}$ Petolescu 1987, 25-26 ; cf. ILJug III 3095 (Mursa), qui mentionne T. Fl. Martinus, d(ecurio) c(oloniae) M(ursensium). La pierre de Denta, encastrée dans un bâtiment, était le plus probablement une « pierre errante ».

11 Patsch 1937, 137.

12 Daicoviciu 1930, 2 ; Daicoviciu 1939-1942, 98, 106 ; Daicoviciu 1941-1943, 294-295; Daicoviciu 1942, 962-963 ; Daicoviciu 1944 ; Daicoviciu, Daicoviciu 1967, 73-83 ; Daicoviciu 1970, 125-129 ; Tudor 1942, 54-55 ; Tudor 1944, 528 (I. Din nou problema Malva).

${ }^{13}$ CIL III 6309 (= 8129) = IMS II 75 = IDRE II 310.

${ }_{14}$ Wolff 1975, 139-147, selon lequel la colonia Malvensis, contemporaine du municipe de Drobeta, aurait eu déjà ce rang sous Marc Aurèle ; il a été suivi de manière confuse par C. C. Petolescu (IDRE, comm. ; et Petolescu 2011, 107). 
par Miroslava Mirkovićn ${ }^{15}$, qui suppose ici QQ M[-], donc un q(uin)q(uenalis) m(unicipii) [---].

\section{S Le nom de la province ou de ses habitants :}

Seulement deux procurateurs de cette province, identifiée par son nom complet Dacia Malvensis, sont connus :

[1] M. Macrinius Avitus M. f. Claud(ia) Catonius Vindex (PIR ${ }^{2}$ M 22) ${ }^{16}$, entre autres p[r]oc(urator) prov(inciae) Dac(iae) Malv(ensis) vers 169/170, comme nous renseigne son épitaphe de Rome ${ }^{17}$.

[2] M. Aurelius Cassianus, praeses prov(inciae) Daciae Malvensis dans la première moitié du $\mathrm{III}^{\mathrm{e}} \mathrm{s}^{18}{ }^{18}$, dans une inscription de Thessalonique, dont il sera question plus bas.

À partir du nom de la province et de son chef-lieu, ses habitants furent appelés les Malvenses. Deux mentions sont connues :

[3] Dans la province-même, une base en marbre d'une statue d'Hercule, partiellement conservée, a été trouvée il y a plus d'un demi-siècle à Cioroiu Nou (dép. de Dolj) (Pl. I/1). Ses trois lignes en gravure soignée ${ }^{19}$ sont abîmées à l'extrémité gauche, ce qui a entraîné des restitutions divergentes : [Aequ]ensium chez C. Daicoviciu ${ }^{20},\left[\right.$ Aqu]ensium chez D. Tudor ${ }^{21}$ et [Mal]vensium chez C. S. NicolăescuPlopşor $^{22}$. Comme l'a observé avec raison C. C. Petolescu ${ }^{23}$, la lettre partiellement visible avant VENSIVM est un $\mathrm{L}$, ce qui exclut les autres lectures proposées. On lira donc :

\section{- M(arcus) Opellius Maximus \\ [dec(urio) M]ontanensium Herculi . \\ [pro sal(ute) Ma]!vensium ex voto posuit.}

Or, si Petolescu préfère considérer cette mention comme un argument pour la localisation de Malva à Cioroiu Nou, I. Piso ne se range pas de cet avis ${ }^{24}$. Nous considérons que la dédicace fut érigée par un décurion d'une ville d'une province voisine pour le bien être des provinciaux de Dacia Malvensis, les Malvenses, ce qui prouve que

15 Et par Ardevan 2000, 117-122.

16 Piso 2013, 275-288 (n $\left.{ }^{0} 121\right)$.

17 CIL VI 1449 = ILS 1107 = IDRE I 17.

18 Piso 2013, 288-292 ( $\mathrm{n}^{\mathrm{o}}$ 122), qui le place entre Sévère Alexandre et le milieu du III ${ }^{\mathrm{e}}$ s., sur la base (erronée, selon nous) de sa lecture de l'inscription IDR II 341 (voir note 62). Il était originaire de Macédoine, où lui, ou bien son fils homonyme (M. Aur. Cassianus), avait été macédoniarque (I. Beroia 76 et 77 ).

${ }_{19}$ IDR II 142 ; Bondoc 2004, 12, $\mathrm{n}^{0} 6$; Bondoc 2010, $27\left(\mathrm{n}^{0}\right.$ 1), 141 ( $\mathrm{n}^{\mathrm{o}}$ 1) (photo et dessin p. 79, Pl. I) ; Müller, Schwaighofer, Piso, Benea 2012, 59, n CN 1 (et photo).

20 Daicoviciu 1965, 655 ; Daicoviciu 1969, 542-543.

21 Tudor 1966a, 854; cette hypothèse s'appuyait aussi sur les rapports entre les Opellii et la ville dalmate Aequum (Ardevan 2005, 125-133). Mais M. Opellius Maximus était décurion de Montana (auj. Mihajlovgrad), en Mésie Inférieure.

22 Nicolăescu-Plopșor 1965, 207.

23 Petolescu 2011, 107-108 et n. 258 (photo et dessin p. 105, Fig. 3).

${ }^{24}$ Car il préfère la localisation traditionnelle à Romula. 
Cioroiu Nou, dont le nom ancien reste inconnu ${ }^{25}$, appartenait à cette province, étant situé par ailleurs à ses marges.

\section{S Un déterminatif d'une ville (Malvenses/Malvensium) ou d'une unité auxi- liaire de la province (Malvensis) : \\ [4] Une dédicace honorifique de Séville détaille le cursus honorum de Sex. Iulius} Possessor (PIR ${ }^{2}$ I 480) ${ }^{26}$, entre autres praef(ectus) coh(ortis) III Gallor(um), praepositus numeri Syror(um) sagittarior(um), item alae primae Hispanorum, curator civitatis Romulensium Malvensium. Dans le cas de sa curatelle, l'épithète Malvensium concerne sans aucun doute (les habitants de) la province de Dacia Malvensis afin de distinguer la ville Romula de cette province lointaine par rapport à son homonyme de Bétique, la colonia Iulia Romula Hispalis, où Sex. Iulius Possessor est par ailleurs honoré. La traduction de F. Vittinghoff « der malvensischer Romulenser ${ }^{27}$, à savoir une civitas des Romulenses Malvenses (voire Malvensium), saisit le mieux le sens de l'expression latine. Sex. Iulius Possessor a été commandant de trois unités auxiliaires en Dacie Inférieure ${ }^{28}$, et en même temps contrôleur des finances de Romula, sans doute vers 168.

En ce qui concerne les épithètes des unités auxiliaires de la province, il est important de noter la distinction entre Malvensium et Malvensis :

[5] le numerus Syrorum Malvensium est évoqué dans l'épitaphe de Sextus Iulius Iulianus, à Césarée de Maurétanie (époque des Sévères) ${ }^{29}$. Originaire de Germanie Supérieure, cet officier équestre avait exercé deux commandements différents : d'abord tribun du numerus Syrorum sagittariorum en Dacie Malvensis, avant d'être chargé d'escorter 1000 recrues « besses », iuniores Bessi - il s'agit de recrues de toute la Thrace, d'après ce terme générique -, de Thrace en Maurétanie Tingitane ; il est vraisemblablement mort en chemin. Selon M. P. Speidel, Malvensium accolé au numerus de Syriens concernerait le lieu de garnison, à l'instar d'autres numeri de Maures, Syriens et Palmyréniens en Dacie: e.g. numerus Maurorum M(iciensium), numerus Palmyrenorum Porol(issensium), numerus Palmyrenorum Tibiscensium, numerus

25 Pour D. Tudor, Aquae ; pour la discussion, voir Bondoc 2010, 10.

${ }^{26}$ CIL II 1180 = ILS 1403 = CILA II, 1, 23 = IDRE I 179 (avec le bon comm. de C. C. Petolescu ; Piso 2013, 160, no 4) (Hispalis, auj. Séville) : Sex(to) Iulio Sex(ti)f(ilio) Quir(ina) Possessori,/ praef(ecto) coh(ortis) III Gallor(um), praeposito nume/ri Syror(um) sagittarior(um), item alae primae Hispa/norum, curatori civitatis Romulensium Mal/vensium, tribuno mi[l(itum) leg(ionis)] XII Fulminat[ae],/ curatori coloniae Arcensium, adlecto / in decurias ab Optimis Maximisque / Imp(eratoribus) Antonino et Vero Augg(ustis), adiu/tori Vlpii Saturnini praef(ecti) annon(ae) / ad oleum Afrum et Hispanum recen/sendum item solamina transfe/renda item vecturas navicula/riis exsolvendas, proc(uratori) Augg(ustorum) ad / ripam Baetis. Scapharii Hispalen/ses ob innocentiam iustitiam/que eius singularem.

27 Vittinghoff 1969, 142.

${ }^{28}$ On retrouve cette partie de sa carrière dans une dédicace érigée par Sex. Iulius Possessor à Mactaris, dans la Proconsulaire, d'où il était originaire (AE 1983, 976 = IDRE II 435): praef(ectus) coh(ortis) Gall(orum), cura/tor numeri Syrorum sagittariorum item / alae primae Hispanorum.

${ }^{29}$ CIL VIII 9381 (= 20945) = ILS 2763 = IDRE II 463 : D(is) M(anibus) s(acrum)./ Sex(tus) Iul(ius) Iulianus,/ ex Germania Superiore $\{m\}, /$ tribunus n(umeri) Syrorum M(a)l/vensium, hic sepultus est,/ dum deducit iuniores Bessos / (mille) in Tingitana (m) provinci (a)m, qui vixit annis $X X X X V$, cui / monimentum fecit / Iul(ius) Ingenuus frater / et heres, curante / Sacimatho / liberto eiusdem / defuncti. Voir Speidel 1973 ; Speidel 1977 (photo p. 345, Fig. 2: ML/VENSIVM pierre). 
Palmyrenorum O(ptatianensium) ${ }^{30}$. Pourtant, à l'instar des inscriptions citées cidessus, il doit s'agir d'une indication en rapport avec la province et, tout comme dans le cas de la dédicace en l'honneur de Sex. Iulius Possesor (par ailleurs, praepositus du même numerus), également d'un moyen d'éviter la confusion avec une unité homonyme - à savoir, le numerus Syrorum de Maurétanie Césarienne, en garnison à Numerus Syrorum (auj. Lalla Maghnia) ${ }^{31}$. Le numerus Syrorum de Dacie Inférieure est bien attesté par des inscriptions et des tuiles à Romula et, dans son voisinage, à Slăveni ${ }^{32}$.

[2] la cohors I Flavia milliaria Brittonum Malvensis, dans l'inscription déjà citée de Thessalonique, de la première moitié du $\mathrm{III} \mathrm{I}^{\mathrm{e}} \mathrm{s}{ }^{33}$; pour elle-aussi, les opinions sont partagées. Cette cohorte a été identifiée à tort par C. C. Petolescu avec la coh. I Augusta Nervia Pacensis Brittonum milliaria, qui la place en garnison à Stolniceni sur l'Olt, important site romain traditionnellement identifié à Buridava. Petolescu estimait que l'épithète Malvensis accolée à la cohorte de Bretons dérivait du nom de la province de Dacia Malvensis. Comme l'a suggéré récemment Florian Matei-Popescu, la coh. I Flavia milliaria Brittonum Malvensis doit être en réalité la coh. I milliaria Brittonum, attestée auparavant en Mésie Inférieure ${ }^{34}$. Nous considérons qu'il s'agit ici de la forme adjectivale Malvensis (et non du déterminatif Malvensium), qui est une épithète toponymique, en lien direct avec le possible lieu de garnison, à Stolniceni. On rencontre le suffixe banal -ensis, si productif en latin pour les dérivés toponymiques, encore une fois accolé au nom d'une autre cohorte de Dacie Inférieure : c'est la cohors Nova Cumidavensis. Quoi qu'il en soit quant au moment précis de création de cette dernière cohorte, le même Petolescu avait conclu avec raison que l'attribut topique Cumidavensis ne concernait pas l'origine (dace) des recrues - même si l'on peut raisonnablement imaginer que beaucoup des recrues étaient à l'époque des Sévères d'extraction indigène - lors de la création de l'unité, mais bien son lieu de garnison, Cumidava (auj. Râşnov, dép. de Braşov) ${ }^{35}$.

${ }^{30}$ Speidel 1973, 172.

31 Voir Petolescu 2002, 144 et n. 10.

${ }^{32}$ Pour cette unité, voir Petolescu 2002, 143-144 (nº 78).

${ }_{33}$ CIL III 13704 = ILS 9009 = IG X, 2, 1, 147 = IDRE II 357 (Thessalonique ; photo dans BCH, 97, 1973, 588, Fig. 2) : B(ona) F(ortuna) / M(arcum) Aurel(ium) Cassi/anum, v(irum) e(gregium), prae/sidem prov(inciae) Daciae / Malvensis, patrem / karissimum,/ MM(arci) Aurell(ii) Phi/lippus, (centurio?), et Cassia/nus, trib(unus) coh(ortis) I / F(laviae) m(illiariae) Bryttonum / Malvensis. Sur ce procurateur, nommé praeses (« gouverneur »), voir Petolescu 2011-2012. On connaît une estampille rétrograde CORSMB à Stolniceni (CIL III 14216, 25 = IDR II 560), lue par Gr. Tocilescu - qui donne comme lieu de découverte Boroneasa - et par la suite par N. Gostar, co(ho)rs m(illiaria) B(rittonum); et d'autres estampilles CIB à Slăveni (IDR II 527), donc $c$ (ohors) I B(rittonum). Une estampille fragmentaire, toujours sinistroverse, du castellum de Mihăieşti-Plută (IDR II 572), près de Stolniceni, a été lue [coh(ors) I]X B(atavorum) par D. Tudor (alors que cette unité n'est pas attestée en Dacie) ; la bonne lecture est sans doute [coh(ors) I] (milliaria) B(rittonum), selon N. Gostar (voir Bichir 1985, 102).

${ }_{34}$ Petolescu 1987, 28 ; Petolescu 2002, 90 (no 25) ; Matei-Popescu 2010b, 395-396. Piso 2013, 291 l'interprète en rapport avec son lieu de garnison, Romula, qui serait identique à Malva; néanmoins, cette unité n'est pas attestée à Romula.

${ }^{35}$ Pour cette cohorte, voir en dernier lieu Dana 2017. 


\section{S La capitale de la province :}

[6] Un diplôme militaire du 7 janvier 230 (lieu de découverte inconnu) ${ }^{36}$, pour un cavalier de la garde impériale, est un témoignage indiscutable aussi bien de l'existence d'une localité du nom de Malva/Malvum en Dacie que de son statut de colonie (colonia Malvensis) dans la première moitié du III ${ }^{\mathrm{e}} \mathrm{s} .(\mathrm{Pl} . \mathrm{I} / 2)^{37}$ :

equitib(us) qui inter singulares militaver(unt) / castris novis Severianis quibus prae/est Aelius Victor trib(unus) (...) ex equite domini n(ostri) Aug(usti) / M(arco) Aurelio Deciani f(ilio) Deciano,/ Colonia Malve(n)se ex Dacia.

L'ancien cavalier auxiliaire, recruté vers 204 (de statut pérégrin) ${ }^{38}$, fut promu quelques années plus tard dans la garde montée de Rome. Il était sans aucun doute d'extraction indigène, non seulement en raison de la citoyenneté récente (après 212), mais aussi puisque son cognomen Decianus - identique par ailleurs à l'idionyme de son père - est un nom d'assonance dace ${ }^{39}$. M. Aur. Decianus n'était pas originaire de la colonie de Malva, mais sans doute d'un village de son territoire, comme la plupart des militaires du III ${ }^{\mathrm{e}}$ s., dont les indications d'origo sont souvent générales et ne précisent dans la plupart des cas que les centres urbains ${ }^{40}$. Certains savants ont pensé que cette colonia Malvensis serait une mention de Romula ${ }^{41}$ (cf. le commentaire de l'inscription de Séville), la seule colonie attestée par d'autres documents en Dacie Inférieure ${ }^{42}$, alors que Sucidava était vraisemblablement un municipe. Pourtant, dans ce cas, on aurait attendu la mention colonia Romulensium ex Dacia.

[7] Un autre militaire originaire du territoire de Malva apparaît dans un catalogue de prétoriens identifiés par leur origines, après 212 : [A]ur(elius) Calminus, domo Malve[nse? $]^{43}$. Cette origine de Dacie est plus vraisemblable qu'un renvoi au municipium

${ }^{36}$ Il est important de préciser que ce diplôme entra dans les collections du musée de Naples avant le milieu du XIX ${ }^{\mathrm{e}}$ s. (vendu par Roberto Betti).

37 CIL XVI 144 = ILS 2009 = IDRE I 166 = Speidel 1994, 103-104, no 76 ; Russu 1980, 41; Dana, Matei-Popescu 2009, 218 ( ${ }^{\circ}$ 40), 226 ; Dana, Zăgreanu 2017, 146, 148, 156 (nº 2). La graphie du toponyme diffère dans les éditions : Malvese Nesselhauf; Malvense Speidel, qui note une sorte de ligature NS. En réalité, on voit que le scribe avait gravé MALVEN, avant de remplacer le $\mathrm{N}$ par un $\mathrm{S}$ et de tracer tout de suite un $\mathrm{E}$ en utilisant la dernière haste verticale du N (Pl. I/2), sans doute pour pouvoir caser toutes les autres lettres de la séquence toponymique sur la même ligne. Sur la consonne $n$ précédant $s$, assimilée et disparue après avoir allongé et nasalisé la voyelle précédente, voir Mihăescu 1978, 205-206, $\mathbb{S} 173$.

${ }_{38}$ Dans la garde montée de Rome on connaît deux autres anciens auxiliaires de la même province, tous les deux de l'ala I Claudia Gallorum Capitoniana, en garnison sans doute à Boroşneul Mare (dép. de Covasna) : Aur. Antonius, nat(ione) Dacus, allect(us) ex ala Gallor(um) (CIL VI $3191=$ ILS $2205=$ Speidel 1994, no 603 = CLE 1460 = IDRE I 50) ; M. Aur. M[---], domu D[acia Infer(iore)?, allectus ex] ala Gallorum (CIL VI 3239a = Speidel 1994, $\mathrm{n}^{\circ}$ 641).

39 Decianus, normalement un dérivé du gentilice Decius, est sans aucun doute un nom d'assonance dace, à partir d'un nom en deci-, tels Decibalus et Decinaeus. Voir Dana, Matei-Popescu 2009, 226 ; Dana 2011, 75-76 ; OnomThrac 115 (cf. les noms daces en deci-) ; Dana, Zăgreanu 2017, 148.

40 Pour des détails, voir Dana, Zăgreanu 2017, 146-147.

41 Macrea 1969, 133 (Drobeta); Ardevan 1998, 28.

42 Pour cette ville, voir Petolescu 2011, 99-102.

${ }^{43}$ CIL VI 32563 = IDRE I 37 = I. Celio 383 = EDR 122398. Photos: SupplImag Roma II 2938 et EDR; Russu 1980, 39. Le cognomen de ce militaire est hapax; il est difficile de l'expliquer par un autre hapax, appartenant à un autre domaine linguistique: Calmenus Sindionis à Piliscsev, au Nord de la Pannonie 
Malvesatium, en Dalmatie (auj. Skelani, Bosnie-Herzégovine) ${ }^{44}$. On peut citer des mentions similaires pour des cavaliers de la garde impériale originaires de Dacie : Aurelius Vitorinus (sic),/ eques singulari(s) d(omini) n(ostri),/ castris prioribus, turma / Sabiniani, inmunis tur(arius), nati/one Daqus, domum Coloni(a) / Zermi(z)egete(nsium) ${ }^{45}$; anonyme, [nat(ione) D]ạc(us),/ [domo Colonia V]lpia [Zermizeget]usa ${ }^{46}$.

De cette révision du dossier épigraphique au sujet de Malva, deux conclusions sont à retenir, étant déjà formulées par F. Vittinghoff en 1969, sans qu'elles soient contredites par les nouveaux documents parus depuis: en Olténie, dans la partie méridionale de la Dacie Inférieure devenue Malvensis, il devait exister une localité inconnue du nom de Malva, qui n'est pas identique à Romula ${ }^{47}$. Ce toponyme donna le nom à la nouvelle province (i.e. à la circonscription financière) et, d'après le diplôme militaire de 230, avait déjà le rang de colonia. Des opinions similaires sur l'existence en Olténie d'une localité du nom de Malva siège du procurateur ont été exprimées et soutenues par I. Piso ${ }^{48}$ et R. Ardevan ${ }^{49}$, tandis que C. C. Petolescu a rejeté à plusieurs reprises l'identification de Malva avec Denta et Romula ; pourtant, il propose, à partir d'une suggestion de C. S. Nicolăescu-Plopşor ${ }^{50}$, de la localiser à Cioroiu Nou, un important site romain, en cours d'exploration ${ }^{51}$.

\section{Localisations}

Le diplôme militaire de M. Aur. Decianus, connu avant le milieu du XIX ${ }^{\mathrm{e}}$ s., précise qu'il était originaire de Colonia Malvensis ex Dacia, sans offrir d'autres détails (par exemple, le vicus). L'imagination des historiens et des archéologues a essayé de supplanter les lacunes des sources et de localiser cette colonia, parfois sans aucun argument ou explication. K. Torma, K. Gooss et K. Miller la plaçaient en Dacie du Nord, Th. Mommsen et D. Detlefsen en Dacie de l'Est ; O. Hirschfeld, J. Jung, H. Kiepert, P. Király et G. Brandis la situaient en Olténie, en particulier à Celei ${ }^{52}$, dont on sait que le nom ancien était Sucidava. Pour ces localisations

Inférieure (RIU III 801). La colonia Apulensis, connue par un dossier épigraphique très riche, apparaît dans IDR III/5, 127 : T. Ael. Onesimus August(alis) col(oniae) Apule(n)se.

${ }_{44}$ Vittinghoff 1969, 132, n. 9.

45 CIL VI 3236 = ILS 2204 = Speidel 1994, nº 599 = IDRE I 55.

${ }^{46}$ Speidel 1994, no 151. Voir aussi d'autres cavaliers de la garde impériale (épitaphes) : M. Vlpius Quartio, C(olonia) Ar(a) A(grippinensium) (Speidel 1994, no 170) ; T. Aur. Priscus, nat(ione) Syrus, C[o]l(onia) Caesarea (Speidel 1994, no 206). Parmi les prétoriens: M. Aur. Dasius, nat(ione) Pann(onius), Colon(ia) Siscia (CIL VI 32680); diplôme militaire du 7 janvier 226 pour M. Aurelius M.f. Col(onia) Senecio Zermizegetusa (RGZM 59).

47 Vittinghoff 1969, 147.

48 Piso 1993, 37, 91.

49 Ardevan 1996, 78 ; Ardevan 1998, 99, n. 554; Ardevan, Zerbini 2007, 57-58, 140, en partic. 150-151 (dans le voisinage de Buridava).

50 Nicolăescu-Plopşor 1965, 203-205; de même Bondoc 2010, 10.

51 Pour l'identité, Petolescu 1983, 51. Contre, Petolescu 1987, 28 ; Petolescu 2000a, 216-218; Petolescu 2000b, 77 ; Petolescu 2000c ; Petolescu 2010, 211-212 (no 2) ; Petolescu 2011, 106-108 (n 14) ; Petolescu 2014, 240-242 ; Onofrei, Blaga 2015 (Malva à Cioroiul Nou).

${ }^{52}$ Sur les localisations, voir RE XIV, 1, 1928, s.v. Malvese, 927 (Fluss) ; Gostar 1951, 170-171 ; Piso 1993, 85 n. 18 ; Haensch 1997, 348 n. 154. 
aucun argument n'est fourni, sauf peut-être le constat que la région du Sud-Ouest et du centre de la Dacie était déjà bien remplie de municipes et colonies connues par l'épigraphie. Les membres de l'École Critique, Gr. Tocilescu, A. D. Xenopol et V. Pârvan, ont opté pour l'Olténie, choisissant comme candidats les points de Celei, Reşca et Răcari ${ }^{53}$.

Une discussion séparée a été lancée par C. Patsch, qui a surévalué l'importance de l'inscription de Denta, supposant que Malva se trouvait dans le Banat ${ }^{54}$, et que la Dacie Malvensis serait le Sud-Ouest de la Dacie. C. Daicoviciu a accepté cette hypothèse et l'a défendue avec ardeur ${ }^{55}$, davantage au plus fort de la controverse avec D. Tudor. Ce dernier propose en $1944^{56}$ une nouvelle lectio pour la fonction de Sex. Iulius Possessor de l'inscription bâtie dans l'église La Giralda de Séville: curatori civitatis Romulensium Malvensium - au lieu de curatori civitatis Romulensium m(unicipii) Arvensium, comme auparavant. La même lecture est proposée par Herbert Nesselhauf vingt ans plus $\operatorname{tard}^{57}$, indépendamment de D. Tudor. La polémique de C. Daicoviciu à l'encontre de D. Tudor a retardé la reprise de la discussion, transformant le problème de Malva dans un combat personnel entre les deux savants ${ }^{58}$. Si la solution épigraphique de Tudor est correcte, les conclusions partisanes sur l'identité entre Romula et Malva, la même ville avec un double nom, latin et indigène ${ }^{59}$, sont selon nous erronées. Néanmoins, l'identité Romula-Malva est devenue une opinion commune ${ }^{60}$. Qui plus est, les doubles noms se composent d'une autre manière, avec un nom latin principal et le nom de la population locale, tels Augusta Vindelicorum, Praetorium Latobicorum, Aquae Iasae ; comme l'observe F. Vittinghoff, dans l'inscription officielle (hochoffiziele) de 248 Romula apparaît seulement comme colonia Romul( $)^{61}$.

L'inscription de Sex. Iulius Possessor n'offre aucun indice sur la localisation de Malva. Deux des commandements de sa militia equestris ont été accomplis sur l'Alutus (Olt) inférieur ${ }^{62}$ : praefectus cohortis III Gallorum et le double commandement praepositus numeri Syrorum sagittariorum item alae primae Hispanorum. Les trois unités ont laissé des traces épigraphiques à Ioneștii Govorii (coh. III Gallorum) ${ }^{63}$, Bivolari, Rădăcinești, Reșca et Slăveni (numerus Syrorum sagittariorum) ${ }^{64}$, respectivement

53 Gostar 1951, 170.

54 Patsch 1937, 137.

55 Supra, n. 12.

56 Tudor 1944.

57 Nesselhauf 1964, 181.

58 Ardevan 2010, 282-284.

59 Tudor 1958, 176 ; Tudor 1968 a, 211 ; Tudor 1978, 189.

${ }^{60}$ TIR L 35 Bucarest, 1969, 49-50, 62 (D. Tudor) ; voir le titre de Tătulea 1994 (Romula-Malva); Gudea, Lobüscher 2006, 22, 24 (peut-être Romula).

${ }^{61}$ CIL III 8031 = ILS 510 = IDR II 324, où l'on peut hésiter entre Romul(a) et Romul(ensium) ; Vittinghoff 1969, 140-141. Voir aussi l'épitaphe d'Ael. Iul. Iulianus (IDR II 357), dec(urio) quaestoric(ius) aedilic(ius) col(oniae) Romul(ensium) - plutôt que Romul(ensis).

${ }^{62}$ Voir Wolff 1976, 113-114 ; C. C. Petolescu, comm. IDRE I 179. À Romula: Piso 2013, 5, 291 (Romula Malvensium). Nous ne suivons pas I. Piso $(2013,291)$ qui interprète la ligne 6 d'une dédicace de Romula (IDR II 341) comme $n$ (umeri) $S$ (yrorum) M(alvensium) (et non pas $p$ (osuerunt)) ; sur cette dernière ligne, les trois lettres - de la dernière seule une haste droite subsiste - sont séparées par des hederae.

${ }^{63}$ Petolescu 2002, 106-107 (nº 41) : à Ioneştii Govorii, puis à Hoghiz.

${ }^{64}$ Petolescu 2002, 143-144 (n $\left.{ }^{0} 78\right)$. 
Slăveni (ala I Hispanorum) ${ }^{65}$. Il est certain que pendant sa milice il a été curateur de la civitas Romulensium, située dans la même province. En fonction du sens accordé au terme de civitas on a essayé de dater la curatelle. Pourtant, civitas Paralissensium apparaît dans une inscription alors que Porolissum était municipium ${ }^{66}$. De même, la curatelle peut dater d'avant la réorganisation des Dacies, probablement en 169, quand, de la province procuratorienne Dacia Inferior, la vallée de l'Alutus (Olt) deviendra une partie des Daciae tres sous le nom de Dacia Malvensis. Le nom existait certainement au moment de l'érection de l'inscription de Séville, sans qu'il soit obligatoirement en cours au moment de l'accomplissement de la curatelle par Sex. Iulius Possessor ${ }^{67}$.

On peut seulement supposer qu'en Dacie Inférieure, sur l'Olt, il existait une localité du nom de Malva, qui donna le nom de la province. Civitas Romulensium et numerus Syrorum reçoivent le déterminatif Malvensium, signalant leur appartenance provinciale (Dacia Malvensis), tandis que la coh. I F(lavia) m(illiaria) Bryttonum, à son tour sur l'Olt, reçoit l'épithète Malvensis le plus probablement en lien avec son lieu de garnison. Le parallélisme avec Apulum et Porolissum indique que dans cette localité du nom de Malva devait se trouver le siège du procurateur ou, du moins, un commandement militaire ${ }^{68}$. Comme l'avaient déjà supposé Ioan Piso ${ }^{69}$ et Radu $\operatorname{Ardevan}^{70}$, la seule localité qui puisse remplir ces conditions est le site de Stolniceni ${ }^{71}$.

C'est ici que des fouilles successives, en particulier les campagnes de Gheorghe Bichir, ont identifié un grand complexe thermal (Pl. II) : à côté des petits thermes, à $200 \mathrm{~m}$ au Sud, il a pu dégager un ensemble désigné comme « les grands thermes 》 (avec six niveaux d'occupation), qui compte parmi les plus importants de Dacie. Leurs murs sont parfois conservés sur $3 \mathrm{~m}$ de hauteur, et conservent des traces de peinture (Pl. III/1). Ce bâtiment a sans doute appartenu à un praetorium, comme l'indiquent les tuiles avec l'estampille PS inscrite dans une tabula ansata ${ }^{72}$, abréviation des pedites singulares, la garde du gouverneur (Pl. III/2). R. Ardevan écrivait déjà en 1998: « nous sommes d'avis qu'il y a une grande probabilité que les futures recherches prouvent ici l'existence de l'hypothétique Malva $\gg^{73}$. Malheureusement, le site de Stolniceni, en partie exploré par les archéologues ${ }^{74}$, qui ont reconnu un établissement civil $(800 \mathrm{x}$ $350 \mathrm{~m}$ ) avec des bâtiments publics et privés, a été beaucoup affecté par les habitations modernes (car il est superposé par le village Stolniceni, à présent quartier de RâmnicuVâlcea), les travaux agricoles et les canaux réalisés pour le combinat chimique Govora.

${ }_{65}$ Petolescu 2002, 71-72 (n ${ }^{\circ}$ 10).

${ }_{66}$ CIL III 2866 = IDRE II 293.

67 Petolescu 1983, 53-55.

68 Piso 1993, 40-41, qui envisage le procurateur présidial à Romula, et le centre de commandement militaire à Buridava/Stolniceni (en raison de la présence des thermes et des estampilles PS, sous Hadrien).

${ }^{69}$ Mais il soutient l'identité Romula-Malva.

70 Supra, n. 49.

${ }_{11}$ Tudor 1968b ; Bichir 1982 ; Bichir, Bardaşu 1983 ; Bichir, Sion, Bardaşu 1992 ; Bichir 1985 ; pour le camp (supposé), voir une synthèse chez Gudea 1997, 88-89 ; Purece 2012 (avec les données numismatiques).

72 IDR II 564; Gudea 1997, 88, Fig. 74, Z 1.

73 Ardevan 1998, 99.

74 1956-1958, 1962-1965 et 1967 (D. Tudor) ; 1971-1992 (Gh. Bichir). Ce dernier préparait une monographie Buridava romană. 


\section{Pourquoi Buridava ne se trouve pas à Stolniceni}

Contre la localisation proposée par I. Piso (pour le commandement militaire) et R. Ardevan (pour Malva) semble s'opposer le fait qu'à Stolniceni a été localisée, depuis Gr. Tocilescu, Buridava, précisément en raison de son emplacement sur la Table de Peutinger ${ }^{75}$, ce qui a donné, dans le langage courant, l'interchangeabilité StolniceniBuridava, similaire à l'équation Romula-Malva ${ }^{76}$. Dans le voisinage, à Ocnița, a été identifié une importante fortification gète de l'époque La Tène, qui a été baptisée par les archéologues du même nom de Buridava (« Buridava gète ») ${ }^{77}$.

Plusieurs sources mentionnent ce toponyme. Il est très probable que les

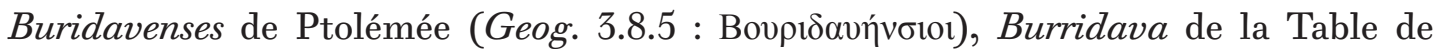
Peutinger (7.5) et Buridava du papyrus Hunt ${ }^{78}$, soient des références géographiques de la même réalité : un établissement Buridava dans la vallée de l'Alutus.

Le seul point des itineraria identifié avec certitude dans la vallée de l'Alutus est Romula, la cité antique située à Reșca (commune Dobrosloveni, dép. d'Olt) ${ }^{79}$. Conformément à la Table de Peutinger, Buridava se trouvait sur la voie logeant le fleuve Alutus (Olt), entre Pons Aluti (Ponte Aluti) et Castra Traiana (Castra Tragana), à 64 millia passuum au Nord de Romula, c'est-à-dire à environ $94,4 \mathrm{~km}^{80}$. Selon D. Tudor, Buridava est à placer à Slăvitești-Boroneasa (identification appartenant à Gr. Tocilescu ${ }^{81}$ ) ou à Stolniceni ${ }^{82}$. Le même D. Tudor a supposé l'existence d'un castellum au dernier point ${ }^{83}$, où étaient cantonnés, comme nous renseignent les estampilles, des détachements des légions I Italica, XI Claudia et V Macedonica ${ }^{84}$, ainsi que des unités auxiliaires comme la coh. II Flavia Bessorum (35 estampilles) ${ }^{85}$ et la coh. I milliaria Brittonum.

Au même endroit, des estampilles tégulaires PS ${ }^{86}$, en grande quantité (90 exemplaires) attestent la présence de la garde du procurateur (pedites singulares) (Pl. III/2) ${ }^{87}$.

${ }^{25}$ Tocilescu 1896, 84 .

76 Tudor 1965, 23 ; Tudor 1976 ; Tudor 1978, 270 ; TIR L 35 Bucarest, 1969, 68-69 (D. Tudor).

77 Berciu 1981 ; Berciu 1973, 615, n $^{\text {os }}$ 6-7, Fig. 5/1-2.

${ }^{78}$ P. Lond. 2851 = ChLA III $219=$ CPL $112=$ RMR 63; dans ce pridianum de la coh. $I$ Hispanorum veterana quingenaria, sous la rubrique intra provinciam, à l'occasion de la seconde guerre dacique (col. II, 1. 28) : Buridavae in vexilla[t]ione. Voir, en dernier lieu, Dana, Nemeti 2016, 81-89 (sur les toponymes Buridava et Piroboridava).

${ }^{79}$ Tătulea 1994.

${ }^{80} 94,656 \mathrm{~km}$, d'après les calculs de D. Tudor (Tudor 1942, 199) ; d'autres calculs chez Tudor 1958 et Tudor 1968a, 57-59; Fodorean 2006, 297.

${ }^{81}$ Tocilescu 1896, 84 .

${ }^{82}$ Pour l'identification avec Stolniceni, voir Bichir 1994, 229-230 ; Gudea 2005, 495 (avec les types d'estampilles, d'après Tudor 1966b et ses dessins) ; Zahariade 2013.

${ }^{83}$ Mais aucun camp n'a été identifié à Stolniceni, en particulier au point « conacul Boroneasa » (voir Bichir 1985). Pour une partie des unités, on peut penser au castellum de Mihăieşti-Plută (voir n. 33).

${ }^{84}$ IDR II 556-559. Ces estampilles sont communément mises en rapport avec les guerres daciques de Trajan ; voir Petolescu, Matei-Popescu 2008, 358 (équation Stolniceni-Buridava) ; Matei-Popescu 2010a, 268.

${ }^{85} \mathrm{C} \bullet$ HIIFLBES, COHIIFLBES, C $\bullet$ HIIFLBE (deux exemples dans IDR II, $\mathrm{n}^{\text {os }} 561-562$ ). Voir Bichir 1985, 95-99; Petolescu 2002, 84-85 (nº 20) ; Matei-Popescu 2010a, 200-201; cette unité est attestée plus tard à Cincşor (dép. de Braşov).

${ }^{86}$ IDR II 564 ; Bichir 1985 (et ILD I 150). Pour Bichir et d'autres historiens (voir infra, n. 88), ces estampilles seraient en rapport avec la présence du gouverneur de la Mésie Inférieure, lors des guerres daciques.

${ }^{87}$ Et une fictive coh. IX Batavorum (?) ; voir Tudor 1964a, 404-410 ; Tudor 1968a, 220-223 ; pour Gostar 1966, 184, l'estampille [-]XB doit être lue [coh(ors) I] (milliaria) B(rittonum). 
Pour D. Tudor, suivi par l'ensemble des commentateurs, la présence des détachements légionnaires et de la garde de pedites singulares serait une preuve qu'ici se trouvait le commandement militaire du gouverneur de la Mésie Inférieure pendant les guerres daciques de Trajan ${ }^{88}$. Toutefois, les fouilles de Gh. Bichir au point Boroneasa (« conacul Boroneasa ») n'ont pas identifié le soi-disant castellum supposé par D. Tudor ${ }^{89}$. En revanche, la présence des estampilles des pedites singulares, corroborées par les découvertes archéologiques (les « grands thermes » fouillés par Gh. Bichir ${ }^{90}$ ), ont déterminé I. Piso à supposer l'existence d'un commandement militaire de la Dacie Inférieure à partir de la réorganisation par Hadrien de la province procuratorienne ${ }^{91}$.

Aucune estampille n'atteste la présence à Stolniceni de la coh. I Hispanorum veterana dont le papyrus Hunt précise qu'elle était Buridavae in vexilla[t]ione. L'unité est attesté en Mésie Inférieure par les diplômes militaires des années 97 et 99, puis en Dacie Inférieure ${ }^{92}$, à Brețcu, sans doute Avyovotía/Angustiae de Ptolémée ${ }^{93}$. Des estampilles tégulaires de cette cohorte ont également été découvertes dans les camps voisins de Comolău et Boroşneul Mare ${ }^{94}$. Deux tesserae appartenant à un librarius ${ }^{95}$, respectivement un decurio $^{96}$, de cette cohorte ont été découvertes dans le camp de Bivolari, constamment identifié à Arutela ${ }^{97}$.

Pour l'identification des toponymes de la vallée de l'Alutus on ne doit pas utiliser les données des distances de la Table de Peutinger dans un sens absolu. Le copiste du manuscrit médiéval de la carte antique a pu ignorer certaines localités et distances. Le papyrus Hunt atteste une vexillation de la coh. I Hispanorum veterana à Buridava. À environ $20 \mathrm{~km}$ au Nord-Est de Stolniceni existe un camp auxiliaire à Sâmbotin (dép. de Vâlcea) ${ }^{98}$ d'où provient une estampille tégulaire de cette coh. I Hispanorum (C HIS $)^{99}$. À Stolniceni n'est pas encore documenté aucun camp, ni d'autres données sur la présence de cette cohorte. Par conséquent, nous pensons que le toponyme antique Buridava doit être lié au camp militaire de Sâmbotin ou, peut-être, de Bivolari, comme on le pensait à la fin du $\mathrm{XIX}^{\mathrm{e}}$ s. ${ }^{100}$. Le centre civil et militaire de Stolniceni, « capitale » d'une province procuratorienne, n'est pas mentionné avec son nom ancien

88 Tudor 1964b; Tudor 1978, 33, 214, 270 ; Petolescu 2002, 146, n. 5.

89 Bichir 1985, 93, n. 8 ; Vlădescu 1986, 43 ; Bogdan Cătăniciu 1997, 68.

90 Bichir 1985 ; Bichir 1988.

91 Piso 1993, 3, 40. Sur les pedites et les equites singulares de Dacie (Apulum), attestés par des tuiles, voir Băluță, Berciu 1980 ; Băluță 1980. Plusieurs estampilles tégulaires PES, pe(ditum) s(ingularium), ont été découvertes à Sarmizegetusa dans le praetorium procuratoris (CIL III 8075, 20 ; voir le commentaire de Piso 1996, 158-159, $\mathrm{n}^{\mathrm{o}}$ 7), siège du procurateur financier de la Dacie Apulensis.

${ }_{92}$ Matei-Popescu 2010a, 215-218; Petolescu 2002, 109-110.

93 Ptol. Geog. 3.8.7 ; Vulpe 1944, 551-559.

94 Vlădescu 1983, 35-36.

${ }^{95}$ CIL III 12602 = IDR II 582 : Valerius Valer[i]anus,/ eq(ues) lib(rarius) c(o)hor(tis) I Hisp(anorum), ex [v]oto pos(uit).

${ }_{96}$ CIL III 12603 = IDR II 581 (sans l'indication de son unité).

97 Poiana Bivolari, village de Păuşa, ville de Călimăneşti (dép. de Vâlcea), voir Vlădescu 1983, 91-100 ; Vlădescu 1986, 46-60 (selon lui, le camp en pierre a été construit par les Suri sagittarii en 138, cf. IDR II 575, 576) ; voir aussi Marcu 2009, 181-187.

98 TIR L 35 Bucarest, 1969, 66 (Castra Traiana) ; Marcu 2009, 230-231.

99 Avram, Avăsiloaiei 1995, 193-195 (AE 1995, 1305 = ILD I 153).

100 Goos 1874, 42. 
ni sur la Table de Peutinger, ni dans l'itinéraire du Géographe Anonyme de Ravenne - et la raison de cette absence est déterminée par la constitution et la finalité de ces documents cartographiques ${ }^{101}$. Il est important de mentionner ici que sur la carte de Giovanni Morando Visconti (1699), architecte italien au service des Habsbourgs, où il fait la distinction entre les ruines des camps et des villes antiques, il note au Sud de Râmnicu-Vâlcea (« Ribnik »), sur la rive droite de l'Olt, un carré avec la légende « Città Romana », qui correspond à Stolniceni ${ }^{102}$.

\section{Malva sur la rive droite de l'Olt}

Nous essayons d'apporter d'autres arguments à l'idée que Malva devrait être placée à Stolniceni, par une analyse des itinéraires antiques qui décrivent la route sur la vallée de l'Olt. Un détail mineur mais néanmoins important, resté inaperçu jusqu'à présent, offre la solution du problème.

C. C. Petolescu a observé que Malva n’est pas mentionnée par les sources géographiques antiques et remarque que son « absence de la Table de Peutinger pourrait sembler au moins curieuse »; de même, il note qu'« en réalité, cette source 'cartographique' fait mention, pour l'Olténie seulement de la route Drobeta - Romula et de la ligne des camps situés sur l'Olt en amont de Romula ; il manque aussi Sucidava et les camps en aval de Romula ${ }^{103}$.

Afin de comprendre la raison de ces absences il faut renoncer aux anciennes identifications et prendre en compte le fait élémentaire que les sources géographiques conservées pour la vallée de l'Olt sont des itineraria antiques, des descriptions des routes et de leurs stationes ${ }^{104}$. Comment est-il possible que les itinéraires ignorent un centre important, soit-il le siège du gouverneur, comme Stolniceni, ou un centre important qui donne le nom d'une province, comme Malva? Tout simplement, pour la simple raison qu'il ne figurait pas sur la route décrite par ces sources, et que Stolniceni et Malva sont identiques.

La Table de Peutinger représente la route Drobeta - Romula ${ }^{105}$ puis à partir de Romula en logeant l'Olt, par le défilé, jusqu'à Apulum ${ }^{106}(\mathrm{Pl}$. IV/1) :

Egeta XXI - Drubetis XXXVI - Amutria XXXV - Pelendova XX - Castris Novis LXX - Romula XIII - Acidava XXIIII - Rusidava XIIII - Ponte Aluti XIII - Burridava XII

- Castra Tragana VIIII - Arutela XV - Pretorio VIIII - Ponte Vetere XLIIII - Stenarum XII - Cedonie XXIIII - Acidava XV - Apula.

101 De même, chez Ptolémée, on ne trouve pas mentionnés les sites de la vallée de l'Alutus, car à l'époque de sa source ils se trouvaient en Mésie Inférieure ; notons toutefois qu'il mentionne les Buridavenses parmi les peuples de Dacie.

102 Mappa della Transiluania e Prouintie contigue (Hermannstadt/Sibiu 1699). Voir Măndescu 2014, en partic. 79-80, 83 (Fig. 2).

103 Petolescu 1987, 31 ; Petolescu 2011, 107, n. 256.

${ }^{104}$ Levi, Levi 1967, 25-32 ; Bosio 1983, 118-126 ; Dilke 1985, 112-120 ; Herrmann 2007, 182-188 ; Dillemann 1997.

105 Sur la route Drobeta-Romula-Apulum, voir aussi Bogdan Cătăniciu 2007, 65-68, avec d'autres localisations (p. 67, la même équation Stolniceni-Buridava).

106 En corrigeant les formes corrompues et en revenant au nominatif, on reconnait Drubeta, Pelendava, Castra Nova, Pons Aluti, Buridava, Castra Traiana, Praetorium, Pons Vetus, Caput Stenarum, Apulum. 
Elle mentionne donc, de Romula à Caput Stenarum, dix stationes avec les distances entre elles, exprimées en miles romaines ${ }^{107}$. Il faut relativiser les distances, qui ont pu être copiées avec des erreurs, et regarder de manière critique les anciennes identifications, qui peuvent nous tromper ${ }^{108}$. Le Géographe Anonyme de Ravenne nous transmet pour le même segment de route seulement quatre stationes au lieu de dix. La sélection qu'il a opérée est révélatrice : le début et la fin de la route, à savoir Romula et Caput Stenarum, ainsi que deux stationes intermédiaires dont les noms sont corrompus, Aluti pour Pons Aluti et Betere pour Pons Vetus ${ }^{109}$. Il n'est pas par hasard qu'il a sélectionné seulement deux stationes-clé et qu'il a omis les différentes mutationes mineures - preuve qu'il possédait pour cette route une autre source que la Table de Peutinger, sans doute l'Itinerarium Antonini ou une source similaire ${ }^{110}$. Ce sont précisément les sites par lesquels la route passait d'une rive à l'autre de l'Olt.

Sur la carte de la Dacie reconstituée à partir des vestiges archéologiques il est visible le fait que la route romaine de Romula/Reșca à Pons Aluti/Ioneștii Govorii se situait sur la rive droite de l'Olt. La ville antique de Romula et les camps de Enoșești et de Drăgăşani (Acidava et Rusidava d'après les identifications habituelles, même si elles ne sont pas assurées) se trouvent à leur tour sur la rive droite. La route passe sur la rive gauche à Ioneștii Govorii (Pons Aluti), parce que plus au Nord de cette localité tous les camps connus et fouillés se trouvent sur la rive gauche du fleuve: Sâmbotin, Bivolari, Racovița-Copăceni, Câineni, jusqu'au passage à nouveau sur la rive droite à Pons Vetus/Boița ${ }^{111}$. Plus en amont, la route continuait sur la rive droite de l'Olt jusqu'à Caput Stenarum - difficile à identifier si la distance de 4/4 miles romaines de la source est correcte. Dans ce cas, à Ioneştii Govorii a été bâti par les Romains un pont sur l'Olt, dont le nom ancien était Pons Aluti, comme il ressort des deux itinéraires conservés, la Table de Peutinger et le géographe anonyme de Ravenne. Les autres stationes enregistrées par les itinéraires au Nord de Pons Aluti se trouvent ainsi, obligatoirement, sur la rive gauche (Pl. IV/2): Buridava (Sâmbotin ?), Castra Traiana (Bivolari-Jiblea ?), Arutela (Racoviţa-Copăceni ?), Praetorium (Câineni ?), jusqu'à Pons Vetus (Boiţa ?) ${ }^{112}$, en ignorant l'agglomération importante de Stolniceni, précisément parce qu'elle était située sur la rive droite de l'Olt, dans une région par laquelle aucune route stratégique et importante de la Dacie Inférieure ne passait.

Indifféremment de l'emplacement sur le terrain des stationes et des mutationes mentionnées dans les sources, si elles sont ou non à placer dans le voisinage des camps sur l'Olt et de leurs établissements civils, une chose est certaine. La route allait de Romula à Pons Aluti sur la rive droite de l'Olt, puis de Pons Aluti à Pons Vetus sur la rive gauche. Cette route ne traversait pas la grande agglomération civile et militaire de Stolniceni, siège du procurateur, ou, du moins, du commandement militaire de la

107 Miller 1916a, 10-11; Miller 1916b, 553-556.

108 Tudor 1942, 199-202 ; Tudor 1968a, 57-59 ; Fodorean 2006, 296-302 ; Fodorean 2014, 109-111.

109 Schnetz 1990, 49.

110 Arnaud 1998, 209.

111 Miller 1916b, 541-543, Fig. 170 ; erroné dans TIR L35 et Barrington Atlas, 22.

112 À l'exception de Racovița, les fortifications entre Boița et Stolniceni sont de petites dimensions (T, Tentea, Matei-Popescu 2015, 119), et sont parfois occupées par des numeri (Suri sagittarii et numerus burgariorum et veredariorum). 
Dacie Inférieure (et par la suite Malvensis), le seul centre important sur la rive droite de l'Olt qui soit situé au Nord de Romula113. Malva n'apparaît pas dans ces sources, en raison du même motif : elle n'était pas placée le long de cette artère de circulation. Dans ce cas, il est impossible d'identifier Stolniceni avec Buridava, qui se trouvait sur la route des itinéraires conservés ; c'est donc ici que devait se trouver la mystérieuse Malva, qui n'est à placer ni à Romula (selon l'opinion commune), ni à Cioroiu Nou (selon les hypothèses plus récentes). Elle a été cachée sous le nom de Buridava à cause d'une interprétation défectueuse d'une source cartographique depuis plus d'un siècle. On peut aussi constater une concentration de sites archéologiques autour de Stolniceni (dont les exploitations de sel d'Ocnița), site par ailleurs doublement protégé par la ligne de l'Olt et par la route fortifiée placée sur l'autre rive.

Aucune inscription sur pierre n'a été découverte, il est vrai, à Stolniceni, mais l'exploration du site n'est que partielle. En revanche, beaucoup d'inscriptions, y compris à caractère officiel, proviennent de Romula ${ }^{114}$, et, dans le reste de la petite province, à Sucidava et Cioroiu Nou, tous les autres sites explorés étant très pauvres en matériel épigraphique, qui se réduit le plus souvent à un caractère militaire. Les futures découvertes archéologiques et épigraphiques établiront si à Stolniceni se trouvait une cité antique, une colonia, siège du procurateur de la Dacie Malvensis, et dont le nom Malva a été utilisé pour la titulature officielle de la province.

\section{Bibliographie}

Ardevan 1996

Ardevan 1998

Ardevan 2000

Ardevan 2005

Ardevan 2010

Ardevan, Zerbini 2007

Arnaud 1998
R. Ardevan, Curator civitatis Romulensium, SpecNov, 12, 1996, 77-82.

R. Ardevan, Viața municipală în Dacia romană, Timișoara 1998.

R. Ardevan, Municipalia Dacica. Drei epigraphische Bemerkungen. In: Gy. Németh, P. Forisek (éds.), Epigraphica I. Studies on Epigraphy, HPS 6, Debrecen 2000, 109-130.

R. Ardevan, Colonia Claudia Aequum und Dakien. Epigraphische Bemerkungen. In: M. Mirković (éd.), Römische Städte und Festungen an der Donau. Akten der regionalen Konferenz, Beograd, 16-19 Oktober 2003, Beograd 2005, 125-133.

R. Ardevan, La divisione amministrativa della Dacia Romana nella storiografia. In: L. Zerbini (éd.), Roma e le province del Danubio. Atti del I Convegno Internazionale Ferrara - Cento, 15-17 ottobre 2009, Soveria Manelli 2010, 279-289.

R. Ardevan, L. Zerbini, La Dacia romana, Soveria Mannelli 2007.

P. Arnaud, Les toponymes en -iana/-ianis des itinéraires: des villes de Ptolémée aux grands domaines? In: P. Arnaud, P. Counillon (éds.), Geographica Historica, Bordeaux - Nice 1998, 201-224.

113 On peut aussi bien reprendre l'hypothèse de I. Piso d'une dualité, avec un centre financier à Romula et le commandement militaire à Stolniceni (Malva, et non Buridava).

114 De Romula provient un document curieux à bien des égards : une copie sur tuile, en écriture cursive, du début d'une lettre (officielle ? ou plutôt un exercice), traduite en grec, dans la seconde moitié du $\mathrm{II}^{\mathrm{e}} \mathrm{s}$.

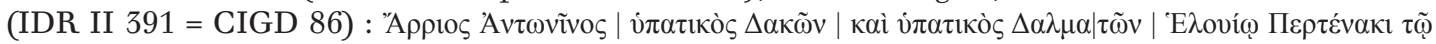

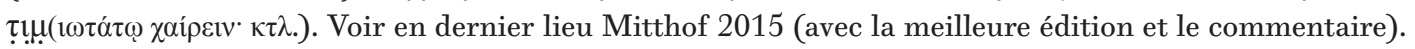


Avram, Avăsiloaiei 1995 R. Avram, D. Avăsiloaiei, Garnizoana romană de la Castra Traiana, SCIVA, 46, 2, 1995, 193-195.

Băluță 1980

C. L. Băluţă, Pedites et equites singulares in Dacia. In: W. S. Hanson, L. J. F. Keppie (éds.), Roman Frontier Studies: 1979, XII. Papers Presented to the $12^{\text {th }}$ International Congress of Roman Frontier Studies, BAR 71, Oxford 1980, 831-840.

Băluță, Berciu 1980

C. L. Băluță, I. Berciu, Pedites și equites singulares în Dacia. Materiale tegulare ştampilate, Apulum, 18, 1980, 109-129.

Berciu 1973

D. Berciu, Scriere cu litere latine în complexul dacic de la Ocnița (Ocnele Mari), jud. Vîlcea, SCIV, 24, 4, 1973, 611-619.

Berciu 1981

Bichir 1982

D. Berciu, Buridava dacică, București 1981.

Gh. Bichir, Cercetările arheologice de la Stolniceni-Rîmnicu Vîlcea, Buridava, 4, 1982, 43-54.

Bichir 1985

Bichir 1988

Gh. Bichir, Centrul militar roman de la Buridava, Thraco-Dacica, 6, 1985, 93-104.

Gh. Bichir, Continuitatea în Dacia după retragerea romană. Așezarea din secolele III-IV de la Stolniceni-Rîmnicu Vîlcea (Buridava romană), Thraco-Dacica, 9, 1988, 101-117.

Bichir 1994

Gh. Bichir, s.v. Buridava, EAIVR, I, 1994, 229-230.

Bichir, Bardaşu 1983

Gh. Bichir, P. Bardaşu, Santierul arheologic de la Stolniceni-Buridava (jud. Vîlcea), MCA, 15, 1983, 336-343.

Bichir, Sion, Bardaşu 1992

Gh. Bichir, A. Sion, P. Bardaşu, Assezarea de la Stolniceni-Buridava, jud. Vîlcea, MCA, 17, 1992, 255-268.

Bogdan Cătăniciu 1997 I. Bogdan Cătăniciu, Muntenia în sistemul defensiv al Imperiului Roman, sec. I-III p. Chr., Alexandria 1997.

Bogdan Cătăniciu 2007 I. Bogdan Cătăniciu, Daci şi romani. Aculturație în Dacia, ClujNapoca 2007.

Bondoc 2004

D. Bondoc, Inscriptiii şi piese sculpturale. Muzeul Olteniei Craiova. Roman Inscriptions and Sculptural Pieces. The Museum of Oltenia, Craiova, Craiova 2004.

Bondoc 2010

D. Bondoc, Cioroiu Nou. 100 descoperiri arheologice. One Hundred Archaeological Discoveries, Craiova 2010.

Bosio 1983

Daicoviciu 1930

L. Bosio, La Tabula Peutingeriana. Una descrizione pittorica del mondo antico, Rimini 1983.

C. Daicoviciu, Banatul și arheologia. Câteva probleme, AB, 3, 2, 1930, 1-3.

Daicoviciu 1939-1942

C. Daicoviciu, Bănatul şi Iazygii, Apulum, 1, 1939-1942, 98-109.

Daicoviciu 1942

Daicoviciu 1941-1943

C. Daicoviciu, Câteva cuvinte în legătură cu organizația Daciei, Transilvania, 73, 12, decembrie 1942, 958-963.

Daicoviciu 1944

C. Daicoviciu, Asupra unor lucrări în legătură cu Dacia romană, AISC, 4, 1941-1943, 282-321.

Daicoviciu 1965

C. Daicoviciu, Nesciendi ars..., Sibiu 1944.

C. Daicoviciu, E Malva la Cioroiul Nou?, ActaMN, 2, 1965, 654-655.

Daicoviciu 1969

C. Daicoviciu, Orașe, tîrguri și sate în Dacia romană, ActaMN, 6, 1969, 537-544.

Daicoviciu, Daicoviciu 1967

C. Daicoviciu, H. Daicoviciu, Noi considerații asupra Daciei Malvensis, ActaMN, 4, 1967, 73-83.

Daicoviciu 1969

C. Daicoviciu, Pe marginea cărților, ActaMN, 7, 1970, 125-133. 
Dana 2011

Dana 2017

Dana, Matei-Popescu 2009

Dana, Nemeti 2016

Dana, Zăgreanu 2017

Detschew 1957

Dilke 1985

Dillemann 1997

Duridanov 1969

Duridanov 1995

Fodorean 2006

Fodorean 2014

Gooss 1874

Gostar 1951

Gostar 1966

Gudea 1997

Gudea 2005

Gudea, Lobüscher 2006

Haensch 1997

Herrmann 2007

Levi, Levi 1967

Macrea 1969
D. Dana, L'impact de l'onomastique latine sur les onomastiques indigènes dans l'espace thrace. In: M. Dondin-Payre (éd.), Les noms de personnes dans l'Empire romain. Transformations, adaptation, évolution, Scripta Antiqua 36, Bordeaux 2011, 37-87.

D. Dana, Le nom de Cumidava et la cohors VI nova Cumidavensis. In: P. Pavel, O. Savu (éds.), Studia in honorem Florea Costea la a 80-a aniversare, Braşov 2017, 111-116.

D. Dana, F. Matei-Popescu, Soldats d'origine dace dans les diplômes militaires, Chiron, 39, 2009, 209-256.

D. Dana, S. Nemeti, Ptolémée et la toponymie de la Dacie (VI-IX), Classica et Christiana, 11, 2016, 69-73.

D. Dana, R. Zăgreanu, Equites singulares Augusti originaires de la province de Dacie: épigraphie, onomastique, iconographie, SAA, 23, 1, 2017, 139-171.

D. Detschew, Die thrakischen Sprachreste, Wien 1957 (réimpr. 1976).

O. A. W. Dilke, Greek and Roman Maps, New York 1985.

L. Dillemann, La Cosmographie du Ravennate, ouvrage édité par Y. Janvier, Latomus 235, Bruxelles 1997.

I. Duridanov, Thrakisch-Dakische Studien. I. Die thrakisch- und dakisch-baltischen Sprachbeziehungen, Linguistique Balkanique 13, 2, Sofia 1969.

I. Duridanov, Thrakische und dakische Namen. In: E. Eichler, G. Hilty, H. Löffler, H. Steger, L. Zgusta (éds.), Namenforschung: Name Studies: Les noms propres. Ein internationales Handbuch zur Onomastik: An International Handbook of Onomastics: Manuel international d'onomastique, I, Berlin - New York 1995, 820-840.

F. Fodorean, Drumurile din Dacia romană, Cluj-Napoca 2006.

F. Fodorean, Pannonia, Dacia şi Moesia în izvoarele geografice antice, Cluj-Napoca 2014.

C. Goos, Studien zur Geographie und Geschichte des Trajanischen Daciens, Programm des evangelischen Gymnasiums in Schässburg, Hermannstadt (Sibiu) 1874.

N. Gostar, Vămile Daciei, SCIV, 2, 2, 1951, 165-181.

N. Gostar, Studii epigrafice II, ArhMold, 4, 1966, 175-188.

N. Gudea, Der dakische Limes. Materialien zu seiner Geschichte, JRGZM 44, 2, Mainz 1997.

N. Gudea, Der untermoesische Donaulimes und die Verteidigung der moesischen Nord und-Westküste des Schwarzen Meeres Limes et Litus Moesiae Inferioris (86-275 n. Chr.), JRGZM, 52, 2005, 319-566.

N. Gudea, Th. Lobüscher, Dacia. Eine römische Provinz zwischen Karpaten und Schwarzem Meer, Mainz 2006.

R. Haensch, Capita provinciarum. Statthaltersitze und Provinzialverwaltung in der römischen Kaiserzeit, Kölner Forschungen 7, Mainz 1997.

P. Herrmann, Itinéraires des voies romaines de l'Antiquité au Moyen $\hat{A} g e$, Paris 2007.

A. Levi, M. Levi, Itineraria picta. Contributto allo studio della Tabula Peutingeriana, Roma 1967.

M. Macrea, Viața în Dacia romană, București 1969. 
Marcu 2009

Matei-Popescu 2010a

Matei-Popescu 2010b

Măndescu 2014

Mihăescu 1978

Miller 1916a

Miller 1916b

Mitthof 2015

Müller, Schwaighofer,

Piso, Benea 2012

Nesselhauf 1964

Nemeti, Dana 2017

Nicolăescu-Plopşor 1965

Onofrei, Blaga 2015

Patsch 1937

Petolescu 1983

Petolescu 1987

Petolescu 2000a

Petolescu 2000b

Petolescu 2000c

Petolescu 2002
F. Marcu, Organizarea internă a castrelor din Dacia, Cluj-Napoca 2009.

F. Matei-Popescu, The Roman Army in Moesia Inferior, The Centre for Roman Military Studies 7, București 2010.

F. Matei-Popescu, Cohortes Augustae Nervianae Pacenses Brittonum. In: H. Pop, I. Bejinariu, S. Băcueț-Crişan, D. Băcueț-Crişan (éds.), Identități culturale locale şi regionale în context european. Studii de arheologie şi antropologie istorică. In memoriam Alexandru V. Matei, Bibliotheca Musei Porolissensis 13, Cluj-Napoca 2010, 395-398.

D. Măndescu, An Almost Forgotten Old Map and the First Mentions of Some Roman Remains on Alutanus and Transalutanus Limites. In: V. Sîrbu, C. Croitoru (éds.), Ancient Linear Fortifications on the Lower Danube. Proceedings of the National Colloquium "Ancient Linear Fortifications on the Left Bank of the Lower Danube", Brăila, 14-16 June 2013, Ad limites orbis Romani 1, Cluj-Napoca 2014, 77-84.

H. Mihăescu, La langue latine dans le sud-est de l'Europe, BucureştiParis 1978.

K. Miller, Die Peutingersche Tafel oder Weltkarte des Castorius, Stuttgart 1916.

K. Miller, Itineraria Romana, Stuttgart 1916.

F. Mitthof, Arrius Antoninus an Helvius Pertinax. Beobachtungen zur Ziegelinschrift IDR II 391 aus Romula-Malva. In: L. Zerbini (éd.), Culti e religiosità nelle province danubiane. Atti del II Convegno Internazionale Ferrara 20-22 Novembre 2013, Bologna 2015, 671-682.

H. W. Müller, B. Schwaighofer, I. Piso, M. Benea, Der Marmor im römischen Dakien, Cluj-Napoca 2012.

H. Nesselhauf, Sex. Iulius Possessor, Madrider Mitteilungen, 5, 1964, 180-184.

S. Nemeti, D. Dana, Malva, la colonie perdue de la Dacie Inférieure, ActaMN 54, I, 2017, 207-231.

C. S. Nicolăescu-Plopşor, Unde a fost Malva?, RM, 3, 2, 1965, 203-207.

C. Onofrei, D. Blaga, Some Issues Regarding the Identification of Ancient Romula with the Urban Ghost Malva. In: S. Cocis, M. Gui, V.-A. Lăzărescu, D.-A. Deac (éds.), Ad finem Imperii Romani. Studies in Honour of Coriolan H. Opreanu, Cluj-Napoca 2015, 323-330.

C. Patsch, Der Kampf um dem Donauraum unter Domitian und Trajan, Wien-Leipzig 1937.

C. C. Petolescu, Sex. Iulius Possessor, SCIVA, 32, 1, 1983, 42-56.

C. C. Petolescu, Colonia Malvensis, SCIVA, 38, 1, 1987, 23-32 (= Petolescu 2007, 180-190).

C. C. Petolescu, Dacia şi Imperiul Roman, București 2000.

C. C. Petolescu, Provincia Dacia Inferior (Malvensis). Discuţii şi ipoteze, Oltenia, 12, 2000, 74-79.

C. C. Petolescu, s.v. Malva, EAIVR, III, 2000, 20-21.

C. C. Petolescu, Auxilia Daciae. Contribuție la istoria militară a Daciei romane, București 2002. 
Petolescu 2007

Petolescu 2010

Petolescu 2011

Petolescu 2011-2012

Petolescu 2014

Petolescu, Matei-

Popescu 2008

Piso 1993

Piso 1996

Piso 2013

Purece 2012

Russu 1969

Russu 1980

Russu 1981

Schnetz 1990

Speidel 1973

Speidel 1977

Speidel 1984

Speidel 1994

Tătulea 1994

Tocilescu 1896

Tocilescu 1902

Tudor 1942

Tudor 1944

Tudor 1958
C. C. Petolescu, Contribuții la istoria Daciei romane, I, București 2007.

C. C. Petolescu, Orassele romane din Oltenia. Note toponimice şi epigrafice, Drobeta, 20, 2010, 209-213.

C. C. Petolescu, Villes de la Dacie romaine, Dacia N. S., 55, 2011, 83-109.

C. C. Petolescu, M. Aurelius Cassianus, praeses Daciae Malvensis, Oltenia, 18-19, 2011-2012, 114-119.

C. C. Petolescu, Dacia. Un mileniu de istorie, București $2014^{2}$ (= 2010).

C. C. Petolescu, Fl. Matei-Popescu, The Presence of the Roman Army from Moesia Inferior at the North of the Danube and the Making of the Dacia Inferior Province. In: I. Piso (éd.), Die Römischen Provinzen. Begriff und Gründung (Colloquium Cluj-Napoca 28. September-1. Oktober 2006), Cluj-Napoca 2008, 357-367.

I. Piso, Fasti provinciae Daciae. I. Die senatorischen Amtsträger, Antiquitas 43, Bonn 1993.

I. Piso, Les estampilles tégulaires de Sarmizegetusa, EN, 6, 1996, 153-200.

I. Piso, Fasti provinciae Daciae. II. Die ritterlichen Amtsträger, Antiquitas 60, Bonn 2013.

S. I. Purece, The End of the Roman Habitation at Buridava (Stolniceni, Vâlcea County), AB S. N., 20, 2012, 91-95.

I. I. Russu, Die Sprache der Thrako-Daker, București 1969.

I. I. Russu, Daco-geții în Imperiul Roman (în afara provinciei Dacia traiană), București 1980.

I. I. Russu, Etnogeneza românilor. Fondul autohton traco-dacic şi componenta latino-romanică, București 1981.

J. Schnetz, Itineraria Romana. II. Ravennatis Anonymi Cosmographia et Guidonis Geographica, Stuttgart 1990.

M. P. Speidel, Numerus Syrorum Malvensium. The Transfer of a Dacian Army Unit to Mauretania and its Implications, Dacia N. S., 17, 1973, 169-177 (= Speidel 1984, 149-160).

M. [P.] Speidel, A Thousand Thracian Recruits for Mauretania Tingitana, AntAfr, 11, 1977, 167-173 (= Speidel 1984, 341-347).

M. P. Speidel, Roman Army Studies, I, Mavors 1, Amsterdam 1984.

M. P. Speidel, Die Denkmäler der Kaiserreiter. Equites singulares Augusti, Köln 1994.

C. M. Tătulea, Romula-Malva, Craiova 1994.

Gr. G. Tocilescu, Neue Inschriften aus Rumänien, AEM, 19, 1896, 79-111.

Gr. G. Tocilescu, Monumentele epigrafice şi sculpturale ale Muzeului Național de Antichități, București 1902.

D. Tudor, Oltenia romană, București 1942.

D. Tudor, Sextus Iulius Possessor în Dacia. In: C. Marinescu et alii (éds.), In amintirea lui Constantin Giurescu la douăzeci şi cinci de ani dela moartea lui (1875-1918), București 1944, 523-531.

D. Tudor, Oltenia romană, București $1958^{2}$. 
Tudor 1964a

Tudor 1964b

Tudor 1965

Tudor 1966a

Tudor 1966b

Tudor 1968a

Tudor 1968b

Tudor 1976

Tudor 1978

Tentea, Matei-Popescu 2015

Vittinghoff 1969

Vlădescu 1983

Vlădescu 1986

Vulpe 1944

Wolff 1975

Zahariade 2013
D. Tudor, Les garnisons de Buridava à l'époque de la conquête de la Dacie. In: Akten des IV. Internationalen Kongresses für griechische und lateinische Epigraphik (Wien, 17. bis 22. September 1962), Wien 1964, 404-410.

D. Tudor, «Pedites singulares » à Buridava, Dacia N. S., 8, 1964, 345-352.

D. Tudor, Tabula Imperii Romani. Drobeta - Romula - Sucidava, București 1965.

D. Tudor, Aquae, en Dacie inférieure, Latomus, 25, 1966, 4, 847-854.

D. Tudor, Comunicări epigrafice IV, SCIV, 17 (3), 1966, 593-603.

D. Tudor, Oltenia romană, București $1968^{3}$.

D. Tudor, Centrul militar de la Buridava, SMMIM, 1, 1968, 17-29.

D. Tudor, s.v. Buridava, PECS, I, 1976, 173.

D. Tudor, Oltenia romană, București $1978^{4}$.

O. T,entea, F. Matei-Popescu, Why There? The Preliminaries of Constructing the Roman Frontier in South-East Dacia, ActaMN, 52, 2015, 109-130.

F. Vittinghoff, War die Kolonie Malva mit Romula (Reșca) identisch?, ActaMN, 6, 1969, 131-147.

C. M. Vlădescu, Armata romană în Dacia Inferior, București 1983.

C. M. Vlădescu, Fortificațiile romane din Dacia Inferior, Craiova 1986.

R. Vulpe, Angustia. In: C. Marinescu et alii (éds.), In amintirea lui Constantin Giurescu la douăzeci şi cinci de ani dela moartea lui (1875-1918), Bucureşti 1944, 551-559.

H. Wolff, Miscellanea Dacica, ActaMN, 12, 1975, 139-158.

M. Zahariade, s.v. Buridava. In: M. Zahariade (éd.), Lexicon of the Greek and Roman Cities and Place Names in Antiquity ca. 1500 B.C.-ca. A.D. 500, fasc. 13, Amsterdam 2013, 1939-1941.

Sorin Nemeti

Université Babeş-Bolyai, Cluj-Napoca nemeti.sorin(a) gmail.com

Dan Dana CNRS/ANHIMA, Paris ddana_ddan(j)yahoo.com 


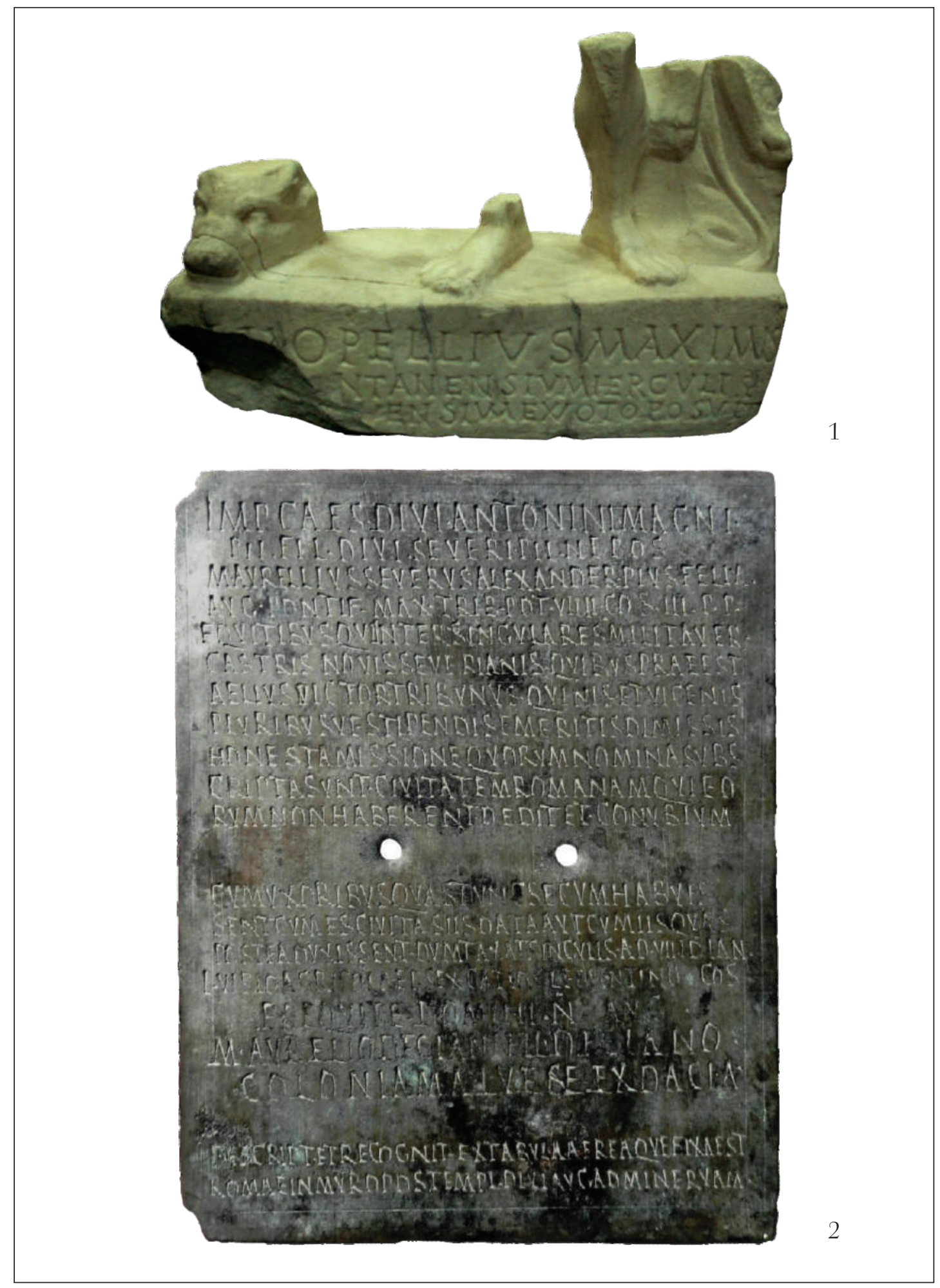

Pl. I. 1. Dédicace de Cioroiu Nou, Musée de Craiova, inv. no I 28243 (cliché D. Bondoc) ; 2. Diplôme militaire du 7 janvier 230, Museo Archeologico Nazionale di Napoli, inv. $n^{0} 4073$ (cliché G. Camodeca). 


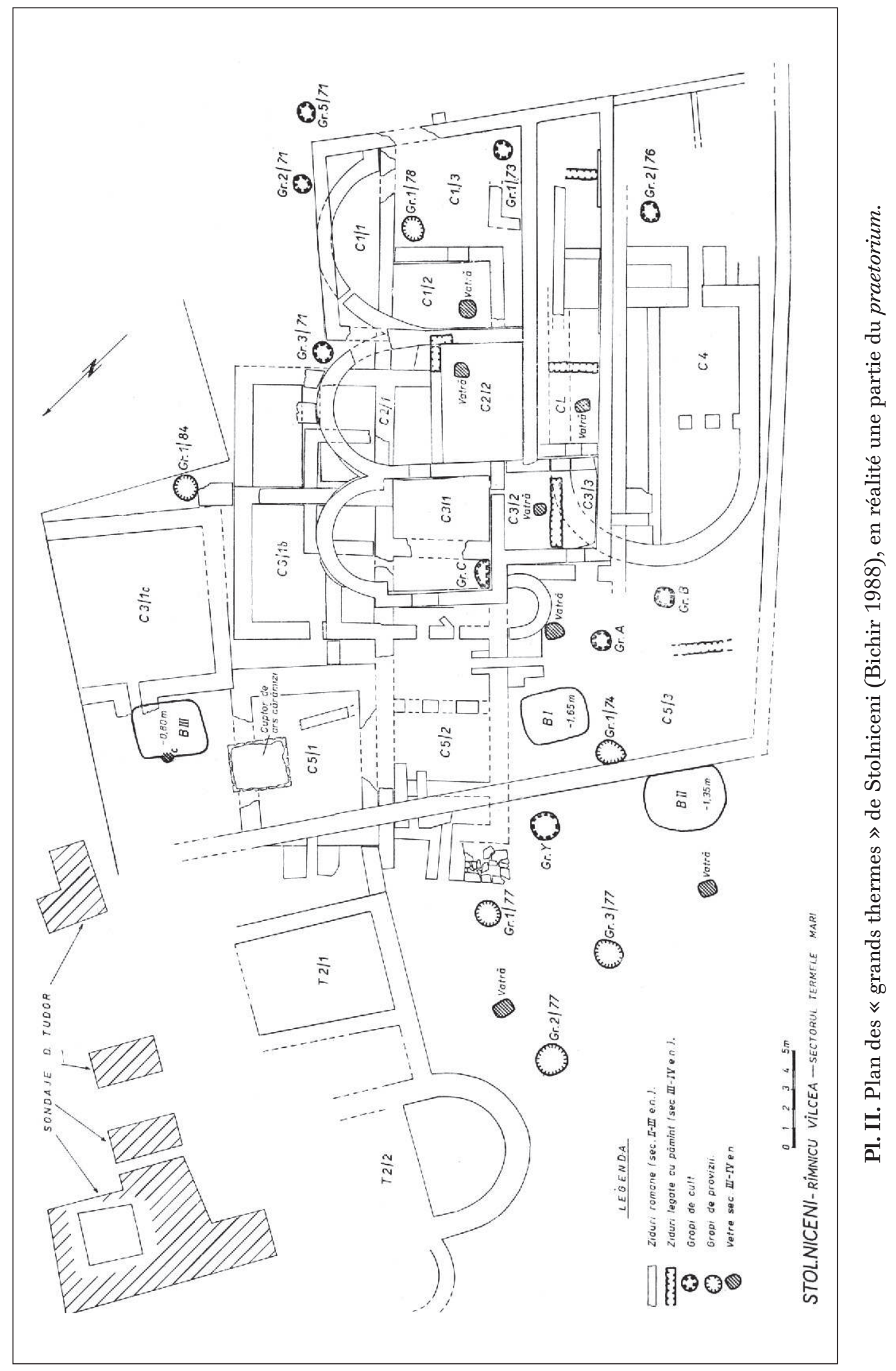




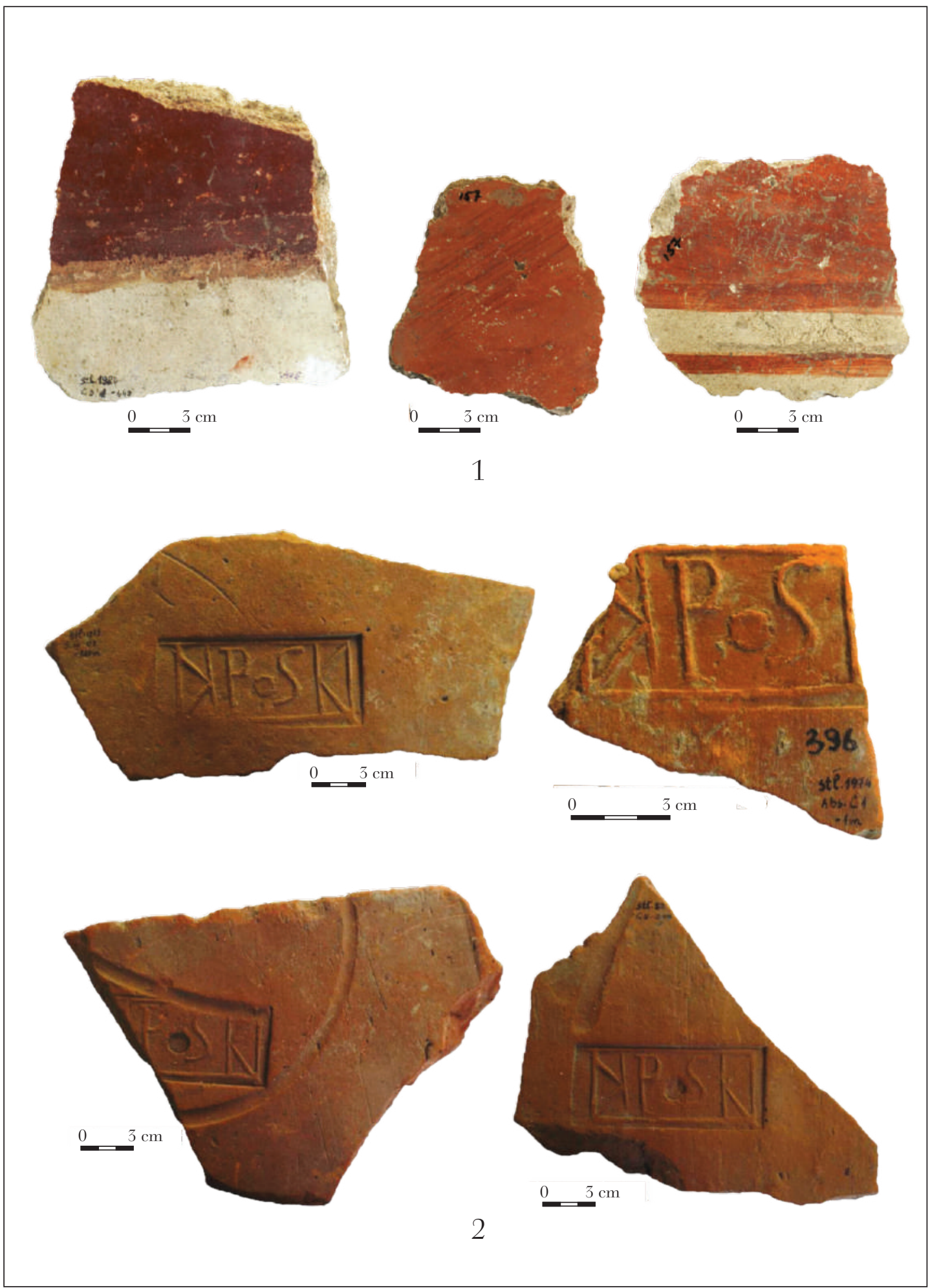

PI. III. 1. Morceaux de mur peint du praetorium de Stolniceni, Musée de Râmnicu Vâlcea (clichés I. Tuțulescu) ; 2. Tuiles avec l'estampille PS du praetorium de Stolniceni, Musée de Râmnicu-Vâlcea (clichés I. Tuțulescu). 


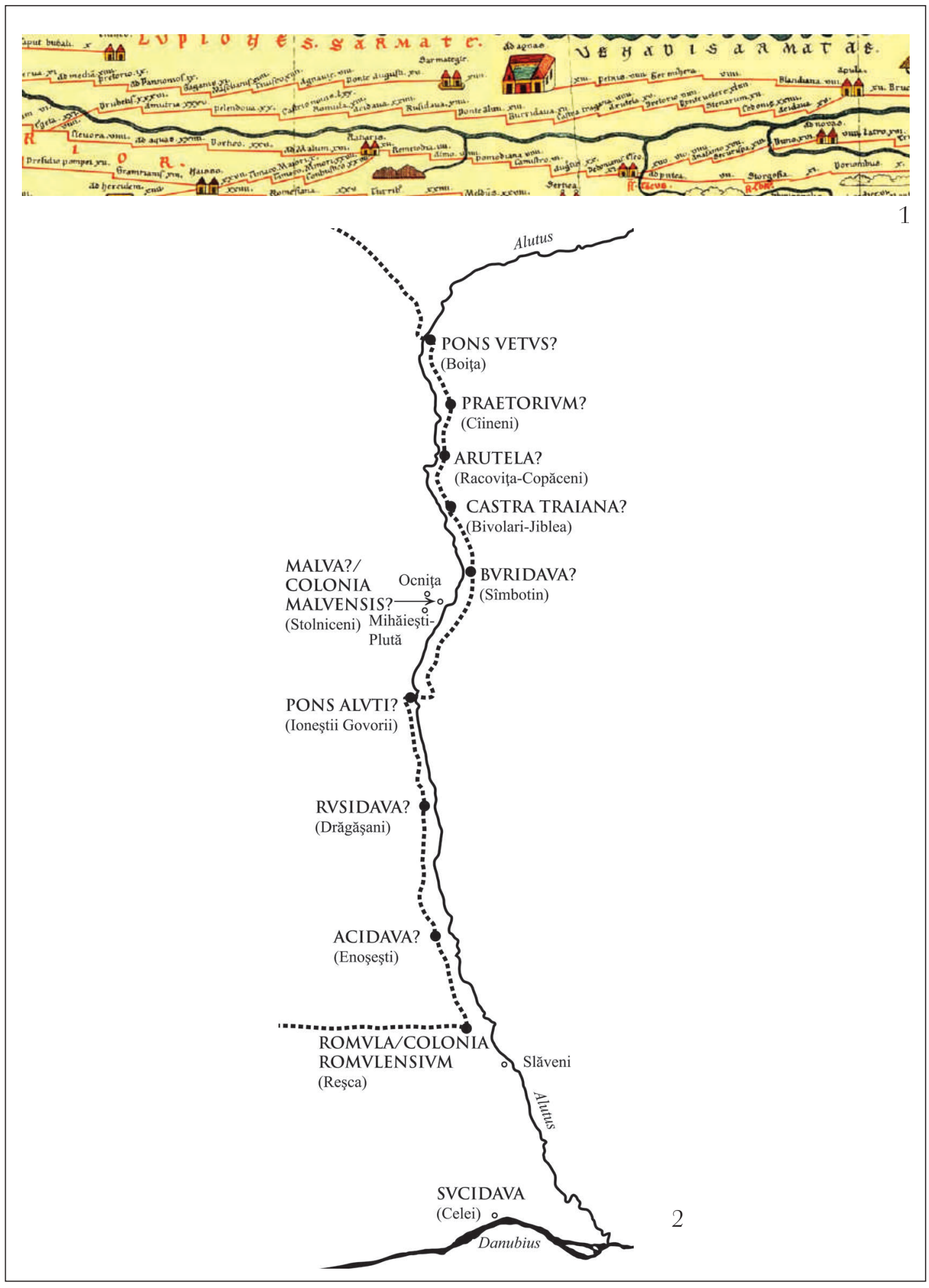

Pl. IV. 1. La route Drobeta - Romula - Apulum (Table de Peutinger) ; 2. La route Romula Pons Aluti - Pons Vetus, d'après les données archéologiques et la Table de Peutinger. 


\title{
THE PANTHEON OF MARCUS HERENNIUS FAUSTUS, LEGATUS LEGIONIS XIII GEMINAE
}

\author{
TIMEA VARGA
}

\begin{abstract}
By shedding more light over the votive altars erected by Marcus Herennius Faustus at Apulum, the aim of this study is to set a clearer picture over the diversity of the pantheons that operated within the provincial religion of Roman Dacia. The study attempts to identify the personal pantheon of Marcus Herennius Faustus as a reflection of the PunicoLybian triad Baal-Hammon, Baal-Addir, Tanit-Astarte, whose cult the commander of the legion must have adopted during his stay at Lambaesis as a tribunus militum in legio III Augusta. Furthermore, the article tries to unravel the possible motifs that determined Marcus Herennius Faustus to choose these rather unusual and definitely rare epithets for his gods: Saturnus Securus, Mercurius Hilaris, Minerva Supera.
\end{abstract}

Keywords: Roman Dacia; Roman religion; Saturnus Securus; Mercurius Hilaris; Minerva Supera.

Rezumat: Prin cercetarea amănunțită a altarelor votive ridicate de Marcus Herennius Faustus la Apulum, studiul urmărește să ofere o imagine mai clară asupra diversității panteonurilor care operau la nivelul religiei provinciale în Dacia romană. Lucrarea încearcă să identifice panteonul personal al lui Marcus Herennius Faustus ca o reflecție a triadei punico-libiene BaalHammon, Baal-Addir, Tanit-Astarte. Comandantul legiunii trebuie să fi intrat în contact cu aceștia în timpul șederii sale la Lambaesis ca tribunus militum în legio III Augusta. În plus, articolul încearcă să deslușeasă motivele care au stat la baza alegerii acestor epitete neobişnuite şi cu siguranță rare pentru zeii adoptaţi de Marcus Herennius Faustus în panteonul personal: Saturnus Securus, Mercurius Hilaris, Minerva Supera.

Cuvinte cheie: Dacia romană; religie romană; Saturnus Securus; Mercurius Hilaris; Minerva Supera.

Two of the votive altars dedicated by Marcus Herennius Faustus to Saturnus Securus (Cat. no. 1) and Minerva Supera (Cat. no. 3) were discovered in 1948, ${ }^{1}$ while a third one, dedicated this time to Mercurius Hilaris (Cat. no. 2) was reported on the shore of the Mureş River fifty years later. ${ }^{2}$ The monuments raised contradictive opinions in the specialty literature ever since, on one hand due to the unusual epithets of the gods, ${ }^{3}$ but mostly regarding the exact function fulfilled by Marcus Herennius Faustus during his stay in Dacia. ${ }^{4}$ Due to the fact that the inscriptions only mentioned Marcus Herennius Faustus as a legatus Augusti the main question raised back then was related to his tenure in Apulum: was he the governor of the province or the legion's legate?

\footnotetext{
${ }^{1}$ Berciu 1947-1949, 200-209.

2 Rodean, Ciută 1998, 151-154.

3 Bărbulescu 1994, 70; Nemeti 2005, 109-111.

${ }^{4}$ Berciu 1947-1949, 200-209; Daicoviciu 1959, 188; Moga 1985, 86; Piso 1993, 214-217; Piso 2013,
} 43-45. 
This problem was solved by Ioan Piso who, based on a series of inscriptions, reconstructed his career in Fasti provinciae Daciae. ${ }^{5}$ Two of these inscriptions recall him as consul suffectus in $121,{ }^{6}$ while an inscription found on the famous "vocal Memnon" from Karnak, Theba, describes his entire career. ${ }^{7}$ He was decemvir stlitibus iudicandis, sevir turma equitum Romanorum, tribunus militum legionis III Augustae that stationed at Lambaesis, quaestor, tribunus plebis, praetor, legatus Augusti legionis XIII Geminae that stationed at Apulum and finally consul suffectus in 121.

The inscription also mentions him having two high honorific titles with religious character. He was one of the sodales or sacerdotes Augustales, an order instituted by Tiberius to attend the maintenance of the cult of Augustus and finally he was also one of the seven viri epulonum, a religious college that was in charge with arranging feasts and public banquets at festivals and games.

All these made I. Piso believe that Marcus Herennius Faustus was the legatus Augusti XIII Geminae between the years $115-117,8$ period during which he erects three rather unusual votive altars to Saturnus Securus, ${ }^{9}$ Mercurius Hilaris ${ }^{10}$ and Minerva Supera. ${ }^{11}$

The presence of Saturnus Securus (Cat. no. 1) among his dedications correlated with the fact that he served as a tribunus militum in the third legion Augusta that stationed at Lambaesis, in Numidia, made M. Bărbulescu ${ }^{12}$ and S. Nemeti ${ }^{13}$ rightfully believe that the dedication does not refer to the classical Greco-Roman Saturnus but in fact to his assimilation with the Punic god Baal Hammon. The cult of this African Saturnus enjoyed a great popularity in the provincial areas during imperial time, especially during the Severan period and is widely known today due to the extensive work of Le Glay. ${ }^{14}$

Equated already from the $5^{\text {th }}$ century BC with Kronos in various Greek literary sources, ${ }^{15}$ the role of Baal Hammon had been overtaken by Saturnus from the Roman occupation onwards. The assimilation of Saturnus with Baal Hammon has been demonstrated by a bilingual inscription found at Sabratha, Tripolitania that equated Dominus Saturnus with Baal. ${ }^{16}$ In fact Dominus is nothing more but the Latin translation of the Punic word Baal, that means "Lord". ${ }^{17}$ Other epithets and attributes used for this god give the picture of a supreme divinity, often threatening

5 Piso 1993, 214-217; Piso 2013, 43-45.

${ }^{6}$ CIL VI 2080; AE 1965, 131.

CIL III 52 = IDRE II 419.

8 Piso 1993, 214-217; Piso 2013, 43-45.

9 Berciu 1947-1949, 200-202, Abb. 1; AE 1962, 206 = AE 1975, 718; Le Glay 1966b, 342, no. 32; Bărbulescu, Cătinaș 1979, 217; Bărbulescu 2009, 70; IDR III/5, 314.

10 Rodean, Ciută 1998, 151-154; AE 1998, 1081; IDR III/5, 708.

11 Berciu 1947-1949, 200-202, Abb. 2; IDR III/5, 265.

12 Bărbulescu 2009, 70.

13 Nemeti 2005, 109-110.

${ }^{14}$ Le Glay 1961; Le Glay 1966a; Le Glay 1966b; Le Glay 1988.

15 Sophocles, Andromeda, 126; Followed by Pseudo-Platon, Minos, 315; Cleitarchus, Scholia Platonica, 337a.

16 AE 1980, 900.

17 Le Glay 1966a, 124-125. 
the position of Juppiter, Deus Aeternus, ${ }^{18}$ sovereign and master over time and death, but also Frugifer, ${ }^{19}$ inventor and protector of agriculture, by bringing rain and assuring the fertility of the fields.

The epithet Securus ("the calm one", "the one without fear") that accompanies Saturnus at Apulum can only be found attached to the god's name in literary sources. ${ }^{20} \mathrm{It}$ is also worth mentioning that Securus is also frequently met among cognomina in Africa. ${ }^{21}$

From this perspective it seems only legitimate to ask ourselves if the other altars dedicated by Marcus Herennius Faustus refer to other African deities hidden under Roman names or not.

Mercurius occupied a privileged place in the pantheon of Roman Africa, where he was often assimilated with the god Silvanus. ${ }^{22}$ Alain Cadotte proposed as the Punico-Libyan counterpart of Mercurius the god Baal Addir, whose cult appeared already in the $5^{\text {th }}$ century BC, particularly in Northern Africa. He was often associated with Baal Hamon and Tanit, forming a divine triad identified later on in Roman period with Saturnus, Caelestis and Mercurius. ${ }^{23}$

Besides its classical function as a patron of commerce, the god takes a wide array of forms in Africa, from a fertile agrarian divinity to a martial one, often having even a funerary function. ${ }^{24}$ His plurifunctionality is mirrored by the unusual epigraphic choices for epithets like Silvius, ${ }^{25}$ Sobrius, ${ }^{26}$ Potens $^{27}$ Genius exercitus $^{28}$ and Fatalis ${ }^{29}$ among others.

Although rarely encountered in epigraphic sources, the epithet Hilarus / Hilara can be noticed more often in ancient literary texts. Artemidorus for example, uses it in reference to divinities, ${ }^{30}$ while Hesychius names the gods who receive sacrifices Hilaroi. ${ }^{31}$ More specifically, the epithet can also be seen accompanying Bacchus ${ }^{32}$ and Aphrodite. ${ }^{33}$

To the best of my knowledge, there is only one epigraphic text that registers the epithet's feminine form Hilara in Roman period. The adjective appears by itself on a votive altar from Naissus, but we could easily guess that in this case at least, it masks the goddess Libera, since it appears in conjunction to Liber Pater. ${ }^{34}$ In this

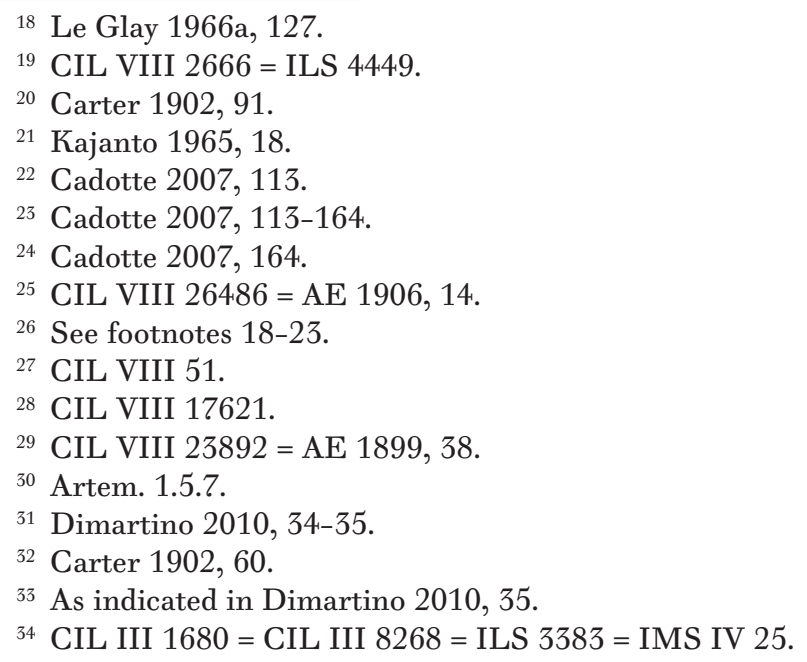


context we also have to mention two limestone slabs dating from the $1^{\text {st }}$ century BC, which mention the epithet Hilara for Aphrodite at Syracuse. ${ }^{35}$ The majority of scholars have seen in this epithet the association of the goddess with a species of comedy known as hilarotragoedia, to which "laughter and eroticism must have been its chief elements" ${ }^{36}$ On the contrary Dimartino has sensed in this epithet a suggestion to the propitious nature of Aphrodite, furthermore suggesting that its Latin correspondent would be Felix, ${ }^{37}$ known to accompany Venus on various epigraphic monuments and coins during the Roman Imperial era. If the Aphrodite Hilara - Venus Felix equalization is correct, we could analogously equate Mercurius Hilaris with Mercurius Felix. ${ }^{38}$

Although the epithet Hilaris has not been recorded so far for Mercurius, a statistical analysis of the epithets accompanying the African Mercurius shows that the opposite of Hilaris i.e. Sobrius, is the second most used epithet for this god, being outruled only by the appellative Deus. ${ }^{39}$ Most of these votive inscriptions dedicated to Mercurius Sobrius come from Vazi Sarra, ${ }^{40}$ where a vast temple has been dedicated to the god. ${ }^{41}$ Other inscriptions have been found at Thuburnica, ${ }^{42}$ Cincari, ${ }^{43}$ and Cirta. ${ }^{44}$ Other than in Africa, this epithet can be seen accompanying Mercurius only at Rome ${ }^{45}$ where this god was imported by the African immigrant population.

Charles-Picard has proposed as a possible explanation for the "sobriety" of the god, the existence of a taboo for wine within its cult. ${ }^{46} \mathrm{~J}$. Toutain believed that the epithet reflects the nature of the libations offered to Mercurius, ${ }^{47}$ a hypothesis that he probably derived from Festus, who tells us that for Mercurius - Baal Haddir, lacte, non vino supplicabatur. ${ }^{48}$ B. Combet-Farnoux thought this ritual to have had a Greek origin, ${ }^{49}$ a theory that later on R. E. A. Palmer disproved with, demonstrating that the spatial layout of the cults where libations in wine were avoided refrained exclusively to Africa. ${ }^{50}$

Although there is no other analogy known, Sorin Nemeti believes that the Mercurius Hilaris from Apulum (Cat. no. 2) is in fact the direct consequence of Marcus Herennius Faustus' attempt to isolate precisely this peculiarity of the African Mercurius, suggesting that the one that he worships at Apulum is open to wine and not milk libations. ${ }^{51}$

35 SEG 60, 1015-1016.

${ }^{36}$ Fountoulakis 2000, 140.

37 Dimartino 2010, 35-36, 40-49.

${ }_{38}$ CIL I 2, 2689; CIL IV 812; CIL XII 5687, 10; CIL XIII 6275; AE 1958, 267; AE 1973, 341-342; AE 1982, 712, 8-9; AE 2000, 952.

39 Cadotte 2007, 140.

${ }^{40}$ CIL VIII 12002, 12006, 12007.

${ }^{41}$ Cagnat, Gauckler 1898, 66-69.

${ }^{42}$ CIL VIII 14690.

${ }^{43}$ ILAf 484 = AE 1915, 40.

${ }^{44}$ CIL VIII 19490 (= 6977).

${ }^{45}$ CIL VI 9483, 9714.

${ }^{46}$ Charles-Picard 1954, 128.

47 Toutain 1905, 297.

${ }^{48}$ Festus, De verborum significatione, 382.

${ }^{49}$ Combet-Farnoux 1980.

${ }^{50}$ Palmer 1997, 80-86.

${ }^{51}$ Nemeti 2005, 110. 
Perhaps he is even identical with the drunken Mercurius that appears in the tragicomedy Amphitryon, a personage built by Plautus as an antagonistic character for the African Mercurius Sobrius. ${ }^{52}$

Other possible explanation for the occurrence of this epithet can be perhaps found in his occasional association to Liber Pater in the Danubian provinces. ${ }^{53}$ In this context it is worth mentioning that the only other inscriptions that register similar epithets are the ones found in Upper Moesia and Dalmatia that mention a Liber Pater Laetus at Pusto Silovo, ${ }^{54}$ a Liber Pater associated with Libera / Hilara at Naissus ${ }^{55}$ and a Deus Laetus at Salona. ${ }^{56}$

Both the Latin adjective laetus, $-a$, -um, and hilaris, - $e$, which comes from the Greek hilaros, mean "cheerful" and must emphasize the role of Liber and Libera as patron gods of wine and vine-growing. Even more adequate in this case, can be the translations of the aforementioned adjectives as "propitious", or even "fertile". These connotations can be sensed in the epitaph of Thaleia from Asia Minor, dating from

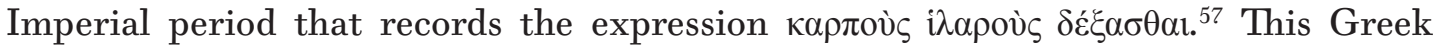
epigraphic formula has been equated by scholars with the Latin expression laetae fruges, where laetus is a direct reference to the fecundity of the fruits, ${ }^{58}$ making thus more plausible the theory that Mercurius Hilaris is in fact an African Mercurius that renounces to his "sobriety" by pairing up with Liber Pater.

If Mercurius and Saturnus could easily be identified with their African equivalents, the main question remains however who is this African goddess that hides behind the flattering epithet of Supera ${ }^{59}$ (Cat. no. 3) that Marcus Herennius Faustus equates through interpretatio Romana with Minerva.

To the best of my knowledge this rather unusual epithet can only be noticed so far accompanying Mercurius in a votive inscription from Badajoz, Hispania, although here with the slightly different form Supernus. ${ }^{60}$ Although unfortunately, the inscription does not yield any significant information other than the dedicator's name, which has the nomen Quintus and a cognomen that begins with the letter "P", it might still offer us a vital clue in deciphering the identity of the Minerva Supera of Apulum.

If we consider Supernus to be an adjectival epithet primarily meaning "the high one", "the superior", "the elevated one", than we could easily equate it with the epithet Caelestis that accompanies Mercurius in a votive inscription from Rome. This inscription dedicated by Quintus Munatius Trochorus to Mercurius Caelestis Fatalis ${ }^{61}$

52 Plaut. Amph. 3.4.

53 Apulum, Dacia: IDR III/5, 200 = AE 1930, 9; Viminacium, Moesia Superior: IMS II 28 = Gavrilović 2010, no. 1; Carnuntum, Pannonia Inferior: CIL III 14356; Virunum, Noricum: AE 1986, 540. Besides these examples, this rare association can be seen in Gallia as well: AE 1980, 627.

${ }^{54}$ AE 1968, 449 = IMS IV 109.

55 CIL III 1680 = CIL III 8268 = ILS $3383=$ IMS IV, 25.

${ }_{56}$ CIL III 8673a = AE 1959, $211=$ AE 1961, 306.

57 SEG 27, 771.

58 Dimartino 2010, 36.

${ }^{59}$ The epithet can be seen accompanying Fortuna as well in a votive inscription from Apulum: IDR III $/ 5,78$.

60 Del Rosario Hernando Sobrino 2003, 317.

61 CIL VI 521. 
can further be compared to a votive altar found at Khanguet el-Bey, where Mercurius is analogously qualified as Fatalis Augustus. ${ }^{62}$ This unusual epithet seems to allude to the presence of a Mercurius Psychopompos that has been identified by Mustapha Khanoussi in Roman Africa through various literary, epigraphic and iconographic attestations. ${ }^{63}$

Khaled Marmouri has remarked upon the association of Mercurius-Baal Addir and Minerva in various epigraphic and archaeological sources of Africa Proconsularis and Numidia, provinces where these gods seem to share a joint cult at Lepcis Magna and Lambaesis or play the role of dii patrii at Gigthis and protective genii at colonia Thrysditanorum. ${ }^{64}$

This local divinity designated under the name of Minerva shares common traits with other Greco-Roman divinities like Juno, Ceres and in particular with Venus. In fact Alain Cadotte believes that Venus, Cybele and Minerva are the Roman interpretations of the same Punico - Libyan divinity Tanit-Astarte/Dea Caelestis, assimilation that he explains through the similarities they share, namely their fertile, poliad and respectively, warrior character. ${ }^{65}$ The most numerous attestations of Minerva in Africa come from the legionary fortress of Lambaesis, ${ }^{66}$ while an inscription from Vezereos, dedicated by Iulius Zeno, optio in legio III Augusta qualifies her as dea patria. ${ }^{67}$

Besides its association with Mercurius-Baal Addir, Minerva can also be seen accompanying Saturnus-Baal Hammon in Africa Proconsularis. A $2^{\text {nd }}$ century AD statuary group from Bulla Regia shows a Saturnus velato capite with cornucopia in his hand, ${ }^{68}$ accompanied by a winged goddess, depicted wearing a mural crown and cornucopia in her hand. ${ }^{69}$ The latter has been identified with Athena-Minerva due to the shield decorated with the head of the Medusa that she carries. ${ }^{70}$ This rather unusual iconographic scheme used for the goddess reminds the image of a $3^{\text {rd }}$ century BC stela kept in the Museum of Bardo that shows Tanit with open wings and turreted crown on her head. ${ }^{71} \mathrm{~A}$ very similar representation can also be observed on the reverse of some Roman denarii struck by Quintus Caecilius Metellus Scipio in 47-46 BC, bearing on the obverse the image of a lion-headed goddess and the legend G(enius) T(errae) A(fricae). ${ }^{72}$

A votive inscription from Zoui, Numidia, associates Caelestis with Saturnus and Mercurius, ${ }^{73}$ an association that recalls the triad worshipped in the punic sanc-

${ }^{62}$ CIL VIII $23892=$ AE 1899, 38.

63 Khanoussi 1990, 647-649.

${ }^{64}$ Marmouri 2008, 141-149.

${ }^{65}$ Cadotte 2007, 219, 225.

${ }^{66}$ CIL VIII 2611, 2612, 2636, 2647, 2648, 4198, 18060, 18225, 18226, 18231, 18234; AE 1899, 89; AE 1902, 11; AE 1914, 245; AE 1919, 28; AE 1920, 22; AE 1957, 86-87.

${ }^{67}$ AE 1909,152 = ILAf 28.

${ }^{68}$ LeGlay 1961, 270.

${ }^{69}$ LIMC II 1984, s.v. Athena/Minerva (in Africa), 1109, no. 3 (G. Ch. Picard). With the same provenance and similar to the one aforementioned is no. 4 as well.

${ }^{70}$ Paz García Bellido 2010, 272.

${ }^{71}$ Paz García Bellido 2010, Fig. 5.

72 Crawford 1974, no. 460, 4.

${ }^{73}$ CIL VIII 17619. 
tuary of El Hofra, in Cirta, where a great number of votive stelai were addressed to Baal-Hammon, Tanit and Baal Addir, ${ }^{74}$ later identified in Roman period with Saturnus, Caelestis and Mercurius. The strong interconnectivity that existed between these gods can also be seen from various collective votive dedications for Saturnus and Mercurius ${ }^{75}$ or Caelestis and Mercurius, ${ }^{76}$ while the attribute of Baal Addir-Mercurius, the caduceus can be seen on numerous votive stela dedicated to Saturnus in Africa. ${ }^{77}$

In conclusion I believe that the altars of Marcus Herennius Faustus are in fact precisely the reflections of these Punico-Libyan divinities Baal Hammon, Baal Addir, Tanit / Astarte, whose cult the commander of the legion must have adopted during his stay at Lambaesis as a tribunus militum in legio III Augusta. ${ }^{78}$ In this respect pleads even the fact that they seem to have been commissioned in the same time, as it is suggested by the same structuring of the inscription on 5 lines, the shape of the letters, the fact that the name of the gods have the first letter bigger that the others and the similar decoration of the altars.

In his introduction to $L a$ romanisation des dieux. L'interpretatio romana en Afrique du Nord sous le Haut-Empire, Cadotte has drawn attention to the necessity of prudence when operating with concepts like "religious syncretism". ${ }^{79}$ Among other examples cited in this context, he also mentions Minerva's case who has often been labeled Sancta within the Capitoline triad, without bearing any Semitic connotation. Sanctus, $-a$ is an epithet applied mostly to Semitic or oriental divinities, being a traditional epiclesis for gods like Baal Hammon, Tanit and Astarte. ${ }^{80}$ In this regard, Cadotte's work accentuates the importance of local particularities that can enable and further ease the process of setting up a more complex and accurate picture of the regional pantheons within the Roman Empire.

Thus the evaluation of the transformation of Tanit-Astarte into Minerva during the Roman period must be done both in terms of continuity i.e. Minerva's syncretic assimilation to Tanit through interpretatio Romana, perhaps mainly due to her poliad and warrior character, but also through discontinuity expressed through intermediary phenomena like oriental influences, innovations and interactions with other gods, i.e. her frequent association to Mercurius, with whom she seems to share a joint cult at Lepcis Magna and Lambaesis and to play together the role of dii patrii at Gigthis and protective genii at colonia Thrysditanorum.

74 Berthier, Charlier 1955.

75 CIL VIII, 8246-8247; AE 1925, 38.

76 CIL VIII 4674, 8433, 17619.

77 Cadotte 2007, Chapter III, footnote 14-16.

78 The possibility that he is of African origin should not be dismissed as well, but remains impossible to prove in the absence of more conclusive evidence.

79 Cadotte 2007, 1-12.

${ }^{80}$ Cadotte 2007, 13-14, 38. 


\section{Catalogue}

1. Berciu 1947-1949, 200-202, Abb. 1; AE 1962, 206 = AE 1975, 718; Le Glay 1966b, 342, no. 32; Bărbulescu, Cătinaș 1979, 217; Bărbulescu 2009, 70; IDR III/5, 314.

Saturno / Securo / M(arcus) Herennius / Faustus /leg(atus) Aug(usti).

2. Rodean, Ciută 1998, 151-154; AE 1998, 1081; IDR III/5, 708.

Mercurio / Hilari / M(arcus) Herennius / Faustus /leg(atus) Aug(usti).

3. Berciu 1947-1949, 200-202, Abb. 2; IDR III/5, 265.

Min[ervae] / Su[perae] / M(arcus) Her[rennius] / Fau[stus] / leg(atus) [Aug(usti)].

\section{Bibliography}

Bărbulescu 2009

Bărbulescu, Cătinaș

1979

Berciu 1947-1949

Berthier, Charlier 1955

Cadotte 2007

Cagnat, Gauckler 1898

Carter 1902

Charles-Picard 1954

Combet-Farnoux 1980

Crawford 1974

Daicoviciu 1959

Del Rosario Hernando

Sobrino 2003

Dimartino 2010

Fountoulakis 2000

Gavrilović 2010

Kajanto 1965
M. Bărbulescu, Africa e Dacia. Gli influssi africani nella religione romana della Dacia. In: M. Bărbulescu, Signum originis. Religie, artă și societate în Dacia Romană, București 2009, 61-76.

M. Bărbulescu, A. Cătinaş, Cultul lui Saturnus în Dacia, Apulum, 17, 1979, 215-223.

I. Berciu, Marcus Herennius Faustus legatus III Daciarum, Apulum, 3, 1947-1949, 200-209.

A. Berthier, R. Charlier, Le sanctuaire punique d'El-Hofra à Constantine, Paris 1955.

A. Cadotte, La romanisation des dieux. L'interpretatio romana en Afrique du Nord sous le Haut-Empire, Religions in the GraecoRoman World 158, Leiden - Boston 2007.

R. Cagnat, P. Gauckler, Les monuments historiques de la Tunisie, I. Les monuments antiques. Les temples païens, Paris 1898.

I. B. Carter, Epitheta deorum quae apud poetas Latinos leguntur, Leipzig 1902.

G. Charles-Picard, Les religions de l'Afrique antique, Paris 1954.

B. Combet-Farnoux, Mercure romain. Le culte public de Mercure et la fonction mercantile à Rome de la République archaïque à l'époque augustéenne, Rome 1980.

M. H. Crawford, Roman Republican Coinage, I, Cambridge 1974.

C. Daicoviciu, Contributi alla storia della Dacia romana alla luce degli ultimi tre lustri di studi epigraphici. In: Atti del III Congresso Internazionale di Epigrafia Greca e Latina, Roma 1959, 183-197.

M. del Rosario Hernando Sobrino, Mercvrivs Svpernvs en un epígrafe inédito de la provincia de Badajoz, Ficheiro Epigráfico, Universidad de Coimbra 71, Coimbra 2003, 317.

A. Dimartino, Venus Felix a Siracusa? Per una rilettura dei decreti della Synodos di technitai di Afrodite Hilara, Epigraphica, 72, 2010, 21-49.

A. Fountoulakis, The Artists of Aphrodite, AC, 69, 2000, 133-147.

N. Gavrilović, A Contribution to the Study of the Cult of God Mercury in Moesia Superior, Archaeologia Bulgarica, 14, 1, 2010, 67-89.

I. Kajanto, The Latin cognomina, Helsinki 1965. 
Khanoussi 1990

Le Glay 1961

Le Glay 1966a

Le Glay 1966b

Le Glay 1988

Marmouri 2008

Moga 1985

Nemeti 2005

Palmer 1997

Paz García Bellido 2010

Piso 1993

Piso 2013

Toutain 1905
M. Khanoussi, À propos de Mercure psychopompe en Afrique, MEFRA 102, 2, 1990, 647-649.

M. Le Glay, Saturne Africain. Monuments 1. Afrique proconsulaire, Paris 1961.

M. Le Glay, Saturne Africain. Histoire, Paris 1966.

M. Le Glay, Saturne Africain. Monuments 2. Numidie-Maurétanie, Paris 1966.

M. Le Glay, Nouveaux documents, nouveaux points de vue sur Saturne Africain. In: E. Lipiński (ed.), Studia Phoenicia VI. Carthago. Acta Colloquii Bruxellensis habiti diebus 2 et 3 mensis Maii anni 1986, Orientalia Lovaniensia Analecta 26, Louvain, Peeters 1988, 187-237. K. Marmouri, Mercurio et Minervae sacrum: l'association de Mercure et de Minerve dans l'Afrique Proconsulaire, Études d'Antiquités africaines, 2008 = Lieux de cultes: aires votives, temples, églises, mosquées. IXe Colloque international sur l'histoire et l'archéologie de l'Afrique du Nord antique et médiévale (Tripoli, 19-25 février 2005), Paris 2008, 141-149.

V. Moga, Din istoria militară a Daciei romane. Legiunea XIII Gemina, Cluj-Napoca 1985.

S. Nemeti, Sincretismul religios în Dacia romană, Cluj-Napoca 2005. R. E. A. Palmer, Rome and Carthage at Peace, Historia Einzelschriften 113, Stuttgart 1997.

M. Paz García Bellido, Á propos de l'identification de Dea Caelestis sur des monuments du Musée du Bardo (Tunis). In: A. Ferjaoui (ed.), Carthage et les autochtones de son empire du temps de Zama, Tunis 2010, 269-280.

I. Piso, Fasti provinciae Daciae I. Die senatorischen Amtsträger, Bonn 1993.

I. Piso, Fasti provinciae Daciae II. Die ritterlichen Amtsträger, Bonn 2013.

J. Toutain, Les cultes païens dans l'Empire romain, I, Paris 1905.

Timea Varga

Babeş-Bolyai University, Cluj-Napoca timeatvarga@yahoo.com 



\section{REVIEWS}





\section{Nathan Badoud, Le temps de Rhodes. Une chronologie des inscriptions de la citéfondée sur l'étude de ses institutions, Vestigia 63, Verlag C. H. Beck, München 2015, 542 pages, 148 illustrations.}

Cette version remaniée d'une thèse (cotutelle Neuchâtel-Bordeaux 3) est une monographie monumentale, qui fera date dans les études rhodiennes. Nathan Badoud part du constat que Rhodes, la grande cité marchande (cf. le titre du livre d'A. Bresson, Bordeaux, 2000) a été infiniment moins étudiée qu'Athènes, en dépit de ses sources abondantes - si l'on met de côté, il est vrai, les « grands textes ». L'objectif ambitieux est de faire ressortir l'intérêt historique des inscriptions, ce que l'auteur a pleinement réussi grâce à un long travail d'analyse et de mise en série.

N. Badoud pose d'emblée les limites chronologiques et géographiques de son ouvrage, à partir du synécisme de 408 des trois cités Ialysos, Camiros et Lindos, qui aboutit à une cité nouvelle, Rhodes, construite à pointe septentrionale de l'île homonyme. Si les trois anciennes cités restent des « communautés 》, avec leurs magistrats, un éponyme, une Assemblée et un Conseil, ce sont les dèmes qui deviennent l'unité de

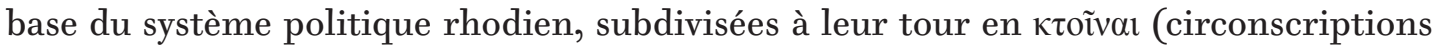
électorales). L'étude d'une grande cité comme Rhodes pose aussi le problème de ses possessions et de sa sphère d'influence, considérable à l'époque hellénistique. Cette réalité explique la nécessite de mettre à contribution la documentation de la Pérée rhodienne, à savoir les vastes possessions en Asie Mineure, notamment en Carie. L'état de l'épigraphie rhodienne est particulier : en effet, seulement deux fascicules sont parus dans les IG, par les soins de Friedrich Hiller von Gaertringen $(1895,1898)$; or, les 5.000 inscriptions rhodiennes publiées depuis, entre 1898 et 2012, sont dispersées dans plus de 200 publications. La seule ville de Rhodes a livré plus d'un millier d'inscriptions, en partie inédites. Ces chiffres donnent une idée du travail colossal de l'auteur, qui s'est accompagné de vérifications sur les inscriptions qu'il a rééditées (cf. infra) ou dans de nombreuses archives en Grèce et dans d'autres pays européens. N. Badoud constate un faciès relativement uniforme de l'épigraphie rhodienne, également défini par la vigueur du dialecte dorien, au point que Rhodes en imposa l'usage même dans les inscriptions rédigées par des étrangers. En plus de quelques rares décrets, Rhodes a livré un grand nombre de catalogues de magistrats, en particulier des dignitaires religieux

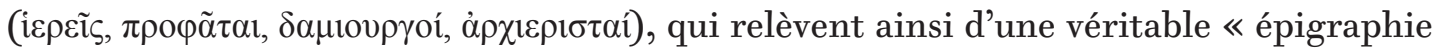
du nom ».

Sur le plan historiographique, cette recherche s'inscrit dans une longue tradition et pratique une analyse transversale des différentes sources, dont deux se détachent. Ainsi, les inscriptions qui émanent de la cité ou de ses subdivisions nous renseignent sur les institutions rhodiennes, qui fournissent une trame religieuse et politique. Un autre dossier abondant est constitué des timbres amphoriques, qui représentent un corpus de 10.000 pièces, sur la base de 1.500 publications ainsi que des fichiers conservés dans les archives, notamment celle de Virginia Grace, de l'American School of Classical Studies d'Athènes. Je rappelle ici que N. Badoud est coordinateur du Bulletin 
Amphorologique hébergé par la Revue des Études Grecques (pour sa plate-forme électronique, voir http://www.amphoreus.org/).

La contribution majeure de l'ouvrage, divisé en huit chapitres, est de dater, par un faisceau d'indices paléographiques, linguistiques et prosopographiques, deux types d'inscriptions : d'une part, les catalogues de magistrats, avec des séries de noms opposés diachroniquement; de l'autre, les listes, avec des noms associés synchroniquement.

Le chap. I est consacré au calendrier rhodien, qui constitue le socle de toute la chronologie des inscriptions - puisque les douze mois rhodiens du calendrier épichorique étaient toujours en vigueur à l'époque impériale. Nathan Badoud étudie ainsi l'ère de Lindos, le catalogue des démiurges, le cycle des fêtes rhodiennes et le mode de désignation des prêtres communautaires. La reconstitution du calendrier rhodien déduite des sources épigraphiques et littéraires est confirmée par l'analyse quantitative des timbres amphoriques. Fondé sur la distinction entre une année « éponymique » héritée des trois anciennes cités et d'une année « civile » instaurée au moment du synécisme, le système s'était maintenu jusqu'à la fin de l'Antiquité. C'est également l'occasion de s'intéresser à des questions très débattues dans la bibliographie. Après avoir analysé la courbe de production des amphores rhodiennes, l'auteur affirme que rien n'indique que les potiers rhodiens aient exercé une quelconque activité agricole. Ces potiers employés à la production des amphores étaient en partie sans doute des esclaves, le rythme de production amphorique étant déterminé par les seules conditions météorologiques.

Le chap. II aborde la datation des fragments du catalogue de prêtres d'Athana Lindia (magistrats éponymes de la communauté de Lindos), qui constitue " l'épine dorsale » de l'épigraphie lindienne. L'auteur éclaircit la « règle triennale », selon laquelle les trois tribus fournissaient tour à tour le prêtre d'Athana. On peut ainsi constater que, dans certains cas au moins, l'adoption avait pour fin exclusive celle de permettre à son bénéficiaire de remplir les conditions d'origine requises par l'exercice de la prêtrise d'Athana ; la vocation première était toutefois la captation d'un héritage matériel et symbolique qui s'affichait à travers l'onomastique.

Le chap. III date la souscription pour la restitution de la parure et des vases à boire de la déesse ainsi que le décret pour les délégués de la communauté à l'Assemblée de Rhodes. Associant numismatique et épigraphie, N. Badoud montre que les Rhodiens ont fondu la parure et les vases d'Athana Lindia, et sans doute la statue de la victoire, afin de frapper des monnaies.

Le chap. IV analyse le catalogue de prêtres de Poséidon Hippios, occasion de

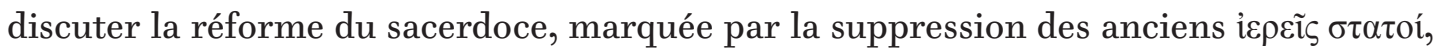
qui se situe non pas vers 325, mais vers 315 .

Le chap. V s'intéresse aux principaux catalogues camiréens : les damiurges (les éponymes de la communauté de Camiros) ; les prêtres d'Athana Polias ; les archiéristai; les prêtres d'Apollon Pythien, Karneios, Mulantios et Digénès. Ces catalogues sont liés entre eux par de multiples synchronismes, ce qui permet à l'auteur de fixer avec une précision absolue la chronologie de plusieurs centaines de magistrats camiréens.

Dans le chap. VI sont étudiées trois catalogues du I ${ }^{\text {er }}$ s. av. J.-C., portant des noms de fêtes en annotations. 
Le chap. VII traite du cycle intercalaire dans son rapport avec la chronologie des timbres amphoriques et aboutit à l'identification de toutes les années intercalaires de la période hellénistique. Cette enquête approfondie mène à la découverte de 47 éponymes associés au mois Panamos deuteros sur les timbres amphoriques.

Enfin, le chap. VIII analyse la chronologie des prêtres d'Halios (les magistrats éponymes de Rhodes) entre la fin du $\mathrm{V}^{\mathrm{e}} \mathrm{s}$. av. J.-C. et le début du $\mathrm{IV}^{\mathrm{e}} \mathrm{s}$. de notre ère, associant les inscriptions de la cité et les timbres amphoriques, à la suite des travaux importants de Virginia Grace, Gérald Finkielsztejn et Christian Habicht. N. Badoud évoque à cette occasion les contours disciplinaires de l'« amphorologie », afin de l'affranchir de l'épigraphie pour la rapprocher de la céramologie. Il constate la nécessité de reprendre le dossier dans son ensemble, afin de repenser la chronologie des deux séries documentaires. Cette section traite ainsi du sacerdoce, de la règle triennale, du contrôle de la production d'amphores, de l'astynome et de l'agoranome. Fort de ces avancées, l'auteur revient dans la synthèse finale sur les bases d'une nouvelle chronologie des inscriptions de Rhodes, en particulier sur les plus grands bouleversements qui ont affecté Rhodes à la haute époque hellénistique, de 330 à 170.

S'ensuit un tableau chronologique de plus d'un millier d'inscriptions rhodiennes (pp. 205-246) et plusieurs annexes : (1) les premières attestations de l'adoption et le développement de la formule d'adoption; (2) la chronologie des éponymes rhodiens, de 407 av. J.-C. à 180 ap. J.-C. ; (3) la chronologie des prêtres d'Halios associés au mois intercalaire sur les timbres amphoriques; (4) la chronologie des sculpteurs rhodiens ou étrangers, avec un recueil de signatures ; (5) des stemmata avec la structure et l'histoire de 14 familles établies dans la cité de Rhodes.

La meilleure idée de l'ampleur de l'enquête est donnée par le catalogue final qui comporte 72 inscriptions rééditées (catalogues, souscriptions, décrets, dédicaces et inscriptions honorifiques), accompagnées d'illustrations de qualité (photos, estampages et fac-similés) et de traductions personnelles (pp. 305-453) ; l'auteur ajoute à l'occasion un $8^{\text {e }}$ fragment au catalogue des prêtres d'Athana Lindia (cat. $\mathrm{n}^{0} 12$ ). Les 10 catalogues et les 3 grandes « listes synchroniques » totalisent plus de 1.500 noms de citoyens rhodiens. Le livre se clôt par les références bibliographiques des sources (inscriptions ; timbres amphoriques), une bibliographie générale, des concordances et des indices très riches.

Alliant érudition, acribie et esprit critique, l'auteur apporte des précisions historiques et des analyses très fines grâce à la mise en série de dossiers complexes, souvent arides et nécessitant des traitements très techniques. Ce livre est un exercice de méthode qui éclaire de façon saisissante l'histoire de l'une des plus grandes cités du monde grec, en associant épigraphie, prosopographie et amphorologie.

Dan Dana CNRS/ANHIMA, Paris ddana_ddan(j)yahoo.com 



\section{S. Musteață, Șt. Caliniuc (eds.), Current Trends in Archaeological Heritage Preservation: National and International Perspectives. Proceedings of the international conference, Iași, Romania, November 6-10, 2013, BAR International Series 2741, 2015, 132 p.}

Article 4 of the European Convention on the Protection of the Archaeological Heritage (revised) adopted on $16^{\text {th }}$ January 1992 at La Valletta recommends: "Each Party undertakes to implement measures for the physical protection of the archaeological heritage, making provision, as circumstances demand: i. for the acquisition or protection by other appropriate means by the authorities of areas intended to constitute archaeological reserves; ii. for the conservation and maintenance of the archaeological heritage, preferably in situ; iii. for appropriate storage places for archaeological remains which have been removed from their original location." Following these recommendations, article 9 of the same documents highlights: "Each Party undertakes: i. to conduct educational actions with a view to rousing and developing an awareness in public opinion of the value of the archaeological heritage for understanding the past and of the threats to this heritage; ii. to promote public access to important elements of its archaeological heritage, especially sites, and encourage the display to the public of suitable selections of archaeological objects." Therefore, the specialists have to understand that the most important aspects related to the archaeological sites nowadays are the preservation, the conservation, the protection and the promotion of the archaeological patrimony, and not necessarily, and not all the time, the excavations.

In the last two decades, across Europe, and not only, the preoccupations for the protection of the archaeological patrimony have significantly increased. To sustain this statement, I will mention here only few books or other contributions focusing on these topics: J. Ashurst (ed.), Conservation of ruins, Oxford 2007; M. Gras, P. Liverani (eds.), Il patrimonio culturale tra tutela e ricerca / Cultural Heritage between Conservation and Research. Atti del convegno internazionale Roma, 30-31 gennaio 2006, Roma 2011; E. Korka (ed.), The Protection of Archaeological Heritage in Times of Economic Crisis, Cambridge 2014; N. Agnew, J. Bridgland (eds.), Of the Past, for the Future: Integrating Archaeology and Conservation, Proceedings of the Conservation Theme at the $5^{\text {th }}$ World Archaeological Congress, Washington D.C., 22-26 June 2003, Los Angeles 2006; C. Borş, Protejarea patrimoniului arheologic din România. Despre situri şi monumente arheologice din perspectiva evolutiei cadrului legislativ în context european, Cluj-Napoca 2014; S. Musteață (coord.), Arheologia şi politicile de protejare a patrimoniului cultural în România. Culegere de studii, Chişinău - Iaşi 2014.

Connected to this trend, in 2011, with the financial support of the Romanian National Council of Scientific Research (CNCS), the project Current trends in the archaeological heritage preservation: the national and the international perspective was implemented at the Institute of Archaeology of the Romanian Academy in Iassi. In 2013, an international conference on this topic was organized here. Circa fifty 
specialists in the protection of the archaeological patrimony participated, from countries as Romania, Moldavia, Germany, United Kingdom, Czech Republic, Netherlands, Spain, Portugal, Poland, Russia, Azerbaijan, Brazil, USA, and India. The volume published in BAR series groups 23 articles, representing the papers presented within the conference.

Michal Bureš, in his study entitled Archaeological heritage management in Czech Republic - between centralism and liberalism (p. 11-14) presents important data regarding the legislation concerning the protection of the archaeological heritage in Czech Republic, information about the Landmark Conservation Act, and some aspects regarding the spatial planning and the archaeological heritage management.

Sergiu Musteață published a study entitled Preserving archaeological remains in situ: from the legal to the practical issues. The Romanian case (p. 15-20). The key analysis of the author focuses on the problems of in situ preservation in Romania, especially in a more recent context, when rescue excavations in Romania extended because of various investment projects.

Hans-Ulrich Voß, Sergiu Musteaţă and Alexandru Popa presented the study Forward-Looking for Conservation. Case Study: Landscape Archaeology in the Cubolta River Valley, Republic of Moldova - the Project "Cultural Relations of the Sântana de Mures Culture between the Rivers Prut and Dniester" (p. 21-25). The authors described the results of a terrain research realized in the Cubolta Valley, in the northern part of Moldavia, where several points with archaeological discoveries, belonging to the Sântana de Mureş-Chernyakhov culture were identified.

Asmita Basu from the Academy for Professional Excellence in Calcutta, India, published a case study entitled Sustainable Development - a Challenge for Archaeological Site Management in the Coastal Areas of West Bengal in Eastern India (p. 27-32). The author gives us a view of the main archaeological sites in the area and some proposals to follow strategic steps useful for the development and implementation of heritage management plans for the region investigated.

Fariz Khalilli and Shola Bayramova, in their contribution entitled Research and Conservation of Public Buildings in the Medieval Agsu Town (p. 33-36), offer some details regarding the conservation and the protection of some important buildings (the bath complex, the water reservoir) discovered during the archaeological excavations in the Medieval Agsu Town archaeological complex.

Giacomo Maria Tabita, from the Italian Society for the Preservation of Cultural Heritage, District of Sicily, Italy, presented some data regarding Italian Civil Protection and Archaeological Heritage: Italian Experiences (p. 37-40). The main focus of the study is the description of the activity of the Italian Society of the Preservation of the Cultural Heritage (Società Italiana per la Protezione dei Beni Culturali).

Ştefan Caliniuc from Arheo Management SRL Romania gives in his study entitled Destruction of archaeological heritage sites by natural risk phenomena in northeastern Romania (p. 41-44) some examples of important archaeological sites located in the Moldavian Plateau (Cucuteni-Cetățuia, Băiceni-La Dobrin, Dealul Mare, La Iaz-Dealul Mândra, and Costeşti-Cier) affected by various causes, such as erosion, alluvial depositing, or landslide. 
Davide Delfino, Luiz Oosterbeek and Nelson Almeida, in their study entitled Yes, we can! Scientific Research and Public Archaeology between the Public and Private Sectors in Central Portugal (p. 45-54), draws a point of view on the archaeology in Portugal. Their contribution refers to issues like state resources and competence, regulations and privates, or the public heritage in the region of the Middle Tagus.

Durga Basu pays attention on important aspects regarding Public Archaeology, its Scope and Limitation in Regional Aspects in India (p. 55-58).

Some facts about The International Exhibition Project "The Terra-Cotta Army: Arms and Armour in Chinese Destiny." Experiences, Results and Perspectives of an Archaeological Mobile Exhibition (p. 59-62) are revealed in Alexey O. Pronin's contribution.

Livia Ştefan and Dragoş Gheorghiu described in their article a mobile application, very useful for the e-cultural tourism (E-Cultural Tourism for Highlighting the "Invisible" Communities - Elaboration of Cultural Routes Using Augmented Reality for Mobile Devices (MAR) (p. 63-66).

Another application of mobile devices is described in the contribution of Andrea Chiricescu, Alexandru Popa and Mihai Chiricescu, The Archaeology Spets into the Smartphone Era! An Application for Mobile Devices, for Signalling, Tracking and Informing on Archaeological Sites from South-east Transylvania - a joint public-private research project (p. 67-72).

E. M. P. González, M. E. C. Álvarez, M. D. C. Massieu, and D. M. Socas analyzed the Archaeological Heritage Management in the Canary Islands (Spain) and Its Relationship with Tourism (p. 73-76).

Andrey Borodovskiy offered a proposal of developing tourism infrastructure within the region of the Altai Mountains, in Monitoring and Integrating the Archaeological Heritage from the Altai Mountains into the Tourism Infrastructure (p. 77-80).

P. Kołodziejczyk presented some interesting data regarding the Polish Archaeological and Scientific Achievements in the Research and Protection of World Cultural Heritage as a Marketing Product? Examples of Promotional Activities (p. 81-90). He described the Polish Archaeological expedition to the Eastern Nile Delta.

Marta Lorenzon (Arica and Parinacota: A Successful Example of Integration between Cultural Tourism and Heritage Preservation, p. 91-96) investigates the modalities of preservation used in the region of Arica and Parinacota (Chile). This particulary region, located between the plateau of the Andes and the so-called Pacific Great Desert, is remarcable because of its hitorical landscape, based on traces dating back over 10000 years. The author of the paper describes the activity of the Fundación Altiplano, born in 2005 with the main purpose focused on the protection and the development of the archaeological and arhitectural heritage. For example, the Fundación Altiplano initiated the restoration of thirty-one churches. The foundation also promoted the idea of the involvement of the community in activities aiming to sustain and promote the patrimony and the heritage of the area.

A very short note is provided by Irina Gusach, in A New Direction of Archaeological Tourism in the South of Russia (On the Example of the "Tanais" Archaeological Reserve Museum (p. 97-98), with reference to the discovery, in 2012, of an ancient 
cult construction close to the Rostov-Don area. Fortunately, the Ministry of Culture of Rostov decided to preserve this newly found building, thus not only protecting the monument, but also decisively contributing to the development of the touristic activities in the area.

Projit Kumar Palit wrote a study about the Cultural Tourism in Tripura, Northeastern India, with special Reference to Bangladesh: an Archaeological Study (p. 99-103), where he described the touristic objectives located in the area of Tripura. Many of the sites known here were excavated since 1955, when the Archaeological Survey of Bangladesh carried out excavations and conservation works here.

Alexandru Popa provided an insight focused on the Multidisciplinary Researches and the Question of Archiving the Analysed Samples and their Results. Case Study: the Roman Camps from South-east Transylvania (p. 105-110). This study is related with the project entitled "Roman Limes in Eastern Dacia", including several key objectives and a series of activities, based on multidisciplinary researches, such as archaeological and archaeometric prospections, the re-inventorying of older excavations, geomagnetic prospections, georadar measurements, and geochemical prospections. Data collected after these investigations are archived. The author enumerates these types of data and offers solutions regarding the interpretation of this information.

Monica Bîră (Seeing the Past through the Eyes of Media - Archaeology and Archaeologists as Depicted by the Romanian Online Press, p. 111-115) offers some information regarding the perception of archaeology reflected in three online Romanian journals (Gândul.info, Adevărul.ro and Jurnalul.ro).

Suzie Thomas (Multiple-Role Actors in the Movement of Cultural Property: Metal-Detector Users, p. 117-124) approaches a very difficult aspect that became more and more a real problem - the trafficking of cultural objects. The author presents the "matrix" which functions on four stages and has as final step the traffic of objects. The first people involved in this "chain" are the extractors, who loot the sites and the monuments. Then, they are followed by the so-called "middle-men", those who connect the extractors with the dealers. Then they are followed by the dealers/traders, and finally, in the fourth stage, by the buyers. The author of the paper also refers to the hobbyist metal-detector users in northern Europe.

Henrique A. Mourão (The Incompatibility between the UNESCO Underwater Heritage Convention and Brazilian Legislation, p. 125-128) refers to a document known as the Federal Bill 7566, which was adopted in 2005 by a small group of specialists, changing the Brazilian legislation with reference to the national underwater heritage.

The final article of this volume is signed by Sergey Tikhonov and it focuses on The Preservation and Use of the Archaeological Heritage in West Siberia Russia) (p. 129-132). It reflects some aspects regarding the status and the state of the native archaeological heritage in Siberia.

Therefore, this book will be very useful for all those specialists interested in the preservation, the conservation, the protection and the promotion of the archaeological patrimony. I recommend it because it provides interesting aspects and it debates upon 
various problems, and details about the legislation, presenting different approaches connected to the sites and the monuments all over the world.

Florin-Gheorghe Fodorean Universitatea Babeș-Bolyai, Cluj-Napoca fodorean_f(oyahoo.com 



\section{IN MEMORIAM}





\section{PROF. DR. IOAN GLODARIU \\ $(01.02 .1940-21.01 .2017)$}

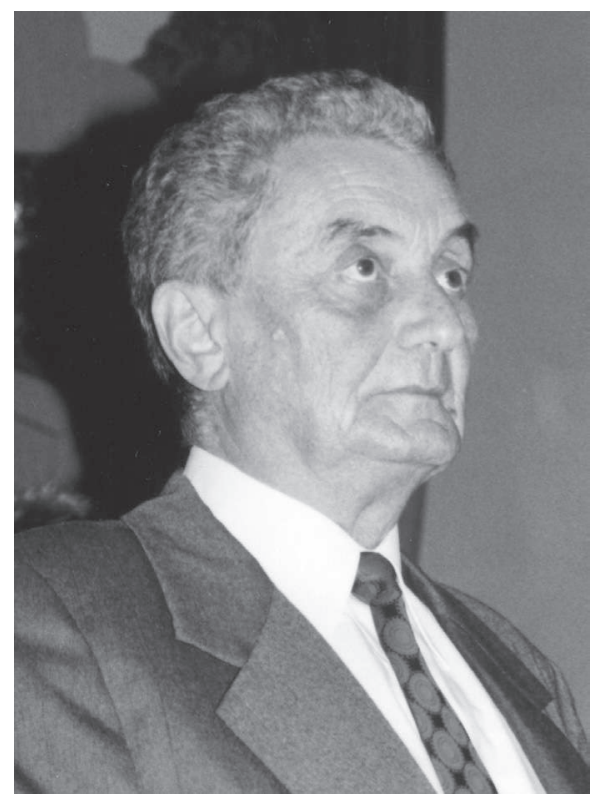

Ioan Glodariu est né le $1^{\text {er }}$ février 1940, à Sibiu. L'attachement pour sa ville natale s'explique par l'excellence de l'école qui l'a formé, par le voisinage des montagnes et aussi par la cohabitation avec les Saxons, parmi lesquels il s'est fait des amis pour la vie.

Après ses études secondaires, il s'est dirigé vers Cluj où, en 1962, il parfait ses études supérieures à l'Université Victor Babeş, avec la spécialisation Histoire Universelle Ancienne et Archéologie. Ioan Glodariu a commencé sa carrière scientifique comme assistant-moniteur dans le département d'histoire de la Roumanie (1962-1966), étant par la suite, pour une longue période, chercheur à l'Institut d'Histoire et d'Archéologie de l'Académie Roumaine. À partir de 1992, il a enseigné à la Faculté d'Histoire et de Philosophie de l'Université Babeş-Bolyai, en tant que professeur du Département d'Histoire Antique et Archéologie.

Pendant un demi-siècle, Ioan Glodariu a été l'un des meilleurs représentants de l'école archéologique de Cluj, en tant que participant et directeur de plus d'une centaine de campagnes de fouilles, certaines d'entre elles étalées sur plusieurs mois, sur de nombreux sites en Transylvanie. Pour ne citer que les plus importants: Dezmir (dép. de Cluj) ; Ocna Sibiului, Guşteriţa-Sibiu, Arpaşu de Sus, Slimnic, Şura Mică (dép. de Sibiu) ; Onceşti (dép. de Maramureş) ; Dedrad, Bernadea (dép. de Mureş) ; Sărățel (dép. de Bistrița-Năsăud) ; Lupu, Cetea, Piatra Craivii, Vîrful lui Pătru, Inuri (dép. d'Alba); Culciu Mare (dép. de Satu Mare); Comana de Jos, Şercaia (dép. de Braşov). 
Entre 1958 et 2008, il a consacré le plus clair de son activité archéologique aux « bourgs daces» des Montagnes Orăştiei, étant présent chaque année sur les sites de la région. Entre Ioan Glodariu et les cités daces s'est créée une parfaite symbiose, résultat d'un rare sentiment du devoir pour les monuments antiques. Les recherches archéologiques qu'il a menées à Costeşti, Blidaru, Căpîlna, Meleia, Fețele Albe et en particulier à Sarmizegetusa Regia, pour ne mentionner ici qu'une partie des toponymes majeurs, lui ont permis de comprendre, sans doute comme nul autre, l'antiquité dace. C'est à Ioan Glodariu qu'on doit la découverte de nombreux édifices militaires, cultuels, civils et artisanaux, devenus, grâce à ses efforts, des repères incontournables de la civilisation dace. Sous sa direction, les Cités Daces des Montagnes Orăştiei figurent désormais sur la liste du patrimoine mondial de l'UNESCO. Nonobstant, il a profondément ressenti les blessures laissées sur les vestiges antiques par les travaux de conservationrestauration de 1980 à Sarmizegetusa Regia (à l'apogée du délire daciste du régime communiste) ou encore par les chasseurs de trésors d'une époque plus récente. Il ne s'est jamais plié à l'inertie, voire à la négligence, des autorités dont le devoir était de prévenir ces phénomènes inquiétants ; de même, il a toujours dénoncé le travestissement ahurissant des réalités archéologiques par la nébuleuse de la dacomanie.

Ses articles, ses études, ses contributions à des divers dictionnaires, encyclopédies et synthèses, et en particulier ses monographies, restent une mine d'informations archéologiques et historiques indispensable pour tous les aspects de la civilisation dace. Sa thèse de doctorat, sous la direction de Constantin Daicoviciu, fut publiée en roumain en 1974 : Relații comerciale ale Daciei cu lumea elenistică şi romană (sec. II î.e.n. - I e.n.) [Les relations commerciales de la Dacie avec le monde hellénistique et romain $\left(I I^{e} s . a v . n . \grave{e} .-I^{e r} s\right.$. de n. è.)]; deux années plus tard, le livre fut republié à Oxford, dans les British Archaeological Reports, sous le titre Dacian Trade with the Hellenistic and Roman World. D'autres ouvrages ont suivi, parfois en collaboration, dont les plus importants sont: Assezarea dacică de la Arpaşu de Sus [Le site dace d'Arpaşu de Sus] (1976), Civilizația fierului la daci (sec. II î.e.n. - I e.n.) [La civilisation du fer chez les Daces (II s. av. n. è. - Irr s. de n. è.)] (1979), Comana de Jos. Assezările de epocă dacică si prefeudală [Comana de Jos. Les sites d'époque dace et préféodale] (1980), Assezări dacice şi daco-romane la Slimnic [Les sites daces et daco-romains de Slimnic] (1981), Arhitectura dacilor. Civilă şi militară (sec. II î.e.n. - I e.n.) [L'architecture des Daces, civile et militaire (II ${ }^{e}$ s. av. n. è. - I ${ }^{e r}$ s. de n. è.)] (1983), Cetăţi şi aşezări dacice în sudvestul Transilvaniei [Cités et sites daces au sud-ouest de la Transylvanie] (1989), Cetatea dacică de la Căpîlna [La cité dace de Căpîlna] (1989), Sarmizegetusa Regia. Capitala Daciei preromane [Sarmizegetusa Regia, capitale de la Dacie préromaine] (1996).

Ioan Glodariu s'est également imposé comme fondateur d'école, puisque de nombreux archéologues, qui lui doivent leur vocation et leur formation, essaient de poursuivre l'activité de celui qui est toujours évoqué - combinant l'appellatif simple et tout le poids de la tradition académique - comme « Monsieur le professeur ». Tous ceux qui l'ont connu n'oublieront jamais sa joie de vivre et son intelligence perçante.

Ses qualités scientifiques ont été récompensées du prix Vasile Pârvan de l'Académie Roumaine (1974) et par sa nomination comme Commandeur de l'Ordre du Mérite Culturel (2004). Il a été président de la Commission Régionale (Transylvanie) 
des Monuments Historiques (1991-1999) ainsi que de la Commission Nationale d'Archéologie (2001-2003).

Ioan Glodariu s'est éteint le 21 janvier 2017, étant enterré, selon son souhait, à Sibiu.

Rămas bun, Domnule Profesor - Adieu, Monsieur le Professeur.

Răzvan Mateescu

Musée National d'Histoire de la Transylvanie, Cluj-Napoca razvanmateescu(d)yahoo.com

(traduit par Dan Dana) 



\section{ABBREVIATIONS}

The following list contains abbreviations which are not included in the list at http:// www.annee-philologique.com/files/sigles_fr.pdf.

AAA

AB (S. N.)

ACMIT

Acta Carnuntina

ActaCD

ActaMN

ActaMP

ActaTS

ActMuz

ACSS

AE

AEA

Aegaeum

AEM

AIIA Cluj

AIIA Iaşi

AIJ

AISC

AJA

Alba Regia

Aluta

American

Anthropologist

AMS

Angustia

ANRW

AO

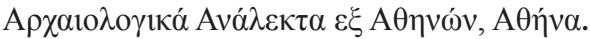

Analele Banatului, Timişoara; Serie Nouă (S. N.): Analele Banatului, Timisoara.

Anuarul Comisiunii Monumentelor Istorice, Secţiunea pentru Transilvania, Cluj.

Acta Carnuntina. Mitteilungen der Gesellschaft der Freunde Carnuntums, Carnuntum.

Acta Classica Universitatis Scientiarum Debreceniensis, Debrecen.

Acta Musei Napocensis, Cluj-Napoca.

Acta Musei Porolissensis, Zalău.

Acta Terrae Septemcastrensis, Sibiu.

Din activitatea muzeelor, Cluj-Napoca.

Ancient Civilizations from Scythia to Siberia. An International Journal of Comparative Studies in History and Archaeology, Bordeaux - Moscow.

L'Année Épigraphique, Paris.

Aegean Archaeology. Studies and Monographs in Mediterranean Archaeology and Civilization, Warsaw \& Chapel Hill.

Aegaeum. Annales d'archéologie égéenne de l'Université de Liège et UT-PASP, Liège.

Archäeologisch-epigraphische Mitteilungen aus Österreich-Ungarn, Wien.

Anuarul Institutului de Istorie şi Arheologie, Cluj-Napoca.

Anuarul Institutului de Istorie și Arheologie, Iaşi.

V. Hoffiller, B. Saria, Antike Inschriften aus Jugoslavien, Heft 1: Noricum und Pannonia Superior, Zagreb 1938.

Anuarul Institutului de Studii Clasice, Cluj-Napoca.

American Journal of Archaeology, Boston.

Alba Regia. Annales Musei Stephani Regis - Alba Regia. A Szent István Király Múzeum Évkönyve, Székesfehérvár.

Aluta. Revista Muzeului Național Secuiesc, Sfântu Gheorghe.

American Anthropologist. Journal of the American Anthropological Association.

Asia Minor Studien. Forschungsstelle Asia Minor im Seminar für Alte Geschichte der Westfälischen Wilhelms-Universität Münster.

Angustia. Revista Muzeului Carpaților Răsăriteni, Sfântu Gheorghe. H. Temporini, W. Haase (Hrsgg.), Aufstieg und Niedergang der römischen Welt, Berlin - New York.

Arhivele Olteniei, Craiova. 
AOAT

Apulum

$\mathbf{A} \boldsymbol{\chi} \chi$

Археологія

ArchAnz

Archaeologia Bulgarica

$\operatorname{A\rho } \chi \Delta \varepsilon \lambda \tau$

ArchHung

ArchKözl

ArhMold

Arheologie şi Studii

Clasice

ArhVest

Banatica

BAR

BCMI

BHAUT

BMC

BSNR

CA

CAB

CAH

CCA

CCCA

CCDJ

CCID

CCIS

Ch\&K

CIG

CIGD

CIL

CILA

CIMRM

Civiltà

Classica et Christiana
Alter Orient und Altes Testament. Veröffentlichungen zur Kultur und Geschichte des Altens Orients und des Alten Testament, Kevelar/Neurkirchen-Vluyn, Münster.

Apulum. Anuarul Muzeului Naţional al Unirii din Alba Iulia, Alba Iulia.

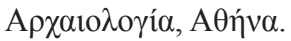

Археологія. Спілка ароехеологів України, Kiev.

Archäologischer Anzeiger, Berlin.

Archaeologia Bulgarica, Sofia.

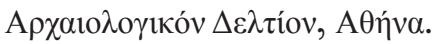

Archaeologia Hungarica. Dissertationes Archaeologicae Musei Nationalis Hungarici a Consilio Arcaeologorum Academiae Scientiarum Hungaricae redactae, Budapest.

Archeológiai Közlemények, Budapest.

Arheologia Moldovei, Iaşi.

Arheologie şi Studii Clasice, București.

Arheološki Vestnik, Ljubljana.

Banatica, Reşița.

British Archaeological Reports, Oxford.

Buletinul Comisiei Monumentelor Istorice, Bucureşti.

Bibliotheca Historica et Archaeologica Universitatis Timisiensis, Timişoara.

H. Mattingly, R. Carson (eds.), Coins of the British Museum, London 1923.

Buletinul Societăţii Numismatice Române, București.

Cercetări Arheologice. Muzeul Naţional de Istorie, Bucureşti.

Cercetări Arheologice în București. Muzeul de Istorie și Artă al Municipiului București.

Cambridge Ancient History, Cambridge.

Cronica Cercetărilor Arheologice din România, Bucureşti.

M. J. Vermaseren, Corpus cultus Cybelae Attidisque VI, Leyden 1989.

Cultură şi civilizație la Dunărea de Jos, Călăraşi.

M. Hörig, E. Schwertheim (eds.), Corpus cultus Iovis Dolicheni, EPRO 106, Leiden 1987.

E. N. Lane, Corpus cultus Iovis Sabazii, Leyden 1985.

Chaos e Kosmos. Per Tommaso Marciano, Roma, http://www.chaosekosmos.it/pdf/2009_01.pdf.

Corpus Inscriptionum Graecarum, I-IV, Berlin 1828-1877.

L. Ruscu, Corpus Inscriptionum Graecarum Dacicarum, HPS 10, Debrecen 2003.

Corpus Inscriptionum Latinarum, Berlin 1863 sqq.

J. González (ed.), Corpus de inscripciones latinas de Andalucía, Sevilla 1989-1991, I-III.

M. J. Vermaseren, Corpus Inscriptionum et Monumentorum Religionis Mithriacae, I-II, The Hague 1956, 1960.

Civiltà romana in Romania, Roma 1970.

Classica et Christiana. Revista Centrului de Studii Clasice și Creștine, Iași. 
CMRDM

CMRED

CNT

CommArchHung

Comunicări de geologie

Crisia

CSIR

A Csíki Székely

Múzeum Évkönyve

Cumidava

DA

Dacia (N. S.)

\section{A Debreceni Déri \\ Múzeum Évkönyve \\ DissPann \\ Dizionario Epigrafico \\ Documenta \\ Praehistorica \\ Dolgozatok/Travaux}

\section{Drobeta \\ EAIVR}

EDCS

EDR

EN

EphEp

Epigraphische Studien

EPRO

Erdély

ErdMuz

'E $\rho$ yov

FolArch

Fundberichte aus

Baden-Württemberg
E. N. Lane, Corpus monumentorum religionis Dei Menis, Leiden 1976.

D. Tudor, Corpus monumentorum religionis equitum Danuvinorum, I-II, Leiden 1969-1976.

Corpus Nummorum Thracorum: https://www.corpus-nummorum.eu/ Communicationes Archaeologicae Hungaricae, Budapest.

Comunicări de geologie. Societatea de Științe Naturale şi Geografie a Republicii Populare Romîne, București.

Crisia. Muzeul Țării Crișurilor, Oradea.

Corpus Signorum Imperii Romani.

A Csíki Székely Múzeum Évkönyve, Miercurea Ciuc.

Cumidava. Muzeul Județean de Istorie, Braşov.

Ch. V. Daremberg, Ed. Saglio, Dictionnaire des antiquités grecques et romaines, d'après les textes et les monuments, Paris 1877-1919.

Dacia - Recherches et découvertes archéologiques en Roumanie; Nouvelle Série (N. S.): Dacia - Revue d'archéologie et d'histoire ancienne, Bucureşti.

A Debreceni Déri Múzeum Évkönyve. Annales Musei Debreceniensis de Frederico Déri nominate, Debrecen.

Dissertationes Pannonicae, Budapest.

E. di Ruggiero (ed.), Dizionario epigrafico di antichita romane, I-III, Roma 1895-1922.

Documenta Praehistorica, Ljubljana.

Dolgozatok az Erdélyi Nemzeti Múzeum Érem és Régiségtárából, Kolozsvár (Cluj) / Travaux de la section numismatique et archéologique du Musée National de Transylvanie à Kolozsvár (Cluj).

Drobeta, Drobeta-Turnu Severin.

Enciclopedia arheologiei și istoriei vechi a României, București 1994-.

Epigraphik-Datenbank Clauss/ Slaby (http://www.manfredclauss. de/).

Ephemeris Dacoromana. Annuario della Scuola Romena di Roma, Roma.

Ephemeris Napocensis, Cluj-Napoca.

Ephemeris Epigraphica: Corporis inscriptionum Latinarum supplementum, Roma 1872 sqq.

Epigraphische Studien, Bonn.

Études préliminaires aux religions orientales dans l'Empire romain, Leiden.

Erdély Honismertető Folyóírat. Az Erdély Kárpát-Egyesűletnek és Múzeumának értesítője, Kolozsvár.

Erdélyi Múzeum. Kiadja az Erdélyi Múzeum Egyesület, Kolozsvár.

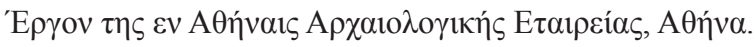

Folia Archaeologica. Annales Musei Nationalis Hungarici, Budapest.

Fundberichte aus Baden-Württemberg, Stuttgart. 
Glasnik

GLIA

HD

A Herman Ottó
Múzeum Évkönyve
Hierá
HPS
HSCPh
HTRTÉ

IDR

IDRE

IG

IGB

IGLNovae

IGLR

ILAf

ILBulg

ILD

ILJug

ILLPRON

ILS

IMS

InscrItal

ISM

Istros

JHS

Journal of Democracy

JSA

Journal of Military

History

Journal of Religion and Journal of Religion and Health, Blanton-Peale Institute.

Health

Közlemények

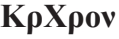

Glasnik Srpskog Arheološkog Društva (Journal of the Serbian Archaeological Society), Belgrade.

S. Mitchell, D. French, The Greek and Latin inscriptions of Ankara (Ancyra), I. From Augustus to the end of the third century AD, München 2012.

Epigraphische Datenbenk Heidelberg, edh-www.adw.uni-heidelberg. de.

A Herman Ottó Múzeum Évkönyve. Annales Musei Miskolciensis de Herman Ottó Nominati, Miskolc.

Hierá. Collana di studi storico-religiosi, Cosenza.

Hungarian Polis Studies, Debrecen.

Harvard Studies in Classical Philology, Cambridge.

A Hunyadmegyei Történelmi és régészeti Társulat Évkönyve, I-XXII, Deva 1880-1913.

Inscriptiones Daciae Romanae, I-III, Bucureşti - Paris 1975 sqq.

C. C. Petolescu, Inscriptions externes concernant l'histoire de la Dacie, I-II, Bucureşti 1996, 2000.

Inscriptiones Graecae, Berlin 1873 sqq.

G. Mihailov, Inscriptiones Graecae in Bulgaria repertae, I-V, Serdicae (Sofia), 1956-1997.

J. Kolendo, V. Božilova, Inscriptions grecques et latines de Novae (Mésie Inférieure), Bordeaux - Paris 1997.

Em. Popescu, Inscripţiile greceşti şi latine din secolele IV-XIII descoperite în România: culese, traduse în româneşte, însoțite de indici şi comentate, Bucureşti 1976.

R. Cagnat, A. Merlin, L. Châtelain, Inscriptions latines d'Afrique, Paris 1923.

B. Gerov, Inscriptiones Latinae in Bulgaria repertae, I, Sofia 1989.

C. Petolescu, Inscripții latine din Dacia, Bucureşti 2005.

A. Šašel, J. Šašel, Inscriptiones Latinae quae in Iugoslavia inter annos MCMXL et MCMLX repertae et editae sunt, Ljubljana 1963.

M. Hainzmann, P. Schubert, Inscriptionum lapidariarum Latinarum provinciae Norici usque ad annum MCMLXXXIV repertarum indices, Berlin - New York 1986.

H. Dessau, Inscriptiones Latinae Selectae, I-IV, Berlin 1882-1916.

Inscriptions de la Mésie Supérieure, I-VI, Beograd 1976-1982.

Inscriptiones Italiae, Roma 1937.

Inscripțiile din Scythia Minor greceşti şi latine, Bucureşti 1980 sqq.

Istros. Buletinul Muzeului Brăilei, Brăila.

The Journal of Hellenistic Studies, Cambridge.

Journal of Democracy, Washington DC.

Journal of Social Archaeology, http://jsa.sagepub.com/.

Journal of Military History, Lexington (VA).

Közlemények az Erdélyi Nemzeti Múzeum Érem- és Régiségtárából, Budapest.

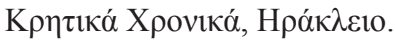




\section{krisis/crisi}

KSK RBS

KunArchiv

KVHAA

LGPN

Libyca

LIMC

L\&S

Lupa

MAL

Madrider Mitteilungen

Marisia

\section{Marmatia \\ MAVORS \\ MCA}

Medicina nei secoli

MelBidez

Memoria Antiquitatis

MGH. AA

\section{Michmanim}

MMM

\section{Montana II}

Musaios

Neohelicon

Novensia

OLD

OPEL

ORA

Oriens et Occidens

Ősrégészeti Levelek

PamátkyArch

PAS

PAT

PAwB krisis/crisi, Roma 2012.

Kleine Schriften zur Kenntnis der römischen Besetzungsgeschichte Südwestdeutschlands, Stuttgart.

Kün Archiv: Arbeiten aus dem Landwirtscaftlichen Institut der Universität Halle, Berlin.

Kungl. Vitterhets Historie och Antikvitets Akademien, Stockholm.

Lexicon of Greek Personal Names, Oxford, http://www.lgpn.ox.ac. $\mathrm{uk} /$.

Libyca. Bulletin du Service des Antiquités. Archéologie, Épigraphie, Alger.

Lexicon Iconographicum Mythologiae Classicae, 1981 sqq.

C. T. Lewis, C. Short, A new Latin Dictionary, New York - Oxford 1891.

Ubi erat lupa, www.ubi-erat-lupa.org.

Atti dell'Accademia Nazionale dei Lincei. Memorie. Classe di Scienze morali storiche e filologiche, Roma.

Madrider Mitteilungen. Deutches Archäeologisches Institut, Madrid.

Marisia. Studii şi materiale. Arheologie, istorie, etnografie, Muzeul Județean Mureş, Târgu Mureş.

Marmatia, Baia Mare.

MAVORS - Institute for Ancient Military History.

Materiale şi cercetări arheologice, Bucureşti.

Medicina nei Secoli, Roma.

Mélanges Joseph Bidez, Bruxelles 1934 (= Annuaire de l'Institut de Philologie et d'Histoire Orientales et Slaves 2, Bruxelles 1933-1934).

Memoria Antiquitatis. Acta Musei Petrodavensis, Piatra Neamţ.

Monumenta Germaniae Historica, Auctores Antiquissimi, Hannover

- Berlin 1826 sqq.

Michmanim.The Bulletin of the Reuben and Edith Hecht Museum. Haifa University.

Fr. Cumont, Textes et monuments figurés relatifs aux mystères de Mithra, II, Bruxelles 1896.

V. Velkov, G. Alexandrov (eds.), Епиграфски паметници от Монтана и района, София 1994.

Musaios, Muzeul Județean Buzău.

Neohelicon. Acta Comparitionis Litterarum Universalis, Budapest.

Novensia: badania Ekspedycji Archeologicznej Uniwersytetu Warszawskiego w Novae, Warsawa.

Oxford Latin Dictionary, Oxford 1968.

B. Lőrincz, F. Redő et alii, Onomasticon Provinciarum Europae Latinarum, I-IV, Budapest 1994-2005.

Orientalische Religionen in der Antike.

Oriens et Occidens. Studien zu antiken Kulturkontakten und ihrem Nachleben, Stuttgart.

Ősrégészeti Levelek. Prehistoric newsletter, Budapest.

Památky Archeologické, Praga.

Prähistorische Archäologie in Südosteuropa, Berlin.

Patrimonium Archaeologicum Transylvanicum, Cluj-Napoca.

Potsdamer Altertumswissenschaftliche Beiträge. 
PBF

PECS

Peuce
Phoenix
PIR
PIR $^{2}$

PLRE

Pontica

Potaissa

Probleme de

Muzeologie

PZ

RCRF Acta

RD

RE

Religion

Religious Studies

Rheinisches Museum

RepCluj

\section{Revista Arheologică \\ RevBistriţei \\ Revista Fundațiilor \\ Regale \\ Revista de Istorie}

RevMuz

Revue Roumaine

d'Histoire

RGZM

RIB

RIT

RIU

Rivista storica

dell'antichità

Rivista di storia della chiesa in Italia
Prähistorische Bronzefunde, Berlin.

R. Stillwell, W. L. MacDonald, M. Holland McAllister (eds.), The Princeton Encyclopedia of Classical Sites, Princeton University Press 1976.

Peuce. Institutul de Cercetări Eco-Muzeale "Gavrilă Simion", Tulcea.

Phoenix. Classical Association of Canada, Toronto.

Prosopographia Imperii Romani, Berlin 1897-1898.

E. Groag, A. Stein et alii, Prosopographia Imperii Romani², Berlin 1933 sqq.

Prosopography of the Later Roman Empire, I-III, Cambridge 1971-1992.

Pontica. Studii şi materiale de istorie, arheologie şi muzeografie, Constanța.

Potaissa. Studii și Comunicări, Turda.

Probleme de Muzeologie, București.

Prähistorische Zeitschrift, Berlin.

Rei Cretariae Romanae Fautorum Acta.

F. Rómer, E. Desjardins, A Magyar Nemzeti Múzeum római feliratos emlékei - Inscriptiones monumentorum Romanorum Musei Nationalis, Acta Nova Musei Nationalis, 1, Budapest 1873.

A. Pauly, G. Wissowa, W. Kroll, K. Ziegler (eds.), Realencyclopädie der classischen altertumswissenschaft, Stuttgart 1893 sqq.

Religion, http://www.tandfonline.com/.

Religious Studies. An International Journal for the Philosophy of Religion, Cambridge.

Rheinisches Museum für Philologie, Köln.

I. H. Crişan, M. Bărbulescu, E. Chirilă, V. Vasiliev, I. Winkler, Repertoriul arheologic al județului Cluj, Cluj-Napoca 1992.

Revista Arheologică, Chișinău.

Revista Bistriței, Bistrița.

Revista Fundațiilor Regale: revistă lunară de literatură, artă şi cultură generală, București.

Revista de istorie. Academia de Științe Sociale și Politice a Republicii Socialiste România. Secția de Istorie și Arheologie, București.

Revista Muzeelor, Bucureşti.

Revue Roumaine d'Histoire, Bucarest.

B. Pferdehirt, Römische Militärdiplome und Entlassungsurkunden in der Sammlung des Römisch-Germanischen Zentralmuseums, I-II, Mainz - Bonn 2004.

The Roman Inscriptions of Britain, Oxford 1965 sqq.

G. Alföldi, Die römischen Inschriften von Tarraco, Berlin 1975.

Die römischen Inschriften Ungarns, I-VI, Budapest - Bonn 1972-2001.

Rivista storica dell'antichità, Roma.

Rivista di storia della chiesa in Italia, Milano. 

Rivista di Studi Liguri
RMD

\section{RMI}

Romanian Journal of Archaeology

RPC I

RR

RSS

SAA

SA

Saggi

Sargetia

Savaria

SAWW

SBA

SCIV(A)

SCN

SEG

Situla

SMMIM

SMSR

Social History of

Medicine

Somogyi Múzeumok

Közleményei

SpecNov

StCl

StComSatuMare

Studii de Preistorie

SympThrac

Terra Sebus

ThesCRA

Thraco-Dacica

TIR

Tisicum

TitAq
Rivista di Studi Liguri, Bordighera.

M. M. Roxan, P. Holder, Roman Military Diplomas, London 1985-1993.

Revista Monumentelor Istorice, Bucureşti.

Romanian Journal of Archaeology, http://apar.archaeology.ro/rja. htm.

A. Burnett et alii, Roman Provincial Coinage I: From the Death of Caesar to the Death of Vitellius (44 BC - AD 69), London, Paris 1992.

Römer in Rumänien. Ausstellung des Römisch-Germanischen Museums Köln und des Historischen Museums Cluj, 12. Februar 18 Mai 1969, Köln 1969.

A. Mócsy, T. Szentléleky, Die römischen Steindenkmäler von Savaria, Budapest 1971.

Studia Antiqua et Archaeologica, Iași.

Studia Archaeologica, Roma.

I Saggi, Roma.

Sargetia. Buletinul Muzeului Județean Hunedoara, Deva.

Savaria. A Vas Megyei Múzeumok Értesítője, Szombathely.

Sitzungsberichte der Österreichischen Akademie der Wiessenschaften in Wien, Philosophisch-historische Klasse, Wien.

Schweizerische Beiträge zur Altertumswissenschaft.

Studii şi cercetări de istorie veche (şi arheologie - since 1975), Bucureşti.

Studii şi cercetări numismatice, Bucureşti.

Supplementum Epigraphicum Graecum, Leiden 1923 sqq.

Situla. Razprave Narodnega Muzeja v Ljubljani - Dissertationes Musei Nationales Labacensis, Ljubljana.

Studii şi materiale de muzeografie şi istorie militară, Bucureşti.

Studi e Materiali di Storia delle Religioni.

Social History of Medicine, Oxford.

Somogyi Múzeumok Közleményei. Mitteilungen der Museen des Komitates Somogy, Kaposvár.

Specimina Nova Dissertationum ex Institutis Historiae Antiquae et Archaeologiae Universitatis Quinqueecclesiensis, Pécs.

Studii Clasice, București.

Studii şi comunicări, Satu Mare.

Studii de Preistorie, http://arheologie.ro.

Symposia Thracologica. Lucrările Simpozionului Anual de Tracologie, Institutul Român de Tracologie, Bucureşti.

Terra Sebus. Acta Musei Sabesiensis, Sebeș.

M. Greenberg (ed.), Thesaurus Cultus et Rituum Antiquorum, Los Angeles 2004.

Thraco-Dacica. Institutul de Tracologie, Bucureşti.

Tabula Imperii Romani.

Tisicum. A Szolnok megyei múzeumi évkönyv, Szolnok.

P. Kovács, Á. Szabó, Tituli Aquincenses, Budapest 2009 sqq. 
Transactions

Philadelphia

Transylvanian Review

TRHR

Tyragetia

UPA

Ziridava

MCDR

MJIAZ

MNIR

MNIT

MNM
University of Pennsylvania. Transactions of the Department of Archaeology, Free Museum of Science and Art, Philadelphia.

Transylvanian Review. Revue de Transylvanie, Cluj-Napoca.

P. Kovács, Tituli Romani in Hungaria reperti. Supplementum, Budapest-Bonn 2005.

Tyragetia. Muzeul Naţional de Istorie a Moldovei, Chişinău. Universitätsforschungen zur Prähistorischen Archäologie, Bonn.

Ziridava. Complexul Muzeal Arad.

Muzeul Civilizaţiei Dacice şi Romane Deva.

Muzeul Județean de Istorie şi Artă Zalău.

Muzeul Naţional de Istorie a României, București.

Muzeul Naţional de Istorie a Transilvaniei, Cluj-Napoca.

Magyar Nemzeti Múzeum, Budapest. 